If you do not need this report after it has served your purpose, please return it to the Geological

Survey, using the official mailing label at the end

UNITED STATES DEPARTMENT OF THE INTERIOR

THE SAN JUAN COUNTRY

A GEOGRAPHIC

AND GEOLOGIC RECONNAISSANCE

OF SOUTHEASTERN UTAH

GEOLOGICAL SURVEY PROFESSIONAL PAPER 188 

If you do not need this report after it has served your purpose, please return it to the Geological Survey, using the official mailing label at the end

UNITED STATES DEPARTMENT OF THE INTERIOR

Harold L. Ickes, Secretary

GEOLOGICAL SURVEY

W. C. Mendenhall, Director

Professional Paper 188

\title{
THE SAN JUAN COUNTRY
}

\section{A GEOGRAPHIC AND GEOLOGIC RECONNAISSANCE OF SOUTHEASTERN UTAH}

\author{
BY \\ HERBERT E. GREGORY \\ WITH CONTRIBUTIONS BY MALCOLM R. THORPE
}

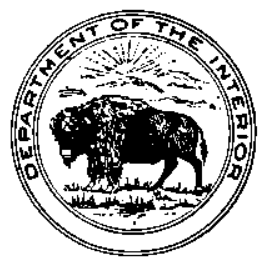

UNITED STATES

GOVERNMENT PRINTING OFFICE

WASHINGTON : 1938

For sale by the Superintendent of Documents, Washington, D. C.

Price 60 cents 



\section{CONTENTS}

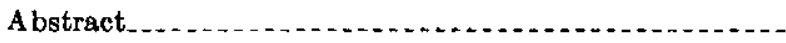

Introduction

Scope and purpose

Previous exploration ...........................

Related investigations............

Acknowledgments . . . . . . . .

Suggestions to travelers . . . . .

Chapter 1. Geography

Location, extent, and accessibility ............

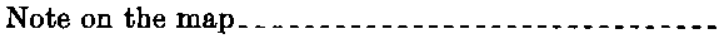

Topographic outline

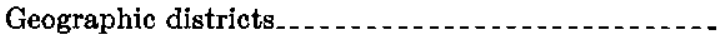

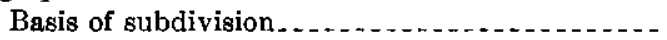

Sage Plain . . .

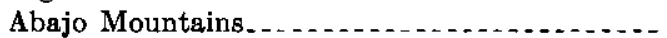

San Juan Valley . .

Elk Ridge.

Allen Canyon country

Grand Gulch Plateau . . . . . . . . . . . . .

Lime Creek Valley

Dark Canyon Plateau. . . . . . . . . .

White Canyon.

Red Rock Plateau. .

Wilson Mesa.

Glen Canyon

Beef Basin

Climate.

General relations

Precipitation . . . .

Records . . . . . . . . . . . . . .

Geographic distribution . . . . . . . . . . . . .

Variation from year to year.

Seasonal distribution

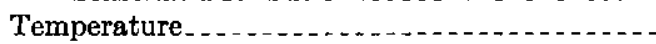

Wind

Soil......

Vegetation

Animal life ...

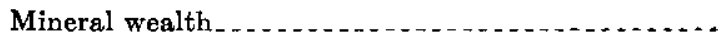

Inhabitants $\ldots$

Basket Makers and Cliff Dwellers. ........

Piutes, Utes, and Navajos.

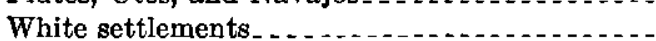

History

Population ...........

Industries. . .

Farming

Stock raising

Chapter 2. Sedimentary rocks.

General stratigraphic relations.......

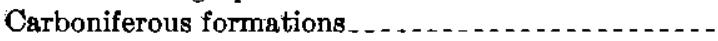

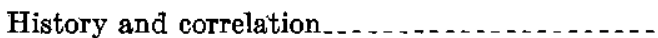

Pennsylvanian formation.

Hermosa formation

Permian formations.

Rico formation.

Cutler formation

Terminology
Page

Chapter 2. Sedimentary rocks-Continued. Carboniferous formations-Continued.

Permian formations-Continued. Cutler formation-Continued.

Halgaito member.

Contact of Halgaito and Cedar Mesa members.

Cedar Mesa sandstone member..... Contact of Cedar Mesa and Organ Rock members.

Organ Rock member................

De Chelly sandstone and Hoskinnini members

Permisn-Triassic erosion interval

Triassic formations

Regional relations................. 47

Moenkopi formation (Lower Triassic) _. . . . . 47

Moenkopi-Shinarump erosion interval........ 48

Shinarump conglomerate $\ldots$

Chinle formation . . . .

Chinle-Wingate contact. ....... 50

Jurassic formations. . . .

General features......... 50

Correlation . . .

Major divisions of the Jurassic . . _........ 53

Glen Canyon group (Jurassic?)

Wingate sandstone....... 54

Kayenta formation $\ldots . . .64$

Navajo sandstone.............

San Rafael group (Upper Jurassic) $\ldots \ldots \ldots$

Distribution........... 56

Carmel (?) formation.......

Entrada sandstone

Summerville (?) formation _.......... 57

Morrison formation (Upper Jurassic) _........ 58

General features $\ldots . . .58$

Bluff sandstone member.

Recapture shale member....... 58

Westwater Canyon sandstone member.... $\quad 59$.

Brushy Basin shale member.... 59

Morrison-Dakota (?) contact........ 60 .

Cretaceous formations ......................... 60 .

Distribution and topographic expression ..... 60 .

Dakota (?) sandstone................... 61 .

Lithologic features...... 61

Stratigraphy and correlation

Mancos shale..... 62 .

Tertiary formations. 63 ;

Quaternary formations. . . 63 .

Stratigraphic sections

Chapter 3. Igneous rocks

Regional relations.... 79 .

Bell Butte dike....... 79 :

Petrography of the Abajo Mountains, by Malcolm R.

Thorpe.... 80 ,

Typical rock..... 80 .

Hornblende andesite from Twin Peaks....... $\quad 80$

Dacite from North Peak........... 81 
Chapter 3. Igneous rocks-Continued.

Petrography of the Abajo Mountains-Continued.

Dacite from Abajo Peak......................

Dacite from Horsehead Peak..............

. Andesite from Mount Linnaeus....

Dacite from Johnson Creek Basin .............

Andesite from South Peak. .

Contact rock from North Creek

Rhyolite from Horsehead Peak . . . . . .

Volcanic breccia at Gold Queen mine........

Andesite (?) from dike in North Canyon.-.....

Trachyte from dike in North Canyon........

Rhyolite from dike in North Canyon.........-

Hornstone in North Canyon. . . . . . .

Dacite dike on Abajo Peak

Andesite dike on Abajo Peak ............

Gold ore from Recapture Creek .........

Andesite from Innis mine. . . . . . . . . . . .

Metamorphic rock from Duckett mine.........

Greenstone from Dream mine..............

Low-grade ore from Dream mine. . . . . . . . . . .

Chapter 4. Structure

Regional relations.....

Sage Plain downwarp

Monument upwarp.

Comb monocline........

Raplee anticline

Mexican Hat syncline . . . . . . . . . . . . .

Mitten Butte anticline.

Oljeto syncline......

Organ Rock anticline............

Balanced Rock anticline..................

Other folds

Faults

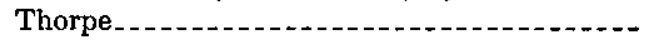

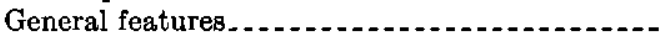

Local features.

Chapter 5. Physiography ..........

Regional relations............

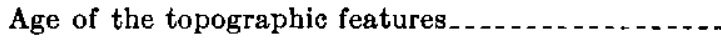

Factors that influence erosion

Climate and run-off

\begin{tabular}{l|} 
Page \\
\\
81 \\
81 \\
81 \\
81 \\
81 \\
82 \\
82 \\
82 \\
82 \\
82 \\
83 \\
83 \\
83 \\
83 \\
83 \\
84 \\
84 \\
84 \\
84 \\
85 \\
85 \\
85 \\
85 \\
86 \\
86 \\
86 \\
86 \\
88 \\
88 \\
88 \\
88 \\
89 \\
89 \\
89 \\
90 \\
92 \\
92 \\
94 \\
94 \\
94
\end{tabular}

Chapter 5. Physiography--Continued.

Factors that influence erosion-Continued.

Stream gradients

Vegetation.......... 95

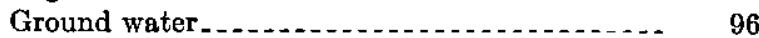

Relation of topography to geology $\ldots \ldots \ldots$

Relation of streams to structure.......... 96

Form of valleys.... 97

Rate of denudation...... 98

Physiographic features . . . . . . . . . . . . . . . . 99

General relations.

Erosion surfaces . . . . . . . . . . . . . . . 100

Gravel-floored terraces. . . . . . . . . . . . . . 100

Canyon fill........................... 101

Alluvial terraces. . . .

Landslides $\ldots \ldots$

White Canyon bridges.................... 103

Arches and windows . . . .

Rock shelters . . .

Sand dunes....... 106

Chapter 6. Economic geology ............ 107

Copper.

Distribution and origin ................ 107

Copper Queen mine................... 107

Dolly Varden and Blue Dike mines....... 107

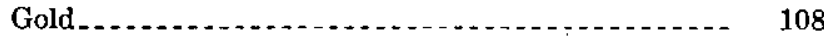

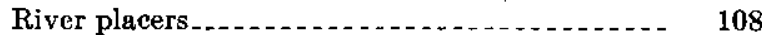

Gold in the Abajo Mountains . . . . . . . 108

Coal

Oil

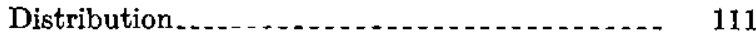

San Juan oil field, by H. D. Miser.

Oil seeps............................ 111

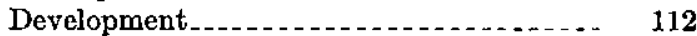

Difficulties of exploration............ 113

Surface water occurrence of oil

Water for stock

Irrigation....................

Ground water

Springs

Wells

lndex ................ 119

\section{ILLUSTRATIONS}

Plate 1. Reconnaissance geologic map and generalized sections of the San Juan country, southeastern Utah.

2. A, Abajo Mountains from western edge of Sage Plain; $B$, Lake on flank of Abajo Mountains between Johnson and Recapture Creeks; $C$, San Juan River 1 mile below mouth of McElmo Creek

3. $A$, San Juan Canyon obove Honaker trail; $B$, San Juan Canyon 6 miles below Spencer Camp; $C$, View looking south across San Juan River at Bluff.

4. $A$, Bears Ears, on south edge of Elk Plateau; $B$, Mexican Hat; $C$, Lime Creek Valley showing erosion surface and vegetation.
Page
Puate 5. $A$, Cataract Canyon; $B$, View looking northwest from head of Armstrong Canyon.-..--

6. A, White Canyon between Rock Springs and Soldiers Crossing; $B$, Clay Hills; $C$, Entrance to Moki Canyon at Red Cone Spring; $D$, Castle Butte on divide between White Canyon and Red Canyon .................

7. Glen Canyon: $A$, View looking upstream at junction of Colorado and San Juan Rivers; $B$, View looking southwest across the canyon at Hite; $C$, View looking downstream at mouth of Moki Canyon....................

8. A, Ruins of cliff house, Hovenweep National Monument; $B$, Ruins of Cliff Dwellers' house, Butler Wash; $C$, Cliff house in White Can-

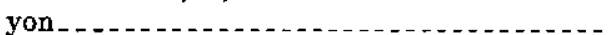

Page 
Plate 9. $A$, Navajo summer house near mouth of Butler Wash; $B$, Red House Cliffs, 4 miles north of San Juan River; $C$, Wall of Johns Canyon near its head; $D$, Sandstone and shale in Armstrong Canyon

10. Columnar sections: $A$, Kaiparowits region; $B$, San Juan country; $C$, Southwestern Colorado.

11. A, View in Johns Canyon near its junction with San Juan Canyon; $B$, Wall of Road Canyon; $C$, Wall of Arch Canyon near its head. .....

12. $A$, Cliff near Star Springs, White Canyon; $B$, East entrance to Clay Hills Pass; $C$, View on Rasp trail; $D$, Variegated marls at Clay Hills ......................................

13. $A$, Divide between White Canyon and Red Canyon; $B$, Wall of Castle Wash; $C$, Dry Creek, Allen Canyon country; $D$, West face of Black Mesa.......................

14. $A$, View near mouth of Cottonwood Wash; $B$, Goblet of Venus; $C$, Brushy Basin......

15. Correlation chart showing relations of the Jurassic formations of the San Juan country to those in adjoining regions. ..........

16. $A$, View on Recapture Creek; $B$, Comb Wash at mouth of Arch Canyon; $C$, Eastern flank of Monument upwarp on Blanding-Kigalia road; $D$, West flank of Raplee anticline at Mexican Hat.

17. Geologic and topographic map and sections of the Abajo area, San Juan County, Utah....

18. $A$, Valley of Butler Creek; $B$, Talus slope on igneous rock in Abajo Mountains; $C$, Bal-

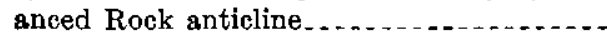

Page

Plate 19. $A$, Comb Wash; $B$, Owachomo Natural Bridge in wall of Armstrong Canyon.......

20. $A$, Valley fill of sand and clay exposed by recent erosion in Comb Wash; $B$, Sipapu Natural Bridge, White Canyon......................

21. Kachina Natural Bridge, White Canyon.....

22. Diagrams showing formation of natural bridges: $A$, Sipapu Natural Bridge; $B$, Kachina Natural Bridge

23. $A$, Fishmouth Cave; $B$, View across White Canyon at Sipapu Natural Bridge; $C$, Cathedral Arch, Arch Canyon...............

24. Natural arches in Arch Canyon: $A$, Cathedral Arch; $B$, Keystone Arch

Figure 1. Diagram showing seasonal and annual distribution of rainfall

2. Structure map of Elk Ridge

3. Erosion surfaces on tilted beds: $A$, Near mouth of Comb Wash; $B$, Along the Causeway between Elk Ridge and the Abajo Mountrins_

4. Rock shelters: $A$, At contact of Dakota (?) and Morrison in Cottonwood Canyon; $B$, In thin-bedded Cedar Mesa strata at Cigarette
Page

106

106

106

106

106

106

106

107

17

87

100 



\title{
THE SAN JUAN COUNTRY
}

\author{
A GEOGRAPHIC AND GEOLOGIC RECONNAISSANCE OF SOUTHEASTERN UTAH
}

By Herbert E. Gregory

\begin{abstract}
The San Juan country includes an area of about 3,800 square miles east of the Colorado River in San Juan County, southeastern Utah. This paper is based on reconnaissance geographic and geologic surveys made in $1910,1915,1925$, and 1927-29. The region described comprises 12 districts characterized by differences in topography, soil, vegetation, water supply, and other factors that affect human activities. It is a semiarid country in which the small population is grouped about the base of the Abajo Mountains and on the San Juan River, where water is available for irrigation. Stock ranching is the chief industry. Exploitation of the mineral resources has proved unprofitable. Of the sedimentary rock formations the oldest exposed is the Hermosa, of Pennsylvanian age. Above it lie the Rico and Cutler formations, of Permian age; the Moenkopi, Shinarump, and Chinle formations, of Triassic age; the Wingate sandstone, Kayenta formation, and Navajo sandstone, tentatively assigned to the Jurassic; the Carmel (?) formation, Entrada sandstone, and Summerville (?) formation, of Jurassic age; the Morrison formation, of Upper Jurassic age; and the Dakota (?) sandstone and Mancos shale, of Upper Cretaceous age.

The igneous rocks include granites and granite gneiss, found at the bottoms of deep wells; augite minette, in a single dike; and hornblende latite, exposed in the laccolithic Abajo Mountains.

The sedimentary beds have been folded into low anticlines and shallow synclines that have a general north-south trend and plunge steeply eastward. The anticlines and synclines affect all the rocks exposed and probably date from a pre-Tertiary period. In the Abajo Mountains the beds are steeply upturned as the result of intrusion that took place probably in early Tertiary time. Here and there the beds are broken by faults of small length and displacement.

The physiographic history is in general that of the Colorado Plateaus, of which the San Juan country is a part. Two cycles of erosion are outlined, the later one divided into epicycles. Conspicuous erosion features are the natural bridges in White Canyon, the dissected Comb anticline, and the deep, verticalwalled canyons within which enormous accumulations of gravel are in process of vigorous removal.
\end{abstract}

\section{INTRODUCTION}

\section{SCOPE AND PURPOSE}

The surveys of Sitgreaves (1851-52), Whipple (1853-54), and Ives (1857-58) in north-central and western Arizona, of McComb (1859) and Hayden (1874-76) in southwestern Colorado and extreme eastern Utah, of Frémont (1842-44), Gunnison (1853), and King (1868-79) in central Utah, and of Powell (1872-75) and Wheeler (1869-79) in southern Utah and northern Arizona resulted in the delineation of the salient features of the Colorado Plateau province.
The reports of these explorers faithfully outline the geography and geology of Arizona west of Echo Cliffs and of Utah west of the Paria River, north and west of the Kaiparowits Plateau in the immediate vicinity of Glen and Cataract Canyons, and along the UtahColorado boundary. The desire for information regarding the unmapped part of the plateau province, in particular the regions north, south, and east of Glen Canyon, led to the formulation of plans for reconnaissance surveys of northeastern Arizona and southeastern Utah. The purpose in view was twofold-(1) to describe the topography, climate, soil, vegetation, and water supply as a guide in the development of vast areas of unallotted lands bordering Glen Canyon; (2) to map and interpret the geologic formations in at least sufficient detail to serve as a basis for comparative regional studies in stratigraphy, physiography, and structure.

In carrying out these plans studies were made of the Navajo country during the field seasons 1909-11 and 1913 and of the Kaiparowits region in 1915, 1918, 1922 , and 1924. The present report gives the results of a continuation of these studies, made with the same scope and purpose. It is based on field work done in 1909-10 and 1915, in connection with previous studies, and in $1925,1927,1928$, and 1929 , with specific reference to the San Juan country. In 1915 a 2 weeks' preliminary survey was made of White Canyon and Elk Ridge in association with Dr. Malcolm R. Thorpe, who remained in the field to map in detail the geology of the Abajo Mountains. Field work of 1925 included studies of the canyons heading in Elk Ridge, of upper Red Canyon, and of Castle Wash west of the Clay Hill Divide. In 1927 the region including Butler Wash, Comb Wash, and middle Grand Gulch was studied, and the traverses made in 1925 were extended from Castle Wash to the junction of the San Juan and Colorado Rivers, along Moki Canyon, Cedar Canyon, lower Red Canyon, and Glen Canyon, to connect with the traverse of White Canyon made in 1915. Routes of travel were chosen with a view to gaining information regarding the large area between Comb Wash and Glen Canyon that had not been visited by scientific parties, thus providing material for a comparison of the structural and stratigraphic features of the Kaiparowits region and upper Glen 
Canyon with those along the San Juan River examined in 1909. During short field seasons in 1928 and 1929 the geologic features of the San Juan Valley and of the canyons northwest of Elk Ridge received chief attention.

The field work was necessarily a reconnaissance, supplemented here and there with more complete geographic and stratigraphic studies. Within the time available detailed investigation was impossible, because of the large size of the area, the diversity of the topographic features, the scarcity of water and forage, and the necessary search for feasible routes of travel. Moreover, except for the borders of the area and the top of Elk Ridge, the existing maps are as misleading as helpful, and the information available from "old timers" relates chiefly to the region east of Comb Wash and the strips of country bordering wellmarked trails from Elk Ridge down White Canyon and Castle Wash. In a scientific sense most of the field traverses of 1915, 1925, and 1927 were pioneer undertakings.

\section{PREVIOUS EXPLORATION}

On his memorable journey from Santa Fe through Colorado, Utah, Nevada, and California in 1776, Escalante followed an Indian trail that before his time had been traversed in part by Fray Alonzo de Posada and by Don Juan María de Rivera, who reached the Colorado near Moab in 1761. From descriptions in Escalante's diary, the route may be traced with considerable accuracy. At his crossing of the Green River near Jensen, the cottonwood trees that sheltered his party still stand. Among his guides was Múñiz, a member of Rivera's expedition, who may have passed on from Rivera the names used in the diary-La Plata Mountains, Sierra Abajo, Datil Mountains (Monument Valley?), La Sal Mountains, and San Xavier (Grand, Colorado) River.

In 1859 an expedition in charge of Capt. J. N. Macomb, Topographic Engineers, U. S. A., crossed Sage Plain, passed the east base of the Abajo Mountains, and descended "Cañon Colorado" (Indian Creek) to its junction with the Grand (Colorado). The homeward route was down "Rito de la S. Abajo" (Recapture Creek or Montezuma Creek) and up the San Juan to Canyon Largo. The descriptions given by Macomb and by Newberry, ${ }^{1}$ geologist of the expedition, supplemented by colored reproductions of sketches made in the field, portray for the first time the outstanding geographic features of southeastern Utah.

In connection with the work of the Hayden Survey, Jackson ${ }^{2}$ made an exploratory traverse that included the San Juan Valley to the mouth of "DeChelly Creek"

\footnotetext{
1 Newberry, J. S., Geological report, in Report of the exploring expedition from Santa Fe, N. Mex., to the Junction of the Grand and Green Rivers of the great Colorado of the West in 1859, pp. 83-109, 1876.

Jackson, W. H., Ruing of southwestern Colorsdo and adjacent territory: U. S. Geol. and Geog. Survey Terr. 10th Ann. Rept., pp. 411-430, 1878.
}

(Chinle Creek), "Epsom Creek" (Comb Wash), and the south base of the Abajo Mountains, and Holmes ${ }^{3}$ made a reconnaissance of northern Sage Plain and the Abajo Mountains. Interesting geographic, archeologic, and geologic features in Utah are shown on the map of Colorado issued by Hayden in 1878. The map retains "Sierra Abajo" and "Sage Plain" as used by Macomb (1859) and for the first time applies the terms "McElmo", "Montezuma", "Recapture", and "Macombs" (now Cottonwood) to tributaries of the San Juan.

The topographic features of all southeastern Utah are depicted in generalized fashion on the Abajo and Henry Mountains reconnaissance maps of the United States Geological Survey, made by P. Holman in 1884. On these maps the new names applied are "Cottonwood Wash" (for Macombs Creek of Hayden), "Butler Wash", "Comb Wash", "Elk Ridge" (Bears Ears Plateau of Holmes), and "Clay Hill Divide."

The first known exploration of the San Juan canyons was made by E. L. Goodridge, an oil prospector who, in 1882 , descended the river in a boat from Bluff to Lees Ferry, investigating on the way the "oil seeps" reported by the Piutes as issuing from "white rock" between the mouths of tributaries now mapped as Lime Creek and Slickhorn Gulch. Reports of gold in gravel bars along the river gave rise to much detailed exploration of the San Juan Canyon during and after the "Bluff excitement" of 1892. During 1893 and 1894 Bert Loper explored the river by boat between Chinle Creek and Nokai Creek, and in 1894 and 1895 Walter E. Mendenhall, a gold prospector, made two trips down the San Juan from "Mendenhall Cabin", about 3 miles below the Goodridge bridge. Some detailed explorations of the San Juan Valley were made in 1909 by Gregory and by Woodruff, but not until 1921---39 years after its first traverse-were adequate maps and descriptions of the river from Comb Wash to its mouth provided. In that year a party of the United States Geological Survey in charge of $\mathrm{K}$. W. Trimble spent 3 months in a detailed study of 140 miles of its interesting canyon.

\section{RELATED INVESTIGATIONS}

In part contemporaneous with these reconnaissance surveys, studies of other kinds have added much to the geographic and geologic knowledge of the eastern part of the Colorado Plateau province. In 1921 the Colorado River and its main eastern tributary, the San Juan, were surveyed in detail by field parties under the general direction of E. C. La Rue ${ }^{4}$ to ascertain "the facts regarding available water supply and all known dam sites." The resulting maps and geographic descriptions gave for the first time an adequate description of the alinement and gradient of these rivers and of the

- Holmes, W. H., Report on the geology of the Sierrs Abajo and West San Miguel Mountains: U. S. Geol. and Geog. Survey Terr. 10th Ann. Rept., pp. 187-195, 1878.

1 La Rue, E. C., Water power and flood control of Colorado Rirer below Green River, Utah: U. S. Geol. Survey Water-Supply Paper 556, 1925. 
topography of their canyons. The geologists associated with these river surveys studied the structure, stratigraphy, and physiography of areas theretofore unknown and amplified the records made by previous investigators. During the course of their field work "the geology of the canyons of Colorado and San Juan Rivers and of the lower parts of tributary canyons was examined continuously, and reconnaissance work was done in the country back from the rivers." Among the resulting publications a paper by Longwell and others ${ }^{5}$ deals chiefly with regional stratigraphy, and papers by Miser ${ }^{6}$ afford a comprehensive geograplic and geologic study of the San Juan Canyon.

To determine the mineral value of public lands a third type of Government survey has been in progress. In these studies chief attention has been appropriately given to plane-table mapping, stratigraphy, and structure. Among the projects in central and eastern Utah that have involved detailed areal work by many geologists have been studies of the coal resources of the Wasatch Plateau by Spieker ${ }^{7}$ and of the Book Cliffs by Clark ${ }^{8}$ and Fisher. ${ }^{9}$ The oil possibilities of the Moab district and of the part of Utah south of the San Juan River have been described by Baker, ${ }^{10}$ of the San Rafael Swell by Gilluly, ${ }^{11}$ of the Circle Cliffs by Moore, ${ }^{12}$ and of the Green River district by Baker. ${ }^{13}$ Special stratigraphic studies made during the course of the economic surveys have been described by Gilluly and Reeside ${ }^{14}$ and by Baker and his field associates. ${ }^{15}$

Insofar as they bear on the interpretation of the geology of the San Juan country the papers resulting from the Colorado River survey and the wider-range economic surveys have been incorporated in this report. The results of the work by Cross and Howe, ${ }^{16}$ Coffin, ${ }^{17}$ Baker and Reeside, ${ }^{18}$ Butler, ${ }^{19}$ and Thorpe ${ }^{20}$ have also been utilized.

\footnotetext{
s Longwell, C. R., Miser, H. D., Moore, R. C., Bryan, Kirk, and Paige, Sidney, Rock formations in the Colorado Plateau of southeastern Utah and nortbern Arizona: U. S. Geol. Survey Prot. Paper 132, pp. 1-23, 1925.

- Miser, H. D. The 8an Juan Canyon, southeastern Utah: U. S. Geol. Survey Water-Supply Paper 538, 1924; Geologic structure of San Juan Canyon and adjacent country, Utah: U. 8. Geol. Survey Bull. 751, pp. 115-155, 1925; Erosion in San Juan Canyon, Utah: Geol. Soc. America Bull., vol. 36, pp. 365-378, 1925.

i Spieker, E. M., The Wasatch Plateau cosl feld, Utah: U. S. Geol. Survey Bull. 819,1931 .

B Clark, F. R., Economle geology of the Castlegate, Wellington, and sunnyside quadrangles, Carbon County, Utah: U. 8. Geol. Survey Bull. 793, 1928.

- Fisher, D. J., The Book Cliffs cosl field in Emery and Grand Counties, Utah: U. S. Geol. Survey Bull. 852, 1936.

10 Baker, A. A., Geology and oil possibilities of the Mosb district, Grand and San Juan Counties, Utah: U. S. Geol. Surrex Bull. 841, 1933; Geology of the Monument Valley-Navajo Mountsin region, San Juan County, Utah: U. S. Geol. Survey Bull. $865,1936$.

"Gilluly, James, Geology and oil and gas prospects of part of the San Rafael Swell, Utah: U. B. Geol. Survey Bull. 806, pp. 69-130, 1929.

${ }^{12}$ Gregory, H. E., and Moore, R. C., The Kaiparowits region, a geographic and geologic reconnaissance of parts of Utah and Arizona: U. S. Geol. Survey Prof. Paper 164, pp. 154-157, 1931.

13 Baker, A. A., Preliminary map showing geologic structure of parts of Emery, Wayne, and Garfleld Counties, Utah, U. S. Geol. Survey, 1933.

"Gilluly, James, and Reeside, J. B., Jr., Sedimentary rocks of the San Hafael Swell and some adjacent areas in eastern Utah: U. S. Geol. Survey Prol. Paper I50, pp. 61-110, 1928.

13 Baker, A. A., Dobbin, C. E., McKnight, E. T., and Reeside, J. B., Jr., Notes on the stratigraphy of the Moab region, Utah: Am. Assoc. Petroleum Geologists Bull., vol. 11, pp. 785-808, 1927.

$145824-38-2$
}

\section{ACKNOWLEDGMENTS}

It is a pleasure to acknowledge the cooperation given by officials of the Forest Service, the Indian Bureau, and the General Land Office, both in Washington and in the field, and the assistance of the stockmen who make their homes in Monticello, Blanding, and Bluff. In laying out preliminary routes of travel and selecting the season for visiting various localities, the knowledge and assistance of friendly "old timers" was invaluable. The interest taken in the field work by such men as Parley Redd, Jacob Adams, John Adams, Cory Perkins, Marion Hunt, H. E. Blake, E. Z. Black, and A. L. Raplee made it possible to procure camp assistants and supplies at reasonable cost and with little loss of time. The resourcefulness and cheerful acceptance of hardships by John Wetherill, Joseph Adams, Zeke "Junior" Johnson, and Lloyd Young, who served as guides in a region much of which they had not previously traversed, are recalled with pleasure.

To R. C. Coffin, chief geologist of the Midwest Oil Co., I am indebted for a structure map of Elk Ridge and for geologic information that facilitated field work in areas imnediately adjoining Colorado.

The value of my investigation has been enhanced by conference with A. A. Baker and E. 'T'. McKnight at Elk Ridge and at localities north of the Abajo Mountains and by discussions of terminology and regional correlation during traverses along the San Juan River and southward in company with A. A. Baker, James Gilluly, and John B. Reeside, Jr.

\section{SUGGESTIONS TO TRAVELERS}

Southeastern Utah seems destined to have many visitors who are attracted by the scenery of a region remote from main lines of travel. In anticipation of lucrative tourist travel the highway from northern Utah and western Colorado through Moab, Monticello, and Blanding to Bluff is in process of much improvement, and plans have been made for reconstructing the road from Bluff across the San Juan at Goodridge and south through the Navajo country to join the transcontinental highway that parallels the Atchison, Topeka \& Santa Fe Railway. When this route is made suitable for automobiles, it will have few rivals as a scenic highway. A good road leads from Monticello to the Indian reservation at Allen Canyon and, except during the winter, is passable as far west as the Natural Bridges, in White Canyon. Most of the San Juan

${ }^{16}$ Crosse, Whitman, and Howe, Ernest, Red beds of southwestern Colorado and their correlation: Geol. Soc. America Bull., vol. 16, pp. 447-498, 1905.

17 Coffin, R. C., Radium, uranium, and vanadium deposits of southwestern Colorado: Colorado Geol. Survey Bull. 16, 1921.

18 Baker, A. A., and Reeside, J. B., Jr., Correlation of the Permlan of southern Utah, northern Arizona, northwestern New Mexico, and southwestern Colorado: Am. Assoc. Petroleum Geologists Buil., vol. 13, pp. 1431-1448, 1929.

16 Butler, B. S., Loughlin, G. F., Heikes, V. C., and others, Ore deposits of Utah: U. S. Geol. Survey Prof. Paper 111, 1920.

20 Thorpe, M. R., Structural features of the Abajo Mountains, Utah: Am. Jour. Sci., 4th ser., vol. 48 , pp. 379-389, 1919. 
country, however, like the Kaiparowits region to the west and the Navajo country to the south, is as yet inaccessible to automobiles; and few places off the main highway can be reached by wagons. For a distance of 140 miles but one bridge crosses the San Juan. There are no bridges or ferries across the Colorado in this region, and the only rowboats are the makeshift-affairs of prospectors, constructed from time to time as needed. The region is distinctly a "foot and horseback country": most of it is accessible only by pack train. Even with a pack train, traverses west of Elk Ridge and Grand Gulch should not be undertaken without careful preparation. Horses accustomed to rough country can make their way up steep slopes, across deep canyons, over bare rock, and through piles of drifting sand and under skilful guidance can reach seemingly inaccessible spots. But forage is nearly everywhere insufficient for horses that have only the night in which to search for food; for pack trains grain must be carried. Here, as in other semiarid regions, the recognized routes are streamways or trails that lead across uplands from one spring to another. "Off the trail" is away from water. The greatest difficulty is presented by the inconvenient spacing of water supplies. Immediately after rains water is plentiful in rock pockets and in ephemeral streams; at other times the valley flats and mesas are almost bare of water holes, and supplies are obtainable only in the bottoms of canyons, which are very difficult to reach. At any time of year it is possible, by making long daily rides, to obtain water on the old Mormon trail to the Hole in the Rock and along the poorly marked trails across Red Rock Plateau or down White Canyon. Trips to the Sipapu Natural Bridge, to points about Elk Ridge and the Abajo Mountains, and to the cliff ruins in Montezuma Canyon and Grand Gulch present few difficulties, and with experienced guides the exceptionally interesting trail through the Clay Hills, Castle Wash, Wilson Mesa, and across the San Juan to Navajo Mountain, and the trail down White Canyon across the Colorado, through the Henry Mountains and the Kaiparowits region to Escalante, are feasible for adventurers who place unusual experiences above daily comforts. Except under the direction of men acquainted with the topography of the plateau province and experienced in finding water holes, tourists are advised to limit their travels to areas reached by automobile or by frequently used trails. In diversity, beauty, and grandeur the scenery thus reached is fortunately a counterpart of the scenery viewed by the scientific explorer whose routine duties lead him to places difficult of access. 


\section{Chapter 1. GEOGRAPHY}

\section{LOCATION, EXTENT, AND ACCESSIBILITY}

As defined in this paper the San Juan country lies between the San Juan River and the north base of the Abajo Mountains and extends from the Colorado line westward to Glen Canyon. (See pl. 1.) It is the part of San Juan County, Utah, that in records of the Mormon Church, in popular literature, and in generalized scientific writings has long been known as the San Juan country, as a ready means of distinguishing it from the Dry Valley district, the Indian Creek country, and the La Sal country, in northern San Juan County, and from the Utah strip and the Navajo country, south of the San Juan River. The average distance across the region in an east-west direction is about 85 miles, in a north-south direction about 45 miles; the area is therefore approximately 3,800 square miles. The commercial center of the area is Blanding, midway between the county seat, Monticello, and the pioneer settlement of Bluff. For the convenience of farmers, post offices are maintained at Lockerby and Urado. At Goodridge (Mexican Hat), 25 miles west of Bluff, a store is intermittently operated, mainly for trade with Navajos who live south of the San Juan River. Trading posts are maintained also at Aneth and in Montezuma Canyon.

Of the routes to the San Juan country the original Hole in the Rock road used by the missionary party in 1879-80 was abandoned the year it was made, and its place was taken by one that crossed Glen Canyon on a ferry at the mouth of Halls Creek and joined the old road in Lake Canyon. This road in turn was soon superseded by one that crossed the Colorado at Dandy Crossing (Hite) and led up White Canyon, across the head of Grand Gulch, and down Comb Wash. For some years a traverse of this route was the only means of bringing the people of central Utah into touch with their friends in far-away Bluff. Soon after the settlements on the San Juan River were made, a trail over which wagons might be taken was constructed from Bluff to Moab and thence to Salt Lake City, but for many years the chief trade route ran along the San Juan River and McElmo Creek from Bluff to Mancos and on to Albuquerque. To reach the ranches east of Elk Ridge a wagon road was constructed across Bluff Bench to the floor of Cottonwood Canyon. After Monticello was established (1886) the Bluff-MoabThompson road was improved and later relocated to include Blanding. During the development of the San Juan "oil field" a road was constructed from Bluff across Comb Ridge and Comb Wash, up Snake Canyon, and down Lime Creek, and a makeshift bridge was built across the San Juan at Goodridge (1910?). In 1926-27 the old road from Blanding through the Indian settlement at Allen Canyon to Elk Ridge was made suitable for automobiles. In 1928 it was extended to the Natural Bridges, in White Canyon. At present (1934) the main artery of travel, the only "good road", runs from Bluff through Blanding, Verdure, Monticello, and Moab to the railroad at Thompson (140 miles), with a branch from Monticello east to Dolores and Cortez (65 miles). Automobiles can be driven from Bluff westward through Goodridge and the Navajo Reservation to Flagstaff (200 miles); from a junction with the Bluff-Blanding road across Recapture Canyon, McCracken Mesa, and Montezuma Canyon to McElmo and Cortez; to some of the farms on Sage Plain, and to Aneth by way of Cortez. Points along the San Juan River above Bluff and below Goodridge, along the Colorado River, and about the Abajo Mountains are accessible only on horseback. A few trails are kept open by cattlemen, and in many places topography marks out feasible routes for pack trains, but for most of southeastern Utah travel consists of rough scrambles in and out of canyons at places that seem at the time most favorable.

\section{NOTE ON THE MAP}

The existing maps of the San Juan country inadequately picture the geographic features; those based on detailed surveys cover but a small part of the region. The General Land Office has mapped the Natural Bridges National Monument, the "oil fields" of Lime Creek Valley, and most of the area between Cottonwood Canyon and the Colorado State line. Maps showing township lines and drainage on and about Elk Ridge have been made by the Forest Service. Accurate maps are available for the San Juan canyons below Bluff and for the entire Colorado River. The Abajo and Henry Mountain reconnaissance topographic maps, made by $\mathrm{P}$. Holman in 1884 and published by the United States Geological Survey, include the San Juan country. They show the mountains, the larger ridges and valleys, and such features as could be seen from selected viewpoints on Elk Ridge and on highlands along the San Juan River. Unfortunately, in this region of deep meandering canyons and interlacing ridges and plateaus, the trend of many drainage lines, the position and size of tributaries, and the distinction between mesa face and canyon wall cannot be determined in distant views. The 1884 maps are therefore of little practical use. 
THE SAN JUAN COUNTRY, SOUTHEASTERN UTAH

On the base map constructed for this report (pl. 1) the features of Sage Plain, of the San Juan canyons, of the Colorado canyons, and of the eastern edge of Grand Gulch Plateau are reproduced from modern surveys. West of Comb Wash and Elk Ridge the map is a record of field traverses checked here and there by instrumental measurements. The names on the map include those on older maps and those locelly in common use. To facilitate description of geographic districts and prominent topographic features, new names have been added. When maps become available on which to represent them, many more interesting features in this little-known region can appropriately be named.

\section{TOPOGRAPHIC OUTLINE}

The San Juan country is part of the Colorado Plateau province; its larger topographic features are duplicated in the Navajo country, to the south, and in the Kaiparowits region, to the west. Throughout most of the region the rocks are flat-lying or slightly tilted and are cut into great sections by steep-walled, deep canyons. East of Comb Wash and the prominent Comb Ridge the topographic pattern is simple; the surface is formed of a single stratum of sandstone into which are sunk canyon trenches of uniform pattern and above which rise a few inconspicuous mounds. West of Comb Wash the landscape is much varied. The flat dome of Grand Gulch Plateau is bordered on the west by the Red House Cliffs, a precipitous terraced sandstone wall that marks the beginning of deep, steepsided, meandering gorges tributary to Glen Canyon. Elk Ridge is a mesa capped by a stratum of resistant sandstone that terminates abruptly at the box head of small canyons. The historic landmarks-the Bears Ears-are two of the many buttes that project above its general surface. The lofty Abajo Mountains consist of a laccolithic mass that reproduces the topographic features of the Henry and La Sal Mountains.

About 50 percent of the San Juan country lies between 6,000 and 7,000 feet above sea level. The areas below 5,000 feet are the benchlands and stream valleys along the San Juan and Colorado Rivers, and those below 4,000 feet are narrow strips within the canyons of these master streams. Elk Ridge stands 8,000 feet above sea level, and the Abajo Mountains are still higher. The extremes of regional relief are Abajo Peak, 11,445 feet, and the mouth of the San Juan, 3,286 feet. The general surface slopes of the area are southward to the San Juan and westward to the Colorado.

Except for a few small meadows and tiny highland ponds the region is thoroughly drained by well-defined channels. Streams entering the San Juan carry the run-off from about two-thirds of the area in canyons, some of which, especially at their mouths, broaden into washes. Streams entering the Colorado directly carry the remaining drainage in channels that retain their canyon form throughout. Only the San Juan and the Colorado are through-flowing. Twice in the last half century even the San Juan ceased to flow below Aneth. Many of the streams are perennial at their heads and at favorable places along their courses; many others flow only in direct response to rainfall. During most of the year the stream channels, except at their heads, are dry beds of sand, boulders, or bare rock; yet the coarse detritus and the driftwood perched on the valley sides testify to the strength of the occasional floods.

Erosion is vigorously active. Most streams at their headwaters are keeping their channels clear of normal rock waste and are rapidly removing the materials piled in by landslides; farther down their courses they are digging out and transporting the enormous masses of sand and gravel deposited during a previous physiographic epoch. Talus is piled deep on the slopes of the Abajo Mountains, along White Canyon, and around the south rim of Elk Ridge, and it forms a basal border along the east wall of Comb Wash. Elsewhere it is irregularly present and inconspicuous; many slopes and most canyon walls present bare rock. On interstream areas, particularly along the San Juan River and west of Grand Gulch, erosion has outlined flat domes, huge angular mesas, and circular buttes that rise above the plateau tops. In many places along the canyon walls soft beds underlying hard beds have been removed to form caves with overhanging roofs, and the massive beds of sandstone have been carved into alcoves, fluted columns, natural bridges, and a variety of miniature features picturesque alike in form and in color. There are no large areas of dunes, but most of the region below the 6,000 -foot contour is unevenly coated with wind-blown sand. Outside the high level areas forest vegetation is insufficient to conceal the rocks. The color of canyon walls and plateuu tops is the color of the rock-red, tan, white, replaced here and there by variegated bands miles in length.

\section{GEOGRAPHIC DISTRICTS}

\section{BASIS OF SUBDIVISION}

Though the San Juan country is a division of the extensive Colorado Plateaus, its diversified features are not readily grouped within a single geographic unit. As regards possibility of future utilization, the parts of the area are decidedly unlike, and such problems as water development, forestation, agriculture, and transportation can best be understood with the local conditions in mind. For this reason it seems desirable to divide the region into geographic districts on the basis of topography, vegetation, water supplies, and other features that affect the human population. The 12 districts thus outlined are described on the following pages. (See pl. 1.) 


\section{SAGE PLAIN}

That part of southeastern Utah lying east of Comb Wash, upper Cottonwood Canyon, and the flanks of the Abajo Mountains is essentially a plain, about 1,200 square miles in area, the western half of the flat surface that extends to the Dolores River and the Mesa Verde in Colorado. To this extensive area of flat land, one of the largest in the plateau country, Newberry ${ }^{21}$ gave the name "Sage Plain." $\mathrm{He}$ speaks of it as "an arid expanse", a scene of "dreary monotony", an "orderly and unbroken arrangement of underlying rocks."

From Surouaro [near the Dolores River] to the base of the Sierra Abajo the physical aspects of the country are everywhere the same - a great plain, to the eye as limitless as the sea; the monotonous outline of its surface varied only by two or three small islandlike mountains so distant as scarcely to rise above the horizon line.

Surface profiles drawn in an east-west direction across almost any part of the plain reveal only small departures from horizontality, but north-south profiles show a regional slope of about 2,000 feet in a distance of less than 50 miles, from 7,000 feet above sea level in the region east of Monticello to 5,000 feet near the mouth of Montezuma Creek. Almost any point on Sage Plain affords uninterrupted views of distant features. From the highway between Blanding and Bluff, Lone Cone of the San Miguel Mountains, the wall of the Mesa Verde, and Ute Mountain rise prominently on the sky line 70 miles to the east; and at the base of the Carrizo Mountains Ship Rock appears as a vessel far out at sea. To the south and southwest the bluffs of the San Juan River are in plain sight, and beyond them the towers of Monument Valley and the precipitous walls of Black Mesa, in the center of the Navajo country. Even from the old Indian trail that crosses the northeast corner of Sage Plain the Spanish scouts of early days recognized the Sierra Abajo, Orejos del Oso (Bears Ears), Calabasa Mountains (South Comb Ridge, the Monuments, and Skeleton Mesa?), Lava Negra (Agathla Needle), and even Sierra Panoche (Navajo Mountain), more than 100 miles distant. Though the remarkably even surface of Sage Plain is surmounted only by scattered low mounds of shale, it is deeply dissected by streamways that begin as canyons and continue as canyons all the way to the San Juan. Even the narrow shallow channels in the least dissected parts of the plain are vertical-walled, for the initial trench is cut through a thick bed of resistant sandstone. To cross the center of the plain in an east-west direction is a difficult undertaking; canyons 100 feet to more than 500 feet deep appear without warning and can be crossed only at the few places where the tops of their enclosing walls are broken by crachs or fringed with talus.

11 Newberry, J. S., Geological report, in report of exploring expedition trom Santa $\mathrm{Fe}, \mathrm{N}$. Mex., to the junction of the Green and Grand Rivers of the great Colorado of the West in 1859, p. 89.1878 .
The road from Blanding to the San Juan is on the flat divide between Cottonwood and Recapture Canyons, which at one point is only 30 feet wide. The road from Blanding to Allen Canyon, which replaces the long road up the sandy floor of Cottonwood Wash, crosses four deep canyons and some shallower ones where expensive construction was required; and the highway between Blanding and Monticello, though it crosses only the headwater tributaries of Recapture and Montezuma Creeks, is a series of costly fills and graded slopes. To construct the much desired road from Blanding directly east to railroad points in Colorado would involve crossing no less than 25 canyons, 10 of them within the first 15 miles. Of the highways that now connect Blanding and Bluff with Dolores and Cortez, one follows the circuitous route around the heads of tributaries to the Montezuma, and the other crosses Recapture and Montezuma Canyons at places not far from their mouths, where the floors of the canyons are broad and their rims somewhat broken down. The canyons of Sage Plain are much alike in form. Starting at the top with a formidable "rim rock", the wall descends by steps or talus-covered slopes to a floor of detritus, below which lies the sandy stream bed. The lower third of Butler Wash occupies a rock-floored, $V$-shaped trench, and here and there in other canyons the water flows over bare rock between high narrowly spaced walls. But most of the canyon floors consist of alluvium in which are embedded huge blocks dropped from the walls. Much of it has been reworked by floods and wind.

In places where water is permanent and the soil suitable the canyon bottoms have long been cultivated. In all the larger canyons and in many tributaries, particularly in the Montezuma, are groups of ruins on the floor, on the rim, and on low spurs within the canyon walls. Here and there are remnants of ancient cornfields. Jackson speaks of "a band of Wiminuche Utes" in middle Montezuma Canyon who "have considerable corn planted." Present-day Piutes practjce agriculture in Cottonwood Wash, and some of them return to their old homes in Montezuma and McElmo Canyons, especially in the winter. Most of the efforts of the Mormon pioneers to "farm the washes" have proved unprofitable. At Verdure and a few other places near the Abajo Mountains where streams have permanent flow, grain and alfalfa are profitably grown. Agriculture at Blanding and at Monticello depends on irrigation water drawn from the mountain tributaries of Recapture and Montezuma Creeks.

On the surface of Sage Plain (pl. 2, A) sagebrush is present everywhere, and within the canyons it seems to be dominant. At Verdure, south of Blanding, between Cottonwood and Montezuma Canyons, near Lockerby, and west of McElmo Canyon it constitutes almost pure stands 3 to 5 feet high. On the floors and lower slopes of canyons it grows in places to a height of 8 feet, form- 
THE SAN JUAN COUNTRY, SOUTHEASTERN UTAH

ing almost impenetrable thickets. Piñon and juniper in constant association are likewise widely distributed. As single trees or small groves they occupy canyons and interstream flats. As viewed from Blanding, continuous forests of piñon and juniper extend westward to the Allen Canyon country and eastward to Colorado. These trees supply fuel for homes and for the small gristmills and sawmills. Oak brush, which is conspicuous on the lower slopes of the Abajo Mountains, appears in the canyons of Sage Plain in small, widely separated, dense groves. On the floors of canyons vigorously growing cottonwoods are abundant.

As an agricultural region Sage Plain, though by no means worthless, offers no large promise. On alluvial slopes extending some miles from the Abajo Mountains and on flat lands where disintegrated shale is sufficient in depth the soil is suitable for most crops, but on much of the plain bare rock is exposed or is thinly coated with highly siliceous materials. Scant precipitation and a short growing season prevent the full utilization of favorable soil. Dry farming in this region at an altitude of 5,000 to 7,000 feet and with an annual rainfall of 8 to 18 inches is likely to be profitable only in times of unusually high prices. Agricultural development depends upon the amount of water that can be brought without prohibitive cost from streams on the Abajo Mountains and from wells sunk deep to water-bearing strata. Land at present irrigated is yielding satisfactory returns, and though the produce raised is prevented by transportation costs from competing in the general market, the local demand is supplied at prices far below those charged for materials brought in.

As a grazing country Sage Plain has small and decreasing value. Stock water is sufficient and spaced at convenient intervals, but much of the grass, perennial plants, and brush suitable for forage has been destroyed as the result of overgrazing, especially by sheep. The region serves mainly as winter range when the highland pastures are buried in snow.

\section{ABAJO MOUNTAINS}

The Abajo Mountains rise from Sage Plain with a slope of 500 feet to the mile between the contour lines of 7,000 and 9,000 feet, 1,000 feet to the mile between the contours of 9,000 and 10,000 feet, and then more steeply to eight independent summits (pl. 2, $A$ ). Below 8,000 feet the mountains constitute a single mass about 16 miles long and 10 miles wide, scalloped by radial valleys except on the west, where the flat-topped Elk Ridge abuts against its flanks. Above 9,000 feet and covering an area of 90 square miles are four groups of peaks-a southern group, including South Peak $(11,000+$ feet $)$ and Abajo Peak (11,445 feet); a western group, dominated by Mount Linnaeus $(11,300+$ feet); a northern group, including North Peak (11,350 feet), Horsehead Peak (11,000+ feet), and Twin Peak $(11,000+$ feet); and at the northwest the isolated mesa- like Shay Mountain $(10,000+$ feet). The peaks constituting these groups are much alike in form and structure. Their tops are rounded, some of them nearly flat; their sides slope steeply and evenly and not far from the summit develop into long spurs, which likewise have broad tops and smooth sides. There are no deep, sharply cut canyons, no steep precipices, and no bold masses of naked rock; the features associated with mountain ruggedness are absent. Trails between South Peak and Mount Linnaeus and between Twin Peak and Abajo Peak present no difficulties. Wagons traversing the road from Monticello to the pass between Abajo and Horsehead Peaks have mainly steepness to contend with.

At altitudes of about 9,000 feet the general smooth outlines of the mountains are replaced by a belt of rough country. Here the sandstones of Sage Plain, which formerly covered the mountains, terminate with steeply upturned edges, forming disconnected hogbacks that in places have been broken up into huge blocks. In this zone also are extensive and thick accumulations of talus from the igneous rock above. (See pl. 2, A.)

The Abajo Mountains give rise to many permanent streams that head in swampy meadows high on the slopes or emerge from the talus lower down. Those flowing south and east unite to form the tributaries of Montezuma Creek, Recapture Creek, and Cottonwood Canyon, all draining to the San Juan River. Those rising on the north slopes form Indian Creek and Harts Draw, which enter the Colorado River. Except for the San Juan River, these headwater tributaries constitute the only reliable supply of water adequate for irrigation. In fact, the rills and brooks of the Abajo Mountains are the life of southeastern Utah. Without them the villages of Monticello, Verdure, and Blanding, the ranches about the base of the mountains, and the Indian reservation in the Allen Canyon country could not be maintained.

Except in areas of unstable talus (slide rock), where only lichens and small tufts of alpine grasses grow, the entire mountain mass is clothed with forest or grass. (See pl. 2, $A, B$.) In general, dense forests cover the northern and northwestern slopes and terminate abruptly at the crests of spurs and ridges; grasses cover the southern and eastern slopes. At the heads of the highest valleys and in favorable places down to an altitude of 8,000 feet are groves and individual trees of spruce and balsam fir. Below them is a forest zone in which yellow pine is dominant, then a zone of piñon and juniper merging down-slope with the vegetation characteristic of the Sage Plain. Aspens seem most at home among the yellow pines and the spruces, but groups grow also with the piñons. About the swampy stream heads are willows, maples, and alders, meadow grasses, and a wealth of flowering annuals. Sagebrush reaches up to the 9,000-foot contour line; oak and service berry likewise seem to be distributed with little regard to altitude or soil. 
Vegetation, climate, and scenery combine to make the mountain meadows and groves at altitudes of 8,000 to 9,000 feet delightful camping places. Jackson ${ }^{22}$ writes:

The southern, eastern, and northern flanks of the Sierra Abajo * * * without exception, the most pleasant spot we have touched since leaving La Plata. Clear and cold mountain streams ripple down through ravines overhung by groves of willow, maple, and quaking aspen, with splendid oaks and stately pines scattered over the uplands, and an abundance of rich, nutritious grass everywhere, that our poor, half-starved animals knew well how to appreciate. The blacktail deer and grouse were in goodly numbers, starting up from under our very noses and leading our hunters many a long chase.

The view from the top of Abajo Peak is of unusual interest. The prominent features of the marvelously carved and marvelously colored Colorado Plateaus within a radius of 100 miles are plainly visible. On clear days the sweep of vision is limited eastward only by the San Miguel and La Plata Mountains, southward by Black Mesa, westward by Kaiparowits and Aquarius Plateaus, and northward by the Book Cliffs. In distant views the La Sal Mountains, Henry Mountains, Ute Mountain, and Navajo Mountain, companions of the Abajo Mountains in structure and setting, appear on the horizon as solitary peaks dwarfed in size by the enormous expanse of surrounding flat surface. The general course of the San Juan can be traced and Cataract Canyon and Glen Canyon located with reference to adjoining features. By alining its projecting teeth the Comb monocline can be followed with the eye far.into the Navajo country. Immediately at hand to the west can be seen the forest-covered flat-topped Elk Ridge, from which rise the brilliantly colored Bears Ears and Woodenshoe Buttes and below which toward the southwest is the intricately eroded area at the head of Comb and Butler Washes. Looking south and east the eye follows down the forested slopes of the Abajo Mountains out across the dull-colored, scantily wooded Sage Plain to stretches of bare rock terminating at Carrizo Mountain, south of the San Juan River in Arizona.

As a grazing area and a source for timber, the Abajo Mountains have high value, and it is not difficult to foresee the time when they will become a center of scenic interest. Of all the high isolated mountains affording extensive views of the plateau country this group is the most easily accessible.

\section{SAN JUAN VALLEY}

Throughout its course in Utah the immediate valley of the San Juan River consists of two unlike parts. Between the Colorado boundary and Butler Wash the river occupies a wide flood plain bordered by gravel terraces that form steps in front of low enclosing walls. (See pls. $2, C ; 3, C$.) At Butler Wash the river enters a remarkably meandering canyon and except for short

\footnotetext{
$n$ Jackson, W. H., Report on ancient ruins examined in 1875 and 1877: U. S. Geol. and Geog. Survey Terr. 10th Ann. Rept., p. 426, 1878.
}

stretches at Comb Wash, Goodridge, and Clay Hill Crossing continues to the Colorado between close-set walls 1,000 to 2,500 feet high. (See pl. 3, A, B.) Like the master stream, the mouths of most of its tributaries are set deep in rock gorges. Within the canyon the alluvial materials consist of piles of boulders and gravel and patches of sand deposited and removed in response to floods. Except for tiny fields near Clay Hill Crossing and Comb Wash the arable lands in the San Juan Valley are the strips of flood plain above the mouth of Cottonwood Creek, most of them on the north side of the river.

Stone-built villages under the ruins of the canyon walls and potsherds on gravel terraces point to long occupation by agriculturists of pueblo times, and hogans and wickiups, some of them habitable, others in decay, show intermittent use of these lands by Navajos and Piutes. These flood-plain lands, cultivated by the Indians and by Cliff Dwellers before them, were the lure that brought the Mormon pioneers to southeastern Utah. (See pp. 31-33.)

During the last 20 years great changes have taken place in the San Juan Valley. The destruction of arable land, the result of changes in the river's current and the neglect of irrigation ditches, has reached a stage where barely 200 acres remains; abandoned machinery and huts mark the sites of "placer mines" and "oil fields"; coarse brush and fields of introduced weeds have replaced the grass and flowering shrubs. Because of intermittent floods it has been found impracticable to maintain a road along the river above Bluff. At low stages of water pack trains can go along the banks for most of the distance from Bluff to Aneth and can cross the river at several places; the difficulties encountered are quicksand and precipitous walls rather than depth and strength of current. Below Bluff the river can be reached at few places. Between Bluff and Goodridge the topography forces a long, sinuous detour that leads to a suspension bridge below the mouth of Lime Creekthe only highway crossing in Utah. Below Goodridge the short road on the north side cf the river is high on the canyon rim; that south of the river is far back. At favorable stages of water the lower canyon can be crossed by pack train at the mouth of Copper Creek and at the mouth of Wilson Creek.

\section{ELK RIDGE}

Except for the Abajo Mountains, Elk Ridge is the most conspicuous topographic feature in the San Juan country. It is plainly visible from the Mesa Verde in Colorado, from Monument Valley, Arizona, and from the Henry Mountains, west of the Colorado River. From Blanding it is an impressive sight-a huge flat block from which rise the Bears Ears (pl. 4, $A$ ) and about which winds a crenulated wall, in places brilliantly colored. From Grand Flat its outstanding feature is a series of long, narrow, steep-sided, flat-topped ridges 
that project from the main mass and terminate abruptly like capes on a rugged seacoast. Elk Ridge is a plateau or mesa like the Kaiparowits or Mesa Verde, and the term "Bears Ears Plateau" as applied by Holmes is much more appropriate than the name now in use. It is a forest-covered surface about 20 miles long and 15 miles wide at an altitude of 7,500 to 8,000 feet above sea level and 1,000 to 2,000 feet above its basal slopes. On the east its bordering wall is a series of cliffs alternating with steep slopes; on the south and west the wall is precipitous; on the northwest it is flanked by slopes broken by steps that descend to Cataract Canyon; on the northeast its surrounding wall is interrupted by the Causeway, which connects Elk Ridge with the Abajo Mountains. At first sight the surface seems flat and even, except for the beautifully colored buttes that rise above it. Instrumental measurements show a long, flat dome-in fact, two domes separated by a shallow swale-with a top at 8,400 feet. The culminating feature is the Bears Ears, 9,040 feet.

The plateau is deeply dissected by streams that flow in profound canyons and divide the surface into segments of very irregular outline. The master drainage line is Dark Canyon, whose tributaries extend from the west nearly across the plateau. The head of Dark Canyon has reached and broken down the eastern wall, producing the "Notch", which separates South Elk Ridge from North Elk Ridge and forms the narrow divide between canyons leading to the San Juan and to the Colorado. Near Kigalia ranger station the vertical walls of Kigalia Canyon, tributary to Dark Canyon, are less than 3 miles from the box heads of Hammond Creek and Arch Canyon, draining to the San Juan. Peavine Canyon and Woodenshoe Creek, the longest tributaries of Dark Canyon, head within a few miles of the precipitous south wall of Elk Ridge. Parts of the plateau are poorly drained. Some of the streamways are merely shallow depressions revealed by the presence of water-loving plants. Standing water appears in small swampy areas immediately under the cap rock and in such shallow ponds as Duck Lake on the road to the Bears Ears and the "lake" near Gooseberry ranger station. Several springs and also the headwaters of streams that lead out from the plateau rim are perennial. They supply water of excellent quality sufficient to meet the needs of stockmen.

Forests of yellow pine cover Elk Ridge and extend down the plateau slopes to points where they are replaced by juniper and cedar. With the pines, in detached areas and on the borders of open parks, quaking aspen, oak, scrub maple, and willow are conspicuous. Such shrubs as the service berry, manzanita, sagebrush, and checkerberry and many grasses serve to increase the ground cover within and outside the dense growth of pine. Many of the most attractive flowers common to the plateau province grow in abundance. (See pp. 23-24; pl. 4, A.)
Elk Ridge is part of the south or Monticello division of the La Sal National Forest. In addition to timber for local use it provides forage for several thousand cattle and horses during the months when lands at lower altitudes are without water sufficient for stock.

During the summer Kigalia and Gooseberry ranger stations and some cabins built long ago are intermittently occupied. During the winter the entire plateau surface is deeply covered with snow.

The southern part of Elk Ridge (the "South Elks") was made accessible to the early settlers of San Juan County by the construction of a road from Cottonwood Canyon to the flat lands about the Bears Ears-a road much better adapted to pack trains than to wagons. Through the combined appropriations of the State, the county, and the Forest Service, part of this road was reconstructed and extended to Blanding. In 1926-27 the Midwest Refining Co. constructed an expensive road from the Junction, near Kigalia, through the Notch, down the walls of Kigalia Canyon, and along the floor of Dark Canyon to its deep well in Reservoir Canyon. The "North Elks" can be reached by horse trails from the Blanding-Kigalia road or from trails that pass around and over the Abajo Mountains and across the Causeway; even wagons have been dragged over the trail from the Notch. In 1927-28 the old road from Kigalia to the Bears Ears was reconstructed and extended over the plateau rim and along the flats bordering Armstrong Canyon to the Natural Bridges, thus making accessible an exceptionally interesting region. After a few hours' ride from Blanding a delightfully cool camp on Elk Ridge may be made among tall forest trees near attractive springs, in the home of flowers and birds. Short walks from camp to the rim of the plateau reveal scenery of surprising beauty and grandeur. To the east the great Sage Plain extends from the base of the Abajo Mountains far away into Colorado and the Comb Ridge traverses the country like a turreted wall; to the south Grand Gulch Plateau presents a seemingly unbroken surface, terminated only by the steep face of Red Rock Plateau and by the towering buttes beyond the San Juan, 50 miles away. Westward the view ranges across the brightly colored White Canyon, Red Canyon, and Clay Hills to the mesas, buttes, and ridges of the Castle Wash and Moki Canyon region and on to the Henry Mountains, the Kaiparowits country, and Navajo Mountain beyond the Colorado. Immediately at the rim is the head of the inaccessible Arch Canyon, formed by beautifully carved red-topped white walls that descend 1,000 feet to a mysteriously hidden floor. Within the whole region from Comb Wash to Dark Canyon, 90 degrees of arc and extending as far as vision permits, the only evidences of human inhabitants are the mummies and skeletons of the Basket Makers and Cliff Dwellers, buried in the sand of washes or resting among the ruined structures in wall recesses of the profound canyons. 


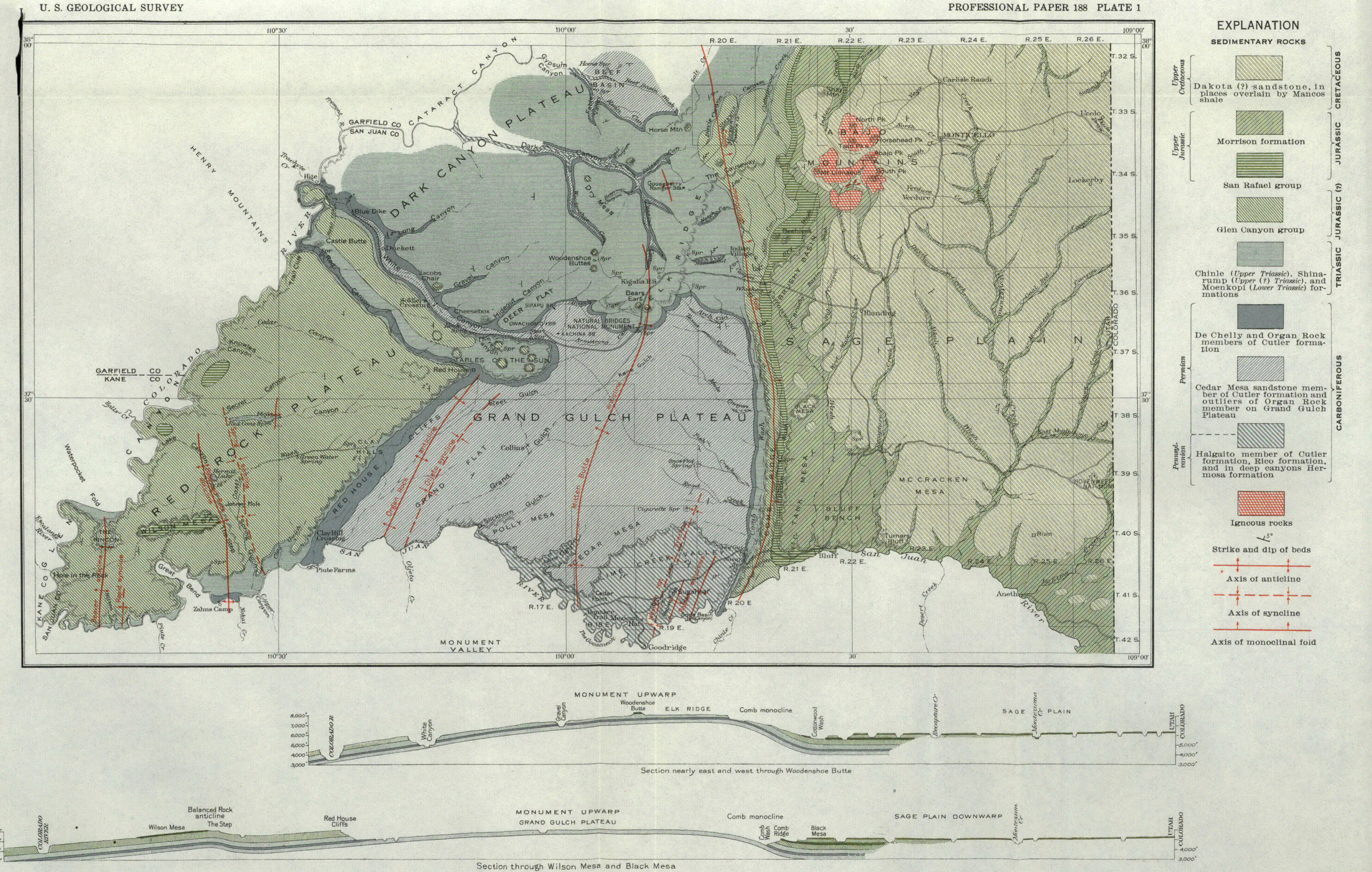




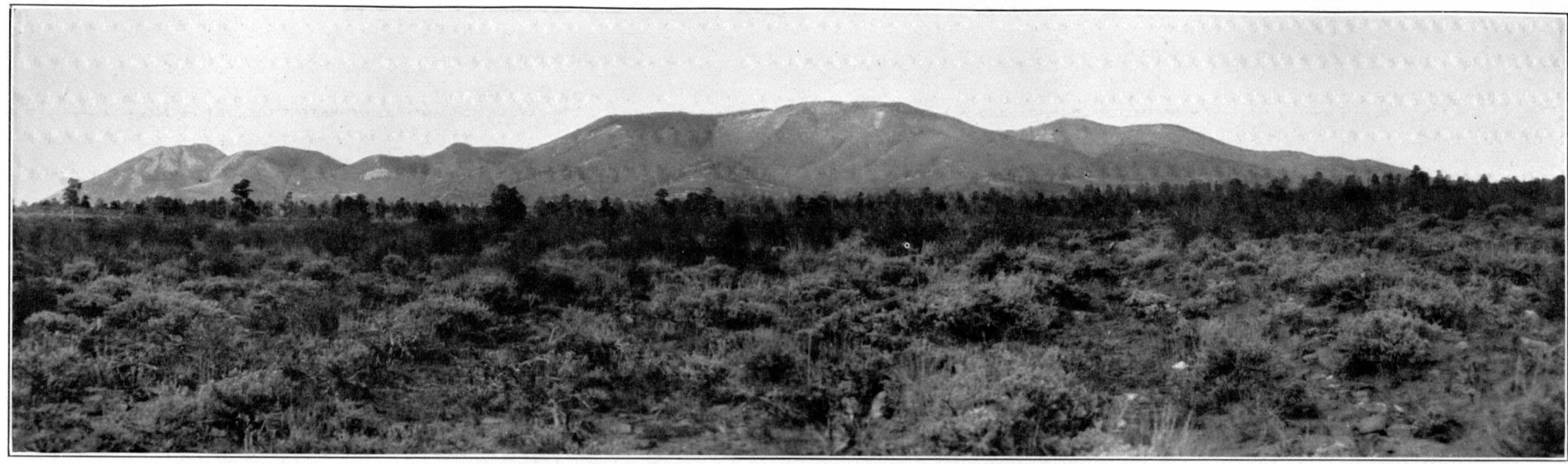

A. ABAJO MOUNTAINS FIOM WESTERN EDGE OF SAGE PLAIN

Viewed at a distance of 8 miles. Panoramic photograph by L. M. (iould

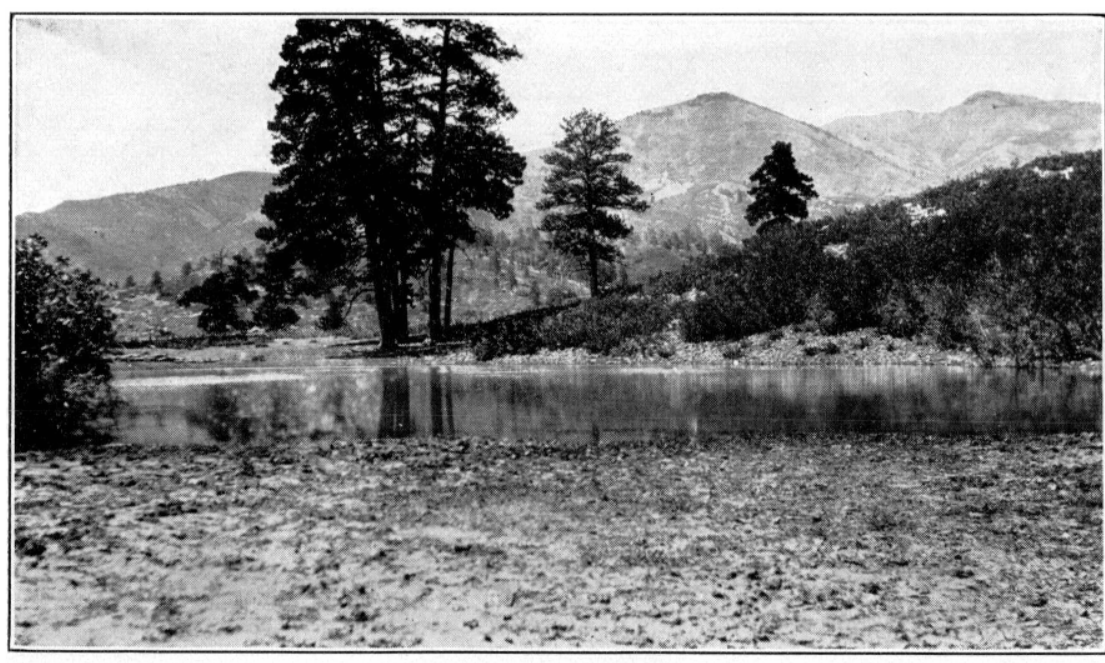

B. LAKE ON FLANK OF ABAJO MOUNTAINS BETWEEN JOHNSON AND RECAI'TUHL Depression in a shect of intrusive rock. Mtotograph by M. It. Thorpe.

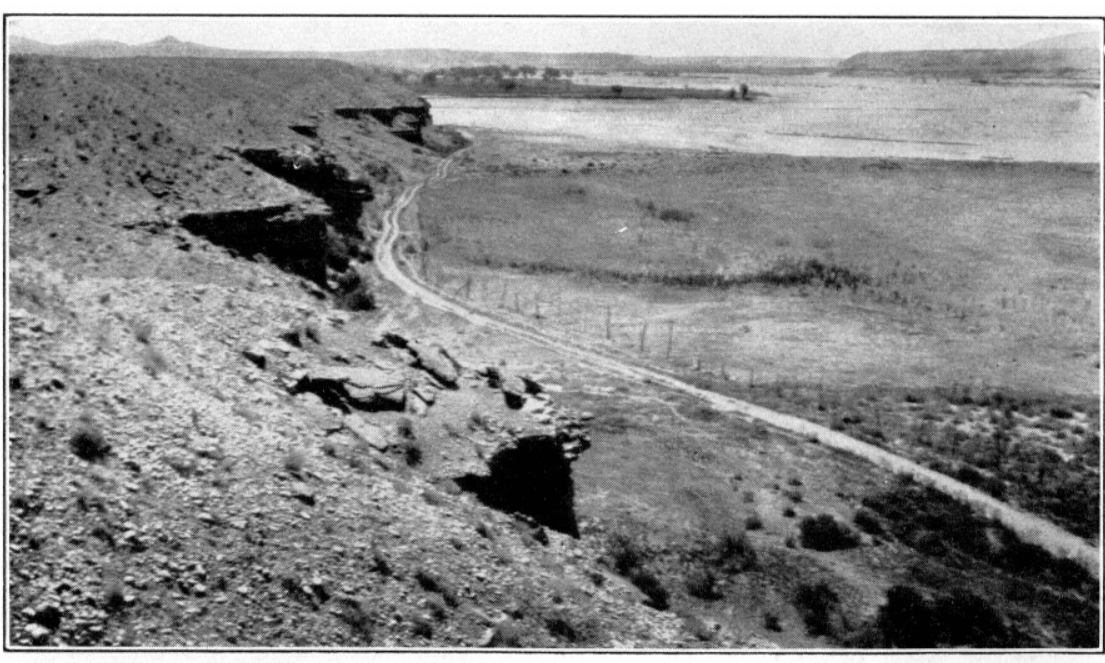

C. SAN JUAN RIVER 1 MULE BELOW MOUTH OF MCELMO CREEK.

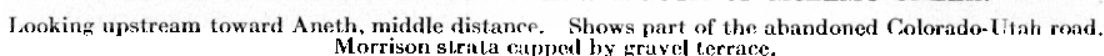




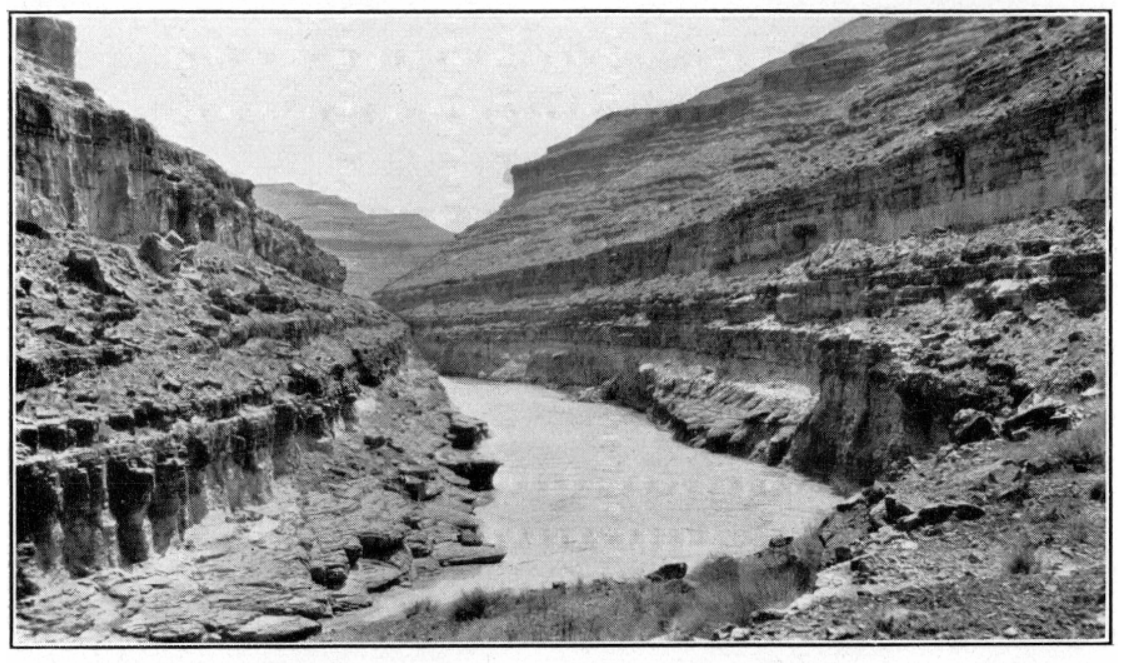

a. SAN JUAN CANYON ABOVE HONAKER TRAIL Permian and P'ennsylvaniun strata. Pholograph by R. N. Allen.

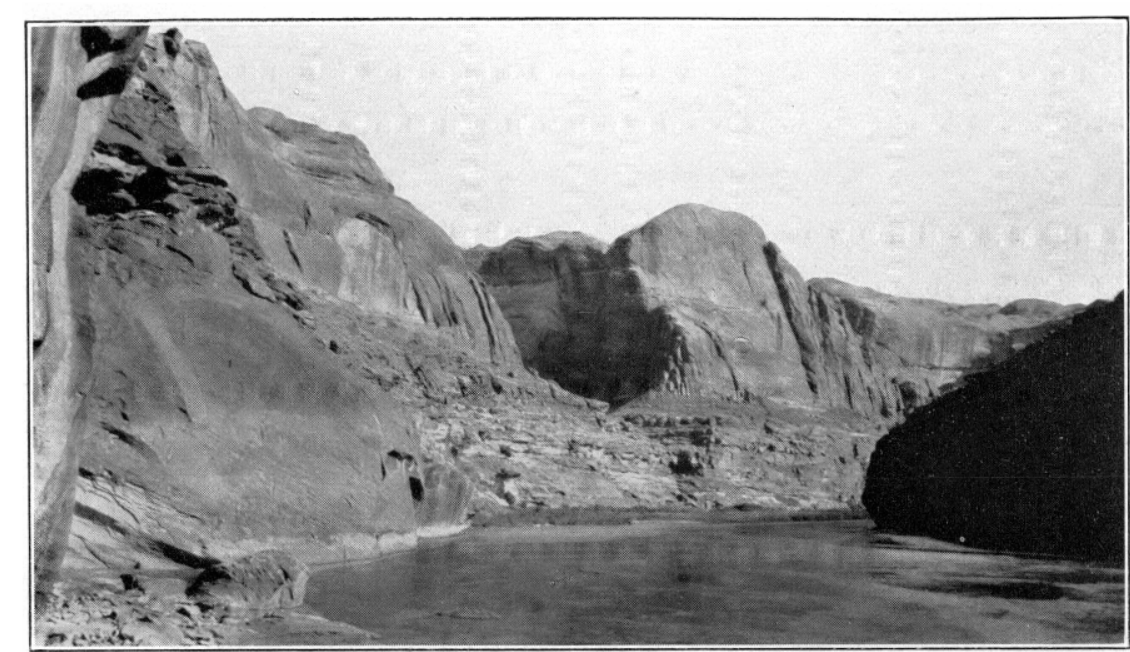

B. SAN JUAN CA VYON 6 MULES BELOW SPENCER CAMP.

Nivajo and Kayenta strata in middlle distance; Wingate sandstone in left foreground. Plotograph

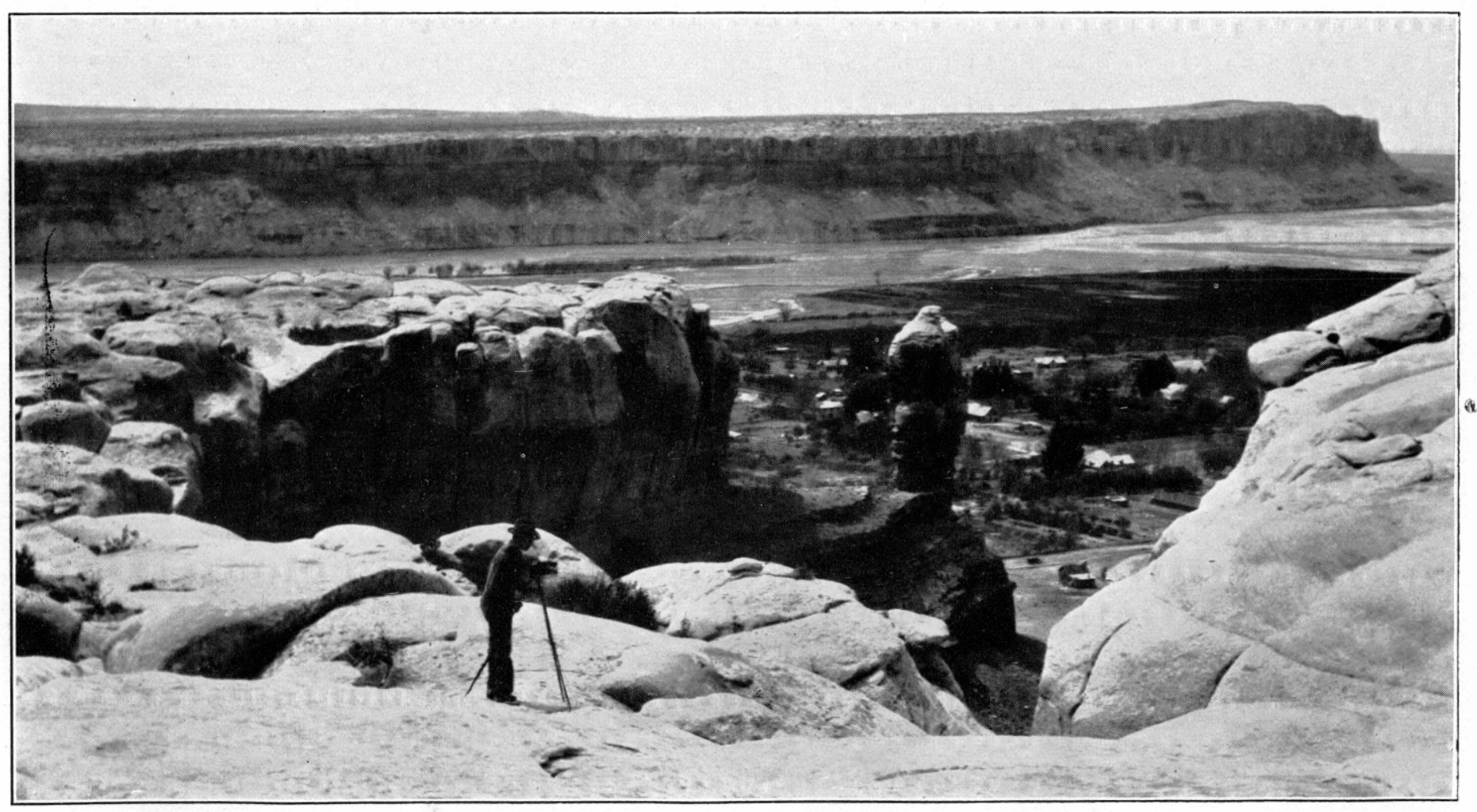

C. VILW LOOKING SOUTH ACHOSS SAN JUAN RIVER AT BLUFF.

Foreground, top of IBluff bench developed on Bluff sandstone. In distance, Bluff sandstone underlain by Summerville (?) and lintrada formations. Pholograph by W. H. HIOpkins. 


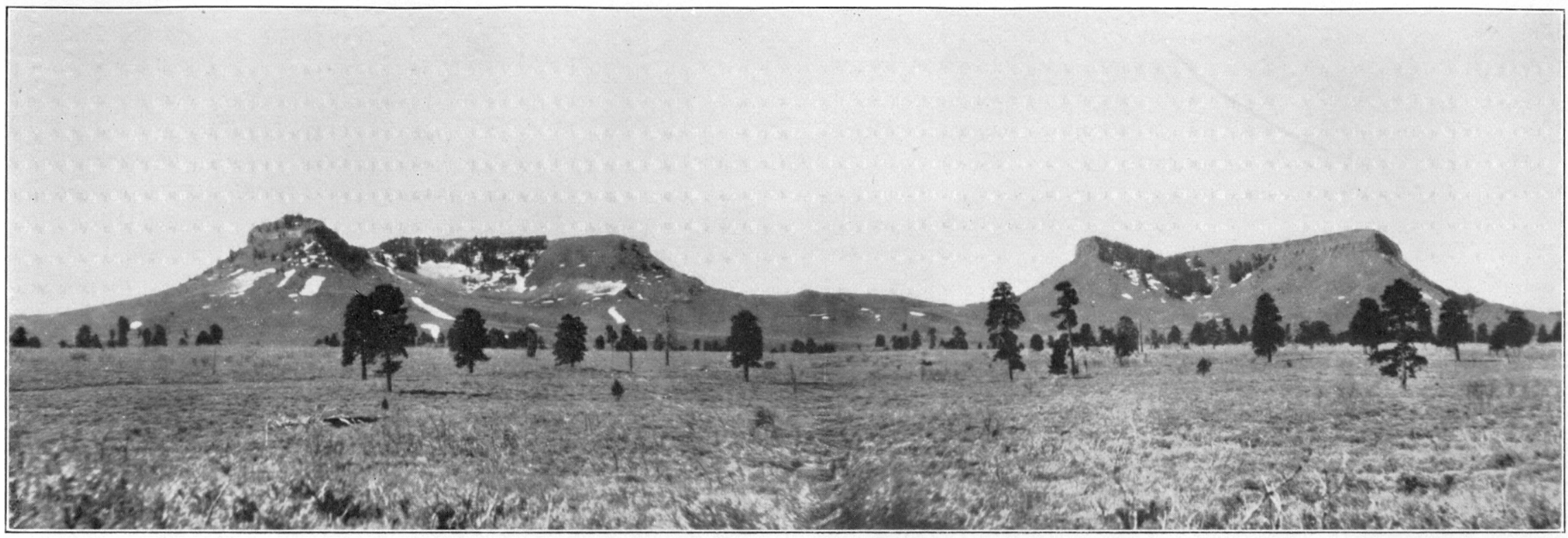

A. BEARS EARS ON SOUTH EDGE OF EIK PlateaU.

Flat in foreground shows general surface of the plateau developed in Shinarump conglomeratc; but les composed of Chinle ghale capped by Wingate sandstonc. Pholograph hy $\mathbf{A}$. A. Baker.

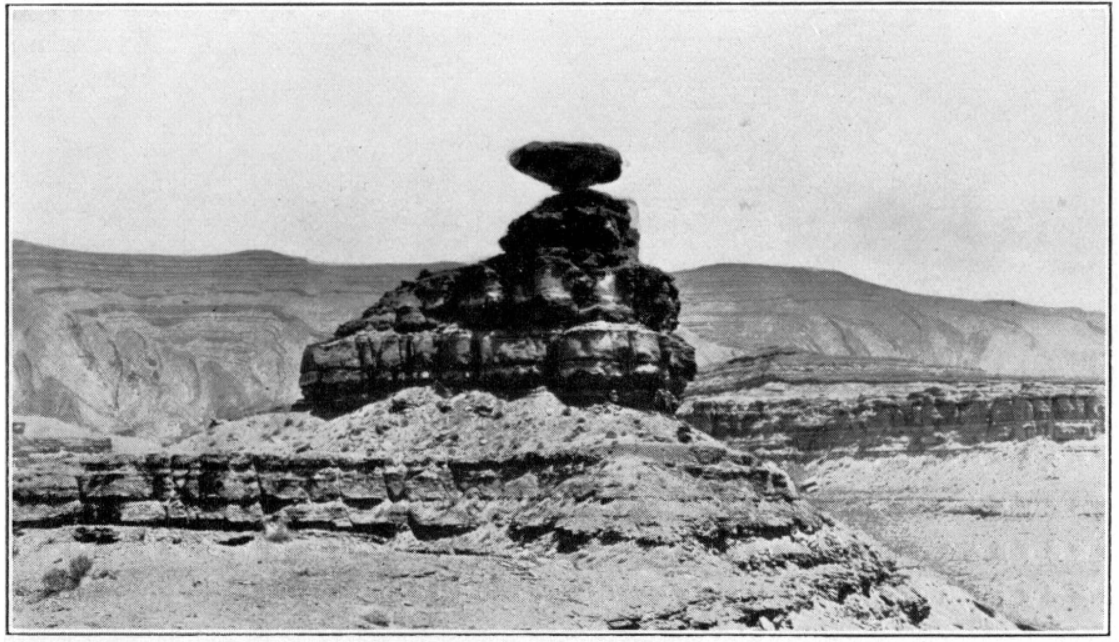

B. MEXICAN HAT,

An erosion remnant of Halgaito strata preserved in the Mexican Hat syncline in Lime Creek Valley.
Raplee anticline in background. Photograph by R. N. Allen.

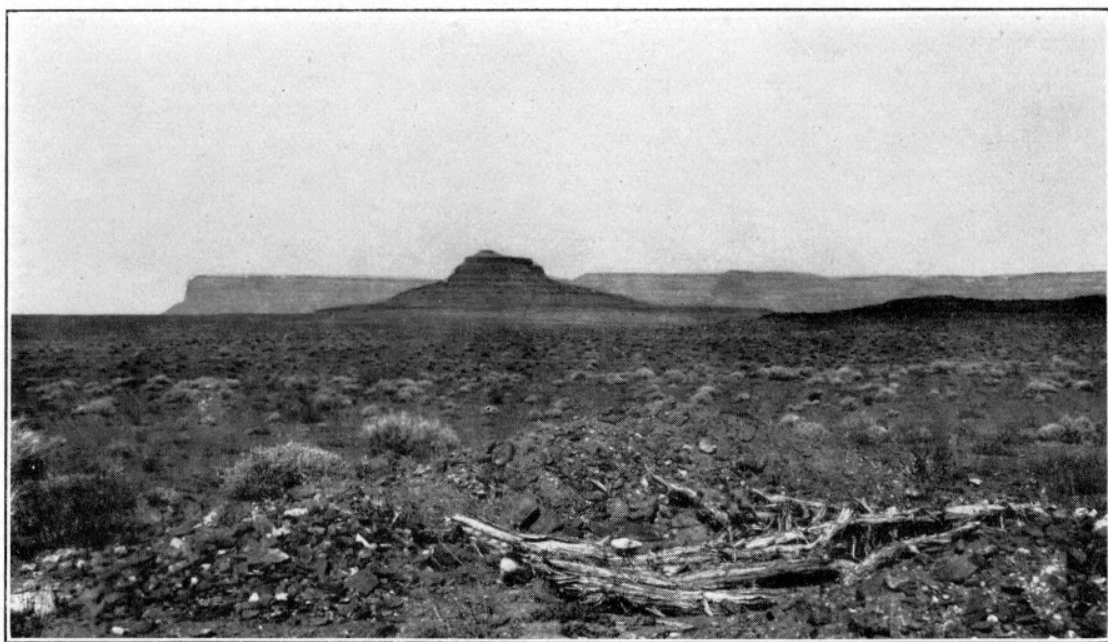

C. LIME CREEK VALLEY SHOWING EROSION SURFACE AND VEGETATION. Butte of Halgaito sandstone in middle distance. South face of Cedar Mesa in distance. Photograph
by E. G. Woodruff. 



\section{ALLEN CANYON COUNTRY}

The head tributaries of Cottonwood Canyon ${ }^{23}$ drain an area of relatively low land walled about by the edge of the Sage Plain, the base of Mount Linnaeus, the Causeway, and the rim of Elk Ridge. These tributaries-Dry Wash, Allen Canyon, Hammond Canyon, and their many short branches-and the Cottonwood itself rise at the base of encircling cliffs and, after gathering run-off from the bordering steep slopes, flow southward to form a single stream that emerges at the point where the walls have been broken down. All these tributary streams have about the same gradient and drain areas of about the same size, but the canyons they have developed differ widely in width, depth, and continuity. The area drained by them has been known as the Allen Canyon country. ${ }^{23 a}$

The east bank of Dry Wash is a terraced wall about 800 feet high; the west bank is a dissected lowland. Hammond Canyon crosses a series of ridges. Allen Canyon and especially its branches, Chippean, Deep, and many less conspicuous gorges, have cut deep crooked trenches into massive red rock. Cottonwood Canyon, in part of its course, is enclosed in high walls, but for long stretches only its eastern wall is prominent; its western tributaries are narrowly spaced, sharply cut canyons that start as box heads beneath the rim of Elk Ridge. The south end of the highlands between Dry Wash and Allen Canyon is carved into brightly banded buttes, capped columns, and mounds of red rock locally known as "Beehives." Mancos Jim Butte is the dominating feature. Farther north the highland, coated with alluvium spread by streams from the Abajo Mountains, becomes an area of flat land (Bailey's pasture) suitable for cultivation. The northwest corner of the Allen Canyon country is intricately dissected. The short wall-like ridges, rounded mesas, and especially the columns of sandstone have suggested the local name "Chimney Park." The massive red walls of Allen and Cottonwood Canyons display niches, pockets, and roofed recesses used as dwellings and storehouses by prehistoric inhabitants.

The attractiveness of the basin is enhanced by the vegetation. The great differences in soil, in altitude, in water supply, and in exposure to sun have produced conditions that favor the development of spots of unlike vegetation in close proximity. In a small section of canyon, yellow pine, piñon, sage, oak, box elder, willow, cottonwood, squaw bush, roses, clematis, ferns, and many grasses and flowering annuals are at home. At the box heads oak brush forms almost impenetrable thickets. In the large groves of cottonwood many trees are 4 to 6 feet in diameter.

\footnotetext{
"On some maps the name "Cottonwood Canyon" is applied to a short strearn that rises in the Causeway near the hesd of Allen Canyon and trends north to Indian Creek. Locally "Cottonwood Creek" is known as Gundlock Creek.

23a As the Allen Canyon country includes lands reserved for use by Piute Indians it has also been known as "Piute Park" and "Piute Basin."
}

The Piute village at Allen Canyon is one of the oldest settlements in Utah. Water, patches of rich soil, protection from wind, house sites in canyon walls, and adjoining hunting grounds made it a desirable spot for Basket Makers and Cliff Dwellers. The Piutes and Utes found the stream flats suitable for planting corn, and early white settlers were attracted by the pasturage and the favorable conditions for small-scale irrigation. The obvious injustice of taking from the Indians land which they had used continuously for many generations led to the present arrangement; the agricultural land in Hammond, Cottonwood, and Allen Canyons and in Dry Wash is allotted to the Indians; the other lands in the Allen Canyon country form part of the national forest, in which the Indians have preferential grazing rights.

\section{GRAND GULCH PLATEAU}

Comb Ridge, the San Juan River, Red House Cliffs, and the south wall of Elk Ridge outline an area of about 1,000 square miles here called Grand Gulch Plateau. It is a unit with respect to its topography, its drainage pattern, and its vegetation. Essentially the surface of the plateau is a single stratum of sandstone on which stand a few low flat-topped mesas and some rounded sandstone "haystacks." It slopes upward from the west and from the east to a broad flat axis, which in turn slopes southward from an altitude of 7,000 feet near Elk Ridge to 5,000 feet in Cedar Mesa, overlooking the San Juan. From viewpoints on Elk Ridge and on mesas in the Red House region the surface of Grand Gulch Plateau seems continuous. In fact, some extensive areas like Grand Flat, Polly Mesa, and those about the heads of Steer Gulch and Road Creek have remarkably unbroken floors on which drainage channels are so faintly outlined that in places water stands after rains. But attempts to traverse the plateau except along carefully selected routes proved futile: the surface is trenched by impassable canyons that reveal their presence only when their rims are reached. The floors of the canyons that cut the eastern slopes of the plateau are accessible only at the canyon mouths. Though the white rocks in which the natural bridges and windows in Arch Canyon are carved are in plain view from the road on Elk Ridge, they can be reached only by a trail from Comb Wash. Likewise the deep trenches of Johns Canyon and Slickhorn Gulch, which cut the southern edge of the plateau, are passable only on worked trails along the banks of the San Juan River. The chief obstacle to traverse is Grand Gulch, which divides the platenu into an eastern and a western part. Though less than 1,000 feet deep, its walls begin with a vertical drop of 30 to 60 feet and continue downward as a series of undercut steps 10 to 40 feet high and 5 to 10 feet broad, impossible to descend, even on foot, except with great caution and at wisely chosen places. Throughout its course the parallel canyon walls wind in and out as a series of closely placed meanders and rise almost vertically from 
a floor which in few places exceeds 500 feet in width. No trails cross Grand Gulch. Access to its floor from the east is impossible except at one point. From the west it may be reached by an artificial trail near Dripping Spring Gulch, at Collins. To avoid Grand Gulch the abandoned wagon road from Bluff to the Colorado River--the only road ever built across the plateau-leads up Road Canyon to the plateau surface bordering Fish Canyon and then north nearly to the base of Elk Ridge, where shallow Kane Gulch, the chief head tributary, is crossed by dugways.

During the winter and immediately after rains in spring and summer, water may be found in broad, shallow streamways on Grand Flat and in pockets scattered over the plateau surface. Water remains throughout the year in Kane Gulch, Dripping Spring Gulch, and Snow Flat and in places on the floors of the larger canyons. Over most of the plateau bare rock is exposed. What little soil is produced by weathering is blown by winds into low dunes, which provide footing for sagebrush, various low shrubs, and grasses. Piñon and cedar thinly spread over the surface send their roots deep into rock cracks and serve as centers for small piles of wind-blown sand.

During times when water is present Grand Gulch Plateau is a grazing ground for small bands of stock. Otherwise it is not utilized. That it was once the center of a considerable population is amply shown by ruined structures and agricultural fields on the canyon floors and walls, and to a less extent on their rims. The steep walls of Grand Gulch appear to have presented little difficulty to the ancient Basket Makers and Cliff Dwellers. Lines of toe holes leading from watered fields on the canyon floor to houses tucked away on shelves and in recesses of the walls and other lines leading to the plateau surface above demonstrate the skill with which the ancient inhabitants gained access to water, to arable ground, to building materials, and to wild animals that might serve as food. Miser ${ }^{24}$ describes the lowermost mile of Grand Gulch as presenting "some of the wildest scenery along the San Juan. It is a dark narrow canyon, with vertical red walls several hundred feet in height, at whose base lie heaps of huge boulders and great piles of driftwood."

\section{IIME CREEK VALLEY}

At its southeastern edge Grand Gulch Plateau overlooks Lime Creek Valley, a lowland area sharply defined on the north and west by the curved wall of Cedar Mesa, on the east by the domelike ridge that borders Comb Wash, and on the south by the San Juan Canyon. Lime Creek and its score of western tributaries rise abruptly in the wall-like face of Cedar. Mesa and, when water is sufficient, flow throughout their courses with moderate gradient in meandering, vertical-walled, shallow trenches. Tributaries from the east are short,

\footnotetext{
3 Miser, H. D., op. cit. (Water-Supply Paper 538), p. 10.
}

steep, angular grooves, cut into the flanks of the remarkably banded Raplee Ridge. The valley includes no towering mesas or deep canyons. Essentially it is a plain broken into irregular tables and short, flattopped ridges from which rise here and there picturesque erosion remnants-Mexican Hat, Setting Hen, Bell Butte, Garden of the Gods-cut in red sandstone and shale.

Lime Creek Valley (pl. $4, B, C$ ) is an inhospitable region-dry throughout the year and hot in the summer. During most of the year a small amount of potable water may be obtained from a spring on the Cedar Mesa rim, but the only reliable source is the muddy San Juan. Lime Creek water is alkaline. Though the altitude of the valley exceeds 4,000 feet, the annual precipitation is probably less than 8 inches. In favorable spots scattered piñons maintain themselves in rock cracks, but the general vegetation consists of shadscale and other tough, low brush characteristic of arid regions. Fully three-fourths of the surface is destitute of plant cover. Though much of the bedrock is limestone, the formation of soil is prevented by the sweep of sudden showers.

Lime Creek Valley afforded no attractions to the prehistoric inhabitants of Utah, nor to the Piutes or Navajos. To the white pioneers it was a necessary part of the route to the well-watered Johns Canyon and to grazing lands beyond. The spring near the head of Lime Creek was a camp site for prospectors who used the overland route to places in San Juan Canyon below Goodridge. During the "oil boom" that began in 1908 with the completion of a well on the bank of the San Juan and continued for several years the valley enrolled a considerable population. A road was constructed from Bluff, a bridge built across the San Juan, and in the mushroom village of Mexican Hat, near Goodridge, three stores did a profitable business with drillers and with Navajo visitors from beyond the San Juan. Since the field has been abandoned by drillers and real-estate speculators, a trading post has been intermittently maintained at Goodridge, and in the winter small flocks of sheep graze on the sparse. vegetation.

\section{DARK CANYON PLATEAU}

Cattle trails from the northwest edge of Elk Ridge lead out to the Dark Canyon country, a plateau that slopes gently westward to the Colorado River, where it terminates abruptly in the walls of Cataract Canyon. (See pl. 5, A.) At the south the plateau terminates in the giant rock steps that border White Canyon. Toward the north it extends to the gorge that carries to the Colorado the drainage of Beef Basin. The dominant feature of the plateau is Dark Canyon, a deep, narrow, meandering watercourse whose headmost tributaries have cut far into Elk Ridge. Below the mouth of Woodenshoe Creek the walls of Dark Canyon are continuous and nearly vertical, and its floor descends 
to the Colorado as a series of steps into which waterfalls have cut irregular grooves. Attempts to traverse the canyon on horseback proved futile, but passage on foot is possible with the aid of ropes. The characteristic vegetation of Dark Canyon Plateau is that common to highlands of the San Juan country above altitudes of 5,000 to 7,000 feet-mile after mile of sagebrush interrupted by groves of piñon and juniper. During seasons when rain is sufficient small widely spaced water holes permit the use of the plateau as grazing ground for cattle.

\section{WHITE CANYON}

White Canyon is the best-known region along the east side of the Colorado between Moab and Lees Ferry. There is reason to believe that it was explored by prospectors as early as 1870 , and since Dandy Crossing (Hite), near its mouth, was discovered, in 1880 , it has served as the route for pack trains and wagon trains that have found occasion to take a direct course from the San Juan country to the settlements in central Utah. Frey Cabin, Soldiers Crossing, Duckett, Blue Dike, and Rasp Trail are historic spots.

In its topographic expression White Canyon is unlike the other draingge channels in southern Utah. Except near its mouth, where the run-off passes through a narrow, sharply meandering gorge, the canyon is a broad, flat floor bordered on the south by almost continous high cliffs and on the north by cliffs alternating with broad areas of lowland buttes, mesas, and ridges. As seen from Elk Ridge, it appears as a roadway of white rock 2 to 5 miles wide that leads indefinitely westward between walls of banded red rock. Into the white rock that constitutes this floor the present White River and its tributaries have cut remarkably sinuous defiles 200 to 500 feet deep - canyons within a canyon. (See pls. $5, B ; 6, A ; 23, B$.) Some tributary canyons are vertical-walled or even undercut trenches much deeper than wide and give no indication of their presence until their very rims are reached. The floor of the inner canyon can be reached by following down the bed of Armstrong Canyon, also by trails constructed at Soldiers Crossing and Duckett. Along the pioneer trail down White Canvon interesting erosion features appear at three levels. On the south rim of the outer canyon stand huge mesas of red sandstone, the Tables of the Sun, and west of them smaller mesas extend in a broken line to the Colorado. On the north rim Jacobs Chair, the Cheesebox, and other picturesque buttes interrupt the otherwise even sky line formed by spurs that lead to Dark Canyon Plateau. The floor of the outer canyon, particularly below Soldiers Crossing, is studded with low mesas, buttes, and mounds. The inner canyon is wonderfully carved. High on the walls and down near the stream bed are long roofed shelves, alcoves, tunnels, windows, pocketlike niches, and a bewildering variety of miniature erosion forms. Undercut walls are common. In three places natural bridges have been developed. (See p. 103.) Along White Canyon piñon, juniper, and sage constitute the dominant vegetation. At the heads of tributary canyons yellow pine appears, and immediately along the streams cottonwood, willow, boxelder, flowering vines, and many annuals grow vigorously. Because of the suitable sites for dwellings, abundant water supply, patches of fertile soil, and convenient hunting range, upper White Canyon was the home of many Cliff Dwellers. The structures built by them, some still undisturbed, are features of interest to tourists who visit the Natural Bridges National Monument. At present the White Canyon region has no inhabitants. Prospecting has revealed no valuable minerals, and the historic road from Dandy Crossing to Bluff has been long abandoned. As grazing ground it has value when forage on the surrounding highlands is buried in snow.

\section{RED ROCK PLATEAU}

The little known "red-rock country" along Glen Canyon, "beyond the Clay Hills", is a highland area bounded by White Canyon, Red House Cliffs, San Juan Canyon, and Glen Canyon. For this region of mesas, domes, and canyons, walled about by lines of cliffs, the term "Red Rock Plateau" seems appropriate. It is an isolated region and difficult of access. From White Canyon the plateau surface may be reached by the Frey trail, at the head of Frey Canyon, and by the Rasp trail, near the Colorado River. From Glen Canyon a stock trail has been constructed up Trail Cliff, near the mouth of Red Canyon, and other difficult trails lead to the plateau surface at Lake Canyon and at a point opposite the Hole in the Rock. From the San Juan River a trail runs up Castle Wash, and opposite Navajo Mountain a trail climbs to the plateau about 1,000 feet in 2 miles. From the east, access to the plateau top presents no great difficulty; the wall formed by the Red House Cliff's is broken down at Red House and at the Clay Hills. From Red House, Red Canyon may be followed to its mouth, but access to the high country is blocked by cliffs. From the Clay Hills, however, trails lead to the plateau surface at places where travel in all directions is feasible. In fact, Clay Hills Pass, discovered and used by the members of the San Juan Mission as part of their memorable route from Escalante to Bluff, is the only entrance to the plateau that could be developed as a wagon road without prohibitive expense. (See pl. 6, B.)

Over the part of the plateau between Castle Wash and Red Canyon the surface is made uneven by mounds, short ridges, and flat tables, few of which rise more than 100 feet above a general level. In this part of the plateau travel is made difficult by the deep-cut Moki, Cedar, and Knowles Canyons with their innumerable short canyon tributaries, rather than by surface irregularities. Between Red Canyon and White Canyon lines of high-walled mesas dominate the topography. 
South of Clay Hills Pass and back of Red House Cliffs the country rises into high domes and mesas among which wind box-headed canyons that lead the drainage down precipitous channels south to the San Juan and west to lower Castle Wash. Along a line paralleling Lake Canyon the surface of Red Rock Plateau curves upward, forming the Step, west of which the plateau continues at a higher level nearly to the Colorado River. Of the separate plateau thus formed only Gray Mesa remains. The rest of it has been eroded by short tributaries to the Colorado and the San Juan to such an extent that canyons alone seem to constitute the landscape. Traverse about the junction of the Colorado and the San Juan is possible only on foot, by scrambling in and out over smooth sandstone walls and following little crooked defiles whose floors break off in terraces toward the river. In a day's walk, covering 2 miles, 25 canyons were crossed. It is a region of bare rock towers, alcoves, arches, and deep vertical-walled grooves - the roughest country seen in the plateau province. (See pl. 6, $C, D$.)

The streamways traversing Red Rock Plateau vary much in form and in details of erosion. Red Canyon is a broad, sheer-walled trench throughout most of its course. Moki Canyon is a narrow gorge with walls 1,000 feet high, unscalable except where sand dunes or landslides have obliterated the cliffs. The upper part of Castle Wash is a wide, open valley, bordered on the north by low sloping walls and on the south by benchlike sandstone cliffs that lead back to high country. The lower part of the wash is a canyon more than 500 feet in depth joined by tributaries equally deep. The tributary along the base of the Step, locally known as Johnny Hole, is a particularly narrow, rough-walled trench, into which a trail descends over the edges of irregularly broken strata. Near its mouth Castle Wash widens, though still hemmed in by walls. This part of the wash, heretofore mapped as an independent canyon (Spring Gulch), presents areas of flat floor and a permanent spring-fed stream. It has been utilized by the Piutes for winter camps.

Lake Canyon, like most of the other stream channels of Red Rock Plateau, is a trench defined by sandstone walls and joined by short, box-headed gulches. At a place near its head the floor of bare rock and sand, usually dry, is replaced by a stretch of meadow land. This is the spot to which "Providence directed" the San Juan Mission in 1879-80, the only place on the long traverse where water and stock feed were abundant. Though Hermit Lake, which cheered the tired scouts, has since disappeared, the meadow remains an attractive feature that contrasts sharply with surrounding areas of bare rock. Its bordering walls are beautifully carved into alcoves and overhanging arches; its alluvial floor is a field of grasses, ferns, wild roses, violets, and mallows, among which grow willows and cottonwoods.

Though most of Red Rock Plateau has an altitude exceeding 5,000 feet and receives annually about 20 inches of rainfall, it is comparatively treeless. Widely spaced piñons and junipers are rooted in rock cracks on the plateau top, on the edges of mesas, and on canyon walls and together with rare willows form small groves in depressions floored with sand that from time to time is soaked with rain. Sage, buckbrush, and cactus, growing as individuals or as groups, seem equally at home on the plateau surface and in canyons. Grass of various kinds and a surprising number of annuals grow in the wind-made flats, low dunes, and mounds built at the base of trees and brush. Outside the canyons the soil is predominantly shifting sand. There are large areas of bare rock continuously swept clean by rain wash and wind.

Red Rock Plateau is a lonely region and doubtless has always been so. The cliff houses in Lake Canyon, Moki Canyon, Knowles Canyon, and elsewhere are few, small, and crudely built. They seem to be the temporary homes of migratory bands or of pioneers who found the situation unfavorable. As remarked by Judd ${ }^{25}$ "These ancient folk, safely cloistered in murky canyons, tarried but a short while; then moved to a happier environment." For the Piutes and Navajos the plateau is a hunting ground for deer and mountain sheep. For white men it is a feeding ground for cattle. But as a cattle range jts use is restricted. There is enough forage for several thousand cattle and enough water to supply tbeir needs. The permanent water supplies, however, are unfavorably placed. Over about 800 square miles of surface there are few perennial springs, and the best grasslands have none. Access to seeps on the canyon bottoms is possible at few places. After rains water stands for days in rock pockets and in favorable seasons may last for weeks. During most years fall rains and winter snow provide sufficient water for livestock. The critical season is summer. By June, or even May, water is no longer available. The stock that can be accommodated in the national forest is driven to Elk Ridge, and the remainder started on the 100-mile trail to the railroad at Thompson.

\section{WIISON MESA}

West of the Step and north of the Great Bend of the San Juan River the characteristically rough surface of Red Rock Plateau is replaced by a level, undissected floor. On the east it terminates just back of the Step; its north and west edges are defined by the box heads of canyon tributaries to the Colorado; its south edge overlooks the San Juan River, 2,000 feet below. To this remarkable feature, the only stretch of flat land along Glen Canyon, the San Juan Mormon band gave the name "Gray Mesa", in recognition of the color of its rock floor and in contrast with the red-rock country north and west of it. In recent years, however, the terms "Wilson Mesa" and "Rustlers Flat" have come

2s Judd, N. M., Beyond the Clay Hills: Nat. Geog. Mag., vol. 45, p. 279, 1924. 
into use. Wilson Mesa is a distinct geographic unit. No piñons, junipers, or other trees grow on the mesa; grass and low, hardy brush cover the surface. As a point from which to view the stupendous work done by the Colorado and San Juan Rivers, Wilson Mesa vies with Navajo Mountain and the Kaiparowits Plateau. In traverses across its surface there was no opportunity to trace the boundaries of Wilson Mesa. The outline shown on the map is therefore highly generalized.

\section{GLEN CANYON}

Throughout most of its course in Glen Canyon the Colorado flows close to the base of its massive sandstone walls 800 to 1,200 feet high. (See pl. $7, A, B$, $C$.) In places the walls are undercut. At low water stages mud flats are exposed here and there at the base of cliffs, and in the river itself sand bars appear. There are also gravel bars above the reach of high waterthe sites of placer claims. Most of the tributaries to Glen Canyon enter through narrow gashes in the walls and join the master stream without passing over flats or deltas. At their mouths their depth and width are about the same as farther back. In fact, in passing through the canyon it is difficult to tell whether some of the vertical grooves in the towering walls are local features or the exits of long streams. Red Canyon and White Canyon join Glen Canyon less abruptly; the last half mile of their courses is a gravel-strewn flat. In general, the color of the canyon walls is the color of the rock, little changed by a coating of vegetation. Only a few piñons and junipers seem to maintain a foothold. At the heads of alcoves and in recesses about water seeps, oak, ferns, and brush of various kinds grow vigorously. The high-level bars support cottonwood, willow, and tamarisk, and the bars exposed at low water are thickly covered with young trees.

Glen Canyon was known to the prehistoric peoples, whose presence is recorded in ruins and picture writing. It has been thoroughly explored by prospectors, who in 1883 to 1900 and intermittently thereafter were at work on placer claims. Compared to Cataract Canyon, above, and Marble Gorge and Grand Canyon, below, Glen Canyon is a quiet stretch of water many times traversed by explorers, miners, and tourists, who reach it from the settlements in central Utah. The trip by boat from Hite to Lees Ferry is a memorable experience attained in a few days' time with little necessary discomfort. At present no one lives in the canyon. Mining has proved unprofitable, and the routes that made use of crossings at Hall Creek and Hite have been abandoned. Except for its scenic interest, its future economic usefulness lies in the possibility of developing water power.

\section{BEEF BASIN}

As viewed from Horse Mountain the Beef Basin country appears as a flat dome, about 20 miles long and
8 miles wide, extending northwestward from the base of Elk Ridge. Into the northern and eastern flanks of the dome tributaries to Indian Creek have cut deep boxheaded canyons. Along its south border Beef Basin extends westward as a wide valley and is joined by tributary canyons that reach north to and beyond the crest of the dome and south into the flanks of Elk Ridge. Springs at several canyon heads, in particular Home Spring, provide a perennial water supply that makes possible the utilization of the basin as a grazing area even in summer. Along canyon walls near the springs cliff houses are numerous. In general views from high points the region appears as an enormous expanse of white sandstone, carved in places deep enough to expose the red beds and dotted by buttes. Toward the west Beef Basin Canyon rapidly deepens, and from the mouth of Fable Valley to Cataract Canyon it is a gorge 1,000 to 2,000 feet deep.

\section{CLIMATE}

\section{GENERAL RELATIONS}

In the San Juan country, as in other parts of the plateau province, the climate is controlled only generally by latitude and the passage of cyclonic storms. In a broad sense, the westerly winds of the winter and the southwesterly winds of July, August, and September, rather than the more variable winds of other seasons, provide conditions favorable for precipitation; but these factors are greatly modified and in some places nullified by altitude and topography. The result is a group of local climates, each with its peculiar distribution of rainfall and temperature. Thus at Bluff, in the San Juan Valley, the mean annual precipitation is about 7 inches; at Blanding, on Sage Plain 27 miles to the north, about 15 inches. At Monticello southeast winds prevail throughout the year; at Blanding, 22 miles distant, the wind is south for 10 months of the year, southwest for 1 month, and north for 1 month.

Rain showers are short and far apart. Most showers last for an hour or less and furnish rain to a few square miles. The number of days in a year on which rain is lacking or is less than 0.01 inch is 323 at Aneth, 314 at Blanding, 327 at Hite, and 311 at Monticello, the wettest station for which records are available. Many of the recorded small monthly rainfalls are in reality the records of single showers, and the larger monthly means may comprise but a few heavy downpours. But during these infrequent showers water seems to be everywhere; the bare rocks are coated, waterfalls drop over the canyon rims, and the dry washes become turbulent, muddy streams. Most of the brief showers of summer and early fall are accompanied by lightning. Bolts from a cloud mass-perhaps the only one in an otherwise clear sky - strike savagely at trees or bare rocks. The precipitation from these showers is slight; it sprinkles the ground with scattered drops or with a few hailstones. 
During July and August 1921 Miser ${ }^{26}$ experienced 23 thunderstorms, yet the precipitation recorded for those months at the nearest station (Bluff) was only 1.65 inches.

As is to be expected, the low-lying canyon settlements Hite, Bluff, and Aneth experience higher mean annual temperatures than the plateau villages Blanding and Monticello, yet the highest temperature recorded in San Juan County is at Blanding $\left(110^{\circ}\right)$ and the lowest at Aneth $\left(-29^{\circ}\right)$. Except in deeper canyons, snow is expected any time between October 1 and June 1. Even in the San Juan Canyon at Aneth the annual snowfall of 5 inches is distributed through 5 months. Snow may fall on Elk Ridge (altitude 8,000 feet) at any time between September and June and on the Abajo Mountains (altitude 11,000 feet) during every month of the year. Extensive snowbanks were encountered near the Bears Ears in May. About Abajo Peak and Mount Linnaeus snow chokes the canyon heads until late in June and supplies water to streams until late in August. During most winters snowdrifts block the Monticello-Blanding highway and make the Blanding-Kigalia road impassable.

Characteristic features of the San Juan climate are the great range of diurnal temperature and the prevalence of clear skies. During summer and autumn a daily range of $50^{\circ}$ is not unusual. Hot days are followed by cool nights beginning soon after sunset. Even in deep canyons during the hottest part of the year few nights are comfortably spent without a covering blanket. On Elk Ridge in July uncomfortably hot days may be followed by nights during which water freezes in camp buckets.

At Hite, Bluff, and Goodridge days with cloudless skies number probably 200 a year. At Blanding the approximate means for the years 1922-27 are, clear, 133 days; partly cloudy, 153; cloudy, 79. Of the cloudy and partly cloudy days, those with rain number about 50 at Blanding and perhaps 40 at Aneth, Hite, and Bluff. West of Elk Ridge and along the San Juan many clear days are to be expected in every month of the year. In spring and fall they may be continuous for 1 or 2 weeks, and throughout the San Juan country days with scattered clouds greatly exceed those with overcast skies. It is estimated that southeastern Utah as a whole receives 85 percent of the possible sunshine.

Because of its clear skies, its low humidity, its large range of daily and annual temperature, and its almost constant gentle winds, the climate of the San Juan country is invigorating. Though the heat of spring

\footnotetext{
${ }^{96}$ Miser, H. D., The San Juan Canyon of southeastern Utab, a geographic and hydrographic reconnaissance: U. S. Geol. Survey Water-Supply Paper 538, p. 16, 1924.
}

and summer days is great, it is not oppressive; it is dry heat, and the coolness of night is equally dry. To escape the discomfort of the hottest days spent traversing the bare ledges and sand-floored washes, it is only necessary to seek the shade of a rock. The edge of a shadow is the dividing line between heat and delightful coolness.

\section{PRECIPITATION \\ RECORDS}

Since the settlement of the San Juan country in 1880 , facts about floods and droughts, the time of killing frosts, snowfall, and ice in the San Juan and the Colorado have been recorded in archives of the Church of Jesus Christ of Latter Day Saints. Diaries and the recollections of old-timers are additional sources of information. Instrumental measurements of the amount and distribution of rain that falls between the ColoradoUtah boundary line and the High Plateaus, 100 miles west, have been made by volunteer observers.

At Aneth the records are complete for 9 years, 7 of them consecutive (1901-7); at Hite, for 12 consecutive years (1902-14); at Bluff, for 14 years, scattered through a period of 24 years. At Monticello the records are substantially complete for 17 years (1911-19, 1924, 1928-34), and when supplemented by measurements at Verdure, 7 miles south of Monticello, and at the nearby Baker ranger station, give a reasonably accurate record of the rainfall for 33 years (1902-34). The most satisfactory records are those at Blanding, which, except for the years 1910 and 1911, are complete and consecutive for 29 years (1905-34).

Unfortunately these six stations are so located as to give information for only a small part of southeastern Utah. Bluff, Blanding, and Monticello are in a northsouth line; Baker ranger station is close to Monticello; Aneth has substantially the same situation as Bluff; and Hite obviously records peculiar conditions. For the higher lands, for the lower San Juan Canyon, and for the great stretch of country between Comb Wash and the Colorado measurements of climatic factors are lacking. Of the records published, those for Blanding are believed to represent best the conditions on the plateau lands, and Bluff those of the canyon floors.

Though the instrumental records are obviously too fragmentary for detailed climatic studies, when supplemented by observations on streamways and vegetation they give a generalized picture of the climate and indicate the amount and distribution of rainfall in those parts of the San Juan country that are adapted for agriculture. (See fig. 1.) 


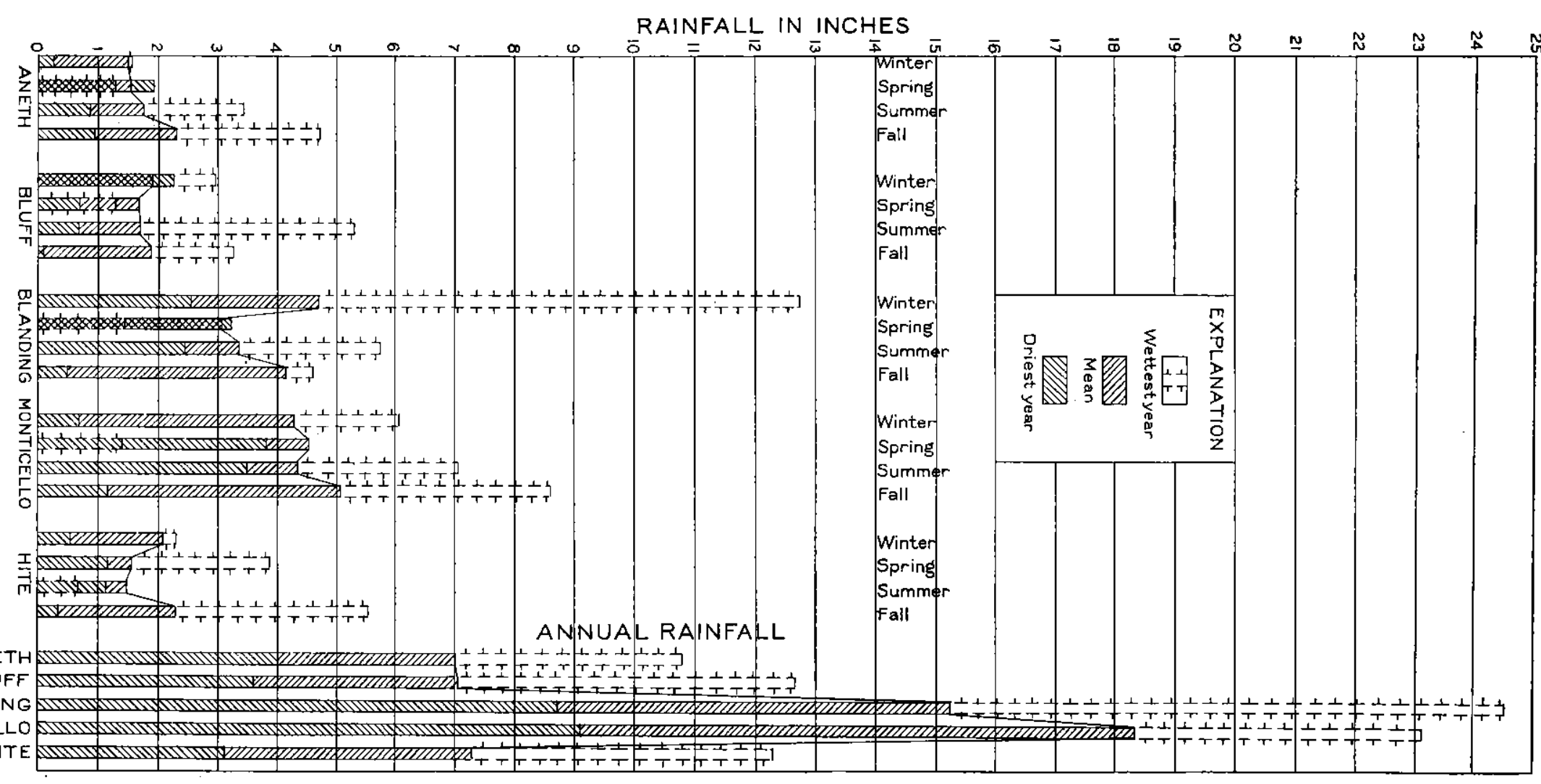

㝵

FfoURE 1.--Diagram showing seasongl and annual distribution of rainfall. 
Precipitation in the San Juan country

Aneth (altitude 4,800 feet)

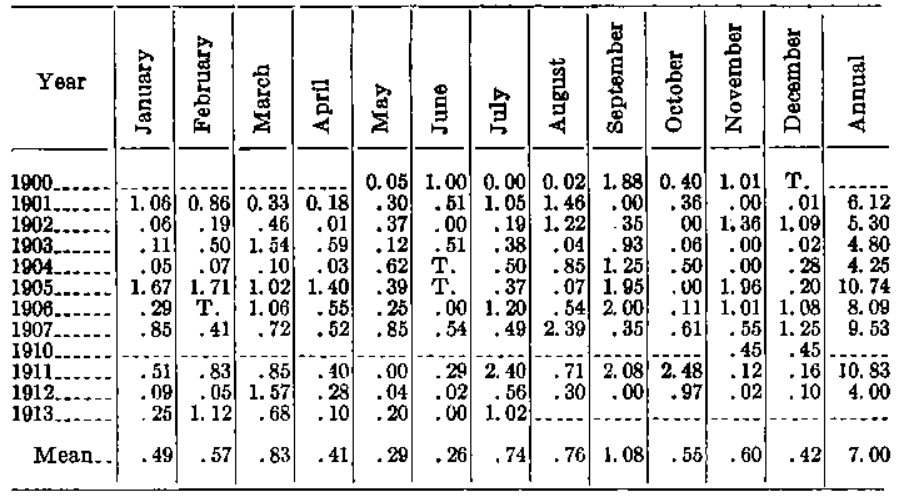

Bluff (alcitude 4,200 feet)

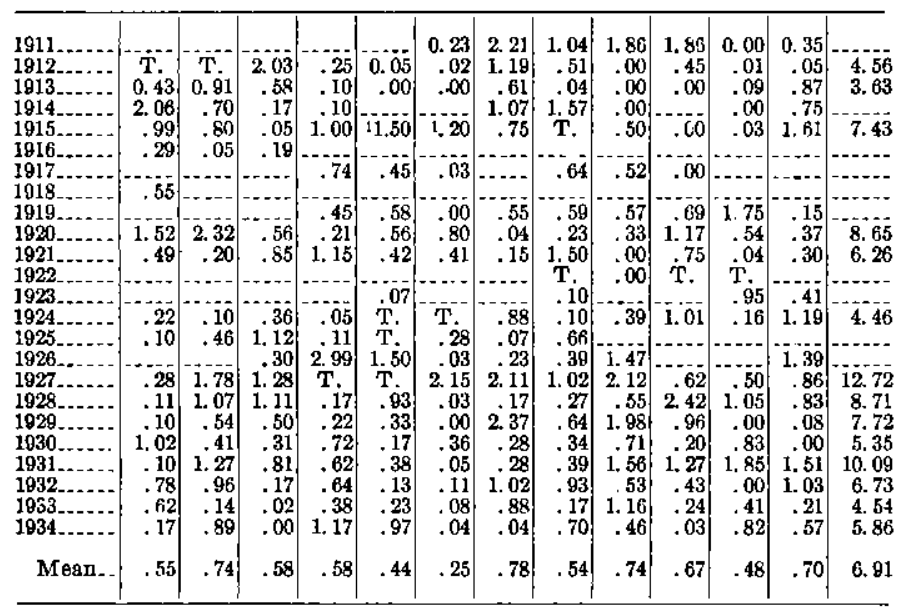

1 Interpolated.

Blanding (altitude 6,400 feet)

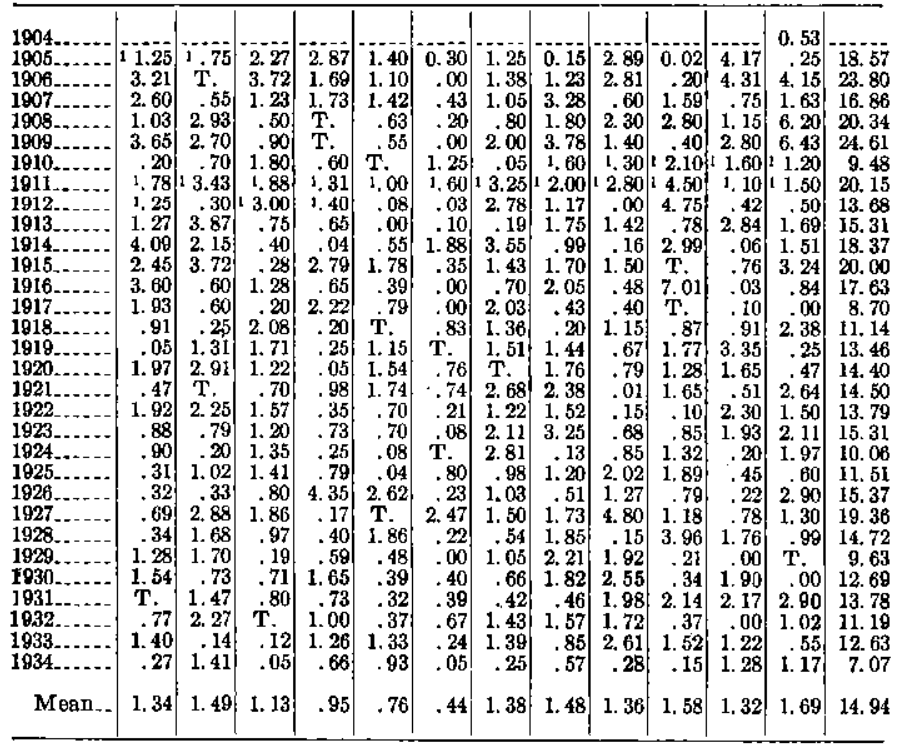

1 Interpolated.

Monticello (altitude 7,400 feet)

[Record for 1905 at Verdure, 7 miles south of Monticello]

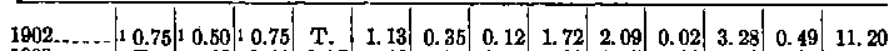

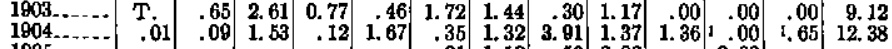

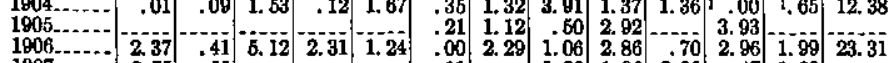

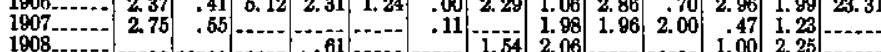

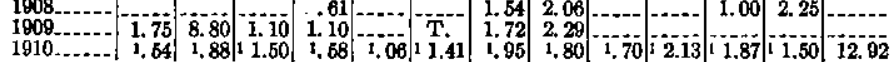

Precipitation in the San Juan Country-Continued

Monticello-Continued

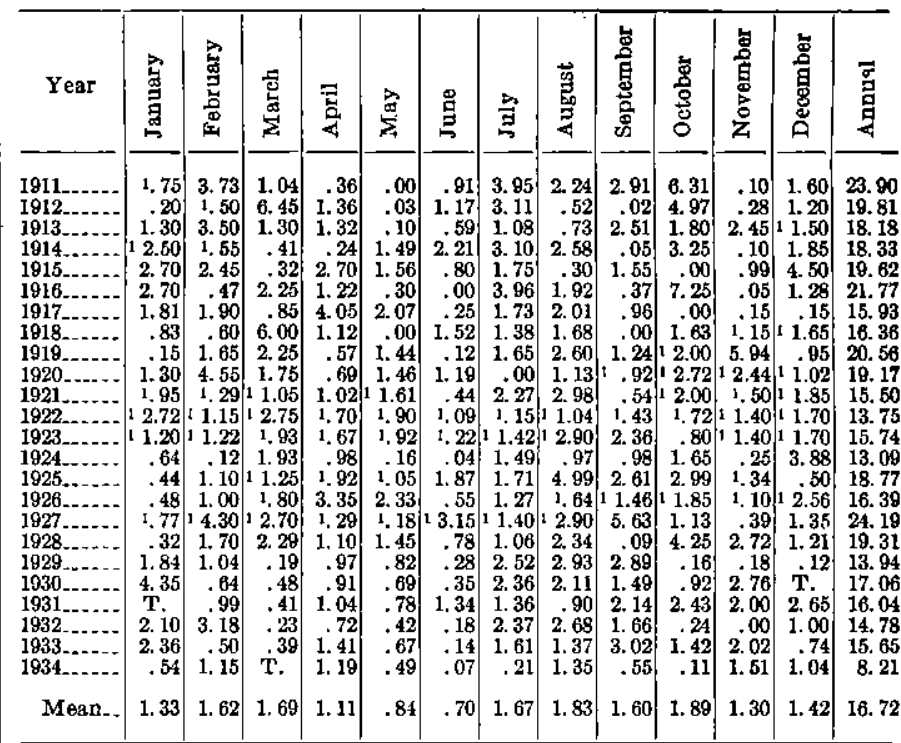

1 Interpolated.

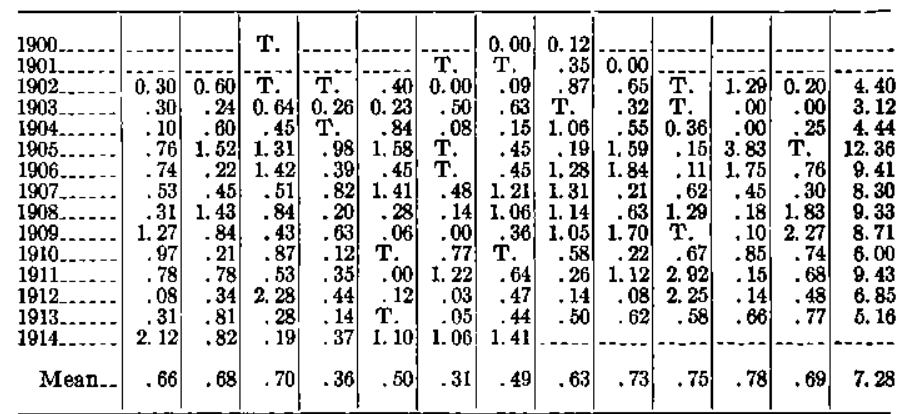

\section{GEOGRAPHIC DISTREBUTION}

All of Utah east of the Wasatch Mountains is deficient in rainfall. In Kane, Garfield, Wayne, Emery, Carbon, and Duchesne Counties, west of the Colorado River, and San Juan, Grand, and Uinta Counties, east of the river, the 35 meteorologic stations record as much as 20 inches of rain and snow only at Alton, on the High Plateaus of Kane County, and Winter Quarters, near the crest of the Wasatch Mountains in Carbon County. At 29 stations less than 15 inches is recorded, and at 19 stations less than 10 inches. With respect to total rainfall, San Juan County, with an annual mean of about 12 inches, is more favored than its neighbors. Grand County receives 7.88 inches; Wayne County, 6.85 inches; Garfield County, 10.30 inches; and Kane County (except for a small area on Paunsaugunt Plateau), about 8 inches.

A comparison of rainfall records of the different stations shows clearly the influence of geographic position. At Hite, Bluff, and Aneth, stations in canyons at altitudes of $3,500,4,200$, and 4,800 feet, the mean annual rainfall is respectively $7.28,6.97$, and 7.00 inches. The mean totals for Bluff and Aneth probably fairly represent conditions in the San Juan Valley east of Comb Wash but, to judge from field 
experience and amount and kind of vegetation, are too high for the region about Goodridge and for the stretches of canyons farther west. The position of Hite, at the base of the Henry Mountains, seems to give it a rainfall greater than that believed to be characteristic of Glen Canyon. For the stations about the Abajo Mountains, Blanding (altitude 6,400 feet) receives 14.94 inches and Monticello (altitude 7,400 feet) 16.72 inches. Records kept for 3 years (1921-23) indicate that somewhat more rain falls at Lockerby, near the Utah-Colorado line, than at Blanding or Monticello. On the higher lands the precipitation undoubtedly exceeds that recorded for any station. The forests, meadowlands, springs, and small bodies of standing water on Elk Ridge and the Abajo Mountains indicate an annual precipitation certainly exceeding 20 inches and perhaps as much as 25 inches. For Kigalia ranger station A. C. Folster, forest supervisor, estimates the precipitation as 23 inches, including the equivalent of the snow, which during most years covers the ground to a depth of about 3 feet from December to April.

\section{VARLATION FROM YFAR TO YEAR}

The precipitation at stations in the San Juan country shows a wide annual range, though somewhat less than that recorded for the Navajo country to the south or the Kaiparowits region to the west. The variation is less at the canyon stations (Aneth, Bluff, and Hite) than at those at greater altitudes. At Hite, where the annual mean is 7.28 inches, 12.36 inches of rain fell in 1905 and 3.12 inches in 1903, a year during which November and December were rainless. At Bluff the extremes are 12.72 inches in 1927 and 3.63 inches in 1913; at Aneth, 10.83 inches in 1911 and 4.00 inches in 1912. At Blanding precipitation of 20 inches or more is recorded for $1906,1908,1909$, and 1915 . The rainfall at Blanding for 1909 (24.61 inches), the heaviest recorded for San Juan County, was two and one-half times that of the following year (9.48 inches) and still greater than that for 1917 (8.70 inches) and 1934 (7.07 inches). In 1906 and 1911 Monticello received more than 23 inches of rain; in 1903 , only 9.12 inches; and in 1934, 8.21 inches. The records show that 1903 and 1934 were dry years at all stations in San Juan County, that 1913 was another dry year at Aneth and Bluff though not at Blanding or Monticello, that 1905 was a wet year at three stations, and that 1906, 1909, $1911,1915,1916$, and 1927 were wet years at two stations.

Long before instrumental records were made the pioneers experienced years of heavy rain and years of drought. As related in diaries it "rained for a solid month" in the summer of 1884, and during the "great drought" of 1896 the San Juan at Bluff could be crossed dry-shod. Dying fish in pools scattered along its sandy bed were caught by Navajos and sold as food. Hot southwest winds caught up the sand from the river bed and swept cultivated fields bare of soil down to the base of plow furrows. In areas adjoining the San Juan intermittent streams ceased flowing, large springs decreased in volume, and small springs disappeared. Except on the mountains the fodder of pasture lands was deficient in amount and quality. In 1934 the San Juan country in common with adjacent regions witnessed extreme aridity. In July the bed of the San Juan River was dry.

Some years of abnormal precipitation in the San Juan country correspond with those in other parts of the plateau province. Others show wide differences. The year 1903 was dry in the Kaiparowits region but unusually wet at Fort Defiance; in 1913 Holbrook and Chinle were dry, but most other stations experienced heavy rains, and Fort Defance received one of its heaviest rainfalls. The year 1905 was wet at stations in the Navajo country and at Alton and Cannonville, in the Kaiparowits region, and 1911 was exceptionally rainy over most of northern Arizona and southern Utah. Likewise at most stations the precipitation for $1906,1909,1915$, and 1916 was somewhat above normal. The records available give no indication of cycles. At many stations exceptionally wet years are immediately followed or preceded by exceptionally dry years.

As the maximum annual precipitation in the San Juan country is insufficient for ordinary agriculture and in places even for grazing, and as the possibility of irrigation for any year depends upon the rain and snow that fall on the Abajo Mountains, these great variations from year to year limit the utilization of the abundant unoccupied land.

\section{GEASONAI DISTRIBUTION}

In the San Juan country the seasonal distribution of rainfall is unfavorable for ordinary farming and for the vigorous growth of forage plants. For all stations March is a relatively wet month, but the combined mean rainfall during April, May, and June is 2.63 inches for Monticello, 2.15 inches for Blanding, 1.27 inches for Bluff, and 0.96 inch for Aneth. In 2 years at Monticello and 3 years at Blanding, Bluff, and Aneth no rain fell during June. Part of even this inadequate supply is unavailable; evaporation during these dry, hot months is great. In a few favored areas the moisture from fall rains, kept intact during the winter and supplemented by the small supplies of spring, is suffcient in some years to bring field crops to maturity, but in most of the San Juan country the success of irrigated crops depends upon the rains of July.

During 30 years at Blanding the July rains amounted to 0.05 to 0.98 inch for 9 years, 1.00 to 2.00 inches for 13 years, and more than 3 inches only in the "good years" of 1911 and 1914. During 32 years Monticello recorded only 9 years with a July precipitation exceeding 2.00 inches. July rains exceeding 1.00 inch fell in 3 out of 15 years at Hite, 3 out of 19 at Bluff, and 4 out of 11 at Aneth. In general the nonirrigated 
crops for years having July rains of less than 2.00 inches are raised at a loss.

The range in monthly rainfall from year to year is large even for semiarid regions. The figures for Blanding during 30 years, in inches, are: January, trace to 4.09; February, trace to 3.87 ; March, trace to 3.72 ; April, trace to 4.35; May, trace to 2.62; June, 0.00-2.47; July, 0.05-3.55; August, 0.13-3.78; September, 0.014.80; October, trace to 7.01; November, 0.20-4.31; December, 0.00-6.43. October 1916, which had the heaviest monthly rainfall recorded (7.01 inches), was preceded and followed by Octobers with only a trace. Corresponding variations appear in the records of other stations. Obviously, agriculture based on an expectation of rain for a certain month or a group of consecutive months and stockraising that depends on ephemeral water supplies are speculative industries.

Except for a relatively dry season that includes April, May, and June, which is characteristic of the plateau province, the meteorologic records for the San Juan country show no uniform seasonal rainfall. In amount of precipitation the seasons rank at Aneth, fall, summer, spring, winter; at Hite, fall, winter, spring, summer; at Bluff, winter, summer, spring, fall; at Blanding, winter, fall, summer, spring; at Monticello, fall, spring, summer, winter. The wettest month of the year is September at Aneth, November at Hite, July at Bluff, December at Blanding, March at Monticello, and April at Baker ranger station. At Bluff November is nearly as dry as June; at Blanding the November rainfall is three times that of June. The distribution of rainfall during the wettest and driest years of record is shown in figure 1.

\section{TEMPERATURE}

As shown by a comparison of the tables for the meteorologic stations in the San Juan country, the mean annual temperature varies with altitude; but in order of the amount of heat experienced, the position of the months differs considerably. The warmest months have the rank July, August, June, September, May. The coldest months have the rank January or December; February or November; March, November, or February.

At Monticello, the coldest station, the thermometer rarely records as much as $90^{\circ}$, and the highest recorded temperature during 32 years was $98^{\circ}$. At the other stations in San Juan County temperatures exceeding $100^{\circ}$ are normal for June, July, August, and September. The maximum figures are, for Aneth, $106^{\circ}$; Bluff, $109^{\circ}$; Blanding, $110^{\circ}$; Hite, $115^{\circ}$. The difference in mean monthly temperature from year to year, though not abnormal, is greatest in September and January. The September variation is a factor of some importance in agriculture. Temperatures below zero have been recorded at all stations; at Monticello and Blanding they may occur at any time during November, December, January, and February. At Bluff temperatures below zero are expected late in December. Because of some local conditions not understood, Aneth, otherwise a warm station, has experienced the lowest temperature $\left(-29^{\circ}\right)$ recorded for San Juan County.

Each year the soil is frozen to depths of 1 to 4 feet and the Colorado and San Juan Rivers freeze over in places. During some years the ice is sufficiently solid to support teams and wagons.

The annual ranges of temperature are great. The maximum ranges recorded are, for Monticello, $119^{\circ}$ $\left(98^{\circ}\right.$ to $\left.-21^{\circ}\right)$; for Blanding, $133^{\circ}\left(110^{\circ}\right.$ to $\left.-23^{\circ}\right)$; for Hite, $116^{\circ}\left(115^{\circ}\right.$ to $\left.-1^{\circ}\right)$; for Aneth, $135^{\circ}\left(106^{\circ}\right.$ to $-29^{\circ}$ ), the highest range recorded for the plateau province and among the highest known.

The daily range of temperature, except on canyon floors, is probably $40^{\circ}$ to $50^{\circ}$. Hot days are followed by cold nights, and passing thunder showers lower the temperature abruptly.

As given in the reports of the United States Weather Bureau, the average period without killing frosts is 145 days (May 17 to Sept. 29) at Blanding, 154 days (May 5 to Sept. 26) at Aneth, 224 days (Mar. 24 to Nov. 3) at Hite, 118 days (May 29 to Sept. 24) at La Sal, and 128 days (May 26 to Oct. 1) at Monticello. In exceptional years killing frosts come later in the spring or earlier in the fall, or both later and earlier, thus reducing the length of the growing season disastrously. During certain years days without killing frosts numbered 130 at Aneth, 90 at Blanding, 179 at Hite, and 78 at Monticello.

As corn requires, on the average, 90 to 150 days, and fruit an even longer period to reach maturity, it is obvious that crops suitable for the San Juan country must be selected with discrimination and that crop failures are to be expected.

Temperature $\left({ }^{\circ} F.\right)$ at stations in the San Juan country [From records of U. S. Weather Bureau]

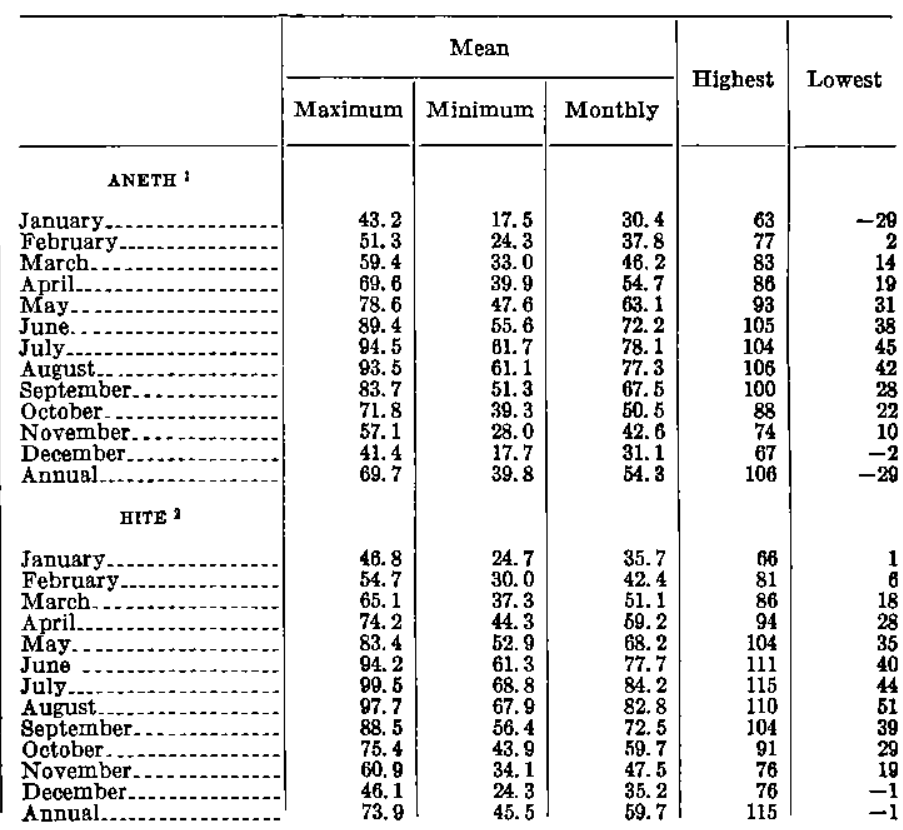


Temperature $\left({ }^{\circ} \mathrm{F}.\right)$ at stations in the San Juan country-Contd.

\begin{tabular}{|c|c|c|c|c|c|}
\hline & \multicolumn{3}{|c|}{ Mean } & \multirow{2}{*}{ Highest } & \multirow{2}{*}{ Lowest } \\
\hline & Maximum & Minimum & Monthly & & \\
\hline \multicolumn{6}{|l|}{ BLUT } \\
\hline 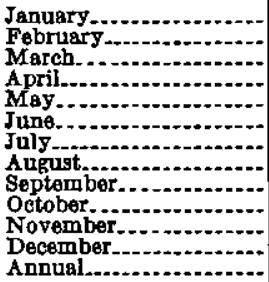 & $\begin{array}{l}39.1 \\
50.0 \\
60.1 \\
69.6 \\
79.8 \\
90.8 \\
94.4 \\
91.9 \\
83.7 \\
71.0 \\
55.0 \\
40.0 \\
68.8\end{array}$ & $\begin{array}{l}16.1 \\
26.6 \\
33.0 \\
40.3 \\
49.7 \\
57.5 \\
65.6 \\
62.3 \\
53.4 \\
40.8 \\
30.2 \\
18.6 \\
41.2\end{array}$ & $\begin{array}{l}27.5 \\
38.3 \\
46.5 \\
55.0 \\
64.7 \\
74.0 \\
80.0 \\
77.1 \\
68.4 \\
56.0 \\
42.6 \\
29.3 \\
55.0\end{array}$ & $\begin{array}{r}62 \\
72 \\
80 \\
88 \\
95 \\
105 \\
109 \\
104 \\
99 \\
89 \\
85 \\
60 \\
109\end{array}$ & $\begin{array}{r}-20 \\
-13 \\
16 \\
20 \\
28 \\
38 \\
40 \\
40 \\
29 \\
20 \\
-1 \\
-18 \\
-20\end{array}$ \\
\hline \multicolumn{6}{|l|}{ BLANDING } \\
\hline $\begin{array}{l}\text { January } \\
\text { February } \\
\text { March } \\
\text { April. } \\
\text { May... } \\
\text { June } \\
\text { July } \\
\text { August } \\
\text { September. } \\
\text { October } \\
\text { November } \\
\text { December } \\
\text { Annual }\end{array}$ & $\begin{array}{l}37.0 \\
44.3 \\
52.6 \\
61.5 \\
70.2 \\
81.7 \\
86.0 \\
84.5 \\
76.5 \\
66.0 \\
52.6 \\
39.1 \\
62.7\end{array}$ & $\begin{array}{l}15.4 \\
21.5 \\
27.5 \\
34.2 \\
41.0 \\
50.3 \\
57.6 \\
55.5 \\
47.4 \\
37.1 \\
26.8 \\
18.0 \\
36.0\end{array}$ & $\begin{array}{l}26.3 \\
32.9 \\
40.0 \\
47.8 \\
55.6 \\
66.0 \\
71.8 \\
70.0 \\
61.8 \\
51.5 \\
39.7 \\
28.4 \\
49.3\end{array}$ & $\begin{array}{r}62 \\
71 \\
86 \\
88 \\
91 \\
110 \\
109 \\
106 \\
100 \\
99 \\
74 \\
65 \\
110\end{array}$ & $\begin{array}{r}-15 \\
-23 \\
4 \\
10 \\
15 \\
28 \\
42 \\
40 \\
20 \\
12 \\
-7 \\
-11 \\
-23\end{array}$ \\
\hline \multicolumn{6}{|l|}{ MONTICELLO } \\
\hline $\begin{array}{l}\text { January } \\
\text { February } \\
\text { March. } \\
\text { April } \\
\text { May... } \\
\text { June... } \\
\text { July } \\
\text { August } \\
\text { Beptember. } \\
\text { October } \\
\text { November. } \\
\text { December. } \\
\text { Annual. }\end{array}$ & $\begin{array}{l}34.4 \\
39.4 \\
46.6 \\
57.3 \\
65.3 \\
76.5 \\
81.4 \\
79.8 \\
72.6 \\
62.7 \\
48.8 \\
36.1 \\
58.4\end{array}$ & $\begin{array}{l}12.5 \\
18.3 \\
24.7 \\
32.1 \\
38.4 \\
47.1 \\
53.4 \\
51.7 \\
44.0 \\
34.8 \\
25.2 \\
15.1 \\
33.1\end{array}$ & $\begin{array}{l}23.4 \\
28.8 \\
35.6 \\
44.7 \\
51.8 \\
61.8 \\
67.4 \\
65.7 \\
58.3 \\
44.2 \\
37.0 \\
25.6 \\
45.4\end{array}$ & $\begin{array}{l}57 \\
80 \\
81 \\
80 \\
85 \\
97 \\
97 \\
98 \\
89 \\
80 \\
70 \\
58 \\
88\end{array}$ & $\begin{array}{r}-12 \\
-21 \\
2 \\
4 \\
14 \\
27 \\
35 \\
37 \\
21 \\
12 \\
-6 \\
-14 \\
-21\end{array}$ \\
\hline
\end{tabular}

1 Length of record, 10 years.

\section{WIND}

At Monticello the recorded direction of prevailing wind was consistently southwest for a 9-year period. At Blanding it was prevailingly south, except for December (southwest) and January (north), for the years 1904-20 and 1923-27, and southwest during 1921-22. These regional directions are those common to the plateau province and are reflected in the shape of trees in exposed positions and in the alinement of dunes and wind-borne debris on the flat surfaces of Sage Plain and Grand Gulch Plateau. But for most of the region the winds are highly variable in direction, strength, and continuity. They blow in and out of canyons, up canyons, down canyons, and around buttes and mesas. They blow up over the box heads of canyons during the day, only to return down canyon at night. During the hot summer days they seem to head from all directions toward sand flats and stretches of naked rocks. The rugged country west of Red House Cliffs provides no long sweeps for the wind, and on the flatter plateaus any material available for wind transportation has long ago been carried eastward and added to the soil of Colorado. Consequently, there are no large areas of dunes, and severe dust storms are infrequent. The most annoying one experienced during field work originated in the plowed fields about Blanding.
SOIL

For the San Juan country as a whole soil is deficient in amount and in fertility. Over Iarge areas it is merely shallow filling of disintegrated material in depressions between projecting rocks, sand temporarily holding its position on wind-swept rocks, or deposits left by storm floods only to be moved by succeeding floods. The patches of soil on canyon and mesa walls, in mountain gullies, and on isolated mesa tops are unfavorably located for utilization. Large areas have no soil at all.

Most of the flat-lying surface rock is siliceous sandstone deficient in mineral plant food. The patches of shale on Sage Plain are small, and the limestones of the "oil fields" are too continuously dry to permit the formation of residual clays. In local parlance the land west of the Clay Hills is "a lot of rocks, a lot of sand, more rocks, more sand, and wind to blow it away." On the whole agricultural soil derived directly from the decomposition of rock in place covers probably not more than 5 percent of San Juan County. The low ground-water tables, the short-lived heavy showers, and the scanty vegetation are unfavorable for the decomposition of rocks and the retention of soil in place.

Nearly all the soil suitable for agriculture is transported soil, carried and deposited in its present position by running water. The soil about Blanding, Verdure, and Monticello, in Mormon Pasture, and along the headwaters of Indian Creek and Allen Canyon is the result of erosion in the Abajo Mountains, which has provided material for transport by the streams that spread from the mountain base. Because this soil is the product of igneous rocks and shale, as well as of sandstone, it includes the necessary inorganic plant foods. The soils about Bluff and Aneth, at the mouth of Red Canyon, and in Montezuma, McElmo, Cottonwood, Comb, and the many other narrow valleys are the tops of flood plains and terraces built by the San Juan, the Colorado, and their tributaries out of materials derived from nearby and distant sources. During the last 50 years most of the soil in these valleys has been carried away by floods. (See p. 102.)

That these transported soils are fertile is shown by the vegetation. Thick sagebrush and oak occupy parts of the alluvial fans about the Abajo Mountains, and groves of cottonwood and willows and dense stands of weeds appear along the San Juan, the Colorado, and most of the wider washes. The ruins of small gardens and cornfields are common about the sites formerly occupied by Cliff Dwellers. At the present settlements, even without irrigation, potatoes and melons are raised, and in favorable seasons wheat yields fairly satisfactory crops. In many places where the soil is suitable in depth and quality lack of water prevents profitable agriculture. 


\section{VEGETATION}

In describing plants collected by the Hayden Survey, Brandegee ${ }^{27}$ speaks of the San Juan Valley above Montezuma Creek as " $a$ line of green a mile wide * * * winding through the gray desert" and flanked by mesas "very barren of vegetation. ${ }^{*} * *$ there are large areas with absolutely nothing growing upon them, and often, even along the streams, our day's journey would be lengthened 4 or 5 miles before grass could be found sufficient for a camping place." $\mathrm{He}$ expressed surprise that the cactus are neither abundant nor large; "the country along the San Juan River has not a single additional species of cactus and lacks very nearly all the species of the eastern (Rocky Mountain) slope." Also "the genus Astragalus is represented by few species, and these are not very abundant." On the other hand, "Eriogonium is well represented in species, and the plants are very abundant $* * *$ nine annual species grow in San Juan Valley; in the Arkansas Valley but three are found and in northern Colorado but one." Eastwood ${ }^{28}$ and also Rydberg ${ }^{28}$ have pointed out certain exceptional features in the flora of the San Juan country, which in general shows a distribution and relative abundance of species common to the Colorado Plateaus.

In the San Juan country, as elsewhere in the plateau province, types of vegetation are related to altitude but are also closely related to topographic features and available water supply. In general the distribution of plant life resembles that of the Kaiparowits region, ${ }^{30}$ but the altitude zones defined in terms of temperature and rainfall are locally much modified by the conditions of isolation imposed by position and height of canyon walls and by the wide range in altitude of the prevailing sandstone soils. Except in forested areas the vegetation is gray, and in places its color is less conspicuous than that of the rocks on which it grows; bright-green plants constitute but dots and short ribbons disposed here and there in the landscape.

Forests of tall trees cover parts of the Abajo Mountains and Elk Ridge, trees of stunted growth cover the plateau stretches at intermediate altitudes, and the lower lands have a sparse and specialized flora. Dense thickets make the heads of many canyons impassable, and masses of reeds grow about little-used springs; but in general the trees are widely spaced, the shrubs grow in clumps, and the grass in separate bunches. (See pls. $2, B ; 4, A ; 5, B ; 6, A ; 11, C ; 16, B, C ; 18, A$.) Continuous turf was seen only in Lake Canyon and in small meadows on Elk Ridge and the Abajo Mountains. Vegetation characteristic of salt flats and of alkali lands

\footnotetext{
" Brandegee, T. S., The flora of soutbwestern Colorado: U. S. Geol. and Geog. Survey Terr. Bull., vol. 2, no. 3, pp. 227-248, 1876.

29 Eastwood, Alice, Report on a collection of plants from San Juan County, in southeastern Utah: California Acad. Sci. Proc., 2d ser., vol. 6, pp. 271-329, 1896.

30 Rydberg, P. A., Report of a trip to southeastern Utah in the summer of 1911: New York Bot. Garden Jour., vol. 12, pp. 237-253, 1911.

to Gregory, H. E., and Moore, R. C., The Kaiparowits region: U. S. Geol. Survey Prof. Paper 164, pp. 24-27, 1931.
}

grows along Lime Creek and in a few other places. (See pls. $4, B, C ; 16, D$.)

Southward from the Abajo Mountains vegetation becomes less and less abundant and the plants decrease in size as the San Juan River is approached, but few areas exceeding an acre are devoid of trees and shrubs; even the canyon walls are partly clothed. Over large parts of Grand Gulch Plateau and of the region between the Red House Cliffs and Glen Canyon, however, plant life is poorly represented. Widely spaced individual small trees rise from the plateaus; shrubs and grasses and weeds appear along valley bottoms and in rock cracks; in places only sand dunes provide the conditions necessary for plant growth. Miles of bare canyon walls and broad stretches of bare surface rock are conspicuous. (See pls. $6, C, D ; 12, D ; 13, A, B ; 18, A$.) A peculiar feature is the absence from Wilson Mesa of the piñon and juniper.

For most of the San Juan country the conspicuous vegetation consists of piñon, juniper, sagebrush, and cottonwood. Except at altitudes above about 8,000 feet, piñon and its running mate, Utah juniper ("cedar"), are nearly everywhere in sight. On the flat lands separating streams leading from Elk Ridge and the Abajo Mountains, on knolls rising above Sage Plain, and on some valley sides they form continuous, vigorously growing forests of closely set trees; "Cedar Flats" and "Cedar Mesa" are local names for scores of benches and flat-topped plateau remnants. (See pls. 2, $C ; 3, C$; $5, B ; 6, A ; 8, A ; 12, A ; 13, C ; 16, B$.) Sagebrush is even more widely spread. Growing with piñon and juniper or standing alone it seems to be the dominant plant at altitudes between 6,000 and 7,000 feet, but it grows well also high on the slopes of the Abajo Mountains and down in the canyons of the San Juan and the Colorado. It forms clumps 5 to 8 feet high at the base of many canyon walls. (See pl. 2, A.) Cottonwoods grow in the alluvial soil of most canyon bottoms. Along the upper San Juan, except where their supporting ground has been removed by floods, cottonwoods form groves of big trees; above Bluff they are continuous for 2 miles. Likewise in upper Glen Canyon cottonwoods are common on the higher stream flats, and thousands of seedlings are crowded on sandbars and close to the banks of the river. On the floors of the long dry washes leading from the Abajo Mountains and Elk Ridge, cottonwoods standing alone or with a few companions extend their friendly branches as protection from the scorching sun. Many of them are old gnarled trees with trunks 4 to 6 feet in diameter. The piles of driftwood along these streams consist chiefly of cottonwood. (See pls. 2, $C$; $3, C ; 9, A$.)

Like juniper, piñon, sagebrush, and cottonwood, oak brush is widely distributed. Small thickets of these tough trees, which the explorer soon learns to go around instead of through, grow in valleys, on ridges, and plateau tops, and particularly near the heads of can- 
yons. At places about the base of the Abajo Mountains oak brush forms almost pure stands several acres in extent.

Certain trees and shrubs and annuals are somewhat definitely localized. Except for a few individuals in exceptionally favorable spots, fir, spruce, balsam, aspen, manzanita, birch-leaf mahogany, Oregon grape, myrtle brush, snowberry, serviceberry, chokecherry, currant, gooseberry, and raspberry were seen only at altitudes exceeding 7,000 feet. Yellow pine, though attaining its greatest abundance and largest size in this zone, grows also in canyons at much lower altitudes. On the Abajo Mountains the forests of fir and pine cover the northern slopes of spurs and ridges; grass covers the top and the southern slopes. In addition to piñon and cedar and sage the most noticeable vegetation of the plateaus, broad canyon bottoms, and rock benches at altitudes between 5,000 and 7,000 feet consists of rabbitbrush, bitterbush, squawbush, bullberry, boxelder, alder, scrub maple, old man, and brigham tea. The rare and beautiful purple sage was found growing in dunes near Moki Canyon. Willows, rushes, some of the sedges, and ferns grow wherever there is water, regardless of altitude and soil.

High on the canyon walls along the San Juan River and Butler Wash the spring line at the base of the bare Bluff sandstone is marked by a band of green vegetation formed by plant species that seem out of place in the present scheme of distribution. In contrast to the vegetation common to the Upper Sonoran zone, growing along the river below and on the mesa tops above, the plants tucked away in moist niches on the cliffs include Aquilegia micrantha, Primula farinosa, Solidago canadensis, Mimulus cardinalis, Oenothera biennis var. grandiflora, Shepherdia rotundifolia, and Epipactis gigantea. Eastwood ${ }^{31}$ speaks of this habitat as "a boreal oasis in the midst of a Sonoran desert", perhaps dating from a time when the climate of the whole San Juan region was colder.

Flowering plants are widely distributed. In appropriate seasons roses, daisies, asters, larkspurs, dandelions, phlox, snapdragons, sego lilies, and Indian paintbrush are abundant. Among the yellow pines of Elk Ridge buttercups, fireweed, green dock, harebell, blue gentian, columbine, meadowrue, mint, stonecrop, strawberry, tansy, yarrow, bluebell, and yellow umbel find a congenial home. At lower altitudes evening primroses appear, and along most trails honeysuckle, plantains, sunflowers, peppergrass, and wallflowers are common. The yellow and purple beeflower (Cleome) lines the washes for miles. Here and there the conspicuous Jimson weed stands out from bare rock walls.

In the La Sal National Forest, a large highland area that includes the Abajo Mountains and Elk Ridge, six vegetation types have been outlined. In brief, their features are as follows:

\footnotetext{
" Eastwood, Alice, Report on a collection of plants from San Juan County in bouthwestern Utah: Californis Acad. Sci. Proc., 2d ser., vol. 6, pp. 271-328, 1898.
}

1. Spruce-balsam type.-Limited to the high rugged mountainous areas between altitudes of 7,500 and 11,500 feet, where both the soil and the air contain a large amount of moisture. The predominant tree is Engelmann spruce, with which grow balsam and some Douglas fir.

2. Yellow-pine type-Characteristic of all high plateaus, between altitudes of 6,700 and 9,000 feet. It grows best on deep soils of sandstone origin; on clay soils it produces open stands and parks. On the Abajo Mountains this type covers about 56,500 acres.

3. Piñon and juniper type.-Altitude 5,000 to 8,000 efet. Consists chiefly of piñon and Utah juniper, with yellow pine, mahogany, oak, and serviceberry, growing on benches and plateaus.

4. Brushland type.-Grows regardless of altitude, soil, or exposure, except under fairly dense stands of trees. Oak and serviceberry are dominant, though manzanita, snowberry, buckbrush, and sage are present. This type covers about half of the area classed as "forest."

5. Sagebrush type.-At altitudes below 9,000 feet sagebrush is commonly associated with the species that constitute the brushland type. Over areas of considerable size it is the dominant shrub.

6. Mountain meadow type.-Range in altitude is 7,600 to 11,000 feet. Found mainly in the form of open grassy parks, consisting of blue, gramma, and pine grasses, bluestem, white clover, sedge, wire grass, and many species of weeds. This type covers less than 1 percent of the highland areas.

Outside the boundaries of the national forest piñon, juniper, and sagebrush continue as the conspicuous vegetation at altitudes above 5,000 feet. Below that altitude, on benches and flats overlooking the San Juan River, shadscale and rabbitbrush are common. At still lower altitudes greasewood and the alkali-loving saltgrass and pickleweed constitute the plant life in a few places.

The following list of plants collected on Elk Ridge and the Abajo Mountains and in areas at lower altitudes west of Elk Ridge has been submitted by Orange F. Olson, of the United States Forest Service:

\section{Plants found at 8,000 to 10,000 feet on Elk Ridge and the Abajo Mountains \\ TREES}

Abies concolor (white fir, black balsam).

Abies lasiocarpa (alpine fir, white balsam).

Picea engelmanni (Engelmann spruce).

Pinus flexilis (limber pine).

Pinus ponderosa (western yellow pine).

Populus tremuloides (quaking aspen).

Pseudotsuga taxifolia (Douglas fir, red pine).

SHROBS

Acer glabrum (?) (scrub maple).

Amelanchier alnifolia (serviceberry).

Arctostaphylos uva-ursi (manzanita, bearberry). 
Artemisia tridentata (sagebrush).

Ceanothus velutinus (chaparral).

Cercocarpus parvifolius (birch-leaf mahogany).

Chrysothamnus sp. (rabbitbrush).

Grossularia sp. (gooseberry).

Lonicera utahensis (twirberry).

Odostemon repens (Oregon grape).

Pachystima myrsinites (myrtle brush).

Peraphyllum ramosissimum (wild apple).

Prunus demissa (chokecherry).

Purshia tridentata (bitterbush).

Quercus gambelii (Gambel oak).

Ribes saxosum (currant).

Rubus strigosus (raspberry).

Salix (several species) (willow).

Sambucus melanocarpa (elderberry).

Symphoricarpos vaccinioides (snowberry).

\section{GRASSES}

Agropyron smithii (bluestem).

Agropyron spicatum (spiked wheatgrass).

Agropyron tenerum (slender wheatgrass).

Agrostis alba (redtop).

Agrostis hiemalis (tickle grass).

Bouteloua gracilis (grama grass).

Bromus marginatus (bromegrass).

Bromus polyanthus (bromegrass).

Bromus porteri (bromegrass).

Calamagrostis rubescens (pinegrass).

Carex (several species) (sedge grass).

Deschampsia caespitosa (tufted hairgrass).

Juncus (several species) (rush grass).

Koeleria cristata (Koeleria).

Phleum alpinum (mountain timothy).

Poa fendleriana (Fendler poa).

Poa sandbergil (Sandberg poa).

Sitanion hystrix (squirreltail grass).

Stipa minor (needlegrass).

Stipa occidentalis (porcupine grass).

Achillea lanulosa (yarrow).

HERBg

Aconitum columbianum (monkshood).

Allium (several species) (wild onion).

Aquilegia sp. (columbine).

Aragalus (several species) (locoweed).

Arenaria canadensis (flower grass).

Arnica sp. (arnica).

Balsamorrhiza sagittata (balsam root).

Bursa bursa-pastoris (shepherd's purse).

Calochortus nuttallii (sego-lily).

Castilleja sp. (Indian paintbrush).

Chamaenirion angustifolium (fireweed).

Chenopodium album (lambsquarters).

Claytonia sp. (springbeauty).

Clematis douglasii (harebell).

Cogswellia sp. (parsley).

Collomia linearis (collomia).

Crepis sp. (mountain dandelion).

Delphinium barbeyi (larkspur).

Erigeron (several species) (fleabane).

Eriogonum (several species) (Indianroot).

Erysimum asperum (wallflower).

Fragaria americana (strawberry).

Frasera jamesiana (elk weed).

Gayophytum sp. (kitchen weed).

Gentiana elegans (fringed gentian).

Geranium viscosissimum (crowfost).
Gymnolomia multiflora (mountain sunflower

Helenium hoopesii (sneezeweed).

Heracleum lanatum (cow cabbage).

Heuchera (red root).

Lapula floribunda (stickseed).

Lathyrus leucanthus (pea).

Leontodon taraxacum (common dandelion).

Linum lewisii (flax).

Lupinus alpestris (wild bean).

Mentha (several species) (mint).

Mertensia (several species) (bluebell).

Mimulus longsdorfii (monkeyflower).

Pentstemon (several species) (snapdragon).

Phacelia sp. (phacelia).

Phlox (several species) (phlox or aweet-william).

Plantago (2 species) (plantain).

Polemonium (several species) (skunkweed).

Polygonum aviculare (knotweed).

Polygonum douglasii (knotweed).

Potentilla filipes (cinquefoil).

Pseudocymopterus tiedestromii (yellow umbel).

Ranunculus sp. (buttercup).

Rumex mexicanus (sour dock).

Sedum gormania (stonecrop).

Senecio (several species) (butterweed).

Solidago sp. (goldenrod).

Sophia incisa (tansy mustard).

Thalictrum fendleri (meadowrue).

Trifolium (several species) (clover).

Urtica gracilis (nettle).

Washingtonia sp. (sweet anise).

Wyethia amplexicaulis (green dock).

Plants found at 4,000 to 8,000 feet between the Colorado River and Elk Ridge

TREES

Acer negundo (boxelder).

Alnus tenuifolia (alder).

Cercocarpus parvifolius (mountain-mahogany).

Juniperus monosperma (red cedar).

Juniperus scopulorum (white cedar).

Juniperus utahensis (Utah cedar or juniper).

Pinus edulis (piñon).

Pinus ponderosa (western yellow pine).

Populus angustifolia (cottonwood).

Populus tremuloides (aspen, around 8,000 feet)

Acer sp. (scrub maple).

SHRUBS

Artemisia aromatica (aroma sage).

Artemisia tridentata (sagebrush).

Atriplex canescens (saltbush or shadscale).

Betula sp. (birch).

Ceanothus velutinus (chaparral).

Chrysothamnus (several species) (rabbitbrush).

Coleogyne racemosissima (blackbrush).

Cornus sp. (dogwood).

Cowania neomexicana (bitterbush).

Crataegus sp. (hawthorn).

Ephedra antisyphilitica (mountain rush or: brigham tea).

Eurotia lanata (white sage).

Peraphyllum sp. (wild apple).

Petradora sp. (Petradora or stone bush).

Purshia tridentata (bitterbush).

Quercus sp. (live oak).

Salix (several species) (willow).

Sarcobatus vermiculatus (greasewood). 
GRASSES

Agropyron smithii (bluestem).

Bouteloua gracilis (grama grass).

Carex sp. (slough grass).

Elymus condensatus (giant ryegrass).

Festuca (numerous species) (fescue grass).

Juncus confusus (wire grass).

Oryzopsis exigua (ricegrass or sandgrass).

Poa (numerous species) (bluegrass).

Sporobolus (dropseed).

Stipa comata (needle-and-thread grass).

HERBS

Achillea lanulosa (yarrow).

Aragallus (several species) (loco).

Arenaria congesta (flower grass).

Aster sp. (aster).

Balsamorrhiza sagittata (balsamroot).

Calochortus nuttalli (sego-lily).

Carduus drummondi (Canadian thistle).

Castilleja sp. (Indian paintbrush).

Chenopodium album (pigweed or lambsquarters).

Cleome lutea (yellow beeflower).

Cleome serrulata (purple beeflower).

Delphinium arizonicum (low larkspur).

Equisetum arvense (horsetail).

Equisetum robustum (horsetail).

Erigeron (several species) (daisy).

Eriogonum (several species) (Indianroot).

Erodium cicutarium (filaree).

Erysimum asperum (wallflower).

Eucephalus engelmanni (tall aster).

Gayophytum sp. (kitchen weed).

Gilia aggregata and others (boneysuckle).

Gutierrezia sp. (snakeweed).

Gymnolomia multiflora (sunflower).

Lappula sp. (stickseed).

Leontodon taraxacum (dandelion).

Lepidium ramosum (peppergrass).

Lithospermum pilosum.

Malva rotundifolia (common mallow).

Onagra sp. (evening-primrose).

Orthocarpus purpureus albus (orthocarpus).

Pentstemon (several species) (snapdragon).

Phlox (several species) (phlox).

Physaria lesquerella (bladderpod).

Plantago sp. (plantain).

Polygonum avieulare (knotweed).

Polygonum douglasii (knotweed).

Salsola pestifer (Russian thistle).

Senecio (several species) (butterweed).

Yucca (3 species) (Indian soapweed).

Zygadenus sp. (deathcamas).

Along the San Juan River between Aneth and Goodridge, Eastwood ${ }^{32}$ recorded the following plants in July 1895:

Abronia cycloptera (sandverbena).

Abronia fragrans.

Abronia turbinata var. marginata.

Actinella leptoclada.

32 Eastwood, Alice, Report on a collection of plants from San Juan County, in soutbeastern Utah: Californis Acad. Sei. Proc., 2d ser., vol. B, pp. 271-328, 1886.
Adiantum eapillus-veneris (maidenhair fern).

Allionia incernata.

Ambrosia (ragweed).

Ampelopsis quinquefolia (woodbine).

Amsonia angustifolia var. texana.

Amsonia brevifolia.

Andropogon scoparium.

Aplopappus gracilis.

Apocynum cannabinum (Indian hemp).

Aquilegia micrantha (columbine).

Arenaria fendleri (starwort).

Argemone intermedia (thistle poppy).

Aristida purpurea.

Asclepias involucrata var. tomentosa (silkweed).

Asclepias stenophylla.

Aster canescens var. aristatus.

Aster laevis.

Aster multiflorus.

Aster spinosus (aster).

Astragalus preussii (locoweed).

Astragalus sabulonum (locoweed).

Astragalus subcinereus (locoweed).

Atriplex (saltbush).

Atriplex canescens (saltbush).

Atriplex caput-medusae (saltbush).

Atriplex confertifolia (saltbush).

Atriplex cornuta (saltbush).

Atriplex powellii (saltbush).

Atriplex truncata (saltbush).

Berberis fremontii (barberry).

Blepharidachene kingii.

Bouteloua oligostachya.

Castilleja linariaefolia (Indian paintbrush).

Celtis occidentalis (hackberry).

Chara sp.

Chenopodium fremonti (goosefoot).

Chenopodium leptophyllum.

Chrysopsis villosa var. scabra (golden-aster).

Cladothrix lanuginosa.

Clematis ligusticifolia (clematis).

Cleome integrifolia (beeweed).

Cnicus rothrockii var. diffusus (thistle).

Coldenia hispidissima.

Comandra umbellata (toadflax).

Cordylanthus wrightii (snakehead).

Cowania mexicana (cliffrose)

Cuscuta arvensis (dodder).

Cycloloma platyphyllum (tumbleweed).

Datura meteloides (thorn apple).

Dicoria brandegei.

Dicoria paniculata.

Elymus canadensis.

Encelia frutescens.

Epipactis gigantea (stream orchid).

Equisetum laevigatum (scouring-rush).

Erigeron bellidiastrum (daisy).

Erigeron canadensis.

Erigeron sparsifolius.

Eriogonum alatum.

Eriogonum cernuum.

Eriogonum cernuum var. umbraticum.

Eriogonum divaricatum.

Eriogonum flexum.

Eriogonum inflatum.

Eriogonum jonesii.

Eriogonum mearnsii.

Eriogonum microthecum var. rigidum.

Eriogonum ramosissimum. 
Eriogonum wetherillii.

Euphorbia fendleri.

Euphorbia flagelliformis (spurge).

Eurotia lanata (winterfat).

Forestiera neomexicana (ironwood).

Franseria hookeriana.

Fraxinus anomala (1-leaved ash).

Frasera utahensis.

Galium acutissimum (bedstraw).

Gaura coccinea (red gaura).

Gilia aggregata (gilia).

Gilia congesta var. nuda (gilia).

Gilia gunnisoni (gilia)

Gilia haydeni (gilia).

Gilia inconspicua (gilia).

Gilia leptomeria (gilia).

Gilia longiflora (gilia).

Gilia multiflora (gilia).

Gilia pumila (gilia).

Gilia subnuda (gilia).

Grayia brandegei.

Grayia polygaloides.

Grindelia squarrosa var. nuda.

Grindelia stylosa (gumweed).

Gutierrezia californica.

Hedeoma drummondii (pennyroyal).

Helianthus petiolaris var. canescens (sunflower).

Heliotropium convolvulaceum (birdseed).

Hilaria jamesii.

Houstonia saxicola.

Hymenatherum pentachaetum.

Hymenopappus filifolius.

Juncus xiphioides (rush).

Juniperus occidentalis var. monosperma.

Krynitzkia jamesii.

Lepidium alyssoides (peppergrass).

Lesquerella fendleri.

Linum aristatum var. subteres (yellowflax).

Lycium andersoni.

Lycium pallidum.

Lygodesmia exigua.

Malvastrum coccineum (red mallow).

Malvastrum leptophyllum (red mallow).

Mentzelia pterosperma.

Mentzelia pumila.

Mimulus cardinalis.

Oenothera biennis var. grandiflora.

Oenothera brevipes (evening-primrose).

Oryzopsis cuspidata.

Oxybaphus angustifolius var. viscidus.

Oxytenia acerosa.

Panicum bulbosum.

Pentstemon bridgesii (red pentstemon).

Petalostemon candidus (prairieclover).

Phacelia crenulata.

Physalis fendleri (groundcherry).

Poliomintha incena.

Polygala acanthoclada var. intricata.

Populus fremontii var. wislizeni (cottonwood).

Primula farinosa (cliff primrose).

Psoralea juncea.

Psoralea micrantha.

Quercus gambelii (oak).

Quercus unrlulata (ogk).

Rhamnus purshiana (cascara).

Rhus canadensis var. simplicifolia (Ute lemonade).

Rosa fendleri (wild rose).

Salix cordata (willow).
Salix lasiandra var, fendleriana (willow).

Salix longifolia (willow).

Sarcobatus vermiculatus (greasewood).

Senecio multilobatus (ragwort).

Shepherdia rotundifolia (buffalo berry).

Sida hederacea (Alaki mallow).

Solidago canadensis (goldenrod).

Sporobolus airoides.

Stanjeya pinnatifida.

Stephanomeria pentachaeta.

Suaeda torreyana (sea blite).

Talinum brachypodium.

Thelesperma gracile.

Thelypodium sp.

Townsendia incana.

Wyethia scabra (compassplant).

Of the 444,348 acres that constitute the national forests of San Juan County, 221,773 acres is classed as timber land, on which it is estimated there are about $99,000,000$ board feet of yellow pine, $50,000,000$ feet of Engelmann spruce, 690,000 feet of Douglas fir, 8,700,000 feet of other conifers, 460,000 cords of aspen, and 14,000 cords of piñon and juniper. Some yellow pine is sawed into timber for local use, but the trees are cut chiefly for poles and for firewood.

\section{ANIMAL LIFE}

The San Juan country is part of the zoologic province that includes southern Utah, southwestern Colorado, northern Arizona, and northwestern New Mexico, and its indigenous animal life is essentially that described for these regions by Coues, ${ }^{33}$ Allen ${ }^{34}$ Cooke, ${ }^{35}$ Gilman, ${ }^{36}$ Barnes, ${ }^{37}$ Woodbury, ${ }^{38}$ and others. The fauna is chiefly that of the upper Sonoran, transition, and Canadian zones as defined by Bailes. ${ }^{39}$ Its species are more closely related to those in the Great Basin region than to those within and east of the Rocky Mountains.

During the field work the mammals most frequently noted at lower altitudes were several kinds of rats, grasshopper mouse, white-footed mouse, harvest mouse, meadow mouse, pocket mouse, prairie dog, spotted squirrel, banded squirrel, pocket gopher, rock chipmunk, jack rabbit, cottontail rabbit, and cave bat. A few coyotes, skunks, and ring-tailed cats were seen on Sage Plain, muskrats and beavers along the San Juan River, and otters in Glen Canyon. Mountain sheep, reported as plentiful in the eighties, seem now to be restricted to lower Dark Canyon, the south end of Grand

sa Coues, Elliott, and Yarrow, E. C., Report upon the collections of mammals mada in portions of Nevada, Utah, California, Colorado, New Mexico, and Arizona during the years 1871, 1872, 1873, and 1874: U. S. Geog. and Geol. Expl. W. 100th Mer. Rept. vol. 5 , pp. $37-129,1875$.

"Allen, J. A., List of mammals collected by Mr. Chas. P. Rowley in the San Juan region of Colorado, New Mexico, and Utah, with descriptions of new species: Am. Mus. Nat. History Bull., vol. 5, pp. 69-84, 1893.

is Cooke, W. W., The birds of Colorado: Colorado State Agr. Coll. Bull. 37, 44, and $56,1807-1900$.

26 Gilman, M. F., Birds of the Navajo Reservation in New Mexico: Condor, vol. 10, pp. 146-152, 1908 .

${ }^{27}$ Barnes, C. T., Mammals of Utah: Utah Univ. Bull., vol. 12, no. 15, pp. 1-166, 1922.

J" Woodbury, A. M., Reptiles of Utah: Utah Univ. Bull., vol. 21, no. 5, 1931.

"Bailey, Vernon, Life zones and crop zones of New Mexico: U. \$. Bur. Biol. Survey

North Amerisan Fauns, no. 35, 1913 


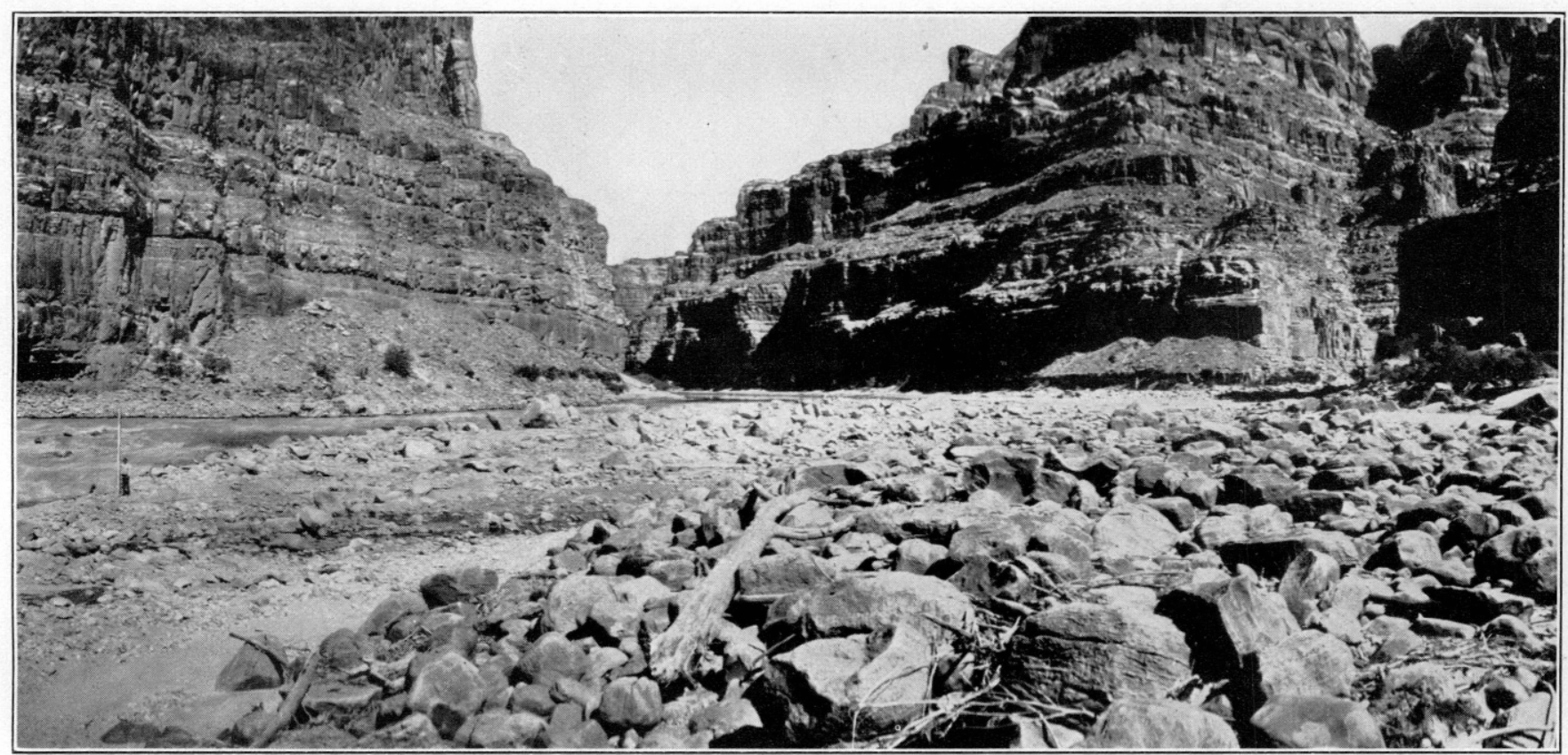

A. CATARACT CANYON.

View louking upstream al moulh of Dark Catyon. Carhoniferous strala

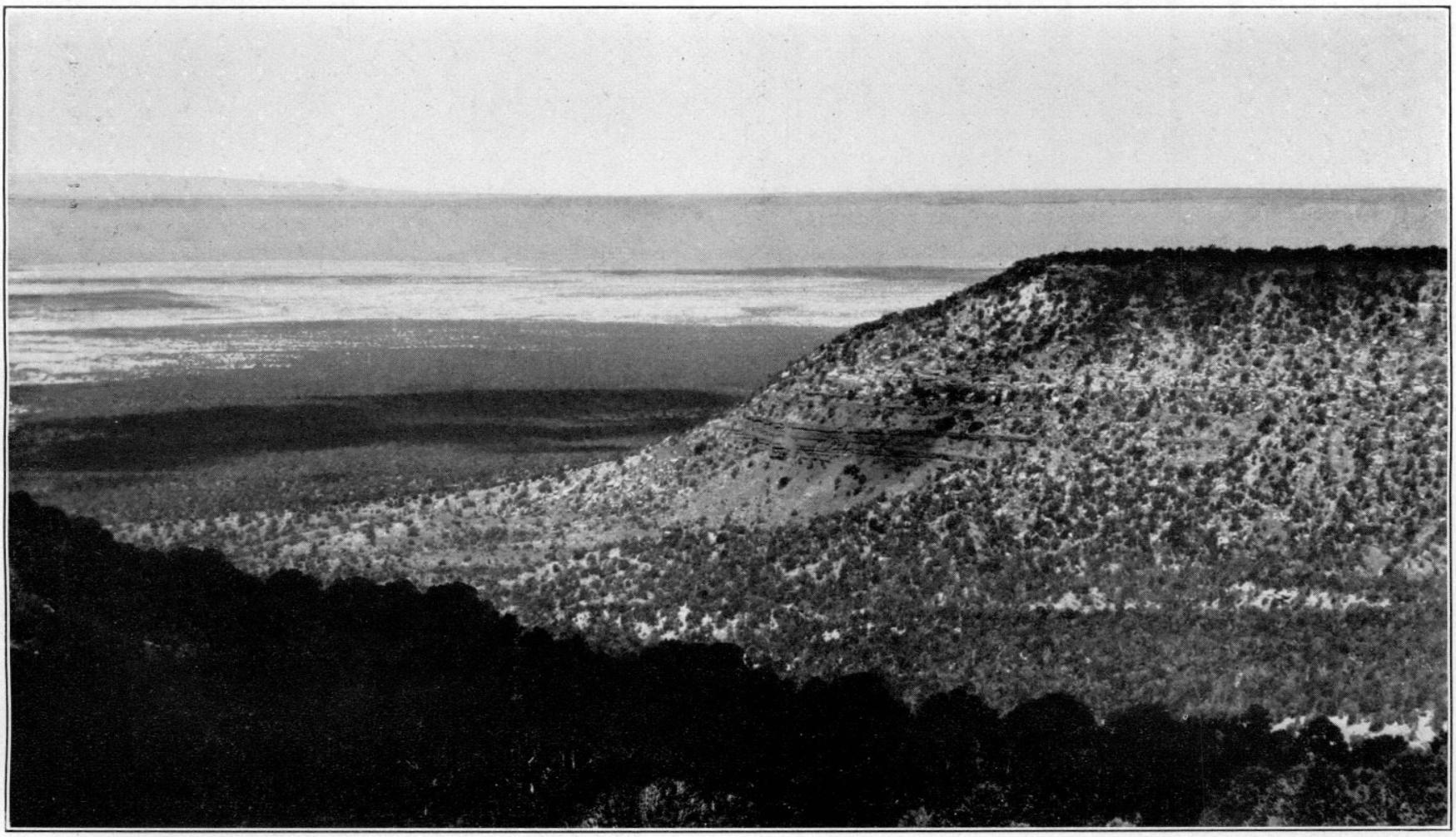

B. YIEW IOOKING NORTIHEST FROM HEAD OF ARMSTRONG CANYON.

Virw across flat into which upper While Canyon and jls tributaries are cul. J'holorraph by W. T. Lar. 


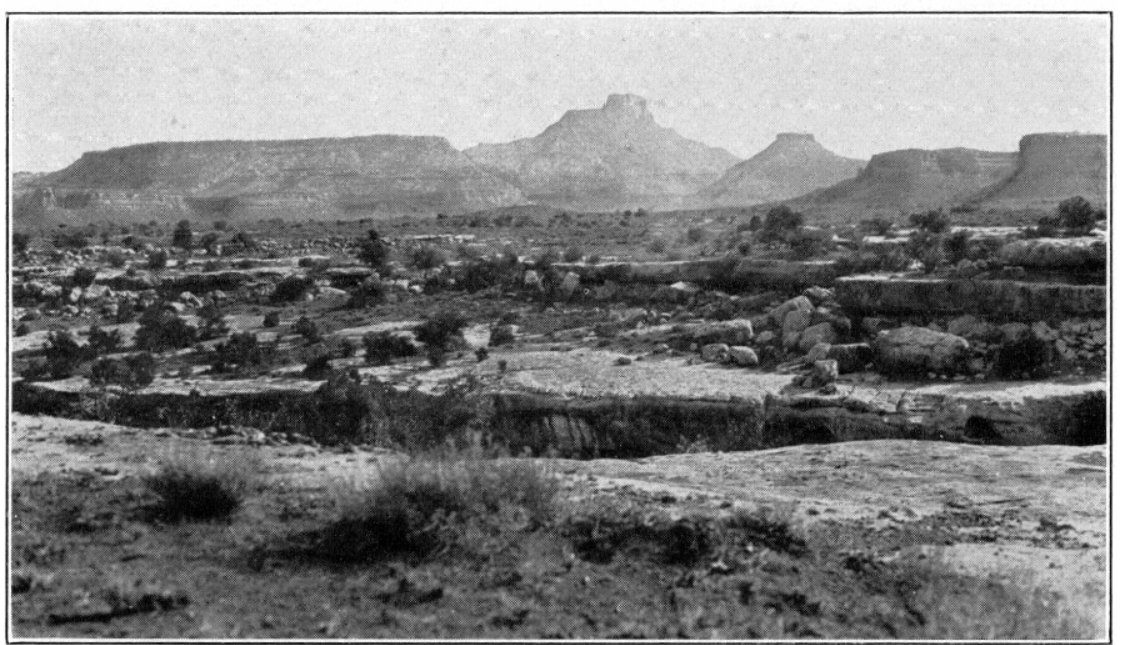

A. WHITE CANYON BETWEEN ROCK SPRINGS AND SOLDIERS CROSSING. Foor of outer canyon developed in Cedar Mesa strata into which (Toreground) the inner canyon is
sunk 300 feet. Wall of outer canyon (distance) consists of Permian and Triassic stral 1 lopjed hy buttes of Jurassic.

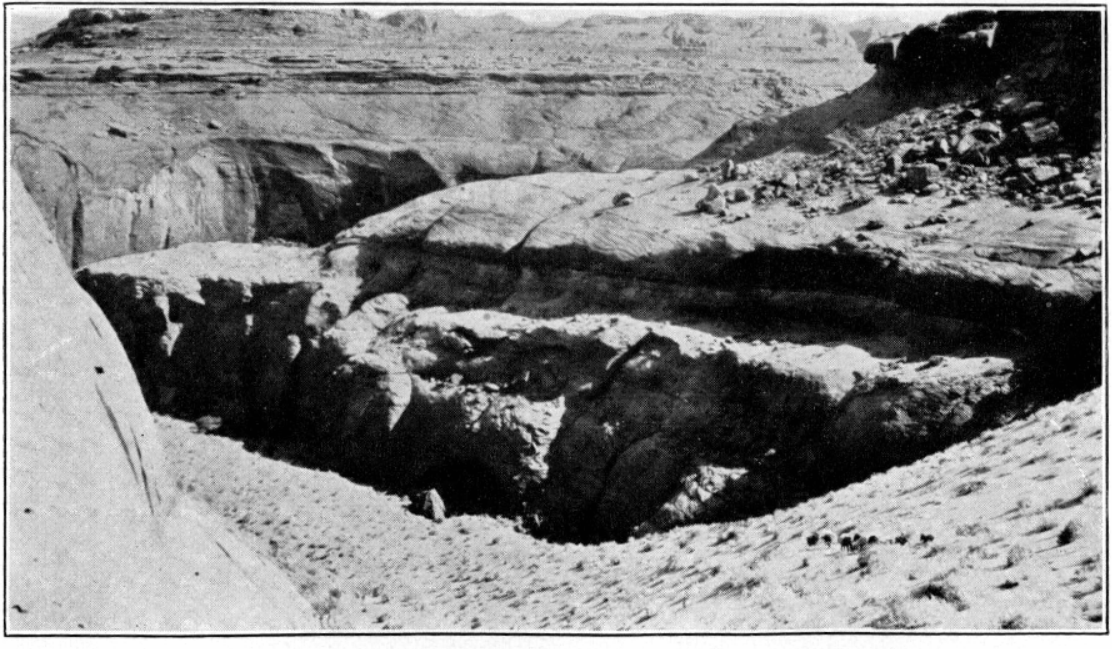

c. ENTRANCE TO MOKI CANYON AT' RED CONE SPHING.

Navajo sandstone capped by strala of San Rafnel proup. Dimensions indic itcd by comparison with

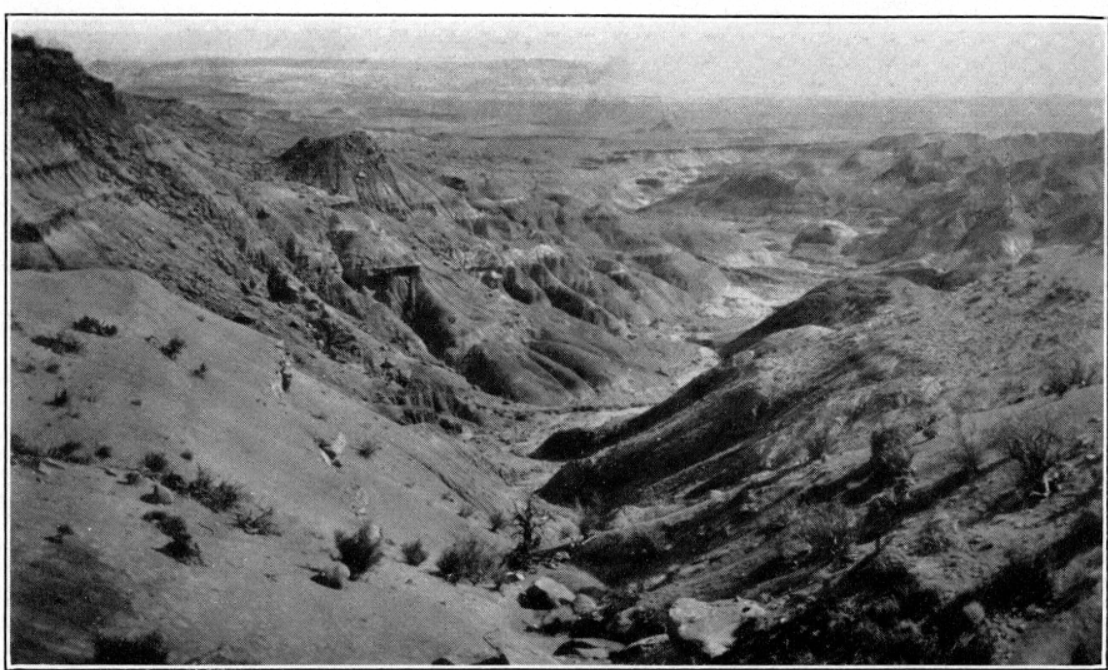

B. CLAY HILLS.

Passage through Red House Cliffs on the Hole in the Rock road from Escalante to Bluff. Chinle formation. I'hotograph by A. A. Kerr.

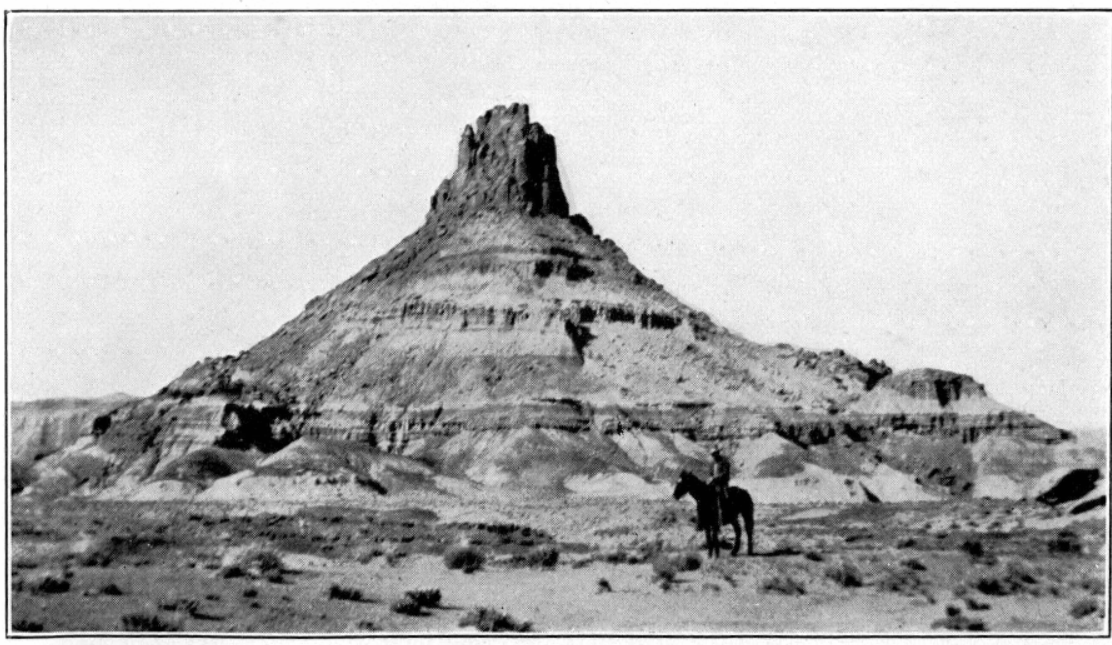

D. CASTLEIBUTte ON DIVIDE BETWEEN WHITE CANYON AND RED CANYON. Chinle strata capped by Wingate sandstone. 


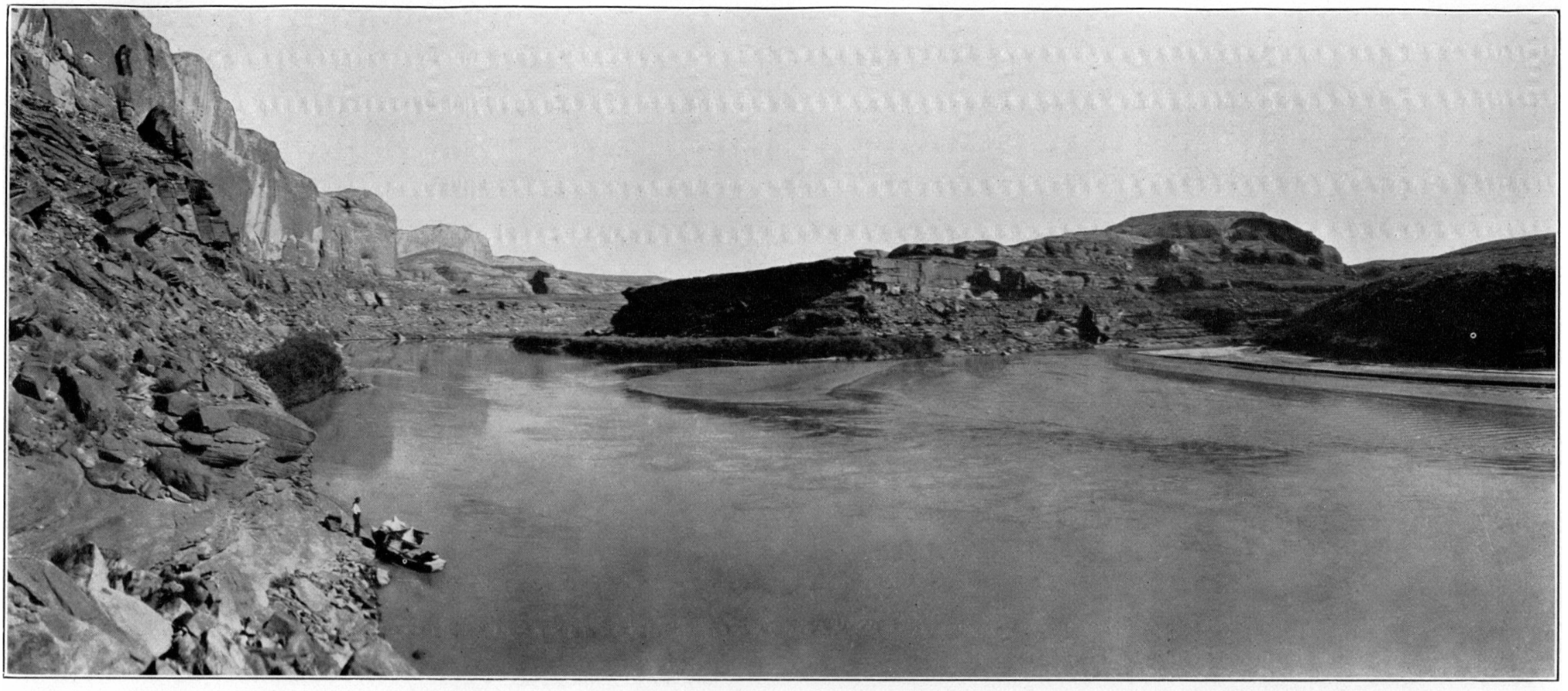

A. VIEW LOOKING UPSTREAM AT JUNCTION OF COLORADO AND SAN JUAN RIVERS. Kaycutu and Navajo strata.

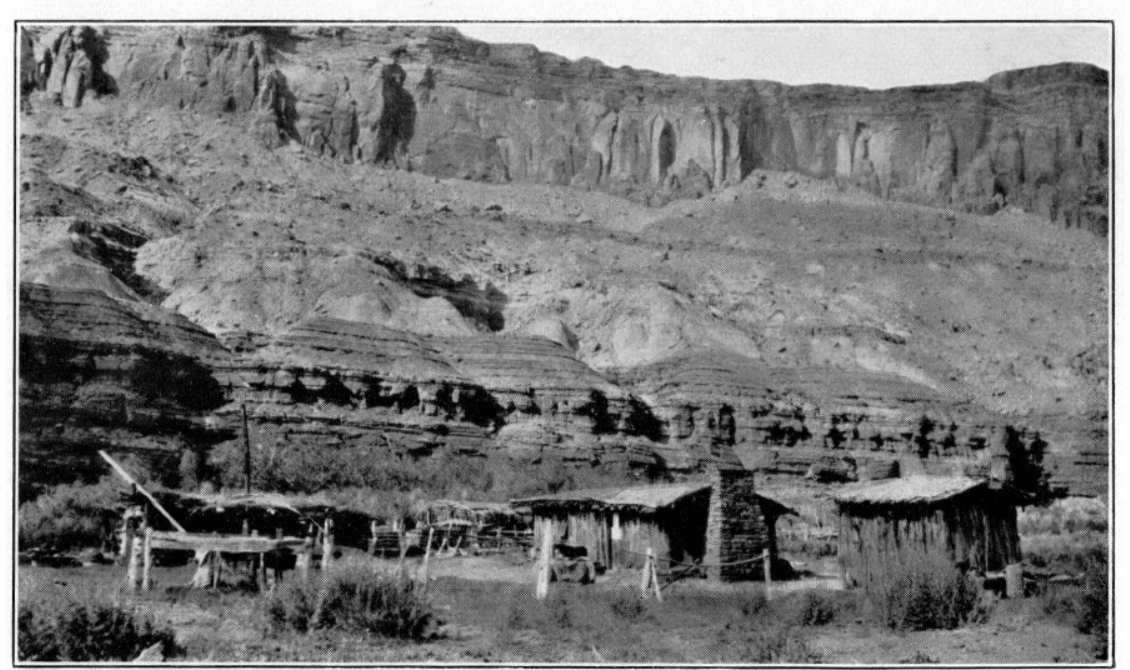

B. VIEW LOOKING SOUTHWEST ACROSS THE CANYON AT HITE.

Wall includes Permian (Organ Rock), Triassic, and Jurassic (?) (Wingate and Kayenta). The Colorado
River flows between buildings and base of cliff. Photograph by M. R. Thorpe,

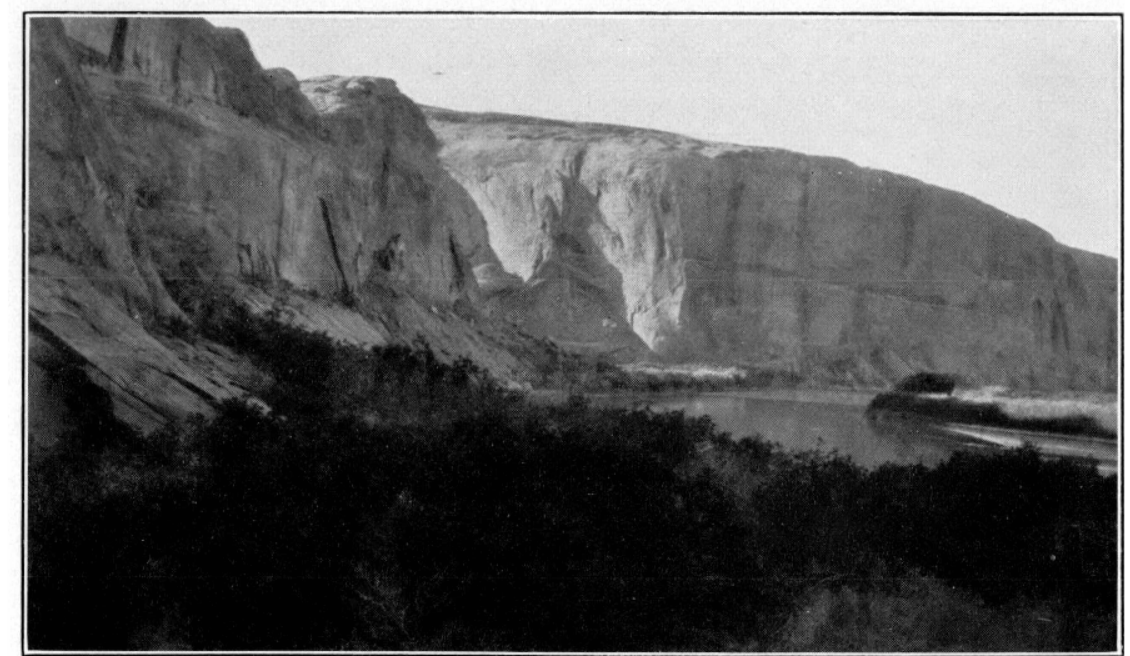

C. VIEW LOOKING DOWNSTREAM AT MOUTH OF MOKI CANYON. Wall of Navajo sandstone $1,600+$ feet high. 


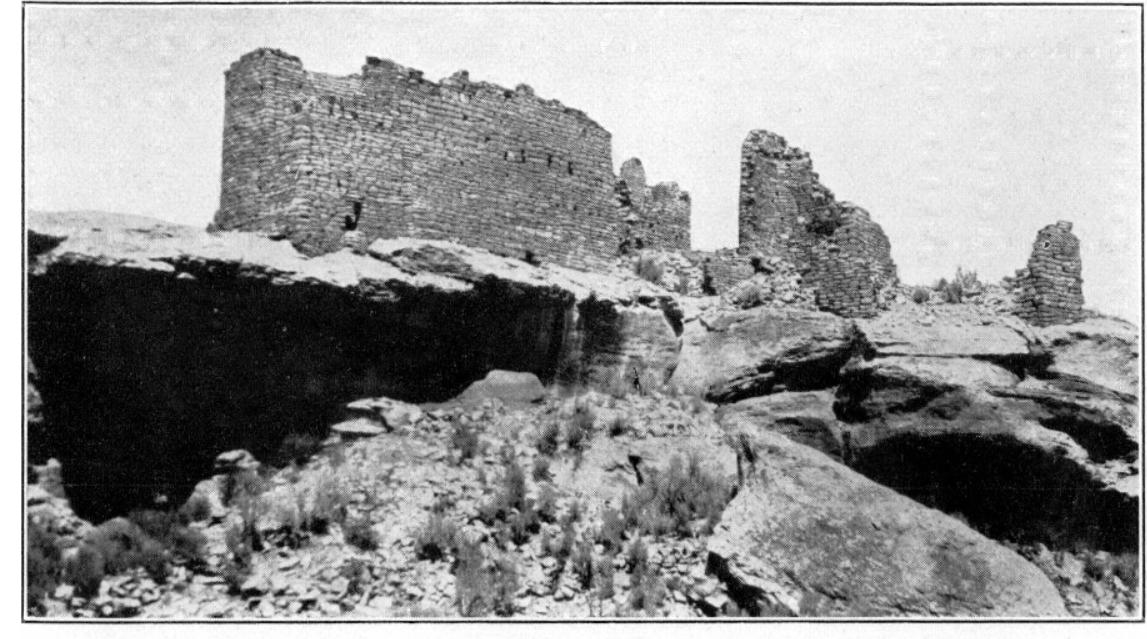

A. BUINS OF CLIFF HOUSE, HOVENWEEP NATIONAL MONUMENT.

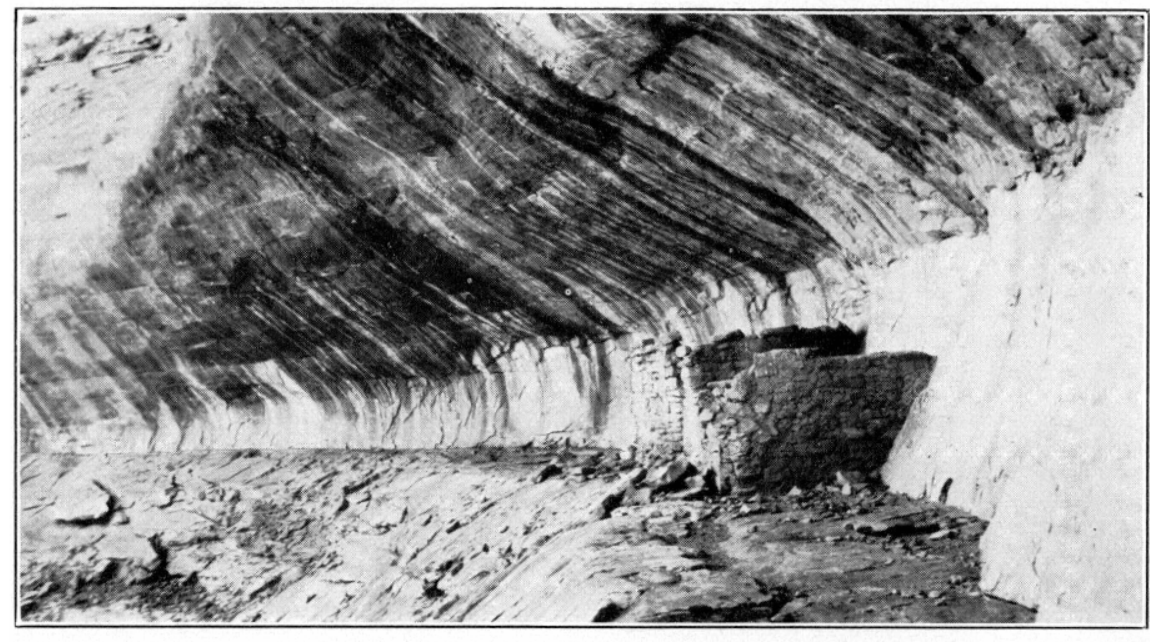

B. RUINS OF CLIFF DWELLERS' HOUSE, BUTLER WASH. Navajo sandstone. Photograph by H. D. Miser.

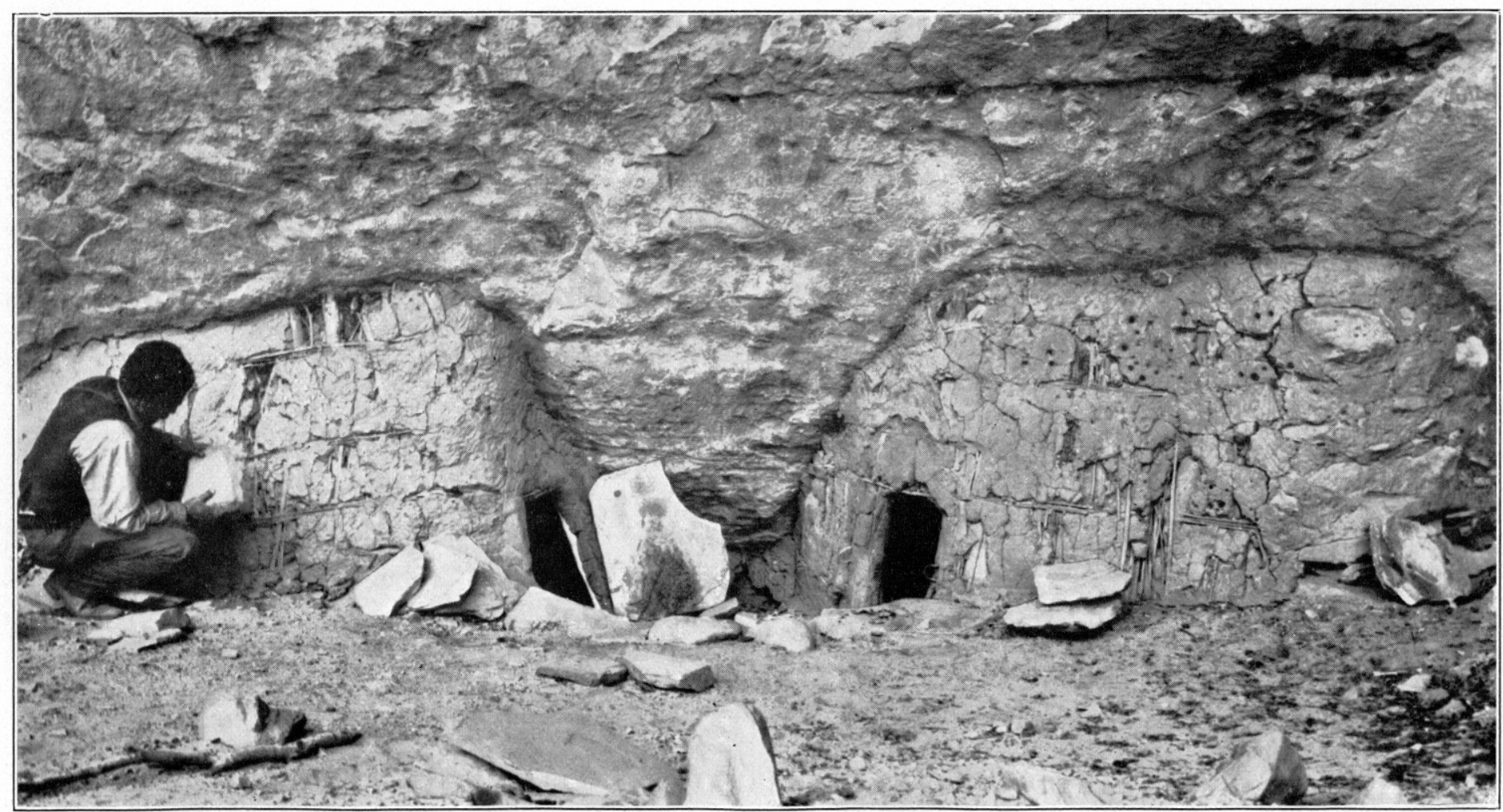

C. CIIFF HOUSE IN WHITE CANYON.

Cedar Mesa strata. Photograph ly W. H. Hopkins. 
Gulch Plateau, and the almost inaccessible mesas between White Canyon and Red Canyon. Miser saw seven along the San Juan Canyon between the Honaker trail and Oljeto Creek. The Piutes tell of large herds of antelopes that ranged throughout southern Utah until exterminated by the whites. They speak also of a "big hairy cowlike creature" that suggests the buffalo. On the higher forested areas, in addition to squirrels, chipmunks, rats, mice, and snowshoe rabbits, there are many porcupines, foxes, bobcats, some mountain lions, timber wolves, lynxes, and a few brown bears. Deer, which are fairly common on Elk Ridge and the Abajo Mountains in summer, are protected by laws that seem to restrain the white man but not the Piutes and Navajos. Elk, which are reported as once abundant, "have not been seen for 40 years."

Of the reptiles some half dozen varieties of lizards, also garter snakes, bull snakes, and rattlesnakes and one box turtle were noted on sand flats and among the rocks. But lizards are much less common than in regions south of the San Juan River, and harmful snakes are surprisingly rare. On long traverses during four field seasons only six rattlesnakes were seen.

Of insects, the most continuously annoying are the flies about the villages, corrals, and Indian encampments, and the ants, which seem always at home on sand bars, the floors of washes, rock slopes, and forested areas. Mosquitoes were found troublesome only in a few swampy areas about water holes, but there they are incredibly numerous. As if resenting the lack of opportunity to live elsewhere, they swarm over the pack train and prevent making camp in their vicinity. Scorpions and centipedes, though not abundant, seem to be where they are not welcome, and tent caterpillars in June force campers into the open. Crickets and many varieties of beetles are common.

The breeding birds most commonly seen are the magpies, mourning doves, piñon jays, sage sparrows, canyon towhees, catbirds, rock wrens, house wrens, sage thrashers, bluebirds, swallows, and chickadees. But the list includes mountain eagles, ravens, ducks, woodpeckers, meadow larks, blackbirds, turkey buzzards, cranes, finches, sapsuckers, flycatchers, grouse, swifts, humming birds, and various warblers. Hawks seem to be always in the sky, and the hoot of owls is the commonest of night sounds. These birds find abundant nourishment in prairie dogs, squirrels, and mice. Sagehens provided food for the early settlers at Bluff.

West of the Clay Hills and along canyons leading from Elk Ridge to the Colorado River are a few wild horses and wild long-haired cattle, remnants of the herds brought from New Mexico about 1885. Members of the Hayden Survey found the Indians in Montezuma Canyon the proud possessors of scrub ponies and dogs. Nowadays herds of cattle and flocks of sheep move from water hole to water hole and from summer to winter grazing ground.

145824-38-3
Because of the great losses sustained by the stockmen a vigorous and successful campaign has been waged against predatory animals. Trapping is a profitable occupation. Seth Shummway, Government trapper, states that the big wolves and cougars formerly abundant are now nearly exterminated, but that about 100 wildcats (lynx cats) and 150 coyotes are caught each year.

\section{MINERAL WEALTH}

Search for valuable metals in the San Juan country, though thorough, has proved to be unprofitable; nowhere have ores of high commercial value been located. A little gold has been taken from placers on the San Juan River and from mines in the Abajo Mountains, and gravel in Glen Canyon has at times yielded enough to cover the cost of mining. The many copper mines and radium mines have had short lives. Wells drilled in search for oil in the Lime Creek Valley, in Johns Canyon, in Soda Basin, in Dark Canyon, and at Boulder Knoll, east of Monticello, have been abandoned after an expenditure for explorations estimated as $\$ 2,000,000$. Thin seams of coal about Monticello have proved unsatisfactory for general use. (See p. 110.)

\section{INHABITANTS}

\section{BASKET MAKERS AND CLIFF DWELLERS}

Before America was known to Europeans the San Juan country was the seat of a flourishing population. Abandoned farms, burial grounds, dams and ditches for conserving water, agricultural and household implements, and the ruins of well-made dwellings point to a people well adjusted to the region chosen for their home and indicate a long period of residence. The densest settlements and those with the longest continuous history are in the drainage basin of Montezuma Creek, Recapture Creek, Cottonwood Canyon, and Grand Gulch, but well-made buildings appear along the San Juan River, Butler Creek, Comb Wash, Allen Canyon, the upper tributaries of White Canyon, Lake Canyon, Moki Canyon, Castle Wash, and sporadically elsewhere on canyon walls, mesas, and plateau rims. This area of ancient settlements extends into Colorado, where villages and isolated dwellings are abundant along the McElmo, Mancos, La Plata, and Animas Riversnorthern tributaries to the San Juan-and into New Mexico and Arizona, where streams entering the San Juan from the south mark the sites of the remarkable ancient villages in Chaco, De Chelly, Del Muerto, Carrizo, and Segihatsosi Canyons. The San Juan drainage basin, like the basin of the Rio Grande, seems to have been fully occupied by these old people. The San Juan Basin appears also to mark the northern boundary of the area densely inhabited by the pioneer tribes. Except for the large village in Indian Creek Valley, some houses in Fable Valley, and a ruin of considerable size near Moab, few sites are known north of 
the Abajo Mountains. At the west, along Cataract Canyon and Glen Canyon, the scattered ruins suggest outposts and hunting lodges designed for temporary occupation. Like the present inhabitants, the ancient colonizers seem to have found their routes blocked by these profound gorges.

Within the area formerly inhabited the ruins are grouped, not evenly distributed. On Sage Plain, on the bench Iands along the San Juan, on Grand Gulch Plateau, on most of the high mesas between the Clay Hills and the Colorado River, on forested Elk Ridge, and on the Abajo Mountains many sherds of pottery are strewn over the surface, but structures are few and inconspicuous. Along Recapture Creek they are bunched in two large settlements. On Montezuma Creek a large group near the mouth of Boulder Canyon is continued downstream as houses on both sides of the valley. Along San Juan Canyon ruined houses and abandoned fields appear near the mouths of Butler Wash, Slickhorn Gulch, and Wilson Creek, and interesting petroglyphs have been found at Clay Hill Crossing. In Grand Gulch scores of cavelike recesses are occupied by houses or burial grounds, most of them small and relatively inconspicuous. In some canyons they are placed like farm houses along a country highway.

The buildings, artifacts, and skeletal remains in the San Juan country reveal the presence of two culturesthat of the Cliff Dwellers, superposed upon a more primitive type-that of the so-called Basket Makers. Since the existence of a culture older than that of the Cliff Dwellers was recognized by Prudden ${ }^{40}$ and its salient features described by Pepper ${ }^{41}$ as the result of collections made in Grand Gulch, much has been learned of the mode of life and distribution of these interesting people. Unlike the Cliff Dwellers, the Basket Makers built no permanent stone houses. Their dwellings seem to have been brush hogans and skin or brush tepees that were abandoned or rebuilt as temporary needs required. For storage of grain, shelter from storms, from cold, and from wild animals, and for burials they utilized natural recesses in the canyon walls, modifying them somewhat by digging pits into their floors. The skeletons were placed in stone-lined cists or in graves dug in soft rock. They show no deformation of the head. The Basket Makers were skilled in making fur cloth and in the use of skins of deer, mountain sheep, badgers, rabbits, and prairie dogs, also feathers, for clothing. They made nets of Indian hemp (Apocynum cannabinum) and had special forms of sandals and cradles. Instead of the bow and arrow they used the stone-pointed dart and the spear thrower (atlatl). They knew little of stonework and pottery. The rare pieces of unglazed pottery are extremely crude in design and workmanship and could have served no particular purpose. In general the

40 Prudden, T. M., An elder brotber of the Cliff Dweller: Harpers Mag., June 1897.

1 Pepper, G. H., The ancient Basket Makers of southeastern Utab: Am. Mus. Nat. History Jour., vol. 2, no. 4, suppl., pp. 3-26, 1902. place of pottery was taken by coiled-work baskets remarkable alike for number, variety, and design. There are trays, platters, dishes, sifters, carrying baskets, and storage baskets of many forms. Corn cobs and squash seeds appear among the ruins, but there is no evidence of cultivation of the bean or of cotton.

The Basket Maker was doubtless the original pioneer in the plateau province, but whether he was replaced by the Cliff Dweller or merely represented an early stage in the development of Cliff Dweller culture remains to be demonstrated. Either because he was a pioneer, unfamiliar with his new home, or because he represented a weak race, incapable of meeting the demands of an exacting environment, he was not fully adjusted to an arid region. He seems not to have understood the storage of water and its use in agriculture or the advantages of a well-built house, and he had no adequate means of capturing the larger wild animals for food-in all these respects strongly contrasting with men of the Cliff Dweller and Pueblo tribes.

The Cliff Dweller culture in the San Juan country is represented by pottery of remarkable abundance and variety and by structures of many kinds in many different settings. There are houses built of selected and fitted slabs of sandstone and limestone with little adobe mortar, houses built of irregular stones and steam-worn boulders with much adobe mortar, stone houses without mortar, houses built entirely or almost entirely of adobe, and houses of jaral (loosely woven withes thickly plastered with adobe). Some of them stand in unprotected places on mesas and valley floors, but commonly they are in niches or rock shelves on canyon walls, behind big talus boulders, on tops of steep-sided buttes, and on the points of narrow mesas overlooking the canyon floors. The dwellings are isolated or distributed in small compact clusters, in rambling groups or in large communal pueblos. Except for watch towers and small structures that may have served as temporary outposts or hunting lodges most of the house groups have three elements in common-rooms for sleeping and storage, a ceremonial kiva or estufa, and a burial ground placed south of the dwelling-constituting what Prudden ${ }^{42}$ aptly terms "the unit type." (See pls. 8, $A, B, C ; 25, A, B, C, D$; 26, $A, B$; fig. 4.)

In selecting dwelling sites, access to water, arable land, and exposure to the sun seem to have been considered essential; many sites otherwise attractive have never been occupied. Accessibility and room for expansion seem not to have been considered. The sites of the large groups of ruins and of most of the smaller ones are along the perennial tributaries of intermittent streams, at the heads of box canyons, and at places

13 Prudden, T. M., The prehistoric ruins of the San Juan watershed in Utah, Arizona, Colorado, and New Mexico: Am. Anthropology, vol. 5, pp. 334-335, 1903. 
along the larger streams where permanent water flows through alluvial valley bottoms. Along narrow, steepwalled canyons and the dry lower parts of broad washes ruined structures are absent or rare; farther headward they are abundant. Along the San Juan the absence of ruins at low levels seems to imply a knowledge of the destructive overflows resulting from seasonal floods.

With the distribution of the ancient settlements in mind, there seems no reason for assuming that the Cliff Dwellers were not adjusted to their geographic environment or that the climatic conditions during the days of their greatest expansion were more favorable than now. For an agricultural people living on corn, beans, and squashes, supplemented by piñon nuts, grass seed, and the flesh of prairie dogs, badgers, and rabbits, the San Juan region today affords a favorable location, and before much of the alluvial bottom lands had been destroyed and the deer, mountain sheep, and antelope driven out, the conditions were still more favorable. It is probable that the Cliff Dwellers had plenty of accessible water. Abandoned ditches and check dams show that they knew something of water conservation and irrigation. Some home sites are near springs, and small seeps of water appear inside some of the communal dwellings. Near many cliff houses arable land is no longer accessible, but no sites were seen where lack of water would prevent reoccupation.

The antiquity of the ruins of Basket Maker and Cliff Dweller and the density of the population are difficult to determine. As might be expected, the better-built houses are the better preserved, and those in protected places are less dilapidated than those in exposed places. Many ruins protected from rain and snow by overhanging ledges appear remarkably fresh. Some houses in exposed positions retain roof timbers well preserved. On the other hand, some houses in caves have fallen into decay, and many on mesa tops and valley floors are mere heaps of rocks. Some houses are buried in sand dunes, in talus, and in stream gravel. Some have been built on the ruins of others. Examination of building sites at which hewn beams, adobe mortar, baskets, sandals, and skeletons have decomposed or crumbled to dust-even in this dry climate - gives an impression of great age. The fact that the Spanish in 1540 could learn of no pueblo inhabitants north of Walpi and Moenkopi suggests that few if any Cliff Dwellers were living along the San Juan at that time. Trees at least 200 years old are growing on burial sites where soil marks of stumps point to still older trees. Yet some of the adobe-plastered walls, timbers with bark, corn cobs, squash seeds, strong textiles, and bright baskets give the impression that the families have merely gone on a long visit.

Although there is no reason to assume that all or even a large part of the ancient dwellings were occupied simultaneously, the number of ruins and their obvious fitness for accommodation of many people suggests a relatively large population for a semiarid region. It seems probable that during their most prosperous days the number of Cliff Dwellers in the San Juan country was twice the present population, and that the larger settlements accommodated more people than are now living at Bluff. The cause for the disappearance of this group of perhaps 4,000 people is unknown. Climatic changes, struggles with nomadic tribes, epidemics from introduced diseases, and absorption by neighboring tribes doubtless all played a part. But as there is no tradition of large-scale migration or slaughter, it seems not unlikely that the race after reaching a stationary culture gradually deteriorated-the death rate overtook the birth rate, and, like the present Hopis, they acquired a psychology of hopelessness that served to hasten their extinction.

\section{PIUTES, UTES, AND NAVAJOS}

The Cliff Dwellers and Pueblo people have entirely disappeared from the San Juan country; their culture is carried on by the remnant tribes in northern Arizona and northern New Mexico-the Moenkopi, Hopi, Zuñi, and the pueblo dwellers of the Rio Grande Valley. The place of the ancient agricultural communities has been taken by nomadic tribes-Piutes, Utes, and Navajos. Just when these vigorous tribes took possession of the lands bordering the San Juan and which of them were the first comers no one knows. The accounts, especially of the Piutes, are meager and conflicting. As the Spanish priests and soldiers seem not to have visited the San Juan country, reliable knowledge of its Indian inhabitants dates only from the days of pioneer settlement-most of it within the last half century.

Newberry met camps of Utes (Piutes?) on his traverse down the San Juan in 1859, and the work of the Hayden Survey in 1871-77 was several times interrupted by the hostilities of these tribes. Jackson ${ }^{43}$ states that the Navajos occupied southwestern Colorado and southwestern Utah "within the remembrance of the older persons" and "were driven beyond the San Juan by the onslaughts of the aggressive Utes." The relations of the Mormon pioneers in San Juan County were with Utes, Piutes, and Navajos. In general it may be said that the prospectors, trappers, and Government exploring parties of the period 1840-70 found the Utes and their linguistic relatives, the Piutes, firmly established in Utah, Nevada, western Colorado, southern Oregon, and southeastern California, and that the Navajos together with their cousins, the Apaches, dominated New Mexico and Arizona. The San Juan River, continued by Glen Canyon and Grand Canyon of the Colorado, seems to have separated two hunting areas or at least two "spheres of influence." During the time immediately preceding settlement by the whites, Navajo visits north of the San Juan seem to have been warlike raids or short-time hunting and trading excursions permitted

\footnotetext{
43 Jackson, W. H., U. S. Geol. and Geog. Survey Terr. 10th Ann. Rept., p. 428, 1878.
} 
by the Utes, and Ute visits to the Navajo country were governed by the same conditions. Tradition records many warlike raids back and forth across the San Juan. Descendants of Navajo slaves among the Piutes and of Piute slaves among the Navajos are evidence of hostile relations. Obviously the boundaries of tribal areas were not sharply defined. Piutes have long lived in Piute Canyon, south of the San Juan, and Navajos at Ute Mountain, in Colorado; Kigalia ranger station, on Elk Ridge, was the home of a Navajo chieftain.

The Mormon pioneers who settled at Bluff in 1880 found Indian communities in Allen Canyon, Cottonwood Canyon, and Montezuma Canyon and a few families along the San Juan. In accordance with their traditional attitude, these representatives of the Church maintained friendly relations with the natives and refrained from occupying the lands which the Indians claimed. Even the fertile Allen Canyon and the choicest bits of soil on the floors of other canyons, though little used by the Piutes, were recognized as "Indian land." In keeping with the traditional customs of their tribe these Piutes roamed rather freely in small independent bands, each under the nominal direction of a chief. During the growing season they remained near permanent water, caring for their small, poorly cultivated fields of corn, squash, and melons and herding their goats and ponies on nearby grass lands. During the colder weather many of them relocated as families or groups in places where snow and cold winds could be avoided and where bright sunshine provided warmth not given by fires in their loosely constructed brush and mat wickiups. (See pl. 9, A.) To supplement the meager food supply obtained from cultivated red and blue corn, the men of the tribe hunted deer, mountain sheep, prairie dogs, badgers, rats, and especially the rabbit, which were killed with the "rabbit stick" or trapped with the ingeniously constructed "flax" twine rabbit net described by Powell ${ }^{44}$ as in use by the Piutes of the Uinkaret Plateau. The women and children and at times the men gathered piñon nuts, acorns, berries, and seeds of grass and herbs-especially Oryzopsis ("mountain rice"), Chenopodium, and Coreocarpus. A Piute "biscuit" is a small, hard, red, unsalted mass of ground-up bullberries, squawberries, grass seed, weed seed, and corn baked in ashes.

Like other Piute tribes on the border of the great Ute region, those in the San Juan country seem to have adapted themselves to only the most obvious features of natural environment and to have borrowed freely from their neighbors. Their homes are modified forms of the tepee of the plains Indians; the rabbit net, the skillfully made and attractively decorated storage and carrying baskets, and the remarkably practicable pitch-coated, wicker water bottles resemble those of the ancient Basket Makers, the aboriginal inhabitants of the Piute fields. Like the Basket Makers, the

It Powell, J. W., Exploration of the Colorado River, p. 127, Washington, 1875.
Piutes know little about pottery, a characteristic feature of Cliff Dweller culture. It is interesting to note that the Hopis and the San Juan Piutes are of the same linguistic stock.

For nearly 40 years after the first white community settled on the San Juan River no official attention was given to the Indians. Though petty thieving and killing of stock caused periodic friction that led to calling in troops from Fort Lewis, the Piutes were permitted to roam at will. Some were given work by the pioneers and in time of famine were fed from their scant stores of provisions, and the Indians on their part refrained from any organized opposition. On the whole the relations were tolerable, if not always pleasant. With the increase in white population, especially of cattlemen, the Ute and Piute leaders seemed to feel that their lands were no longer safe. Many disagreements arose between stockmen and Indians. In 1923 a trouble developed that called for governmental action. As related by $\mathrm{E}$. Z. Black, the local representative of the Bureau of Indian Affairs, a band of Piutes caught robbing a sheep camp were arrested and sentenced to jail. After a bloody riot the prisoners broke away from the sheriff and, aided by their friends, escaped to the canyons bordering their ancestral homes. A posse was then formed to round up all the Indians and to "teach the robbers a lesson." After a tiresome hunt one Indian was killed. The leader, "Old Posey", though wounded, refused to surrender and died in an abandoned cave protected by his faithful followers. In the meantime word had gone to Washington, and a conference was arranged under the direction of General Hugh L. Scott, who was well known among all the tribes of Utah and Arizona and whose wise and just attitude toward the Indians had been many times tested. The proposal that future trouble be forestalled by removing the Indians to lands south of the San Juan or to the Ute Reservation in Colorado was met with the stoical reply, "Our fathers have always slept here." Recognizing that only superior force could drive the Indians from their hereditary homes, the conference reached the decision that the two bands of Piutes and Utes who acknowledged the leadership of "Old Posey" and "Polk" should be allotted lands in Cottonwood Canyon and its tributaries, Hammond Canyon, Allen Canyon, and Dry Wash, and Whiskers Creek. Each allotment consists of 40 acres of irrigable land, 80 acres of dry-farm land, or 160 acres of grazing land that may not be sold or leased without the consent of the Indian Bureau. The 45 allotments made comprise all the suitable areas within this region.

At the present time the Indians who make their home in San Juan County number about 180. Most of them are Piutes, but among them are perhaps a score of Utes and a few Navajos. Their official residence is at the Indian village at Allen Canyon, where they are encouraged to develop their allotments and to utilize their 
grazing rights on Elk Ridge. They are supposed to work their lands, to cut timber, and to supply themselves with food from their crops and livestock, but it has been found impracticable to discontinue food rations. Under a capable superintendent, who is wise enough to treat a little crop as a "big crop" and a straggling band of sheep as a "herd", the Indians are making some progress, but supervised industry and a fixed abode afford little attraction. They want to live their lives in their own way. In particular they resent the Government decision to keep their children in school 100 miles away, in Colorndo.

\section{WHITE SETTLEMENTS}

\section{HISTORY}

The history of white settlements in southeast Utah is the record of explorations and of systematic attempts to utilize some 5,000 square miles of grazing and agricultural land. The exploratory adventures of Posada and Rivera (1761) and of Escalante (1776) in eastern Utah and western Colorado were not followed by Spanish settlements, and the pioneer journey of the American Wolfskill (1830) seems to have been soon forgotten.

The topographers of the Hayden Survey in 1874 found "Parrott City" (two log houses) on the La Plata River, "the only white settlement in southwest Colorado." They reported no white men in the area now constituting San Juan County. Doubtless a few adventurous trappers and prospectors found their way along the San Juan River and to the base of Abajo Mountains during the decade $1870-80$. It is known that in 1879 Patrick O'Donnell occupied a hermit cabin near the present Monticello, that Peter Shirts, a roving trapper, was camped at the mouth of Montezuma Creek, and that the Mitchells, the first white family in southeastern Utah, were living at the mouth of McElmo Creek. But the recorded history of the San Juan country begins with the settlement of Bluff in 1880 .

From unpublished records made accessible by the historian of the Church of Jesus Christ of Latter Day Sajnts, from a manuseript history of San Juan County by Albert Lyman, from information furnished by Truman Jones, Bishop Redd, and other old-timers, the salient features of this outstanding adventure in pioneering have been assembled. While working among the Navajos in the region east of Marsh Pass, Jacob Hamblin and other missionaries investigated opportunities for irrigation, farming, and stock raising along the San Juan River north of Carrizo Mountain. Their favorable report led to a decision by the church to establish a settlement as near as possible to Four Corners, "but in Utah." Leaving Cedar City April 14, 1879 , the party consisting of about 30 men ( 2 with their families), 20 wagons, and many saddle horses under the leadership of Silas S. Smith, proceeded by way of Panguitch, Kanab, Lees Ferry, Moenkopi, Marsh Pass, and Boundary Butte and reached the San Juan at "Allan Bottom", between Montezuma and McElmo Creeks, on June 1, 1879. On the way they were forced to build raads, dig wells on dry wash bottoms, and overcome as best they could the suspicion and opposition of the Indians. There was particular trouble with the Navajo chief "Peogament", who "claimed the river and all the lands north." With Allan Bottom as a base the river was explored down to Butler Wash (John Butler) and up to Alamosa, and the base of the Abajo Mountains was studied as a source of water, timber, and forage. As a site for a settlement a stretch of meadowland 2 miles above the mouth of Montezuma Creek was chosen. For protection a stockade, Fort Montezuma, was built. Claims were staked for 18 miles along the San Juan. Leaving two families (Harriman and Davis) at the "fort", the party returned to Cedar City by constructing a road up Recapture Creek, across the headwaters of Montezuma Creek, down Peters Hill, across Dry Valley, over the pass to Moab, thence on across the Colorado and Green Rivers and the High Plateaus. During the period April 14 to September 17 more than 1,000 miles of little-known country had been traversed and 400 miles of new wagon road had been made. The enthusiastic reports of Silas Smith met with an equally enthusiastic reception. A picturesque region rich in farm land and grazing land, supplied with timber and water, and occupied only by a few Indians awaited settlement. Within a few weeks a call of the church was issued to settle the San Juan country.

The proposed new colony was peculiarly isolated. To the north across Utah the only white people were a few families at Moab, 110 miles distant; eastward was the small settlement at Mancos, 70 miles away; southward for 160 miles was the Navajo country; westward the nearest settlement was Escalante, 115 miles distant. The nearest markets and reliable sources of supplies were Albuquerque, 225 miles distant, and Salt Lake City, 350 miles distant. But the church authorities who planned the settlement on the San Juan were fully aware of the economic and social difficulties incident to isolation and were prepared to pay the price; in their opinion sacrifices that resulted in permanent occupation of "desirable places" were justified. It was obvious, however, that unless the proposed new settlement was to be entirely self-contained, roads suitable for wagons must be built to connect it with existing settlements. The natural connection is with Colorado, up the San Juan or across the level Sage Plain. The topography is favorable for roads planned to reach the Spanish settlements on the Mancos and the La Plata and, farther on, Albuquerque.

But the geographic advantages of nearness and ease of travel were outweighed by the call for a "compact population of adherents to the Church of the Latter 
Day Saints." To the leaders of the church it seemed highly desirable that the outlying settlements should be brought into social and political contact with the "Saints" in Utah rather than with the "Gentiles" in Colorado.

To put into effect this desire for closer union involved the construction of roads from the High Plateaus of central Utah to the spots chosen for colonization on the middle San Juan River. Three routes were possible-a northern one, across the Wasatch Mountains, down the Price River, and southward along the UtahColorado line; a southern one, through Arizona; and a central one, directly eastward from Panguitch and Escalante. The northern route involved the crossing of the Green River and the Colorado River and a long traverse through country inhabited only by hostile Utes. The southern route involved crossing the Colorado River at the mouth of the Paria or of the Virgin and a traverse of 150 miles through rough country held by the Navajos. The central route required a crossing of the forbidding Glen Canyon and of long stretches of exceedingly rough and arid country on both sides of the Colorado. Partly because of its shorter distance and its freedom from hostile Indians and partly because the "Saints called to settle on the San Juan" were residing in Cedar City, Parowan, and Panguitch, the central route was chosen-a decision which led to the construction of the Escalante-Bluff road, in many respects the boldest pioneer adventure in the history of the plateau country.

With only a knowledge of the country west of the Colorado and the report of Charles Hall that a crossing of Glen Canyon at Hole in the Rock, an old Indian trail, was feasible, 25 wagons constituting the vanguard of the San Juan mission left Cedar City and the scattered settlements about Panguitch in October 1879. In November they were camped at 40-mile spring and 50-mile spring, on the Escalante Desert at the base of the Kaiparowits Plateau. Here they were joined by others who had responded to this "call" until about 80 wagons and some hundreds of horses, the means of transport for 60 men, most of them with families, were gathered in these inhospitable places. The situation was desperate. Scouts had reported that the Hole in the Rock crossing was formidable and the country east of the river was so intricately cut by deep canyons in solid rock as to make traverse with wagons impossible. But though months of the hardest work lay ahead and provisions were nearing exhaustion, a return to the settlements was extremely difficult; heavy snow blocked the trails across the High Plateaus, and the scant season's forage had been eaten up by the hundreds of horses and cattle that accompanied the expedition. In council the leaders decided to go ahead. Albert Lyman states that on December 14 most of the party moved to the Hole in the Rock, a region without wood or water, and in the cold of winter, men, women, and children were en- gaged in "working out a shute" down to the river. On January $26,1880,24$ wagons were taken through the Hole and ferried across the river on a boat made of lumber sawed out at Escalante. The crossing was completed on February 10, and 7 days was spent in getting the wagons up a canyon in the east wall of the river. "It took four to seven span of horses or the same number of oxen to move one wagon." After traversing the rough sandstone gorges adjoining the Colorado and the flattopped Wilson Mesa beyond, they spent " 7 cold, wet, windy days" in making a road for wagons down "slick rocks", the wall of a tributary leading northward to the Colorado. On February 28 the party reached Hermit Lake, in Lake Canyon, thence proceeded along Castle Wash, and completed a road down the Clay Hills on March 12. (See pl. 6, B.) Finding the road east of the Clay Hills and along the San Juan blocked by impassable canyons, they selected a route northward across the head of Grand Gulch, thence southeastward over the Grand Gulch Plateau to Comb Wash, and down Comb Wash to the San Juan, which was reached on March 31. Four days was spent in making a "dugway through the Comb" (mouth of Butler Wash) (pl. 9, $A$ ). On April 5 the party reached the mouth of Cottonwood Creek and established camp. Though their proposed destination was Fort Montezuma, 18 miles up the San Juan, they could go no farther. The 225 men, women, and children, who had survived the continuous hardships for 170 days, were exhausted, and the diminished herds of horses and cattle were "barely able to move." Contact was made with Fort Montezuma by sending scouts with provisions for the families left there the previous year. ${ }^{45}$

My traverse of the Escalante-San Juan road on foot, on horseback, and by swimming makes it easy to understand why it was used but once.

West of the Colorado is the almost waterless " 50 -mile desert" (Escalante Desert). Hole in the Rock is a difficult and dangerous crossing-the worst on the Colorado. Though the river here is favorable for boats or for swimming with horses, the only access from the west is through a crooked, smooth-sided slit in a towering wall. ${ }^{46}$ East of the river the road ascends a bench, then enters a maze of knobs, pits, boxes, shelves, and "dry waterfalls" that constitute features of interlacing big and little high-walled canyons. Among the many dry stream channels leading to the plateau above, only one can be ascended, and that one only after building trails over and around bare rock shoulders. Topography of this type continues to a point some 12 miles from the river, where the flat top of Wilson Mesa furnishes an easy route. But the descent from the mesa must be made over the bare

\footnotetext{
4s According to Mr. Albert Lyman, of Blanding, the statement that the entire party of emigrants reached Fort Montezuma is based on erroneous information. (See Gregory, H. E., U. S. Geol. Survey Prof. Paper 164, p. 11, 1931.)

${ }^{16}$ Gregory, H. E., and Moore, R. C., The Kaiparowits region: U. S. Geol. Survey Prof. Paper 164, pp. 11-12, 1931.
} 
surface of sandstone knobs whose steep sides lead downward to deep, narrow gorges. Only by cutting steps and building up retaining walls on the "slick rocks" is passage with wagons possible. Even on horseback the road is dangerous. Hermit Lake is a delightful oasis of water and grass in a region of bare rocks. In making the road from the lake to the Clay Hills only sand dunes on the uplands and the irregularity of canyon floors need be overcome, but Clay Hills Pass presents difficulties. It is easy to understand that "a company of 60 men with horses and scrapers" needed 3 days to construct a passage through a mile of slippery clay heaped with huge talus blocks. From the Clay Hills up Grand Flat, across the head tributaries of Grand Gulch, and down Comb Wash to the San Juan the road makers encountered no serious obstacles. The chief work was shaving down the sides of narrow gullies, building runways to ledges, cutting brush, and assisting teams through sand. To take the wagons up the San Juan River from the mouth of Comb Wash it was necessary to build a roadway in rock around the end of Comb Ridge, thence up and across Butler Canyon. It seems clear that missionary zeal rather than a knowledge of topography guided this heroic but futile undertaking.

Fortunately an examination of the bottom lands along the San Juan had shown that the wide alluvial flats at the mouth of Cottonwood Canyon-the place where exhaustion had ended the long, arduous journey of the San Juan mission-was the best place in the valley for an agricultural settlement. Without delay preparations were made for planting a crop--an urgent necessity if starvation was to be avoided later in the year. From 8 to 20 acres of farm land was assigned to each family, in addition to unrestricted grazing rights and a 1-acre lot in the village, organized April 6, 1880, as "Bluff City." Local government had already been provided: by an act of the legislature (Feb. 17, 1880) San Juan County had been established and the leaders of the mission band appointed as its officers when as yet it had no inhabitants.

Life at Bluff during the first few years must have been discouraging. Official reports and personal records speak of "continuous trouble with irrigation ditches"; "floods from the Cottonwood covered fields with mud"; as protection from Indians "women and children lived in a fort"; "stock had to be herded to prevent stealing"; crops for $1880,1881,1882$ were "very poor"; 10 families moved to the mouth of Montezuma Wash, others to the mouth of Recapture Creek; in the fall of 1880 "about half of the population moved away"; in 1880 and again in 1883 the desire of the settlers to "abandon the place" was overruled by the church officials.

"The church had a definite object and purpose in settling a colony in this wild region"; money was made by trading with the Indians and by working as team- sters in Colorado; the "great flood" of June 1884 drowned the farm lands above Bluff, destroyed the settlement at Fort Montezuma, and "changed the meadows on Cottonwood Creek into sand flats"; in 1885 more farm land was destroyed; by 1886 " 20 miles of farms along the San Juan in 1880 had become at most 700 acres served by one ditch at Bluff." At one time it was proposed to set aside San Juan County as an Indian reservation.

Though the people of dwindling Bluff accepted the decision of the church that the mission be held in spite of hardships, "for the sake of more fruitful places", their experience had proved that farming in the San Juan Valley was unprofitable. Exploration of the lower San Juan, Castle Wash, Red Canyon, White Canyon, and the "little valleys" east of Elk Ridge showed that these places also lacked land and water suitable for irrigation farming but that forage for stock was abundant. Beginning about 1885, stock raising replaced agriculture as the primary industry. Sheep were introduced, eattle ranches owned by men from Bluff were established in Allen Canyon, Dark Canyon, and Comb Wash, and the right to graze stock on Elk Ridge was purchased from the Indians.

The opportunities to supplement summer forage in the Abajo Mountains by raising alfalfa and grain on dry farms and fields irrigated by headwater tributaries of the Montezuma attracted settlers from Bluff and from Mancos and led to the organization of the "tough cattle town" of Hammond (now Monticello) in 1887, Carlisle in 1889, and Verdure in 1894 and to the starting of ranches in Strawberry Creek (Mormon Pasture), Cottonwood Canyon, ${ }^{468}$ and Indian Creek. In the hope of success from dry farming a few settlers took up land east of Monticello and on Sage Plain at Lockerby, Ucolo, and a few other places. The last important shift in population came with the establishment of Blanding (formerly Grayson) in 1905, the largest village in San Juan County.

Blanding owes its existence to the foresight and persistence of Walter C. Lyman, the father of the irrigation project that brought the waters of the Abajo Mountains to some 3,000 acres of favorably lying land on "White Mesa." The site had been prepared by constructing a ditch line (in 1903), clearing of rank sagebrush, and harvesting an experimental crop. In 1905 the first settlers arrived-chiefly those whose farms had been ruined by the San Juan River at Bluff and those driven from Mexico by political and religious persecution.

Three ephemeral events have interrupted the normal development of settlement in the San Juan countrythe gold excitement on the San Juan (1890-92), the mining boom in the Abajo Mountains (1892-93), and the oil boom at Mexican Hat, which reached its height between 1907 and 1910. The unverified report of Bill

46. See footnote 23 , p. 11 . 
Williams that rich placer gravel "was strewn all along San Juan Canyon" brought "about 2,000 people through Bluff" in 1892, and the shift of the disillusioned miners to stream bottoms and ledges of the Abajo Mountains still left Bluff as the outfitting point. "Forty to fifty miners passed in a day." "Bluff was amazingly prosperous." In 1909 and the next few years work in the oil fields temporarily increased the population of Bluff and built up a small settlement at Goodridge (Mexican Hat).

\section{Population}

The history of white settlement in southeastern Utah is the record of a systematic attempt to make use of some 5,000 square miles of agricultural and grazing lands and to exploit possible mineral resources. The region has proved disappointing. On the San Juan River less than 100 people at Bluff, 1 family at Goodridge, and 1 at Aneth constitute the present population; elsewhere on the river the former population of farmers, traders, missionaries, miners, and oil men has disappeared. On Sage Plain east of Recapture and Montezuma Creeks abandoned farms are more numerous than occupied farms. West of the Abajo Mountains and Cottonwood Creek no white man maintains a residence. This vast region is visited in summer by cattlemen, forest rangers, and a few tourists and in winter by trappers and now and then a prospector. Essentially the population centers in the villages of Monticello and Blanding-two oases that owe their existence to streams from the Abajo Mountains. The fluctuation in population during the 50 years since the first settlers arrived is shown in the following table:

Population of San Juan County, 1880-1930

\begin{tabular}{|c|c|c|c|c|c|c|}
\hline & 1880 & 1890 & 1900 & 1910 & 1920 & 1930 \\
\hline Bluff _... & 225 & 190 & 1315 & 160 & & \\
\hline Blanding ...- & $\ldots$ & $-\overline{11 z}$ & & 385 & 1,072 & 1,001 \\
\hline $\begin{array}{l}\text { Monticello } \ldots \ldots \ldots \\
\text { La Sal }\end{array}$ & $-\ldots$ & 115 & $\begin{array}{r}180 \\
97\end{array}$ & $\begin{array}{r}375 \\
30\end{array}$ & $\begin{array}{l}768 \\
? 87\end{array}$ & $\begin{array}{r}763 \\
2211\end{array}$ \\
\hline Settlements and & & & & & & \\
\hline farms & & 60 & 271 & & 231 & 221 \\
\hline Total whites & $\ldots$ & 365 & 863 & 959 & 2,508 & 2,266 \\
\hline Indians_....... & & ..... & 160 & & 871 & ${ }^{3} 1,230$ \\
\hline Total & 225 & 365 & 1,023 & 959 & 3,379 & 3,496 \\
\hline
\end{tabular}

I Includes about 150 prospectors.

2 La Sal, at the base of the La Sal Mountains, though in San Juan County, is not included in the "San Juan country."

3 Includes about 1,000 Indians in the "Utah strip", part of the Navajo country south of the San Juan River.

For 10 years after its establishment the pioneer settlement Bluff contained almost the entire population of San Juan County and nearly half of the population of Utah east of the Colorado and Green Rivers. Growth of the population began with the coming of farmers and stockmen to lands bordering the Abajo Mountains and continued with marked increase to a peak in 1921. Since 1918 small settlements have grown up at Lockerby, Cedar Point, and Summit Point. On the other hand, the 53 inhabitants of Indian Creek in 1900 were represented in 1934 by one family. The former settlements on the San Juan above Bluff, including 168 people in the McElmo precinct, have dwindled to two families, and the oil-boom population of Goodridge and Mexican Hat is represented by the keeper of a trading post.

Like the rest of Utah in general, San Juan County has a remarkably virile population of almost pure Nordic stock. As shown by the census for 1920, the population exclusive of Indians consists of native-born whites and foreign-born whites from Great Britain, Canada, Scandinavia, and Germany. The list includes 3 Mexicans but no orientals or negroes. For all census years the males exceeded the females; children under 7 years of age constituted about one-third of the population, and those under 14 years more than half.

After 50 years of settlement the white population of San Juan County was 2,266 , or about 0.3 person to the square mile. Yet this small number is probably all that the country can support under present conditions. More and more the outlying farms and ranches are being abandoned and the population is becoming concentrated on irrigated tracts, particularly at Blanding and Monticello. Increase in population would involve fuller utilization of the streams issuing from the Abajo Mountains, the sinking of deep wells, the development of small suitably placed water supplies in the grazing districts, and the selection of grains and roots appropriate for dry farming.

\section{INDUSTRIES}

\section{FARMING}

Experience covering half a century has demonstrated that few areas in the San Juan country are adapted to farming and that without irrigation the raising of food and forage crops is unprofitable. The floors of canyons in Grand Gulch, Red Rock, and Dark Canyon Plateaus have few patches of arable land, and most of the canyon floors in Sage Plain lack both suitable land and adequate water. The broad alluvial flats that attracted the pioneers to the San Juan and the Cottonwood have been largely destroyed by shifting floods. Of the "20 miles of farms" once grouped along the San Juan, there remain about 40 acres at Aneth and 200 acres at Bluff, in part irrigated by artesian wells. Three irrigated patches of alfalfa along Indian Creek, one in Comb Wash, a garden patch at the mouth of Red Canyon, and small plots intermittently cultivated in Piute Park and in Montezuma Canyon complete the list of "farms" on alluvial bottom lands. It is interesting to note that the canyon floors found suitable for cultivation by white men are those used by the Indians and by the Cliff Dwellers and Basket Makers before them.

Dry-land farming on Sage Plain east of Montezuma Creek started in 1887 and was vigorously developed during the war period, when more than 100,000 acres of previously unoccupeid land was taken up as farms. 
The crop for 1919 was the largest and most valuable and covered the largest acreage of those recorded for San Juan County. During that year the value of farm lands and buildings exceeded $\$ 3,500,000$, more than five times that of 1910 and twice that of 1925 or 1930 . These dry-land farms demonstrated that much of the region between the Abajo Mountains and the Colorado line is well adapted for the production of oats, corn, and dry-land wheat. Prof. A. Merrill, of Utah Agricultural College, says that "without question San Juan County ranks as the best dry-farming county in the State." But the cultivation of dry-land farms has proved to be unprofitable under normal conditions. Except in an inflated market, the cost of hauling grain 100 miles to the railroad at Thompson prohibits export. At present few dry-land farms justify continued cultivation; failures outnumber successes. More than half of those occupied in 1920 have been abandoned.

Farming for profit in the San Juan country is essentially restricted to the outer slope of the Abajo Mountains, round about Blanding, Verdure, Monticello, and Carlisle, where headwater tributaries of Recapture and Montezuma Creeks are available for irrigation. Unfortunately the amount of water during "good years" is sufficient for covering but a small part of the land otherwise suitable for farming, and in dry years fields distant from the head ditches receive no water during part of the growing season. The land considered available for irrigation by the existing systems of canals is estimated as 14,158 acres. In $1920,13,469$ acres was irrigated; in 1930, 9,525 acres, a decrease of 29.3 percent. For Blanding, the largest irrigation district, the land accessible to water has ranged between 7,500 acres in 1921 and 4,000 acres in 1928 .

For all San Juan County (nearly 5,000,000 acres) the area of land classed by the Census Bureau in 1930 as "farms" was 110,477 acres. Of this amount 25,183 acres was "crop land", 55,964 acres "pasture land", and 29,330 acres "other land"-that is, land on which no crop was planted and land on which the crop failed to mature. Of the "crop land" 15,832 acres was harvested. During the decade 1920 to 1930 the farm land decreased from 167,639 to 110,477 acres, but the number of farms increased; in 1930 about one-fourth of all farms in the county comprised less than 20 acres each. The average value of farm land is reported as about $\$ 20$ an acre in 1920 and $\$ 12$ in 1930 .

As at present practiced, farming in San Juan County consists of raising wheat, potatoes, fruit, and garden vegetables for family use and oats, barley, alfalfa, and corn for stock feed. The production of more than 50,000 bushels of wheat, 1,000 bushels of apples, and large quantities of peaches gives a surplus of these crops for export. The alfalfa grown is insufficient for local needs, and each year many tons of oats are imported. The cultivation of food crops and orchards on irrigated lands has yielded satisfactory returns.

$145824-38-4$

\section{STOCK RAISING}

San Juan County, Utah, which includes the area described in this paper, is essentially a grazing district-a great expanse of free range. The villages serve primarily as homes and supply points for cattlemen and sheepmen. The chief business of the farms is to supply feed for cattle, horses, and sheep. Of a total area of 7,761 square miles, 4,988 square miles of grazing land is unappropriated, most of it unsurveyed, and 890 square miles of grazing land is reserved for the use of Navajos and Piutes. This large area is further increased by 723 square miles included within the national forest, the chief purpose of which is to provide feed for stock during the summer season. Over most of the free-range lands the grass and "browse", though scarce and unevenly distributed, is very nutritious. In large parts of the area 1 square mile can supply forage for about 6 head of cattle or 20 head of sheep, provided due attention is given to the selection of feeding grounds in dry years. The region west of Comb Wash and Elk Ridge seems not to be overstocked; water from rain and snow is sufficient in late fall, winter, and early spring, but it is wholly insufficient in summer. During most years the herds must leave the lower country in May, and those which cannot be accommodated on the national forest must be sent to market. The lands along Comb Wash, Cottonwood Canyon, and Recapture and Montezuma Creeks and out on the mesas beyond Iime Creek have been overgrazed; their present carrying capacity is much less than that for the period 1880 -1900, and some sort of periodic reservation seems necessary to bring the range back to more profitable use. Were it not for the national forest, stock raising in San Juan County would be a hazardous undertaking except where supplemented by irrigation farming.

In response to the annual variations in the condition of the range, the amount and distribution of water, and the state of the market for beef, mutton, and wool, the number of cattle and sheep shows a wide range. Census figures are as follows:

\begin{tabular}{|c|c|c|}
\hline & Cattle & Sheep \\
\hline $\begin{array}{l}1910 \\
1920 \\
19250 \\
1930\end{array}$ & $\begin{array}{l}20,316 \\
15,764 \\
26,184 \\
13,527\end{array}$ & $\begin{array}{r}92,507 \\
44,060 \\
109,482 \\
+60,200\end{array}$ \\
\hline
\end{tabular}

\section{t Estimated.}

Stock raising is the most important source of income. For the years $1920-30$ the value of sheep averaged about $\$ 230,000$, of cattle about $\$ 395,000$, and of the wool clip about $\$ 90,000$. A small amount of butter, an important source of revenue in the early days of settlement, is manufactured for export. Cream is shipped regularly from.Blanding and Lockerby. 


\section{Chapter 2. SEDIMENTARY ROCKS}

\section{GENERAL STRATIGRAPHIC RELATIONS}

Nearly all the consolidated sedimentary rocks in the San Juan country are of Permian, Triassic, Jurassic, and Cretaceous age. For short distances in San Juan, Dark, and Cataract Canyons strata of Pennsylvanian age are exposed, and drill holes that reached "mica schist" at a depth of 4,422 feet in Reservoir Canyon, Elk Ridge, and 3,633 feet at Soda Basin, in the San Juan Canyon, penetrate great beds of limestone and of resistant sandstone and shale that probably represent most of the lower Paleozoic of the plateau province. The youngest strata (Mancos shale) appear on the surface of the synclinal Sage Plain and in the broken roof of the laccolithic Abajo Mountains; the oldest (Hermosa formation) in Dark Canyon and Cataract Canyon and in the Raplee and Mitten Butte anticlines where these are trenched by the San Juan. All the formations mapped in the San Juan country, also the absent Tertiary and uppermost Cretaceous, are represented in adjoining regions, and some of the Triassic and Jurassic formations are approximately coextensive with the Col- orado Plateaus. For example, the Navajo sandstone, which may be traced almost continuously across southern Utah and southward into Arizona, shows everywhere closely similar lithology, peculiarities of weathering, and topographic expression; the Chinle retains its characteristic features at exposures in Utah, Arizona, and Nevada; the remarkable Shinarump conglomerate shows little change over thousands of square miles, and the Moenkopi of Red Rock Plateau is but the eastern extension of that formation in the Escalante, Paria, Kanab, and Virgin River Valleys, Utah; the Little Colorado Valley, Arizona; and the Muddy Mountains, Nevada. On the other hand, in lithology and sequence the Permian beds of southeastern Utah are unlike those farther west. Of the Grand Canyon formations the Coconino is absent and the Kaibab, Hermit, and Supai are not clearly represented. Their place in the time scale is occupied by the Cutler and Rico formations. The general stratigraphic features of formations in the San Juan country are summarized in the accompanying table. (See also pl. 10.)

Generalized section of the rock formations in the San Juan country

\begin{tabular}{|c|c|c|c|c|c|}
\hline System & Series & \multicolumn{2}{|r|}{ Group, formation, and member } & Character & Thickness (feet) \\
\hline \multirow[t]{2}{*}{ Cretaceous. } & \multirow[t]{2}{*}{$\underset{\text { ceous. }}{\text { Upper }}$ Creta- } & \multicolumn{2}{|c|}{ Mancos shale. } & $\begin{array}{l}\text { Steel-gray to brown argillaceous and sandy shale } \\
\text { and irregularly bedded sandstones; some coal; con- } \\
\text { tains Ostrea, Exogyra, Gryphaea, and other fossils; } \\
\text { forms mounds and badlands. }\end{array}$ & $0-350$ \\
\hline & & \multicolumn{2}{|c|}{ Dakota (?) sandstone. } & $\begin{array}{l}\text { Gray to nearly white sandstones, conglomerates, and } \\
\text { sandy shales, quartz, lime, and iron cement; irregu- } \\
\text { larly bedded; contains coal; forms cliffs. }\end{array}$ & $92-200+$ \\
\hline \multirow{4}{*}{ Jurassic. } & \multirow{4}{*}{ Upper Jurassic. } & \multirow{2}{*}{ 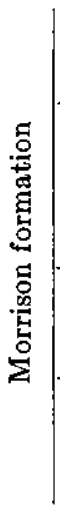 } & $\begin{array}{l}\text { Westwater Tank } \\
\text { sandstone mem- } \\
\text { ber. }\end{array}$ & $\begin{array}{l}\text { White to buff coarse sandstones; very irregularly } \\
\text { bedded; many lenticular beds of conglomerate, } \\
\text { sandy shale, and sandstone; contains chert, con- } \\
\text { cretionary clay, fragments of petrified wood, and } \\
\text { dinosaur bones; forms cliffs and benches. }\end{array}$ & $222-295$ \\
\hline & & & \multirow{2}{*}{$\begin{array}{l}\text { Bluff sandstone mem- } \\
\text { ber. } \\
\text { Unconformity? - } \\
\text { Summerville (?) for- } \\
\text { mation. }\end{array}$} & $\begin{array}{l}\text { White to gray-brown massive or thick-bedded, cross- } \\
\text { bedded sandstone; in places thin-bedded; includes } \\
\text { quartz aggregates, clay balls, and mudstones; } \\
\text { forms cliffs and platforms. }\end{array}$ & $100(?)-350$ \\
\hline & & \multirow{2}{*}{ 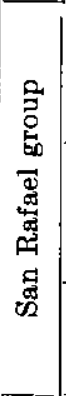 } & & $\begin{array}{l}\text { Varicolored thin calcareous sandstone and mud- } \\
\text { stone, cross-bedded and lenticular; gypsiferous } \\
\text { and calcareous shale; includes lime pellets and } \\
\text { chert concretions; forms banded cliffs. }\end{array}$ & $42-132$ \\
\hline & & & $\begin{array}{l}\text { Entrada sandstone. } \\
\text {-Local unconformity - } \\
\text { Carmel (?) forma- } \\
\text { tion. } \\
\text {-Unconformity }\end{array}$ & $\begin{array}{l}\text { Brick-red to orange-brown fine, even-grained sand- } \\
\text { stone; some irregularly bedded sandstone and } \\
\text { shales form benches; weathers into round-edged } \\
\text { ledges, spools, and "rock babies." }\end{array}$ & $8 \rightarrow 80$ \\
\hline
\end{tabular}


Generalized section of the rock formations in the San Juan country-Continued

\begin{tabular}{|c|c|c|c|c|c|}
\hline System & Series & \multicolumn{2}{|c|}{ Group, formation, and mernber } & Character & Thickness (feet) \\
\hline \multirow{3}{*}{ Jurassic(?) } & & \multirow{3}{*}{ 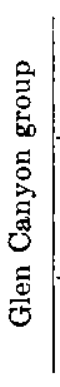 } & \multirow{2}{*}{$\begin{array}{l}\text { Navajo sandstone. } \\
\text {-Local unconformity } \\
\text { Kayenta formation. }\end{array}$} & $\begin{array}{l}\text { Cream-yellow to buff-white (?) cross-bedded sand- } \\
\text { stone; one massive stratum and thick bed separated } \\
\text { by sandy shale; includes lenses of dense limestone; } \\
\text { weathers as mounds, alcoves, and niches. }\end{array}$ & $300-880$ \\
\hline & & & & $\begin{array}{l}\text { Dark red-maroon coarse-grained sandstone; maroon, } \\
\text { brown, and lavender sandy shales; dense limestone } \\
\text { and limestone conglomerate; all in thin irregular } \\
\text { beds; weathers as a banded slope. }\end{array}$ & $40(?)-220$ \\
\hline & & & Wingate sandstone. & $\begin{array}{l}\text { Reddish-brown massive cross-bedded sandstone; } \\
\text { crops out commonly as prominently jointed vertical } \\
\text { cliffs. }\end{array}$ & $300 \pm$ \\
\hline \multirow{2}{*}{ Triassic. } & Upper Triassic. & \multicolumn{2}{|c|}{ Chinle formation. } & $\begin{array}{l}\text { Highly variegated calcareous friable shale ("marl"); } \\
\text { red-brown and gray fine-grained sandstone most } \\
\text { abundant at the top; limestone and limestone con- } \\
\text { glomerate; contains petrified wood; weathers as } \\
\text { banded, benched slope. }\end{array}$ & $400(?)-856$ \\
\hline & Lower Triassic. & \multicolumn{2}{|c|}{ Moenkopi formation. } & $\begin{array}{l}\text { Chocolate-brown to yellow shale and sandstone } \\
\text { dominantly thin-bedded, platy, and ripple-marked; } \\
\text { includes locally thick-bedded sandstone, limestone, } \\
\text { and conglomerate of clay balls; weathers as a } \\
\text { ribbed slope. }\end{array}$ & $186-290$ \\
\hline \multirow{6}{*}{ Carboniferous. } & \multirow{5}{*}{ Permian. } & & Hoskinnini member. & Red sandstone and shale. & $0-50$ \\
\hline & & \multirow{3}{*}{ 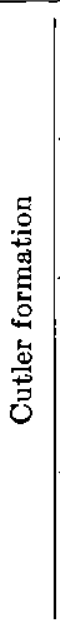 } & $\begin{array}{l}\text { De Chelly sandstone } \\
\text { member. }\end{array}$ & $\begin{array}{l}\text { Gray sandstone, in part cross-bedded, and associated } \\
\text { conglomerate of quartz, clay balls, lime pellets, } \\
\text { and shale fragments; appears as gray band on cliff } \\
\text { faces. }\end{array}$ & $4-90$ \\
\hline & & & $\begin{array}{l}\text { Organ Rock member. } \\
\text {-Local unconformity - } \\
\text { Cedar Mesa sand- } \\
\text { stone member. }\end{array}$ & $\begin{array}{l}\text { Red sandstone and sandy shale, uniformly fine- } \\
\text { grained and calcareous; lower part thin-bedded, } \\
\text { weathering as slope; upper part thicker, more } \\
\text { resistant beds, weathering as fluted wall. }\end{array}$ & $250-421$ \\
\hline & & & $\begin{array}{l}\text { - Local unconformity - } \\
\text { Halgaito member. }\end{array}$ & $\begin{array}{l}\text { Light-red to brown-red thin fine-grained ealcareous } \\
\text { shaly sandstones, irregularly bedded in detail; } \\
\text { subordinate thin, dense gray limestones; at base in } \\
\text { places conglomerate of limestone fragments; } \\
\text { weathers a steep benched slope. }\end{array}$ & $203(?)-464$ \\
\hline & & \multicolumn{2}{|c|}{ Rico formation. } & $\begin{array}{l}\text { Red and gray thick- and thin-bedded calcareous } \\
\text { sandstones; sandy shales; resistant gray limestones; } \\
\text { contains oil and fossils; weathers as flights of steps. }\end{array}$ & $300-325$ \\
\hline & Pennsylvanian. & \multicolumn{2}{|c|}{ Hermosa formation. } & $\begin{array}{l}\text { Drab hard cherty limestones, thieker and more } \\
\text { numerous at the base; gray, buff, and red calcare- } \\
\text { ous sandstones and sandy shales; fossiliferous; } \\
\text { alternating hard and soft beds; weathers as stair- } \\
\text { ways on canyon walls. }\end{array}$ & $436-1,086(?)$ \\
\hline
\end{tabular}

\section{CARBONIFEROUS FORMATIONS HISTORY AND CORRELATION}

In the plateau province and adjacent regions the Carboniferous has long been recognized. Strata of this age on Coconino and Kaibab Plateaus, in Grand Canyon, Marble Gorge, and Cataract Canyon, in the Zuñi Mountains, and in the San Juan Mountains are described in publications by Marcou (1856), Newberry
(1861), Powell, Dutton, Gilbert, and Marvine (187585), and Holmes and other members of the Hayden Survey (1874-78). In the Grand Canyon region the work of the early geologic explorers has been carried on by Noble, Darton, Robinson, and others, with the result that the subdivisions called "Lower Carboniferous" ("Redwall limestone"), "Upper Carboniferous" ("Aubrey sandstone" and "Aubrey limestone"), and 
"Permo-Carboniferous" have been reclassified as five formations-Redwall limestone (Mississippian) and Supai formation, Hermit shale, Coconino sandstone, and Kaibab limestone (Permian). Likewise the Carboniferous strata of southwestern Colorado, classified by the Hayden Survey as "Carboniferous", "Middle Carboniferous", "Upper Carboniferous", and "red beds below the Trias" have been redefined by Cross and his coworkers as three formations: Hermosa (Pennsylvanian), Rico (Permian), and Cutler (Permian). The formations thus established in the San Juan Mountains, Colorado, and the Grand Canyon, Ariz., have remained standards for the correlation of stratigraphic sections in Colorado, Utah, Arizona, and Nevada. In the region between these guideposts recent field work has brought to light other areas of Carboniferous rocks. Along San Juan Canyon, Pennsylvanian and Permian formations, reported by Gregory, ${ }^{47}$ have been studied in detail by Woodruff, ${ }^{48}$ Miser, ${ }^{49}$ and Baker and Reeside. $^{50}$ In the Moab region the extension of the Pennsylvanian and Permian formations of Colorado has been established by Baker and his coworkers. ${ }^{51}$ Permian formations of the Grand Canyon type in the San Rafael Swell have been described by Gilluly and Reeside, ${ }^{52}$ and those at Circle Cliffs and Paria Valley by Gregory and Moore. ${ }^{53}$

Throughout the vast region that lies between the San Juan Mountains, Colo., and the Muddy Mountains, Nev., the Carboniferous lies unconformably below Triassic beds-Moenkopi (Lower Triassic) in Utah, Arizona, and Nevada and Chinle (Upper Triassic) in Colorado. In the Grand Canyon and the Muddy Mountains the lowest Carboniferous beds (Mississippian) lie unconformably above the Devonian; elsewhere in the plateau province the base of the system is not exposed. But although the stratigraphic limits of the Carboniferous are generally recognized, there is a wide range of interpretation regarding the number, lithology, sequence, and age of formations at different localities.

The difficulties of satisfactory correlation are great. Two faunal provinces and widely diverse conditions of sedimentation are involved; most of the beds are unfossiliferous and, like bedded terrestrial deposits elsewhere, lack continuity; and the areas of type out-

\footnotetext{
1i Gregory, H. E., The San Juan oil field, San Juan County, Utah: U. S. Geol. Survey Bull. 431, pp. 11-25, 1911.

4 Woodruff, E. G., Geology of the San Juan oil field, Utah: U. S. Geol. Survey Bull. 471, pp. 76-104, 1912.

40 Miser, H. D., Geologic structure of San Juan Canyon and adjacent country, Utah: U. S. Geol. Survey Bull. 751, pp. 115-155, 1924.

so Baker, A. A., and Reeside, J. B., Jr., Correlation of the Permian of southern Utah, northern Arizona, northwestern New Mexico, and southwestern Colorado: Am. Assoc. Petroleum Geologists Bull., vol. 13, pp. 1413-1438, 1929.

31 Baker, A. A., Dobbin, C. E., McKnight, E. T., and Reeside, J. B., Jr., Notes on the stratigraphy of the Mosb region, Utah: Am. Assoc. Petroleum Geologists Bull., vol. 11, pp. 787-808, 1927.

32 Gilluly, James, and Reeside, J. B., Jr., Sedimentary rocks of the San Rafacl Swell and some adjacent areas in eastern Utah: U. S. Geol. Survey Prol. Paper 150, pp. 15-21, 1928.

ss Gregory, H. E., and Moore, R. C., The Kaiparowits region, a geographic and geologic reconnaissance of parts of Utah and Arizona: U. S. Geol. Survey Prof. Paper 164, pp. 38-45, 1931.
}

crops are far apart. In southeastern Utah the fossiliferous marine limestones in the lower walls of San Juan Canyon near Goodridge are now identified as belonging to the Hermosa formation (Pennsylvanian) of southwestern Colorado and are also correlated with formations of that age in the Mississippi Valley. Likewise the limestones and red shales that rim the canyon between Comb Wash and Grand Gulch are now identified as belonging to the Rico formation (Permian) of southwestern Colorado. These two formations are believed to extend northeastward without significant change for about 75 miles beneath covering beds. West of outcrops in the San Juan country the Carboniferous includes no formations like the Hermosa and the Rico, and fossils in the Permian limestone (Kaibab) belong to a western province-perhaps Asiatic. Somewhere beneath the 140-mile stretch of existing post-Permian rocks is the boundary between two regions in which during Pennsylvanian time and at least part of Permian time the topography and faunas were unlike.

The Permian strata that lie above the fossiliferous Rico present even greater difficulties of correlation. In southwestern Colorado these beds constitute a single unit (Cutler), described by Cross ${ }^{54}$ as "red beds" 1,000 to 2,000 feet thick. In the Moab region, Utah, these beds, here also assigned to the Cutler, ${ }^{55}$ are 400 to 600 feet thick and include not only red beds but, toward the west, white sandstone at the base and the top. Along the Kaibab trail, in the Grand Canyon, Permian red beds (Supai and Hermit), 825 feet thick, have much the same stratification and composition. In the San Juan country the outstanding feature of the Permian beds above the Rico is a thick-bedded, cross-bedded white sandstone (Cedar Mesa) that at Elk Ridge is more than 1,000 feet thick. Red beds below this sandstone resemble in a general way both the Cutler and the Supai but include limestones at several horizons. The beds above the Cedar Mesa likewise arc dominantly thin sandstones, mudstones, and sandy shale of various shades of red but include massive red beds, gray shales, limestone conglomerates, and white sandstones. Both the upper and lower series of red beds include many unconformities.

In such diverse sediments, in which guides for subdivisions are color, texture, and composition rather than fossils, only broad subdivisions can be recognized with profit. Minor subdivisions, though clearly exposed at one place, may be almost or quite different at places 20 miles distant.

Satisfactory regional correlation has been hindered by the interpretation of the paleontologic evidencemany times revised. Of the Colorado faunas, that in

34 Cross, Whitman, and others, U. S. Geol. Survey Geol. Atlas, Telluride folio (no. 57), 1899; La Plata folio (no. 60), 1899; Rico folio (no. 130), 1905; Engineer Mountain folio (no. 171), 1910; and Silverton folio (no. 120), 1905.

ss Baker, A. A., Dobbin, C. E., McKnight, E. T., and Reeside. J. B., Jr., op. cit.. pp. $794-796$ 
the Rico was formerly classed as Pennsylvanian ${ }^{58}$; then as "Permo-Pennsylvanian" with the statement that "no unequivocal Permian fauna has come to light" ${ }^{57}$; again as Pennsylvanian ${ }^{58}$; and finally as doubtful Permian by some paleontologists and true Permian by others. Reporting on the fossils in strata from top to bottom of the Honaker trail, San Juan Canyon, Schuchert ${ }^{59}$ states that "all the lots are of the Pennsylvanian", and Girty ${ }^{60}$ writes, "With one exception all the collections are clearly of Pennsylvanian age, and that lot (165) [51 feet above the base] is an exception merely because it is not sufficiently diagnostic to show that it is not Mississippian." As the strata comprising the San Juan section obviously are not the equivalents of those in any Pennsylvanian formation elsewhere, they were grouped by Woodruff ${ }^{61}$ in the †Goodridge formation ${ }^{6: 2}$ (Pennsylvanian) -a procedure followed by Gregory ${ }^{83}$ and by Miser. ${ }^{6 *}$ A restudy of the collections led Girty ${ }^{65}$ to the conclusion that

The Goodridge formation, as described by Woodruff, comprises two widely different faunas. The lower fauna, which contains almost no true Mollusca, changes abruptly at bed no. 55 of his transverse section to one that contains almost nothing else. * * * The general faunal resemblance would tend to correlate the upper part of the Goodridge with the Rico formation * * * and the lower part with the Hermosa. *** Developments of the last 10 years have brought about the assignment of the Rico formation to the Permian (?).

These conclusions were strengthened by a study of collections from the Carboniferous of the Moab region, regarding which Girty ${ }^{66}$ states:

Few paleontologists would question the Pennsylvanian age of the older fauna (Hermosa) in these collections $* * *$. In my judgment the later faunas (Rico) *** may be assigned to the Permian, * * * though the assignment should be recognized as provisional.

Giving full value to existing paleontologic and stratigraphic evidence, we may place the Rico without question in the Permian. There is little doubt that the limestones and associated strata at the Honaker trail are appropriately correlated with the Hermosa and Rico of Colorado. The term "Goodridge formation" is therefore discarded.

\footnotetext{
${ }_{66}$ Cross, Whitman, and others, U. S. Geol. Survey Geol. Atlas, Silverton folio (no. 120), 1905.

"7 Cross, Whitman and others, U. S. Geol. Survey Geol. Atlas, Rico folio (no. 130), 1905.

st Cross, Whitman, and others, U.S. Geol. Survey Geol. Atlas, Engineer Mountain folio (no. 171), 1910.

so Schuchert, Charles, in Gregory, H. E., The San Juan ofl field, San Juan County, Utah: U. S. Geol. Survey Bull. 431, p. 19, 1911.

${ }^{60}$ Girty, G. H., in Woodruff, E. G., Geology of the San Juan oil field, Utah: U. S. Geol. Survey Bull. 471, p. 83, 1912.

ot Woodruff, E. G., op. cit., pp. 80-85.

${ }_{62}$ A dagger ( $\dagger$ ) preceding a geologic name indicates that the name has been abun. doned or rejected for use in classification in pubilications of the U. S. Geolugieal Survey. Quotation marks, formerly used to indicate abandoned or rejected names, are now used only in the ordinary sense.

os Gregory, H. E., Geology of the Nuvajo country, a reconnaissance of parts of Arizons, New Mexico, and Utah: U. S. Geol. Survey Prof. Paper 93, p. 20, 1917.

os Miser, H. D., Geologic structure of San Juan Canyon and adjacent country, U tah: U. S. Geol. Survey Bull. 751, pp. 119-121, 1924 .

os Girty, G. H., in Longwell, C. R., Miser, H. D., Moore, R. C., Bryan, Kirk, and Paige, Sidney, Rock formations in the Colorado Plateau of southeastern Utah and northern Arizona: U. S. Geol. Survey Prof. Paper 132, pp. 7-23, 1923.

66 Girty, G. H., in Baker, A. A., Dobbin, C. E., McKnight, E. T., and Reeside, J. B., Jr., op. cit., p. 792.
}

The unfossiliferous Cutler, 1,000 to 2,000 feet thick, which embraces nearly all the red beds of southwestern Colorado, was long assigned to the Triassic, then provisionally referred to the Permian with the remark "but may prove to belong to the Pennsylvanian." 67 The fact that in lithology, in number and position of limestone beds, and in sequence the red beds that overlie the Rico of San Juan Canyon resemble more closely the Supai and Hermit than the Cutler, led Miser ${ }^{68}$ to designate these beds the "Supai (?) formation" and in most reports relating to exploration for oil the term "Supai" is applied to red beds underlying white sandstone at Cedar Mesa, on Elk Ridge, and along the Colorado canyons.

Harrison ${ }^{69}$ assigned to the Cutler the formations then known as the "Coconino", "Moenkopi", and "De Chelly" and termed the beds below them "Rico or Supai." He described as "Moenkopi" all the "red sandstones and shales" that lie above the Coconino; and the Shinarump as a sandstone above the De Chelly.

Prommel,${ }^{70}$ who used the term "Moenkopi-Cutler", remarked that in the series between the Shinarump and the Rico, " 1,300 to 1,400 feet thick", "the lower portion $* * *$ resembles very closely the Cutler formation of Colorado, while the upper part is very similar to the Moenkopi as described by Gregory."

For some 30 years after the description by Walcott of faunas in Kanab Valley the Permian was thought to include the group of fossiliferous shales, sandstones, and limestones that unconformably underlie the Shinarump conglomerate and overlie the Kaibab limestone (where present). These beds where exposed in the Little Colorado Valley were described by Ward $^{71}$ as the "Moenkopie" [Moenkopi formation], with the remark, "It is very probable that the lower portion of the Moenkopie beds belong to the Permian." Guided by these paleontologic conclusions, Gregory classed some 200 feet of imbricated, ripple-marked, slabby, thinbedded red and chocolate-brown shales, sandstones, and limestones near Fort Defiance as Moenkopi (Permian?). ${ }^{72}$ Likewise in San Juan Valley Woodruff ${ }^{73}$ and Gregory ${ }^{74}$ included in the Moenkopi all beds betweeen the Shinarump and the limestone of the Goodridge oil field, then thought by Girty ${ }^{75}$ as possibly at the same "geologic level" as the Kaibab. They recognized that in composition, color, and sequence of beds the lower part of the Moenkopi of southeastern Utah is unlike that in the Little Colorado Valley and that in stratigraphic position it corresponds with the Cutler of Colorado.

of Cross, Whitman, and others, op. cit. (Folio 171).

68 Miser, H. D., op cit. (Bull. 751), D. 121.

${ }^{69}$ Harrison, T. S., Colorado-Utah salt domes: Am. Assoc. Petroleum Geologists Bull., vol. 11, p. $115,1927$.

io Prommel, H. W. C., Geology and structure of portions of Grand and San Juan Counties, Utah: Am. Assoc. Petroleum Geologists Bull., vol. 7, p. 389, 1923.

" Ward, L. F., Geology of the Little Colorado Valley: Am. Jour. Sci., 4th ser. vol. 12, pp. 403-404, 1901.

is Gregory, H. E., op cit. (Prof, Paper 93), pp. 27-29.

3 Woodruff, E. (G., op. cit. (Bull. 471), pp. 86-88.

¿ Gregory, H. E., op. cit. (Prof. Paper 93), pp. $29-31$.

75 Girty, G. H., in Woodruff, E. G., op. cit., p. 83. 
A restudy of fossils from Arizona and southern Utah by Girty and others resulted in transferring the Moenkopi formation from the Permian to the Triassic, thus restricting the Permian and establishing for the plateau province a formation of Lower Triassic age. Using this new classification, Miser ${ }^{76}$ recognized the Supai and the Coconino as subdivisions of the Permian of the San Juan Valley, and more recent study has added other subdivisions. The regional unconformity below the accepted Moenkopi has been traced throughout most of the plateau province, and Permian fossils have been found below it. In the San Juan country between this pre-Triassic unconformity and the top of the Hermosa formation (Pennsylvanian) lie four thick, well-differentiated series of beds, a fifth thin but persistent series, and in places a sixth series less well defined. (See pp. 46-47.)

\section{PENNSYLVANIAN FORMATION}

\section{HERMOSA FORMATION}

Beds assigned to the Hermosa formation crop out in the San Juan Canyon at the Honaker trail and Soda Basin, in Dark Canyon, and in other tributaries to Cataract Canyon. Along the San Juan the base of the formation is not exposed. In Dark Canyon all the formation, also formations below, are represented in the well drilled by the Midwest Refining Co. Starting in the Rico formation this well penetrates 4,422 feet of strata, of which about 70 percent is limestone, and terminates in schist just below "blue hard sandy shale."

As the Hermosa beds combine with the overlying Rico to form a single wall in which no marked change in topography or lithology is observed, the boundary between these formations is drawn at the horizon where a dominantly brachiopod fauna (Hermosa) changes abruptly to one characterized by abundant pelecypods. Fortunately the measured sections of the $\dagger$ Goodridge formation are so related to the faunas that the division line can be drawn with assurance. Thus the Hermosa part of the fGoodridge formation at the Honaker trail is 1,086 feet as measured by Woodruff ${ }^{77}$ and 975 to 985 feet as measured by Miser. (See sec. 1, p. 65.) At the mouth of Slickhorn Gulch the Hermosa exposed measures 436 feet and in the Raplee anticline as much as 600 feet. The thickness of the Hermosa in exposures of †Goodridge in Dark Canyon (400 to 1,000 feet) and in Cataract Canyon (1,500 feet) has not been determined. (See pl. 5, A.)

The Hermosa consists of conformably interbedded limestones, sandstones, and shales-a series of alternating hard and soft beds which on erosion produce the remarkable steps shown in photographs of canyon walls. In the lowest one-third of all outcrops examined limestone is dominant. Beginning as beds 20 to 40

\footnotetext{
" Miser, H. D., op. cit., fig. 18, pp. 121-122,
}

n Woodruff, E. G., op. cit., pp. 81-82. feet thick, separated by shales and thin calcareous sandstones, the limestone continues upward, progressively decreasing in number and thickness of beds. As analyzed by Woodruff, ${ }^{n 7}$ the lowest 725 feet of the Hermosa at the Honaker trail contains 652 feet of limestone, 493 feet of which is in six beds. The limestones are predominantly drab, with shades of gray and of blue. Most of them are massive, hard, and crystalline and include nodules and lenses of red, gray, and jet-black chert. The top and the base of some massive limestone beds are coated with limestone conglomerate.

The sandstones are commonly gray but include buff, greenish, white, and (toward the top) red beds. They appear as massive beds 3 to 15 feet thick and as groups of thin beds that grade along the strike into shale. Most of them are fine-grained and consist chiefly of rounded quartz fragments cemented by lime.

The shales, like the sandstones, are dominantly gray, but there are black, green, and yellow beds and near the top of the formation shades of red are common. Most of the shale, particularly that of the red beds, is arenaceous and highly calcareous. In composition it differs little from the shaly sandstone and sandy limestone. The thinly foliated black shales are argillaceous; a few are bituminous. In sections measured along the San Juan, shale constitutes about 50 percent of the uppermost 200 feet and 15 percent of the lowermost 200 feet.

Fossil marine organisms collected from several beds and determined by Girty establish the Pennsylvanian age of beds in San Juan Canyon and serve as a means of correlating these beds with the Hermosa of Colorado. The faunal correlation is strengthened by similarity in composition and stratigraphic sequence, which indicates like conditions of deposition.

\section{PERMIAN FORMATIONS}

\section{RICO FORMATION}

Strata of the Rico formation are continuously exposed on the crests and flanks of the Raplee and Mitten Butte anticlines, where the topmost thin limestone forms the surface over large areas. They constitute the rim rock of the San Juan and tributary canyons between Comb Wash and Slickhorn Gulch, except along Lime Creek, where they are lost to view in the Mexican Hat syncline. The Rico is exposed in Dark Canyon, Beef Basin, and Fable Valley, and beds provisionally assigned to this formation appear in Mule, Arch, and Hammond Canyons. In the walls of canyons and gulches the limestone and hard sandstones interbedded with shale and soft sandstones form flights of colored steps that lead from the bottom to the top. On steep structural slopes bright-red sandstone is revealed by scores of meandering gullies that have cut through the cover of blue-gray limestone. Viewed from the west, the 
Raplee anticline is an exceptionally attractive feature (pls. $3, A ; 11, A$ ).

The Rico is made up of sandstones, shales, and limestones. The sandstones are prevailingly "red"bright red, dark red, pink, purple-but a few beds are brown, gray, or white. They include massive beds 10 to 20 feet thick and serjes of thin, lenticular beds. They are calcareous fine- to medium-grained rocks composed of quartz, calcite, some mica, and a little feldspar. The gray cross-bedded pitted sandstones that constitute the four oil sands in the Rico near Goodridge consist of clear quartz grains cemented by lime, the removal of which has produced a porosity favorable for the accumulation of disseminated petroleum. The shales are sandy and differ from the sandstones chiefly in thinness of bedding. They might be classed as thin, irregularly bedded, lenticular, in places cross-bedded sandstone units that lose their identity in short distances along the strike. The limestones are blue-gray, resistant, fossiliferous rocks that form benches. They are continuous and impervious enough to form caps for water and oil under pressure beneath. In sections measured at the Honaker trial four beds of limestone constitute about 11 percent of the rock exposed.

The bottom of the Rico is the top of the Hermosathe place in the fGoodridge formation where a Pennsylvanian fauna changes to one characteristic of the Permian. The top of the Rico is arbitrarily defined as the highest bed of limestone in the walls of San Juan and Johns Canyons, which generally is the highest fossiliferous stratum in the region. As thus limited, the Rico in the walls of the San Juan Canyon is 300 to 325 feet thick.

Beds assigned to the Rico in the San Juan country have the same relation to the underlying Hermosa as at Rico, Colo. Permian fossils from the Honaker trail are characteristic of the type Rico, but those from Dark Canyon contain suggestions of the Manzano fauna. In lithology, considerable differences appear. As described by Cross ${ }^{78}$ the sandstones in the Rico of Colorado

are mostly coarse or conglomeratic, always showing grains of fresh feldspar mixed with mica flakes and quartz. When conglomeratic the pebbles are chiefly of schists and quartzite. * * * The shales, aside from the sandy varieties, are of two kinds-the fine-grained, unlaminated red marly beds $* * *$ and the equally fine-grained, laminated clay shales of a green color.

In Utah the sandstone beds are finer-grained and less arkosic and contain oil; the shales show less variation in bedding and composition.

Except for the fossils and the larger numbers of persistent limestone beds in the Rico there is little to distinguish "that formation from the overlying Cutler. Both are Permian red beds, both are dominantly calcareous, irregularly bedded, more or less arkosic sandstones with considerable range in texture. Were it not for established usage the Rico and the lowest Cutler (Halgaito member) might be combined in one formation that derived its sediments from Colorado high lands and deposited them westward in shallow sea waters that intermittently withdrew. The periods in which the land provided red sediments seem to have increased progressively in length during the whole time represented by the Hermosa, the Rico, and the Halgaito.

The section of the Hermosa and Rico formations shown on pages $64-65$ (sec. 1) is representative of several that accompany the descriptions of the fGoodridge formation by Woodruff, Miser, and Gregory already cited. (See also sec. 2, p. 66.)

\section{CUTLER FORMATION TERMINOLOGY}

As defined by Cross ${ }^{79}$ the Cutler formation is that division of the Permian red beds that overlies the Rico and unconformably underlies the Dolores (Chinle in part). In Colorado it has been treated as a unit within which the differences in lithology and the unconformities are not sufficiently persistent nor diagnostic to justify separation into members. Where beds above the Rico reappear in southeastern Utah, some 75 miles west of the typical Cutler outcrops, four or in places five clearly marked Permian subdivisions and two Triassic subdivisions occupy the Rico-Chinle interval.

Field work by Baker and Reeside ${ }^{80}$ and the investigation on which the present paper is based have resulted in the separation of the Permian and the Triassic and demonstrated that post-Rico Permian time in the San Juan country and neighboring districts is represented by a lower series of red beds, a great thickness of white sandstones, and an upper series of red beds and may include also a persistent bed of gray conglomerate along White Canyon and a thin series of red shales leading upward in turn to the Permian-Triassic unconformity at the base of the Moenkopi. The rank that should be given to these lithologic subdivisions and their correlation with unlike sediments recognized elsewhere are necessarily matters of opinion. The few fossil plants and bone fragments indicate Permian age, but the parts of this long period represented by the formations and the relations of the strata to established Permian formations in Colorado and west of Glen Canyon are imperfectly known.

In the present paper the series of Permian beds above the Rico are assigned to the Cutler formation and divided into five members, in ascending order the Halgaito, Cedar Mesa, Organ Rock, De Chelly, and Hoskinnini. As these names have been published by Baker and Reeside for subdivisions south of the San Juan River, they are here used for the region north of the river, where substantially the same units are represented. Of the five members assigned to the Cutler by Baker and Reeside all except the Halgaito are here

19 Cross, Whitman, op. cit. (folio 130), p. 4.

so Baker, A. A., and Reeside, J. B., Jr,, Jop, cit. 
considered as doubtfully corresponding to the Cutler formation as represented in Colorado. (See secs. 2 to 13, pp. 66-72.)

\section{HALGAITO MEMBER}

The Halgaito member (Halgaito tongue of Baker and Reeside) of the Cutler formation is that division of the Permian red beds that immediately overlies the Rico formation. In Lime Creek Valley it forms the base of Mexican Hat, Bell Butte, and other picturesque erosion remnants (pls. 4, $B, C ; 9, C$ ). Westward along the San Juan River it is well displayed in Cedar Mesa and the steep walls of Johns Canyon and Slickhorn Gulch. North of Lime Creek Valley it forms an undetermined part of Rico-Cutler sections in Fish, Road, Mule, and Arch Canyons, tributary to Comb Wash, in Hammond Canyon, and in branches of Dark Canyon north of Elk Ridge. Viewed from a distance, low cliffs and long steep slopes of Halgaito strata appear as uniform horizontal layers of alternating hard and soft red sandstone banded with purple and gray, but the bedding is irregular. Sandstone in beds 2 to 10 feet thick, sufficiently massive and resistant to form a protruding ledge, changes in short distances along the strike to shaly beds that on weathering form slopes. Most of the sandstone splits readily into sheets 2 to 6 inches thick not susceptible of further subdivision; the shale into beds about an eighth of an inch thick. The bedding planes are commonly lumpy with overlapping plasters of mud, though a few are smooth and glistening. Some show ripple marks and mud cracks; others show shallow erosion channels and depressions filled with the material of the overlying beds. Measured sections include three to seven widely spaced beds of gray limestone as uniform and continuous as the sandstones. They also include thin beds or bands of white sandstone that in composition are like the red beds and perhaps are red beds from which the iron cement has been leached by ground water.

Here and there at the base of the formation is a thin conglomerate composed of fragments of red sandstone or of pebbles, slabs, and angular chunks of gray, blue, and black limestone. It suggests a plane of unconformity between the Rico and the Halgaito and is so interpreted by Miser. ${ }^{81}$

The massive and shaly sandstone alike include lenses of limestone conglomerate, iron, lime, and sand concretions. Some strata are cross-bedded, and many include dark areas surrounded by white or blue zones that suggest leaching of vegetable matter. (See secs. 3 to 6 , pp. 67-69.)

As typically exposed in the San Juan Valley the materials classed as sandstone and shale are essentially alike in color and composition. In general the shale is brighter red, more uniformly fine-grained, and slightly less calcareous, but all the red beds range in

\footnotetext{
"Miser, H. D., Geologic structure of San Juan Canyon and adjacent country, Utah: U. S. Geol. Survey Bull. 75!, p. 120, pl. 15, 1924.
}

color from light red to brown, consist mostly of grains too small to be distinguished with the unaided eye, and are so calcareous that the local term "red limestone", the source of the name "Lime Creek", seems reasonably appropriate. The chief constituents are poorly rounded grains of clear quartz, calcite or dolomite, and iron as cement and scattered particles. Muscovite and gypsum are present in small amounts, also microscopic bits of feldspar, magnetite, and garnet (?). Near the top of the formation in Johns Canyon are slightly carbonaceous beds.

The top of the Halgaito is marked by the lowest bed of sandstone typical of the Cedar Mesa member. Its base is marked by the highest limestone bed in the Rico. As thus limited it is 380 feet thick at Slickhorn Gulch, 464 feet in Johns Canyon, 425 feet near Cedar Point, 392 feet at the head of Lime Creek, 402 feet at Navajo Springs, Comb Wash, and 203 feet in Fish Creek Canyon. Northward about Elk Ridge its limits have not been definitely established, and it may be absent.

The strata here described as the Halgaito member of the Cutler were included in the Moenkopi formation (then recognized as Permian) by Woodruff ${ }^{82}$ and Gregory ${ }^{83}$ and classed as the Supai (?) formation by Miser ${ }^{84}$ and most geologists of oil companies. Though its lithology is like that of the Supai or, even more, the Hermit shale, it is correlated with the Cutler of Colorado chiefly because of its relations to the underlying Rico. Fragmentary bones in the limestone conglomerates and plants in formations above prove its Permian age.

\section{CONTACT OF HALGAITO AND CEDAR MESA MEMBERS}

At outcrops where both members are well displayed the red, shaly, slope-forming Halgaito strata terminate abruptly at the base of a prominent cliff composed of buff to white thick-bedded massive Cedar Mesa sandstone. In sections measured at Polly and Cedar Mesas the contact is marked (1) by an irregularly continuous bed of conglomerate composed of clay mud balls and lozenges, concretionary limestone, and fragments of sandstone, (2) by an earthy nodular limestone including clay pellets, short shale lenses, and coarse grains of quartz, or (3) by thin even beds of fairly coarse sandstone with hardened and ripple-marked surfaces. The wavy contact is the zone of springs and seeps. Unconformity is further suggested by the study of sections exposed in the Monument upwarp. In Fish Creek Canyon strata assigned to the Halgaito are about half the thickness of those 10 miles farther south and are weathered at the top. In Arch Canyon the contact of Cedar Mesa sandstone with underlying

82 Woodruff, E. Q., Geology of the San Juan oil Gield, Utah: U. S. Geol. Survey Bull. 471, pp. 86-88, 1912.

8s Gregory, H. E., The Navajo country: U. S. Geol. Survey Prof. Paper 93, pp. 29-30, 1917.

s Miser, H. D., Geologle structure of San Jusn Canyon and adjacent country Vtah. U. B. Geol. Survey Bull. 751, p. 121, 1924. 


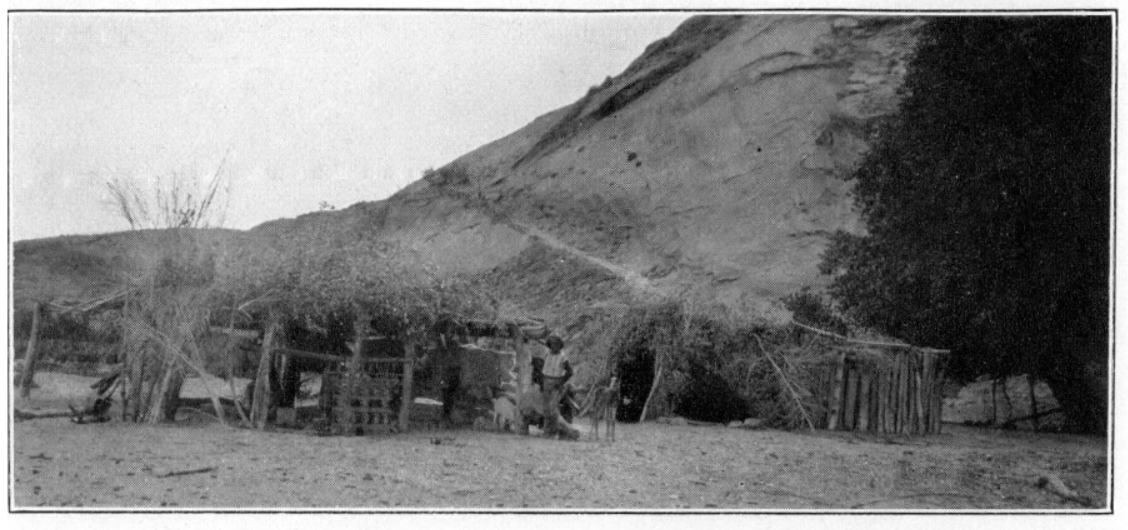

A. NAVAJO SUMmer hoUSE NEAR MOUTH OF BUTLER WASH.

Dugway on old Escalante-Bluff road cut in Navajo sandstone of Comb Ridge. Photograph by
R. N. Allen.

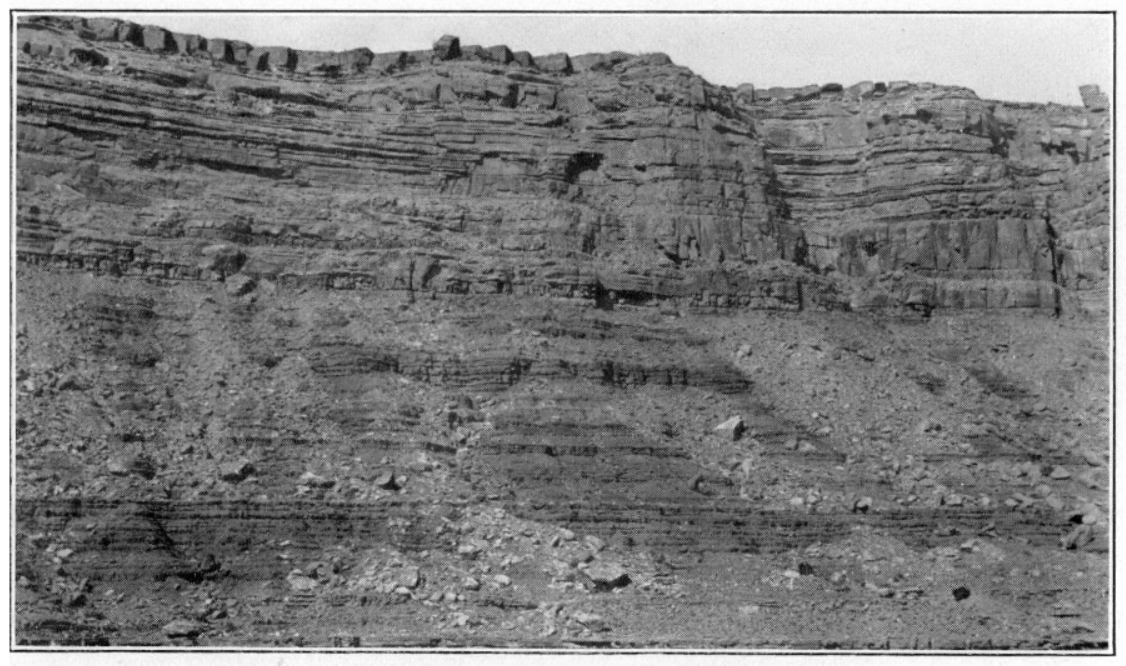

C. WALL OF JOHNS CANYON NEAR ITS HEAD.

Halgaito strata (lower half) and Cedar Mesa strata (upper half). Top bed of Rico formation in
foreground.

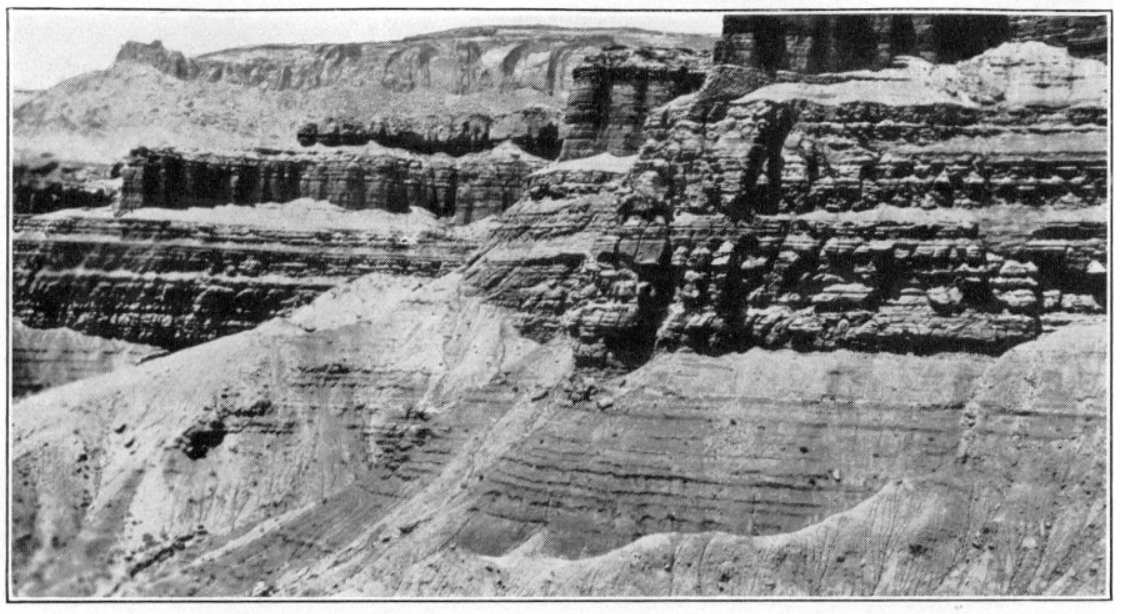

B. RED HOUSE CliFF, 4 MIJES NORTH OF SAN JUAN RIVER. Organ Rock member of the Cutler formalion: Iower part (division A), shaly sandslone: upper part
(division 13), resistant sandstone. Clinle and Wingate covered by Kayenta in left distance.

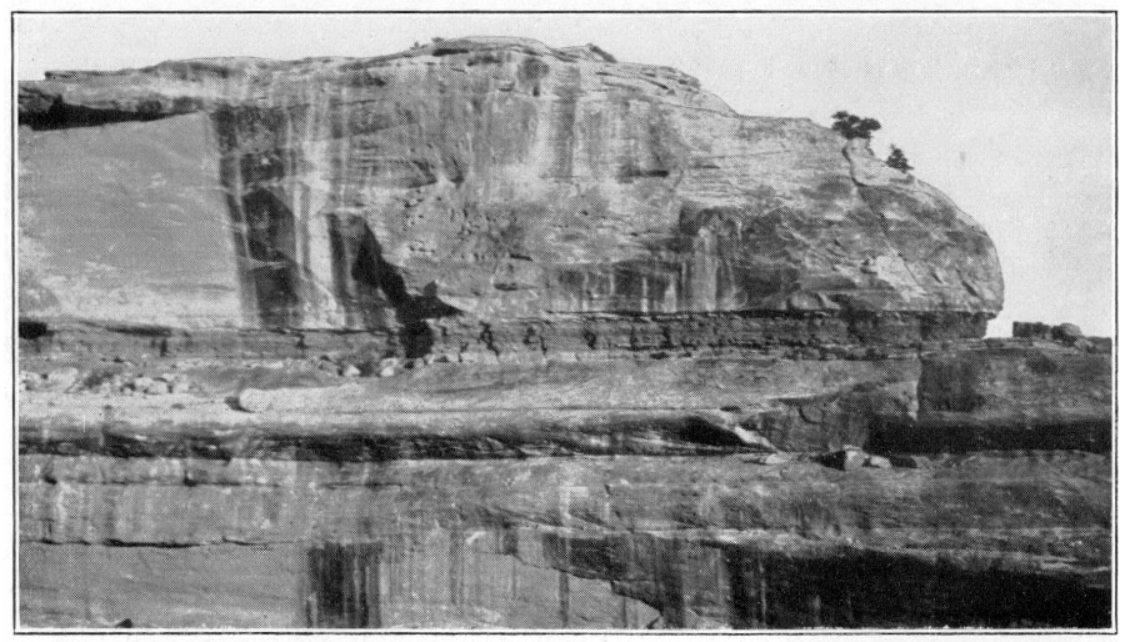

D. SANDSTONE AND SHALE IN ARMSTRONG CANYON. Upper part of Cedar Mesa member of the Culler formation. 



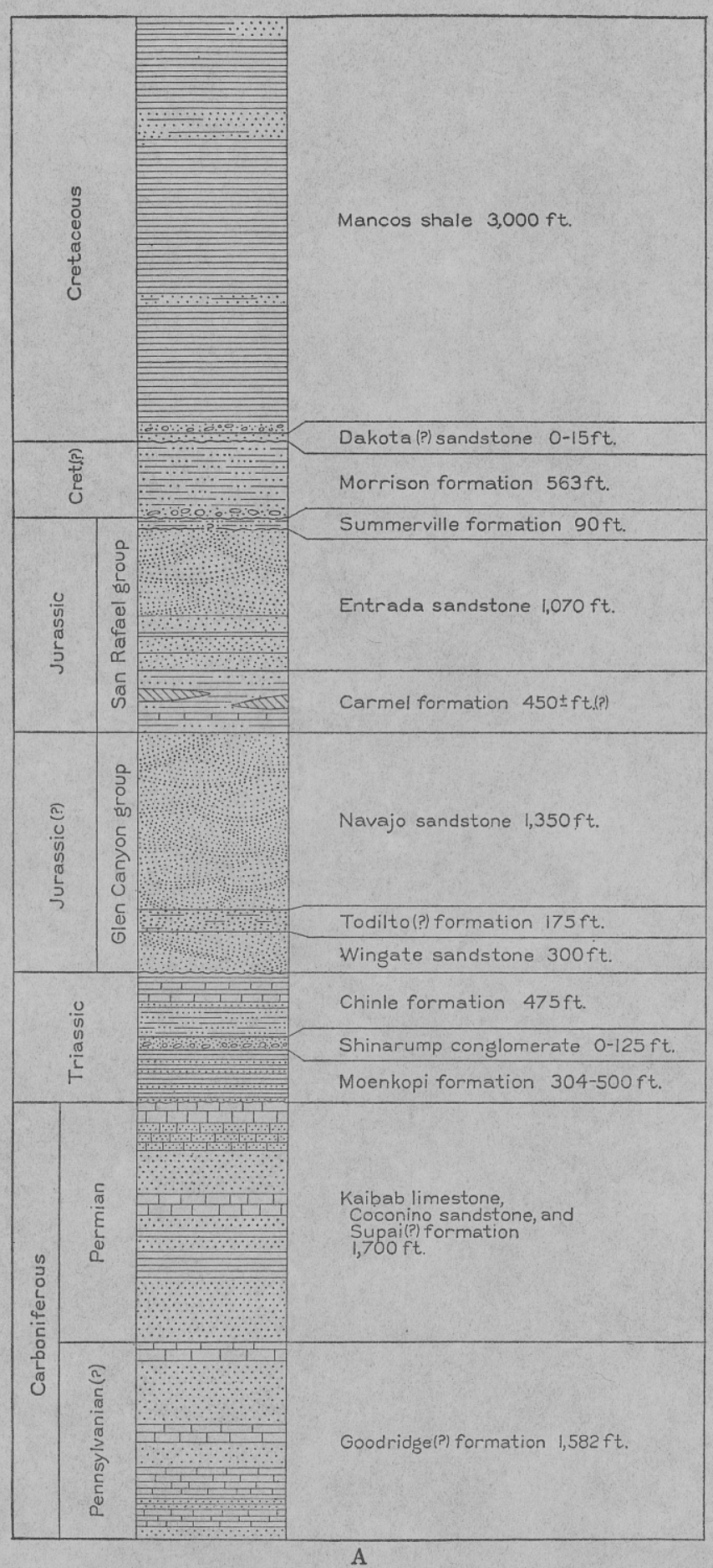

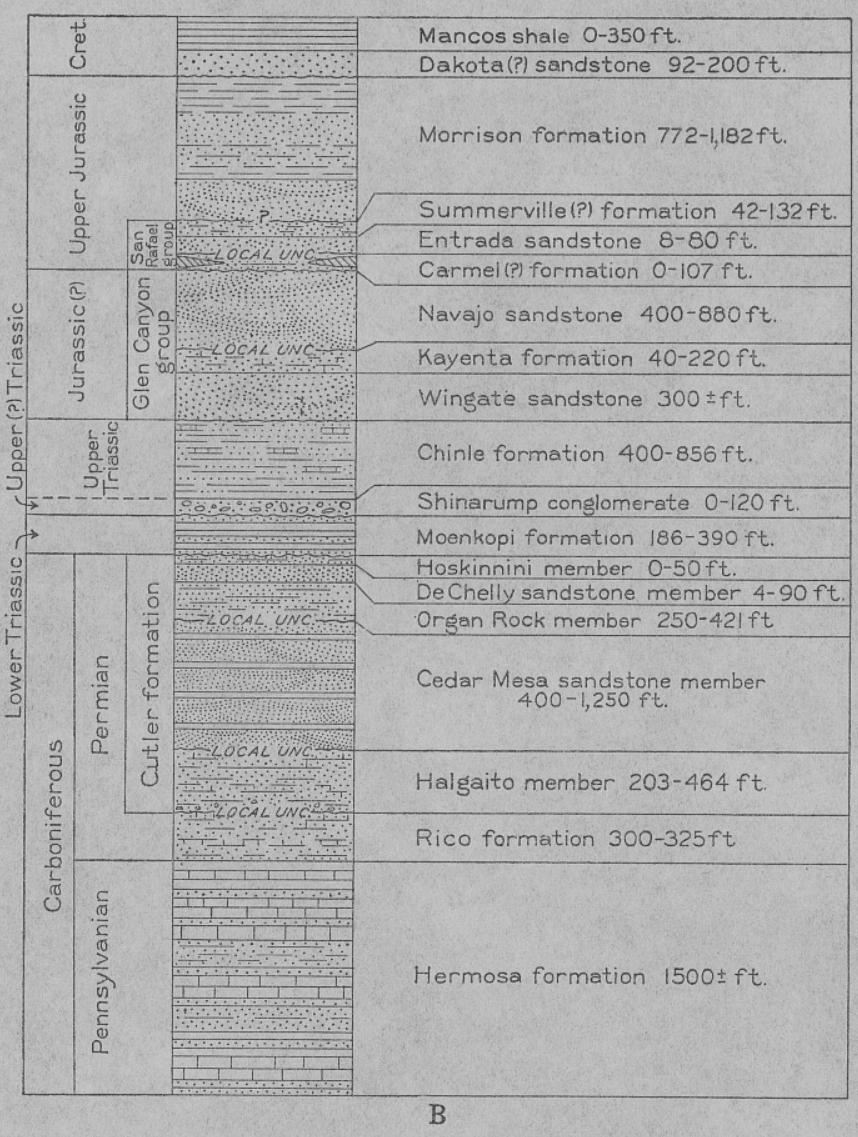

COLUMNAR SECTIONS.

Kaiparowits region (after Gregory and Moore, Prof. Paper 164).

$B$. San Juan country.
$C$ Southwestern Colorado (after Cross and Spencer, Geol. Atlas, Rico folio no. 130).

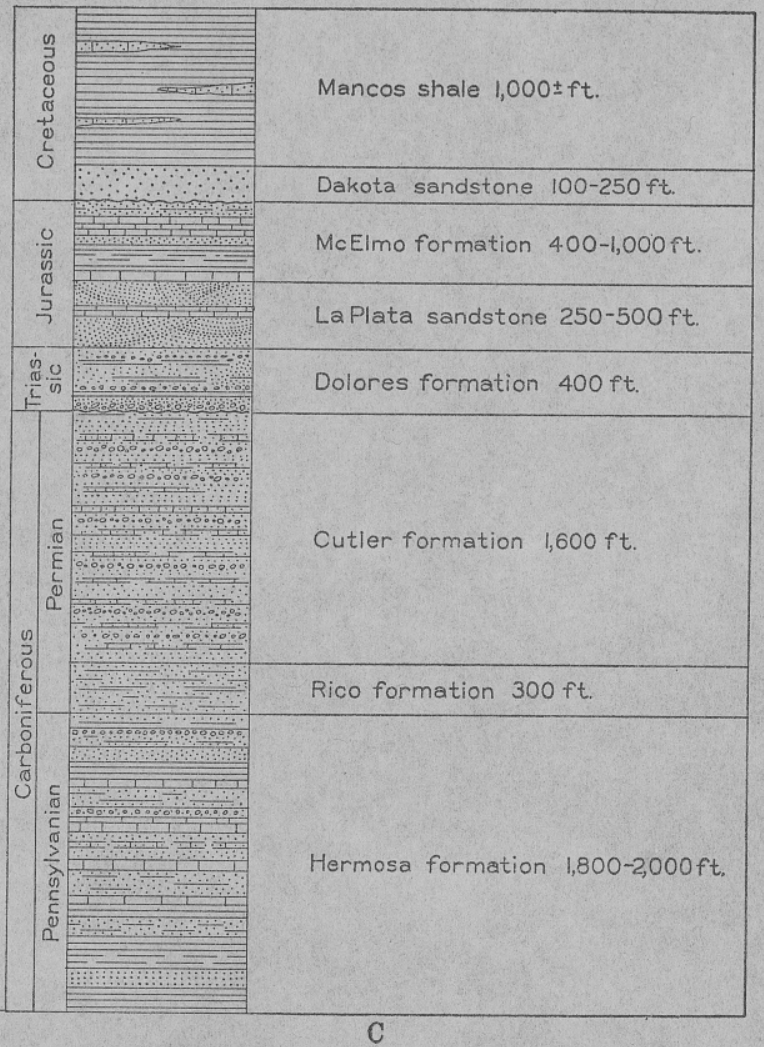

C 

red beds is a surface of erosion on which lie large diskshaped cherts, irregularly disposed lenses of clay shale, black carbonaceous sandstone, and strings of quartz pebbles. Only a few feet of red beds lie between the plane of unconformity and limestones that contain a fauna which has the facies of the Rico formation. In Hammond Canyon no typical Halgaito beds were seen. In Dark Canyon the few red beds among the gray sandstones and fossiliferous limestones that lie below the Cedar Mesa are quite unlike those in the Halgaito of the San Juan Valley. On the Spanish trail, near the mouth of the Green River, Prommel and Crum ${ }^{85}$ noted an erosion surface at the base of the Coconino [Cedar Mesa] - the result of "an upwarp at the close of Rico-Supai time." The contact of the Halgaito and the shaly phase of the Cedar Mesa member in Road Canyon is shown in plate 11, $B$.

The stratigraphic significance of this unconformity is not clearly understood. If the northward thinning and final disappearance of the Halgaito can be explained as the result of erosion, the unconformity represents a considerable interval of time. On the other hand, if the Halgaito is thought of as the western extension of the lowermost Cutler of Colorado-not everywhere deposited-and the Cedar Mesa merely a modified form of the typical Cutler, no important lapse of time need be predicated. Baker and Reeside ${ }^{86}$ treat the Halgaito and the Cedar Mesa as conformable members of the Cutler that grade laterally into each other. They consider that the variation in thickness of the red Halgaito records the degree to which it has been replaced by the white Cedar Mesa.

\section{CEDAR MESA SANDSTONR MEMBER}

Overlying the "lower red beds" (Halgaito member) and underlying the "upper red beds" (Organ Rock member) of Permian sections in the San Juan country is the series of sandstones and subordinate shales and limestones here identified as the Cedar Mesa sandstone member of the Cutler formation.

This member is widely displayed. Along the San Juan River it is the cap rock of mesas between Comb Wash and Clay Hill Crossing and of erosion remnants in Lime Creek Valley and at Zahns Camp. It forms the surface of Grand Gulch Plateau and continues along the White River and its tributaries nearly to the Colorado River as a white floor into which the canyons are cut and above which rise red cliffs. About Elk Ridge it is prominently exposed in Dark Canyon, Fable Canyon, and Beef Basin and at the heads of canyons tributary to Cottonwood Canyon and Comb Wash. (See pls. $5, B ; 6, A ; 8, C ; 9, D ; 11, C$.)

\footnotetext{
Bs Prommel, H. W. C., and Crum, H. E., Salt domes of Permian and Pennsylvanian age in southeastern Utab and their influence on oil accumulation: Am. Assoc. Petroleum Geologists Bull., vol. 7, pp. 384-390, 1923.

b8 Baker, A. A., and Reeside, J. B., Jr., Correlation of the Permian of southern Utah, northern Arizona, northwestern New Mexico, and soutbwestern Colorado: Am. Assoc. Petroleum Geologists Bull., vol. 13, p. 1432, 1929.
}

In thickness the Cedar Mesa ranges from about 400 feet on the south face of Grand Gulch Plateau to 600 to 1,000 feet in canyons that head in Elk Ridge. Warren O. Thompson, of the Midwest Refining Co., gives a maximum thickness of 1,250 feet ("Coconino-sandstone and massive limestone, white"). For some 20 miles in Grand Gulch and 30 miles in White Canyon the streams have cut 200 to 500 feet in to the member without reaching its base.

The sandstone that constitutes the bulk of the member appears in beds 20 to 40 feet thick, some as much as 80 feet thick, that retain their individuality for miles. Many thick beds change along the strike into a group of thin beds, and some beds appear as long lenses. Few beds are even and smooth at their tops or bottoms. Cross-bedding is common but varies much in amount, kind, and distribution. An outcrop about 150 feet thick in Hideout Canyon includes no cross-bedded strata, but below Collins all beds examined in the wall of Grand Gulch are cross-bedded. In Cedar Mesa and Polly Mesa the basal strata are much less crossbedded than those at the top; in a branch of Cottonwood Canyon cross-bedded strata underlie and overlie a series that lacks this feature. Few thick beds are cross-bedded throughout. Most of the cross-bedding is angular; sets of parallel oblique laminae terminate sharply at a horizontal line. Near Sipapu Natural Bridge and elsewhere some beds show long curves that gradually flatten and become tangent to a basal plane. In general, cross-bedding in the Cedar Mesa seems neither so prominent nor so uniform as that in the Coconino and resembles little the great curves and fine scroll work of the Navajo.

The sandstone consists chiefly of quartz cemented by lime. The grains in some of it are distinguishable with the eye, but in most of it they are revealed only by the microscope, which shows rounded grains of clear quartz, some fragments of calcite, and black bits of iron cemented by calcite (and dolomite?) that seems to have been generously supplied. It weathers to a powderlike substance readily swept away by winds. The rock includes many hard limestone concretions, some white and red chert, and here and there cavities shaped like cross sections of coral. Two shell casts were found. The amount of lime varies widely. Of fragments tested, some are nearly pure quartz sandstone; others nearly pure limestone. Most of them effervesce freely with acid and give the impression that as a comprehensive term "arenaceous limestone" is about as good as "calcareous sandstone." No consistent regional distribution of the less calcareous material was noted, but in general the upper beds are somewhat more calcareous than the lower, and outcrops near Glen Canyon more calcareous than those farther east. In color the sandstone is cream white and weathers buff tan or yellow brown. In contrast with the red rocks above, it is 
white and is so thought of in naming "White Canyon", "white arches", "white peaks", and "white road."

The shale that separates the beds of sandstone is microscopically fine-grained lime silt with sufficient iron to produce various shades of red and brown. In places it is well stratified and fissile, but generally it is lenticular in detail, and beds a few inches to 8 feet thick thin and thicken along the strike in a seemingly capricious manner. Interbedded with the shale are lenses of thin blue-gray limestone, strings of red and white chert in flattened masses 1 to 8 inches in diameter, and plasters of fairly large quartz grains.

Limestone in the Cedar Mesa appears not only with the red shales but also in the sandstones, where it is represented by very thin beds of hard gray rock and of concretionary conglomerate that extend for a few tens of feet and by isolated fragments. A limestone bed 2 feet thick in Fable Valley is exceptional. (See secs. 6 and 7, pp. 69-70.)

Because the sandstone beds are dominantly finegrained and calcareous, the outcrops are rounded; straight-edged steps and sheer vertical cliffs are rare. As the shale weathers more readily than the sandstone, most canyon walls are like grooved moldings - outwardcurving and inward-curving elements in parallelism. Deeply recessed grooves high on canyon walls serve as trails for animals and as sites for cliff houses. Vertical joints that cross individual sandstone strata combine with bedding seams to outline masses which on weathering appear like a row of elongated biscuits placed on the canyon rim. Joints that traverse the whole formation in Arch Canyon, in lower Notch Canyon ("Chimney Park"), and elsewhere outline towers detached from canyon walls. Joints aided by cross-bedding have developed arches, windows, and natural bridges in White Canyon and Arch Canyon, "haystacks" on Grand Gulch Plateau, and picturesque erosion remnants at many other places.

As pointed out by Woodruff, ${ }^{87}$ the thick-bedded Cedar Mesa sandstone that caps Cedar Point loses its characteristic features in passing southeastward.

To the south it is composed chiefly of soft light-pink sandy shale, with darker shaly sandstone interbedded. To the north * * * [it] consists of massive tan-colored sandstone beds forming Cedar Mesa. * * * The transition of the shale of the south into the sandstone of the north begins $* * *$ southwest of Navajo Spring. In this area the shale beds that predominate to the south are interstratified with thin sandstone lenses which thicken rapidly to the north and replace the shale.

Along lower Comb Wash the Cedar Mesa member, as represented elsewhere, is scarcely recognizable. The dominant resistant sandstones give way to weak strata and, in consequence, the usual cliffs are replaced by slopes and mounds of crumbling rock. As shown in section 4 (p. 68) the Cedar Mesa here includes not only beds of white sandstone but also red-pink gypsiferous

i7 Woodruff, E. G., Geology of the San Juan oil fleld, Utab: U. S. Geol. Survey Bull. 471, p. 86, 1912. shales, brown shaly sandstones, conglomeratic and even-bedded dense limestones, chert, and much gypsum. Though the section includes beds of typical tan-colored Cedar Mesa sandstone, the thickest measures only 22 feet. Most of them are sheets a few inches to a few feet thick that appear as if inserted between layers of shale, of shale and gypsum, and of limestone and darkred thin sandstones. Some of them taper to extinction; others grade laterally into thin beds or thick beds that differ from the type only in color; still others grade along the strike and down the dip into gypsiferous or arenaceous shales with or without change in color. South of the San Juan River strata approximately in the stratigraphic position of those along Comb Wash include only red beds; deposits of Cedar Mesa time, if ever present, have lost their identity. These evidences of "transition" first noted by Woodruff ${ }^{88}$ suggest that the Permian white beds of southeastern Utah merge gradually into the Permian red beds of Colorado; that the Cedar Mesa sandstone should be treated as part of the Cutler formation. This interpretation seems not to take sufficiently into consideration the erosional unconformity at the base of the Cedar Mesa and the conspicuous unlikeness in lithology between this member and any part of the typical Cutler in Colorado as described by Cross. ${ }^{89}$ Furthermore, casts of fossils, the type of cross-bedding, and arrangement of subordinate beds in the Cedar Mesa suggest conditions of sedimentation not applicable to the Cutler.

Northward from Navajo Springs the gypsiferous beds thin to disappearance, the beds of white sandstone thicken, and the red shale becomes more prominent until at Fish Creek, Texas Canyon, and Arch Canyon the canyon walls show the alternating white sandstone and red shale characteristic of the Cedar Mesa. (See secs. 4 and 6, pp. 67-68,69.)

Beds comprising the Cedar Mesa member at its southernmost outcrops were included in the Moenkopi by Woodruff ${ }^{90}$ and Gregory. ${ }^{91}$ They were classed as Coconino sandstone in a published paper by Miser ${ }^{22}$ and in manuscript reports by other geologists. The member has generally been described as the eastern continuation of the Coconino or as having closely similar lithologic features. But the Coconino and the Cedar Mesa have little in common. Unlike the stratified Cedar Mesa, the Coconino appears as a single massive bed of uniformly fine-grained, well-rounded quartz with a cement so siliceous that the rock does not effervesce with acid. It includes no division planes of shale or other material. At all exposures examined it makes strong vertical cliffs or hogbacks characterized by persistent angular cross-bedding that separates the rock into huge wedges. Furthermore, as shown by

\footnotetext{
is Woodruff, E. G., op. cit.

Cross, Whitman, U. S. Geol. Survey Geol. Atlas, Rico folio (no. 130), 1905

oo Woodruff, E. G., op. cit. (Bull. 471), pp. 86-88.

"I Gregory, H. E., op. cit. (Prof. Paper 93), pp. 29-30.

${ }^{92}$ Miser, H. D., Geologic structure of San Juan Canyon and adjacent country. Utah: U. S. Geol. Survey Bull. 751, pp. 121-122, 1924.
} 
Gregory and Noble ${ }^{93}$ the Coconino of Grand Canyon, 330 feet thick, thins northward and northeastward across Kaibab Plateau and is absent from sections measured in Kaibab Gulch. East of the Paria Valley no unmistakable Coconino has been recognized. Even in upper Marble Gorge, where both formations are fully exposed in a single wall, limits of the Coconino and the Kaibab have been recognized with doubt; in substantially the same section near Lees Ferry recorded thicknesses of the Coconino range from 57 to 300 feet. In part the difficulty seems to lie in the general view that the Coconino is a "cross-bedded sandstone" and the Kaibab a "regularly bedded limestone." But though the typical Coconino is noncalcareous and strongly cross-bedded, the Kaibab is everywhere arenaceous and much of it is cross-bedded.

Thus Noble ${ }^{94}$ shows that of 562 feet of the Kaibab at the Bass trail, 136 feet is "buff and reddish fine-grained sandstone" and 134 feet "buff" sandstone and limestone in alternating beds"; and that a section 717 feet thick at Kaibab Gulch includes 272 feet of "sandstone" and 445 feet of thin-bedded limestone with which are incorporated beds of "calcareous sandstone." Gregory ${ }^{95}$ describes the Kaibab of the Little Colorado Valley as ranging between an arenaceous limestone and a calcareous sandstone. Gilluly and Reeside ${ }^{96}$ state that the Coconino [Kaibab?] of San Rafael Swell "is dominantly lime-cemented and somewhat friable. $* * *$ The basal 40 feet of the thickest exposure $*^{*} *$ is chiefly limestone." At the Waterpocket Fold, as reported by Gregory and Moore," "the Coconino sandstone $* *^{*}$ differs in no respect from the sandstone in the lower part of the Kaibab." Additional proof of the invalidity of the correlation of the Cedar Mesa with the Coconino is presented in a recent paper by $\mathrm{McKee}^{98}$

The Cedar Mesa member is here considered to occupy the stratigraphic position of the combined Coconino and Kaibab formations of the Kaibab Plateau and to be partly equivalent in lithology to the Kaibab. Substantially it is the sandy phase of the Kaibab, which, extending eastward, constitutes an increasingly large part of the formation and finally the whole.

\footnotetext{
${ }^{93}$ Gregory, H. E., and Noble, L. F., Notes on a geological traverse from Mohave, Calif,, to the mouth of the San Juan River, Utah: Am. Jour. Sei., 5th ser., vol. 5. pp. 229-238, 1923. Noble, L. F., A section of the Kaibab limestone in Kaibab Gulch, Utah: U. S. Geol. Survey Prof. Paper 150, pp. 43-46, 1928.

"Noble, L. F., A section of the Paleozoic formations of the Grand Canyon at the Bass trail: U.8. Geol. Survey Prof. Paper 131, p. 26, 1923; A section of the Kaibab limestone in Kaibab Gulch, Utah: U. S. Geol. Survey Prof. Paper 150, pl. 12, 1928.

is Gregorg, E. E. Geology of the Navajo country, a reconngissance of parts of A rizona, New Mexico, and Utah: U.S. Geol. Survey Prof. Paper 93, p. 20, 1917.

os Gilluly, James, and Reeside, J. B., Jr., Sedimentary rocks of the San Rafael Swell and some adjacent areas in eastern Utah: U. S. Geol. Survey Prof. Paper 150, p. 63, 1828.

"Gregory, H. E., and Moore, R. C., The Kaiparowits region, a geographic and geologic reconnaissance of parts of Utah and Arizons: U. S. Geol. Survey Prof. Paper 164, p. 40,1831 .

${ }^{\circ} \mathrm{McK}_{e e}, \mathrm{E} . \mathrm{D} ., \mathrm{The}$ Coconino sandstone-its origin and history: Carnegie Inst. Washington Pub. 440, pp. 77-115, 1933.
}

CONTACT OF CEDAR MESA AND ORGAN ROCK MEMBERS

An unconformity at the top of the Coconino was noted by Miser ${ }^{99}$ in San Juan Valley and by Prommel ${ }^{1}$ in Cataract Canyon. About the mouth of the Fremont River, where the Coconino [Cedar Mesa] is overlain by maroon and red shales of the lower Moenkopi [Organ Rock member], Longwell ${ }^{2}$ found that "the resistant Coconino preserves large areas of the pre-Triassic erosion surface almost unchanged. $* * *$ Recent canyons are cut through the contact, revealing it as a distinct wavy line overlain by conglomerate in which all the pebbles are sandstone." In the San Juan country the contact plane of the Cedar Mesa and Organ Rock members ranges in unevenness from slightly wavy surfaces to those that have a relief of 5 to 10 feet within areas of about a quarter of a square mile. In some places the overlying red shales occupy the depressions, but commonly beds or patches of conglomerate intervene. In lower White Canyon the conglomerate consists chiefly of fragments of white and red sandstone, red shale, quartz grains, and flattened pellets of gray clay limestone, associated with which are huge limestone concretions and some chert, probably of secondary origin. At a place between Fish and Mule Creeks the conglomerate shows angular limestone fragments and chert embedded in coarse sand, all firmly cemented by lime and iron. It rests in hollows eroded in the top of a thick bed of white sandstone. At places on Grand Flat and northward along Steer Gulch the conglomerate, composed chiefly of fragments of limestone and clay mud balls, rests on a mud-cracked surface of shaly calcareous sandstone.

The regional extent and stratigraphic significance of the unconformity at the top of the Cedar Mesa member are not known. Obviously it is not the erosion surface that separates the Lower Triassic Moenkopi from Permian formations, for that lies some 300 feet higher in the same sections. The conclusion of Longwell ${ }^{3}$ and others that the erosion surface at the top of the Coconino [Cedar Mesa] marks the division between Permian and Triassic time and that the unconformity "about 400 feet" higher records but an interruption in Triassic deposition is opposed by the fact that plants of Permian age appear in the "Iower Moenkopi." If the unconformity represents but a brief and somewhat localized interruption of Permian sedimentation, the red beds above it constitute deposits of Kaibab age quite unlike those elsewhere in the plateau province.

$"$ Miser, H. D., Geologic structure of San Juan Canyon and adjacent country Utah: U. S. Geol. Survey Bull. 751, p. 120, 1924.

' Prommel, H. W. C., Geology and structure of portions of Grand and San Juan Counties, Utah: Am. Assoc. Petroleum Geologists Bull., vol. 7, pp. 384-390, 1923.

' Longwell, C. R., Miser, H. D., Moore, R. C., Bryan, Kirk, and Paige, Siđney, Rock formations in the Colorado Plateau of southeastern Utah and northern Arizon: U. S. Geol. Survey Prof. Paper 132, p. 8, 1923.

Idem, pp. 9, 10 
Baker and Reeside "define the Cedar Mesa sandstone as an integral part of the Cutler formation, conformable with red beds above and below.

\section{ORGAN ROCK MEMBER}

The sedimentary rocks here classed as the Organ Rock member of the Cutler formation comprise a series of dominantly red sandstones and sandy shales that rests on the Cedar Mesa sandstone and extends upward to a gray band of sandstone and conglomerate of the De Chelly sandstone member, which in most of the area unconformably underlies the Moenkopi formation. The member is exposed in cliffs and canyon heads about Elk Ridge, in cliffs along the east face of Red Rock Plateau from the head of Steer Gulch southward to points beyond the San Juan, and as outliers on Grand Gulch Plateau. Along White Canyon and its tributaries the Organ Rock member constitutes a red bordering wall that contrasts sharply with the white platform into which the canyon is sunk. At the mouth of White Canyon it is displayed at the base of walls on hoth sides of the Colorado River. For many miles along the Red House Cliffs and White Canyon the topographic expression of the Organ Rock member is much the same. The lower part (division A) begins as a thin cover on the white Cedar Mesa sandstone and as a slope of red rocks broken by minor steps extends upward in thin beds to the base of a vertical red cliff (division B), 50 to 120 feet high, that in places seems massive but generally appears as a series of relatively resistant thick beds cut by strong vertical joints. Between these divisions in places are thin beds of white sandstone and of finegrained limestone conglomerate. (See pls. $9, B ; 12$, $A, B$.)

The Organ Rock member is 310 feet thick in Hideout Canyon, 347 feet at Soldiers Crossing, 259 feet near Red House, 280 to 350 feet along Armstrong Canyon, 421 feet at the head of Arch Canyon, 360 feet at the head of Comb Wash, 278 feet at the Rasp trail, 320 feet at the south end of Elk Ridge, and 270 feet at Rock Springs. Along Glen Canyon, according to Longwell, it is about 400 feet. Miser gives measurements of 450 feet at Zahns Camp, on the San Juan River, and 500 feet 3 miles southeast of Piute Farms.

In general view the bedding in the Organ Rock is regular. The shalelike beds of the lower part and the thicker sandstone beds above are parallel to a degree remarkable for sedimentary strata that otherwise show evidence of fluviatile origin and rapid deposition. In detail, however, the beds show many irregularities. The shales are nonfissile and in part lenticular and weather into angular chunks. Their surfaces are made uneven by overlapping flakes of hardened mud. The sandstone in some beds is massive, with or without cross-bedding, and retains its thickness for a long dis-

\footnotetext{
- Baker, A. A., and Reeside, J. B., Jr., Correlation of the Permian of southern Utah, northern Arizona, northwestern New Mexico, and southwestern Colorado: Am. Assoc. Petroleum Geologists Bull., vol. 13, p. 143i, 1929.
}

tance, but most of it breaks irregularly into thinner beds. It weathers with rounded surfaces, from which curved slabs and chips peel off. About a mile north of the San Juan a section includes 4-inch beds of white calcareous sandstone 230 and 280 feet above the base, and similar beds were observed at Comb Wash and elsewhere. In places the formation is streaked with seams of gray-white gypsiferous sandstone. Except in bedding and firmness of cement, the upper and lower parts of the Organ Rock are much alike. They consist essentially of microscopic grains of quartz with some specks of iron, calcite, and muscovite held together by lime-iron mud. All parts tested effervesce vigorously with acid.

The uniformly fine grain and high calcareous content of the Organ Rock number are unfavorable for the production of sheer cliffs, angular recesses, or big subordinate steps. Guided by bedding planes and joints, weathering has produced horizontal and vertical flutings rounded in cross section. If the protecting cap were removed, further weathering would develop erosion remnants like the picturesque Organ Rock, in the Navajo country. (See sees. 4, 8-11, and 13, pp. $67-68,70-72,72-73$.

The strata comprising the Organ Rock were included in the Moenkopi (Permian?) by Gregory ${ }^{5}$ and described by Longwell 6 as "lower Moenkopi (Triassic)." They are the northward extension of the beds that make up the Organ Rock tongue of the Cutler as defined by Baker and Reeside. ${ }^{7}$

\section{DE CHELLY SANDSTONE AND HOSEINNINI MEMBERS}

The De Chelly (de-shay') sandstone, with features characteristic of typical outcrops in the Navajo country, appears southwest of Navajo Springs as a bed about 80 feet thick that thins northward and finally is lost to view in the floor of Comb Wash. Generally in the San Juan country its stratigraphic position is held by gray medium- to coarse-grained, in part cross-bedded sandstone with associated conglomerate. In most places these gray beds, a few inches to some 20 feet thick, overlie the Organ Rock and directly underlie the Moenkopi, but in the cliffs south of Clay Hills Pass 30 to 50 feet of red shales and sandstone like those in the Organ Rock lie between the gray beds and the Moenkopi and constitute a northward continuation of the beds called Hoskinnini tongue (of the Cutler formation) by Baker and Reeside. ${ }^{9}$

The De Chelly varies much in texture and arrangement of beds. Along White Canyon for some 20 miles

\footnotetext{
5 Gregory, H. E., Geology of the Navajo country, a reconnaissance of parts of Ari zona, New Mexico, and Utah: U. S. Geol. Survey Prof. Paper 93, p. 30, 1917.

- Longwell, C. R., Miser, H. D., Moore, R. C., Bryan, Kirk, and Paige, Sidney. Rock formations in the Colorado Platesu of southeastern Utah and northern A rizona: U. S. Geol. Survey Prol. Paper 132, p. 10, 1923.

7 Baker, A. A., and Reeside, J. B., Jr., Correlation of the Permian of southern Utah. northern Arizona, northwestern New Mexico, and southwestern Colorado: Am. Assoc. Petroleum Geologists Bull., vol. 13, pp. 1421-1422, 1929.

Gregory, H. E., op. cit., pp. 31-33.

- Baker, A. A., and Reeside, J. B., Jr.. op. cit., pp. 1431-1432.
} 
above its mouth this conspicuous horizon marker is in many places conformable with the Organ Rock; in some places a plane of unconformity lies within the gray mass between sandstone conformable with the Organ Rock and overlying conglomerate. In the walls of Glen Canyon between White and Red Canyons a thin conglomerate rests in hollows on top of massive sandstone about 10 feet thick. At the head of Arch Canyon and in Hammond Canyon this gray band is merely a stratum of coarse cross-bedded sandstone about 2 feet thick; near Red House it includes a few pebbles of concretionary limestone; at the head of Comb Wash it is chiefly a conglomerate of small black and white quartz grains, calcite, and iron; in Hideout Canyon about 90 percent of the pebbles are lime pellets and white and red clay balls; at the Rasp trail and elsewhere near the mouth of White Canyon it is a lenticular mass of angular white chert and sandstone pebbles one-fourth to 1 inch in diameter, firmly embedded in a coarse quartz grit (pl. 12, C). Longwell ${ }^{10}$ found that west of the Colorado this gray band consists of cross-bedded sandstone a few inches to 60 feet thick, which he correlated with the De Chelly sandstone lentil, unconformable below conglomerate a few inches to 25 feet thick that marks the base of the upper member of the Moenkopi. Northward through Cataract Canyon the sandstone appropriately called the "White Rim" may prove to be an extension of the De Chelly. (See sec. 4, p. 68.)

\section{PERMIAN-TRIASSIC EROSION INTERVAL}

In the San Juan country, as elsewhere in the plateau province, the Perminn beds unconformably underlie Triassic beds. The contact is a surface of erosion, which in places is merely an uneven surface but generally shows pits, channels, and broad depressions filled with conglomerate. The unconformity is further shown by the relation of the lowest Triassic formation (Moenkopi) to formations below. Near the San Juan River the Moenkopi rests on thin beds (Hoskinnini?) associated with the Organ Rock; along. White Canyon and the Colorado River it rests on the De Chelly; farther west it rests on the Kaibab. Near Moab all the Permian beds have been cut out, and the Moenkopi rests on the Hermosa (Pennsylvanian). ${ }^{11}$

\section{TRIASSIC FORMATIONS}

REGIONAL RELATIONS

The Triassic of the San Juan country embraces three subdivisions-the Moenkopi formation, Shinarump conglomerate, and Chinle formation. All of them extend into adjoining regions. In composition, color, and manner of erosion they differ little from correspond-

\footnotetext{
${ }^{10}$ Longwell, C. R., Miser, H. D., Moore, R. C., Bryan, Kirk, and Paige, Sidney, op. eit., p. 10.

it Baker, A. A., Dobbin, C. E., MeKnight, E. T, and Reeside, J. B., Jr., Notes on the stratigraphy of the Moab region, Utah: Am. Assoc. Petroleum Gooloeists Bull., vol. 11, p. 796, 1927 .
}

ing units that are exposed in the Navajo country and westward across northern Arizona and southern Utah into Nevada. In many places the three formations constitute a single steep slope in which the red and brown Moenkopi shales, the dark-gray band of the Shinarump, and the brilliantly colored Chinle are readily distinguished. In other places they appear as two slopes: the lower one includes the Moenkopi resting unconformably on Permian red beds and capped by a vertical cliff of Shinarump; the upper one consists of Chinle beds set far back on the Shinarump platform and capped by Jurassic (?) sandstone.

The geologists of the Powell and Wheeler surveys treated the strata here classed as Moenkopi, Shinarump, and Chinle as undefined parts of a †Shinarump group, tentatively assigned to the Triassic. No doubt has been cast on the Triassic age of their "upper Shinarump" [Chinle], but its fossil fish scales, saurian bones, and plants are now regarded as Upper Triassic types. The Shinarump conglomerate includes fossil plants like those in the Chinle and is therefore probably of Upper Triassic age; and it is regarded as the basal conglomerate of the series of beds that make up the Chinle. The "lower Shinarump" [Moenkopi] of the early geologists, originally included in the Triassic, was assigned to the Permian after Walcott had described "Permian fossils" from shale beds below the Shinarump conglomerate in Kanab Valley. A restudy of this fauna by Girty, however, proved its equivalence with that which characterizes the Triassic of Idaho, and evidence from several sources seems ample to prove the Lower Triassic age of the Moenkopi.

The descriptions here given are supplementary to the detailed discussions of the composition, stratigraphy, distribution, and age of the Triassic formations in regions bordering the San Juan country as included in published reports. ${ }^{12}$

\section{MOENKOPI FORMATION (LOWER TRLASSIC)}

The Moenkopi formation is part of all Triassic outcrops between Comb Ridge and the Colorado River and appears on the walls of the Glen Canyon at the mouths of Red Canyon and White Canyon. At Elk Ridge and its capelike projections that border White Canyon, Grand Gulch, and Mule Canyon, it is almost continuously exposed as a steep slope just below the cap rock of Shinarump conglomerate. Down Comb Wash it may be traced to the San Juan River as a series of upturned beds. Most sections of Moenkopi

\footnotetext{
"Gregory, H. E., Geology of the Navajo coluntry, a reconnaissance of parts of Arizons, New Mexjeo, and Utah: U. S. Geol. Survey Prof. Paper 93, pp. 35-50, 1917. Miser, H. D., Geologic structure of San Juan Canyon and adjacent country, Utah: U. S. Geol. Survey Bull. 751. pp. 122-124, 1924. Longwell, C. R., Miser, H. D., Moore, R. C., Bryan, Kirk, and Paige, Sidney, Rock formations in the Colorado Plateau of southesstern Utah and northern Arizons: U. S. Geol. Survey Prof. Paper 132, pp. 9-11, 1923. Gregory, H. E., and Moore, R. C., The Kajparowits region, a geographic and geologic reconnsissance of parts of Utah and Arizona: U. S. Geol. Survey Prof. Paper 164, pp. 46-58, 1931. Baker, A. A., Dobbin, C. E., McKnight, E. T., and Reeside, J. B., Jr., Notes on the stratigraphy of the Moab region, Utah: Am. Assoc. Petroleum Geologists Bull., vol. 11, pp. 796-801. 1927.
} 
THE SAN JUAN COUNTRY, SOUTHEASTERN UTAH

are easily recognized; they lie between formations marked by different color and topographic expression, but where the gray-white bands of De Chelly sandstone and the gray-brown Shinarump conglomerate are poorly developed the lower and upper limits of the formation are not easy to define. As shown in sections 4,8 , and 14 (pp. 68,70,73), the greater part of the Moenkopi is thin-bedded fine-grained sandstone. Groups of shalelike beds weather easily into slopes and in some exposures show considerable thickness of slightly gypsiferous variegated shales that crumble into fluffy masses somewhat like the "marls" in the Chinle formation. Some of the sandstones, commonly those in the middle of the formation, are 2 to 10 feet thick, remain massive for some hundreds of feet or split into thinner, even or lenticular beds, and are resistant enough to form cliffs. Thin lenses of conglomerate composed of clay mud balls and fragments of shale and sandstone appear in many sections. Beds with ripple-marked, sun-hardened surfaces may be numbered by the hundreds. They are characteristic of the formation and indicate deposition in shallow water of rivers, lakes, or the sea and intermittent exposure to the atmosphere. (See pl. 12, C.)

In color the Moenkopi is dominantly chocolate brown but includes a few white sandstones, and some fresh surfaces are banded red and green gray.

Though no fossils were found in the Moenkopi of southeastern Utah, its stratigraphic relations and lithologic features permit correlation with the type Moenkopi of the Little Colorado Valley, Ariz., and with beds in Kanab Valley, Virgin Valley, and elsewhere that carry marine fossils of Lower Triassic age. As interpreted by Miser, Longwell, and others, the series of beds here called Moenkopi is the uppermost member of a threefold Moenkopi that included the De Chelly sandstone and the red shales below (Organ Rock, Permian).

In the San Juan country measured sections of the formation range in thickness from 200 to more than 400 feet.

\section{MOENKOPI-SHINARUMP EROSION INTERVAL}

The top of the Moenkopi is an erosion surface over which is spread the Shinarump conglomerate. In the development of this surface parts of the Moenkopi and perhaps higher beds not now anywhere represented were removed from large areas of the plateau province. Erosion continued until both flat-lying beds and tilted beds were worn down to a surface of low relief that marked the end of a physiographic cycle. For beginning a succeeding cycle the conditions were suitable for the deposition of sheets of conglomerate (Shinarump). Where the stratification of the two formations is essentially parallel, shallow channels carved in red-brown shales are flled with gray grits. Where the dip of the Moenkopi beds differs from that of the Shinarump, the grits extend more or less evenly across beveled edges of shale beds. In most places the Moenkopi-Shinarump contact is not conspicuous, and where the Shinarump is poorly represented and the topmost Moenkopi beds are colored shales it seems gradational.

\section{SHINARUMP CONGLOMERATE}

Though the thickness of the Shinarump conglomerate in few places exceeds 100 feet, it is a remarkably persistent formation. In southeastern Nevada, southern Utah, and northern Arizona it is an unmistakable horizon marker and generally a maker of prominent cliffs and platforms. Throughout the plateau province its exposures are much alike-massive units of coarse cross-bedded sandstone interbedded with lenses of conglomerate that exhibit the same wide range in thickness, texture, color, bedding, and composition.

In the San Juan country the Shinarump is exposed on the eastern flank of the great Monument upwarp, in the bed of Comb Wash and northward along upper Cottonwood Creek and down Mormon Pasture Creek. It is likewise exposed on the western flank of the upwarp, in the Red House Cliffs from the San Juan River northward to Armstrong Canyon and westward down White Canyon to the Colorado River. On the crest of the upwarp many square miles of Shinarump form the surface of Elk Ridge and its capelike projections. The formation varies widely in thickness and composition. At the head of Comb Wash the exposed part of the Shinarump, 64 feet thick, is about three-fourths coarse gray sandstone and one-fourth conglomerate with pebbles as much as a quarter of an inch in diameter of black and red quartzite, gray chert, shale lumps, and worn wood. It includes plant impressions and broken logs. The Shinarump that caps Elk Ridge to a thickness of 60 to 120 feet is chiefly gray grit composed of glistening grains of rounded and angular quartz. It appears as huge cross-bedded lenses separated by irregularly deposited yellow-gray fine sandstone. Generally at the base and here and there at higher levels are lenses and stringers of conglomerate composed chiefly of pebbles of red and black quartzite, white quartz, and white chert an eighth to half an inch in diameter. Near Soldiers Crossing most of the 35 feet of Shinarump is yellow-gray sandstone and ripple-marked brown mud shale with plant impressions, fragments of wood, and big iron concretions that resemble tree trunks. Below Duckett Tanks much of the fossil wood is stained green, and some of it is replaced by copper minerals. At the head of Frey Canyon the Shinarump is exceptionally coarse, consisting almost entirely of cross-bedded lenticular grits that include concretionary masses of limestone 1 to 8 inches in diameter, slabs of sandstone 3 to 8 inches long, big chips of petrified wood, and pebbles of white chert, and gray, black, brown, and white quartz and quartzite more than an inch across.

In and near Clay Hills Pass the Shinarump is a coarse lenticular ash-gray sandstone only 1 to 8 feet thick that 
consists of aggregates and strings of subangular quartz, quartzite, and chert pebbles; in places it is preserved only in depressions carved in the underlying Moenkopi. Along White Canyon it is less than 50 feet thick and shows an unusual assemblage of grits, ripple-marked sandy shales, green shales, clay-lime balls as much as 1 inch in diameter, and widely scattered small pebbles of quartz. In some places it is represented by plasters of quartz, limestone, and chert less than 1 foot thick; in others by lenticular coarse sandstone and limestone conglomerate. It is quite possible that some of these outcrops may have been mistaken for beds in the Chinle. Where the plane of unconformity is inconspicuous and shales lie both above and below the thin conglomerate the sequence appears gradational and the contacts are somewhat arbitrarily drawn. (See secs. 11 and 12, pp. 71-72.)

Pebbles of quartz, quartzite, chert, limestone, and petrifed wood and beds of green-gray shale are features common to all outcrops examined, but in general the Shinarump in the San Juan country appears to be less thick and less conglomeratic and to contain less fossil wood and quartzite but more clay, limestone, and chert than in regions south of the San Juan River and Glen Canyon.

The physiographic conditions under which the Shinarump was deposited are difficult to visualize. What conditions could be so persistent and so uniform as to permit the deposition of a thin sheet of material essentially alike over thousands of square miles in Utah, Arizona, and Nevada? The lenticular bedding, the abrupt lateral and vertical change in composition and texture, and the absence of thick deposits point to a land surface of slight relief over which intermittent and ephemeral streams, perhaps also perennial streams of fluctuating volume, all flowing in poorly defined channels, transported and deposited material available for distribution. After the coarse material was exhausted in filling depressions in the Moenkopi surface and building above them, the streams deposited sand in increasingly broader, more regular, and finer-grained beds, until with change in climate the conditions became favorable for the deposition of the marl-like shales and fresh-water limestones of the Chinle formation. The Shinarump marks the beginning of the cycle of deposition that followed the cycle of erosion represented by the Moenkopi-Shinarump unconformity. It seems to be the basal conglomerate of the Upper Triassic Chinle formation.

The unsolved problem of Shinarump lithology is the source of the pebbles in the conglomerate. The slabs of sandstone and clay balls may have come from underlying beds, the cycads doubtless grew where their fossils are found, and the petrified trees are probably driftwood. Some of the limestone fragments may represent beds in a once much thicker Moenkopi; others may have come from places like Moab, where pre-
Shinarump erosion has locally exposed the Hermosa formation. But no Triassic or Carboniferous formation so far mapped includes material that might supply the varicolored quartz and quartzite. The quartzites differ in no essential from those in the pre-Cambrian of Utah and Arizona.

\section{CHINLE FORMATION}

Strata assigned to the Chinle formation in the San Juan country are exposed in San Juan Canyon at the mouths of Clay Gulch, Castle Wash (Spring Gulch), Piute Creek, and Wilson Creek. North of the San Juan River they form part of the prominent cliff that extends to Armstrong Canyon and down the south wall of White Canyon and terminates in Castle Butte overlooking the Colorado. Bears Ears, Woodenshoe Buttes, Horse Mountain, and similar landmarks on the plateaulike Elk Ridge, also Jacobs Chair and other isolated buttes between White Canyon and Dark Canyon, consist of Chinle beds resting on Shinarump conglomerate and capped by remnants of Wingate sandstone. Partial or complete sections of the formation are exposed in Comb Ridge and in canyon branches of Cottonwood Canyon. Here and there on Red Rock Plateau streams tributary to the Colorado have cut through the overlying sandstones and exposed Chinle beds. (See pls. $6, B, D ; 12, D ; 13, A$.)

The position of the relatively soft Chinle between two cliff makers accounts for its preservation in a region where erosion is vigorous. Where combined with the Wingate in a single steep slope the formation displays its full thickness for miles, but with the removal of its protecting cover it weathers into a mass of fluffy-topped mounds and benches that resist neither rain wash nor streams. In many places the lower part of the formation is covered by landslides.

Like the Shinarump conglomerate, the Chinle formation is nearly coextensive with the plateau province and presents at all exposures much the same lithology and erosion forms. Its outstanding features are fossil wood, a peculiar limestone conglomerate, and series of richly colored variegated shales-gray, red, pink, lavender, yellow, green - that weather in the manner of marls. In the San Juan country, as in regions immediately adjoining, measured sections of the Chinle show four rough subdivisions-(1) at the base, brown and gray sandstones that weather into steps and benches; (2) variegated sandy and calcareous shales or "marls" that weather as mammillary mounds and immature mesas with typical badland expression; (3) light-red, dark-red, and mottled shales and massive or conglomeratic limestone in alternating beds, weathering as a stepped slope on which the resistant limestone forms the top of long, narrow benches and small mesas; (4) red and brown sandstone and sandy shale, weathering as a cliff that, continued upward, includes the Wingate sandstone. Although these subdivisions are 
generally recognizable and the beds that compose them combine to give the Chinle an appearance unlike that of the formations above and below, the variation in composition, texture, color, and order of deposition is extreme. In no two sections are the relative amounts of sandstone, limestone, and shale or the position of these strata in the series the same. Most beds are lenses that within short distances along the strike are replaced by rock of other kinds. Near the head of Cottonwood Canyon the limestones and the variegated "marls" are concentrated near the base, and at Clay Hills Pass these beds rest directly on the Shinarump. At the head of Comb Wash a single bed of limestone conglomerate 4 feet thick caps the friable "marls." In Moki Canyon the top 164 feet of the Chinle is mostly red sandstone; near the mouth of Red Canyon shales and limestones immediately underlie the Wingate. In nine sections measured the limestone ranges, in round numbers, from 3 to 20 percent, the shale from 30 to 70 percent, and the sandstone from 10 to 20 percent. Fossil wood appears generally in the lower half of the formation but is not abundant. (See secs. 11, 12, 16, and $17, \mathrm{pp} .71-72,73$. )

Measured sections of the Chinle range in thickness from 580 to 856 feet. It is thinnest at the mouths of Red Canyon and White Canyon and thickest along the San Juan River. As a whole the Chinle of southeastern Utah is thinner, is less brilliantly colored, and contains less petrified wood and seemingly less red sandstone than at typical exposures in northeastern Arizona and southwestern Utah. No "fossil forests" were discovered, and the great sandstone ledges in the middle of the Chinle on the Virgin River are lacking.

In detail, published descriptions of the lithology of the Chinle in the Navajo country and in the Kaiparowits region apply equally well to exposures of this formation in the San Juan country and need not be repeated here. Correlation with the Chinle at its type locality and with part of the Dolores formation of Colorado is made with assurance.

\section{CHINLE-WINGATE CONTACT}

At most places where the two formations are in contact the massive, strongly cross-bedded, vertically jointed Wingate seems to overlie conformably 30 to 60 feet of regularly bedded sandstone. In tracing the contact, however, evidences of a lithologic break and of a surface of erosion appear. Near the head of Clay Hills Pass the Wingate rests on a wavy surface that slightly truncates beds of brown sandstone and white limestone conglomerate, red shale, and blue-gray clay. The contact is a horizon for springs and seeps. In the walls of the Tables of the Sun the lowermost beds of Wingate are lenticular and conglomeratic and fill depressions in the underlying Chinle. Along the north side of Red Canyon the contact is marked by discontinuous accumulations of limestone concretions, mud balls, and pellets of clay; at the head of Comb Wash, by ripple-marked and mud-cracked shale. Though in color, mass composition, and general texture the sandstones above and below the contact are much alike, the differences suggest that the Wingate sands were derived in part from disintegrating Chinle, in part from the same source as the Chinle, and in part from other sources. The evidence is sufficient to show that the topmost Chinle was exposed to erosion before the Wingate was laid down.

\section{JURASSIC FORMATIONS}

general features

Newberry ${ }^{13}$ speaks of "Jurassic or Triassic rocks" north of Abajo Mountains, and in the Atlas of the Hayden Survey †Jura-Trias red beds are shown in middle Montezuma Valley and along the San Juan. The outcrops noted by these pioneer geologists are but samples of the Jurassic beds conspicuously displayed in the San Juan country-on both sides of the San Juan River from Aneth to its mouth, in many canyons heading in the Abajo Mountains, and in the region of cliffs and mesas between Elk Ridge and the Colorado River. The Jurassic rocks in these areas are in turn but large samples of formations widely exposed in southern Utah, northern Arizona, and western Colorado. The descriptions by Baker, ${ }^{14}$ Cross, ${ }^{15}$ Coffin, ${ }^{16}$ Gregory, ${ }^{17}$ Miser, ${ }^{18}$ Longwell, ${ }^{19}$ and others apply substantially to the Jurassic of the San Juan country. Though many differences appear in thickness and continuity of individual formations and some in texture and bedding, the major divisions and the age are broadly the same, and the physical conditions controlling deposition seem to have been common to the whole region.

The Jurassic of the San Juan country is essentially a series of brightly colored sandstones. It includes beds nearly 1,000 feet thick and beds as thin as cardboard, but massive beds and shaly beds alike are composed predominantly of quartz grains. Beds of organic material are absent, limestone and gypsum are rare, and most of the beds described as shale might equally well be termed thin sandstones. True argillaceous shale is represented chiefly by patches and thin irregular lenses associated with local unconformities. Cross-

13 Newberry, J. S., Geological report, in Report of an expedition trom Santa Fe, N. Mex., to the junction of the Grand and Green Rivers of the Colorado River of the West in 1859 , p. $99,1876$.

- Baker, A. A., Dobbin, C. E. McKnight, E. T. and Reeside, J. B., Jr., Notes on the stratigraphy of the Moab region, Utah: Am. Assoc. Petroleum Geologists Bull., vol. 11, no. 8, pp. 785-808, 1927.

is Cross, Whitman, and others, U. S. Geol. Survey Geol. Atlas, Teliuride tolio (no. 57), 1899; La Plata folio (no. 60), 1899; Rico follo (no. 130), 1905; Engineer Mountain folio (no. 171), 1910; Silverton folio (no. 120), 1905.

${ }_{16}$ Coffin, R. C., Radium, uranium, and vanadium deposits of southwestern Coiorado: Colorado Geol. Survey Bull. 16, pp. $61,77,79,83,86-92,95,1921$,

${ }^{17}$ Gregory, H. E., Geology of the Navajo country, a reconnaissance of parts of Ari20na, New Mexico, and Utah: U. S. Geol. Survey Prof. Paper 93. pp. 51-68, 1917.

18 Miser, H. D., Geologic structure of San Juan Canyon and adjacent country , Utah: U. S. Geol. Survey Bull. 751, pp. 124-125, 1924

18 Longwell, C. R., Miser, H. D., Moore, R. C., Bryan, Kirk, and Paige, Sidney, Rock formations in the Colorado Plateau of soutbeastern Utah and northern Arizona: U. S. Geol. Survey Prof. Paper 132. pp. 11-14, 1923. 
bedding and lenticular structure are characteristic features. Except for the rare lenses of siliceous limestone and the few beds of dense calcareous sandstone, the Jurassic rocks are friable. Unlike the limestones of the Pennsylvanian and Permian, the Shinarump conglomerate in the Triassic, and the sandstones in the Cretaceous, the Jurassic strata are not conspicuous as overhanging rim rocks or as level plateau floors. In making the high Jurassic cliffs weathering has been influenced chiefly by texture and minor structural features. Accumulations of talus from Jurassic rocks are nowhere large. The weakly cemented fragments pried from the ledges by frost soon disintegrate and form materials readily removed by torrential rains.

As here tentatively delimited the Jurassic embraces an assemblage of strata that lie between the Chinle formation (Upper Triassic) and the Dakota (?) sandstone (Cretaceous), but it is recognized that the age of the Glen Canyon group has not been proved and that it well may be uppermost Triassic. Outside the San Juan country the Carmel formation, in the middle of the succession, carries in places unmistakable basal Upper Jurassic fossils; the Curtis contains middle Upper Jurassic fossils; and the Morrison contains late Jurassic dinosaurs and mammals. The formations present combinations of physical features unlike those that characterize the known Cretaceous formations above and the known Triassic below, and they are remarkable for extent, continuity, thickness, composition, and color. Doubts regarding the assignment of the whole series to the Jurassic rest on the lack of satisfactory paleontologic evidence rather than on field observations that would justify a different assignment. But though the evidence for a common age and sedimentary history seems strong, it is quite possible that paleontologic studies may result in placing the lower boundary within or above the Glen Canyon group and the upper boundary definitely at the top of the Morrison.

\section{CORRELATION}

Correlation of the Jurassic formations mapped in the San Juan country with those west of Glen and Cataract Canyons presents no special difficulties. With the exception of the fossiliferous Curtis formation, all subdivisions of the Jurassic in the Kaiparowits region and San Rafael Swell are recognizable in Butler Valley, in the Allen Canyon country, and north of the Abajo Mountains. But in the Jurassic of southwestern Colorado and western New Mexico none of these subdivisions have been established with assurance. It is therefore not surprising that attempts to establish in Utah, Arizona, and Nevada the equivalents of the Jurassic formations in Colorado and New Mexico have led to unlike conclusions.

In his systematic study of the San Juan Mountains and adjacent territory Cross ${ }^{20}$ found it desirable to

\footnotetext{
Cross. Whitman, U. S. Geol. Survey Geol. Atlas, Telluride folio (no. 57), p. 3, 1899.
}

give formation names to the two very unlike parts of the Jurassic, both of which were included in the †Gunnison formation of Eldridge.21 For "the alternating sandstones and variously colored marls and shales of the upper part of the section" the term " $\mathrm{Mc}$ Elmo" was chosen in consequence of a report by Gane that rocks of this kind were well exposed in McElmo Canyon and had been mapped by the Hayden Survey. The "heavy sandstones of the lower portion" of the tGunnison (prominent in the La Plata Mountains) were called tLa Plata formation and defined as "two massive sandstones with an intermediate member of more thinly bedded sandstones and a variable amount of bluish fresh-water limestones." The †McElmo and tha Plata were consistently mapped as the two formations that constitute the Jurassic, in the Telluride, La Plata, Rico, and Engineer Mountain quadrangles. During a reconnaissance traverse from Dolores, Colo., through Monticello to Moab, Utah, Cross ${ }^{22}$ recognized the "McEImo beds in characteristic development" in Dry Valley, Utah, a region from which Newberry (1859) had obtained skeletal remains of Dystrophaeus viaemalae Cope in rocks described as Jurassic (?). Cross recognized also the tLa Plata formation, regarding which he states that "the upper sandstone of the La Plata, * * * about 300 feet in thickness," forms "low mesas or ridges between the branches of Dry Valley"; that the "main floor" of the valley is "near the upper surface of the lower La Plata sandstone," which is "about 250 feet thick"; and that "the middle calcareous member" comprises less than 100 feet of thin-bedded sandstone "with shaly and impure calcareous layers between."

With the knowledge then available, the correlation of strata (Navajo, Carmel, Entrada) along the Monticello-Moab road through Dry Valley with the †La Plata formation at Rico was reasonable, even though exposures are many miles apart. In both areas two massive red sandstones, separated by about 100 feet of calcareous sandstones and shale, are overlain by the $\nmid \mathrm{McElmo}$ formation. Cross had no reason to suspect the existence of a third massive red sandstone and a second series of calcareous shales within the stratigraphic zone occupied by the tha Plata. Correlation by Cross of the upper †La Plata with the tWhite Cliffs sandstone (Navajo) of central Utah also seemed reasonable.

To ascertain the westward extension of the Jurassic of Colorado, Gane, ${ }^{23}$ who assisted Cross in mapping the Telluride and La Plata quadrangles, traversed a route down McElmo Canyon, along the San Juan River, and across Red Rock Plateau to Glen Canyon. He recognized the "massive La Plata sandstone" in San Juan Valley and states that "opposite Waterpocket

21 Eldridge, G. H., U. S. Geol. Survey Geol. Atlas, Anthracite-Crested Butte folio (no. 9), 1894

22 Cross, Whitman, Stratigraphic results of a reconnaissance in western Colorado and eastern Utah: Jour. Geology, vol. 15, pp. 639-640, 1907

Idem, pp. 638. 642, 643 . 
Fold the canyon of the Colorado, $*^{*} *$ mainly cut in La Plata beds, is 1,000 feet or more deep." Obviously Gane correlated the †La Plata with beds now classed as Navajo and Wingate.

A study of the Jurassic outcrops along the Dolores River and in McElmo Canyon in 1909 gave Gregory a basis for adopting †La Plata and $† \mathrm{McElmo}$ as stratigraphic terms applicable to northeastern Arizona. For the Navajo country the Navajo sandstone was correlated with the upper member of the †La Plata, the Todilto formation with the middle member, and the Wingate sandstone with the lower member. As the mapping was carried westward in 1915, it was found that, particularly about Navajo Mountain and along lower Glen Canyon, the characteristically calcareous Todilto became dominantly arenaceous and in places inconspicuous or absent, that the Navajo was capped by a fossiliferous limestone, and that a massive red sandstone above the limestone became increasingly prominent until north of Glen Canyon it vied with the Navajo as a cliff maker. These observations led to combining the strata in the walls of Glen Canyon into a Glen Canyon group and treating the calcareous shale and limestone (Carmel) immediately above the Navajo and the massive sandstone (Entrada) above the limestone as two formations not previously recognized.

In traverses across the Kaiparowits Plateau, Waterpocket Fold to San Rafael Swell, and through the Henry Mountains, Elk Ridge, and the Abajo Mountains to Monticello and Moab (1915, 1918) Gregory found that the post-Navajo strata along Glen Canyon, now classed as Carmel, Entrada, and Morrison, also the Wingate, Todilto (?), Navajo, and strata similar to the $† \mathrm{McElmo}$, were displayed on both sides of the Colorado. At the end of the traverse in northern San Juan County a perplexing problem was presented. Church Rock, between Monticello and Moab, which tracing had shown to occupy a stratigraphic position above the Navajo sandstone, had been correlated by Cross with the upper †La Plata, which in turn had been correlated with the Navajo. In reconciling these diverse conclusions it was thought possible that the sandstone (Entrada) represented by this erosion remnant lost its identity or disappeared in passing beneath covering beds in the 80 -mile stretch between Dry Valley and Rico. The assumption derived support from the fact that in the San Juan country the Entrada and other formations in the San Rafael group thin out, change in composition, or disappear as they are traced southeastward. As they were deposited near the margin of a Jurassic basin, progressive changes in lithology were to be expected.

In reports of the geologists ${ }^{24}$ associated with engineering parties in a survey of the Colorado canyons in 1921, the Wingate, Todilto (?), Navajo, and $\nmid \mathrm{McElmo}$ are

\footnotetext{
w Longwell, C. R., Miser, H. D., Moore, R. C., Bryan, Kirk, and Paige, Sidney, Rock formations in the Colorado Plateau of southesstern Utah and northern Arizona: IT. S. Geol. Survey Prof. Paper 132, pp. 1-23, 1923.
}

described as formations and two unnamed groups of strata between the Navajo and the $\dagger \mathrm{McElmo}$ are listed.

Field work by Gregory and Moore ${ }^{25}$ (in the Kaiparowits region) (1918-24) and by Gilluly and Reeside ${ }^{26}$ in the San Rafael Swell (1924-26) resulted in subdividing the strata between the Navajo sandstone and the Dakota (?) into the Carmel, Entrada, Curtis, Summerville, and Morrison formations. It was recognized that these five formations occupy the stratigraphic position of the $† \mathrm{McElmo}$ as defined by Cross and by Gregory ${ }^{27}$; that the topmost formation (Morrison) is equivalent to the upper part of the $† \mathrm{McElmo}$; but that some if not all of the other formations are older than any beds in the type $\dagger \mathrm{McEImo}$. As the upper part of the $\nmid \mathrm{McElmo}$ is similar to the type Morrison of eastern Colorado, the term "Morrison" was adopted for corresponding lithologic units in Utah, and f"McElmo" as a formation name was discarded.

After exploratory studies by Prommel, Harrison, Crum, and other geologists of oil companies (1920-24), members of the Geological Survey mapped the stratigraphy and structure of the sedimentary formations in parts of Emery, Grand, and San Juan Counties, Utah, and for correlation with formations in adjoining regions made reconnaissances of type localities in the San Juan Mountains and in the San Juan River Valley. As interpreted in their reports ${ }^{28}$ the hitherto accepted correlation of the Jurassic formations of Utah and Arizona with those described in Colorado is probably erroneous. As stated with doubt by Lee but with assurance by Baker and others, the tha Plata formation is the equivalent of the Navajo, Carmel, and Entrada, not of the Wingate, Todilto (?), and Navajo. Lee and his coworkers regarded the Wingate as possibly the equivalent of sandstone at the top of the Dolores, and the $†$ McElmo as the equivalent of the combined Summerville and Morrison formations. The uncertainty in the correlation of these unfossiliferous beds is well shown in the radically different interpretations of boundaries, thicknesses, and sequence in essentially the same sections.

For the Glen Canyon group differences in correlation relate in part to the stratigraphic position of the Todilto(?), which has been treated as equivalent to the middle †La Plata, to the Carmel, and to some undetermined part of the Morrison. Recently Baker, Dane,

\footnotetext{
${ }^{25}$ Gregory, H. E., and Moore, R. C., The Kaiparowits region, a geographic and geologic reconnsissance of parts of Utah and Arizons: U. S. Geol. Survey Prof. Paper 164, pp. 69-89, 1931.

"a Gilluly, James, and Reeside, J. B., Jr., Sedimentary rocks of the San Rafael Swell and some adjacent areas in eastern Utah: U. S. Geol. Survey Prof. Paper 150, pp. 73-82, 1928 .

" Gregory, H. E., Geology of the Navajo country, a reconnaissance of parts of Arizona, New Mexico, and Utah: U. S. Geol. Survey Prof. Paper 93, p. 59, 1917.

${ }^{29}$ Lee, W. T., Gilluly, James, Boyer, W. W., Baker, A. A., McKnight, E. T., Dobbin, C. E., and Reeside, J. B., Jr., Geology and oil in southeastern Utah: U. S. Dept. Interior Press Mem., July 29, 1927. Lee, W. T., Continuity of formations in western Colorado and eastern Utah (U. S. Geol. Survey manusc.ipt on flle, 1925). Baker, A. A., Dobbin, C. E., McKnight, E. T., and Reeside, J. B., Jr., Notes on the stratigraphy of the Moab region, Utah: Am. Assoc. Petroleum Geologists Bull., vol. 11, no. 8, pp. $785-808,1927$.
} 
and Reeside ${ }^{29}$ have expressed the opinion that the type Todilto lies above the Navajo sandstone, and that "Todilto" should therefore be discarded as the formation name for the limestones, calcareous sandstones, and shales "that separate the Wingate and Navajo." For the unit between the Wingate and Navajo they have introduced the term "Kayenta formation."

All these views of the stratigraphic position of the Todilto(?) are necessarily tentative. The obstacles that hinder satisfactory correlation of the Jurassic of Utah and Arizona with type sections in Colorado and New Mexico are many. For 60 miles east of Bluff and 40 miles southeast of Todilto Park the Glen Canyon and San Rafael groups are covered by younger beds. Where they reappear at Rico and McElmo Canyon, Colo., and Fort Wingate, N. Mex., some members are lacking and others are much modified or absent. Some 3,500 feet of strata embracing seven formations in southcentral Utah are represented in Colorado by 300 to 750 feet of unfossiliferous strata that constitute three units of one formation (the †La Plata). The great sandstone beds of the tentative Jurassic-Wingate, Navajo Entrada, and La Plata - are so alike in range of composition, structure, color, and manner of weathering that hand specimens are practically indistinguishable, and outcrops in the field can be recognized with certainty only where the whole series is present in the same or nearby exposures. Likewise the intervening shaly beds-Kayenta, Carmel, and Summerville-have many features in common.

In the plateau province as a whole the Jurassic is most fully represented in the north-south strip of country that includes the San Rafael Swell, the Waterpocket Fold, the Kaiparowits Plateau, and the Rainbow Plateau. Of the eight Jurassic formations in the Kaiparowits region only the Navajo and the Carmel are clearly identifiable in western Utah and only the Morrison ( $† \mathrm{McElmo}$ ) in Colorado. That the Wingate of New Mexico and the †La Plata of Colorado are equivalents of some part of the combined Glen Canyon and San Rafael groups is shown by the presence of Chinle beds below them and Morrison beds above. Possibly they are deposits on the border of a widespread Jurassic basin, thus lacking the lithologic, stratigraphic, and paleontologic features of the great accumulations exposed in Glen Canyon and along the rim of the Paunsaugunt and Markagunt Plateaus. The subdivisions of the Jurassic as outlined by geologists for regions immediately adjoining the San Juan country are shown in plate 15 . The extent, age, and relationship of the formations assigned to the Jurassic of the plateau country are discussed in a recent paper. ${ }^{30}$

\footnotetext{
29 Baker, A. A., Dane, C. H., and Reeside, J. B., Jr., Correlation of Jurassic formations of portions of Utah, Arizona, New Mexico, and Colorado: U. S. Geol. Survey Prof. Paper 183, pp. 5, 17, 1936.

${ }^{2}$ Baker, A. A., Dane, C. H., and Reeside, J. B., Jr., op. cit.
}

MAJOR DIVIGIONS OF THE JURASAIC

The major divisions of the Jurassic established for the Kaiparowits region and elsewhere in the plateau province are represented in the San Juan country. Of these the Glen Canyon group, of Jurassic (?) age, including the Wingate, Kayenta, and Navajo formations, is unmistakable; the San Rafael group, of Upper Jurassic age, though somewhat differently constituted, is readily recognized; and most of the beds classed as Morrison retain their characteristic fentures. The plane of separation between the Glen Canyon and San Rafael groups is an unconformity, probably of regional extent, but the division between the San Rafael and the Morrison has not been satisfactorily established. These groups of strata include many unconformities and show near their contact wide variation in composition and structure of beds. The thickness of the Jurassic in the San Juan country is about 3,000 feet.

The subdivisions and descriptions that follow are presented as an analysis of present knowledge regarding the Jurassic of southeastern Utah.

Glen Canyon group (Jurassic?).-In massiveness, uniformity, and boldness of sculpture the Glen Canyon stands first among groups of strata in the San Juan country. Its essential components are two huge brightly colored cross-bedded sandstones - the Wingate below and the Navajo above. In most places these great beds are separated by a variable thickness of shaly calcareous sandstones and thin, dense, lenticular limestones that constitute the Kayenta (formerly Todilto?) formation. Though the Wingate and Navajo have some individual general features, they are so much alike in composition, color, and texture that in the absence of the Kayenta they appear as a single bed, 1,000 feet or more in thickness. The Glen Canyon of the San Juan country is the stratigraphic equivalent of the Glen Canyon group of the Kaiparowits region, to the west, and of the †La Plata group as defined for the Navajo country. (See pls. $7, A, C ; 13, A, B$.)

San Rafael group (Upper Jurassic).-The San Rafael group embraces the strata lying between the Navajo sandstone and the Morrison formation. In the San Rafael Swell, where all formations are represented, the base of the group is the Carmel formation, above which in turn lie the Entrada, the Curtis, and the Summerville formations. As it extends eastward and southeastward from the San Rafael Swell, its type locality, the group as a whole loses some of its salient features but continues to include massive and shaly sandstone, thin limestones, chert, and gypsum. In the San Juan country the beds identified as probably Carmel are unfossiliferous and include more shale than limestone; the Entrada sandstone, elsewhere conspicuous for thickness, massiveness, and large-scale sculptural forms, is less than 100 feet thick; the Curtis has not been recog- 
nized; and the beds identified as Summerville, where present, are thin, are somewhat indefinitely bounded, and only in position and mass composition resemble those well displayed west of Colorado River. The formations comprised in the San Rafael group form the base of the $\dagger \mathrm{McElmo}$ as that term is used by Gregory for the Navajo country and part of the †McElmo and perhaps also part of the †La Plata as defined by Cross for southwestern Colorado. (See secs. 18-22, pp. 74-76.)

Morrison formation (Upper Jurassic).-The sloping cliffs of variegated shaly sandstone that characterize the Morrison at its many outcrops in Colorado, New Mexico, and Arizona are reproduced as conspicuous topographic features in Utah. In the San Juan country these brightly colored shales lie at the top of the Morrison. Below them and also prominent as a cliff maker is a series of discontinuous, coarse, lenticular gray sandstones that appear to have the position of the Salt Wash sandstone, as that bed is defined in geologic descriptions of areas in Grand and Emery Counties, Utah. Below this sandstone in turn are two distinctive stratigraphic units-a series of calcareous and gypsiferous shales interbedded with thin hard sandstones, and a massive cliff-forming sandstone. For convenience of description these four groups of strata that constitute the Morrison as here defined are given local names derived from the places where they are well exposed for study. In descending order they are the Brushy Basin shale member (Brushy Basin Wash), Westwater Canyon sandstone member (West Water Canyon), Recapture shale member (Recapture Creek), and Bluff sandstone member (village of Bluff). The upper two members are believed to be regional in extent. The lower two, though also termed "members" in accord with prevailing terminology, are subdivisions that may prove to be restricted to the San Juan Valley. The Morrison was included in the $\nmid \mathrm{McElmo}$ as defined by Cross and Gregory. Parts of it were correlated with the San Rafael group by Lee and his coworkers. (See secs. 23-26, pp. 76-78.)

\section{GLEN CANYON GROUP (JURASSIC?)}

The most prominent outcrops in southern Utah are the red, tan, and white sandstones of the Glen Canyon group. They can be traced almost continuously from the Virgin River, along the rim of Markagunt and Paunsaugunt Plateaus, the base of Kaiparowits Plateau, and up the Colorado River to points beyond Moab. In the San Juan country they form Comb Ridge and Red Rock Plateau, border the Abajo Mountains on the west and north, and extend northeastward toward the La Sal Mountains. Remnants of these brightly colored formations appear as mesas on Elk Ridge and along White Canyon. Except at the Rincon and a few other places where the underlying beds have been exposed by erosion, the whole of Glen Canyon and many of its tributaries are but gashes cut in rocks of this group.
Throughout this great area the Glen Canyon red beds seem everywhere in view, and in some places they constitute the entire visible landscape.

\section{WINGATE SANDSTONE}

As displayed in the San Juan country, the Wingate sandstone is characteristically a single ledge of finegrained cross-bedded massive sandstone that maintains an average thickness not far from 300 feet. It is cut by strong vertical joints that outline huge blocks and facilitate the making of vertical cliffs. Many buttes and small mesas, capped by Wingate sandstone, are rimmed about with a palisaded wall of vertical columns impossible to climb. In most cliffs that include the whole Glen Canyon group the faces of the Wingate are more nearly vertical and continuous than those of the much thicker Navajo. The Wingate consists almost entirely of uniformly fine, round grains of white quartz. The cement consists of lime and iron oxides that give to weathered surfaces a prevailing red-brown color. In some places the lowermost few beds of the Wingate are lenticular, conglomeratic, or for short distances regularly bedded, but as a whole the formation is crossbedded on a scale that ranges from markings revealed only by weathering to conspicuous oblique truncated laminae arranged in a crisscross pattern.

The Wingate is exposed in the walls of San Juan Canyon at Comb Ridge and below Clay Hill Crossing. Complete or partial sections appear in upper Cottonwood Wash and its western tributaries that cut deeply into tilted beds along the flanks of Elk Ridge. Castle Wash, Moki Canyon, Cedar Creek, and other gorges that carry the drainage of Red Rock Plateau to the San Juan and the Colorado reveal the Wingate, and many mesas on the divide between Red Canyon and White Canyon, likewise the Bears Ears, Woodenshoe Buttes, and other picturesque landmarks on Elk Ridge, are capped with this rock. (See pls. $4, A ; 13, A$.)

\section{EAYENTA FORMATION}

In most sections that include all three formations of the Glen Canyon group the Kayenta is easily recognized. Even at a distance it appears as a dark-red, maroon, or lavender band of thin-bedded material between two thick, massive, cross-bedded strata of buff, tan, or light-red color. Its position is also generally marked by a topographic break. Its weak beds form a bench or platform developed by stripping the Navajo sandstone back from the face of the Wingate cliffs. The Kayenta is made up of beds of sandstone, shale, and limestone, all lenticular, uneven at their tops, and discontinuous within short distances. They suggest deposits made by shifting streams of fluctuating volume. The sandstone beds, from less than 1 inch to more than 10 feet thick, are composed of relatively coarse, wellrounded quartz grains cemented by lime and iron. The thicker beds are indefinitely cross-bedded. The shales 
are essentially fine-grained, very thin sandstones that include lime concretions and balls of consolidated mud. The limestone appears as solid gray-blue beds, a few inches to a few feet thick, and as lenses of limestone conglomerate. Most of the limestone lenses are less than 25 feet long, but two were traced for nearly 500 feet and one for 1,650 feet. On the Hammond trail, which crosses Comb Ridge opposite the mouth of Arch Canyon, a conglomerate of lime mud balls that weather into a spongy mass is a distinctive feature. In Moki Canyon interbedded limestone lenses and shales that contain fragments and concretionary masses of limestone make up a calcareous zone as much as 50 feet thick. In places along Castle Wash the Kayenta is obscure; the upper two-thirds of a continuous wall is marked off from the lower third by thin beds and fat, short lenses of blue, green, and white limestone. On lower Cedar Creek the Kayenta is exceptionally well displayed as the floor of an esplanade that 100 feet above the stream extends back from the canyon rim nearly a mile. Here the basal beds are sandstones and limestone conglomerates in long, thin lenses and thick, short, stub-ended masses that are replaced along the strike by dark-red mudstone decorated with green bands that mark joints and incipient faults. The middle part is a series of 10 massive, friable, cross-bedded layers 2 to 5 feet thick marked on bedding surfaces by mud cracks. Less than a mile distant the limestones occur only at the top.

In different sections the limestone beds range from 5 to 18 in number and constitute 9 to 25 percent of the material. The formation is 200 feet thick at the head of Comb Wash, 140 feet thick on the Hammond trail, 160 feet in Castle Wash, and 220 feet in Cedar and Knowles Canyons. Immediately west of the Colorado and along the lower San Juan thicknesses ranging from 125 to 249 feet are recorded.

Viewed as a whole the Kayenta is readily distinguished from the formations above and below it. It is unlike them in composition, color, manner of bedding, and sedimentary history. Obviously the conditions of sedimentation changed in passing from the Wingate to the Kayenta and from the Kayenta to the Navajo, but the nature and regional significance of the changes have not been determined. In some measured sections the transition from Wingate to Kayenta is gradual; the material in the basal Kayenta beds seems to have been derived from the Wingate immediately below and redeposited with only the discordance characteristic of fluviatile sediments. But in many sections the contact between the two formations is unconformable; the basal Kayenta consists of conglomerate and lenticular sandstone that fills depressions eroded in the underlying beds. In Moki Canyon near Red Cone Spring nearly 10 feet of Kayenta limestone conglomerate rests in a long meandering valley cut in Wingate. Likewise, the contact between the Kayenta and the Navajo in places seems to be gradational, but generally a thin jumbled mass of sandstone and shales, chunks of shale and limestone, mud balls, and concretions of lime and iron lies at the base of the fine-grained, cross-bedded Navajo. Mud cracks, a few ripple marks, and incipient drainage channels were observed in the topmost bed of the Kayenta on Red Rock Plateau; and west of Glen Canyon wide sand-filled cracks appear at this horizon. These features indicate that, in places at least, the Wingate and Kayenta were exposed to erosion before their overlying formations were deposited, and it may be that the range in thickness of the Kayenta is thus in part accounted for. However, unconformities within and between formations are so common in the Mesozoic of the plateau province that the field geologist hesitates to give regional significance to breaks in sedimentation that have not been correlated with changes in faunas and large-scale tectonic movements.

\section{MAVAJO SANDSTONE}

In the San Juan country the Navajo sandstone is exposed in the east and west flanks of the broad Monument upwarp. The sandstone forms the crest and eastern slope of the "Comb", the prominent ridge that crosses the San Juan and extends northward between Comb Wash and Butler Wash as a steeply dipping monocline, and continues to crop out along the east base of Elk Ridge and across the Causeway into the Indian Creek country. The walls and mosques and alcoves that make the "wonderland" of the Allen Canyon country are chiefly exposures of Navajo sandstone.

In the remote Red Rock Plateau the Navajo is magnificently developed. The plateau is essentially one great sheet of sandstone, cut into huge segments by the San Juan, Castle, Moki, Red, and Colorado Canyons. On this plateau the Navajo shows its characteristic features of erosion. Along canyons and at their boxlike heads it forms vertical or even undercut walls-sheer cliffs 400 to 600 feet high that can be ascended only at fracture zones or on sand dunes that extend from the bottom to the rim. A traverse of miles of canyon floor may reveal no place where the walls can be climbed. Though the Navajo stands first among cliff makers in the plateau province, it does not form platforms or mesa tops. Unlike the Dakota(?) of Sage Plain and the Shinarump of Elk Ridge, which form extensive nearly horizontal plateaus, the Navajo shows very uneven surfaces. Its composition, texture, and structure combine to produce smooth or ribbed mounds on which streamways are poorly defined. Between the San Juan River and upper Castle Wash and at the junction of the San Juan and the Colorado the surface of Red Rock Plateau is a maze of domes and saucerlike depressions. The intricate network of

s1 Through an error in drafting the geologic map accompanying the report on the Navajo country (U. S. Geol. Survey Prof. Paper 93, pl. 2, 1917), the Navajo formation is represented as extending some miles east, of Bluff. Fortunately the error is obvious; the formations are prominent and distinctive and the relations unmistakable. 
narrow, deep canyons that carry the run-off from bare slopes seems to be arranged with little regard to surface topography.

The published descriptions of the Navajo sandstone in the Navajo country and in the Kaiparowits region apply equally well to the San Juan country and need only be generalized here. In fact, the composition, structure, texture, and style of bedding of the Navajo are remarkably alike throughout the Colorado Plateaus: the differences relate chiefly to thickness, color, and degree of massiveness. Essentially the Navajo is a single massive bed of fine-grained, marvelously crossbedded sandstone composed of crystal-clear grains of quartz cemented by lime and iron. Cross-bedding is a scroll work of curves and parallel lines etched on the surface and strengthened here and there by projecting seams of quartz and rows of cylindrical iron concretions. The Navajo sandstone includes lenises of thin regularbedded sandstone and lenses of resistant limestone a few inches to 5 feet thick and a few hundred feet long. On the rim of Lake Canyon dense blue-gray dolomitic limestone near the top of the Navajo caps low mesas and provided building materials for the walls of prehistoric structures. Numerous vertical and oblique joints outline slabs on cliff faces and in conjunction with cross-bedding determine the position and shape of buttresses, recesses, and alcoves on canyon walls and the caves once occupied by Cliff Dwellers. (See pls. $6, C ; 13, B$.)

As most of the Navajo in the San Juan country has been long exposed to erosion, its original thickness has been reduced. At Comb Ridge and in the Allen Canyon country 300 to 600 feet remains. In the south wall of Wilson Mesa, where the Navajo is overlain by younger strata, a complete section measured 880 feet. At most places west of the Colorado River measured thicknesses exceed 1,000 feet; at Zion Canyon, nearly 2,500 feet.

\section{SAN RAFAEL GROUP (UPPER JURASBIC)}

DISTRIBUTION

The San Rafael group, typically exposed in the San Rafael Swell and a prominent assemblage of strata in the Kaiparowits region, is poorly displayed in the San Juan country. Of its four constituent formations the beds that appear to represent the Carmel (elsewhere in part a richly fossiliferous marine limestone) consist of calcareous shales and sandstones. The Entrada, a great cliff maker west of the Colorado and to the north about Moab, is here a thin though characteristic bed; the fossiliferous Curtis formation is not recognizable; and the beds tentatively assigned to the Summerville lack clear-cut diagnostic features and perhaps should be classed as Morrison. Apparently the group, 600 to 2,000 feet thick at the San Rafael Swell, 385 to 625 feet at Moab, and 420 to 800 feet along Glen Canyon, thins southeastward and disappears in the ieighborhood of
Bluff. Beds exposed on the floor of Montezuma Canyon at the mouth of Verdure Creek, tentatively assigned to the San Rafael, measured about 80 feet. (See secs. 18 to 22 , pp. 74-76.)

In the San Juan country the group is best represented in a narrow band that, beginning at the base of Tank Mesa, extends northward along Butler Wash and middle Cottonwood Wash into and begond the Allen Canyon country, where in canyon walls and rims of mesas it contrasts sharply with the underlyirg Navajo and the overlying Morrison. The lowermost beds of the group form the cap of Wilson Mesa and flat-topped remnants near Lake Canyon and Knowles Canyon. Elsewhere in the wide belt between the Comb monocline and Glen Canyon all members of the San Rafael have been stripped away.

\section{CARMEL (?) FORMATION}

As its type locality in Parunuweap Valley, near Mount Carmel village, the Carmel formation measures 222 to 269 feet, of which about 100 feet is limestone that contains a marine fauna of Upper Jurassic age. Northeastward from Mount Carmel the formation maintains its thickness and stratigraphic features at places as far distant as the San Rafael Swell, but southeastward across the Paria River and along the base of the Kaiparowits Plateau it thins gradually and loses its limestone, until near the mouth of Rock Creek it is represented by some 50 feet of calcareous sandstone with which is interbedded 2 inches of unfossiliferous hard, brittle limestone. As represented in the San Juan country the Carmel consists of red and white earthy, lumpy, unevenly bedded sandstones and earthy red mud shales that range in total thickness from 107 feet to the vanishing point.

Near the mouth of Allen Canyon the formation embraces 10 to 40 feet of friable red imbricated shales that weather into chips. At the head of Butler Wash it consists of 24 feet of red thin-bedded slabby sandstone. Southward along the wash the formation is thicker and includes not only sandstone and shales of various shades of red and wide range in bedding and composition, but also beds of white sandstone. On Wilson Mesa the highest bed is a knobby arenaceous limestone that weathers like caliche.

In the San Juan country, as elsewhere in the plateau province, the Carmel where present rests unconformably on the Navajo sandstone. The top surface of the Navajo is uneven and in most places is coated with particles of lenticular, nodular, even conglomeratic red shales and sandstone. In the Allen Canyon country masses of lumpy red, gray, and yellow shale occupy depressions and channels in the Navajo as much as 25 feet deep. In places the curved laminae in the Navajo were truncated before the lowest bed of Carmel was deposited. Though this unconformity may mark the division between the Lower or Middle Jurassic and the 
Upper Jurassic, it probably does not indicate a long interval of erosion. (See secs. 18, 20, and 22, pp. 74, 75-76.)

\section{ENTRADA SANDSTONE}

The Entrada sandstone is the most conspicuous formation of the San Rafael group. West of the Colorado River, where its thickness is measured in hundreds of feet, it resembles the Navajo sandstone in massiveness, structure, and boldness of sculpture. In the San Juan country the formation maintains the characteristic composition and erosion features, though diminished in thickness to less than 100 feet. Exposures in Dry Canyon, in the walls of Cottonwood Wash, and southward along Butler Wash show a conspicuous band of brick-red or orange-red rock that contrasts strongly with the dark-red and green-gray Morrison above and the tan-colored Navajo below (pl. 13, $C$ ). Essentially the Entrada is a fine, even-grained sandstone with subordinate amounts of bright-red shale. In some places it is a single massive, strongly cross-bedded ledge; in other places a series of thick-bedded sandstones or sandstones interbedded with shales, within which are local unconformities. The rock consists chiefly of round and angular grains of quartz, a little feldspar, and a few flakes of biotite. The cement is commonly calcite and ferric iron, in proportions that determine the color tone. Because the cement is weak and the grains small and nearly uniform in size, the Entrada where massive weathers into low domes and round-edged ledges. Where lenses of relatively resistant materials make up part of the bed, erosion produces forms like spools, hour glasses, and "rock babies." The "Beehives" along Dry Canyon, the "Goblet of Venus" (pl. 14, B) on the Blanding-Kigalia road, and the "hoodoos" at the head of Buck Canyon, west of Bluff, are representative features. In most sections the beds at the base of the Entrada grade downward through a series of red sandstones to the Carmel beneath. In other sections an erosional unconformity separates the two formations and doubtless accounts for the difference in thickness of the Carmel at places not far apart. In Dry Wash only discontinuous patches of the Carmel remain, and in places the Entrada rests directly on the eroded surface of the Navajo. (See secs. 18, 20, and 21, pp. 74-75.)

\section{SOMMERVILLE (?) FORMATION}

As mapped by Gilluly and Reeside ${ }^{32}$ the Summerville at its type locality, the San Rafael Swell, comprises "thin-bedded chocolate-colored sandstone, earthy redbrown sandstone and shale, some gypsum, and a little limestone" that conformably overlie the fossiliferous Curtis formation and unconformably underlie strata referred to the Morrison. In the Kaiparowits region Gregory and Moore ${ }^{33}$ found few outcrops that could definitely be correlated with the Curtis and experienced difficulty in fixing the stratigraphic limits of a series of

s2 Gilluly, James, and Reeside, J. B., Jr., op. cit. (Prof. Paper 150), table facing p. 62. st Gregory, H. E., and Moore, R. C., op. cit. (Prof. Paper 164), pp. 78-89. red and variegated sandstones and shales comparable in position and mass composition with the Summerville. Many measured sections were therefore classed as "San Rafael group and Morrison formation undifferentiated."

In his studies of the Moab region Baker ${ }^{34}$ found the Curtis formation absent and not represented by an unconformity, recognized the Summerville (25 to 65 feet thick) and correlated it with "the thick and distinct Summerville formation in the San Rafael Swell", and placed the top of the Summerville "at the base of the first ledge of white sandstone in the Morrison", where an "apparent unconformity" was observed. In the San Juan country strata in the position of beds reasonably assigned to the Summerville are little like those at the type locality, and the contact of the Summerville and Morrison is somewhat arbitrarily drawn. In cliffs bordering the San Juan River, in Butler Wash and northward, the formation includes red, brown, white, and yellow sandstones and mudstones; red and variegated shale; some conglomerate of quartz, lime pellets, and mud balls; and a few thin lenses of limestone, gypsum, and large chert concretions. The sandstones are foliated or cross-bedded, lenticular, and weakly or firmly cemented with lime and iron. Most of the shale is gypsiferous and flaky; some of it is wrinkled or cut by tiny faults. All the beds tested are very calcareous. The evidence is insufficient to determine the conditions under which the Summerville was deposited. The relatively large quantities of chert suggest marine origin, but the lenticular bedding and the capricious changes in texture are more characteristic of stream deposits (pl. 14, A).

An unconformity at the base of the Summerville that might represent the absent Curtis formation was not demonstrated. In Allen Canyon and in upper Butler Wash lenses of coarse white sandstone fill shallow channels in the Entrada, but at Tank Mesa and on the back of the Comb monocline east of Arch Canyon the Entrada seems to grade regularly upward into interbedded white sandstone and red shale. Baker ${ }^{35}$ reports "that the Curtis formation grades laterally into the Summerville formation near Dellenbaugh Butte, on the Green River." The upper limit of the Summerville (?) along the San Juan is more clearly marked. The contact of the brightly colored calcareous and gypsiferous sandstones and shales assigned to the Summerville (?) with the overlying massive, cliff-making buff and white sandstone classed as basal Morrison (Bluff sandstone member) is characterized by an abrupt change in lithology and in most places by an unconformity in bedding that suggest regional erosion before the upper beds were laid down. The significance of this relation is uncertain in view of the fact that somewhat similar breaks in continuity of sedimentation appear above and

$\boldsymbol{u}$ Baker, A. A., Geology and oil possibilities of the Moab district, Grand and San Juan Counties, Utah: U. S. Geol. Survey Bull. 841, p. 51, 1933.

ss Baker, A. A., op. cit. (Bull. 841), p. 51. 
below the contact. The division plane may prove to lie at one of several horizons within 500 feet of Summerville (?) or of Morrison sediments. The strata here called Summerville (?) are the "crinkled beds" of Lee ${ }^{36}$ and his coworkers, who correlated them with the Carmel formation. (See secs. 18 to 21, pp. 74-75.)

\section{MORRISON FORMATION (UPPER JURABSIC)}

GENERAL FEATURES

Strata assigned to the Morrison formation in the San Juan country rise as cliffs on both sides of the San Juan River from Butler Wash eastward to the Colorado State line. Across Sage Plain they are exposed beneath the Dakota (?) rim rock in all canyons tributary to the San Juan and terminate westward in attractive cliffed slopes along upper Butler Wash and middle Cottonwood Wash and in Piute Park. Characteristic sections are readily accessible on the BluffBlanding road and in Big Canyon and Brushy Basin on the Blanding-Kigalia road.

In general appearance, style of bedding, mass composition, and age the outcrops at all these places resemble those defined as Morrison or †McElmo in western Colorado, New Mexico, and Arizona and as a whole are correlated with them. Here, as elsewhere, the upper limit of the formation is the base of the Dakota (?) sandstone, and the lower limit an unconformity that has not been everywhere definitely placed in the stratigraphic column. However, the study of widely separated sections leaves the impression that fuller knowledge of unconformities and conditions of sedimentation will result in the recognition of two or more formations within the Morrison, perhaps even of different ages. The coarse thick-bedded lenticular sandstones, the thick massive sandstones, and the interbedded red shales and white sandstones in the Morrison of the San Juan drainage basin would seem out of place in the Morrison section of eastern Colorado.

In most sections the Morrison in eastern Utah includes two strongly contrasted parts-a lower part comprising thin-bedded and massive red sandstone, sandy shale, gray cross-bedded lenticular conglomerate, together with subordinate limestone, clay, and gypsum; and an upper part consisting of "variegated shales." In the San Juan country the Morrison formation comprises four rather distinctive lithologic groups or members, which are described below. (See secs. 23 to 26 , pp. $76-78$.)

\section{BLUFF SANDSTONE MEMBER}

The Bluff sandstone member is white, brown-stained commonly cross-bedded, and made up of medium to coarse quartz grains. Typically it is one massive bed 200 to 350 feet thick that here and there includes aggregates of large quartz grains, clay balls, and short thin

\footnotetext{
${ }^{36}$ Lee, W. T., Continuity of formations in western Colorado and eastern Ut3
} (C. S. Geol. Survey manuscript on file, 1925). lenses of red mudstone. In some places it is arranged as long overlapping sandstone wedges bordered by a little red shale, and in other places as poorly defined beds 20 to 40 feet thick. Traced eastward, the Bluff sandstone that forms the top of Tank Mesa is less persistently massive. Near the mouth of Montezuma Canyon 10 to 20 feet of bedded white sandstone are incorporated in red sandy shale that thins, thickens, bunches up, or flattens out along the strike. Traced northward along Butler Wash and Cottonwood Canyon the Bluff sandstone is represented in places by three or more beds. (See pl. 3, C.) Vertical joints outline square columns and long slabs that weather in place as monuments and furnish huge blocks to the talus. Weathering on cliff faces produces elongated niches, pockets, and "owl holes" suitable for nests of birds and bats, and at the base of the sandstone deeply recessed grooves with flat floors and overhanging roofs, chosen by Cliff Dwellers as building sites. The Bluff sandstone derives its name from the town of Bluff, where, on both sides of the San Juan River, it is the outstanding topographic feature.

\section{RECAPTURE SHALE MEMBER}

The interval between the Bluff sandstone member and the lowermost bed characteristic of the Westwater Canyon sandstone member is occupied by a series of strongly colored shales and sandstones 100 to 300 feet thick. They appear in many places as sloping platforms at the base of cliffs and are particularly well displayed near the mouth of Recapture Creek, from which the name is derived. The shales are prevailingly dark red, but some are variegated-pink, ash, brown, and gray. Many of them include firm, strongly calcareous beds that break into slabs and friable, imbricated gypsiferous beds that weather as tiny cliffs. The sandstones are white beds of glistening quartz cemented by lime, few of them more than a foot thick or continuous for more than 1,000 feet. Some are gypsiferous and friable, but most are more resistant than those in the Bluff or the Westwater Canyon member and are represented in the talus as angular blocks. The shales and sandstones combine to form slopes, low mesas, and platforms, and the edges of sandstone beds appear as shelves and small benches. The outcrops are attractively color-banded, but as the shale and sandstone feather out and replace each other along the strike the arrangement of sections 1,000 feet apart is quite different. The amount of sandstone in the Recapture shale member is generally about 15 percent; at the base of Turners Bluff it constitutes so small a part that the shales weather like marls. In gross lithology the strata of the member resemble those observed in the Morrison about 8 miles south of Woodside, Utah, which Gilluly and Reeside ${ }^{37}$ place at the base of the Salt Wash sandstone member.

7" Gilluly, James, and Reeside, J. B., Jr., op. eit. (Prof. Paper 150), pp. 102-103, 


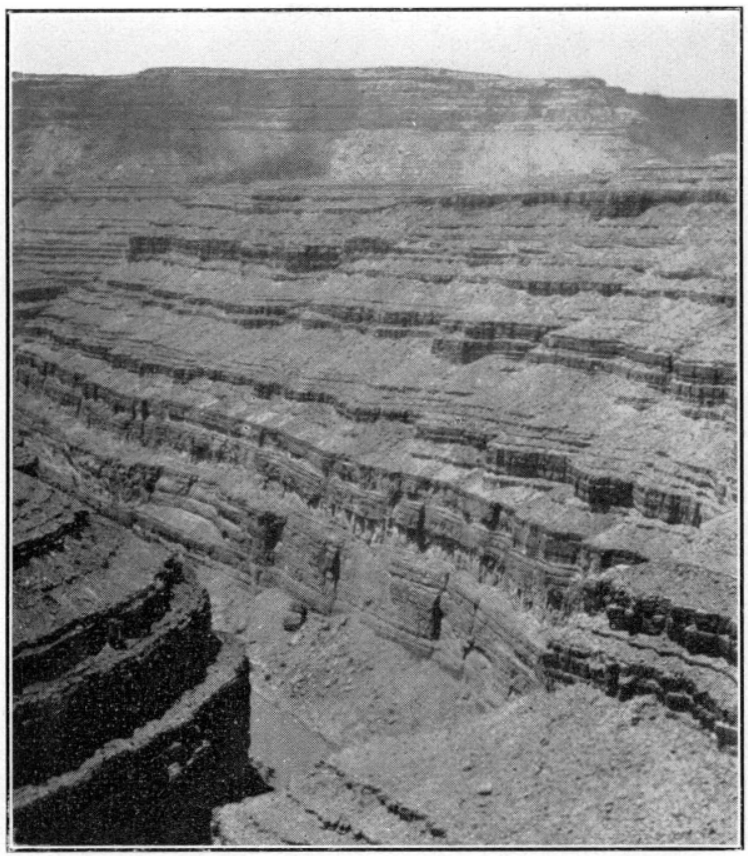

A. VIEW IN JOHNS CANYON NEAR ITS JUNCTION WITH SAN JUAN CANYON. Hermosa and Rico in canyon wall; Halgaito and Cedar Mesa in distarce.

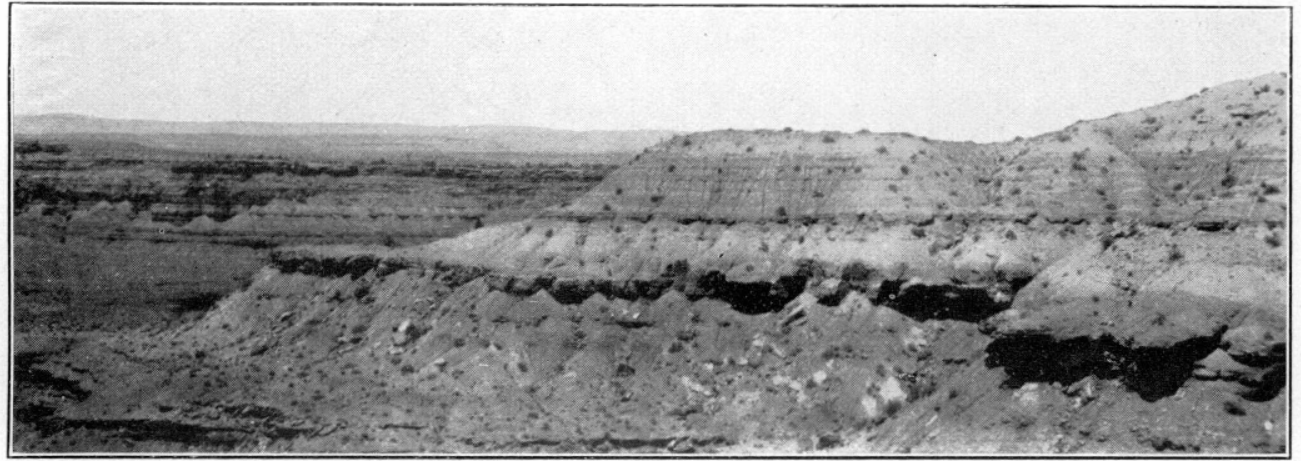

B. WALL OF ROAD CANYGN.

Halgailo strata (lower parl.) and shaly phitise of Cedar Mesa (upper part).

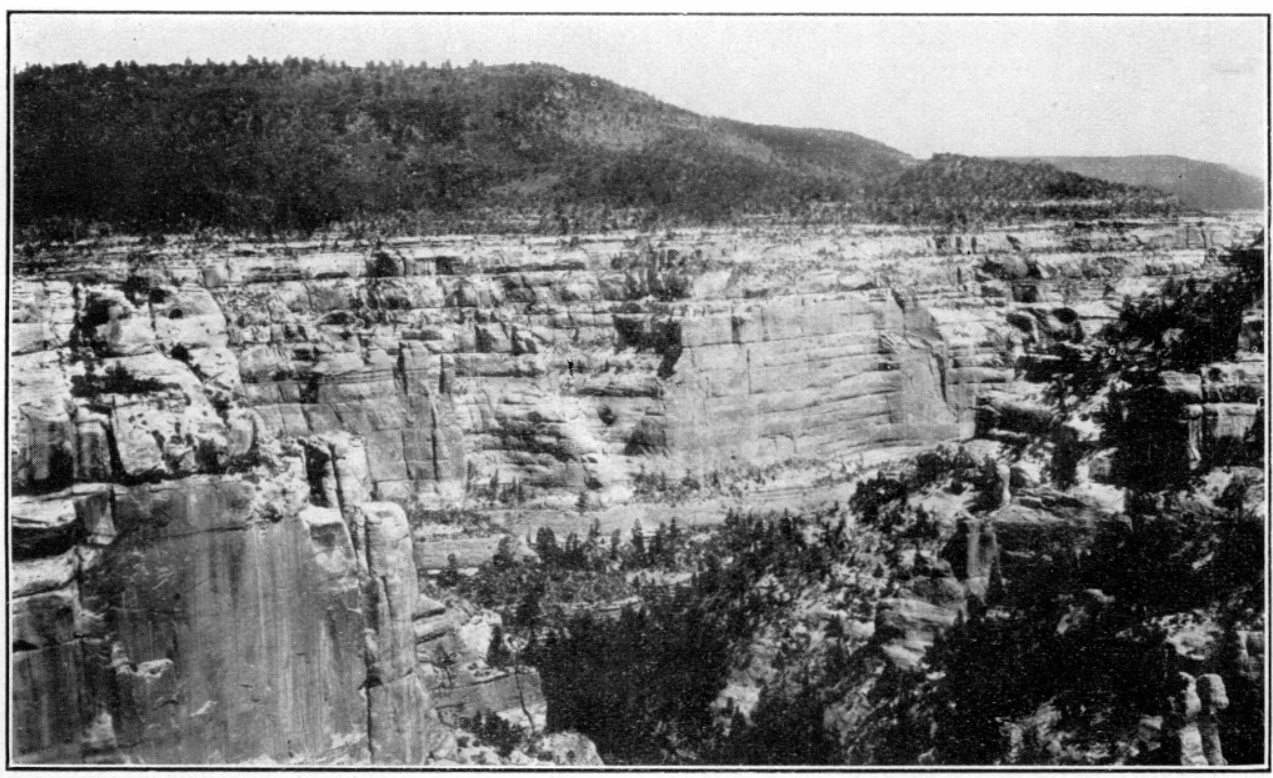

c. WALL OF ARCH CANYON NEAR I'TS HEAD.

Composed of Cedar Mesa sandstone overlain by Organ llock, De Chelly, and Moenkopi beds. 


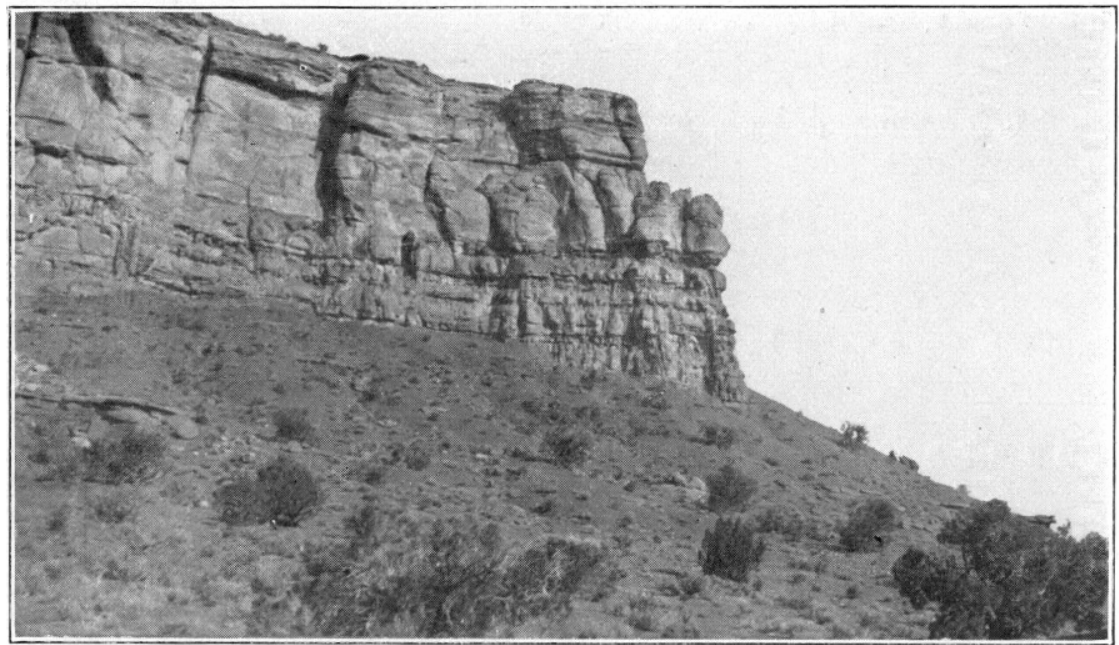

A. ClifF NEAR STAR SIRINGS, WHITE CANYON. Stands on Cedar Mesa sandstone. $\begin{gathered}\text { Slope and verlical wall composed of Organ Fock shales and sandstone. } \\ \text { Top thin bed of De Chelly sandstonc. }\end{gathered}$

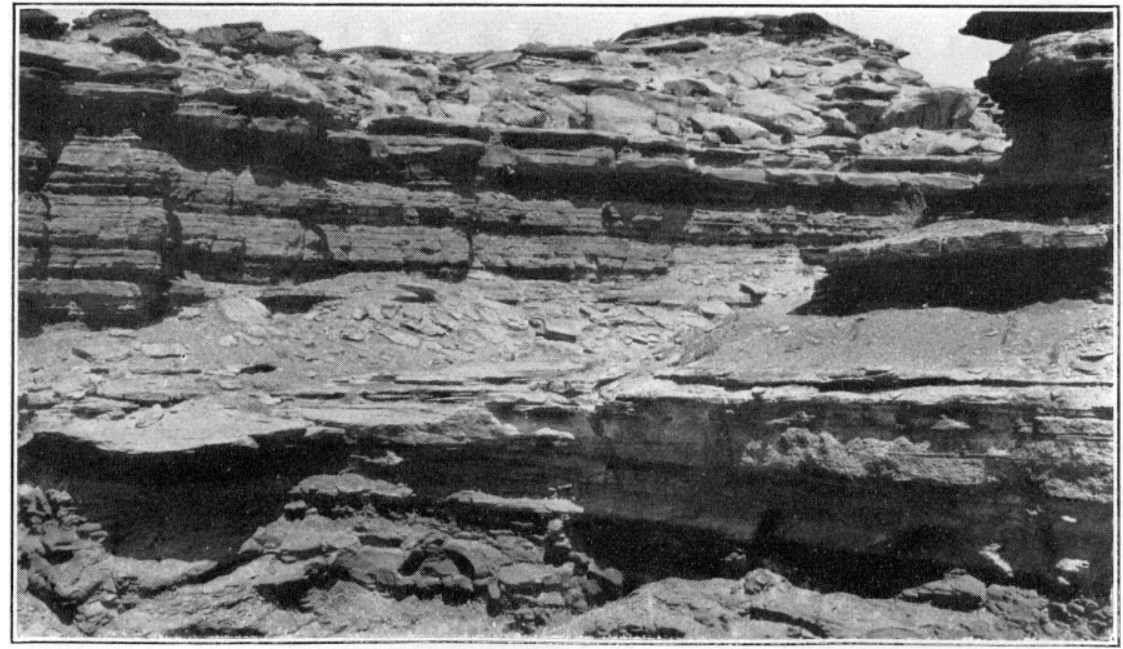

C. VIEW ON RASP TRAIL.

De Chelly sandstone (at the base) and Moenkopi.

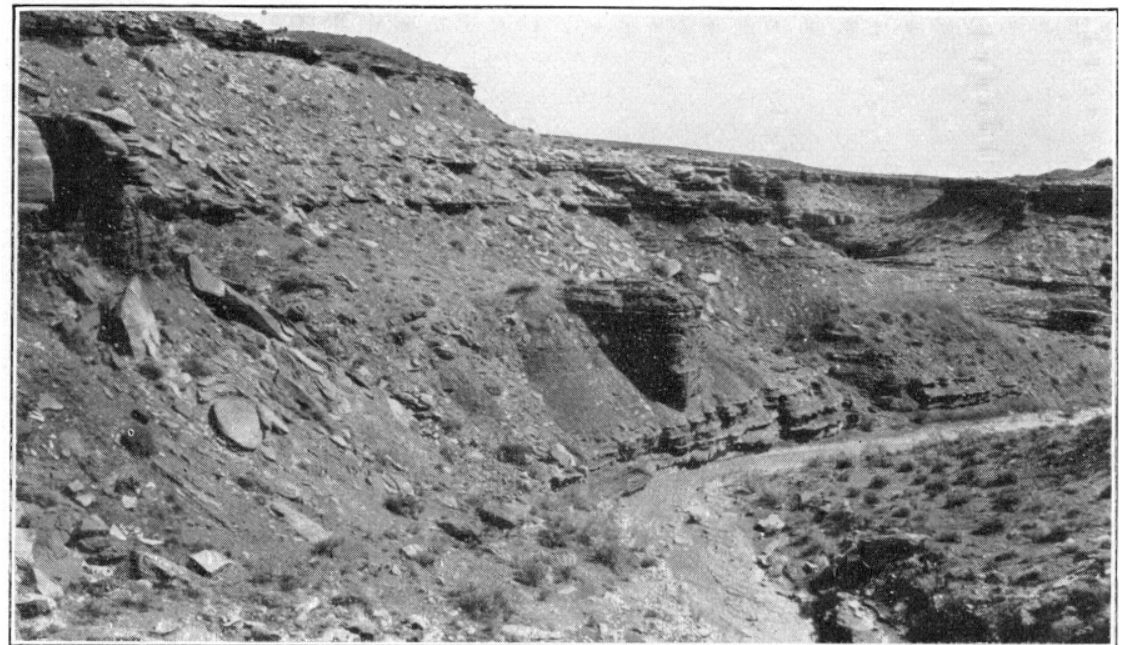

B. EAST ENTRANCE TO CLAY HIILLS PASS.

Moenkopi formation overlying strata at the top of the Oryan Hock member of the Culler formation.

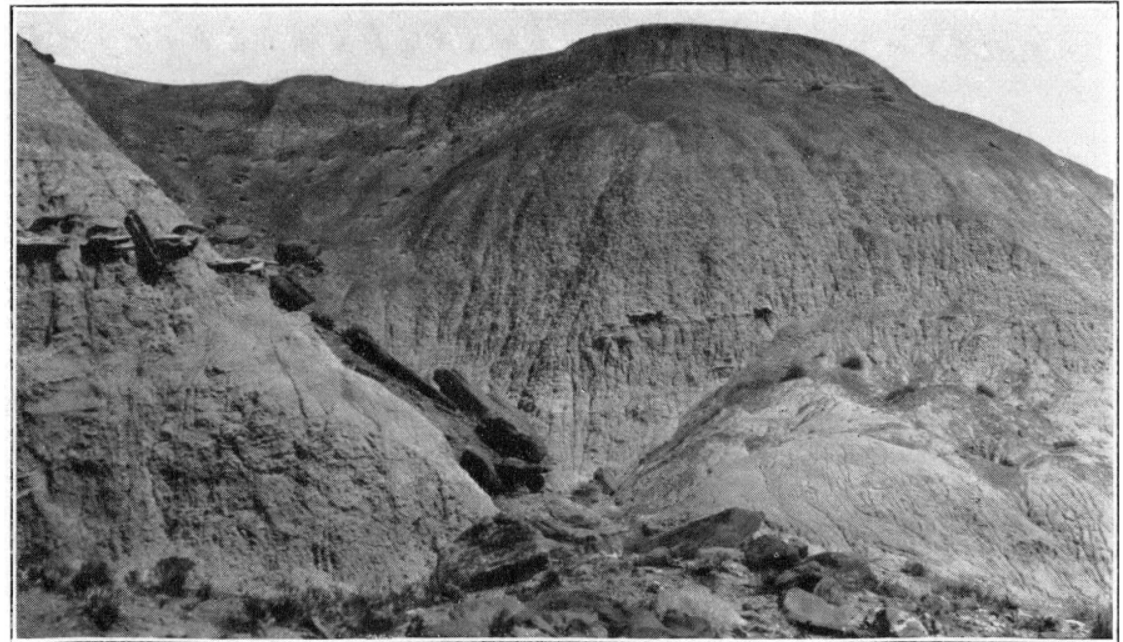

D. VARIEGATED MARLS AT CLAY HILLS. Chinle formation. 


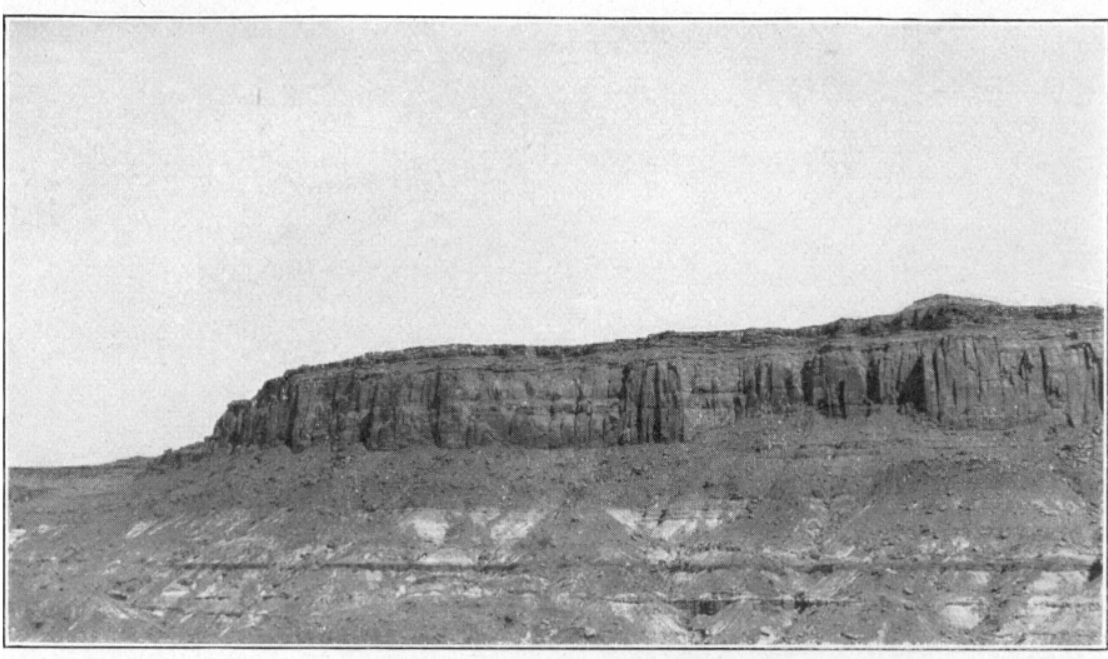

A. DIVIDE BETWEEN WHITE CANYON AND RED CANYON. Chinle, Wingate, and Kayenta strata

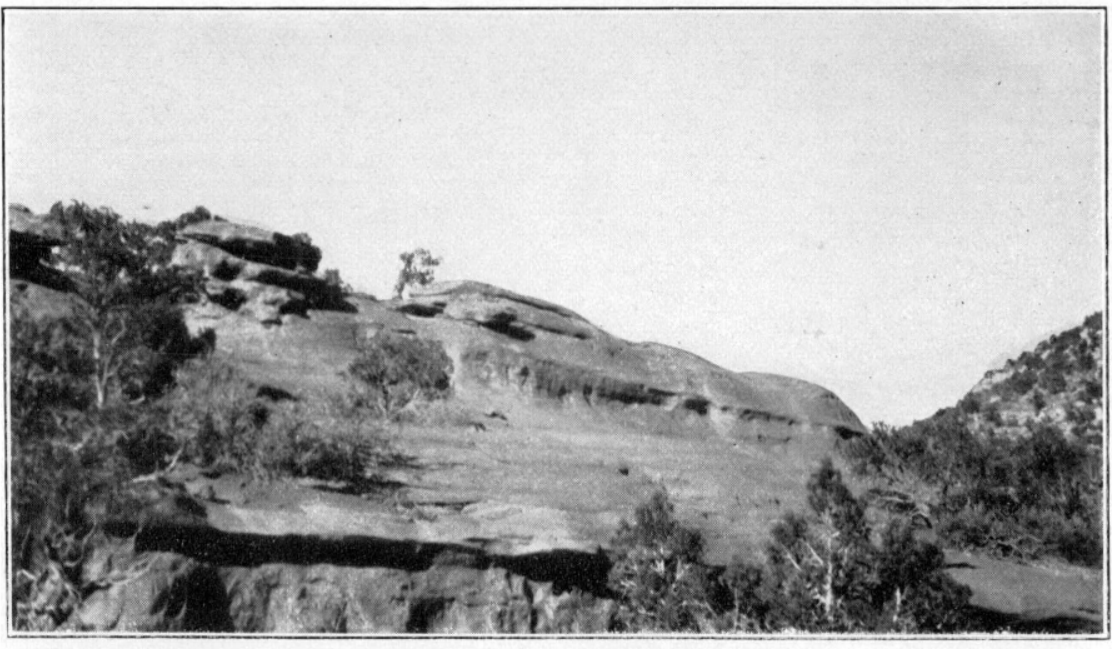

C. DRY CREEK, ALLEN CANYON COUNTRY.

Entrada formation unconformably overlying Navajo sandstone (lower left)

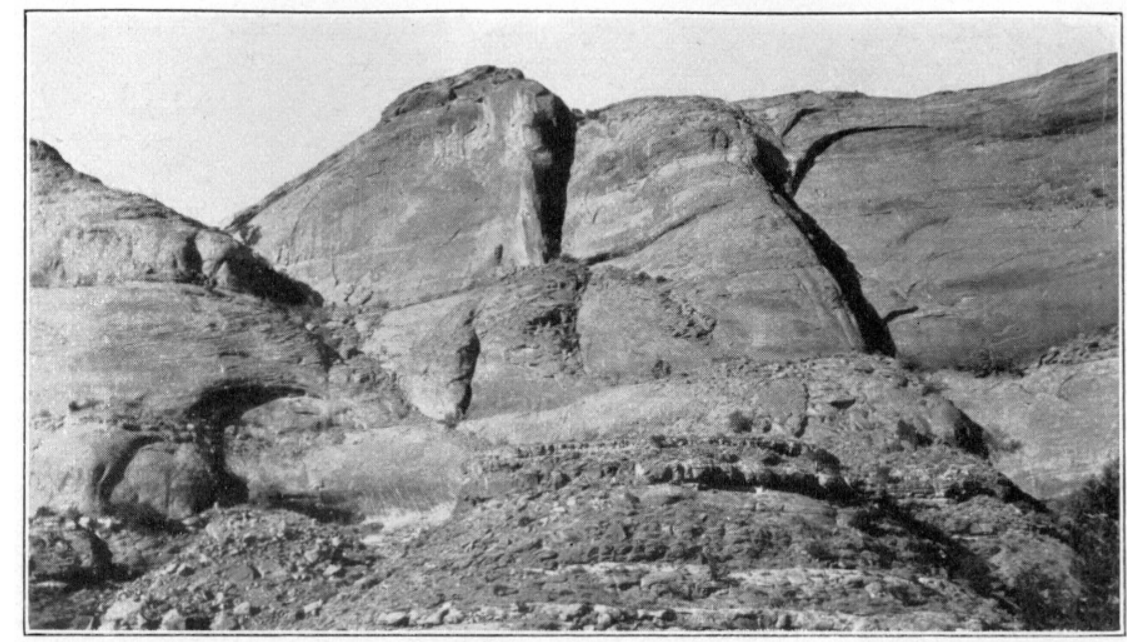

$B$. WALL OF CASTLE WASH.

Kayenta and Navajo loormalions.

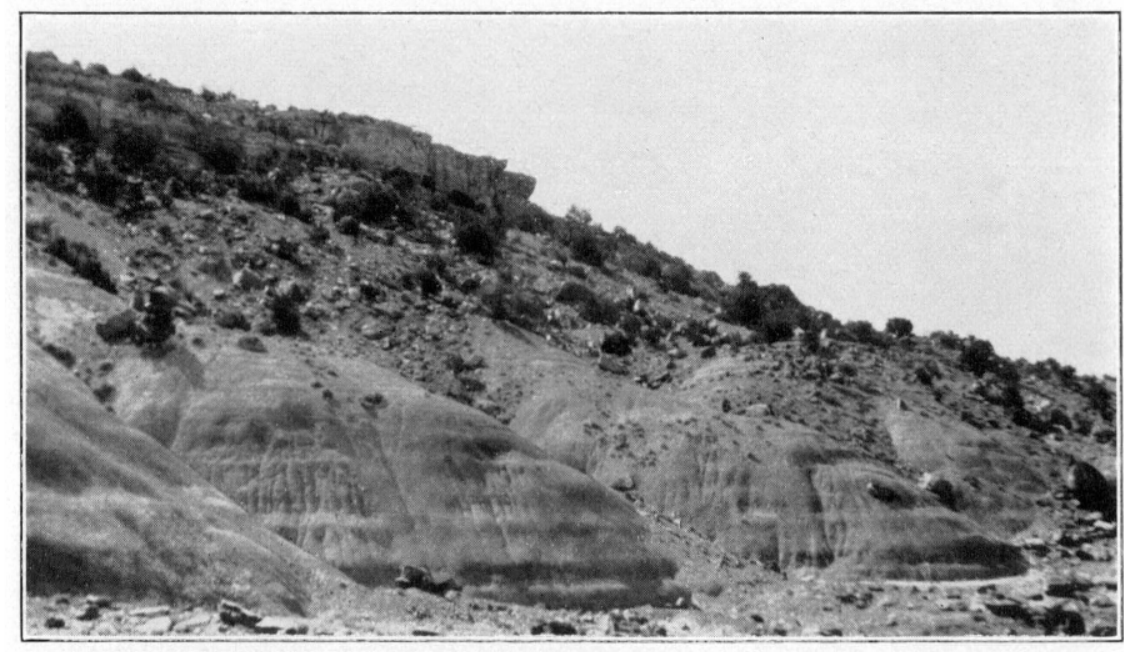

D. WEST FACE OF BLACK MESA.

Upper part of Morrison formation (Brushy Basin shale member) capped by Dakota (?) sandstone. 
P'MOFESSIONAL PIIPR 188 PLATE IA

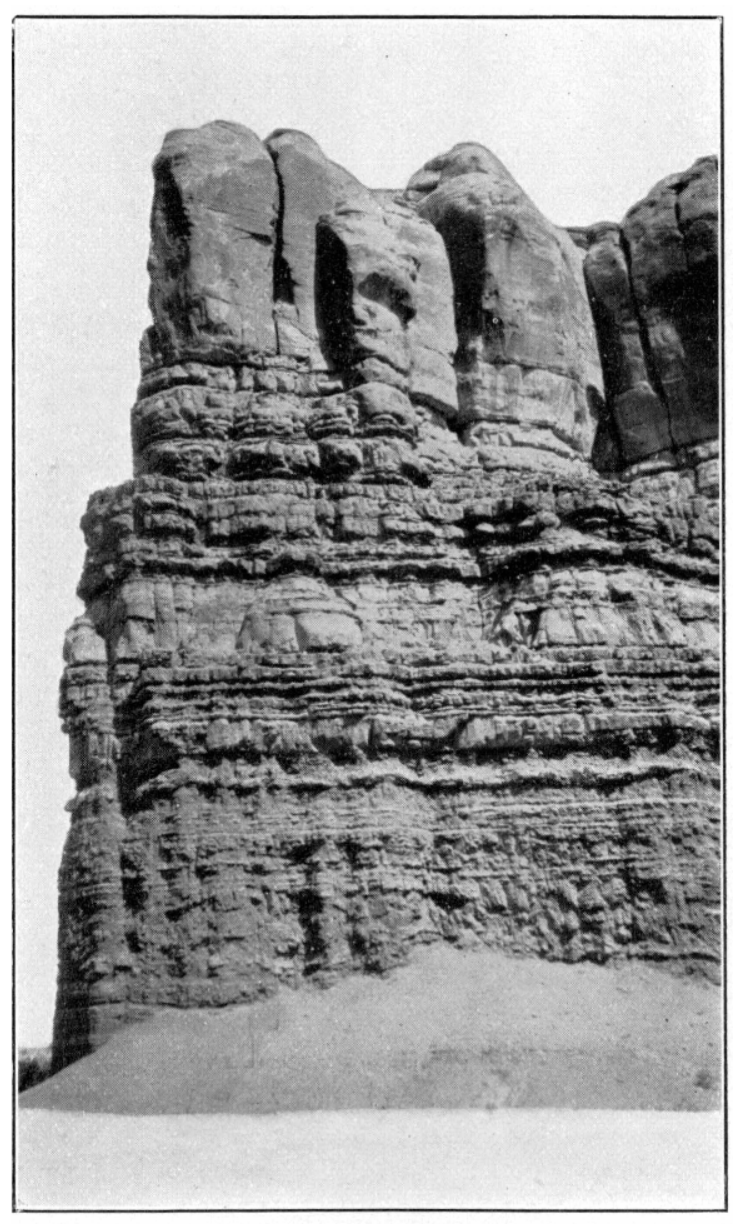

A. JHW NAAR MOLTI OF COTTONWOOD WASI Summerville (i) Rermation cappeyd hy Blunf sundstone incmler of

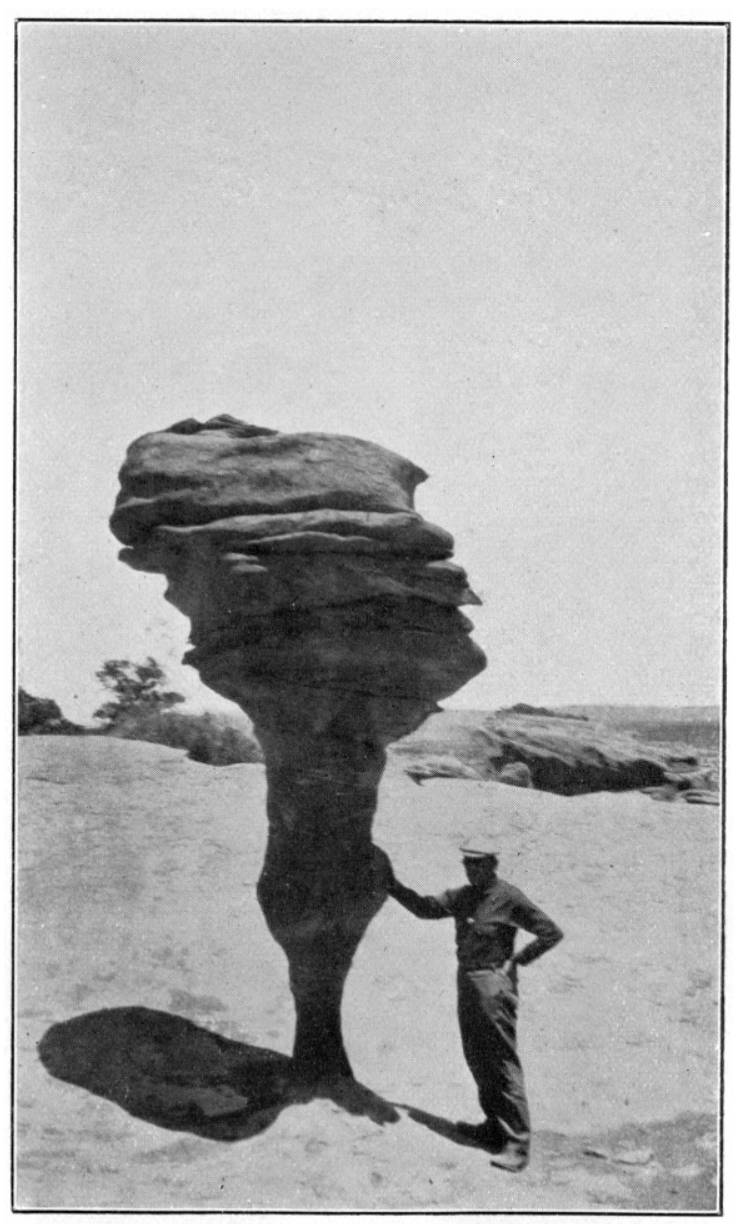

B. GORLET OF VENIS

Jirosion remnant in Entrada saudstonte on Blanding-Kigalia road.

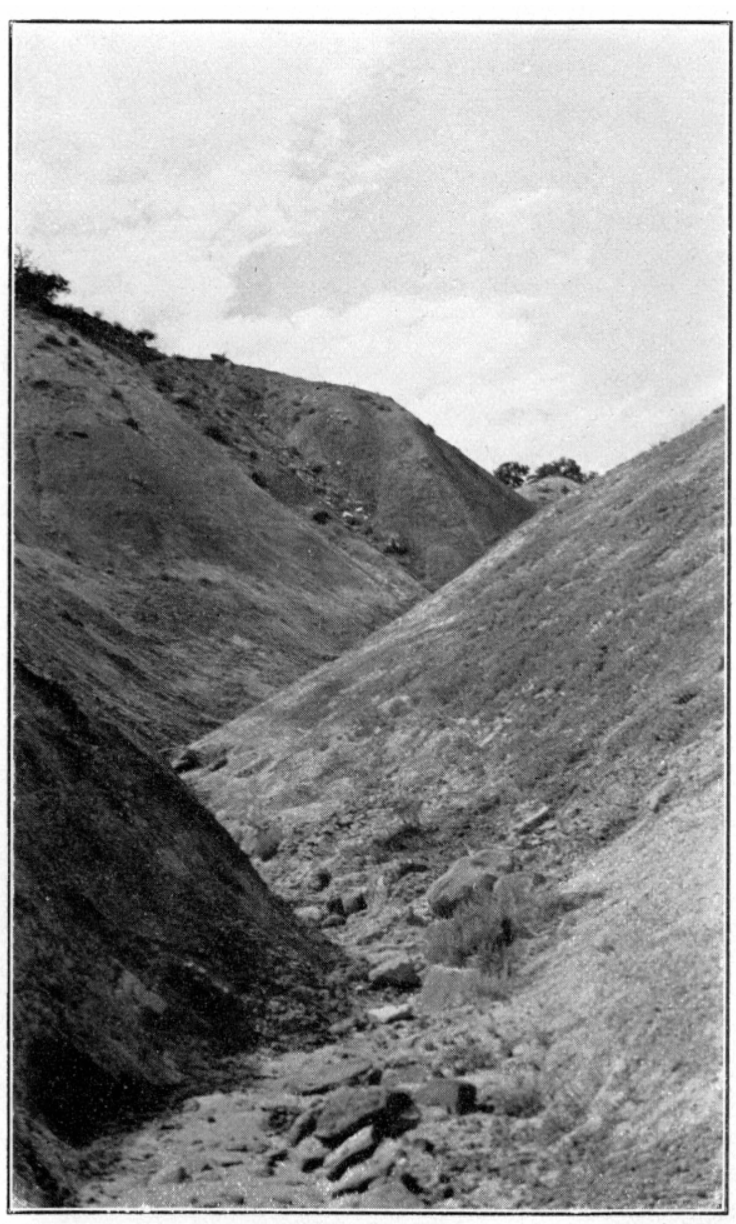

C. BRUSHY BASIN. lirushy Busin shale. 
GEOLOGICAL SURVEY

1
Generaalized section of Circle Cliffs,
Waterpocket Fold, and Henry
Mountains

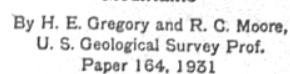

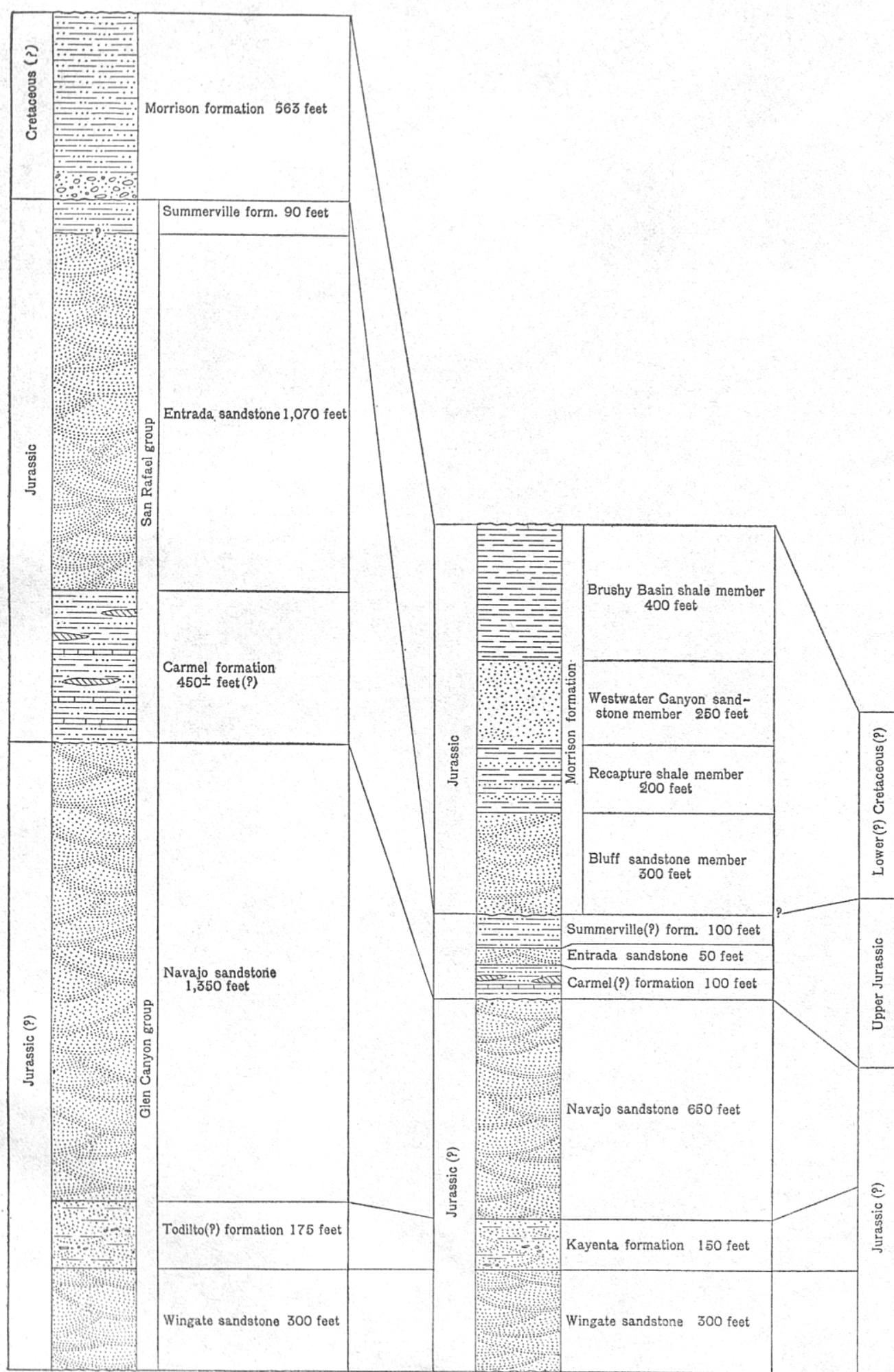

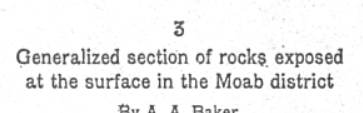

By A. A. Baker,
U. . . Ceological survey Bull. 841 ,
1938

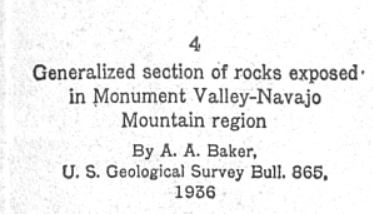

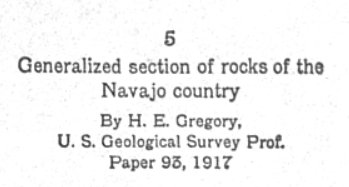

PROFESSIONAL PAPER 188 PLATE 15

6
Generalized section of sedimentary
rocks of the La Plata quadrangle

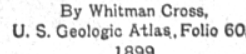

CORRELATION CHART SHOWING RELATIONS OF THE JURASSIC FORMATIONS OF THE SAN JUAN COUNTRY TO THOSE IN ADJOINING REGIONS. 



\section{WESTWATER CANYON SANDSTONE MEMBER}

In reports on the geology of the region north of Moab and other places in east-central Utah Lupton ${ }^{38}$ described a coarse-grained "gray conglomeratic sandstone", in places lenticular and cross-bedded, that forms cliffs about 350 feet from the top of the Morrison-strata sufficiently uniform and persistent to serve as a datum plane for mapping. For this sandstone he proposed the name "Salt Wash member of the McElmo formation." As classified by Gilluly and Reeside ${ }^{37}$ the Salt Wash sandstone member lies at the base of the Morrison and includes not only gray conglomeratic sandstones but also clay, limestone, and gypsum. Baker ${ }^{39}$ defines this member as "white conglomeratic sandstones interbedded with red sandy mudstones and red shale" that occupy the lower half of the Morrison south of Moab.

In the San Juan country a sandstone that appears to lie in the position of the Salt Wash member as defined by Lupton plays a large part in developing the topography. It stands as cliffs and forms the base of many canyon walls that continue upward through variegated shale to a rim rock of Dakota (?) sandstone. Along the San Juan River north and northwest of Bluff, between Brushy Basin and middle Cottonwood Canyon, and in other places where the variegated shales have been removed, this sandstone appears as mesas, ridges, and the tops of broad platforms. Tentatively the local name "Westwater Canyon sandstone member", derived from West Water Canyon, is here given to this sandstone, because its exact equivalency to the typical Salt Wash sandstone has not been satisfactorily established.

This member is essentially a series of white sundstones composed of rounded medium to coarse grains of quartz, cemented by calcium carbonate and arranged in lenticular, irregular beds 1 to 30 feet thick. They include conglomeratic bands and stringers composed of quartz aggregates, colored chert, concretionary masses of compact green-white clay, and rare fragments of petrified wood and dinosaur bones. Interbedded with the sandstones are red earthy soft fine-grained sandy shales-perhaps better called "mudstones"--that thin, thicken, or disappear in short distances. With them are associated a few thin short lenses of gray limestone conglomerate. These mudstones, which make up 8 to 20 percent of measured sections, are extremely irregular. A bed in Big Canyon 14 feet thick disappears in a distance of 120 feet, and one less than 2 feet thick in Montezuma Canyon was traced for half a mile. Few beds of shale or of sandstone retain their individuality

${ }^{37}$ Gilluly, James, and Reeside, J. B., Jr., op. cit. (Prof. Paper 150), pp. 102-103, 1928 .

${ }^{38}$ Lupton, C. T., Oil and gas near Green River, Utah: U. S. Geol. Surrey Bull. 541, pp. 125-127, 1914; Geology and cosl rasources of Castle Valley in Carbon, Emery, and Sevier Counties, Utah: U. S. Geol. Survey, Bull. 628, pp. 23-26, 1916.

Baker, A. A., Geology and oll possibilities of the Moab district, Grand and San Juan Counties, Utah: U. S. Geol. Survey Bull. 841, pp. 52-53, 1933.

$145824-38-5$ for as much as a mile. Unconformable contacts at the base of the Westwater Canyon member were observed at several places. Features that indicate exposure of the top beds before the Brushy Basin shale was laid down were noted in McElmo Canyon, but generally the sandstone grades upward through a series of gray sandy shales and merges into the variegated shales at different horizons. The relation is somewhat like that between the Shinarump and the Chinle, and the Westwater Canyon sandstone may prove to mark the beginning of a cycle of sedimentation that continued until interrupted by pre-Dakota (?) erosion. The thickness of eight measured sections of the Westwater Canyon sandstone member ranges from 222 to 295 feet.

\section{BRUSHY BASIN SHALE MEMBER}

The upper part of the Morrison of the San Juan country consists of the well-known variegated shales (Morrison shales, †McElmo shales) that generally in Utah and western Colorado lie immediately below the Dakota (?) sandstone. In fact, they owe their preservation to the resistant Dakota cover. Directly beneath cliffs of Dakota (?) sandstone they stand in almost vertical walls; where the sandstone has been stripped back they form slopes that continue outward into mounds and ridges spread over a platform of Westwater Canyon sandstone. Their appearance is everywhere the same-brightly variegated masses that are exceeded in beauty of coloring only by the Chinle "marls." The dominant beds are white, gray, green, purple, and red sandy shales and sandstones. (See pls. $13, D ; 14, C$.) Subordinate beds are gray, pink, blue, and gray limestones; conglomerates of red, green, and white cherts; and buff hard sandstones. The buff sandstone is more abundant near the base and seems to increase in amount eastward toward the Colorado line. South of the San Juan River much of the bedded shale is replaced by massive white or green-white sandstone. At the "Jump-off" on the highway between Blanding and Bluff some of the shale is evenly stratified, but generally all beds are lenticular. In Brushy Basin, where the variegated shales are admirably displayed for study, the thickness is 450 feet. (See sec. 25, p. 77.) Other sections measure 350 to 470 feet. Dinosaur bones from the lower part of the Brushy Basin shale in McEimo and other canyons of Sage Plain are included in local collections of curios. Parts of a skeleton gathered from the talus in Montezuma Canyon by the late Willis T. Lee were described by C. W. Gilmore as

the greater portion of a coracoid, two anterior caudal centra, one medium caudal centrum, and portion of a distal caudal vertebra, all apparently of one individual, a sauropod dinosaur of the Brontosaurus-Apatosaurus group. Associated with this material is the upper articular end of a tibia pertaining to a carnivorous dinosaur. Its size would indicate that it might be tentatively identified as Antrodemus (Allosaurus), the largest carnivorous dinosaur to be found in this country associated with sauropod remains. 


\section{MORRISON-DAKOTA (?) CONTACT}

In the San Juan country the strata assigned to the Dakota (?) formation are everywhere accompanied by those classed as Morrison, and everywhere the contact between the two formations is a zone of unconformity. But Morrisonlike sedimentary beds lie above what appears to be the major unconformity, and unconformities are present at horizons not far below. At most places a siliceous conglomerate lies with well-expressed unconformity immediately above beds accepted generally as Morrison ( $\nmid$ McElmo of Cross and others). In a few places this conglomerate with some sandy shale and thin-bedded sandstone constitutes most of the section between the Morrison and the Mancos, but in many places a basal conglomerate or its equivalent in sandstones is overlain by or interbedded with a series a few inches to 50 feet thick consisting of gray, red, green, or even variegated shales arranged as lenses or short regular beds. These beds seem out of place in the Dakota (?). They may represent reworked material brought in from Morrison or post-Morrison areas that were exposed to erosion while the lowest gravel of the Dakota (?) was being laid down in stream channels. It is possible, however, that these shales together with the underlying conglomerate are parts of an undefined formation of pre-Dakota (?) age. In mapping the economic geology of southwestern Colorado Coffin ${ }^{40}$ used the terms "Dakota", "pre-Dakota", and postMcElmo" for subdivisions of the Cretaceous lying above clearly recognized †McElmo (Morrison). His reasons for introducing new terms are given as follows:

Certainly the massive sandstone conglomerate and the unconformity used as the upper limit of the McElmo mark a definite change of conditions of sedimentation. Above this massive stratum are beds of more or less pure limestone, massive beds of chert; and much green shale strata the like of which have never been included in the Dakota. As there are no fossils to aid in the proper placing of these beds, lithologic character and stratigraphic position alone remain as usable evidence of their age. * * * The character of these beds would not admit of their inclusion in the "Dakota" even with the qualified application of this term. Further, to place them in the McElmo formation would require the use of this term in a sense different from that in which it was first applied-to strata in McElmo Canyon.

Properly to place the lower limit of the Dakota (?) is but part of the Dakota-Morrison problem. The exact age of these formations and the stratigraphic units that constitute them are alike imperfectly known.

\section{CRETACEOUS FORMATIONS}

DISTRIBUTYON AND TOPOGRAPHIC EXPRESSION

As noted by Newberry ${ }^{41}$ and also by Holmes, ${ }^{42}$ strata of Cretaceous age (Dakota (?) and lowermost

\footnotetext{
${ }_{10}$ Coffin, R. C., Radium, uranium, and vanadium deposits of southwestern Colorado: Colorado Geol. Survey Bull. 16, pp. 97-112, 1921.

11 Newberry, J. S., Geological report. in Report of the exploring expedition from Sants Fe, N. Mex., to the Junction of the Grand and Green Rivers of the Great Colorado of the West, in 1859, pp. 10, 104-105, 1876.

12 Bolmes, W. H., Geological report on the San Juan district: U. S. Geol. and Geog. Survey Terr. 9th Ann. Rept., pp. 257-264, pls. 35, 36, 1875.
}

Mancos) flank the Abajo Mountains and floor Sage Plain; elsewhere in the San Juan country they have been removed by erosion. Westward they terminate abruptly in cliffs bordering Dry Canyon, middle Cottonwood Canyon, and Butler Wash and next appear in the Henry Mountains and the Kaiparowits Plateau, 70 to 90 miles distant. Southward the Cretaceous of Sage Plain ends in narrow interstream plateaus and detached mesas that above Aneth directly overlook the San Juan River but farther west recede 5 to 10 miles. The beds that terminate along Butler Wash and Cottonwood Canyon reappear in Black Mesa, in the Navajo country, 50 miles south of the San Juan. The northern limit of the Cretaceous in the San Juan country is the crenulated escarpment at the heads of the streams that drain Dry Valley, north of Monticello. Eastward the strata continue with little change far beyond the Utah line; in fact, the Cretaceous strata in southeastern Utah are but short extensions of equivalent beds in the huge Cretaceous deposits of southwestern Colorado. Over most of the area in which Cretaceous strata are present the Dakota (?) sandstone forms the surface, in many places bare or thinly coated with patches of soil. But scattered over the Dakota (?) on Sage Plain are small mesas, buttes, and broad, flat mounds of Mancos shale, and near the Abajo Mountains the shale is sufficiently thick and continuous to conceal the Dakota (?) except in canyons. The Mancos is readily distinguished from the Dakota (?), however, and these two formations from the Morrison beneath. On plateau faces and in canyons the exposures are everywhere alike-brilliantly banded and variegated slopes (Morrison) capped by a gray and brown vertical cliff (Dakota?) over which lie sprawling masses of blue-gray crumbling gullied shale (Mancos). In the absence of the protecting Mesaverde sandstone, the Mancos is openly exposed to the attack of erosive agents, to which it readily yields. Much of the mud dumped into Recapture, Montezuma, and McElmo Creeks comes directly from areas of this shale. In contrast with its function in the Mesa Verde Plateau, the Mancos in the San Juan country takes no part in forming great cliffs. The Dakota (?), however, is a maker of prominent cliffs. It is the most resistant of the sandstones in this region and is favorably placed with reference to the friable underlying Morrison shales. For this reason it forms the rims and box heads of main and tributary canyons and caps outlying mesas. The lofty Shay Mountain owes its preservation to a cap of Dakota (?) sandstone. The presence of impervious though friable shale immediately below porous sandstone makes the base of the Dakota (?) a zone of erosion by ground water. On many cliffs weathering at this horizon has produced recesses and wide-mouthed caves chosen by the Cliff Dwellers as building sites. Deepening of these recesses undermines the ledges until huge blocks are broken off. On slopes below the rim of West Water and Devil 
Canyons slabs of Dahota (?) sandstone measuring as much as 30 by 15 by 10 feet were seen, and about the highest peaks of the Abajo Mountains talus blocks are much more abundant than outcrops of beds in place.

On Sage Plain the Cretaceous sediments are nearly horizontal, forming a floor broken only by canyons. Where upturned on the flanks of the Abajo Mountains they form hogback ridges, the steeper ones worn into pinnacles along their crests. Parts of beds carried upward by igneous intrusions lie in various positions.

\section{DAKO'TA (?) SANDATONE}

\section{LITHOLOGIC FEATURES}

As represented in the San Juan country, the Dakota (?) is a group of sedimentary rocks, rather than a bed or a mass of homogeneous material, traversed by bedding planes. Its persistent general features are predominance of sandstone, lenticular arrangement, cross-bedding, and wide range in composition, color, and thickness of the subordinate shale. Its outstanding local feature is coal. The sandstone is prevailingly coarse, much of it conglomeratic. Most of the material called "shale" is in reality thin-bedded sandstone, and even the coals and the layers of macerated plants are mingled with sand. The formation is everywhere lenticular: few beds of uniform thickness and texture are continuous for as much as 50 feet. Thick wedges, thin wedges, and curved lenses of conglomerate, coarse sandstone, fine sandstone, and shale overlap or end abruptly and are replaced along the strike by different materials. Some masses of coarse sandstone are completely surrounded by shale, and at a place on Alkali Creek conglomerate borders a coal bed. Most of the individual beds are likewise irregularly lenticular. The sandstones are commonly cross-bedded. In the coarser ones straight laminae meet each other at various angles; in the finer ones curved laminae also appear. In places the parting planes between laminae are so evenly spaced as to outline readily worked building blocks.

Plant impressions on sandstone were observed at several localities, also cobbles of petrified wood. Sun cracks, ripple marks, and worm tracks are common in the shales and in the finer-grained, even-bedded sandstone. Local lateral unconformities and features due to channeling are conspicuous.

In composition and texture the Dakota (?) varies widely. The coarser parts consist chiefly of subangular pebbles that average less than half an inch in diameter but include strings of pebbles 1 to 3 inches in diameter. The most abundant pebbles are white, gray, and brown quartzite and quartz, but black and white chert, feldspar, and dense black limestone are fairly common. The conglomeratic beds include also angular fragments of greenish-white mud shale 2 to 6 inches long, rounded shale balls and sand balls, short slabs of sandstone, ironstone and sand-lime concretions, and tiny chunks of carbonized wood. At a place on middle Recapture
Creek angular fragments of chert and chalcedony constitute as much as one-tenth of a bed 20 feet thick, and in specimens collected in upper Big Canyon the only large grains are kaolinized feldspar.

The cement of the Dakota (?) is calcareous, ferruginous, and siliceous. At outcrops where calcite forms the cement the rock readily crumbles, sand piles replace talus, and holes bored by bees appear in the soft finergrained beds. The much more abundant iron cement holds the pebbles firmly together, forms hard black concretionary masses, and gives dark-brown and yellow tones to exposed surfaces. The black color patches on many ledges and the glistening black coating (desert varnish) of boulders on Black Mesa and along the Blanding-Bluff road are doubtless derived from the iron cement. Where the cement is siliceous the rock is especially resistant. It breaks about as readily through the constituent pebbles as around them and forms the least-weathered cliffs in the region. At contacts with igneous rock on the Abajo Mountains all beds, regardless of texture, composition, and cement, liave been metamorphosed to quartzite. The weathering of the lime cement, the removal of mud pellets and sand balls, and the decomposition of the feldspar and vegetable remains have given the Dakota (?) a porosity which fits it for a ground-water reservoir.

\section{STRATIGRAPHY AND CORRELATION}

The Dakota (?) of the San Juan country includes the sandstone and conglomerate beds, the shale, and the thin seams of coal that lie between the thick Morrison formation (Jurassic) and the remnant masses of fossiliferous shale (Mancos) of Benton age. The base of the formation in many places is a bed of gray conglomerate that lies unconformably above brightly colored Morrison shales or sandstones, but in sections measured along Butler Wash and Montezuma Creek the lowest beds are white sandy shale. The top of the formation likewise is in some places a single bed of conrse sandstone, in other places thin-bedded brown sandy shale that grades conformably upward into gray-blue fossiliferous shale, so that the plane of contact of Dakota (?) with Mancos cannot be drawn with assurance. For the region as a whole the total thickness of beds assigned to the Dakota (?) is less than 200 feet. The thinnest section measured is 92 feet.

In most sections measured three subdivisions are recognizable-(1) a basal conglomerate with subordinate shale; (2) thin-bedded sandstones, shales, and coal; (3) sandstone, most of it coarse or conglomeratic. In color, thickness, composition, and continuity these subdivisions show great variation. Their constituent beds interfinger to such a degree that no two sections have the same sequence. The bottom subdivision in 14 sections measured ranges in thickness from 20 to 65 feet. (Thorpe records 84 feet in a well hole 
$1 \frac{1}{2}$ miles east of Monticello.) In six of the sections this subdivision is essentially a massive cross-bedded stratum; in the others it consists of two or more lenticular conglomeratic or sandstone beds with thin sandstones beneath and shale, a little carbonaceous material, and impure limestone here and there on parting planes. (See secs. 27 and 28, p. 78 .)

The middle subdivision ranges in thickness from 10 to more than 60 feet. Along lower Recapture, Montezuma, and McElmo Creeks it constitutes 3 to 15 percent of the Dakota (?) present; on northern Sage Plain about 20 to 50 percent. Most of the beds are thin, platy sandstones, but this subdivision includes layers of red, brown, green, gray, and black shales, also coal. A little carbonaceous shale but no coal beds were observed in sections studied along Big Canyon, West Water Canyon, and lower Recapture and Montezuma Canyons, but earthy coal is common at Monticello, and farther east these beds become persistent and in places thick enough to mine. (See p. 110.)

The topmost subdivision, where its surface has not been reduced by erosion, is 30 to 80 feet thick. The highest figures are for outcrops at the northeast base of the Abajo Mountains. Like the sandstone at the buse of the formation, those at the top are displayed as massive beds or thick short lenses. In general they are less coarse but include conglomerates with pebbles an inch or more in diameter. In places the coarse, thick, strongly cross-bedded strata are replaced by thin, regular sandstone beds or even by shale.

Having in mind the lithologic differences on which subdivisions of strata classed as Dakota (?) are based and especially the significance of the coal-bearing shales between beds of coarse sandstone, Boyer and Lee ${ }^{43}$ argued for the substitution of the term "Dakota formation", as applied by Cross, ${ }^{44}$ for the more widely used term "Dakota (?) sandstone."

The stratigraphic and textural features of the Dakota(?) imply topographic and climatic conditions favorable for the deposition of sand and gravel in streamways and on deltas and for the accumulation of silt in water bodies shallow enough to permit the growth of swamp vegetation. The formation rests on an erosion surface which in pre-Dakota(?) time approached baselevel throughout southern Utah and northern Arizona. The mud lumps, sand balls, and fragments of limestone and of highly colored shales in the basal Dakota(?) beds and colored shales higher in the section suggest reworking of sediments derived from the underlying Morrison

\footnotetext{
4 Boyer, W. W., and Lee, W. T., Coal in the Dakota (?) formation in southwestern Colorado and eastern Utab (manuscript on file in U. S. Geol. Survey). J.ee, W. T., Continuity of formations in Colorado and Utah (manuseript on file in U. S. Geol, Survey).

1 Cross, Whitman, U. S. Geol. Survey Geol. Atlas, Telluride folio (no. 57), 1899.
}

or post-Morrison beds. The dominant pebbles of quartzite and quartz were derived from unknown, distant sources. The sequence and composition of beds and the local unconformities indicate progressive changes, but with many interruptions, from a forested landscape marked by streams and fresh-water ponds to one that included bodies of brackish water and to a final complete submergence by an advancing sea. As elsewhere in the plateau province, the clastic lignitic deposits that constitute the Dakota(?) of the San Juan country are believed to represent a basal phase of Colorado deformation-an oscillating progression from near-shore to marine sedimentation.

For the San Jaun country the fragmentary invertebrate fossils in the shaly beds and the pieces of wood in the conglomerates are not sufficiently diagnostic to place the Dakota(?) accurately in the time scale. But fossils, lithologic features, stratigraphic position, and regional relations prove equivalence with beds previously mapped as Dakota(?) in western Colorado, northern Arizona, and northwestern New Mexico. It is significant that the beds in the Dakota(?) pass without known interruption into those marked by a marine fauna of unquestioned Upper Cretaceous age.

\section{MANCOS SHALF}

The fossiliferous marine shales that conformably overlie the Dakota(?) in the San Juan country are undoubtedly the stratigraphic and lithologic equivalents of the lowermost beds in the Mancos shale prominently displayed in the Mesa Verde Plateau south of Cortez, Colo. In that region the Mancos has a thickness of 2,000 feet and is overlain by great beds of Mesaverde sandstone. West of the Colorado line the Mancos is poorly represented and the Mesaverde is absent. Generally on Sage Plain the Mancos constitutes small mesas and ridges that rise 10 to 100 feet above the Dakota(?) sandstone. On the lower flanks of the Abajo Mountains, where, protected by piedmont gravel, sections show thicknesses exceeding 200 feet, and near Baker ranger station, about 350 feet of Mancos sedimentary beds are preserved in a shallow syncline. Along the San Juan River below Aneth and west of Elk Ridge the formation is absent.

The Mancos is predominately steel-gray sandy shale but includes stringers of earthy coal, impure limestones, and many thin beds of fine-grained yellow and brown sandstone composed chiefly of subangular and angular quartz grains cemented by lime. Gypsum appears in some beds, and selenite crystals are common in the talus. In some sections the sandstones are more numerous and closer together at a horizon 100 to 150 feet from the base and form the caps of mesas. A generalized section of a butte 2 miles east of Blanding shows the following beds: 
Section of Mancos shale in butte 2 miles east of Blanding

3. Sandstone, impure, thin-bedded, lenticular, in part cross-bedded, some coal seams; the abundant fossils include shells of Ostrea, Exogyra, and Gryphaea newberryi

2. Shale, slate-colored, gypsiferous

1. Sandstone, gray and brown, fine-grained, in regular beds 3 inches to 4 feet thick, and sandy brown shales containing Inoceramus fragments, Exogyra, and

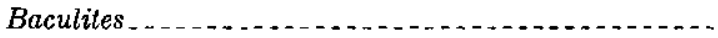

\section{TERTIARY FORMATIONS}

No sedimentary rocks of Tertiary age have been mapped in the San Juan country. Possibly the pebbles of calcareous sandstone and of concretionary limestone in the yellow, firmly cemented gravel that appears as small patches on the high mesas are fragments of Tertiary beds. Likewise some of the chunks of limestone in the piedmont gravel of the Abajo Mountains may date from the Tertiary. That sediments and lavas of Tertiary age once covered all or part of this region is suggested by their presence in adjoining regions--the Animas and Mancos Valleys of Colorado, the Chuska Mountains of New Mexico and Arizona, the Uinta Mountains and the High Plateaus of Utah.

It is probable that during Wasatch time deposition prevailed in southern Utah, southwestern Colorado, and northern Arizona but that the conditions of sedimentation in this vast area varied from place to place. The basal beds are not lithologic equivalents, the sequence is different, and in composition the beds are predominantly limestone, shale, or sandstone. The known parts indicate deposition in several basins, with here and there overlapping rims. It seems unnecessary to follow Dutton in assuming that all the Tertiary sediments of the Colorado Plateaus were laid down contemporaneously in a single large depression.

\section{QUATERNARY FORMATIONS}

In the San Juan country sediments of Quaternary age include talus, wind-blown sand, gravel on rock-cut terraces, piedmont gravel, valley fill, and lacustrine deposits.

Talus in great quantity is piled about the spurs of the Abajo Mountains beneath the southern and eastern rims of Elk Ridge, along Red House Cliffs, and on the south wall of White Canyon. Small patches of talus cling to the walls of canyons of Red Rock Plateau, Grand Gulch Plateau, and Sage Plain. In general the talus is more abundant and more widespread than in regions south of the San Juan River, but few slopes are coated by it from top to bottom. The talus resulting from disintegration of the igneous masses of the Abajo Mountains, from the mounds of Mancos shale, and from the slopes formed on Organ Rock, Chinle, and Morrison shales consists of fragments of small size, but that from the Dakota(?) and Shinarump is made up largely of huge blocks about which the climber must select his route with care.

The wind-blown sand is distributed as thin sheets or as small areas of dunes over plateau tops and along floors of washes; in no place is it a conspicuous topographic feature.

Gravel presumably of Quaternary age lies on the rock-cut benches along the Colorado, the San Juan, and other streams. On the bare rock surfaces of Bluff Bench, about 500 feet above the present San Juan, and on mesas west of Elk Ridge at much higher levels scattered pebbles and continuous sheets of well-worn quartzitic gravel occupy favorable positions. Gravel also coats terraces cut in canyon walls at several different levels above the present stream beds and partly covers the bottoms of high-level meanders no longer used by streams. Most of these deposits range in thickness from 1 to 5 feet, several measure 10 to 15 feet, and near the mouth of Recapture Creek and at a few other places they form huge piles as much as 50 feet thick. In composition and texture the gravel deposits differ in accordance with their source and the position of the streams which formed them. On Sage Plain the highest gravel represents rocks in the Abajo Mountains; that at lower levels is chiefly disintegrated Dakota (?) conglomerate. Along the San Juan, especially above Comb Wash, the gravel consists predominantly of quartzite-in places as much as 80 percent-with porphyries and other crystalline rocks of the kinds common in the San Juan, Ute, and Carrizo Mountains. The materials range in size from pebbles smaller than buckshot to cobbles a foot in diameter. Probably 75 percent have diameters less than 2 inches. Below Comb Wash they include large amounts of Carboniferous limestone from the Goodridge region. All along the San Juan River sandstone fragments are also present, especially on the lower terraces, and at the mouths of some tributary streams they attain sizes exceeding 8 feet in diameter. In Glen Canyon the "placer gravel" that covers the rock-cut terraces 5 to 60 feet thick consists of igneous, metamorphic, and sedimentary rocks in great variety and large range in size, much of it from distant sources. Gravel on the rock terraces along Red Canyon, White Canyon, and Dark Canyon is made up chiefly of sandstone and concretionary limestone from the bordering walls but includes many quartzite pebbles from disintegrating Shinarump conglomerate; which caps Elk Ridge and underlies mesas farther west.

Throughout the San Juan country the pebbles and cobbles that cover rock benches are well rounded, and many of them, especially those along the San Juan, are lens-shaped. In most places they are loosely piled without sorting, except that the large ones are near the bottom. In much of the gravel the spaces between the cobbles are devoid of filling, and a gravel bank quickly slumps down in excavations. In some deposits the 
cobbles at their points of contact are cemented by a mixture of fine sand and calcium carbonate. In a few places, particularly where it rests in channels, the gravel is firmly cemented, and on Wilson Mesa it forms the framework for a considerable mass of caliche.

The flanks of the Abajo Mountains are generally coated with coarse deposits of piedmont gravel. On the south, southeast, east, and northeast they form continuous bench lands between the mountain tributaries of Recapture and Montezuma Creeks and northwestward to Harts Draw. On the southwest, west, northwest, and north slopes of the mountains, about the headwater tributaries of Indian and Cottonwood Creeks, they are represented by isolated patches of coarse gravel that extend upward from the canyon rims. High on the mountain flank at altitudes of about 9,000 feet the deposits are 10 to 50 feet thick; at the junction of mountain and plain, where regional slopes decrease from 20 feet in 100 to 7 feet in 100, Thorpe measured thicknesses as great as 150 feet. Outward from the mountain base the deposits gradually thin to a layer of loosely compacted soil spread over the country rock. As continuous exposures most of the gravel ends about 7 miles from the mountains, but small thin patches lie on the Causeway, on mesas in the Allen Canyon country, and on Sage Plain east of Blanding. Isolated boulders of igneous rock and of metamorphosed sandstone that were once part of the piedmont gravel lie on the rock platforms along the San Juan. Narrow bands of piedmont gravel border parts of Elk Ridge; from its south edge they extend 3 to 4 miles. About the high mesas of Red Rock Plateau accumulations of piedmont materials are absent or inconspicuous; merged into the talus they form a collar of broken rocks between vertical rock walls and flat-lying sandstone surfaces. On the slopes of the Abajo Mountains the gravel consists essentially of angular and slightly rounded boulders of porphyry and sandstone identical in composition with the rocks exposed on the mountain peaks. Near the mountains fragments 5 to 8 inches in diameter are common, and with them are embedded blocks as much as 10 feet in diameter and also lenticular masses of coarse sand.

The once widespread, essentially continuous sheet of piedmont gravel is now much dissected. Its surface is trenched by many gullies and by a score of canyons that extend through the deposit and into the rock below. Over considerable areas it has been entirely removed. It seems obvious that the gravel was deposited in a previous physiographic cycle, probably in the late Pleistocene, when conditions were favorable for rapid aggradation.

Valley fill displayed as stretches of sand on the floor of the washes and in the terraces that border the streamways is a conspicuous feature in the San Juan country. In enormous amounts this valley fill, deposited, eroded, and transported with changing volume of streams, has been furnished to the canyons and broad, shallow valleys by caving banks, landslides, wind-driven sand, and the debris swept from the surface by torrential rains. It is prevalently fine sand but includes also silt, gravel, boulders, and vegetable debris. (See p. - .)

Lacustrine deposits are exposed here and there where swamps and lakes once stood. Most of them are mere patches on valley walls or thin beds exposed along streamways in recently drained swamps. In Lake Canyon at its junction with "East Branch", lacustrine sediments, about 80 feet thick, consist essentially of partly consolidated, extremely fine sand and silt arranged in strata less than one-tenth of an inch thick. They include near the top several layers of black pent 2 to 4 feet thick, which contrast strongly with the otherwise nearly white beds. Minute fossil shells are abundant.

Glacial deposits are lacking on the Abajo Mountains, and if any part of the mountains was glaciated the traces have been obliterated. Thorpe reported "no cirques, no hanging valleys, no moraines of any kindnot even indications of nivation-except on the higher summits in certain limited localities." The absence of glaciation on the Abajo peaks (altitude about 11,000 feet) is worthy of note, inasmuch as nivation is evident on Navajo Mountain (altitude 10,416 feet), and moraines appear on the High Plateaus at 10,000 to 12,000 feet, on the La Sal Mountains at 10,000 feet, and on the San Francisco Mountains at 9,700 feet. Some part of the piedmont gravel on the Abajo Mountains, especially that high on the mountain flanks, may be glacial drift in place, and doubtless streams of glacial time carried much debris from the high lands; but the topography of the mountains is unfavorable for the retention of masses of snow sufficiently large and long-lived to permit the formation of actual glaciers. It seems probable that the gravel on the benches bordering the San Juan River in its course through Utah is, in part at least, the extension of outwash gravel from Pleistocene glaciers in the San Juan Mountains of Colorndo.

\section{STRATIGRAPHIC SECTIONS}

1. Section of Hermosa and Rico formations at Honaker trail on San Juan River

[Measured as tGoodridge formation by $\mathbf{H}$. D. Miser, U. S. Geol. Survey Bull. 75], Rico formation: pp. $127-129,1924]$

1. Gray hard fine-grained limestone; top bed of formation. . . . . . . . . . .

2. Red earthy sandstone and sandy shale; gentle

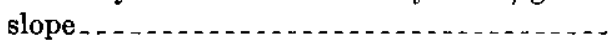

3. Massive gray pitted cross-bedded sandstone (Baby oil sand) ..........................

4. Red earthy sandstone; forms gentle slope; layer of gray limestone 1 foot thick near

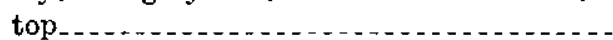

5. Gray pitted soft friable sandstone; forms ledge (Goodridge oil sand) . . . . . . . . . . . . . .

6. Gray coarse-grained fossiliferous limestone....

7. Red earthy' sandstone and sandy shale; forms

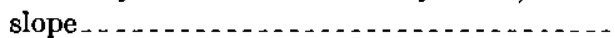


1. Section of Hermosa and Rico formations at Honaker trail on San Juan River-Continued

Rico formation-Continued.

8. Massive medium-grained fossiliferous limestone; sandy and cross-bedded; forms ledge at head of Honaker trail

9. Red and purple shales and sandstones; gentle

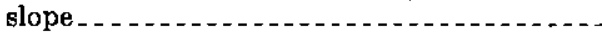

10. Gray pitted soft cross-bedded sandstone (Third oil sand)

11. Red and purple shales and sandstones; gentle slope . . . . . . . . . . . . . . .

12. Gray pitted cross-bedded soft sandstone; ledge (Mendenhall oil sand)

13. Red shale and sandstone; slope . . . . .......

14. Gray thin-bedded medium-grained limestone; ledge; Woodruff's fossil lot 158 obtained from this bed. This is base of the upper Goodridge fauna.

Total Rico 314-324

Hermosa formation:

15. Red and lavender sandy shales; slope.......

16. Gray sandy limestone with black flint nodules_

17. Gray coarse-grained limestone with nodules of red flint; the base of this bed appears to be the horizon of the Little Loop oil sand. Woodruff reports a thickness of $3 \frac{1}{2}$ feet of the sandstone on the Honaker trail . ......

18. Red, lavender, and gray sandy shales; slope -

19. Red, lavender, and gray sandy shales containing coarse-grained fossiliferous limestone in upper half

20. Compact dove-colored limestone; massive at top; grades downward into shaly limestone; contains nodules of jasper................

21. Massive compact dove-colored limestone with nodules of variegated chert. . . ..........

22. Gray and black shales with thin layers of lime-

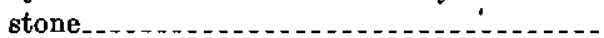

23. Drab knotty limestone and some gray shale.-

24. Cherty drab limestone and some gray shale...

25. Gray and lavender shales and some thin beds of knotty limestone; slope..............

26. Massive gray coarse-grained limestone, free

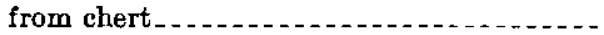

27. Limy gray shale ............

28. Cherty drab limestone

29. Gray shale with thin layers of drab limestone

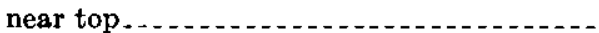

30. Massive compact dove-colored limestone; breaks with conchoidal fracture...........

31. Gray shale interbedded with equal amount of gray fine-grained cross-bedded sandstone.--

32. Massive compact dove-colored limestone; breaks with conchoidal fracture

33. Gray shale with beds of calcareous sandstone near top and base; cherty knotty limestone in lower half; slope..........................

34. Massive cherty fine-grained drab limestone

35. Gray shale and shaly limestone with a bed of knotty black chert in lower half; chert

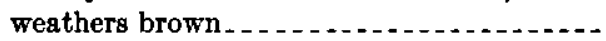

reet

Hermosa formation-Continued.

36. Cherty drab fine-grained massive limestone; forms top of point known as "The Horn", which overlooks canyon . . . . . . . . . .

37. Brownish sandstone.......................

38. Massive gray medium-grained limestone with chert nodules.

1. Section of Hermosa and Rico formations at Honaker trail on San Juan River-Continued

39. Knotty and cherty limestone in upper part; grades upward into overlying bed and grades downward into gray shale in lower part . . - . . . . .

40. Cherty drab limestone

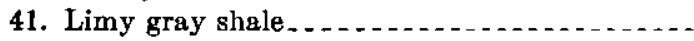

42. Massive drab limestone .

43. Concealed.

44. Massive drab fine-grained cherty limestone-.-

45. Massive drab sandy limestone .

46. Drab sandy shale, grading into overlying bed.

47. Gray shale containing knotty black chert.-.-

48. Black papery shale.

49. Gray shale and drab limestone interbedded; crops out on bench along which trail runs to north for half a mile or more........

50. Dove-colored fine-grained massive limestone; 7 feet below top 1 foot of limestone contains sulphur in cavities as much as $I$ inch in their longest dimension

51. Limy gray shale with a few nodules of black chert near base. .............................

52. Shaly limestone and sandy limestone with black chert nodules. . . . . . . . . . . . . . .

53. Drab sandy fine-grained limestone.......

54. Massive, compact drab limestone with black chert nodules in upper part. . . . . .........

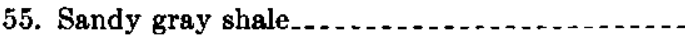

56. Drab limestone with black chert nodules....-

57. Drab limestone with nodules of black chert.--

58. Limestone like that above but more massive.-

59. Yellow cross-bedded fine-grained sandstone. -

60. Concealed......

61. Massive drab fine-grained limestone, grading into earthy sandy limestone below . ......

62. Sandy and limy gray shale.....................

63. Thin-bedded drab limestone.........

64. Sandy and limy gray shale

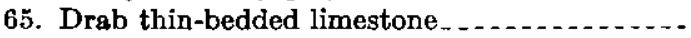

66. Sandy and limy gray shale $\ldots . . .$.

67. Drab limestone.

68. Calcareous fine-grained gray sandstone......

69. Drab cherty limestone...... . . . . . . . . .

70. Calcareous sandstone

71. Massive drab cherty limestone.......

72. Limy gray sandstone.

73. Cherty drab sandy limestone.

74. Limy fine-grained gray sandstone

75. Sandy gray shale

76. Massive drab limestone ........

77. Calcareous fine-grained gray sandstone.....

78. Talus to river.

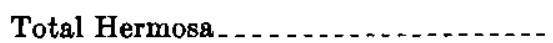

Total exposed thickness of $†$ Goodridge

formation . . . . . . . . . . 1, 299-1, 309

\section{Feet}

16 $41 / 2$

4
25

5

10

30

25

15

5

6 
2. Section of top part of Rico (?) formation in Dark Canyon between Poison and Trail Canyons

Cedar Mesa sandstone member of Cutler formation.

Unconformity.

Rico (?) formation:

10. Limestone and limestone conglomerate in short lenses separated by irregular masses of red and gray shale; includes fragments of brown sandstone and red chert; thins along strike; fossils of lot 3 (see below) probably from this horizon.

9. Sandstone, white, red-streaked, and red, whitestreaked, calcareous, thin, irregularly bedded, friable; upper part dense, platy, cross-bedded; weathers in round-edged beds. . . . . . . . . .

8. Sandstone, gray, calcareous

7. Shales and thin sandstones, red...........

6. Sandstone, white, very calcareous; fossils of

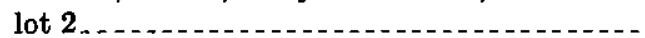

5. Shale, sandy, thin mudstones, or fine-grained sandstones, red

4. Limestone, gray, sandy, lenticular, conglomeratic in part; fossils of lot 1........

3. Sandstone, red, white-streaked, calcareous; in part cross-bedded and lenticular; breaks into thin beds; includes aggregates of calcite crystals, iron-lime concretions, and some fossil wood

2. Sandstone, white, dense, very calcareous; shale at base; mottled purple and green; a prominent ledge.

1. Limestone, gray, sandy in upper part (base not exposed)

Total Rico (?) measured . . . . . 239

The fossils from Dark Canyon, collected in association with Arthur A. Baker and E. T. McKnight, were determined by George H. Girty in connection with a study of specimens from the Indian Creek region. Girty reports:

All the collections appear to be of Permian age, though those from Dark Canyon show certain peculiarities in their pelecypod representation not shown in those from Indian Creek, Salt Creek, etc. The Dark Canyon collections contain suggestions of the Manzano fauna; the other collections contain suggestions rather of the Rico. Neither group of collections presents a facies at all comparable to the Kaibab fauna.

Lot 1:

Aviculipecten sp.

Bellerophon sp.

Patellostium? sp.

Lot 2:

Fenestella sp. Spiriferina kentuckyensis. Composita subtilita. Nucula levatiformis. Schizodus curtiformis? Deltopecten occidentalis. Streblopteria? sp. Pseudomonotis? sp. Pteria sulcata.

Pteria longa.
Lot 3:

Composita subtilita.

Edmondia gibbosa.

Nucula levatiformis.

Schizodus sp.

Deltopecten occidentalis.

Deltopecten sp.

Pseudomonotis sp.

Myalina aff. M. perattenuata.

6 Pteria longa.

Point between Lavender (?) and Davis Canyons, at base of white sandstone (Shinarump):

60 Spirorbis sp.

11 Edmondia gibbosa?

32 Nucula levatiformis.

Deltopecten occidentalis.

Aviculipecten sp.

Pteria sulcata.

Pleurophorus sp.

\section{Section of Permian rocks in Arch Canyon}

[Combination of three sections spaced about 1, 5 , and 7 miles from mouth of canyon

Cedar Mesa sandstone member of Cutler formation.

Unconformity: uneven surface overlain in places by conglomerate; in other places massive sandstone fills depressions eroded in lower beds.

Halgaito (?) member of Cutler formation and Rico (?) formation:

12. Limestone, blue gray, earthy, in part conglomeratic, irregularly interbedded with lumpy masses of red sandstone and gray and slate-colored mud shales; includes much red chert and fragmentary shells; in places absent; forms bench in front of white cliffs

11. Sandstone, mudstone, or sandy shale, red, calcareous, very fine-grained; in places forms compact, seemingly massive ledges 1 to 8 feet thick but generally splits into thin curved or flat beds; includes lenses of brown conglomeratic limestone and of mottled gray shale. Near Angels Arch the sandstone is dominantly white (weathering buff) and strongly cross-bedded; at Cathedral Arch the lower half of the unit consists of alternating beds of red, brown, white, and purple shale and white sandstone; one carbonaceous bed

10. Limestone, gray, firm, in three to seven regular beds; in places conglomerate with tiny lime concretions; fossils determined by George $\mathrm{H}$. Girty as Septopora sp., Orbiculoidea aff. $O$. meekana, Composita subtilita, Deltopecten occidentalis, Pleurophorus sp., Bellerophon sp.;

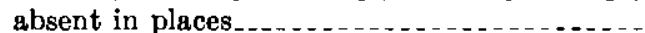

9. Sandstone or mudstone, light red, thin, irregularly bedded in places; a series of alternating red and white beds, some of them crumpled and otherwise distorted.....

8. Limestone and red and blue-gray shale; jumbled mass of shale fragments, knobs, stringers, and lenses of limestone and red chert in pancakes, balls, and elongated forms; in some places merges into no. 10 , in others represented only by chert; rests on eroded surface of no. 7... Unconformity. 
3. Section of Permian rocks in Arch Canyon-Continued

Halgaito (?) member of Cutler formation and Rico (?) formation-Continued.

7. Sandstone; thinly foliated or sandy shales in uneven bands of red and white that along the strike range in thickness from 6 inches to 13 feet; one section shows massive white-streaked cross-bedded sandstone 22 feet thick; includes thin short lenses of limestone and porous calcareous material like travertine; upper and lower parts discontinuously separated by plasters of white mud balls and slabs ... . . . . 23-56

6. Limestone, blue-gray, fossiliferous, in places conglomeratic; not everywhere present. ... . . . . 0-4

5. Shale, sandy, or mudstone, red............. 3-8

4. Sandstone, white, highly calcareous, friable; weathers as a slope................. 6-14

3. Limestone, blue gray, friable; observed in one section only ............. 0-3

2. Shale, red brown, sandy, flaky, in part imbricated, slightly gypsiferous, and sandstone, white, red-streaked; near Cathedral Arch includes a 2-foot bed of knobby, earthy, gray, sparingly fossiliferous limestone and a 6 -inch bed of dense blue-gray limestone

1. Sandstone, red, blotched and streaked with white, very fine-grained; lowest stratum measured in Arch Canyon................. 20+

Total thickness of beds represented, approximately -

4. Section on east flank of Raplee anticline west and southwest of Navajo Springs

[Beds dip $20^{\circ}-50^{\circ}$ E. Nos. $52-96$ messured 2 miles north of nos. 1-51]

Floor of Comb Wash.

Moenkopi formation:

96. Sandstone, greenish white, gypsiferous; splits into shale-like beds that crumble readily to sand; base not exposed........................

95-90. Shales and thin sandstones, brown; a few white bands; in part regular-and evenbedded, in part lenticular; some crossbedding; many weathered slabs show rill marks, mud cracks, and abundant ripple marks _... . . . . . . . . . .

89. Sandstone, brown, with streaks and beds a few inches thick of white sandstone; very irregularly bedded; at base lenticular beds of greenwhite mud shrles

Incomplete Moenkopi

Unconformity: regional erosion surface not clearly shown in this section.

De Chelly sandstone member of Cutler formation (Per$\operatorname{mian})$ :

88. Sandstone, light red to buff, massive, strongly cross-bedded; at the base includes lenses and thin beds of shaly sandstone; prominent horizon marker; thickness estimated.
4. Section on east flank of Raplee anticline west and southwest of Navajo Springs-Continued

Organ Rock member of Cutler formation:

87-73. Shale and sandstone like nos. 71 and 72 , red, somewhat darker color and more solidly bedded toward top; at a distance appears fairly even-bedded but in detail shows much irregularity; some cross-bedding; a few white bands . . . . . .

72. Sandstone, fine-grained, calcareous; appears massive but splits on weathering into thin slabs

71. Shales, sandy, or thin mudstones, fine-grained; weather to fiat and curved cliffs. .........

Total Organ Rock member Feet

Unconformity(?); suggested by abrupt change in color, texture, style of bedding, and topographic expression.

Cedar Mesa sandstone member of Cutler formation, typically thick-bedded:

70. Limestone or highly calcareous sandstone, unevenly lenticular; many foliation surfaces; includes aggregates of calcite crystals and some chert; along strike becomes conglomeratic, with gray limestone concretions and fragments of brown sandstone........

69. Sandstone and shale, like nos. 62-67........

68. Shale, light red; weathers to thin chips like mica; includes two lenses of nodular limestone, each about 3 inches thick; persistent for long distances. . . . . . . . . . . . . . . . . . . . . . . .

67-62. Sandstones, white, calcareous in part, crossbedded, 2 to 5 feet thick, and red sandy mud shales, irregularly bedded. . . . . . . . . . . .

61. Sandstone, white, very fine-grained, even-bedded; red-purple band at bottom and top. ........

60-56. Shales or thin sandstones, light red, slightly gypsiferous, interbedded with white calcareous cross-bedded sandstones 6 inches to 2 feet thick . . . . . . . . . . . .

55. Limestone, nearly black, lumpy, concretionary; joint cracks filled with gypsum; bed traced for half a mile.

54. Shale and thin sandstones in fairly regular beds, red and gray; much gypsum in seams, beds, and disseminated in rock; weathers to rounded, powdery knolls; largely concealed...........

53. Gypsum, white, interbedded with dark sandstone; includes limestone concretions and chert; a lens about 400 feet long. ...........

52. Sandstone, light red and white, in thin irregular beds, gypsiferous; includes thin, short lenses

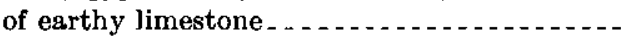

51. Sandstone, buff, cross-bedded, massive, thickness 14 to 30 feet $\ldots$

50. Shales, red, white-banded . . . . .

49. Sandstone, buff to white, cross-bedded, in places stained red; thickness along strike increases to 18 feet.

48-41. Shales, red, sandy, gypsiferous; crumble to powder; interbedded with white to pink slabby sandstone in beds a few inches thick; includes a few thin short lenses of earthy limestone...

145824-38-6 6 
4. Section on east flank of Raplee anticline west and southwest of Navajo Springs-Continued

Cedar Mesa sandstone member of Cutler formationContinued.

40. Sandstone, white to buff, massive, cross-bedded on large and small scale; in places separated into lenticular beds by red clay shale.......

39. Sandstone or arenaceous limestone, white and purple; extremely irregular in bedding and texture; includes red chert, gray mud lumps, and concretionary aggregates of hard blue limestone; top is porous; a prominent bed that along the strike is 3 to 15 feet thick . . .......

38-35. Sandstone, white, in uneven lenticular beds 2 to 15 feet thick, interbedded with variegated sandy gypsiferous shale; 1,000 feet to the north along the strike becomes cross-bedded white, red-stained sandstone; to the south becomes more than half shale; forms steep slope banded dark reddish white and grayish yellow

34. Limestone, nearly black, composed of pellets and irregular forms; much white and red chert at the base...................................

33-30. Shale, light red to pink, gypsiferous, increasingly arenaceous toward top; includes irregular lenses of white cross-bedded calcareous sandstone as much as 8 feet thick...

Total Cedar Mesa member

Unconformity (?).

Halgaito member of Cutler formation:

29. Limestone, gray, black-spotted, conglomeratic, with pellets and lozenges of concretionary limestone, clay mud balls, and fragments of red shale; thickens, thins, or disappears as traced along the strike........

28-20. Shale and sandstone, red, like no. 1 ; at 42 feet above the base includes a lens of greenish-white mud lumps

19. Sandstone, red, poorly bedded, slightly gypsiferous; in three divisions separated by brightred shales; some specked with mica; shows mud cracks, worm trails, and impressions of plants;

forms prominent step.
18-12. Shale, red, like no. 1; slope of sandy unevenly bedded shale crossed by round-edged steps of sandstone 3 to 6 feet high; includes 3 -inch lens of nodular limestone 6 feet above the base_ 116

11. Sandstone and shale, red, purple, and white; very irregular, lumpy; rests on wavy surfaces of no. 10 .

10. Limestone, gray, sandy, resistant; forms cap of local mesas.....................................

9. Shale, red, like no. 1

8. Sandstone, gray, very calcareous, firm, in evenly foliated beds about 2 inches thick; forms low escarpment for more than a mile...........

7. Shale, like no. 1 ; top 12 feet compact and forms cliff - .

6. Sandstone, grayish brown, red-stained along strike; represented by two beds separated

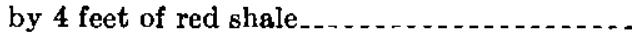

5. Shale, red, like no. 1....

4. Limestone, gray, irregular lens; disappears along strike-

4. Section on east flank of Raplee anticline west and southwest of Nan'ajo Springs--Continued

Halgaito member of Cutler formation--Continued.

Feet

3. Shale, red like no. $1 \ldots$

2. Limestone, blue gray, nodular. . . . . . . . . . . 1

1. Shale, sandy, red; in places appears as sandstone in beds as much as 12 feet thick, which, however, split readily into thin sheets with glistening surfaces; some mica; at 12 feet from base thin band of slabby limestone . .........

Total Halgaito member . . . . . . . . . . . $402+$

Unconformity?

Rico formation (Permian): Top bed is cherty limestone 2 feet thick; depressions in its upper surface filled with intermingled red, yellow, and blue-gray shale.

In the foregoing section the thicknesses of units are approximate, and the boundaries of the members below the De Chelly sandstone are tentative. Local unconformities, abrupt changes in composition and texture along the strike, and marked differences in sequence of sections no more than 1,000 feet apart are features subject to more than one interpretation. Likewise variation in dips and the concealment of outcrops by disintegration of gypsiferous beds prohibit satisfactory measurements by clinometer-compass and pacing.

\section{Section of Halgaito member of Cutler formation in Johns Canyon}

Cedar Mesa sandstone member of Cutler formation.

Unconformity(?).

Halgaito member:

21. Sandstone, dark red, fairly coarse-grained, some mica and feldspar; most of it in regular beds about one-eighth inch thick that weather as slatelike slabs as much as 3 by 6 feet; at the top a bed of white sandstone 3 feet thick marks a horizon of springs and seeps ....... 16-30

20. Sandstone, nearly black, nodular, and dark-red, white-streaked shales intermingled as fragments and lenses that suggest reworking of material; zone of unconformity (?)

19. Sandstone, light red, most of it even-bedded; some ripple marks; forms cliff . ...........

18. Shale, dark red, streaked with white, argillaceous. arranged in thin lenses; surface sun-baked and ripple-marked.

17-16. Mudstone or shaly sandstone, red, with four lenses of limestone conglomerate; much like no. 14; at the top is a persistent band of white sandstone about 6 inches thick

15. Sandstone and shale, forming a cliff: (1, at bottom), gray massive calcareous muscovitic quartz silt, coarser in grain than red beds below, with vertical tubes like worm holes filled with yellow earthy limestone, 9 feet; (2) even-bedded blue-gray clay shales, 1 foot; (3) black massive, very fine-grained carbonaceous sandstone decorated with white circles and cylindrical areas that resemble worm holes or root tubes, 6 feet; (4) yellow and gray evenbedded clay shales, 2 feet. This series is absent from a section 2 miles distant; it seems to occupy a local depression.
Feet 
5. Section of Halgaito member of Cutler formation in Johns Canyon-Continued

Halgaito member-Continued

14. Mudstone or shaly sandstone, red, like no. 1 ; some disseminated gypsum; a few thin, short lenses of limestone and of white sandstone; forms steep slope.

13. Limestone conglomerate; persistent as bed 6 inches to 2 feet thick for nearly half a mile

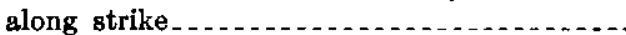

12. Mudstone, red, shaly, like no. 1.............

11. Limestone, dark purple, composed of angular fragments, aggregates, and concretions of limestone; capped by bed of white sandstone

10. Mudstone or shaly sandstone, light red, in thin, flat, and curved beds; like no. 1 , but includes two thin beds of limestone conglomerate, each capped by a layer of white sandstone; forms slope broken by benches.

9-7. Limestone, blue gray, nodular, resistant, 5 feet thick, overlain in turn by 5 feet of white finegrained sandstone that contains lenses of limestone conglomerate and 2 feet of lumpy red shale; forms cliff . . . . . . . . . . . . . . . . .

6. Mudstone, red, shaly, or thin-bedded lumpy sandstone; abundant brown iron concretions and aggregates of white quartz grains

5. Sandstone, white, hard, glistening, very fine, even-grained; traced 1,000 feet along strike..

4. Mudstone, shaly, red, like no. 1............

3. Sandstone, white; weathers buff; appears massive but splits readily into fairly even slabs about 4 inches thick; abundant dark-blue and black concretionary masses that simulate plant stems

2. Limestone, dense, gray, in lenticular beds; form cliff . . . . . . . . . . . . . . .

1. Shale, sandy, thin sandstone or sandy mudstone, maroon to dark red-purple; composed essentially of poorly rounded grains of quartz invisible to the naked eye. some specks of iron, muscovite, and red feldspar cemented with lime-iron-clay mixture; beds regular but lack uniformity in details; tops and bottoms are lumpy and otherwise irregular; the most shalelike beds split into layers sbout oneeighth inch thick; most of the sandstonelike beds, 3 inches to 6 feet thick, have no division planes; some are cross-bedded and are represented in the talus by irregular blocks and by flat and curved chips; includes a band of white sandstone; forms slope............

Total Halgaito member....................

Rico formation (Permian); top is bed of blue-gray firm limestone 2 feet thick.

\section{Section of Cedar Mesa and Halgaito members of Cutler formation in "Dry Wash" branch of Fish Creek}

[Measured as Supai and Coconino formations by R. W. Sherman (unpublished

Cedar Mesa sandstone member:

19. Massive tan sandstone; weathers to brownish red; forms rim at top of canyon..........

18. Dark brownish-red shale Feet

Feet

6. Section of Cedar Mesa and Halgaito members of Culler formation in "Dry Wash" branch of Fish Creek-Continued

7. Section of Cedar Mesa sandstone member of Culler formation in Grand Gulch near Collins

11. Sandstone, white, in three beds, separated by thin layers of red shale like no. 7; includes chert; forms top of canyon wall . . .

10. Shale, red purple, like no. 4; includes lenses of limestone and sandstone; weathers as a groove beneath a round-edged projecting ledge of sandstone; at nearby places the site of Basket Maker storehouses 
7. Section of Cedar Mesa sandstone member of Cutler formation in Grand Gulch near Collins-Continued

9. Sandstone like no, 1; even-bedded at base; massive, cross-bedded at top. ..............

8. Shale, sandy, or thin-bedded sandstone, redbrown . . . . . . . . .

7. Sandstone like no. 1 , in beds 8 to 20 feet thick; in part cross-bedded; interbedded with shales like nos. 2 and 4, 2 inches to 4 feet thick; includes thin limestones; forms cliff with horizontal grooves. . . . .

6. Shale like no. 2 ; thickness along strike 6 inches to 3 feet.

5. Sandstone like no. 1; less cross-bedded; no limestone . . . . . .

4. Shale, red brown, sandy, calcareous, paper-thin; overlapping layers along strike include thin

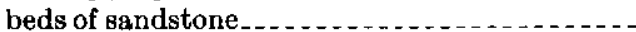

3. Sandstone like no. 1; includes two thin short lenses of gray limestone......................

2. Shale, red, calcareous, in even beds, with lumpy surfaces; thickness along strike 2 to 8 feet....

1. Sandstone, cream white, calcareous, fine-grained, cross-bedded, some curved lamina folded and otherwise distorted; weathers to powder; extends to bottom of canyon wall ............

Incomplete thickness of Cedar Mesa member.

\section{Section at head of Comb Wash}

Shinarump conglomerate.

Unconformity.

Moenkopi formation (Lower Triassic):

15. Shale and sandstone, 1 to 3 feet thick, chocolate brown, in regular beds and lenses; some red and white bands; on talus large ripple-marked slabs are common; partly concealed........

14. Sandstone, dark red, white at base and top; weathers into white-streaked rounded knobs; along strike appears as beds 1 to 4 feet thick, ripple-marked.

13-11. Shale, red and brown, and thin sandstone, imbricated; weather as cliffs . ..............

10. Sandstone, red brown, thin beds combined to form a ledge

9. Shale, chocolate-colored or red brown, fissile; breaks readily into thin slabs; surfaces of top beds marked with mud cracks, worm borings, and ripples

Total Moenkopi formation

390

Organ Rock member of Cutler formation (Permian):

8.' Sandstone, light red, hard, very calcareous; appears as one massive bed with lines of holes to represent division planes; along the strike bedding and vertical joints developed by weathering into "organ pipes" . . . . . . . . . . .

7.1 Sandstone, white; fine conglomerate of black and white quartz, lime and iron grains, resting

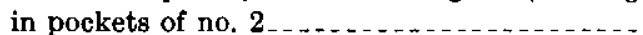
Unconformity.

1 As nos. 7 and 8 lie above an unconformity, they should perhaps be included in the Moenkopi.
8. Section at head of Comb Wash-Continued

Organ Rock member of Cutler formation-Continued.

5-1. Sandstone, red, calcareous, or sandy shale, in beds 4 to 6 feet thick, rounded by spalling at top and bottom; and shalelike beds; whiteblotched; includes three thin beds of white sandstone, one of them persistent for half a mile; some beds show plasters and inclusions of gray-blue limestone; a slope with steps. . . .

Total Organ Rock member...........

Unconformity; uneven surface coated with plasters of limestone and nodular red clay.

Cedar Mesa sandstone member of Cutler formation in walls of canyon.

\section{Section of cliffs 4 miles north of Clay Hills Pass}

6. Shale, red, in general even-bedded but irregular in detail; includes bands of white sandstone 1 to 6 inches thick; forms slope but in places weathers as grooved columns. ............ Shinarump conglomerate.

Unconformity.

Moenkopi formation (Lower Triassic):

10. Shales, brown, sandy, rippled and variegated, and earthy shales; upper part concealed by landslide; thickness estimated............

9. Shales and shaly sandstones, brown and dark red; produce a "slab talus" of large, very thin sheets with rill marks, worm trails, mud cracks, and ripples; resemble typical Moenkopi of the Little Colorado Valley ...................

8. Shales, sandy, fissile, and thin sandstones, chocolate brown, traversed by greenish-white bands; gypsum in seams, in a 3 -inch bed, and disseminated............................

Unconformity.

6. Sandstone, light red and gray, in places conglomeratic, with limestone pellets. In position of De Chelly sandstone..............

Organ Rock member of Cutler formation (Permian):

5. Sandstone like no. 4; weathers to steps and

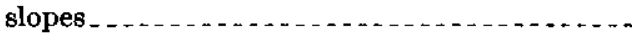

4. Sandstone, red, in thick beds; composition and texture like no. 1 but more firmly cemented; weathers in part like shale; bedding and vertical jointing made prominent by weathering, combine to produce fluted cylindrical columns like mass of organ pipes, the effect intensified by white bands; top is thin bed of limestone; forms an unscalable wall .............

3. Shale like no. 1; some beds mottled greenish white; with nos. 1 and 2 forms slope broken by steps . . . . . .

2. Conglomerate, gray; pellets, lozenges, short fat lenses, and irregular masses of limestone mingled with fragments of calcareous sandstone; a persistent ledge; forms bench ...... 360 
9. Section of clifs 4 miles north of Clay Hills Pass-Continued

Organ Rock member of Cutler formation-Continued.

1. Shale, sandy, thin sandstone or mudstone, very fine-grained, calcareous, red; parts appear as massive beds but weather into thin slabs; base not exposed.

Cedar Mesa sandstone member of Cutler formation.

10. Section 3 miles southwest of Kachina Natural Bridge

Shinarump conglomerate (Triassic):

12. Grits arranged as lenticular wedges, lenses of conglomerate with pebbles as much as half an inch in diameter of brown, red, and white quartz and quartzite, gray chert, and fragments of sandstone; some petrified wood; and cliffed edge of a platform that extends backward for more than a mile

Unconformity.

Moenkopi formation (Lower Triassic):

11. Shale, largely covered by landslides. Part exposed includes thin brown sandstone and sandy shale, variegated in blotches and bands, red, ash, brown, and greenish white; includes lenses of yellow limestone conglomerate, strips of mud balls, and a bed 8 inches thick of dense resistant green sandstone. Talus includes many large chunks of red chert. Forms a. slope

10. Sandstone like no. 4

9. Shale like no. $5 \ldots$

8. Sandstone like no. 4

7. Shale like no. 5

6. Sandstone like no. $4 \ldots \ldots \ldots$

5. Shale, brown, banded with white, slightly gypsiferous; weathers as broad, thin ripple-marked slabs

4. Sandstone, brown and gray, in beds about 1 foot thick, with division planes of greenish shale; beds split readily into sheets an inch or less thick, most of them profusely rippled; a cliff..

3. Sandstone, thin-bedded, and sandy shales, chocolate brown, lime- and iron-cemented; ripple marks, sun cracks, worm borings; forms slope

Total Moenkopi formation.

Unconformity; erosion surface and abrupt changes in lithology.

Organ Rock member of Cutler formation (Permian):

2. Division B: Mudstone, red; composition and texture essentially like that of division $A$ but thicker-bedded and more firmly cemented. Weathering has produced horizontal curved fluting along beds and vertical fluting on unevenly placed joints. The base is marked by a bed of greenish-white sandstone about 1 foot thick that may be traced for miles. An unscalable cliff that in 3 miles along the strike ranges in height from 60 to 120 feet....

1. Division A: Shales or mudstones, light red and dark red, in thin regular beds, extremely fine-
10. Section 3 miles southwest of Kachina Natural Bridge-Con.

Organ Rock member of Cutler formation-Continued. Feet grained, highly calcareous; some beds or lenses show no division planes in thicknesses of 10 feet or more and appear as steps; all beds weather as flat or disk-shaped chips that partly cover the round-edged beds; forms a

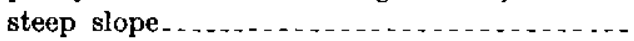

Total Organ Rock member........... 351 Unconformity (?); wavy surface and accumulation of coneretions.

Cedar Mesa sandstone member of Cutler formation.

11. Section of Permian and Triassic formations at Rock Springs, White Canyon

Wingate sandstone (Jurassic?).

Unconformity (?).

Chinle formation (Upper Triassic):

10. Sandstone, red, uniformly fine-grained, evenbedded, in part cross-bedded; strata 3 to 10 feet thick separated by thin layers of red

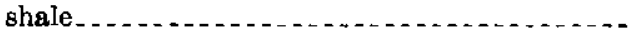

9. Shales, red, purple, ash gray, and greenish white; includes two beds of hard green sandstone, three beas of dense blue-gray limestone, and many lenses of limestone conglomerate; petrified wood common; most of it weathers into mounds with fluffy surfaces

Total Chinle formation. 580

Moenkopi formation (Lower Triassic):

7. Shales, sandy, gray, purple, and white, largely concealed by slides and talus.

6. Sandstone like no. 4; weathers into ripple-marked

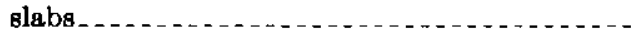

5. Shale, sandy, chocolate-colored, streaked with white, slightly gypsiferous, imbricated; weathers into large thin slabs with smooth, hard, shining surfaces decorated with ripples, herring-bone patterns, and deeply filled sun cracks..... . . . . .

4. Sandstone, brown and buff, in four to six irregular beds parted by evenly foliated layers of ripplemarked chocolate-colored shale ............

3. Shales and thin sandstones, checolate-colored; foliation surfaces are sun-baked and show ripples, rill marks, and sun cracks 1 to 6 inches deep filled with consoldated yellow mud; at the base and in lenses just above are discontinuous conglomerate beds composed chiefly of lozenges, balls, and irregular fragments of clay shale, red sandstone, and iron and lime concretions. 
11. Section of Permian and Triassic formations at Rock Springs, White Canyon-Continued

Unconformity; erosion surface and abrupt change in lithology; conglomerate.

Organ Rock member of Cutler formation (Permian):

2. Division B: Mudstones or sandstones, red, calcareous, extremely fine-grained; in places appear massive, but generally a series of very uneven beds; weathering has developed bedding planes and joints into grooves on unscalable cliff

1. Division A. Shales sandy, and calcareous mudstones, red; beds very irregular in thickness and extent; eroded as round-edged benches combined to form slope; crumbles to flat and curved chips; top marked by band of white sandstone

Total Organ Rock member

Unconformity (?).

Cedar Mesa sandstone member of Cutler formation.

12. Section of Permian and Triassic at Rasp trail, 5 miles above mouth of White Canyon

Wingate sandstone (Jurassic?), 300 feet thick.

Chinle formation (Upper Triassic):

15. Sandstone, red, in fairly even thin and thick beds separated by red and gray claylike shales; measured at point 1 mile distant

14. Shale, banded red, gray, and white; weathers as a slope like "marls"; thickness estimated....... .

13. Shale, chiefly pink and white, highly calcareous, and beds of blue, gray, pink, and mottled limestone; forms series of vertical cliffs; thickness

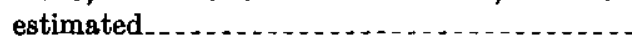

12. Sandstone, white, coarse-grained quartz with calcareous cement . . . .

11. Shale, banded pink and white, highly calcareous; few lenses of limestone conglomerate and of

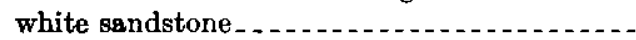

10. Sandstone, greenish white, lenticular, friable $\ldots$

9. Shale, variegated

8. Sandstone, brown, white-striped, in part crossbedded; contains concretionary limestone pellets; lower third mostly limestone conglomerate in short irregularly overlapping lenses. - -

7. Shale, variegated, chiefly green, yellow, and gray; forms a slope with loose porous surface.....

6. Sandstone, greenish gray, coarse, calcareous, in thin overlapping plates; forms a cliff . ......

5. Shale, banded yellow, ash gray, brown, and purple; fragments of fossil wood; on weathering forms "marls"; a slope.

Total Chinle formation 80
$-\quad 640$

Shinarump (?) conglomerate (Triassic):

4. Conglomerate and grits of chert, and clay pellets in patches distributed unevenly over top surface of no. 3

Moenkopi formation (Lower Triassic):

3. Shale, sandy, chocolate-colored, regularly bedded, and lenticular beds of brown sandstone; shaly beds and massive beds alike split readily into thin ripple-marked slabs.
12. Section of Permian and Triassic at Rasp trail, 5 miles above mouth of White Canyon-Continued

Moenkopi formation-Continued.

2. Conglomerate, gray; chiefly angular and partly rounded fragments of white chert and crystalline quartz as much as 3 inches in diameter, cemented by coarse grit; lenticular; in position of DeChelly sandstone: thickness along strike 2 to 8 feet . . . . . . . . . . . . . . . . . .

Total Moenkopi

Unconformity: jumbled mass of clay balls and lenses on uneven surface of no. 1 .

Organ Rock member of Cutler formation (Permian):

1. Mudstone or sandstone and sandy shale, red, alternately massive thick beds and thin beds, all irregular; lower part (largely covered) a slope formed of thin beds, upper part a cliff fluted horizontally; base not exposed........ 278+

Cedar Mesa sandstone member of Cutler formation.

\section{Section al head of Arch Canyon}

Shinarump conglomerate (Upper (?) Triassic); forms top of Elk Ridge.

Unconformity.

Moenkopi (Lower Triassic):

20. Sandstone and shale, largely concealed by talus and slides; not measured.

19-11. Shales, dark brown, sandy, imbricated, fissile; on talus sheets as thin as cardboard show ripples and mud cracks; a few thicker sandstone beds and a few very thin white beds.....

10. Sandstone, red brown, cross-bedded; appears massive, but along strike breaks up into beds 1 to 6 inches thick; forms cliff

(1)

\section{Unconformity (?).}

Organ Rock member of Cutler formation (Permian):

8. Sandstone, white, coarse, in shalelike layers, with some lenses of fine conglomerate; position of De Chelly sandstone. . . . . . . . . . .

7. Sandstone, red, massive; forms strong eliff

6. Shale, sandy, red; weathers as flakes . ........

5. Sandstone or mudstone; composition and texture like no. 4; appears as compact beds 5 to 20 feet thick, separated by thin shales; weathers as rounded shoulders from which curved and straight chips peel off; in part blotched and striated with white; forms succession of cliffs and slopes.

4. Shale, sandy, or thin mudstones, red; appear evenly bedded but beds irregular in detail; form slope with steps.

3. Shale, white, fissile, sandy ................

2. Sandstone, yellow and gray, fine-grained, calcareous, uneven-bedded.................
Feet

(1) 
13. Section at head of Arch Canyon-Continued

Unconformity (?).

Cedar Mesa sandstone member of Cutler formation:

1. Sandstone, buff, highly calcareous, in beds 10 to 40 feet thick separated by red shale; unevenly coated with gray nodular concretionary limestone; forms canyon walls; thickness estimated.

14. Section of Moenkopi formation at Long Point, south end of Elk Ridge, head of Grand Gulch

Shinarump conglomerate (Upper ? Triassic).

Unconformity.

Moenkopi formation (Lower Triassic):

5. Shale; from a lower part like nos. 2 and 3 changes gradually in color, texture, and bedding to an upper part that consists of a series of friable, sandy, slightly gypsiferous shales; variegated red, brown, gray, and purple.

4. Sandstone, buff and brown; appears as a single massive bed, in part cross-bedded, but is easily separated into thin ripple-marked layers......

3. Shale, sandy, brown, very thin-bedded, with some parting planes of greenish white; most beds profusely ripple-marked, sun-cracked, and crossed by incipient channels; breaks readily into slabs and flat chips that show glistening specks of gypsum . ...........

2. Sandstone, purple and brown; appears massive; bedding indicated by lenses of brown glistening shale and black streaks of manganese (?) -.-

1. Shale, sandy, or thin-bedded sandstone, brown; largely concealed by talus

Total Moenkopi formation

Unconformity; conglomerate of clay balls and fragments of sandstone and limestone.

Organ Rock member of Cutler formation (Permian): Red mudstones.

15. Section of Shinarump conglomemate at Elk Ridge, near head of Arch Canyon

11. Sandstone, white; grades upward into sandy shale mottled black, white, and yellow; pebbles abundant at the base.................

10. Shales, black and grayish blue, carbonaceous, full of iron concretions and scattered pebbles...........

9. Sandstone, gray, coarse, with strings and scattered

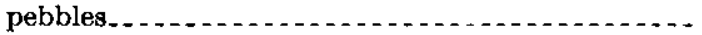

8. Shale, gray, sandy, in overlapping beds

7. Sandstone, white, coarse, glistening ..............

6. Shale, yellowish brown, sandy, with layers of carbonaceous matter

5. Conglomerate; pebbles of white chert and quartzite, well rounded, 1 to 3 inches in diameter.........

4. Shale, brown, sandy

3. Sandstone, gray, cross-bedded, porous; includes strings of pebbles and impressions of plants. . ...

2. Shale, yellowish brown, sandy . .

1. Sandstone, grayish brown, glistening, coarse; includes conglomerate lenses of quartzite, quartz, chert, and petrified wood; top of Elk Ridge. . . _. 23

Total
16. Condensed section of Chinle formation at the Bears Ears, Elk Ridge

Wingate sandstone (Jurassic?).

Unconformity (?).

Chinle formation (Upper Triassic):

33-22. Shales, red and yellow, sandy, and thin irregularly bedded red sandstone; abundant mud lumps and some limestone conglomerate associated with shales form steep slopes.-.-

21. Limestone conglomerate, greenish white, in six lenticular beds separated by red shale.......

20. Shale, light yellow, sandy, friable; mud balls, ripple marks impressions of plante...-...-.

19. Limestone, conglomerate, greenish white, and purple sandstone irregularly cross-bedded; includes clay balls, concretionary lime pellets, saurian bones, and fragments of sandstone and shale........

18-11. Shale, light red and yellowish red, calcareous, friable, and red imbricated sandstone in alternating beds 3 to 12 feet thick . . . - . . - . -

10-2. Shales, variegated, friable, calcareous, and five beds of limestone conglomerate 1 to 3 feet thick; brightly colored "marl" slope on which limestone forms shelves................

1. Shale, purple, ash, blue, green, red, and brown, and gray thin-bedded sandstone. Flat slope largely concealed by talus and landslide. Thickness estimated

Total Chinle formation

Shinarump conglomerate (Upper? Triassic):

17. Condensed section of Chinle formation at Clay Hills Pass

Wingate sandstone (Jurassic?).

Unconformity.

Chinle formation (Upper Triassic):

18. Sandstone, dark brown, slightly cross-bedded in six to ten lenticular beds; includes lenses and rounded aggregates of brown mud balls, lone pellets of greenish-white clay and lenses of coarse limestone conglomerate more abundant near the base

17. Limestone conglomerate with lenses of brown sandstone

16. Shale, yellow, sandy .........................

15-10. Sandstone, white, hard, alternating with pink limestone conglomerate in beds 2 to 4 feet

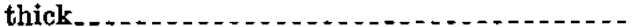

9-7. Shale, yellowish red, sandy, indistinctly banded; includes four beds of compact finegrained white sandstone. . . . . . . . . . . .

6-2. Shales, prevailingly red and pink, friable, with lenses of calcareous white sandstone and limestone conglomerate that weathers as shelves and pancakes on an otherwise even slope. A bed of pink limestone conglomerate at the top 4 feet thick and another near the middle are continuous for at least a mile...........

1. Shales, brown, red, green, ash, and purple, with many balls and short lenses of limestone conglomerate and a few lenses of gray calcareous sandstone; some dinosaur (?) bones; weathers as a brightly variegated slope and marl-like material.

Total Chinle formation ..................

$100+$ Shinarump conglomerate (Upper? Triassic). 
18. Section of Morrison formation and San Rafael group on south face of Tank Mesa

Morrison formation (Bluff sandstone member): Persistent ledge, buff, white, greenish white, red-stained,

lenticular on a huge scale

Unconformity (?); abrupt change in color and lithology; sinuous contact.

San Rafael group:

Summerville (?) formation:

15. Sandstone, white, stained red, in beds 1 to 4 feet thick, and thin red, white-blotched, highly calcareous shale; chert in large pancakes abundant in uppermost shale beds.

14. Sandstone, white to brown, roughly bedded, cross-bedded, and thin discontinuous bands of imbricated shale. At a distance nos. 14 and 15 appear as color-banded portion of vertical cliff below Bluff sand-

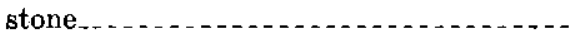

13. Shale, yellow, tan near base, banded dark red, brown, ash, and gray above, all sandy and gypsiferous; includes thinly laminated brown ripple-marked sandstone and thin short lenses of limestone; forms steep slope over which are scattered thin chips of red shale, angular fragments of limestone, and red chert.........

Total Summerville (?) formation......
Feet

$n$

18. Section of Morrison formation and San Rafael group on south face of Tank Mesa-Continued

San Rafael group-Continued.

Carmel (?) formation-Continued.

3. Shale, light red, in which are lenses of $\mathbf{r t}$, white, and spotted, very calcareous sand.

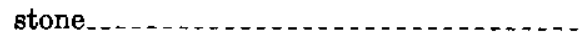

2. Sandstone like no. 6

1. Shale, light red; fits into pockets and channels of Navajo sandstone.

Total Carnel (?) formation

Unconformity.

24 Navajo sandstone (of Glen Canyon group).

Traced along the strike, groups $13-15$ of the Tank Mesa section show extraordinary range in color, bedding, and composition. Within half a mile 20 beds may be replaced by 1 , and the color may change from brown and dark red to light red and pink; a group of shale layers is in one place even-bedded, in others nodular or wrinkled; gypsum, a constituent of most beds, ranges in amount from lenses to disseminated grains; chert appears in the upper 50 feet of the section as widely scattered pellets and as lenses almost continuous for more than 100 feet. All the beds assigned to the Summerville difter in color, composition, texture, and bedding from the overlying Bluff sandstone member of the Morrison.

\section{Section at the village of Bluff}

Morrison formation (Bluff sandstone member).

Unconformity (?); uneven, slightly eroded surface.

Summerville (?) formation: lower part appears as roughly defined beds 6 to 8 feet thick

Carmel(?) formation:

11. Sandstone, light red, uneven, wavy, nodular beds 1 to 5 feet thick, in part cross-bedded; alternately bedded with dark-red shale 1 to 4 feet thick; white streaks along joints, tiny faults, and some cross-bedding laminae ...................

10. Sandstone, white, Iumpy, lenticular; includes

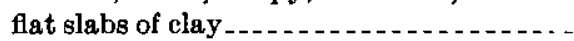

9. Shale, light red, sandy; forms slope interrupted by little benches formed by lenses of more calcareous material ..........

8. Sandstone; lower 11 feet massive, dark red, nodular; upper 5 feet poorly bedded, light red and white; top dense white calcareous resistant bed; forms broad bench........

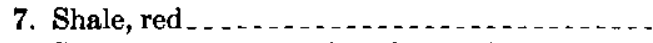

6. Sandstone, pure white, fine-grained quartz, some specks of garnet and iron, loosely cemented with lime; imbricated nodular beds break into irregular thin slabs........

5. Shale, dark red, with white spots

4. Sandstone, red, highly calcareous, or limestone; breaks into slabs about 1 inch thick; profusely ripple-marked.
6. Sandstone, white (tan-coated), progressively coarser and more cross-bedded from bottom to top.-

5. Sandstone, dark brown, separated unevenly into beds by lenses of extremely fine-grained darkred clay-mud shale with greenish-white spots; all calcareous and gypsiferous; weathers into recesses and breaks into shapeless slabs; top is a zone of seeps

4. Sandstone, white, relatively coarse; white quartz grains, some black and red grains and gypsum; decreases in thickness along strike........ .

3. Sandstone, white and red, in fine beds with intervening dark-red shale that ranges in amount from one-third to two-thirds of the section. No bed continues for more than 100 yards; in places a single ledge of white sandstone makes up one-third of the group. All seems

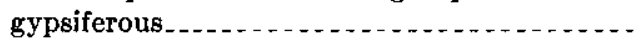

Feet

2. Shale, red at base, banded dark brown and white above, calcareous and gypsiferous; most of it irregularly bedded and lumpy. In nearby places some of the gypsiferous shale beds at this and higher horizons are conspicuously wrinkled and are separated by angular unconformities. -

Total Summerville (?) formation...........

1. Sandstone, bright red, massive, cross-bedded, very fine-grained, streaked with white; may be top

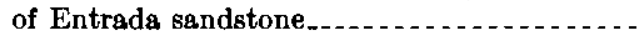

2 
20. Section of Morrison formation and San Rafael group at head of Butler Wash

Morrison fórmation: Sandstone, gray, coarse, lenticular, in part cross-bedded, and irregular beds of brown calcareous shale.

San Rafael group:

Summerville (?) formation:

13. Shale, red, earthy; breaks into flat slabs . - -

12. Sandstone or mudstone, red, resistant; forms surface of broad bench. . . ............

11. Shale, red, and white sandstone, in beds 1 to 4 feet thick; forms brightly banded slope.

10. Shale, dark red, lumpy, friable; breaks into flakes like mica; includes three beds 8 to 12 inches thick of gypsiferous ripplemarked white sandstone...............

9. Sandstone, white, thin, uneven beds, ripplemarked; includes black iron sand and concretions; weathers to knobby surface.

8. Shale, dark red, earthy; breaks readily into thin flakes...........................

7. Sandstone, white, cross-bedded, gypsiferous; crumbles to dust

6. Shale like no. 8.

5. Sandstone, white, in thin overlapping beds; forms bench .........................

4. Shale like no. 10 ; on uneven surface of no. 3 .

Total Summerville (?) formation....

Feet

26

5

38

Entrada sandstone:

3. Sandstone, orange red or brick red, massive, cross-bedded, streaked with white; weathers into arched cavities, pedestals, and bobbins.

Unconformity (?); conglomeratic mass of shale, calcareous sandstone and lime mud balls; lies on uneven surface of no. 2 .

Carmel (?) formation:

2. Shale, red, lenticular, very calcareous, crumbles readily ...................

1. Sandstone, dark red, calcareous, slabby, in beds 1 to 4 feet thick; weathers like shale; limestone concretions at the base .....

Total Carmel (?) formation........ .

Uneonformity.

Navajo sandstone (of Glen Canyon group), white, yellow, stained.

In a section about 6 miles south of the head of Butler Wash 315 feet of strata are classed as Carmel (?)-a succession of alternating red and pink shales 3 inches to 35 feet thick and white calcareous sandstone 8 inches to 6 feet thick. The topmost thin beds of shale and sandstone are firmly cemented and form a platform at the base of the Entrada. In this section the Summerville seems to be absent; a grayish-white crossbedded lenticular sandstone 125 feet thick, considered the Bluff member of the Morrison, lies unconformably above the Entrada.
21. Section of Morrison formation and San Rafael group in Dry Wash, Allen Canyon country

Morrison formation: Sandstone, gray, coarse, with lenses of gray sandy shale and conglomerate of white chert, lime balls, clay balls, and quartz.

Unconformity.

San Rafael group:

Summerville (?) formation:

12. Shale, red, peaty, friable, calcareous; some wrinkled beds............................

11. Sandstone, greenish white, resistant ......

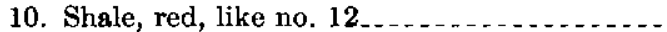

9. Sandstone, white, firın, cross-bedded .....

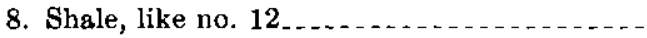

7. Sandstone, like no. 9

6. Sandstone, yellow, coarse, coated on surface with sand balls; weathers like travertine.

5. Sandstone, yellow, fine-grained, in thin lenticular beds, including bands and blotches of dense pink sandstone. . . . .........

4. Shale, pink, friable, calcareous and gypsiferous; includes very thin lenses of resistant white sandstone ..............

3. Sandstone, buff, very unevenly bedded, and thin lenses of red calcareous shales.......

2. Shales, red, sandy, friable, with three lenses of white sandstone 1 to 4 inches thick .-

Total Summerville (?) formation..... 131

Unconformity (?).

Entrada sandstone:

1. Sandstone, orange red, massive, crossbedded, fine-grained; weathers as roundedged ledge..........................

Unconformity; erosion surface represents absent Carmel

Feet

14

1

16

1

8

1

20

30

23

5

12

formation.

Navajo sandstone (of Glen Canyon group).

In the Allen Canyon country within a radius of 4 miles the Carmel (?) formation ranges in thickness from a knife edge to 55 feet (?); the Entrada sandstone from 45 to 205 feet, including interbedded red shale: and the Summerville formation from 127 to 283 feet. In several places the Entrada rests directly on the Navajo sandstone.

22. Section of Carmel (?) formation at west edge of Wilson Mesa

Carmel (?) formation:

10. Limestone, firm, knobby; weathers like caliche; forms top of mesa

9. Shale, light red, with discontinuous thin bands of white sandstone. . . . .

8. Sandstone, white, black, spotted, very finegrained, resistant; grades downward into no. 7 . . . . .

7. Shale, red, sandy

6. Sandstone, red, white, blotched, very calcareous

5. Shale, red, sandy, very irregularly bedded and nodular; forms slope. . . . . . . . . . . . . . . . . .

4. Sandstone, gray, part stained black, irregular beds; forms persistent ledge. . . . . . . . . . . . . .

3. Shale, red, sandy series of overlapping thin lenses.
Feet 
22. Section of Carmel (?) formation at west edge of Wilson MesaContinued

Carmel (?) formation-Continued.

2. Sandstone, red, lenticular

1. Shale, red, lumpy, and some calcareous pellets; rests in depression of underlying rock

pets

Total Carmel (?) formation

-92-94

Unconformity.

Navajo sandstone.

23. Section of Morrison formation along canyon of Recapture Creek

[Combined from six partial sections. See pl. 16, A]

Dakota(?) sandstone.

Unconformity.

Morrison formation:

Division D (Brushy Basin shale member):

19. Shale, greenish yellow, and thin greenishwhite soft sandstone; at the base a 6-inch bed of resistant sandstone...

18. Sandstone, greenish white, massive, cross-bedded; along strike replaced by interbedded maroon shales and white sandstone, very lentioular.-.-

17. Sandstone, soft, white; includes lenses of conglomerate made up of red, black, and gray chert, quartz, and fragmentary bones; concretions of lime and of mud shale at base

16. Shale, pink, maroon, yellow, ash, and white; includes long, thin lenses of greenish-white shaly sandstone, pink, black, red, white, and mottled limestone, and chert conglomerate......

15. Sandstone, greenish gray, hard, brittle; forms bench ......................

14. Shale, green and gray, irregularly bedded; in places nearly all green shale; includes conglomerate of concretions and white sandstone fragments at the base...............

Estimated total, Brushy Basin member.

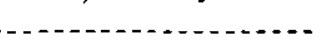

Division C (Westwater Canyon sandstone member):

13. Sandstone, white and yellowish white, soft, massive, in part cross-bedded; lenses of greenish-white mud shale; lens of conglomerate made up of concretionary pellets of limestone and fragments of shale and sandstone; top surface hardened; weathered surfaces show cavities and grooves; forms lower wall of Recspture Canyon.-.-

Unconformity; fragments of shale and conglomerate of no. 13 on eroded surface of no. 12; relief as much as 20 feet in 500 feet.

12. Shale, gray and greenish white, and lenticular beds of hard green sandstone.

11. Sandstone, white, some greenish white, in three to eight cross-bedded lenticular strata separated by thin lenses of ash-gray shale and greenish-white
210-228

...

20-30

8-23
23. Section of Morrison formation along canyon of Recapture Creek-Continued

Morrison formation-Continued. Feet Division C-Continued. clay pellets; strong vertical joints; at base lenses of chert and quartzite conglomerate; along strike includes gray shale . . . . . . . . . . . . . .

10. Shale, gray, ash, yellowish green $\ldots . .$.

9. Sandstone, white and yellowish green, coarse, cross-bedded; lenses of conglomerate and gray shale; indefinitely parted into three or four beds; forms vertical cliffs

8. Shale, red and greenish white, with thin lenses of white sandstone........

7. Sandstone, white, massive, cross-bedded, with a few shale lenses; appears porous on weathered surfaces..........

Total Westwater Canyon member.- 180-253

Division B (Recapture shale member):

6. Shales, predominantly maroon, some ash gray, in groups of strata 6 to 45 feet thick, interbedded with white soft cross-bedded sandstone 3 inches to 3 feet thick, more abundant near the top; weathers as attractively banded slope in which thin sandstones project as steps; shale constitutes more than 85 percent of the beds. . - 111-230

5. Sandstone, white, flaky, in thin overlapping ledges................

4. Shale, dark red and ash gray, flaky, mottled, irregular beds . . . . . ....

3. Sandstone, tan, coarse, lenticular, soft, porous on weathered surfaces.......

Unconformity (?); uneven surface of no. 2 coated with jumbled fragments of green and red clay.

2. Sandstone, red, brown, and tan, in very uneven beds 6 inches to 10 feet thick; shale, dark red, flaky, irregularly bedded, 2 inches to 2 feet thick; all beds highly calcareous, some gypsiferous; thickness and structure change rapidly along strike; weathers as banded column and bosses.......

Total Recapture member. . . . 220-290 40-55 Division A (Bluff sandstone member):

1. Sandstone, white; weathers tan; firm, cross-bedded, massive; base not exposed.............................

Bed of San Juan River.

24. Section of Morrison formation on east side of Butler Wash, about 14 miles from its mouth

Division D (Brushy Basin shale member); not measured. Division C (Westwater Canyon sandstone member):

24. Sandstone, white; weathers somewhat yellow; coarse-grained, cross-bedded; lime cement; lenses of conglomerate, chiefly chert pebbles; lenses of green shale 1 to 30 inches thick, 1 to 50 feet long; generally soft but top surface casehardened; on weathered surface appears porous; forms nearly vertical cliff and platform 
24. Section of Morrison formation on east side of Butler Wash, about 14 miles from its mouth-Continued

Division C-Continued.

23-18. Sandstone, white, lenticular, unevenly deposited as beds 2 to 12 feet thick; greenishwhite shale in thin lumpy bands........

17-16. Sandstone, white and gray, in beds 2 to 3 feet thick, alternating with red shale .......

15. Shale, red, with greenish-white bands .........

14. Sandstone, white, friable, lumpy, cross-bedded in irregular lenses 6 inches to 2 feet thick....

13-11. Shales, red, interbedded with white coarse friable sandstone

10. Sandstone, white, cross-bedded, lenticular, weakly cemented with lime; at base and along cross-bedding laminae strings and aggregates of greenish-white mud lumps; suggest uncon-

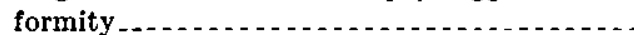

Total Westwater Canyon member . . . . . .

Division B (Recapture shale member):

9. Shales, red, streaked with white; top surface

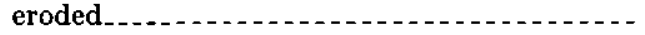

8-5. Shale, red, sandy, irregularly bedded; includes several thin bands and two thick short lenses of white sandstone

4. Sandstone, white; weathers yellow and light red; unevenly bedded; includes lenses consisting chiefly of hardened clay balls..............

3. Shale, red, made of short overlapping flakes. ...

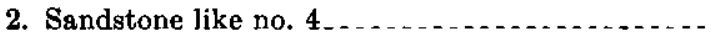

1. Shale, red, calcareous, argillaceous; near the base are lenses of green mud and fragments of red shale.

Total Recapture member.

Division A (Bluff sandstone member) -

25. Section of Morrison formation in Brushy Basin

Dakota (?) sandstone.

Unconformity.

Morrison formation:

Brushy Basin shale member:

28-24. Shale, red and white, sandy, and white lenticular coarse-grained porous sandstone, in alternating beds; forms stepped

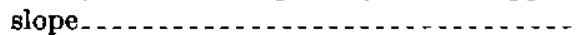

23. Sandstone, white and greenish yellow, coarse, very lenticular, in part crossbedded; lenses of conglomerate consist chiefly of red and black chert, fragments of green sandstone, and clay balls; includes round white aggregates of quartz and elongated brown concretions of iron and sand; forms cliff

22-20. Shale, red, ash gray, yellow, and green, sandy, and lenses of white sandstone; forms color-banded slope...............

19. Sandstone, dark green, hard, very finegrained, persistent ledge.............

18. Shale, red, yellow, green, purple, and white; color distributed in regular bands and in blotches to form variegated slope; beds include lenses of pink, purple, and white limestone, white and brown sandstone, and limestone conglomerate consisting of
25. Section of Morrison formation in Brushy Basin-Continued

Morrison formation-Continued.

Brushy Basin shale member-Continued. concretionary balls, chert, and bone fragments; weathers to form loose, fluffy, marl-like material, partly concealed by landslides.............................

17. Sandstone, dark green, resistant, like no. 6 - -

16. Sandstone, brown; appears as massive ledge but weathers readily to shalelike beds....-

15. Shale, dark red, unevenly bedded; thin band of white powder-fine sandstone at top and base.

, red and slate-colored Total Brushy Basin member........ 450

Westwater Canyon sandstone member:

13. Sandstone, white and greenish yellow, with lenticular partings of greenish shale; top surface hardened and uneven..............

12. Shale, banded red and greenish white, flaky, and thin white sandstone, in overlapping lenticular beds............................

11. Sandstone, white, thin-bedded, and red shale, irregularly interfoliated; forms broad platform . ...........

10. Sandstone like no. 1 but coarser-grained; forms strong ledge..................

9. Shale, red, streaked greenish white . . . . . .

8. Sandstone like no. $1 \ldots$

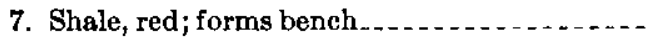

6. Sandstone like no. 1 ; base firmly cemented mass of fragments of sandstone, red shale, and white mud shale; rests in hollows and about ridges at top of no. 5 . . . . . . . .

5. Sandstone, greenish-white, and lumpy mud shale; contains lime concretions and fragments of carbona ceous materisl..........

4. Shale, red; forms platform

3. Sandstone like no. 1...

2. Shale, red, unevenly bedded, imbricated; weathers to leaf-like chips . . . . . . . . . . .

1. Sandstone, white; weathers yellowish white, most of it cross-bedded and lenticular; lenses of conglomerate made up chiefly of lozenges and scales of greenish-white clay, chert, and fragments of shale; a few very thin short lenses of red shale; weakly cemented with lime; round holes and slots give weathered cliff face a spongy appearance...................................

Total Westwater Canyon member exposed.

26. Section of Morrison formation at Decker ranch, 10 miles above mouth of Cottonwood Canyon

Westwater Canyon sandstone member:

17. Sandstone, yellow, buff, and white, coarse-grained, in lenticular beds 6 to 30 feet thick, separated by yellow and gray sandy shales; includes lenses of conglomerate composed of white chert; lenses of blue and green clay mud balls and lozenge-shaped masses of yellow carnotite (?); forms cliff; thickness exposed 
26. Section of Morrison formation at Decker ranch, 10 miles above mouth of Cottonwood Canyon-Continued

Unconformity by erosion.

Recapture shale member:

16-9. Sandstone and shale in alternate layers. Sandstone white, brown, and green, calcareous, in beds about 1 foot thick, much of it porous and friable; shale red, white, and gray, lenticular; breaks into tiny chips............. -

8. Shale, white, yellow, and light red; forms banded

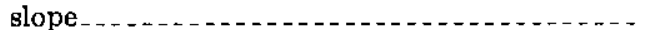

7. Sandstone, olive green, dense, very resistant; forms cliff

6-1. Shale, light red and purple, white-streaked, sandy, and white sandstone in beds about 1 foot thick. Sandstone irregularly bedded, some cross-bedded, porous where greenishwhite mud fragments have weathered out....

Total Recapture member............. 154

Bluff sandstone member

27. Section of Dakota (9) sandstone in Bulldog Canyon opposite Grayson ranger station

[Measured by M. R. Thorpe]

26. Sandstone, soft, brownish, thin layers...........

25. Sandstone, hard, massive, cross-bedded; ledge maker

24. Sandstone, soft, thin-bedded, cross-bedded, finegrained, with local lenses of conglomerate.

23. Conglomerate, coarse . . . . . . . . . . . . . . . . .

22. Sandstone, very strongly cross-bedded, thin-layered, soft; some conglomerate in thin bands. ..........

21. Sandstone, massive, cross-bedded, fine-grained; ledge maker

20. Sandstone, cross-bedded, thin-bedded; local layers of fine conglomerate; lower half fine-grained sandstone, upper half more conglomerate . . . . . . . . .

19. Shale, greenish, with thin layers of fine conglomerate

18. Sandstone, with conglomerate in wedges, lenses, and irregular shapes; fine to medium coarseness.

17. Sandstone, fine-grained, coarsely cross-bedded, bluish gray, with small reddish and brownish spots and blotches, also purplish streaks about a quarter of an inch in width .............

16. Sandstone, even-bedded, thin layers, fine-grained.-

15. Sandstone, thick-bedded, fine-grained, with narrow bands of cross-bedded laminae; conglomerate wedges and lenses between cross-bedded laminae........................................

14. Sandstone, soft, white, with yellow blotches, slightly cross-bedded - . - with yellow blotehes, slightly

13. Conglomerate in sandstone matrix; pebbles of

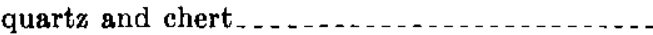

12. Sandstone, thick-bedded, and small streaks of conglomerate; not very resistant. ..............

11. Conglomerate, fine, cross-bedded . . . . . . . . . .

10. Sandstone, massive, thick-bedded; weathers almost black; cross-bedded to some extent...........

9. Conglomerate in layers with coarse calcareous cement. . . . . . . . . .

8. Sandstone, coarse-grained, cross-bedded, reddish brown; contains bands of fine conglomerate with a few large pebbles

7. Sandstone, gray, fine-grained, even-bedded, with thin streaks of fine quartz pebbles
27. Section of Dakota (?) sandstone in Bulldog Canyon opposite Grayson ranger station-Continued

6. Conglomerate, gray Ft. in

5. Sandstone, fine-grained, gray, not cross-bedded.--

4. Conglomerate

3. Sandstone, smooth, gray, with minute quartz pebbles, not cross-bedded . . . . . . . . . . . .

2. Conglomerate cemented by sandstone matrix; pebbles angular to subangular, a few rounded; large percentage of quarta; some pebbles an inch in diameter, most less than a quarter of an inch; cross-bedded with finest pebbles at the top.....

1. Dakota (?) talus; huge blocks of strongly crossbedded sandstone...................... 80

Total $197 \quad 3$

28. Section of Cretaceous beds on west side of Recapture Canyon [Dakota (?) sandstone measured about 13 miles south, and Mancos shale 2 miles esst of Blanding]

Mancos shale:

Feet

12. Sandstone, impure, thin-bedded, lenticular, in part cross-bedded; some coal seams; the abundant fossils include shells of Ostrea, Exogyra, and Gryphaea newberryi..................

11. Shale, slate-colored, gypsiferous

10. Sandstone, gray and brown, fine-grained, regular beds 3 inches to 4 feet thick, and sandy brown shales containing Inoceramus fragments, $E x$ ogyra, and Baculites

Unconformity.

9. Sandstone, yellowish gray, coarse, cross-bedded, composed of clean glistening grains of quartz and lenses of conglomerate 6 inches to 6 feet thick and 10 to 60 feet long, consisting chiefly of pebbles of quartz and quartzite with some chert and hard limestone; forms rim of canyon for many miles

8. Sandstone, fine-grained, white, with long, thin lenses of greenish-gray sandy shale.........

7. Sandstone, gray, coarse-grained, thin, evenbedded ..............................

6. Shale, dark red, short overlapping lenses and reg-

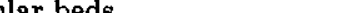

5. Sandstone, yellowish gray, thin, irregular beds; eroded into slabs

4. Shale, reddish brown, sandy; disappears in 30 feet along strike ...............................

3. Sandstone, grayish green, with red blotches, finegrained.

2. Sandstone, buff yellow, medium-grained, lenticu lar beds 1 to 4 inches thick, and yellowish-gray sandy shale in beds that thicken, thin, and disappear along strike; form with nos. 3 to $8 \mathrm{a}$ steep terraced slope. .....................

1. Sandstone, brownish gray, coarse, and conglomerate consisting of well-worn round and flat pebbles of quartz, quartzite, chert, and compact clay one-eighth to $1 \frac{1}{2}$ inches In diameter; mud lumps, sand balls, and fragments of limestone at the base; strongly cross-bedded; a single resistant ledge.

Total Dakota (?) sandstone.............

Morrison formation: Variegated shales, white sandstone, pink limestone.

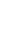

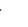




\section{Chapter 3. IgNEOUS ROCKS}

\section{REGIONAL RELATIONS}

Though widely distributed in adjoining regions, igneous rocks are rare in the San Juan country. No extrusives have been mapped within the belt, some 170 miles long and 100 miles wide, that extends from the Aquarius Plateau eastward across Utah and well into Colorado: the lavas and tuffs that may have spread over parts of this great region during Tertiary time are now represented only in the escarpments of the High Plateaus and the cliffs at Telluride. Intrusives likewise are poorly represented. They are exposed in the Henry Mountains and Abajo Mountains, but for many miles north of the San Juan River and lower Glen Canyon only one dike has been observed.

In the San Juan country deep-seated granite and granitic gneiss have been penetrated in oil wells at Soda Basin and in Dark Canyon. On the surface and in stream channels east of Comb Wash, also along the San Juan and Colorado Rivers, pebbles of igneous rock, chiefly from the Abajo and Carrizo Mountains and from mountains in Colorado, are widespread. So far as observed, the black rocks on mesa tops and flats adjoining Cottonwood Wash, known locally as "lava" or "malpais", are fragments of quartzite and sandstone coated with desert varnish. Outcrops of igneous rock have been mapped only in the Abajo Mountains and Lime Creek Valley. (See pl. 17.)

The igneous rock characteristic of the Abajo Mountains is similar in appearance and composition to that which constitutes the bulk of the laccoliths in Carrizo Mountain, Ariz., the Henry and La Sal Mountains, Utah, and Ute Mountain, Colo., and doubtless has the same general source and history.

In the Abajo Mountains the dominant rock is porphyritic hornblende latite, and the subordinate masses range from trachyte to andesite. (See p. 80.) In Carrizo Mountain Emery ${ }^{45}$ found a central mass of porphyritic diorite and small dikes of shonkinite, minette, and dacite. The laccolithic mass in the Henry Mountains as described by Gilbert ${ }^{46}$ consists essentially of "porphyritic trachyte", perhaps better described as porphyritic hornblende diorite. For the La Sal Mountains, rocks analyzed by W. F. Hillebrand ${ }^{47}$ show a large igneous mass of porphyritic monzonite cut by dikes of monzonite, syenite, pulaskite, and

\footnotetext{
is Emery, W. B., The igneous geology of Carrizo Mountain, Ariz.: Am. Jour. Sci., 4th ser., vol. 42, pp. 354-359, 1916.

16 Gilbert, G. K., Report on the geology of the Henry Mountains, pp. 60-66, U. S. 16 Gilbert, G. K., Report on the geology of the $\mathrm{H}$
Geog, and Geol. Survey Rocky Mtn. Region, 1877.

4 Clarke, F. W. Analyses of rocks and minerals from the laboratory of the United States Geological Survey, 1880 to 1914: U. S. Geol. Survey Bull. 591, p. 145, 1915.
}

noselite-syenite. The core of Ute (El Late) Mountain as described by Holmes ${ }^{48}$ and by Coffin ${ }^{49}$ consists of andesitic or dioritic porphyry, composed chiefly of plagioclase and hornblende phenocrysts in a microcrystalline groundnass of feldspar, hornblende, and magnesite.

Unlike those in the laccolithic Abajo, Carrizo, Henry, La Sal, and Ute Mountains, the dikes and volcanic necks along the San Juan River in the Navajo country are basaltic. Augite is present in all specimens examined and is the predominant mineral in most of them. With the augite are the potassic minerals biotite, sanidine, and leucite. This association of minerals places the rocks in such classes as leucite basalt, melilite basalt, trachydolerite, monchiquite, limburgite, augite minette, and augitite. They represent high differentiation toward the mafic end of a strongly alkalic series.

\section{BELL BUTTE DIKE}

Near Bell Butte, about 5 miles north of Goodridge, the continuity of the limestone surface is interrupted by a low dike about a mile long and 2 to 8 feet wide, trending N. $10^{\circ} \mathrm{W}$. Like Alhambra Rock and other intrusives south of the San Juan River, this dike is not massive or uniform in texture. It appears as a series of vertically overlapping schistlike laminae of ferromagnesian rock with which are mingled angular fragments of granite gneiss, schist, limestone, and sandstone, derived from the rocks through which the plastic magma ascended. The dike has not appreciably metamorphosed its bordering sediments and seems to have no relation to the accumulation of oil in the beds that it traverses. As seen in a hand specimen, the igneous part of the dike, of greenish-brown color, consists of much brown biotite and green augite and some feldspar and calcite. The prominent hexagonal plates of brown biotite are so arranged as to give the rock a platy fracture, suggesting an original fluidal arrangement. In thin section a porphyritic texture is revealed: abundant phenocrysts of biotite (phlogopite?) and augite and a few of orthoclase and plagioclase are set in a groundmass composed of lath-shaped orthoclase crystals intermingled with some diopside, biotite, and unidentified material. Bright-green, strongly pleochroic aegirite-augite forms borders of many large augite crystals and completely replaces some of the

Holmes, W. H., U. S. Geol. and Geog. Survey Terr. 9th Ann. Rept., for 1875 pp. 272-273, 1877.

" Coffin, R. C., Radium, uranium, and vanadium deposits of southwestern Colorado: Colorado Gesl. Survey Bull 16, p. 121, 1921. 
smaller ones. Calcite, analcite, and zeolite are also present as minerals of secondary origin. The rock differs little from a typical augite minette.

\section{PETROGRAPHY OF THE ABAJO MOUNTAINS}

By Malcolm R. Thorpe

Typical rock.-The whole laccolithic mass of the Abajo Mountains is homogeneous, and the igneous material must have all come from the same reservoir, notwithstanding the fact that intrusion took place at three or more different horizons in the sedimentary strata. Rock specimens collected at many localities, when studied under the microscope, show similarity of composition. There is no evidence pointing to differentiation products except in a few places near the contacts between the igneous and sedimentary rocks.

The typical igneous rock is a bluish-gray porphyritic rock with large crystals of feldspar embedded in a finegrained groundmass. Microscopic study of 42 thin sections of the igneous rock from different laccolithic bodies shows 27 to range from trachyte to andesite, but as a group they are best classed as hornblende latites. Gilbert has called this group of rocks, showing no mica, hornblende trachytes, and Cross has called them porphyrites.

These rocks contain both feldspar and hornblende phenocrysts. The feldspar crystals range from 1 to 4 millimeters in length and are about twice the diameter of the hornblende crystals. The hornblende ranges from light yellowish brown to green. Augite is rare and occurs only as small residual areas in hornblende. The only mica observed is a little fibrous secondary material. In 13 specimens quartz was found as muchcorroded phenocrysts, but it is abundant only in the groundmass.

Orthoclase was identified in a specimen from the lowest tunnel of the Gold Queen mine, although in many specimens the faintness of twinning in some oligoclase phenocrysts and the alteration of the rocks make the distinction between the two feldspars difficult. A fresh orthoclase rock from South Peak contains phenocrysts with a graphic intergrowth of quartz and untwinned feldspar, but most phenocrysts are the usual twinned plagioclase. A dozen other rocks show a few phenocrysts that lack the albite twinning and may be partly orthoclase. These rocks resemble those of neighboring regions, in which orthoclase is rarely identified but is certainly present, as shown by the analyses, and probably forms a considerable part of the groundmass. Of the phenocrysts, which make up 30 to 75 percent of the rock, plagioclase is much more abundant than hornblende and is in general the bestpreserved mineral of the rock. The plagioclase ranges from sodic oligoclase to andesine; it shows zonal structure in about half of the thin sections and is probably obscured by weathering in others. These plagioclase crystals range in size from less than 1 millimeter to 4 millimeters. The plagioclase of the groundmass is usually needlelike in form and sodic in character. Hornblende is second in abundance to plagioclase. Titanite forms characteristic wedges as small phenocrysts in about half of the rocks. Magnetite or ilmenite is present in nearly all the specimens, occurring as small phenocrysts and resorption residues around the hornblende and as dust in the groundmass. Apatite can be fourd as needles in the groundmass and as larger crystals in nearly all the rocks. Zircon is visible as very small grains in only two specimens, one from the eastern peak of Twin Peaks and the other from the igneous sheet in the Johnson Creek Basin. Allanite, which has been reported in rocks from nearby regions, was not identified, but it may be present in small amounts. Nephelite was not observed and probably is not to be expected in rocks that are so siliceous.

Alteration of the common propylitic type has affected the whole series more or less. Pyrite is abundant in only one specimen, which came from the Dream mine. Sericite, epidote, chlorite, carbonates, and quartz are present in many specimens and brownish uralitic aggregates in a few. There has been but little dynamic action in this area. A few veins are filled with epidote and quartz. In most of the rocks examined alteration has affected the hormblende before the feldspar. The hydrothermally altered rocks are especially subject to weathering.

The groundmass ranges in average grain from 0.1 to less than 0.01 millimeter. Five of the rocks differ from this fine granular texture in that they show an obscure poikilitic intergrowth, ghostlike grains about 0.1 millimeter in size enclosing several smaller grains.

The rocks of the Abajo Mountains fall into two classes-laccolithic rocks and fragmental contact dike rocks and ores. Descriptions of typical specimens are given below.

Hornblende andesite from Twin Peaks.-The rock forming the eastern peak of Twin Peaks is dark brownish gray in the hand specimen, has an even granular texture, and weathers into small reddish-brown fragments. It is characterized by white to gray phenocrysts of plagioclase and less abundant ones of hornblende, which together form about 60 percent of the rock. A microscopic study shows that the hornblende forms slender needles 0.1 to 0.2 millimeter in length, which are more highly weathered than the plagioclase. The plagioclase has zonal structure and is partly altered to sericite. Next in abundance is uralitic hornblende, which is for the most part brown but shows gradations to the more ordinary green type. Secondary magnetite is found as an alteration product. Apatite occurs in unaltered needles and irregular masses. The groundmass is poikilitic, with the host grains as much as 0.1 millimeter in diameter and the inclusions less than 0.01 millimeter. Plagioclase, secondary biotite or uralitic hornblende, minute grains of magnetite, a small 
amount of apatite, and probably orthoclase are the chief recognizable constituents, but probably quartz and orthoclase make up much of the groundmass.

Dacite from North Peak. - A hand specimen of the typical porphyritic dacite of North Peak shows feldspar and hornblende enclosed in a fine-grained groundmass. The color of a fresh surface is dark blue, witb gray feldspar and black hornblende crystals. Weathering turns the color to a brown and causes the rock to break up into angular, more or less oblong fragments a few inches thick and 2 or 3 feet in maximum length. The rock is massive, heavy, hard, and very resistant to weathering. The plagioclase grains are both large and small, some oblong and some spherical. The hornblende crystals occur as grains and as long, slender laths 6.0 millimeters in maximum length. A microscopic study shows that the phenocrysts make up 50 percent of the rock. They are somewhat irregular in shape, show carlsbad twinning, and are embedded in a fine-grained groundmass. The feldspar phenocrysts, which appear to be plagioclase, are much altered to sericite. Quartz occurs in small rounded grains and also as large irregular-shaped forms. Primary magnetite is characterized by sharp edges; secondary magnetite occurs in small grains that are an alteration product of hornblende and probably of biotite. The groundmass is composed of grains about 0.02 millimeter in diameter. Quartz, orthoclase, and plagioclase are the chief components; minute grains of zircon and irregular grains of magnetite are also present.

Dacite from Abajo Peak.- The rock at the summit of Abajo Peak is a typical porphyritic dacite much like that found elsewhere in the mountains, a greenish-gray rock in which the feldspar and hornblende stand out prominently. As seen in the hand specimen, a grayishwhite feldspar is very abundant in oblong or irregularshaped crystals. A small quantity of quartz is present as rounded grains, some of considerable size. Hornblende is not abundant and occurs both as rounded grains and as laths. A microscopic study shows that this rock contains about 60 percent of phenocrysts that are somewhat ragged in outline (perhaps from alteration), embedded in a medium-grained groundmass. Among the phenocrysts, plagioclase, with twinned crystals, is the most abundant, but there may be some orthoclase. Hornblende occurs in greenish irregular grains, and a considerable amount of quartz is present as irregular grains of medium size. The magnetite forms irregular-shaped grains that are for the most part a secondary alteration product, but a few clear-cut crystals are primary. The groundmass is mediumgrained, and its crystals, which average about 0.1 millimeter in diameter, include quartz, plagioclase, probably orthoclase, sericite, carbonates, brown biotite as an alteration product, and grains of magnetite.

Dacite from Horsehead Peak.-The rock at the summit of Horsehead Peak is porphyritic with a grayishgreen groundmass, which weathers to a deeper brown.
On weathering it breaks up into angular fragments that reach a maximum length of 6 or 8 inches. Phenocrysts of plagioclase, quartz, and hornblende form about 40 percent of the rock. The feldspar crystals are gray to white and reach a maximum length of 10 millimeters. A small amount of orthoclase may also be present. Quartz forms rounded grains. Hornblende is present as small green rounded grains and as slender crystals that reach 5 millimeters in length. Magnetite and titanite complete the list of phenocrysts. The groundmass is very fine, with grains averaging 0.03 millimeter, and is composed of quartz, feldspar (probably both plagioclase and orthoclase), and grains of magnetite.

Andesite from Mount Linnaeus.-The rock at the summit of Mount Linnaeus is a porphyritic andesite in which phenocrysts make up about 50 percent. The primary essential minerals are zoned plagioclase, hornblende, quartz, and possibly some orthoclase. The primary accessory minerals are apatite, magnetite, and titanite. The secondary alteration products are calcite, chlorite, and sericite. The groundmass is poikilitic, composed of quartz (?) and feldspar, darkened by a good deal of opaque iron oxide dust. The poikilitic areas are a little more than 0.1 millimeter in diameter, but some granular areas, as well as inclusions, are much smaller.

Dacite from Johnson Creek Basin.--The rock forming the igneous sheet that covers several acres in the foothills of the Abajo Mountains on both sides of Johnson Creek is a brown, very much weathered dacite. It has a porphyritic texture, and the irregular and corroded phenocrysts make up about 60 percent of the rock. The primary essential minerals are medium sodic plagioclase, orthoclase (?), rounded quartz, and ferromagnesian minerals, which are now wholly altered. The primary accessory minerals are magnetite, apatite, and zircon (?). The secondary alteration products are limonite, kaolin, sericite, and brownish uralite. The quartz crystals are rounded and resorbed. The limonite stain permeates nearly the whole rock, and a brownish radial fibrous mineral, resembling biotite, is very abundant. Few grains have any resemblance to the original ferromagnesian minerals, and many are now very fine mineral aggregates. There are also dusty areas of feldspar that have been altered to sericite and kaolinitic material, which may have been ortboclase. Zircon is abundant. The fine grains of the groundmass are less than 0.01 millimeter in diameter.

Andesite from South Peak.-The main mass of South Peak is composed of andesite, gray where fresh and very light brown on a weathered surface. The texture is porphyritic, with medium to small phenocrysts of feldspar and hornblende, which form about 50 percent of the rock. The primary essential minerals are sodic plagioclase, orthoclase, corroded quartz, and hornblende that has been wholly altered. The primary 
accessory minerals are magnetite, titanite, and apatite. The secondary alteration products are sericite and uralite. Some phenocrysts show a graphic intergrowth of quartz and orthoclase. The groundmass is a very fine granular aggregate much dusted with brown grains that reach 0.05 millimeter in diameter and are probably the same as the larger brown uralite.

Contact rock from North Creek.-The rock at the contact between the laccolith and the Mancos shale at the head of North Creek is gray, with large inclusions of black irregular-shaped masses of shale and small rounded quartz pebbles. It is hard and does not weather readily, although some specimens are much altered. One of the thin sections shows an extremely fine-grained rock, whose grains are about 0.1 millimeter in size. The structure is fragmental, and the specimen is composed of quartz, small irregular grains of magnetite, small rounded grains of apatite, minute shreds of sericite, much secondary calcite, and a small amount of feldspar. Another thin section, of a much-altered rock, shows fine-grained groundmass and phenocrysts of feldspar, altering to sericite, irregular masses and grains of magnetite, a small amount of quartz as aggregations and rounded grains, biotite, and much-altered hornblende. Other fragments seem to be quartzite and such substances as devitrified rhyolite. The groundmass shows an aggregate structure and consists of magnetite, quartz, feldspar, sericite, and biotite.

Rhyolite from Horsehead Peak.-About 50 yards south of the crest of Horsehead Peak is a circular igneous plug with a diameter of about 20 feet. It consists of slabs about 2 inches thick standing in a vertical position. The rock is even-grained and is composed of feldspar, hornblende, and quartz. The color is grayish green on the fresh surface, but on weathering it turns brownish green or dark green. Though the minerals are igneous, the hand specimen shows some angular dark fragments, and the section as a whole shows few good phenocrysts, for all are angular and look fragmental. The feldspar is chiefly orthoclase, but some plagioclase is present in the form of laths and angular or rounded grains and has undergone sericitization and replacement by carbonates. Grains of magnetite are probably primary. Green hornblende, a few small grains of quartz, brown biotite, a very small amount of apatite, sericite, and secondary epidote make up the remainder of the mineral constituents. The groundmass consists of quartz, ferromagnesian minerals, and titanite.

Volcanic breccia at Gold Queen mine.-Angular slabs of volcanic breccia a few inches thick and a few inches to 2 feet in length cover an area of about 2 acres on the ridge about a quarter of a mile southeast of the Gold Queen mine. The slabs represent an outcrop broken up by weathering. This rock is a typical volcanic breccia or agglomerate, composed of large crystals of gray feldspar and included fragments of shale. Quartz and fine particles of magnetite, which can be seen megascopically, make up the remainder of the rock. Some of the feldspar crystals are more than an inch in length, and none of these have clear-cut outlines. The rock on a fresh surface is grayish brown to grayish blue; on a weathered surface it is light brown and has a pitted appearance. It is of about medium weight and easily fractured. This rock contains a very large amount of feldspar, which has been so extensively altered to kaolinitic material that its original character is obscured. The feldspar is mostly plagioclase, in grains of irregular shape. There is a considerable amount of magnetite, both primary and secondary, as square and irregular grains. Brown biotite, much altered and decomposed, occurs in irregular patches, and there is also some sericite as an alteration product of the feldspar. All the fragments are angular, and the predominant constituent is altered feldspar.

Andesite (?) from dike in North Canyon.-An igneous mass, about 100 yards long and 15 feet wide, known as Black Dike, appears on the west wall of North Canyon, below the Innis sawmill. It trends northwest. On a fresh surface the rock is dark gray, but weathering turns it to a light brown with a pitted appearance. The general appearance of the rock is sandy, with cleavage faces of some mineral apparently enclosing many grains of sand size. The secondary alteration products are carbonates, kaolinitic material, limonite, and quartz, and garnet occurs as a product of metamorphic recrystallization. The most striking feature of this rock is the appearance of a granular fragmental texture by reflected light under the microscope. This appearance, however, is deceptive, to judge from the mineral conposition, which is that of a contact-metamorphic zone. Dusty and apparently weathered carbonate material is intergrown with quartz that is almost equally dusty. The garnet crystals, being cracked and full of inclusions, do not stand out so distinctly as in most other rocks.

Trachyte from dike in North Canyon.-White Dike is a band of trachyte just below Black Dike on the west wall in North Canyon. It trends northwestward, is about 10 feet wide and crops out intermittently for a distance of about 600 feet. This rock is composed chiefly of feldspar with some calcite. The color on a fresh surface is dirty white to gray, from the feldspar, which is probably a soda-lime variety. The rock is even-textured, light, and easily broken. The feldspar is in irregular-shaped grains and is not clearly defined. This rock, whose original texture was massive, contains about 45 percent of phenocrysts. The primary essential minerals are orthoclase (?), a little sodic plagioclase, and possibly some perthite; the accessory minerals are titanite, hormblende, and apatite. Secondary alteration products are carbonates, quartz, and leucoxene. The small amount of ferromagnesian minerals is the most striking characteristic of the rocks, but there are 
indications of their former presence in greater abundance. Some areas of feldspar are still fresh, but other areas are dusted over with leucoxene and in polarized light show an aggregate of carbonates and feldspar, which are evidently secondary. The groundmass, though mostly very light colored feldspar, is peppered with leucoxene and earbonates as well as apatite. Probably there is some quartz in the rock.

Rhyolite from dike in North Canyon.-A dike of rhyolite on the west wall of North Canyon, near its head, trends northeast. It is several feet wide and extends for more than half a mile down the canyon.

This is a light-gray, fine-grained porphyritic rock of fragmental appearance, with large dark inclusions. It has medium sandlike grains, and the variation in size makes it impossible to draw a line between phenocrysts and groundmass. The primary essential minerals are medium-sized plagioclase, orthoclase, hornblende, and quartz, with titanite, magnetite, and apatite as accessory minerals. The alteration products are magnetite, quartz, and uralite. In a rock of megascopic porphyritic appearance it is surprising to find the mineral grains angular and probably fragmental. The grains range from 0.2 millimeter down to submicroscopic size. The hornblende is twinned and zoned and has partly altered to a fine-grained mineral aggregate. The cement or groundmass is very fine and siliceous, resembling the groundmass of an ordinary porphyritic rock, but is unusually variable in size of grain.

Hornstone in North Canyon.-On the west wall of North Canyon, just above Innis sawmill, an outcrop of banded hornstone is easily traceable for more than half a mile along the canyon wall. Its trend is northeast. The original rock was sedimentary with well-defined bedding, but it is now fragmental and very fine-grained, with grains averaging 0.04 millimeter in diameter. The bands range in color from light to dark green and in thickness from microscopic streaks to bands about 6 millimeters thick. The rock is hard and resistant to weathering. The only primary essential mineral is quartz, which makes up about 50 percent of the rock. The metamorphic recrystallization minerals are epidote, 15 percent; chalcedony, 20 percent; and hornblende and garnet in minor amounts. Epidote and quartz have also been introduced into the rock. This rock has undergone some recrystallization, but apparently the quartz retains an original fragmental condition, and the sedimentary bedding planes are clear. The thin section shows that epidote forms some distinct veins in addition to the grains intergrown with quartz. A definitely later quartz vein crosses all these minerals. The materials identified as garnet are minute colorless isotropic grains, well scattered apparently along certain beds.

Dacite dike on Abajo Peak.-Near the summit of Abajo Peak is a dike of light-gray, even-grained dacite
5 feet wide. Feldspar, quartz, and a ferromagnesian mineral, probably hornblende, are the chief constituents. Light-gray feldspar, probably soda-lime plagioclase, forms the main body of the rock, but it is impossible to make out the size or shape of the crystals. The quartz occurs as small rounded grains and is not abundant. The hornblende is lathlike in shape and is likewise not very plentiful. This rock is soft and of medium weight. Weathering penetrates far below the surface, producing irregular cavities that have a very dark-brown lining. Weathering reduces the rock by fairly rapid stages until it becomes almost as fine as powder. Many corroded phenocrysts, making up about 40 percent of the rock, lie in a fine-grained groundmass. These phenocrysts comprise large rounded and irregular-shaped quartz crystals with wavy extinction, very much altered feldspar, which is largely plagioclase, irregular masses and grains of magnetite, pyrite, and sericitic alteration masses after hornblende. The groundmass is made up of quartz, iron ore, sericite, orthoclase, and plagioclase in grains averaging about 0.02 millimeter in size.

Andesite dike on Abajo Peak.-Near the summit of Abajo Peak is a dike of andesite (locally known as "Black Dike"), 10 feet wide, that trends southeast. No traces of it could be found on either side of the ridge. It is a massive darh-colored rock that is extremely hard, is coarsely jointed, and resists weathering. The rock is composed of phenocrysts of feldspar in a dense fine-grained groundmass. The feldspar phenocrysts are nearly all of uniformly small size and nearly all oriented the same way. They are very prominent in contrast to the dark groundmass, which is made up of feldspar and a ferromagnesian mineral. About 50 percent of the rock is composed of fairly well formed phenocrysts, most of which are feldspar, chiefly plagioclase. The crystals are very large, and many of them show zonal structure. Other phenocrysts are quartz in rounded masses that are largely secondary, hornblende, magnetite, sparse grains of apatite, sericite in large amounts, and small grains of titanite. Secondary epidote, chlorite, and carbonates after hornblende are also present. The groundmass is very fine-grained, has a brownish color, and shows ghostlike poikilitic texture. It is composed of innumerable microscopic grains of magnetite, sericite, carbonate, quartz, and feldspar, averaging 0.01 millimeter in size.

Gold ore from Recapture Creek.-On the Log Cabin claim, at the head of Recapture Canyon, a specimen of gold ore was taken from the contact between the porphyry and the Dakota (?) sandstone. It is composed chiefly of brecciated rhyolite and porphyry. The rock is fragmental and has been much altered by hot solutions. The porphyry is very soft, brown, and traversed by minute fractures that have been filled with iron pyrites. The rock contains feldspar, nearly all of which has been largely altered to kaolinitic 
material and sericite and whose original character has been largely destroyed, though it was mostly plagioclase. A large amount of secondary magnetite is present, with carbonates. Quartz is found in medium amount in small interlocking pieces and in large angular or rounded fragments. Sericite (?) has filled the cracks in the feldspar.

Andesite from Innis mine.-The rock near the end of the long tunnel at the Innis mine, North Canyon, is a fine-grained medium- to light-gray andesitic porphyry with small well-formed phenocrysts that make up about 40 percent of the rock. The primary essential minerals are orthoclase (?), sodic plagioclase, and almost wholly altered hornblende; the accessory minerals are titanite, apatite, and quartz (?). Calcite, epjdote, chlorite, and iron ores are the alteration products. The groundmass is probably made up of orthoclase and quartz and is very fine-grained but with ghostlike areas about 0.05 millimeter in size, poikilitically enclosing smaller ones.

Another specimen from the Innis mine was collected at the extreme end of the long tunnel, where it penetrates not more than 2 feet into the andesite. This rock is composed of feldspar, hornblende, and some quartz. The feldspar is plentiful in phenocrysts of various sizes; the hornblende is chiefly in minute rounded grains or slender lathlike crystals. Quartz is very rare. The texture is porphyritic, the phenocrysts being enclosed in a fine dark-gray groundmass of the same composition. The phenocrysts make up about 45 percent of the rock and are rather irregular in form. The primary essential minerals are sodic plagioclase, hornblende, and quartz (?); the only accessory mineral is granular iron ore. Iron ore occurs also as an alteration product. The rock has an altered appearance on the whole but is very fresh. The groundmass is largely feldspathic, in grains mostly 0.01 millimeter in diameter but with some larger ones scattered through the rock.

A third specimen from the Innis mine was found in contact with the black andesite at the extreme end of the long tunnel. . This rock is a white porphyritic andesite with phenocrysts of quartz and a little hornblende that constitute about 50 percent of the whole. As the rock is light gray, the feldspar is not prominent. The primary essential minerals are sodic plagioclase, some orthoclase(?), and hornblende, which has been wholly altered. Iron oxide is the only accessory mineral. The alteration products are magnetite, kaolinitic material, quartz, and hematite. The groundmass has a fine texture and is mostly feldspar dusted with dark minerals and perhaps a little quartz in grains about 0.01 millimeter in diameter.
Metamorphic rock from Duckett mine.-At John Duckett's mine on Jackson Ridge, just east of Mount Linnaeus, a metamorphic rock covers an area of not more than an acre.

In general appearance this rock is fine-grained and black. Its texture is granular, and the original structure was probably fragmental. Under the microscope this metamorphic rock shows the recrystallization minerals garnet, quartz, calcite, amphibole, epidote, chlorite, and graphite or iron ore. The rock has a spotted appearance, and the coarse calcite and finer-grained quartz in smaller amount is peppered with garnet of a very dustlike granular habit. The garnet grains are so filled with birefracting inclusions and the calcite and quartz so full of inclusions of high relief that the distinctions are not everywhere clear.

Greenstone from Dream mine.-The east crosscut of the long tunnel of the Dream mine, near the head of Johnson Creek, has penetrated a few feet into greenstone. The hand specimen appears as an impure greenish sandstone, with a fragmental texture of angular grains in a fine matrix. There is an indication of bedding showing the original structure. The primary essential minerals are quartz, microcline, plagioclase, and orthoclase, with tourmaline as an accessory mineral. The secondary alteration product is leucoxene. Pyrite and hematite are introduced substances. The angular grains make up probably 85 percent of the rock, and the matrix 15 percent. Subangular to angular quartz constitutes about 90 percent of the grains. The cement is mostly chalcedonic or opaline silica, with some sericite.

Low-grade ore from Dream mine.-At the end of the Dream mine, near the head of Johnson Creek, a specimen of low-grade ore was collected in the tunnel that runs along a brecciated zone for about 10 feet. This rock is brecciated mineralized vein material, with some of the porphyritic wall rock. The original structure was porphyritic. The primary essential minerals are calcite, quartz, pyrite, and a black opaque mineral. Leucoxene occurs as an alteration product, and a quartz veinlet has been introduced. The thin section shows a coarse breccia, not readily interpreted. In one area the intergrowth is very fine-grained, mostly quartz, pyrite, and a black opaque mineral. This possibly represents a fragment of some sedimentary rock, now graphitic and mineralized. Another area is more like a mineralized porphyritic rock that includes large calcite and pyrite crystals in a silicified groundmass, but no indications of original minerals now remain unless the leucoxene is to be so taken. There are no clear signs of texture, but some calcite aggregates may be pseudomorphs after phenocrysts. 


\section{Chapter 4. STRUCTURE}

\section{REGIONAL RELATIONS}

The large-scale structural features that characterize the Colorado Plateau province are represented in the San Juan country by an upwarp like the Kaibab and the De Chelly, a downwarp like the Kaiparowits and the Tusayan, monoclinal folds like Echo Cliffs and the Waterpocket Fold, and a laccolithic mass like the Navajo, Henry, Carrizo, Ute, and La Sal Mountains. The synclines and anticlines present are but modifications of larger features, and the faults are short and of small displacement. There are no deep, sharply bounded synclines comparable to that which has preserved the coal beds at Gallup, N. Mex., and no master faults such as outline the Paunsaugunt and Markagunt Plateaus of Utah. The cones and lava felds of the Grand Canyon region and the volcanic necks of the Navajo country are likewise not represented.

Here as elsewhere in the plateau region the prominent folds have a general north-south trend and dip steeply eastward. They affect all the rocks exposedUpper Cretaceous down to Pennsylvanian-and so far as known date from a pre-Tertiary period of regional crustal movement. All the larger folds and many of the smaller ones cross the San Juan River, and published descriptions by Woodruff, ${ }^{50}$ Gregory, ${ }^{51}$ Miser, ${ }^{52}$ and Baker ${ }^{53}$ of structural features along and south of the river apply equally well to those north of it. In fact, the walls of the San Juan canyons present an excellent cross section of the warps and folds that have distorted the sedimentary rocks of southeastern Utah.

As no adequate base map was available, structural features were determined in the field by measurements of dips and by study of drainage patterns. The position, length, and height of anticlines and the depth and boundaries of synclines and downwarps shown in sections (pl. 1) are therefore only approximate. Detailed mapping undoubtedly will reveal many small anticlines, synclines, and faults not recognized in reconnaissance traverses.

\section{SAGE PLAIN DOWNWARP}

In a broad view the surface of Sage Plain seems to be almost flat in an east-west direction and to slope gently southward to the San Juan River, but measurements of

\footnotetext{
so Woodruff, E. G., Geology of the San Juan oil field, Utah: U. S. Geol. Survey Bull. 471, pp. 92-93, 1912.

si Gregory, H. E., Geology of the Navajo country, a reconnaissance of parts of Arizons, New Mexico, and Utah: U. S. Geol. Survey Prot. Paper 93, pp. 100-116, 1917. s2 Miser, H. D., Geologic structure of San Juan Canyon and adjacent country, Utah: Geol. Survey Bull. 751, pp. 131-140, 1924.

53 Baker, A. A. Preliminary map showing geologic structure of the Monument Valley-Navajo Mountain region, San Juan country, Utah, U. S. Geol. Survey, 1933; Geology of the Monument Valley-Navajo Mountain region, San Juan County, Utzh: U. S. Geol. Survey Bull. 865, pp. 63-75, 1936.
}

dips on the Dakota (?) sandstone, which generally floors the plain, indicate a shallow regional depression with a broad troughlike bottom about 10 miles northeast of Bluff, from which the strata slope upward toward the north, east, south, and west. Northward dips of $1^{\circ}$ to $2^{\circ}$ measure the inclination except where the strata are steeply upturned on the flanks of the Abajo Mountains; eastward dips that average less than $1^{\circ}$ extend beyond the Utah-Colorado border and at Ute Mountain steepen to more than $20^{\circ}$; southward dips of $1^{\circ}$ to $2^{\circ}$ increase to about $4^{\circ}$ beyond the San Juan River; westward dips of generally less than $2^{\circ}$ continue to Butler Wash and upper Cottonwood Wash, beyond which the strata bend steeply upward in Comb Ridge. Only the western border of this basin has been defined.

The regional slopes of the downwarp are interrupted by minor folds at Ucolo, on Boulder Creek, near the mouth of Recapture Creek, about 8 miles above the mouth of Montezuma Creek, and at the head of Brushy Basin. Local steepening of dips was observed at several places. The axis of most of these folds is parallel with the north-south strike of the rocks on which they are superposed, and the upbowing is insufficient to bring to view rocks below those in the canyon walls. But just below the mouth of Verdure Creek a fold that trends approximately northwest reveals Jurassic beds of a type not exposed in nearby canyons.

In the Sage Plain downwarp are preserved the Jurassic and Cretaceous strata which elsewhere in southeastern Utah have been stripped from the Navajo sandstone. The southern extension of the downwarp is the structural basin in the Navajo country mapped by Gregory as the Gothic Mesa syncline.

\section{MONUMENT UPWARP}

Among the structural features of the San Juan country the Monument upwarp ranks first in size and as a control in the development of topography. In the plateau province as a whole it is equaled in length, breadth, and height only by the Kaibab upwarp, and it resembles that great fold in that its surface features are plainly exposed and its interior is revealed by a canyon sunk deep into its southern slope. Beginning 30 miles south of the San Juan River with dips of $8^{\circ}$ to $20^{\circ}$, the axis of the Monument upwarp slopes gently upward to the top of Elk Ridge, 30 miles north of the river, then descends with steepened dips into Beef Basin and the valleys tributary to Indian Creek. Throughout its length the crest of the upwarp is poorly marked; over large areas the cap rocks lie nearly flat. The eastern flank is clearly marked by Comb Ridge, a 
monocline with dips exceeding $50^{\circ}$. The western flank is a region of plateaus and cliffs in which the strata, with dips of $1 / 2{ }^{\circ}$ to $2^{\circ}$, extend 30 to 50 miles to the Colorado River and continue beyond the river as features of the downwarp in which rest the sediments of the Kaiparowits Plateau. Erosion of the upwarp has brought into view strata of Pennsylvanian age (Hermosa formation) and succeeding beds up to the Dakota (?) sandstone. The youngest formation exposed on the western flank is the Carmel (?); on the crest, the Wingate sandstone; on the eastern flank, the Navajo sandstone in Comb Ridge and the Morrison in Butler Wash. The Wingate sandstone at the Bears Ears stands at an altitude of 9,040 feet, in Glen Canyon at 3,200 to 3,500 feet, and in Comb Wash at 4,200 to 4,400 feet. As thus outlined the Monument upwarp is about 110 miles long and 40 to 60 miles broad and represents a displacement of about 5,500 feet. However, its northern and western edges have not been defined, and the few measurements recorded are subject to revision.

Though in general the Monument upwarp is characterized by a broad, nearly flat top, gentle westward slope, steep eastward slope, and moderate slopes at its north and south ends, none of its slopes have a consistently uniform attitude. Locally on Grand Gulch Plateau dips of $1^{\circ}$ to $3^{\circ}$ flatten within short distances to horizontality or increase to as much as $5^{\circ}$, and on steeper slopes local changes in dip of as much as $10^{\circ}$ appear. Short low synclines and anticlines and elongated domelike uplifts appear at several places. Furthermore, toward the northeast and the southwest the regional inclination of slopes has been greatly modified by the in trusion of igneous rocks at the Abajo and Navajo Mountains. On the crest of the upwarp two low anticlines are present at Elk Ridge (fig. 2), and two strong anticlines in the Goodridge oil field. The broad west flank of the upwarp is irregularly corrugated by unevenly spaced synclinal, anticlinal, and monoclinal flexures, with axes roughly parallel to that of the main uplift. Most of them are gentle bowings revealed in the walls of White, Red, Moki, Castle, and San Juan Canyons, and though their extent and their relation to each other and to structural features outside the San Juan country are not known, they are thought of as local features. Two of the flexures-the Step, at the head of Lake Canyon, and the Rincon, on the Colorado River-are prominent features of the present topography. In lower White Canyon the regional westward dip of about $2^{\circ}$ changes gradually to $8^{\circ}$; the Moenkopi beds high on the canyon walls above Duckett form the base of the walls in Glen Canyon.

The following description of folds that modify the Monument upwarp is supplementary to those previously given in published reports by Woodruff, Gregory, and Miser.

Comb monocline.-The Comb monocline-the steeply downfolded eastern edge of the Monument upwarp- extends from Marsh Pass northward to the northeast base of Elk Ridge, a distance of more than 100 miles. (See pl. 16, B, C.) Near the San Juan River dips of $35^{\circ}$ to $60^{\circ}$ were measured; at the head of Comb Wash of $30^{\circ}$. Along upper Cottonwood Canyon, over the Causeway, and down Mormon Pasture Creek the dips decrease gradually from about $25^{\circ}$ to $12^{\circ}$. Everywhere the steep eastern dips change to dips of $1^{\circ}$ to $2^{\circ}$ within a distance of a mile; near the head of Butler Wash and at Notch Canyon sharply upfolded beds become nearly horizontal within 1,000 feet. For a distance of about 35 miles north of the San Juan River erosion has carved the monocline into the narrow cuestalike Comb Ridge, a barrier difficult to pass. Comb Wash has isolated the ridge from the main part of the Monument upwarp by carving a subsequent valley bordered on the west by regional dip slopes of the Cedar Mesa sandstone and on the east by precipitous cliffs as much as 1,000 feet high cut in the edges of Chinle, Wingate, and Navajo strata. A parallel subsequent stream, Butler Wash, that flows at the east base of the monocline has stripped away the higher beds and revealed the massive Navajo sandstone as a core rock that forms the crest and the eastern flank of the structure. North of Whiskers Creek the eastern slope of the monocline is generally exposed, but its top is not well defined. Cross sections of its structure are revealed in Hammond, Notch, and other canyons tributary to Cottonwood Canyon.

Raplee anticline.- The fold defined in published reports as the Raplee anticline is an elongated dome sharply bounded on the east and west by monoclines. Beginning near the mouth of Comb Wash, the beds of Rico limestone that form the cap rock of the anticline rise abruptly westward from beneath higher beds with dips of $15^{\circ}$ to $40^{\circ}$, flatten to less than $3^{\circ}$ across the crest, then bend sharply downward and disappear beneath beds of the Cutler formation in the Mexican Hat syncline. As a structural and topographic unit the anticline is 15 miles long and 4 to 6 miles wide and at Soda Basin stands 1,000 feet above its eastern and western edges. As mapped by Woodruff, its top is not a continuous structural ridge. Instrumental surveys show low anticlines with ends that overlap. In the intervening shallow synclines Sugar Loaf and other buttes, composed of strata younger than the Rico, have been preserved (pl. 16, D).

Mexican Hat syncline.-Parallel with the western base of the Raplee anticline and extending across the Mexican Hat loop of the San Juan River, strata of Rico and Cutler age lie in a shallow trough, with sides that slope upward at angles of about $4^{\circ}$. This trough, which has appropriately been named by Miser the Mexican Hat syncline, has been traced for about 18 miles. South of the San Juan River the syncline is occupied by the valley of Gypsum Creek; north of it by Lime Creek.

Mitten Butte anticline.-The Rico and younger beds that make up the western limb of the Mexican Hat 


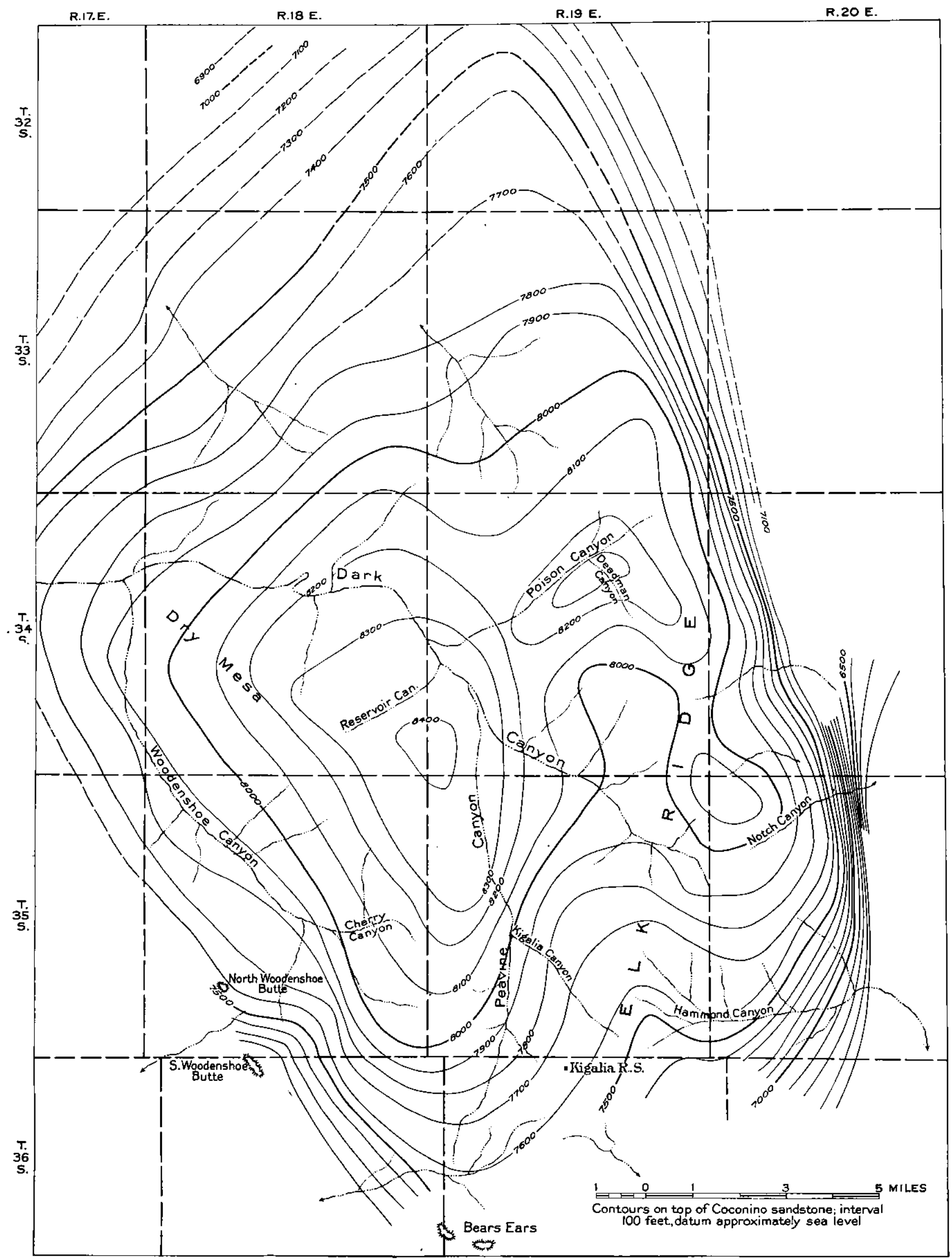

FigUre 2.-Strueture map of Elk Ridge. By Warren O. Thompson; courtesy of Midwest Oil Co. 
syncline continue their upward inclination but with decreasing dip until in the vicinity of Cedar Point they form the cap of an uplift in which beds dip about $1 / 20$ both east and west. This is the crest of the broad, high Mitten Butte anticline, in which the San Juan River has sunk itself 1,300 feet at the Honaker trail. South of the San Juan the anticline lies between Gypsum and Oljeto Creeks, and north of the river it extends beyond Grand Gulch. A few miles west of the summit the long western slope of the anticline has a regional dip of $2^{\circ}$ to $4^{\circ}$, then decreases to about $1^{\circ}$. Along the San Juan River the Mitten Butte anticline is essentially the summit of the Monument upwarp, but toward the north it seems to merge into other features and may be genetically related to the anticlines on Elk Ridge.

The Raplee ("East") and Mitten Butte ("West") anticlines and the Mexican Hat ("Lime Creek") syncline are the "oil structures" on which wells of the San Juan oil field have been located. The producing wells are in the Mexican Hat syncline west of its axis.

Oljeto syncline.-The Oljeto syncline, which in the Navajo country underlies the floor of Oljeto Valley, crosses the San Juan River and extends an unknown distance northward. The beds of sandstone that constitute its broad eastern flank and its narrow western flank slope upward at angles of $1^{\circ}$ to $4^{\circ}$ to the bordering Mitten Butte and Organ Rock anticlines, to which the syncline is roughly parallel.

Organ Rock anticline.-Miser describes the Organ Rock anticline as "a terracelike fold" that "trends N. $10^{\circ} \mathrm{E}$. from Organ Rock, crossing the San Juan River and apparently fading out in the vicinity of Clay Hill Pass." Where trenched by the San Juan Canyon the Cedar Mesa sandstone displayed in the fold lies flat on the crest, dips eastward to the floor of the Oljeto syncline at an angle of $3^{\circ}$ and westward for about 5 miles at angles of $1^{\circ}$ to $3 \frac{1 / 2}{2}$. North of the San Juan River the fold flattens but continues as a structural and topographic unit for about 3 miles, beyond which its features are not clearly recognizable. Along the western edge of Grand Gulch Plateau, on Grand Flat, also at Red House, Clay Hills, and other places in the wall of Red Rock Plateau the regional dip of strata involved in the Monument upwarp is interrupted by slight upbowings, some of which may prove to be closely related to flexures in the San Juan Canyon. The Organ Rock anticline is probably the northward continuation of the prominent structural feature mapped by Gregory ${ }^{54}$ as the Hoskinnini monocline.

Balanced Rock anticline.-From the head of Clay Hills Pass, where it stands at 6,000 feet, the Navajo sandstone slopes generally westward across Red Rock Plateau to the rim of Glen Canyon, at an altitude of 4,000 feet. Along upper Castle Wash, also near the Colorado River, the regional dip is modified by minor

\footnotetext{
st Gregory, H. E., o p. cit. (Prof. Paper 93), p. 114.
}

folding and at the head of Lake Canyon is sharply interrupted by a huge monocline in which the Navajo and underlying beds are bent steeply upward to a height of perhaps 800 feet. This fold, the Balanced Rock anticline, indicated by dip symbols on the map of the $\mathrm{Na}$ vajo country and later described by Miser, ${ }^{55}$ is represented in the topography along Nokai Creek and northward across the San Juan nearly to the Colorado River. In the wall of San Juan Canyon at Zahns Camp the fold has revealed a remarkable section of Permian, Triassic, and Jurassic rocks. As revealed in lower Castle Wash (Spring Gulch), Johnny Hole, and Lake Canyon, where the Navajo and Wingate sandstones have been deeply trenched and exposed here and there, the Chinle, the eastern flank of the fold, dips eastward $20^{\circ}$ to $25^{\circ}$ near the San Juan River; $30^{\circ}$ at the head of Johnny Hole Canyon, where the fold is highest and broadest; and $6^{\circ}$ at Hermit Lake, north of which dips as low as $2^{\circ}$ were measured. From a flat summit the western flank of the anticline, measured on strata of Carmel (?) age, at the top of Wilson Mesa dips $1^{\circ}$ to $2^{\circ}$. Near the San Juan River Miser recorded dips "ranging from $5^{\circ}$ to less than $10^{\circ} . "$ (See pl. 18, C.)

Paralleling the Balanced Rock anticline on the east a synclinal trough appears near the junction of Johnny Hole and Castle Wash and as an inconspicuous feature may be traced for several miles northward. Southeastward it extends across the San Juan River as the Spring syncline, described by Miser.

\section{OTHER FOLDS}

Numerous folds that stand as wrinkles on the broad west flank of the Monument upwarp are revealed in canyon walls and in cliffs that border mesas. In regularly bedded strata such folds are easy of recognition, but in the wide expanses of cross-bedded Navajo sandstone the determination of the position, extent, and curvature of small folds proved impracticable.

About 5 miles below the mouth of Piute Creek a symmetrical fold with dips of $8^{\circ}$ to $10^{\circ}$ on the east slope and $2^{\circ}$ to $5^{\circ}$ on the west slope crosses the San Juan Canyon and may be traced a few miles north. Parallel with it on the east is a syncline with dips of $1^{\circ}$ to $2^{\circ}$. The anticline was named by Miser the "Navajo Mountain anticline" and later by Baker the "Beaver anticline." The syncline was named by Miser the "Rapid syncline".

Wilson Mesa doubtless has a general synclinal structure. The strata upturned in the Balanced Rock anticline dip toward it from the east, those near the Great Bend of the San Juan dip slightly from the southeast, and those in the Rincon from the west and northwest. As most of the mesa is floored by the strongly cross-bedded, intricately dissected $\mathrm{Na}$ -

os Miser, H. D., op. cit. (Bull. 751), pp. 131-135. 
vajo sandstone, the axis, dimensions, and amount of displacement of the structure can be established only by instrumental surveys. If the structure of the mesa is of the regional type, the Beaver and Rincon anticlines may be genetically related and a syncline with northsouth axis lie east of the Rincon.

The Waterpocket Fold, an outstanding topographic and structural feature in the Kaiparowits region, crosses the Colorado and appears in the San Juan country as the Rincon. This canoelike end of the fold is recognizable for some 5 miles south of the river. Its maximum eastward dip is $6^{\circ}$; its western and southern dips, $1^{\circ}$ to $2^{\circ}$. Streams developed along the strike of the curved ends have cut a horseshoelike trough in Chinle beds surrounding an island of Navajo sandstone.

Moki Canyon is crossed by three low folds that trend approximately north-south, and near the trail into the canyon at Red Cone Spring the strata form a dome trending northeast with dips as high as $8^{\circ}$.

On Fish Creek a dome about 4 miles wide and 10 miles long consists of two low anticlines that trend about $\mathrm{N}$. $40^{\circ} \mathrm{W}$. and $\operatorname{dip} 1^{\circ}-3^{\circ} \mathrm{W}$. and $2^{\circ}-3^{\circ} \mathrm{E}$. An intervening shallow syncline has determined in part the position of drainage channels. The dome has been mapped as an "oil structure."

The floor of Arch Canyon is slightly upwarped in several places. One fold that brings into view fossiliferous limestone may be the northern continuation of the Fish Creek fold.

The crest of the Monument upwarp on Elk Ridge consists of two anticlinal flexures that as topographic features correspond to West Elk Ridge and East Elk Ridge. (See fig. 2.) The East Elk anticline is low and short and merges into the Comb monocline. The West Elk anticline, likewise low and inconspicuous, is an independent fold, the highest part of the Monument upwarp. From a high point near Reservoir Canyon its southward-sloping axis passes through the Bears Ears and probably could be traced some distance out onto Grand Gulch Plateau.

In White Canyon west of Duckett the Cedar Mesa sandstone is arched up in a broad, low fold through which the stream has cut a narrow, deep trench. About 6 miles above the mouth of White Canyon the regional westward dips of $1^{\circ}$ to $3^{\circ}$ change to $8^{\circ}$ and bring the Moenkopi beds down to the river's edge.

Along the south border of Beef Basin the Monument upwarp appears to terminate as a flattened dome with dips east, west, and north of about $2^{\circ}$. The north side of the basin is a low anticlinal fold with an axis trending northwest through Home Spring. Near the junction of Beef Basin and Fable Creeks a fold of unknown extent shows southwest dips as high as $20^{\circ}$. These folds have brought into view a large expanse of white sandstone, below which red beds and limestones are exposed in canyon walls and above which stand buttes capped by Shinarump conglomerate.

\section{FAULTS}

Small-scale fractures and faults are common in the San Juan country, but except in the Abajo Mountains faults with displacement sufficient to exert topographic control were not observed. Most of the faults lie along folds where changes in dip are greatest. Near the mouth of Verdure Creek a fault with a downthrow of 70 feet on the south trends N. $70^{\circ}$ W. across Montezuma Canyon, and 20 miles to the south another fault crosses the canyon. In the walls of San Juan Canyon several faults were mapped by Miser, one of them with a throw of 60 feet. Short faults with displacements of 1 to 3 feet break the strata in canyons on Red Rock and Grand Gulch Plateaus, in the Comb monocline, and at the head of Beef Basin. Along White Canyon below Duckett faults are associated with wide joint cracks now filled with yellow sandstone. The three parallel faults at the Hole in the Rock, one of which crosses Glen Canyon, are discussed by Miser. ${ }^{56}$

\section{STRUCTURE OF THE ABAJO MOUNTAINS}

By Malcolm R. Thorpe

\section{GENERAL FEATURES}

Newberry ${ }^{57}$ recognized the core of the Abajo Mountains as an intrusive mass which made its way upward, perhaps to the surface, through Mesozoic and probably also Paleozoic strata, and said that the Cretaceous strata on the mountain flanks are "apparently the remnants of a plateau corresponding to, and once connected with, the Mesa Verde."

Holmes ${ }^{58}$ clearly expressed the view that the Abajo Mountain system was formed by intrusion and that Cretaceous beds formerly covered the igneous rock. As part of a comprehensive geologic study of the Abajo Mountains the writer recorded and discussed the structural features in detail. ${ }^{59}$ From a manuscript that served as a source for this published paper most of the following descriptions have been compiled. (See also pl. 17.)

The Abajo Mountains owe their existence to intrusions of magma into sedimentary beds of Jurassic and Cretaceous age in such manner as to produce a group of laccoliths. The main features of laccolithic bodies are well represented: the ground plan is roughly circular; the superincumbent strata have been lifted by doming instead of by faulting; the rock is porphyritic in texture and regardless of locality shows remarkable uniformity in composition; features of extrusives are absent; dikes, sills, and sheets associated with the large igneous masses

ss Miser, H. D., Geologic structure of San Juan Canyon, Utah: U. S. Geol. Survey Bull. 751, pp. 139-140, 1924.

"7 Newberry, J. S., Geological report, in Report of the exploring expedition Irom Santa Fe, N. Mex., to the Junction of the Grand and Green Rivers of the great Colo. rado of the West in 1859, p. 100 , Washington, 1876.

${ }^{8}$ Holmes, W. H., Report on the geology of the Sierra Abajo: U. S. Geol. snd Geog. Survey Terr. 10th Ann. Rept., for 1876, pp. 191-192, 1878.

${ }^{60}$ Thorpe, M. R., Structural features of the Abajo Mountains, Utah: Am. Jour. Sei., 4th ser., vol. 48, pp. 379-389, 1919. 
are in crosscutting relations with the sediments; at both the lower and the upper contacts with the igneous rock the sediments are metamorphosed. The structure, however, is not simple. The laccoliths composing the mountains differ in both horizontal and vertical position. Part of the floor of a laccolith is the uneven roof of the one next below. The original cover of the individual laccoliths has been unequally removed.

The cover of Shay Mountain remains intact except for a small dike or plug that rises from the igneous mass beneath. At North Peak more than half of the cover has been removed; at the other laccoliths one-third to one-half. The remnants of the former roof consist of Morrison, Dakota (?), and Mancos strata. Mesaverde, now absent, probably was once present. Measured from the top of the Mancos the depth of original cover over Shay Mountain is about 2,750 feet; over Mount Linnaeus, Abajo Peak, and South Peak, 1,500 feet; and over Horsehead, Twin, and North Peaks, 1,200 feet.

In the roofs of the laccoliths metamorphism has affected the sediments for distances of 10 to 200 feet from the contact. Sandstones have been changed to quartzites and shales to argillites, without, however, changing their structure or content except for slight mineralization. (See p. 91.) The metamorphosed sediments resist erosion, and their edges stand as ridges and revetment crags. The igneous mass is little changed by contact with the sediments.

No evidences of stoping or assimilation were observed in the Abajo Mountains, and it seems almost certain that the mountains owe their existence to injection in which the magma was aggressive and forced up the overlying strata in order to form a chamber for itself.

\section{LOCAL FEATURES}

Shay Mountain is essentially a dome of sedimentary rock. Dakota (?) sandstone forms the top of the mountain; Morrison and Glen Canyon strata are exposed in canyons on its flanks. The dip on the east side of the dome is $12^{\circ}$, on the south $5^{\circ}$, on the west $9^{\circ}$, and on the north $15^{\circ}$, with a gradual flattening out to $5^{\circ}$. At the crest of the mountain is a plug or dike of blue porphyry about 110 square yards in area which has broken through the roof of the laccolithic chamber. As all the strata from Glen Canyon to Dakota (?) have been involved in the doming of the uplift, it is reasonable to suppose that the igneous material spread out in the Chinle formation. A synclinal ridge, whose axis trends east-west and pitches west, joins Shay Mountain and Mount Linnaeus. The Dakota (?) sandstone that caps the ridge forms dip slopes on the south side of Shay Mountain and on the north slope of Mount Linnaeus.

Mount Linnaeus is a partly uncovered laccolith. Dakota (?) sandstone overlaps its northeast side; Morrison sandstones and shales the other sides. These strata, if projected in accordance with their dips, would form the cover of the laccolith. The horizon of intrusion of the magma is most probably the middle Morrison except on the northeast, where the magma broke through to the base of the Dakota (?) sandstone. Patches of the roof rock are present in several places and at different altitudes on the mountain. On Duckett Ridge three isolated patches of Dakota (?) sandstone, metamorphosed to quartzite, have been floated up to an altitude of more than 10,250 feet, and at the south end of this ridge, above 10,000 feet, is a large patch of red Morrison shales that $\operatorname{dip} 20^{\circ} \mathrm{N}$. A small unmetamorphosed patch of Mancos shale overlies Dakota (?) sandstone on the west side of Dry Wash at an altitude of 9,500 feet. The north side of the ridge that forms the west end of Jackson Divide is formed of Dakota (?) sandstone with a dip of $15^{\circ} \mathrm{N}$; the south side is almost entirely made of fine porphyry talus with no indications of sedimentary strata.

The area including Abajo Peak, South Peak, and the east end of Jackson Divide is stmucturally like the south and west sides of Mount Linnaeus. Dakota (?) and upper Morrison beds so thoroughly flank the mountain sides that igneous rock is well exposed only near the summits. On the south and east sides the Dakota (?) slopes up with a gentle but constantly increasing dip until it reaches well up the flanks. In this area the Dakota (?) and Morrison shales unquestionably formed the cover at the time of intrusion. Southwest of South Peak the intrusive rock is exposed between strata of the Morrison formation. On the east side of Abajo Peak at an altitude of more than 11,000 feet the Dakota (?) sandstone is changed to a quartzite that contains numerous vugs filled with a fine mesh of quartz crystals of all sizes. Beneath the Dakota (?) lie the metamorphosed Morrison strata. At the base of the principal eastern spur, where Holmes' party encamped in the fall of 1876 , there is a double row of revetment crags, formed of Dakota (?) and Morrison strata that dip as much as $45^{\circ}$.

In the area that includes Horsehead Peak, North Peak, and Twin Peaks the magma was intruded at or near the base of the Mancos shale-a higher horizon than elsewhere in the Abajo Mountains. Only on the east slope of Horsehead Peak does the Dakota (?) overlap the igneous body. A large mass of highly metamorphosed Mancos shale forms the divide between the head of Indian Creek and North Creek. Isolated patches of the same material appear on top of North Peak and in other places at altitudes of more than 11,000 feet. Fossils in these argillites were identified by T. W. Stanton as middle Mancos-an indication that the igneous mass was intruded at or near the base of the Mancos, as local contact metamorphism would hardly extend through several hundred feet of strata. On the summit of North Peak these strata forming blocks of tilted and folded argillite dip southwest and 


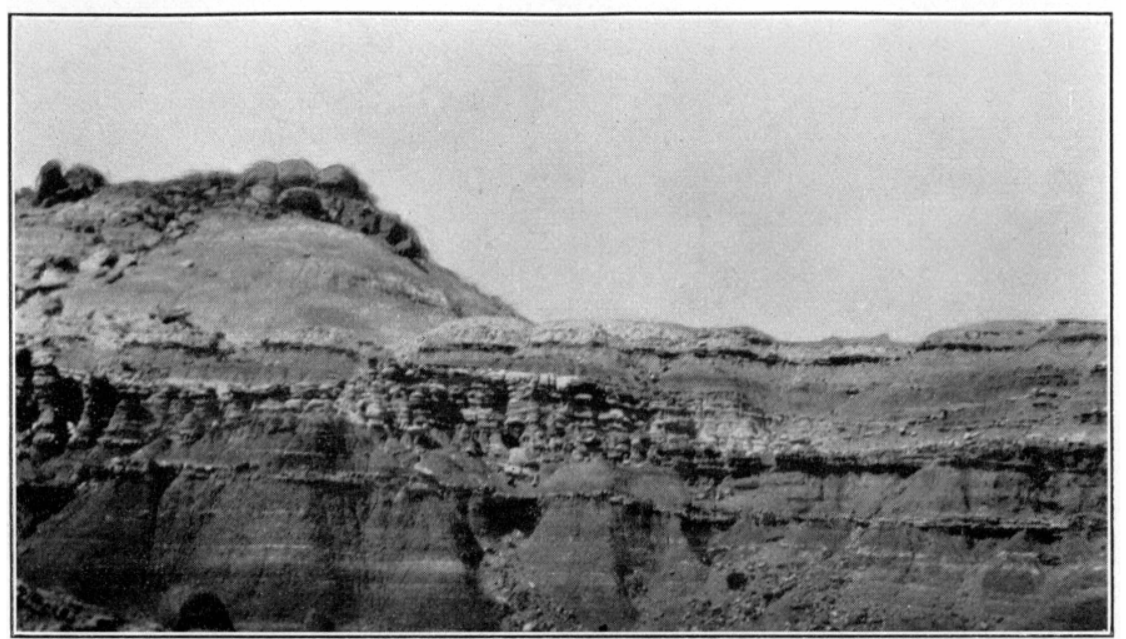

A. VIEW ON RECAPTURE CREEK.

Undifferentiated Morrison formation.

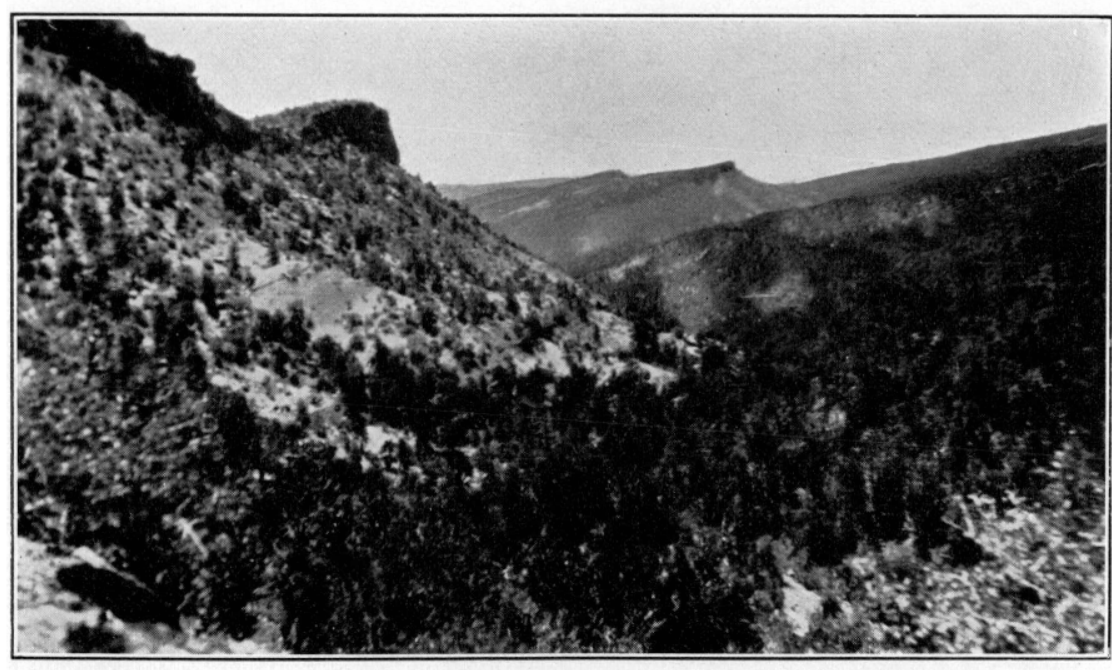

C. EASTERN FLANK OF MONUMENT UPWARP ON BLANDING-KIGALIA ROAD. View looking south. Chinle capped by Wingate at center and left and in center distance. Forest-
covered Shinarump sloping upward to Elk Ridge at right.

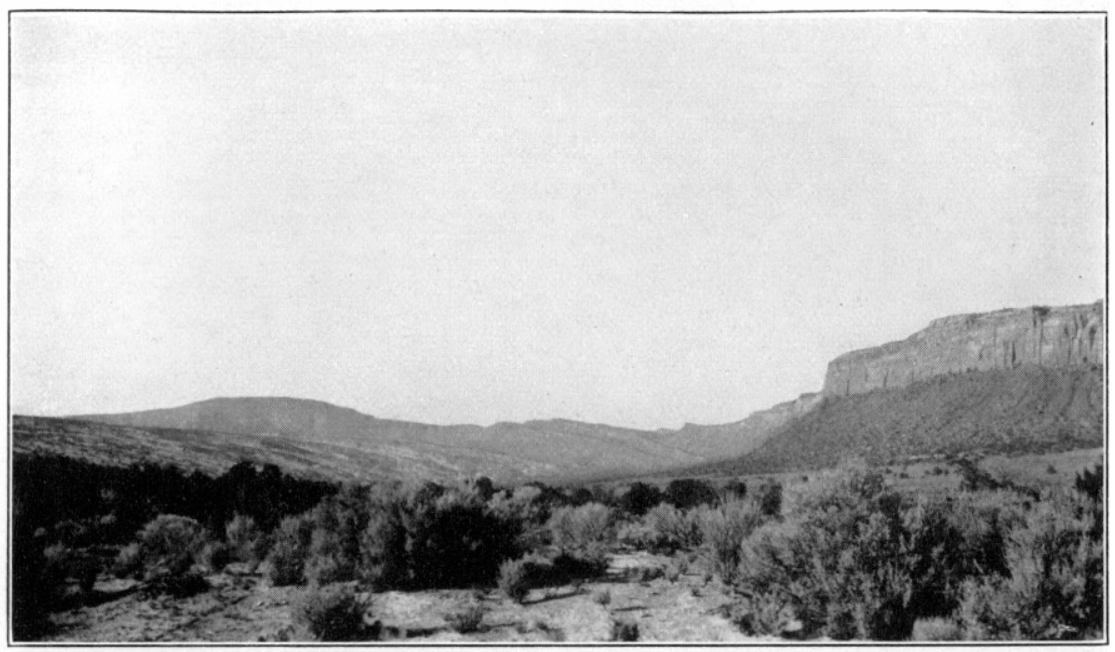

B. COMB WASII AT MOITII OF ARCII CANYON

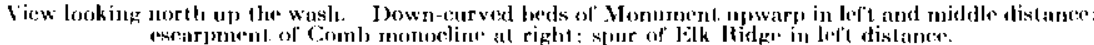

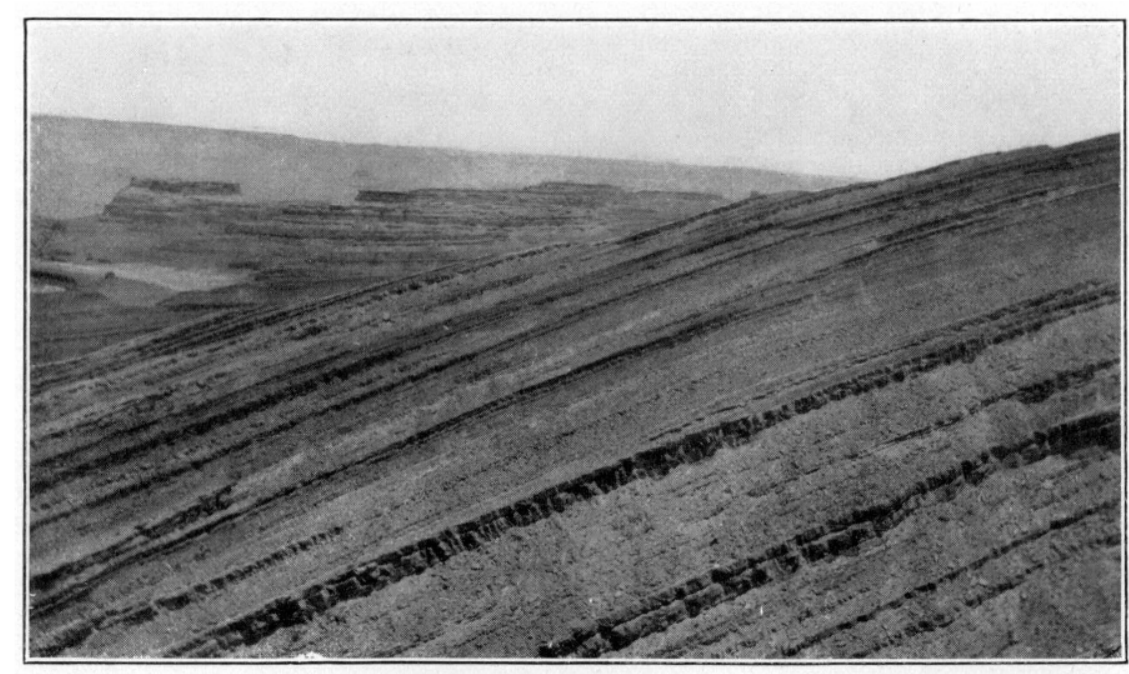

D. WEST FLANK OF RAPLEE ANTICLINE AT MEXICAN HAT.

View looking north across Lime Creek Valley toward Cedar Mesa. Rico strata in foreground. Hal-
gaito in middle distance. Photograph by E. G. Woodruff. 




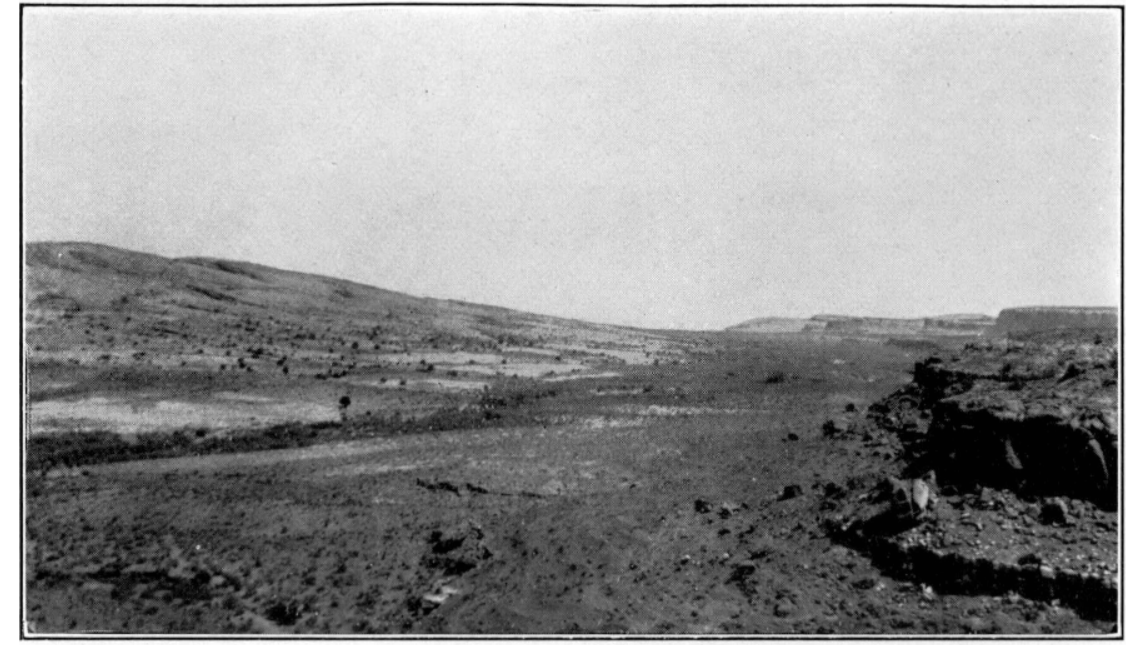

A. VALLEY OF BUTLER CREEK.

View looking north. Subsequent valley developed on the back slope of Comb monocline. Stream ocupies narrow canyon cut into the floor. Navajo sandstone overrain by formations of the San
Rafael group. Bluff sandstone member of Morrison formation in right distance.

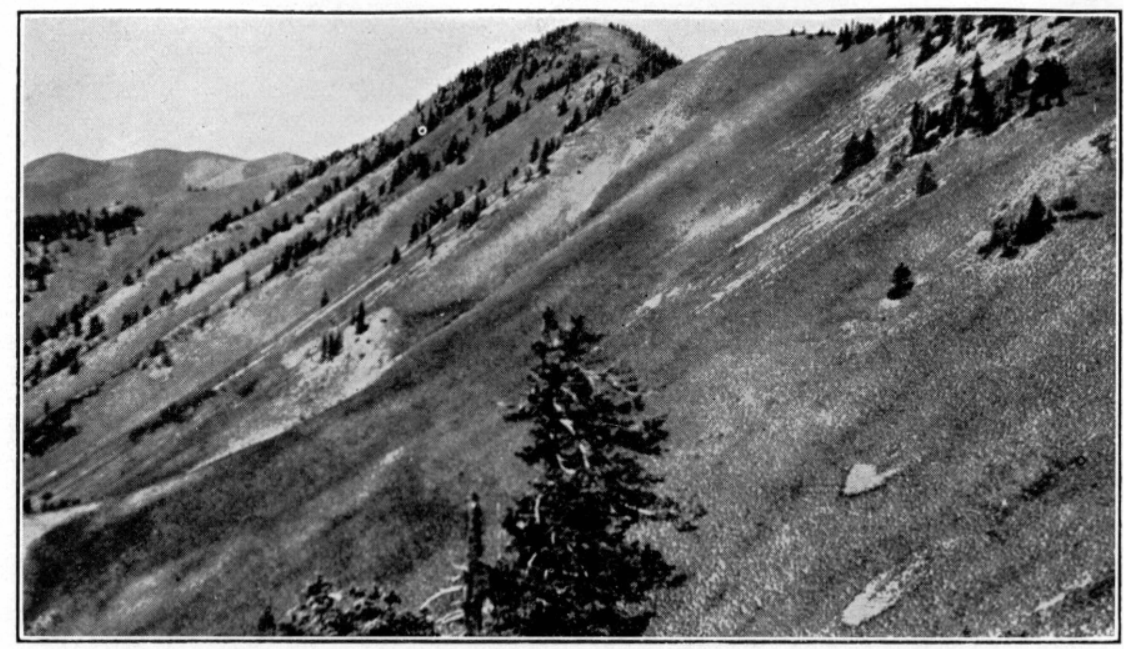

B. TALUS SLOPE ON IGNEOUS ROCK IN ABAJO MOUNTAINS. Photograph by M. R. Thorpe

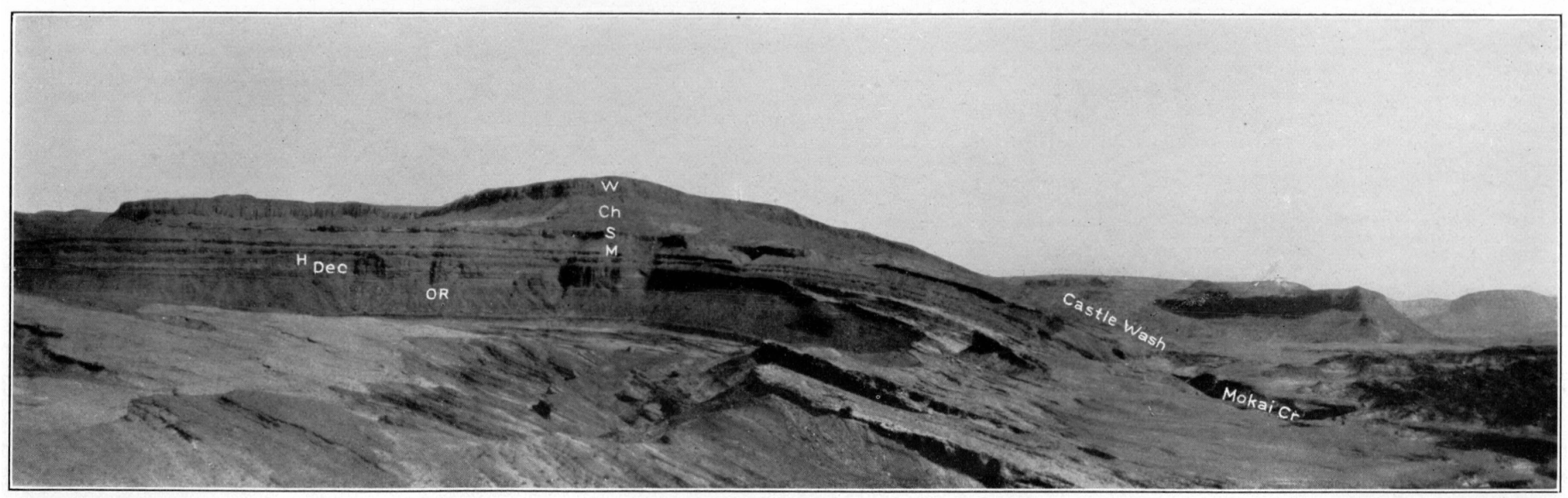

C. BAIANCED ROCK ANTICLINE. View looking north across the San Juan River, here deeply entrenched. Castle Wush at foot of dip slope. Organ Rock member (OR) in canyon wall ant above it, in turn, De Chelly (DeC), Hoskinini (II),
Moankopi (M), Shinarump (S), Chinle, (Ch), and Wingate (W) strata. Photograph hy J. B. Rerside, Jr. 

northeast at an angle of $5^{\circ}$. On the east side of the saddle between Harts Draw and the head of Indian Creek (altitude 10,350 feet) the shale dips S. $27^{\circ} \mathrm{W}$. At the head of Indian Creek (altitude 10,600 feet) the dip is S. $24^{\circ} \mathrm{W}$. At the head of North Canyon the dip is $\mathrm{N} .30^{\circ} \mathrm{W}$. In North Canyon, where the shale is in contact with blue porphyry, the igneous rock encloses fragments of argillite. At the head of Harts Draw the Mancos shale is in contact with a dike of igneous rock that extends northeast from the eastern peak of Twin Peaks and ends at an altitude of 9,800 feet. In the dugway that leads up to Innis' sawmill about 10 feet of highly metamorphosed shale is enclosed in the blue porphyry. In a butte near the dugway, where the contact between the roof and the intrusion is displayed, the Dakota (?) within a few feet of the contact dips at an angle of $80^{\circ}$ away from the igneous body. At a distance of about 200 feet it flattens out to $16^{\circ}$ and then gradually decreases still more. In the Twin Peak-Horsehead Peak region the Dakota (?) sandstone is apparently the floor of the laccolith except on the east side, where the magma, instead of breaking through the sandstone, arched it up.

Between Recapture Creek and Johnson Creek, south of Jackson Divide, is a large sheet of dacite, an offshoot of the major intrusions. Its roof is represented by many isolated patches of Dakota(?) sandstone and some beds of Morrison shale (not shown on the map). The upper surface of this sheet was originally somewhat uneven, and, now that the roof is removed, shallow water-filled depressions are left. On the eastern edge of this sheet Dakota (?) sandstone dips $16^{\circ} \mathrm{S}$. and strikes east. The east half of the floor of the sheet is within the Morrison formation, but the west half lies at a deeper horizon. Intrusion has produced faulting along the western margin.

Few faults are associated with the laccoliths in the Abajo area. None of them are shown on the map (pl. 17). The most conspicuous fault, that at the base of South Peak, trends nearly north and has a throw of about 500 feet. Its steep western escarpment is the eastern wall of Recapture Canyon. This fault is crossed at right angles by another fault with a southward-facing escarpment that attains its greatest height at its west end. The two faults combined form a block whose surface dips $12^{\circ} \mathrm{E}$. until it merges with the regional dip of $3^{\circ} \mathrm{E}$. At many places on the mountains marginal faulting has broken off strata and carried them to the mountain summits or high on their flanks. In Pole Creek faulting has left about 500 feet of Morrison and Dakota (?) strata far above their normal horizon. On the west side of North Canyon, above Innis' sawmill, many slickensides were observed, and at the Copper Queen mine large blocks of slickensided Dakota (?) sandstone have been blasted out. The sheet of dacite between Johnson and Recapture Canyons is bounded on the west side by an intrusion fault which has brought the Dakota (?) and the Morrison in touch with the igneous rock along a well-defined contact. On the eastern border of this dacite sheet upturned strata of Navajo, Morrison, and Dakota (?) formations dip $38^{\circ}$ to $75^{\circ} \mathrm{E}$. Faulting and the tilting of strata about the igneous intrusives have determined the location of the headwater tributaries of Montezuma, Recapture, and other streams draining the east and south sides of the Abajo Mountains. Indian Creek between Shay Mountain and North Peak follows a line of structural weakness. 


\section{Chapter 5. PHYSIOGRAPHY}

\section{REGIONAL RELATIONS}

The physiography of the San Juan country is closely related to that of the adjoining Navajo country, the Kaiparowits region, and the wide belt of plateau lands north and south of the Grand Canyon. The stratigraphic series in which the topographic features are developed, the kind and date of diastrophic movements, and the time of igneous intrusion correspond in general with those for the Colorado Plateaus as a whole. Likewise the topographic features are similar in form and have in general the same history. Outstanding differences are the absence of faults of large displacement; the absence of Tertiary sedimentary rocks, which probably once extended across southern Utah; and the fact that beds of Jurassic age occupy the highest altitudes, and the Cretaceous strata, which beyond Glen Canyon and the San Juan form lofty mesas, lie at relatively low altitudes.

The physiographic history of the Colorado Plateaus is essentially one of post-Eocene erosion, conditioned by climate, altitude, and tectonic deformations. The present topography measures the progress of adjustment of drajnage to structure and to rock hardness.

As it appears today the plateau country is a region of plateaus, mesas, cliffs, and canyons. Except for such laccolithic masses as the Abajo, Carrizo, Navajo, and Henry Mountains and the volcanic San Francisco and Uinkaret Mountains, the highlands are flat or slightly inclined tables, benches, and steps bordered by precipitous cliffs; and the streamways are high-walled, flat-bottomed trenches. In distant views the plateau surfaces are conspicuous. Long stretches of sky line seem nearly horizontal, and platforms at different levels seem interrupted only by scattered buttes and mesas that rise above their surfaces. The canyons are lost in the general levelness. Unlike the graceful outlines of mountains and valleys in humid climates, the landscape is bold and rugged; curves are replaced by angles. In further contrast the protecting cover of vegetation is largely lacking; the dominant grays and greens of humid regions give way to whites, reds, and brownsthe colors of the rocks themselves.

In the development of the characteristic topography the stripping and recession of cliffs are major processes. The dominant stripping of weak formations from resistant formations has produced many surfaces that are essentially residuals of widespread postmature erosion surfaces. But unlike old-age surfaces developed under humid conditions, those produced by stripping tend to be flats in soft rocks and slopes that conform in steep- ness with the dip of the strata in hard rocks. Cliffs, as they weather back, maintain steep profiles; they are not transformed into slopes that decrease in declivity with age. The mural aspect of much of the plateau scenery is due to the fact that cliffs once formed retain the appearance of topographic youth until the canyons and mesas which they bound are entirely destroyed.

The topography of the plateau province is obviously not the work of a single cycle. Superimposed drainage, discordant profiles, and the juxtaposition of old-age and youthful surfaces indicate periods in physiographic history when dominant aggradation was replaced by degradation, uplifts by still-stands, and humid by arid climates. To reconstruct the successive events involves the interpretation of such outstanding features as postmature topography of plateau tops, truncated folds in Cretaceous and older beds, graded platforms adjoining deep canyons, entrenched meanders, incipient peneplains, gravel-floored rock terraces, canyon fill, and alluvial terraces. As discussed more fully elsewhere, ${ }^{80}$ these heterogeneous elements in the present topography serve to outline a series of long and short erosion cycles during each of which distinctive landscapes were developed. The oldest cycle of which there is clear evidence-the pre-canyon cycle-began with a postEocene uplift, which raised widespread, low-lying Tertiary limestones nearly to the height of the present plateaus. The slopes and inequalities of this newly made high-level surface are believed to have determined the position and gradients of the ancestral Colorado, the San Juan, and their oldest tributaries. The Paunsaugunt, Kaiparowits, and Chuska Plateaus and other scattered remnants of this broad expanse of early Tertiary sedimentary beds in Utah and Arizona show the maturely dissected slopes that characterize an advanced stage of denudation.

During the long pre-canyon cycle of erosion all the Tertiary sedimentary rocks, most of the Cretaceous, large parts of the Jurassic and Triassic, and some of the Permian of southeastern Utah were stripped away. As the gradients of the ancient Colorado and its tributaries were reduced to a gentle slope, meanders developed and topographic inequalities were subdued.

${ }^{6}$ Dutton, C. E., Tertiary history of the Grand Canyon district: U. S. Geol. Survey Mon. 2, pp. 206-229, 1882. Davis, W. M., An excursion to the Grand Canyon of the Colorado: Harvard Coll. Mus. Comp. Zoology Bull., vol. 38, pp. 118-121, 167-169, 1901. Gregory, H. E., Geology of the Navajo country: U. S. Geol. Survey Prof. Paper 93, pp. 122-123, 130-132, 1917. Gregory, H. E., and Moore, R. C., The Kaiparowits region: U. S. Geol. Survey Prof. Paper 164, pp. 138, 139, 143-144, 1931. Gregory, H. E., Colorado plateau region: 16th Internat. Geol. Cong. Guidebook 18, 1932. Robinson, H. H., The Tertiary peneplain in the plateau district and adjacent country in Arizona and New Mexico: Am. Jour. Sci., 4th ser., vol. 24, pp. 115-118, 1907. 
Much of the country, in particular the strips along the main drainage channels, was reduced to a plain where the valleys were shallow and the hills conspicuous. That parts of this old surface stood on a level so uniform that the streams lacked the power to entrench themselves deeply is shown by erosion surfaces that extend without significant inequalities across hard and soft rocks and across faults and folds. At such widely spaced areas as Hopi Buttes, in the Navajo country; Black Point, in Little Colorado Valley; Echo Cliffs, east of the Marble Gorge; and Mount Trumbull and Hurricane Cliffs, in northwestern Arizona, fragmentary peneplains are preserved beneath lavas. Similar flat lands, likewise developed with little regard to rock composition or structure, are characteristic of interstream areas along Glen Canyon, in Paria Valley, and generally about the base of the High Plateaus. In sharp contrast with the present youthful topography, these representatives of a former surface retain the features of a mature or even postmature landscape on which drainage was fully developed. A study of these remnant landscapes leads to the belief that they are essentially local features; no amount of reasonable interpretation can regard them as parts of a regional peneplain on which drainage had reached baselevel. Throughout the pre-canyon cycle the old-age surfaces along the larger streams terminated at the base of cliffs whose tops also had reached old age. There is thus presented an unusual topographic complex-two immediately adjoining regions, one 2,000 to 5,000 feet higher than the other and both characterized by an advanced stage of denudation.

The extension and full development of the erosion surfaces produced during the pre-canyon cycle were inhibited by a regional uplift that initiated the canyon cycle (the present major cycle) of erosion. The physiographic evidence for this uplift is the readjustment of drainage by shifting of divides, the stripping of talus and accumulated alluvium from cliff faces and lowlands, and the cutting of deep, narrow, verticalwalled canyons with ungraded floors. It seems evident that the position and habit of the streams, now so completely out of accord with the structure, were established at a time when the structure had not been revealed by erosion, and that the enclosed meanders of the Colorado. the Virgin, the San Juan, the Kanab, and many smaller streams mark courses inherited from the pre-canyon cycle.

The evidence for the uplift that introduced the canyon cycle is conclusive. The erosion surfaces produced during the pre-canyon cycle have been deeply and intricately dissected. Steepened gradients have enabled the streams to convert their former shallow valleys into profound gorges and to dig hundreds of new trenches, thus substantially remodeling the topography, The present meandering streamways are trenches cut in a former graded surface from which to a large degree their alinement and pattern have been inherited. Widely distributed peneplain remnants afford supplementary evidence. In fact, most of the features that make the Colorado canyons an outstanding illustration of stream work belong to the canyon cycle.

The pre-canyon and canyon cycles of erosion as outlined mark undefined stretches of time during which conditions were generally favorable for the destruction of high-lying land. The tectonic movements and the climatic conditions that initiated the cycles and prevailed throughout their courses are imperfectly known. Likewise the dates of uplift, of still-stands, and of changes in conditions of sedimentation and erosion can be assigned with only rough approximation. It seems improbable that the stages of topographic development were contemporaneous or uniform over the entire plateau province.

For the pre-canyon cycle no subdivisions have been recognized. Existing maps are inadequate for the correlation of small-scale topographic features. Even with much fuller knowledge of form and position, differences in altitude of the remnant erosion surfaces and in the extent to which inequalities of hard and soft rocks were in different places obliterated would greatly hinder if not prevent satisfactory definition. However, there is no reason to believe that the first uplift was accomplished all at one time, that once started it continued at a uniform rate, or that the same climate prevailed throughout.

For the canyon cycle the subdivisions are more readily established. Throughout this cycle erosion, though dominant, has not been continuous. The intermittency of down-cutting is clearly in evidence. The ungraded floors of all the canyons and the discordance in longitudinal profile between the side canyons and the master canyons indicate rather recent rejuvenation. On the other hand, rock-cut, gravelfloored terraces at different levels on the canyon walls mark periods when normal vigorous erosion changed to deposition. The relative lengths of the pauses in downward erosion are indicated roughly by the extent and evenness of the eroded surfaces and the thickness and texture of the covering gravel, also by the depth and distribution of canyon fill. The canyon cycle includes at least two epicycles-the inner-canyon epicycle, during which a pause in dominant down-cutting provided conditions favorable for aggradation, and the terrace epicycle, marked by a renewal of vigorous erosion and consequent development of alluvial terraces. During the inner-canyon epicycle many canyons were so completely filled with alluvium that their uneven rock bottoms were converted into relatively smooth gravel floors at a higher level. The existing remnants of these floors along the large streamways are at grade with those in side canyons and thus represent a surface of wide extent. In contrast with the body of the gravel deposits, their tops are much weathered, and 
here and there silt-filled channels and lacustrine sediments mark the course of slow-moving winding streams that flowed in and out of ponds. This evidence that the gravel floor, once completed, remained intact for a considerable period is reinforced by the appearance of the canyon walls-weathered rock above the gravel surface and fresh rock below. The inner-canyon epicycle was followed by the terrace epicycle. Aggradation gave place to erosion, which is still in vigorous progress. The inner-canyon gravel floors have been generally dissected into terraces that border the present streams; in places the canyon fill has been entirely removed, and the streams are once more running on rock. (See pp. 101-102.)

\section{AGE OF THE TOPOGRAPHIC FEATURES}

The topographic features in the plateau province have been developed in post-Eocene time, but the length of the cycles and epicycles of erosion has been determined only with wide approximation. Dutton dated the pre-canyon cycle as Miocene and Pliocene. In his view the "great erosion" ${ }^{11}$ of the plateau was most probably accomplished in Miocene time but continued with diminished rapidity throughout the Pliocene; the erosive work of the Pliocene ended with the production of the "outer" rim of the Grand Canyon and corresponding features along other streams. In the light of present knowledge it seems reasonable to assign most of the work of the canyon cycle to late Quaternary time.

Blackwelder ${ }^{62}$ has recently expressed the extreme view that no intergraded drainage system existed in the plateau province in Miocene or Pliocene time and that the Colorado "may actually be a young river that did not exist until about the beginning of the Pleistocene period."

The inner-canyon and terrace epochs of the canyon cycle are assigned to late Pleistocene and Recent time, with the possibility that the formation and partial destruction of some gravel terraces mark stages of waning glaciation.

The events of the inner-canyon and terrace epicycles may be ascribed to changes of climate that for long periods profoundly affected the rate and manner of weathering and corrasion. In the absence of contradictory evidence it seems equally reasonable to explain the periods of alternating degradation and aggradation as evidence of tectonic movements and to class them as the latest in the series of uplifts and still-stands which, since the beginning of the pre-canyon cycle, have controlled the development of plateau topography.

\footnotetext{
o1 Dutton, C. E., Report on the geology of the High Platesus, p. 21, U. 8. Geog. and Geol. Survey Rocky Mtn. Region, 1880.

6a Blackwelder, Eliot, Origin of the Colorado River: Geol. Soc. America Bull. vol. 45, pp. $551-565,1934$.
}

\section{FACTORS THAT INFLUENCE EROSION} CIIMATE AND RUN-OFF

The climate of the San Juan country is "spotted." Though the region as a whole is arid, rainfall and temperature vary widely in time and with respect to topographic position. The mean annual rainfall at three valley stations is 7.37 inches, including years with less than 4 inches. The average for two plateau stations is 16.15 inches, for the driest year 8.90 inches, for the wettest year 23.44 inches. The Abajo Mountains and Elk Ridge probably receive in most years as much as 20 inches of combined rain and snow. At all stations the range in amount received each month is extreme. The intermittent supply of rain is insufficient to keep the streams going throughout their courses. Even if the rainfall were evenly distributed the average flow would be small and might be largely counterbalanced by evaporation during the dry, hot days of summer. As regards erosion the most significant feature of the rainfall is the violence of showers. Most rains are short-lived, widely spaced, torrential downpours. The precipitation for a month or even two months may be the result of a single storm that lasts only half an hour and covers only a few square miles. (See p. 15.)

In this region, where bare rock is more widespread than soil and vegetation, most of the precipitation is represented in the run-off. The falling rain gathers at once into gullies and flows swiftly to larger drainage channels. Where gullies are lacking it flows as a sheet of water that temporarily comes to rest in some local depression or continues to a canyon rim, over which it plunges as a sheet waterfall. During their short, vigorous lives these ephemeral streams sweep from the surface wind-blown sand, disintegrated rock, and stray bits of vegetation and carry them to nearby canyons. In the canyons themselves streams of muddy water quickly form and, as more and more side gullies make contributions, increase to turbulent floods. In narrow canyons, dry for a month or more, the water of a newly made, swift-flowing stream may reach a height of 10 feet or more within an hour and disappear in another hour. Some of these flood streams, particularly those flowing on bedrocks, eventually join their master streams, but many of them lose their water within a few miles by sinking into the porous gravel of the canyon floor.

In the generally dry air of the San Juan country, supplemented in spring and summer by high temperature, the run-off and consequently the transportation of sediment are affected by evaporation. In night time and on cloudy days streams from springs of uniform supply lengthen, and streams appear on canyon floors that at other times are dry. During the passage of 
the hot winds that occasionally sweep along canyons and across lowlands, water in such shallow streams as Comb Wash markedly diminishes in volume or even disappears.

Frost is an active agent. Temperatures below the freezing point are recorded for 7 months of the year in Glen Canyon, 9 months in the San Juan Valley, and 10 months on the plateau at Blanding. During most of these months periods of freezing and thawing alternate. Blocks quarried by frost are strewn thickly about the peaks of the Abajo Mountains, the rims of Elk Ridge and Wilson Mesa, and the cliffs between Red and White Canyons. Though most of the fragments that are pried from canyon walls, from cliffs of thick-bedded sandstone, and from steep slopes in thinly stratified rock are removed about as fast as they are formed, talus of large and small blocks borders many streamways and forms patches on the face of plateaus. (See pl. 18, B.) Some of it is incorporated in landslides. (See pp. 102-103.)

\section{STREAM GRADIENTS}

The longer streams in the San Juan country rise in the Abajo Mountains and Elk Ridge at altitudes of 8,000 to 10,000 feet and join the San Juan or the Colorado at points 3,500 to 4,500 feet above sea level. All of them have steep gradients. Below their headwaters, which above 7,000 feet descend as rapidly as 500 feet in a mile, Montezuma, Recapture, and Cottonwood Creeks flow on an average slope of about 50 feet a mile. The gradient of Grand Gulch is about 90 feet a mile, of White Canyon about 80 feet a mile. Typical of streams that cross Red Rock Plateau, Moki Canyon, some 25 miles long, has a gradient of about 100 feet to the mile. Streams 3 to 8 miles long that drain the west end of the plateau have average falls of more than 200 feet to the mile. In .contrast with these steep gradients the San Juan River below the mouth of Comb Wash has a total fall of 950 feet in about 132 miles, an average of 7.17 feet to the mile, and the Colorado in Glen Canyon has a gradient of only about 2 feet to the mile.

The gradient of the streams is far from regular. Instead of a curve, steep at the headwaters and flattened lower down, the valley profile is a succession of steep and gentle gradients. Waterfalls, rapids, and stretches of relatively smooth water are distributed at irregular intervals. In some places the stream flows over bare rock, in others over thin sheets of gravel and sand, and in still others over deep valley fill. No stream is graded throughout its course. Flood waters carry great quantities of fine rock waste across steep and gentle slopes alike and push forward along their bottoms coarse gravel, boulders, and angular blocks torn from adjoining cliffs. In flat stretches the smaller streams and even the great Colorado are barely able to carry the load of waste supplied by their tributaries.
Little energy is available for deepening their beds. In steep stretches the transportation of huge loads is but part of the general work of down-cutting.

\section{VEGETATION}

In parts of the San Juan country the effect of vegetation in regard to run-off and checking erosion is obvious; elsewhere it is inconspicuous. On Elk Ridge and adjoining flat lands at altitudes above 8,000 feet forests of pine, aspen, and oak, together with the undergrowth of shrubs, grasses, and annuals, provide forest litter that prevents rapid formation of gullies. Much of the precipitation soaks into the ground or remains here and there as swamps and ponds. On these plateaus the flatness of the surface and deep layers of snow seem as effective as vegetation in retarding run-off. Thus on the flat but unforested Wilson Mesa the drainage system is poorly developed; on the steep-sided forested Abajo Mountains it is clearly defined. On Sage Plain, Grand Gulch Plateau, and other surfaces 5,000 to 6,000 feet above sea level stands of piñon and juniper with a density of 2 to 100 trees to the acre interfere somewhat with the run-off, particularly in places where sage and other hardy plants occupy spaces between the trees. Over many square miles plants serve as centers for the accumulation of windblown sand, which temporarily blocks the tiny channels, thus forcing the rain-born rivulets to delay long enough to remove the obstruction or to establish a new roundabout course. Throughout large areas the vegetation is too scanty to exert an appreciable influence. In general the potential effectiveness of the plant cover is greatly diminished by its habit of growth. Trees, shrubs, grass stalks, flowering annuals, and weeds rise as individuals from a floor of rock or alluvium; areas of closely spaced trees, matted grasses, and sod are rare. Between the plants the drainage channels are little interrupted.

In loosening joint blocks and prying them from cliffs and canyon rims, plants are effective agents. As the depth of soil is in few places sufficient for the development of roots, cracks and bedding planes are utilized to an extent unknown in humid regions. Most of the trees and larger shrubs, outside of the highland forests and the alluvial washes, appear to be anchored in cracks. Their roots extend along the cracks, descend deeply into them, or pass from one crack to another around rightangled turns. In removing tree stumps large joint blocks come with them, and uprooted shrubs show a basketlike mesh of root fibers enclosing a block that fits nicely into the general ledge. At the top of canyon walls many cubes of unweathered rock 3 to 8 feet in diameter have been separated from their ledges by growing roots, aided, no doubt, by freezing water for which roots have provided a channel. In interstream spaces roots have aided in breaking the surface beds into a pavement of loosened blocks outlined by joints. 


\section{GROUND WATER}

As a factor in erosion in arid regions ground water holds a prominent place. Working alone or in cooperation with other agencies, it is the chief agent in producing rock shelters and other recesses along bedding planes at the top of impervious strata and innumerable alcoves, "caves", pits, elongated niches, arches, and bridges in the thick cross-bedded sandstones. Even more effective is the water that seeps through the body of the sandstones, removing or weakening the cement and leaving on the surface loosened grains that are removed by the first shower. In landslides the work of ground water is further shown. (See pp. 102-103.)

\section{RELATION OF TOPOGRAPHY TO GEOLOGY}

In the San Juan country, as in the adjoining Navajo and Kaiparowits regions, the topography reflects the control exercised by the composition, texture, and attitude of the rocks. The drainage and sculpture may be almost completely described in terms of rocks (hard and soft), upwarps, and monoclinal folds. Features produced by faulting and by interruption in cycles of erosion are few and inconspicuous. As elsewhere stated, ${ }^{63}$ it is readily observed that the surface of each broad bench or mesa is upheld by a rock mass that is resistant to erosion. From most benches the overlying weak rocks have been stripped away so that the present surface coincides closely with the top of the hard beds. The cliffed borders of plateaus and of canyons are likewise determined by hard rocks. In fact, the dominance of cliffs in the landscape is a reflection of the topographic influence of rock composition. Hard beds determine the broadly level plateau surfaces; where they are gently inclined the surface is similarly inclined; and where they dip steeply the topography is mainly controlled by the sloping surface of the beds. Monoclines are represented in the topography by hogback ridges or by prominent lines of cliffs that are developed on the harder rocks. The surface exposures of weak beds are in general characterized by slopes or by gently undulating topography. Where the weak formations are disintegrated by weathering and by the corrosion of streams they strongly affect the configuration of valleys and the position of drainage lines.

In the present stage of physiographic development erosion, guided by rock texture and composition, has made of the San Juan country a region of cliffs. High cliffs outline the major topographic features, and low cliffs combine to make the prevailing steep slopes. Gentle slopes are elements in the late mature topography on Sage Plain, Elk Ridge, and smaller areas where the cap rock is a continuous stratum in essentially horizontal position, but such slopes are quite out of

\footnotetext{
${ }^{63}$ Gregory, H. E., and Moore, R. C., The Kalparowits region, a geographic and geologic reconnaissance of parts of Utah and Arizona: U. S. Geol. Survey Prof Paper 164, p. 127, 1931.
}

harmony with the mural escarpments, the platforms, steps, and horizontal moldings that characterize the region as a whole.

Weathered surfaces show that the sandstone beds, which constitute fully 80 percent of the strata exposed, terminate in cliffs at the edges of plateaus and mesas and in canyon walls; that the limestones, even in beds less than 1 foot thick, everywhere present cliff faces; and that because of differences in such structural features as jointing, stratification, and cross-bedding the cliffs developed in each stratigraphic unit are distinctive. For example, the limestones in the Rico formation are so uniformly dense and so resistant to erosion in this dry climate that the cliffs are chiefly vertical joint planes; in the conglomeratic, lenticular Dakota (?) and Shinarump sandstones the cliffs, though generally vertical, are indented by pits and long oblique gashes and extend as crooked walls broken down at places where undermining by ground water is effective; in the friable, thick-bedded Cedar Mesa sandstone and to a much greater degree in the massive, strongly crossbedded Navajo sandstone cliff profiles are straight or undercut at the base and rounded at the top, and surfaces between canyons weather into domes, haystacks, rounded ridges, and tepees; in the Wingate sandstone the dominant vertical jointing tends to produce a palisade-like wall; in the Halgaito member of the Cutler formation and the Moenkopi formation the long low cliffs that interrupt the general slopes are the edges of strata of limestone or of sandstone more firmly cemented than adjacent beds; in the predominating shaly Morrison formation the thin sandstones and limestone conglomerates weather as low steps, the massive Bluff sandstone member as a crenulated wall, and the Westwater Canyon sandstone member as pronounced cliffs of highly irregular vertical and horizontal profile.

The dominance of cliffs is the result not only of lithologic and stratigraphic controls but also of climate and physiographic age. In consequence of rapid runoff incident to infrequent torrential rain, products of disintegration are promptly carried away. Successive layers of weathered rock are removed from cliff faces and from surfaces beyond their tops, and blocks are broken from the cliff wall without destroying the profile. The streams are young and, though intermittently powerful, have so far been unable to grade their floors. In cutting their immediate runways deeper and wider they increase the height and maintain the steepness of the bordering walls. Under these unfavorable conditions the reduction of cliffs and canyon walls to slopes with mature profiles seems almost impossible.

\section{RELATION OF STREAMS TO STRUCTURE}

Many streams in the San Juan country are obviously adjusted to structure. Johnson Creek, North Creek, and other headwater tributaries of Recapture and 
Montezuma Creeks occupy synclinal troughs tilted downward in harmony with the slopes of the Abajo Mountains, and below the junctions their master streams continue down the dip slope of northern Sage Plain. McElmo Creek and the eastern tributaries to Montezuma Creek slope toward the axis of the Sage Plain downwarp. Butler Wash and the upper part of Cottonwood Creek follow the base of the Comb monocline, and in weak beds of the monocline Comb Wash has developed as a subsequent stream that affords a runway for Arch, Mule, Fish, and other consequent streams established on the east flank of the Monument upwarp (pls. 18, $A ; 19, A$ ). Upper Castle Wash and the streams in White, Red, and Moki Canyons are roughly in accord with the westward-sloping limb of the Monument upwarp. Lower Castle Wash (Spring Gulch), continued northward as Johnny Hole, and upper Lake Canyon are in synclines at the base of the Balanced Rock anticline. But although many drainage channels are thus wholly or in part well adjusted to structure, some disregard it in part, and others entirely. Grand Gulch follows the crest, crosses the crest, and passes obliquely down the west flank of the Monument upwarp. The Colorado River crosses the Waterpocket Fold without evident deviation from its course, and the meandering San Juan River cuts squarely across downwarps, upwarps, anticlines, synclines, and flat-lying beds. Among the existing structural features no more unsuitable routes for these streams could have been chosen. It is evident that in their present courses these streams are superposed on structural features that have been revealed by erosion. Once established, they maintained their courses across folds, with only such shiftings in position and changes in grade as were required for adjustment to new-found conditions.

In developing their runways the small, weak streams of the San Juan country have been guided by structure, rock hardness, and local slopes; the strong streams are deepening channels inherited from previous physiographic cycles. (See p. 92.)

\section{FORM OF VALLEYS}

The typical valley in the San Juan country is a flat-bottomed, steep-sided gorge with a longitudinal profile made up of steps separated by stretches of steep or gentle gradients. The influence of rock composition and texture is obvious. Where hard rocks are exposed the valley walls are near together and precipitous and the stream gradient steep; where soft rocks underlie and border the streamway the valley is more open and the gradient less steep. But because the outcrops of soft rocks are small and down-cutting by streams is vigorous, valleys with $V$-shaped sections are rare: even in alluvial deposits the canyon form prevails. Valleys with flaring sides are conspicuous only on Elk Ridge, Wilson Mesa, and Sage Plain. So persistent is the causal relation between rock hardness and valley form that with a general knowledge of regional stratigraphy the type of canyon may be predicted. The explorer soon learns that areas of the Mancos, Chinle, and Morrison formations present no serious obstacles to travel, and that by following gullies and taking advantage of talus and landslides, routes for pack trains may be found across slopes built of Halgaito, Organ Rock, Moenkopi, and San Rafael strata, but that feasible routes across the Cedar Mesa, Wingate, and Navajo sandstones, and in places the Dakota (?), are few. The walls of Cedar Mesa sandstone in White Canyon and its tributaries, Armstrong, Long, and Gravel Canyons, can be descended on horseback at Soldiers Crossing and Duckett, but those that border Grand Gulch form an impassable barrier for about 30 miles. The one practicable crossing of Moki Canyon, lined from its source to its mouth with Navajo sandstone, is made possible by sand dunes on the south wall and faulted rocks on the north. The San Juan below Bluff and the high dividing mesa between White Canyon and Red Canyon can be crossed where along folds the cliffs of Navajo sandstone give way to Chinle and Moenkopi beds and numerous joints are present in the Wingates. To reach the opposite side of a canyon in these resistant formations may require a day of travel. Climbing with the aid of ropes is a common experience.

Valleys such as Comb Wash and Butler Wash, which are developed in soft beds upturned in a monoclinal fold, are fairly straight for long distances; they follow the trend of the structure. But nearly all the canyons are sinuous to a remarkable degree; their tortuously winding courses include open curves, horseshoes, and almost right-angled turns, so close-set that in many places the parallel canyon walls are visible for less than half a mile. Though held between towering walls, the streams are as crooked as those on wide flood plains. The San Juan River through the "Goose Necks" travels 23 miles to cover an air-line distance of 7 miles, and in the Great Bend it wanders $8^{1 / 2}$ miles where the direct-line distance is about 1 mile. From Comb Ridge to the Colorado River the San Juan Canyon is 135 miles long; the overland distance is 63 miles. By eliminating the meanders in Glen Canyon its course could be shortened 62 miles. The course of the streams in Grand Gulch, Dark Canyon, Moki Canyon, and other deep trenches is likewise tortuous. In White Canyon the loops and angular turns leave little room for tangent stretches; the alinement of the lowest 5 miles is remarkably complex.

Many or perhaps most of the meanders in stream channels of the San Juan country are the result of normal vertical and lateral corrasion during the life of the drainage system, but as discussed in detail elsewhere ${ }^{84}$ the magnificent series of entrenched meanders in Glen Canyon, San Juan Canyon, and similar high-

Gregory, H. E., and Moore, R. C., The Kaiparowits region: U.S. Geol. Survey Prof. Paper 164, pp. 124, 135-138, 1931. 
walled gorges in the plateau province are believed to have been inherited from ancestral streams. Field evidence indicates that these streams developed their meandering habit while flowing on a graded surface which once stood above the present canyon rims, and that a regional uplift enabled them to sink their beds deeply without greatly altering their courses.

In longitudinal profile the floors of valleys in the San Juan country are very uneven. The floor of many a canyon is a series of steps, some of them bare ledges, over which the stream progresses by rapids and waterfalls separated by stretches of steep or flat gradient. In general the steps in tributary streams are more numerous and higher near the headwaters and near their mouths, thus making the generalized stream profile a curve steep at both ends. These interruptions in the general gradient of individual valley floors are but a feature of the regional discordance of drainage channels. Of streams tributary to the San Juan, McElmo, Cottonwood, and Comb Creeks meet their master stream at grade, and in stages of high water their mouths are flooded; Recapture Creek, Johns Canyon, Grand Gulch, and some smaller tributaries terminate as ephemeral waterfalls 30 to 80 feet high over relatively resistant thick strata. Likewise the mouths of the streams in Red Canyon and White Canyon are accordant with the level of water in Glen Canyon, but the smaller streams from Red Rock Plateau join the Colorado by passing over ledges or descending steep slots cut in thick-bedded sandstone. Many tributaries of the second and third order occupy hanging valleys in hard rocks and soft rocks alike, and where valleys are poorly defined ephemeral sheet streams drop water directly into box-headed canyons.

The walls of most canyons in the San Juan country rise from the floor as a single series of steps or of steps and slopes determined by the position and relative hardness of the stratigraphic units. White Canyon has two sets of walls. The outer walls enclose a flat floor of rock 1 to 3 miles broad and some 30 miles long, into which the present stream has cut a deep, narrow meandering trench-an inner canyon within an outer canyon. From Elk Ridge, Deer Flat, and the tops of mesas at the head of Red Canyon, the position of White Canyon is shown by a broad roadway of white rock bordered by lofty cliffs. The canyon itself is invisible, for, though it is several hundred feet deep, it is in most places less than 200 feet wide and meanders so intricately that no long stretches can be seen. Only at a few places is it practicable to enter the canyon, and within it only the steep white walls of a crooked defile are in sight. To form the broad esplanade at the top of the inner canyon the upper red beds of the Cutler formation have been stripped from the white Cedar Mesa sandstone. Along Cedar Creek an esplanade has been formed on flat-lying Kayenta beds and is bordered by cliffs of Navajo sandstone. Along the
San Juan River west of Comb Wash the undulating floor of a platform abruptly terminated by cliffs has been developed on Rico limestones.

On the poorly marked drainage divides between the Colorado and the San Juan some stream channels are being lengthened and others correspondingly shortened by shifting of divides, accompanied in some places by stream capture. At the northern edge of Sage Plain, east of Monticello, streams flowing north to the Colorado are cutting back into the region now occupied by tributaries of the southward-flowing Montezuma Creek. Farther east tributaries to Montezuma Creek rise almost on the rim of Dolores Canyon; a trench about 200 feet deep would permit the Dolores River to join the San Juan. At the Causeway the southward-flowing Cottonwood Creek is successfully competing with tributaries of Indian Creek, and along the east face of the Balanced Rock anticline the stream in Johnny Hole has invaded the territory previously drained by Lake Canyon.

\section{RATE OF DENUDATION}

The present base-level of erosion for streams in the San Juan country is at the head of Marble Gorge, where the Kaibab limestone greatly retards the down-cutting of the Colorado. Back of this barrier the streams in Glen Canyon and in the lower canyons of the San Juan are no longer actively deepening their channels. They flow on alluvial fill, which they seem unable to move, and are barely able to transport the rock waste contributed each season from bordering lands. Until the load of waste is much decreased or Marble Gorge is deepened these streams are likely to maintain their present positions and thus constitute a temporary baselevel to which hundreds of tributary streams are seeking adjustment. Unlike these master streams, their many branches are not only carrying all the waste supplied in the present cycle but are removing sediments deposited in previous cycles and cutting into rock beneath. They are obviously quarrying and transporting enormous quantities of material. That down-cutting of canyons is rapid js shown by the freshness of rock and alluvial walls and by the fact that meander belts have shifted little. In open curves and sharp angular bends alike the opposite walls of a canyon are equally steep; slip-off slopes are generally absent. On the nearly fiat lands that lie between gullies and canyons on Elk Ridge, Sage Plain, Gray Mesa, and Dark Canyon Plateau streams are doing little work, and because of the arid climate the limestones that form the surface of the Raplee and Mitten Butte anticlines are remarkably resistant to weathering. On the sloping surfaces of sandstone-the prevailing type of rock-disintegration is facilitated by weak cement, lack of soil cover, and sharp fluctuations in temperature and rainfall. The regional rate of erosion is indicated by the amount of 
rock waste carried by the master streams. The Bureau of Reclamation ${ }^{65}$ estimated the silt carried by the San Juan River each year as 24,000 acre-feet, or about 1 acre-foot from each square mile of the drainage basin. Even this large figure is much too small, for, as pointed out by Miser, ${ }^{68}$ it "does not take into account the bed load of sand, pebbles, cobbles, and boulders which slide, roll, and make short hops and skips"-materials that because of the frequent floods constitute a large part of the total load. The San Juan is always muddy, at times carrying nearly as much silt as water, and is also a settling basin in which at intervals part of the sediment is stirred up and carried forward into Glen Canyon.

Though estimates of the rate of erosion based on measurements of suspended silt are unsatisfactory, those based on rate of disintegration of rocks on plateaus, cliffs, and canyon walls are even more so. The rate is different for each type of rock and each topographic position. At the bottoms of canyons, especially those filled with alluvium, and on rounded bare surfaces of weak sandstones it is remarkably fast; near the top of canyon walls, on cliff faces, and on exposed flat surfaces of limestone and siliceous conglomerate it is much slower; on small erosion remnants it is inappreciable. The pedestals, hoodoos, and rock babies carved in massive sandstones seem almost invulnerable. In the San Juan Valley hammer marks made beneath the cap of erosion remnants in 1909 showed no appreciable weathering in 1929, and in the Allen Canyon country, on Whiskers Creek, and on the rim of Moki Canyon areas 1 foot square coated in 1925 with chalk had retained most of this superficial covering after an exposure of 4 years. In protected places steps cut in rock perhaps 400 years ago may still be used as approaches to cliff houses. It is therefore not surprising that Bryan and La Rue ${ }^{67}$ found substantially identical details in photographs of "The Twins" at Bluff taken in 1875, 1909, and 1925. Even if the rate of erosion at Bluff were as fast as the estimated average for the Colorado drainage system ( 1 inch in 440 years), the vertical cliff that includes The Twins would have retreated only about one-eighth of an inch in 50 years.

Though no quantitative measure for regional denudiation seems practicable, the impression gained from field work is that erosion in the San Juan country is as rapid as in other parts of the plateau province and more rapid than in most humid regions; also that the present rate is as fast or even faster than at any other time since the dissection of the Tertiary highlands began.

os U. S. Recl. Service 18th Ann. Rept., p. 404, 1919.

${ }_{66}$ Miser, H. D. Erosion in San Juan Canyon, Utah: Geol. Soc. America Bull., vol. 36 , p. $375,1925$.

o7 Bryan, Kirk, and La Rue, E. C., Persistence of features in an arid landscape: Geog. Rev., vol. 17, pp. 251-257, 1927. 145824-38- 8

\section{PHYSIOGRAPHIC FEATURES • GENERAL RELATIONS}

For the San Juan country as a whole the flat or slightly inclined beds, the warped beds, and the intrusive igneous masses have guided the development of topography. In a broad sense they have organized the agents of erosion; but when viewed close at hand, the development of the landscape seems little influenced by regional controls.

Innumerable canyons, cliffs, and mesas and a few sharp-crested ridges have been carved in sedimentary beds that vary widely in hardness and thickness. The edge of each plateau block and mesa cap is a cliff cut from a single stratum, a single formation, or several formations combined. The San Juan River from Butler Wash to the town of Bluff and parts of White Canyon, Comb Wash, and Cottonwood Canyon are bordered by walls of different material and unequal height; but most canyons are rimmed on both sides by the same stratum, at the general level of the plateau top. So completely do the surfaces on one side of the canyon seem to merge into those on the other that the canyon itself appears only on close approach. Within a mile of their rums the presence of even such profound gorges as Dark Canyon, San Juan Canyon at Polly Mesa, and Glen Canyon at Trail Cliff are not clearly revealed by the topography. Likewise the surfaces that at a distance seem broad and smooth are intricately dissected or broken into long platforms by canyons, some of them hundreds of feet deep.

As seen from Abajo Peak an apparently even surface, broken only by the Ute and Carrizo Mountains, extends far into Colorado and across the San Juan River into Arizona and New Mexico-the position of some 20 canyons sunk deeply into Sage Plain cannot be determined. From the cliffs above Clay Hills Pass the Red Rock Plateau appears as an area of overlapping low mounds unbroken by definite drainage channels. No features suggest the presence of such gorges as Moki, Cedar, and Lake Canyons. A traverse of the plateau surface involves climbing in and out of straight-walled canyons, ascending and descending cliffs at places where sand dunes or talus slopes provide a practicable route.

As major elements in the landscape, irregularities produced by igneous activity and by tectonic movements are little less conspicuous than the subhorizontal plateaus. The laccolithic Abajo Mountains, which culminate in Abajo Peak at an altitude of 11,445 feet, rise 5,000 feet above the surrounding country, and toward them all beds bend upward. This mountain group is the collecting ground for the waters that have carved the canyons of western Sage Plain and the Indian Creek country. The lofty Comb monocline, 
which extends almost without break for more than 100 miles, separates two areas of plateau lands and has locally controlled the development of drainage. Likewise the Balanced Rock anticline is the common border of two platforms at different levels. It has produced an alinement of streams that does not conform to the regional pattern.

\section{EROSION SURFACES}

The San Juan country is a region of vigorous youthful erosion. Areas in which the topography presents features of maturity or old age are not prominent. Evidences of widespread peneplanation that might serve to correlate stages in Tertiary erosion in Colorado, not consequents of tectonic movements. Local erosion surfaces of late Pleistocene and Recent time are represented by remnants at many places. Along the San Juan, the Colorado, and some smaller streams they have been preserved by sheets of gravel, and where developed on tilted strata they are conspicuous. The surface of the Causeway, now much dissected, is believed to represent a surface of considerable extent produced by benching the edges of strata upturned in the Comb monocline and the Abajo Mountains. Along lower Comb Wash and southward across the San Juan River, remnants of old erosion surfaces at approximately accordant grades extend for nearly 5 miles as old-age surfaces developed on tilted Permian and Triassic

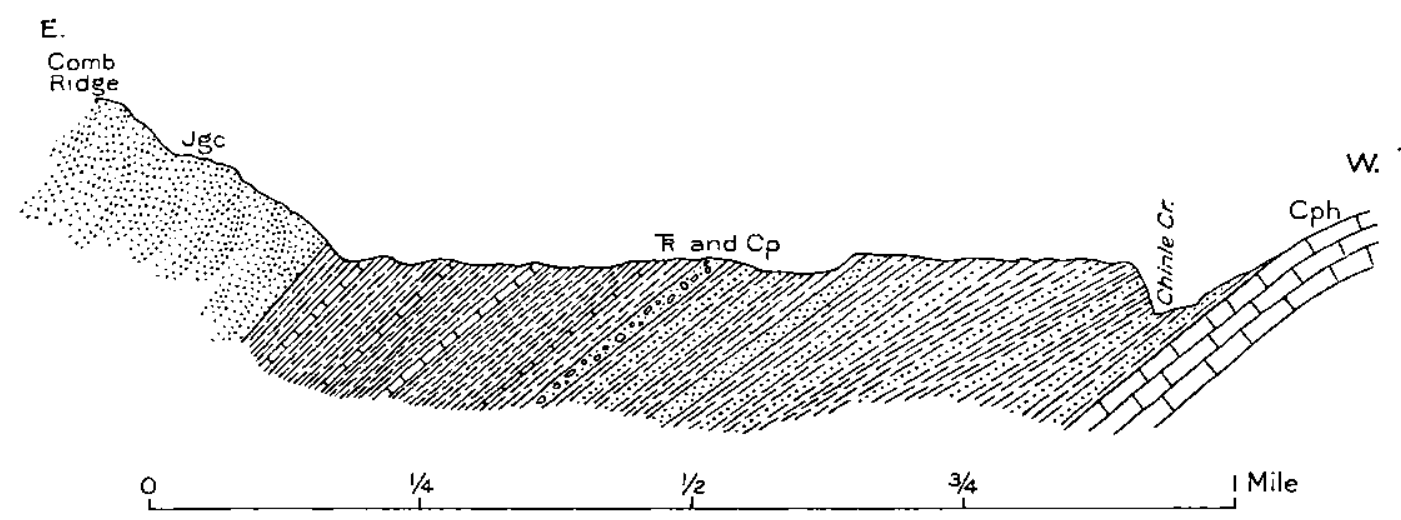

A

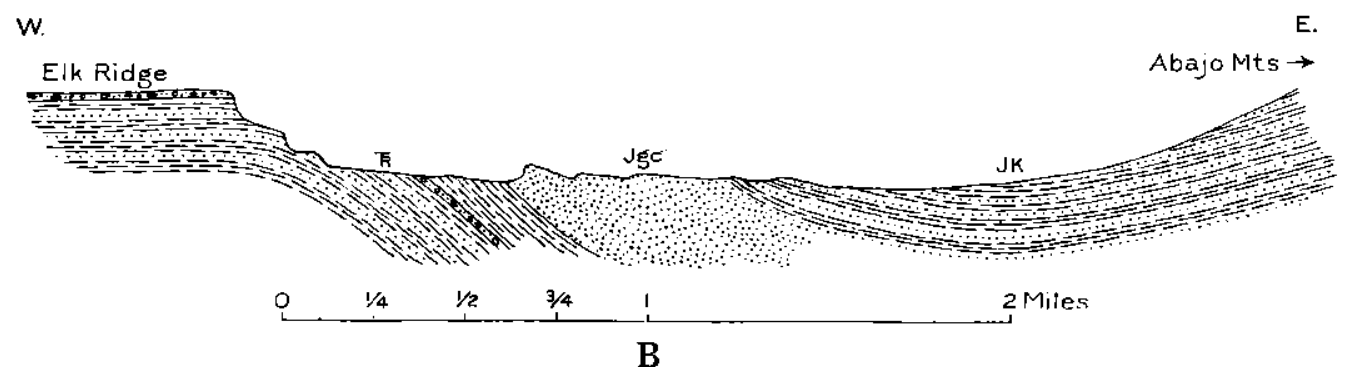

FIGURE 3.-Erosion surfaces on tilted beds. A, Near mouth of Comb Wash; B, AJong the Causeway between Elk Ridge and the Abajo Mountains. JK, Dakota (?) and Morrison formations and San Rafael group; Jgc, Glen Canyon group; K, Triassic rocks; $\mathrm{k}$ and Cp, Triassic and Permian rocks; Cph, Hermosa formation (Pennsylvanian).

Arizona, Utah, and Nevada call for too much interpolation to justify acceptance. The larger areas that reveal old-age features are floored with resistant flatlying rocks that even in a single cycle would show features older than those in adjoining areas, and they stand at different altitudes. Thus the surface of Elk Ridge (in reality a plateau), developed on Shinarump conglomerate; of Wilson Mesa, on calcareous sandstone and shales of the Carmel (?) formation; of the intercanyon flats of Sage Plain, on Dakota (?) sandstone; and of parts of Grand Gulch Plateau, on Cedar Mesa sandstone, are all characterized by low relief-wide, shallow valleys, swales, and rounded low divides. In altitude these old-age surfaces range from about 4,000 to 8,000 feet, and so far as known their positions are beds (fig. 3). Likewise the strata upturned in the Balanced Rock anticline have been worn down to conform with horizontal beds farther west. (See pl. 2,C.)

\section{GRAVEL-FLOORED TERRACES}

Sheets of gravel made of rounded and flattened pebbles a fraction of an inch in diameter and cobbles 1 to 4 inches in diameter rest on rock terraces along the San Juan and within some of its tributary canyons. They appear also on the floors of high-level abandoned meanders. In some places the sheets are narrow bands, parallel with the present stream and a quarter to half a mile long. In other places they are distributed as irregular-outlined patches that range from an acre to a few square yards. Most of the remnant sheets are 1 
to 10 feet thick, several exceed 50 feet, and at a few places Miser ${ }^{68}$ recorded measured thicknesses as much as 100 feet.

In most places where the gravel terraces are present cross sections of the canyon show two or more terraces in vertical sequence on one or both sides of the present channel. Along the San Juan River above Goodridge, the approximate positions of the terraces above high water are 30,75, 200, and 400 (?) feet near Aneth; 30 and 210 feet near the mouth of Recapture Canyon; 20 (?), 130, and 450 feet at Bluff; 135 and 275 feet at Butler Wash and Comb Ridge; 125 feet at the mouths of Comb Wash and Chinle Creek; 20, 50, 125, and 275 feet between Soda Basin and Goodridge Bridge. Below Goodridge the heights of gravel terraces along the San Juan are given by Miser ${ }^{69}$ as $600 \pm$ feet at the mouth of Oljeto Creek; 50, 165, 245, and "several terraces up to 300 feet" at Clay Hill Crossing; 50, 160, and 240 feet at Zahns Camp; 400 feet at Spencer Camp (east end of Great Bend); and 400 feet on the floor of an abandoned canyon near the junction of the San Juan and the Colorado. In Glen Canyon thick deposits of gravel appear in patches 20 to 40 feet above high water, and pebbles of material foreign to the San Juan country lie in protected places about 220 feet above the river at the Rincon and near the mouth of Knowles Canyon.

In the canyons tributary to the San Juan and the Colorado gravel terraces are less readily recognized. The resistant, distinctive quartzites are generally lacking, and the erosion of alternating hard and soft beds has produced innumerable terraces that serve as temporary resting places for fresh products of local disintegration. In a few places gravel older than that of the present cycle lies on truncated spurs and where the walls are low extends some distance from the stream. Such terraces were observed in McElmo Canyon at a height of 50 feet; in Montezuma Canyon at 20, 50, and 130 feet; in Cottonwood Canyon at 40 and 180 feet; in Comb Wash at 20 and 100 feet; in Grand Gulch at 60 and 200 feet; and in tributaries to White Canyon at 30 and 175 feet. Gravel in small pockets on southern Sage Plain and at the top of walls of canyons tributary to Comb Wash which now lie 200 to 400 feet above the nearest stream bed may also represent terraces.

The distribution of these gravel deposits, their texture and composition, and the leveled rock surfaces on which they lie constitute evidence of pauses in the down-cutting of canyons. The gravels are not the deposits of flood plains; they are thick and coarse and rest on benches on steep, high walls. The floors on which they lie are local peneplains developed indifferently in flat and tilted strata, the end products of several cycles or epicycles of erosion. The number of cycles represented and their duration are alike unknown;

\footnotetext{
os Miser, H. D., Erosion in San Juan Canyon, Utah: Geol. Soc. America Bull. vol. 36, p. 369, 1925.

BO Miser, H. D., unpublished notes.
}

satisfactory correlation of widely spaced deposits at different levels must await the preparation of detailed topographic maps. Likewise the age of the terraces can be determined only relatively. Their development occupied part of the time consumed in excavating Glen Canyon, Grand Canyon, and their major tributaries. $\Lambda$ s tributaries of the San Juan in Colorado once derived their water and sediments from glaciers, it seems probable that the San Juan terraces are extensions of the morainal and interglacial gravel deposits of Pleistocene age in the Mancos and Animas Valleys.

\section{CANYON FILL}

The canyons in the San Juan country were deeply sunk into rock and then filled with sediments 5 to at least 100 feet deep and thus bear evidences of a cyclical change from dominant erosion to dominant deposition. The fill consists of interbedded sand, gravel, and silt that varies widely in extent, thickness, and coarseness and shows the lacustrine beds and the lateral unconformities common to fluviatile deposits. Erosional unconformities mark temporary pauses in deposition. In places where the fill has been removed the bottom of the old canyon is revealed as a floor cut by sheer-walled trenches or by grooves and crossed here and there by ledges over which the streams pass as waterfalls. The length of time represented by the filling is unknown. If the average rate of deposition is assumed as 1 inch a year and the average thickness 30 feet, 360 years would have been required. Some such period is suggested by decayed corncobs and ash heaps about 15 feet above the base of the deposit in Grand Gulch and Montezuma Canyon and fragments of pottery higher up-material left by the Basket Makers and Cliff Dwellers, who are thought to have occupied this region intermittently during the period 1300 (?) to $1700 \mathrm{~A}$. D. Trunks of still living cottonwood trees 100 to 200 years old are buried 10 to 30 feet by the fill. On the other hand, greater antiquity is suggested by zones of decomposed material along erosional unconformities and by top layers that have weathered into soil suitable for agriculture. Hermit Lake, a feature of the aggradation cycle, lasted long enough to permit the accumulation of about 85 feet of silt, peat, and marl. The aggradation may have been contemporaneous with the development of the erosion surfaces in Comb Wash and elsewhere and of the lowest gravel terraces in the San Juan Valley.

\section{ALLUVIAL TERRACES}

The typical tributary to the San Juan and the Colorado flows between alluvial terraces within rock-walled canyons. The canyon fill of a previous cycle has been cut into flat-topped, steep-faced segments by streams of the present cycle (pl, 20, A).

In making terraces the streams have been effective in accordance with their size, their gradient, the width of their floors, and the number of violent showers that 
fall within their drainage basins. In general the terraces are increasing in length by headward erosion and in height by down-cutting, but all stages of development are represented. In some places the two terraces that border a stream are separated by a narrow vertical trench; in other places they are far apart and may even appear as flat-topped embankments pressed close against opposing canyon walls. In places the terraces are absent and the original eanyon fill remains intact or has been so completely removed that the position of the terrace is indicated only by patches of sand that cling to the canyon wall, and its height by a band that separates zones of unequally weathered rock. In parts of their courses some streams have cut entirely through the alluvium and into the rock below. As downcutting and undermining are more rapid than surface weathering, the fronts of most terraces are vertical. To climb these walls of crumbling sand is no easy task. To find a place where their tops can be reached, pack trains may have to travel many miles. The construction of these terraces involves erosion on a large scale. For example, the amount of fill removed in a typical 1-mile stretch is estimated as 1,000,000 cubic yards for Grand Gulch, 800,000 cubic yards for Cottonwood Canyon, and 650,000 for Butler Wash. North of Wilson Mesa a canyon 6 miles long, 160 to 200 feet wide, and once filled to a depth of nearly 80 feet has been entirely stripped of alluvium.

It seems reasonable to assume that the time consumed in tearing up and transporting such great quantities of sand, gravel, and silt from hundreds of canyon floors would be measured at least by centuries, but nearly all the terraces have been formed during the last 50 years, many during the last 10 years, and each year adds to their number. In place of the present wide washes floored with sand moved about by ephemeral streams and bordered by flat-topped banks of alluvium, the pioneers of 1880 found "broad fields", "meadows", "clear streams flowing through willows and alders", "cane swamps", "little ponds", "canyons floored from wall to wall with level, fertile fields." The Piutes say that the trouble began with the coming of the white man.

The date and the extent of terracing in the San Juan country are duplicated in canyons south of the San Juan, west of Glen Canyon, and generally through Arizona, New Mexico, and southwestern Colorado. The channeling that produced the terraces may be the result of climatic changes, of uplift, or of these two agencies combined. The immediate cause of much of it is overgrazing. With the destruction of the protective vegetation the run-off became spasmodic, and the streams were intermittently given power to remove canyon fill. As discussed more fully elsewhere, ${ }^{70}$ the balance between aggradation and degradation in the

\footnotetext{
to Gregory, H. E., Geology of the Navajo country: U. S. Geol. Survey Prof. Paper 93, pp. 130-132, 1917. Gregory, H. E., and Moore, R. C., The Kajparowits region; U. S. Geol. Survey Prof. Paper 164, pp. 30-31, 143-144, 1931.
}

plateau province is so closely adjusted that slight changes in rainfall, amount and kind of plant cover, or gradient of streams are sufficient to change stream habit. "The construction of a dam or an irrigation ditch, the killing off of beavers, the building of roads, and the plowing of fields may begin far-reaching changes."

The enormous amount of material supplied by tributary streams during the present cycle of degradation has almost choked the San Juan canyons. Though its gradient below Comb Ridge is steep and its volume in flood times great, the San Juan River flows on unconsolidated material piled thickly on the canyon floor. Near Bluff a well shows 32 feet of river sediment above bedrock, a figure believed to represent the approximate thickness of fill between Comb Ridge and Aneth. Miser ${ }^{71}$ gives estimated depths of less than 10 feet at the "narrows" in Soda Basin and above and below Goodridge, an average between 30 and 40 feet for the lowermost 100 miles of river, and a maximum of 105 feet at the mouth of Piute Creek. These figures are in harmony with measurements at Lees Ferry, where borings reveal 78 feet of fill. The overloaded river is unable to remove the debris dumped into its channel by tributary streams; at the mouths of side canyons the river is pushed toward the opposite wall or crosses the gravel deposits as rapids. At low-water stages islands of sand, gravel, and boulders are conspicuous. That the river is incompetent to transport the material provided is shown by widely swinging braided channels on the alluvial flats at and above Bluff, at Clay Hill Crossing, Piute Farms, and Zahns Camp. As remarked by Miser, ${ }^{72}$

long stretches of the San Juan present most of the time the peculiar example of an alluvial or aggrading stream flowing between close towering walls of solid rock. Yet on the assumption that much or all of the canyon fill is moved at times of high flood the river is in reality not an alluvial or aggrading stream but a degrading stream. To determine whether any of the present canyon fill is or is not a permanent deposit can be settled only by observations over a period of at least a few decades.

\section{LANDSLIDES}

In the San Juan country many slopes are bare or coated with ribbons and scattered patches of debris: they are too steep to permit the accumulation of much talus. On the nearly vertical walls developed in thickbedded sandstones, on the steep slopes in the mudstone of the Permian red beds, and on the gentle slopes of limestone caps of anticlines the products of disintegration are removed about as fast as they are formed. The water that the slopes receive from rains and ephemeral sheet floods disappears before the surface rocks are saturated, and the little talus that accumulates rests directly on dry rock. The conditions favorable

7 Miser, H. D.. The San Juan Canyon, southeastern Utah: U. S. Geol. Survey Water-Supply P9per 538, pp. 67-71, 1924.

${ }^{72}$ Idem, p. 59. 
for landslides are lacking. On the other hand, many slopes developed in the Moenkopi, Chinle, and Morrison shales are heavily coated with talus, which from time to time moves downward in a mass.

About the rim of Elk Ridge the weak Moenkopi shales that lie just below a zone of ground-water seepage provide a sliding plane for fragments of Shinarump conglomerate weathered from the cliffs just above. Down this plane jumbled masses of pebbles, angular boulders, joint blocks, and slices of the cliff have slid several hundred feet. In canyons on Sage Plain similar conditions account for the presence of fragments of Dakota(?) sandstone and Mancos shale on slopes of Morrison shale. In the Chinle formation the conditions for producing slides are exceptionally favorable. The thin sandstone beds readily break into talus fragments, and the "marl" beds when saturated seem to move by their own weight. Talus from the formation itself and from the Wingate, Kayenta, and Navajo above rests on a surface that when wet is slippery. Along the south side of White Canyon landslides in the Chinle appear as a band about a mile wide so continuous that the bedded rocks beneath are concealed except in gullies. In general their downward movement is arrested at the top of the Shinarump conglomerate, but at several places it continues across the Moenkopi and Organ Rock strata and even to the Cedar Mesa sandstone that floors the canyon, thus forming feasible routes of travel up otherwise unscalable cliffs. The material is a heterogeneous mass, 5 to 200 feet thick, composed of angular fragments of limestone, sbale, and sandstone a few inches to as much as 20 feet in diameter. Its surface is exceedingly rough. In the cliffs south of Clay Hills Pass sections of the Chinle have slid from their original position and now stand as tilted ridges on Shinarump and Moenkopi beds.

That the slides are not all of one age is shown by the differences in position, shape, and degree of weathering of the fallen masses. Part of the material is decomposed and is trenched by gullies that seem as old as the present cliffs. Considerable age is indicated also by weathered boulders that lie 1,000 to 2,000 feet in front of slides-the remnants of accumulations destroyed by erosion. In contrast with these evidences of age the slide rock in places consists of slabs, blocks, and pebbles unmodified by weathering, includes upturned living trees, and shows no defined drainage system. It is reported that trails have been blocked by slides within the last 20 years. Instability is further shown by mud flows that after heavy rainfall issue from the base of slides. In places recurrent movement is indicated by the arrangement of material in parallel ridges on Chinle slopes and by unconformities in the piles of debris successively pushed over cliffs. The evidence that talus has been largely stripped from many slopes, that old slide material has been deeply eroded, and that some of the existing slides are active finds a place in the discussion of physiographic cycles and the rates of regional denudation. (See p. 98.)

\section{WHITE CANYON BRIDGES}

The walls of White Canyon and its principal headwater tributaries are wonderfully carved with bays, alcoves, niches, and rounded overhanging ledges, many of them the sites for cliff dwellings. The most spectacular features are three natural bridges-Kachina and Sipapu, in White Canyon, and Owachomo, in the adjoining Armstrong Canyon. (See pls. 19, $B$; $20, B ; 21 ; 22, A, B ; 23, B$.) In this region the streams are readjusting their roundabout courses, and the conditions are favorable for eliminating meanders by undercutting. The canyon walls consist of layers of porous sandstone lenticularly interbedded with relatively impervious shales, forming suitable conditions for the seepage of ground water from the upstream to the downstream sides of meander necks; the meanders are close pressed, the necks of some of them less than 100 feet wide; the streams have steep gradients and in time of flood vigorously attack the concave meander walls. The process of bridge formation is clearly shown at the Kachina arch, which is still in a youthful stage of development. Here a bed of porous, coarsegrained sandstone 100 feet wide and 170 feet thick, underlain by dense thin-bedded sandstone, constitutes the wall between two meander bends. Water seeping through the wall at the contact of the massive and shaly beds has established underground runways and progressively enlarged them into a slit through which the entire White River passes. Since the river assumed this new course it has deepened the opening by cutting through the shales and into an underlying sandstone. The opening has been further enlarged by spalling of slabs from the top and sides, developing a rough-hewn arch with a span of 203 feet and a height between girder and stream bed of 108 feet. The abandoned channel of the White River, with its bed on shale, passes around the east end of the bridge between high curved walls of sandstone. (See pls. 21, 22, B.)

The conditions that permitted the formation of the Sipapu Bridge duplicate those at the Kachina, but the bridge is older. The stream has cut deeper, spalling and decomposing of the sandstone top have proceeded much further, and curves and rounded edges have replaced angular profiles. The bridge spans the stream as a graceful flat arch, 53 feet thick, 268 feet long between abutments, and 167 feet above the canyon floor. The top sandstone that once constituted the rim of the meander neck has been reduced to a roadway 30 to 50 feet wide. (See pls. $20, B ; 22, A ; 23, B$.) Of known natural bridges Sipapu is exceeded in size only by the wonderfully symmetrical Nonnezoshie arch (Rainbow Bridge) at Navajo Mountain, which rises 309 feet above the stream and has a span of 278 feet. 
The Owachomo Bridge, like the Kachina and the Sipapu, is the remnant of a neck that once separated the concave walls of two meanders, but unlike the other bridges it extends across a passage between two roughly parallel streams that flow on different levels. Seepage through the walls of the higher unnamed canyon into the more deeply cut Armstrong Canyon disintegrated the sandstone above the impervious shale in a zone that later became an opening. The bridge thus outlines a huge perforation near the top of a canyon wall. (See pl. 19, B.) The Owachomo arch is old. The short ephemeral stream that flows beneath it has cut a channel some 50 feet below its abandoned bed, and the wall that once separated the two streams has been reduced to a slab 27 feet wide and less than 10 feet thick at its middle point. Slow weathering has widened the original slit to a span of 180 feet and increased its height nearly 100 feet.

The region that includes the White Canyon bridges was the home of the Basket Makers and a hunting ground for Navajos, Utes, and Piutes. It is not unlikely that prospectors and trappers from Colorado saw the bridges as early as 1870 , but the first recorded visit of a white man was that of Cass Hite, who in 1880 established a mining camp at Dandy Crossing (Hite), the head of Glen Canyon. In the fall of 1883, under the guidance of Piute Indian Joe, this adventurous prospector spent several days among the interlaced upper tributaries of White Canyon, during which he located "copper streaks", "Moqui houses", and three large bridges, two "over the river" and one "on the canyon wall." Hite's picturesque reports attracted the attention of placer miners on the Colorado River and of cattle men at Elk Ridge and led to visits by the pioneer settlers at Bluff, Moab, and Hanksville. To the outside world the three big arches became known chiefly through an illustrated article by Dyar, ${ }^{73}$ who described an excursion by a mining engineer, Horace J. Long, in 1903, under the guidance of James Scorup, of Bluff. In 1905 an expedition under the auspices of the Salt Lake Commercial Club ${ }^{74}$ procured measurements and sketches of the bridges, on which the widely known paintings by H. L. A. Culver are based. In 1907 additional information, including good photographs, was obtained by the University of Utah expedition under the leadership of Prof. Byron Cummings. ${ }^{75}$ By a Presidential proclamation dated April 16, 1908, a tract of unsurveyed land immediately surrounding the three bridges was set aside as a national monument. After surveys in 1908 by W. B. Douglass, of the General Land Office, the limits of the monument were established. As defined in the Presidential proclama-

\footnotetext{
73 Dyar, W. W., The colossal bridges of Utah, a recent discovery of natural wonders: Century Mag., August 1904; [abstract], Nat. Geog. Mag., vol. 15, pp. 367-368, September 1904.

7 Bolmes, E. F., The great natural bridges of Utah: Nat. Geog. Mag., vol. 18, pp. 199-204, 1907; articles in the Salt Lake Tribune and Deseret News, April and May 1905.

"s Cummings, Byron, The great natural bridges of Utah: Utah Univ. Bull., vol, 3 , no. 3, pt. 1, pp. 1-24, 1910.
}

tion of September 1909, the Natural Bridges National Monument includes not only the three bridges but also Snow Flat Cave Spring, on a tributary to Fish Creek and Cigarette Spring, near Road Canyon.

The dimensions of the bridges as measured by Douglass are as follows:

Dimensions, in feel, of nalural bridges in San Juan country

\begin{tabular}{|c|c|c|c|}
\hline & $\underset{\text { mo }}{\text { Owacho- }}$ & Kachina & Sipapu \\
\hline $\begin{array}{l}\text { Height of bridge above lowest } \\
\text { floor of wash. }\end{array}$ & $105 \frac{1}{2}$ & 210 & 220 \\
\hline $\begin{array}{l}\text { Depth of arch (thickness of } \\
\text { girder. }\end{array}$ & 9 & $\begin{array}{c}93 \\
2031 / 4\end{array}$ & 53 \\
\hline Length of span & 180 & $\left\{\begin{array}{c}\text { (north side) } \\
350 \\
\text { (south side) }\end{array}\right.$ & 268 \\
\hline $\begin{array}{l}\text { Width at narrowest point (top } \\
\text { of girder). }\end{array}$ & $273 / 4$ & 44 & 31 \\
\hline Width at narrowest point (under & 809 & $103 \frac{1}{2}$ & \\
\hline Length of bridge rock, on top & 802 & - - - & 858 \\
\hline
\end{tabular}

In descriptions of the bridges several sets of names have been used. Cass Hite called them the President, the Senator, and the Congressman. Horace Long named the larger bridge in White Canyon, Augusta, after his wife, the smaller one Carolyn, after the mother of James Scorup, and the huge structure in Armstrong Canyon Little Bridge. The Commercial Club accepted Augusta and Carolyn as satisfactory names but rechristened Little Bridge as Edwin Bridge, after Col. Edwin F. Holmes, of Salt Lake City. Cummings adopted this terminology. In the Presidential proclamation more appropriate terms are used. For the massive flat arch that spans the main fork of White Canyon in a region of cliff houses and ancient granaries, the Hopi name Sipapu ("the gateway through which the souls of men come from the underworld and finally return to it") replaces President and Augusta; for the unfinished archway over White Canyon near the mouth of Armstrong Canyon, Kachina ("the sacred dance"-an interpretation of the symbols carved on the bridge) replaces Senator and Carolyn; and the elevated roadway spanning a dry tributary of Armstrong Canyon locally known as the Congressman or Edwin Bridge has been rechristened Owachomo ("flat-rock mound"), from a nearby lookout point, mentioned in Indian tradition.

These three magnificent bridges represent stages in the process of eliminating meanders-a process now in operation. Along many tributaries of White Canyon and in other canyons walls of Cedar Mesa sandstone enclose winding channels. At several places water is seeping through meander necks, and here and there cavelike slits extend far into the rock walls from the downstream sides. There are many abandoned meander curves at different levels above present streams, and in some trenchlike cut-offs the worn buttresses of ancient bridges still cling to the canyon walls. Pack ${ }^{78}$ speaks of a broken arch, the "Fallen Monarch", that

76 Pack, F. J., Natural bridging in the High Plateaus: Pan-Am. Geologist, vol. 37, p. 223, 1922. 
once spanned the White River 2 miles above the Sipapu Bridge, and states that the abutments of the arch "are still standing, one of them in excellent state of preservation."

In Grand Gulch the elimination of meanders has left several abandoned horseshoe bends at different levels above the floor. In some places water is seeping through meander necks, and in others the stream passes through high-walled chutes that have not been long in use. Prospectors report that about 2 miles below Collins the buttress of a ruined bridge stands like a tower on the canyon floor between the present channel and the abandoned channel, and farther downstream the stub end of a broken bridge girder projects almost horizontally from the wall. Bridges in process of formation and others in ruins seem to be characteristic of intricately meandering, swif $t$ streams deeply entrenched in canyons.

\section{ARCHES AND WINDOWS}

As agents involved in the erosion of walls of massive sandstone, decomposition and disintegration seem subordinate to quarrying. Weathering is effective in producing films of loosened grains that are continuously stripped from the ledge by rain storms, but the walls retreat mainly in consequence of the removal of whole sheets and blocks outlined by structure planes. The scars left on the wall reflect the number, spacing, and inclination of joints, the regularity of stratification, and the type of cross-bedding.

In rocks that are evenly bedded or angularly crossbedded blocks pried loose by frost or by undermining commonly have angular outlines. In rocks with curved cross-bedding the detailed sculpture is characterized by curved surfaces in both vertical and horizontal directions. Thus on many bare exposures of Navajo sandstone, also in places on the Cedar Mesa, Entrada, Wingate, and Bluff sandstones, cross-bedding outlines arches. (See pls. 14, B; 23, A.) Some of these arches appear as if drawn on the smooth rock face; others form the borders of panels and blind windows recessed in the cliff faces; still others serve as the roofs of niches and rock shelters. As erosion continues most of the arched structures are detached from the walls and, lacking adequate support, collapse in response to gravity, exposing new curves and arches behind them. Some arches retain their individuality for long periods, and as the surrounding rock is worn away they stand like hoops with ends firmly attached to the ledge high above present stream beds. Thus in Dark Canyon an arch with a space of about 100 feet clings to the sandstone wall, and arehes in various stages of development stand here and there on Grand Gulch and Red Rock Plateaus. Miser ${ }^{77}$ describes two picturesque arches developed in the Navajo sandstone, one 2 miles below the mouth of Piute Creek and the other near the junction of the San Juan and the Colorado. As explained

\footnotetext{
" Mises, H. D., The San Juan Canyon, southeastern Utah: U. 8. Geol. Survey Water-Supply Paper 538, p. 15, 1924.
}

elsewhere ${ }^{78}$ the free-swinging arches develop most readily at the heads of short box canyons, where erosion is most vigorous and continuous.

As alcoves are recessed deeper and deeper into canyon walls there is a tendency for surface water to make its way through the arched roof along vertical joint planes, a process which if continued under favorable conditions results in a crack open to the sky. Enlargement of this long, narrow skylight permits the outer part of the alcove roof to stand alone as an arch separated from the canyon wall by the width of the opening. Further erosion gives the arch the form of a hoop rising above the general rock surface or detaches it completely from the wall, making a bridge which spans the original alcove.

In the walls separating closely spaced canyons, in narrow meander necks, in projecting buttresses, and in detached dikelike ridges erosion from opposite sides may be so directed as to produce perforations-the wellknown "natural" windows. In size these windows range from mere peek holes to openings many feet in diameter, and in shape from oblong to rectangular. Many of the windows are but the spaces left by the removal of joint blocks, and their square or rectangular frames are flush with the adjoining walls. Many rounded ones are the result of slow disintegration and spalling guided by cross-bedding and are deeply recessed. The frames of many windows are broken.

The three beautiful windows in Arch Canyon (Cathedral Arch, Angel Arch, and Keystone Arch) are perforations in detached walls of interbedded shale and sandstone. (See pl. 24, $A, B$.) The top and the bottom of Cathedral Arch (pl. 23,C) and Angel Arch and the bottom of Keystone Arch are flat bedding planes; the windows have been developed in the intervening sandstone by the falling of successive blocks, producing openings 60 to 100 feet wide and 50 to 140 feet high. As the thick bed of sandstone is cross-bedded and also vertically jointed, removal of the blocks and sheets has left a frame made of both curved and plane surfaces.

Arches and windows seem to have the same physiographic history as rock shelters, bridges, and the multiform cavities in walls of porous sandstone. In early life they express the work of ground water; with their later development all agencies of erosion are concerned; at all stages rock structure is an influential control.

\section{ROCK SHELTERS}

In the San Juan country the canyon walls, especially those made of the thick-bedded sandstones, are sculptured in a remarkable way. As elsewhere in the plateau province the characteristic large-scale features-sheer walls, overhanging walls, box heads, rincons, buttresses, and alcoves-are decorated by carvings in relief and intaglio. Rounded bosses, capped columns, bobbins, "goblets", miniature pilasters, moldings, and frames of blind windows project from many rock surfaces, into which have been carved also innumerable niches, decorative grooves, and lines. The round, oblong,

${ }_{78}$ Gregory, H. E., and Moore, R. C., The Kajparowits region: U. S. Geol. Gurvey Prof. Paper 164, p. 144, 1931. 
curved, and angular cavities in the walls range in size from tiny "eyes" and "toe holes" to caves as much as 50 feet high and 100 feet wide and sunk 10 to 40 feet into the rock. Many of the large cavities protected from rain, from the heat of the sun, and from wind and sandstorms were utilized by the ancient inhabitants as sites for dwellings and storehouses-"rock shelters" or "cliff caves" as termed by archeologists. Access to the sites is generally effected by steps cut into the steep rock wall.

These rock shelters are of two types-flat-roofed recesses, eroded from shaly beds beneath a cap of resistant sandstone, conglomerate, or limestone, and arch-roofed structures, developed within strata of cross-bedded sandstone. In Montezuma Canyon and elsewhere on Sage Plain the grooves cut in Morrison shales at the base of the Dakota (?) sandstone provided ample space for houses. On the San Juan River the overhanging ledge of Bluff sandstone determined the site of Casa del Eco and many smaller structures. In Arch Canyon, Grand Gulch, and the tributaries to White Canyon the longitudinal recesses at the contact of sandstone and shale in the Cedar Mesa sandstone were utilized for building sites. Niches in the Navajo sandstone in the Allen Canyon country and in the Cedar Mesa sandstone of Beef Basin, Fable Valley, and White Canyon are occupied by small isolated buildings, some of them mere caches for grain and seeds. The houses and villages that occupy cavities in the Navajo and De Chelly sandstones of the Navajo country are not duplicated north of the San Juan. On Red Rock Plateau, where many suitable building sites are available, the known ruins are few and small. (See pls.25, 26; fig. 4.)

Both the flat-roofed and arch-roofed rock shelters of all sizes and shapes are essentially the work of ground water. In regularly stratified rocks water seeping from the contact of porous and impervious beds has developed recesses by undermining the Dakota (?) sandstone, the Bluff sandstone, and in less degree the sandstone beds in the Cedar Mesa member. In the thick, massive sandstone beds the first stage in the development of cavities is the seepage of water along the surface of some locally impervious lens, with consequent removal of the cement, then the grains from the base of porous, saturated rock. This slight undermining permits grains and thin laminae to fall in response to gravity. As the process continues, shell after shell is detached from the roof and, because the cement has been largely removed by percolating water, reaches the floor as a disintegrated mass that is borne to the mouth of the cave by intermittent run-off. The back walls of many rock shelters are moist and thinly coated with waterloving plants. Some give rise to springs; others are coated with alkali or salt "bloom"; still others, especially those above the local water table, are dry. No field evidence supports the popular notion that the cavities in the walls of canyons have been produced by sand blasts. On the contrary, little wind enters them. Most of the small ones contain leaves, wings of insects, and dust that even a slight breeze would remove. Birds, bats, and rodents live in them, and during severe windstorms the large ones serve as refuges for beasts and men.
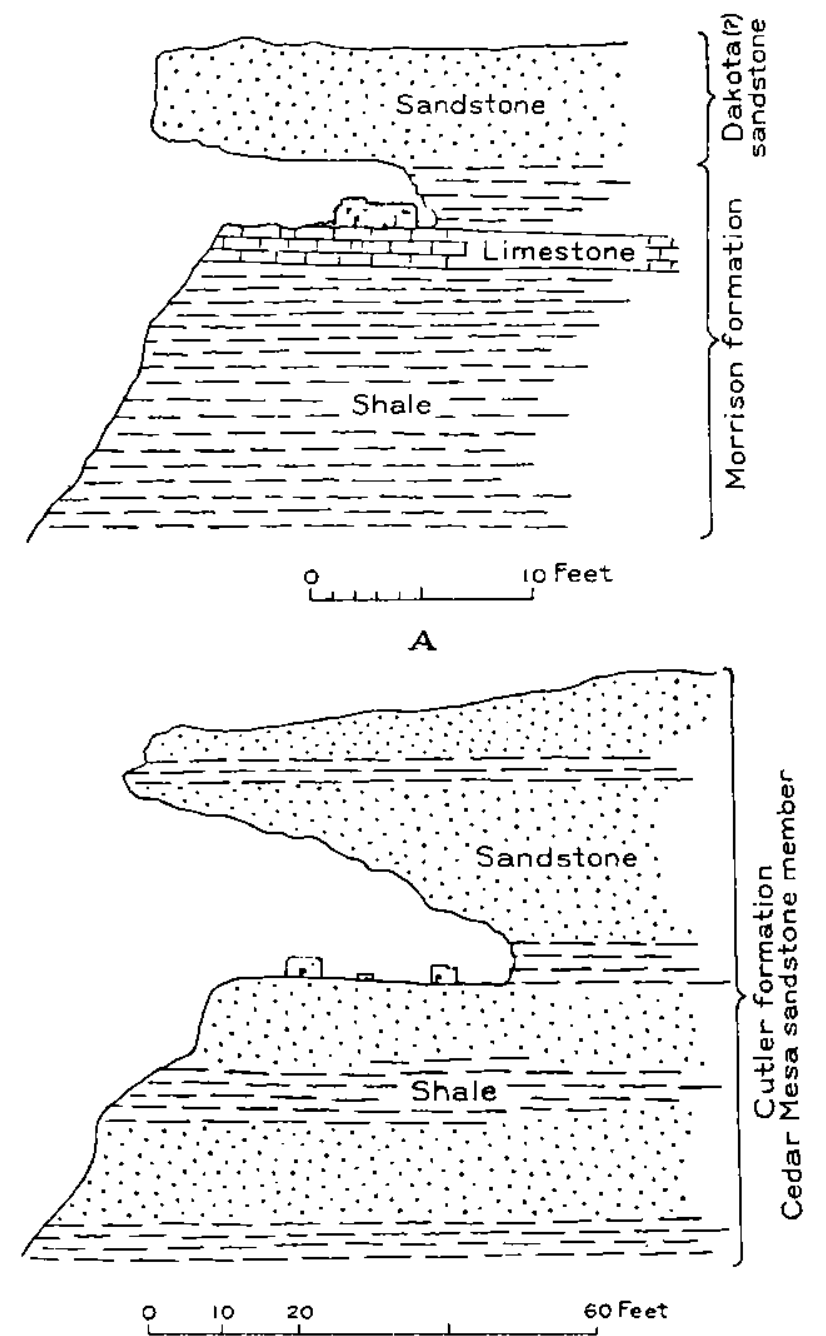

$\mathrm{B}$

Figure 4.-Rock shelters: $A$, At contact of Dakota (?) and Morrison in Cottonwood Canyon; $B$, in thin-bedded Cedar Mesa strata at Cigarette Spring.

\section{SAND DUNES}

No large dunes or large areas of persistent small dunes were seen in the San Juan country. Here and there on the generally bare rock surface of Red Rock and Grand Gulch Plateaus sand dunes form and migrate, and on the floors of washes they are common. During the infrequent but severe wind storms great quantities of dust are swept from the ground and carried high into the air, but most of the wind-blown sand accumulates about the base of shrubs and trees or in the sheltered places on canyon walls. The topography is unfavorable for large-scale wind erosion or deposition. 


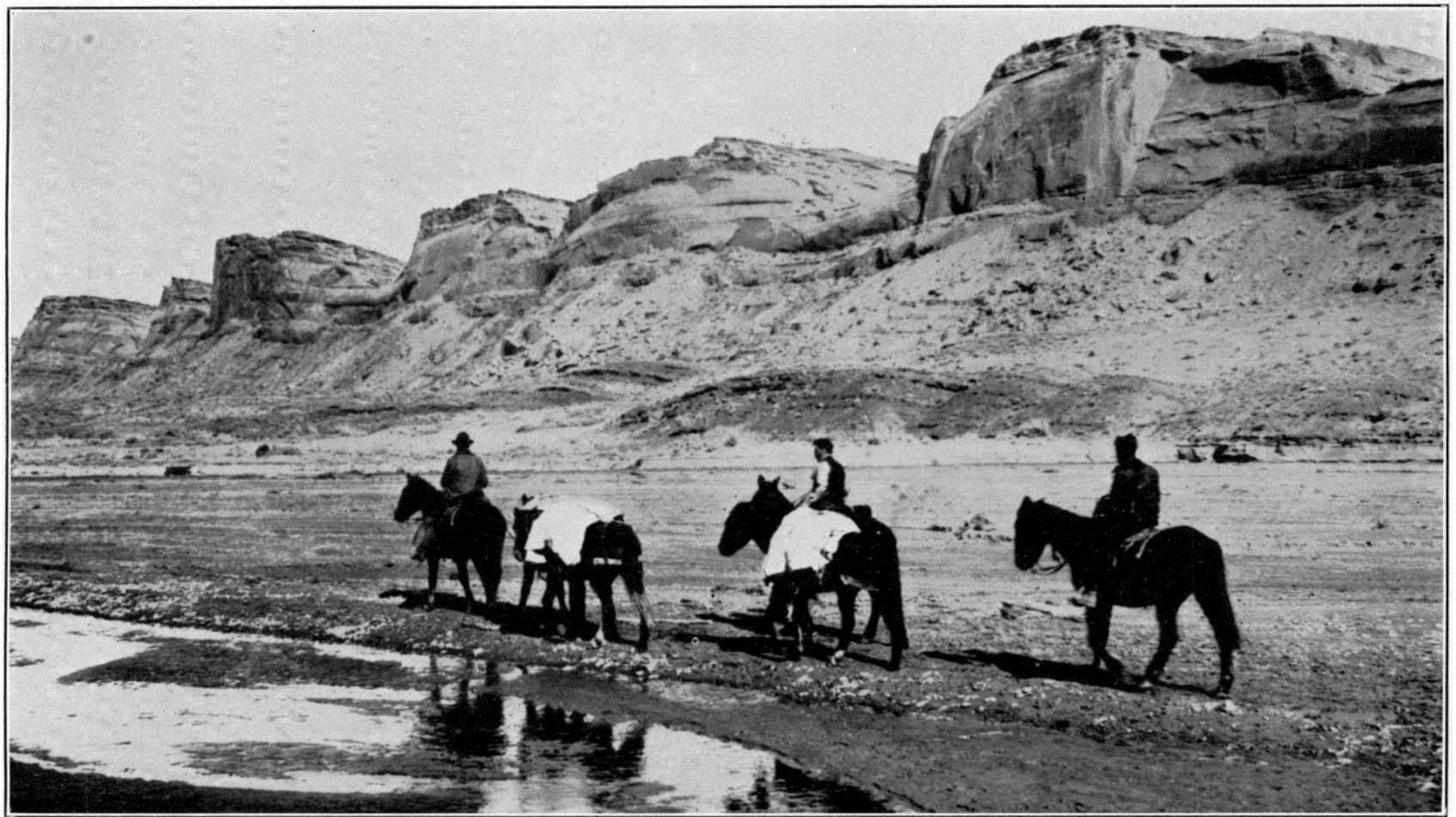

1. COMIS WASII.

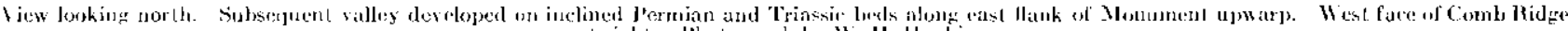

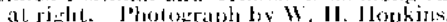

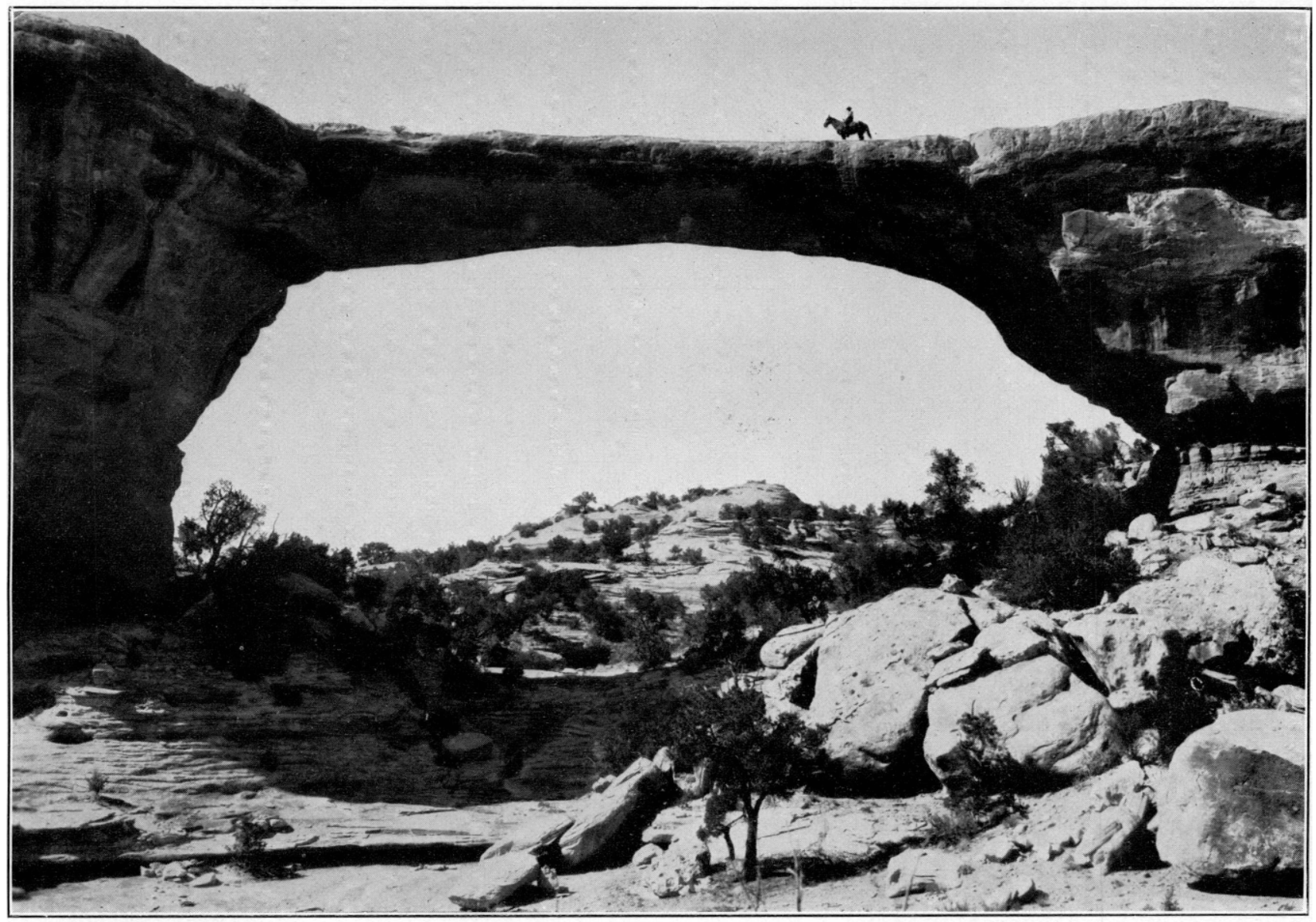

B. OWACHOMO NATURAL BRIDGE IN WALI. OF ARMSTRONG CANYON.

Celar Mesa sandsionie. Plholorrapht by II. T. Lex". 


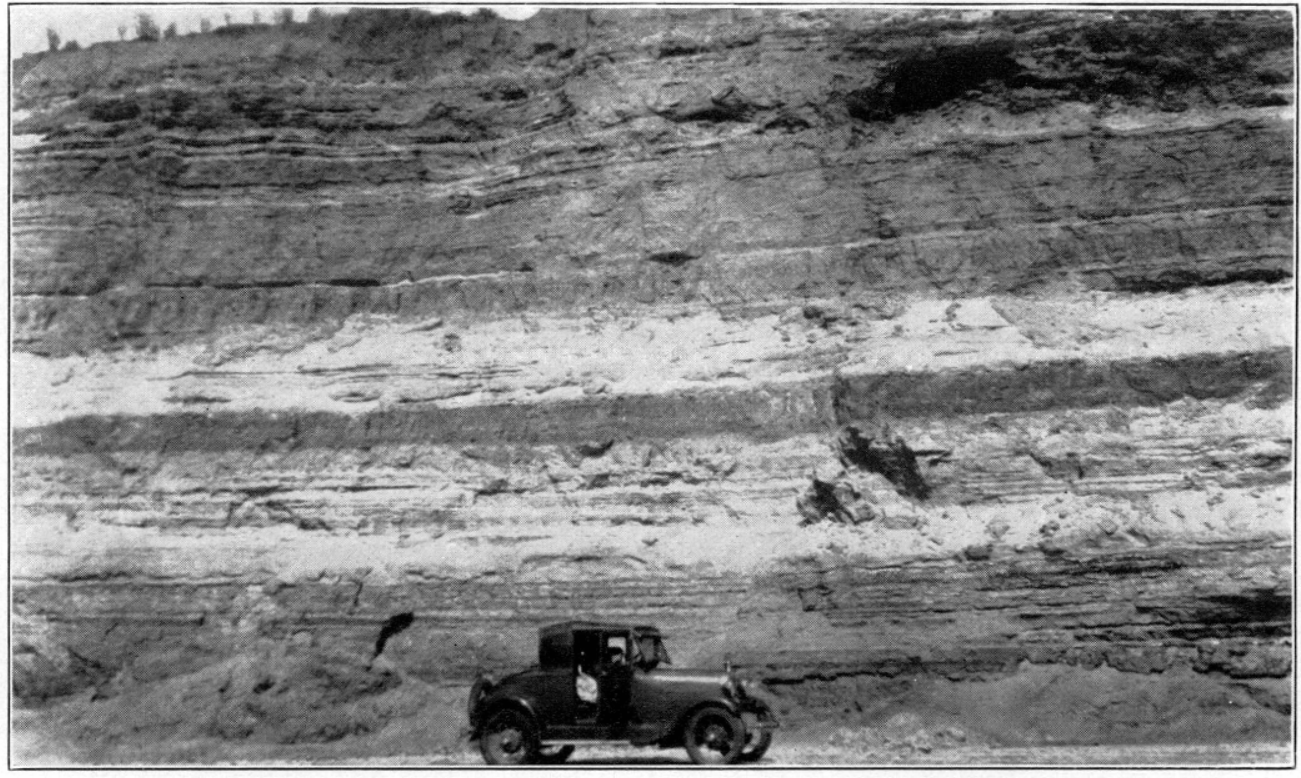

A. VALLEY FILL OF SAND AND CLAY EXPOSEI) BY RLCENT EHOSION IN COMIB WASH.

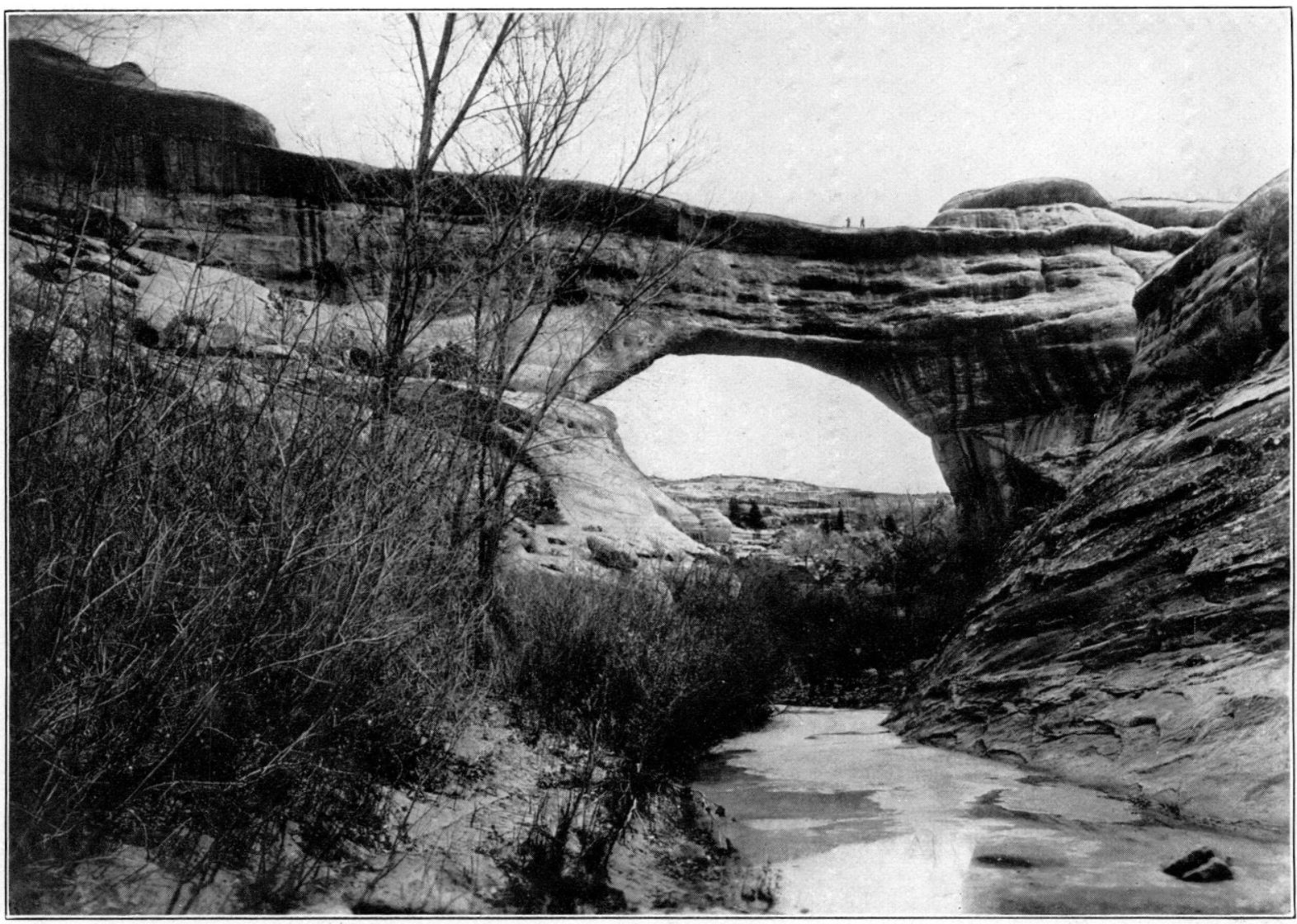

B. SIPAPU NATURAL BRIDGE, WIITE CANYON.

Cedar Mesa sundstone. Photograph by W. H. Hopkins. 


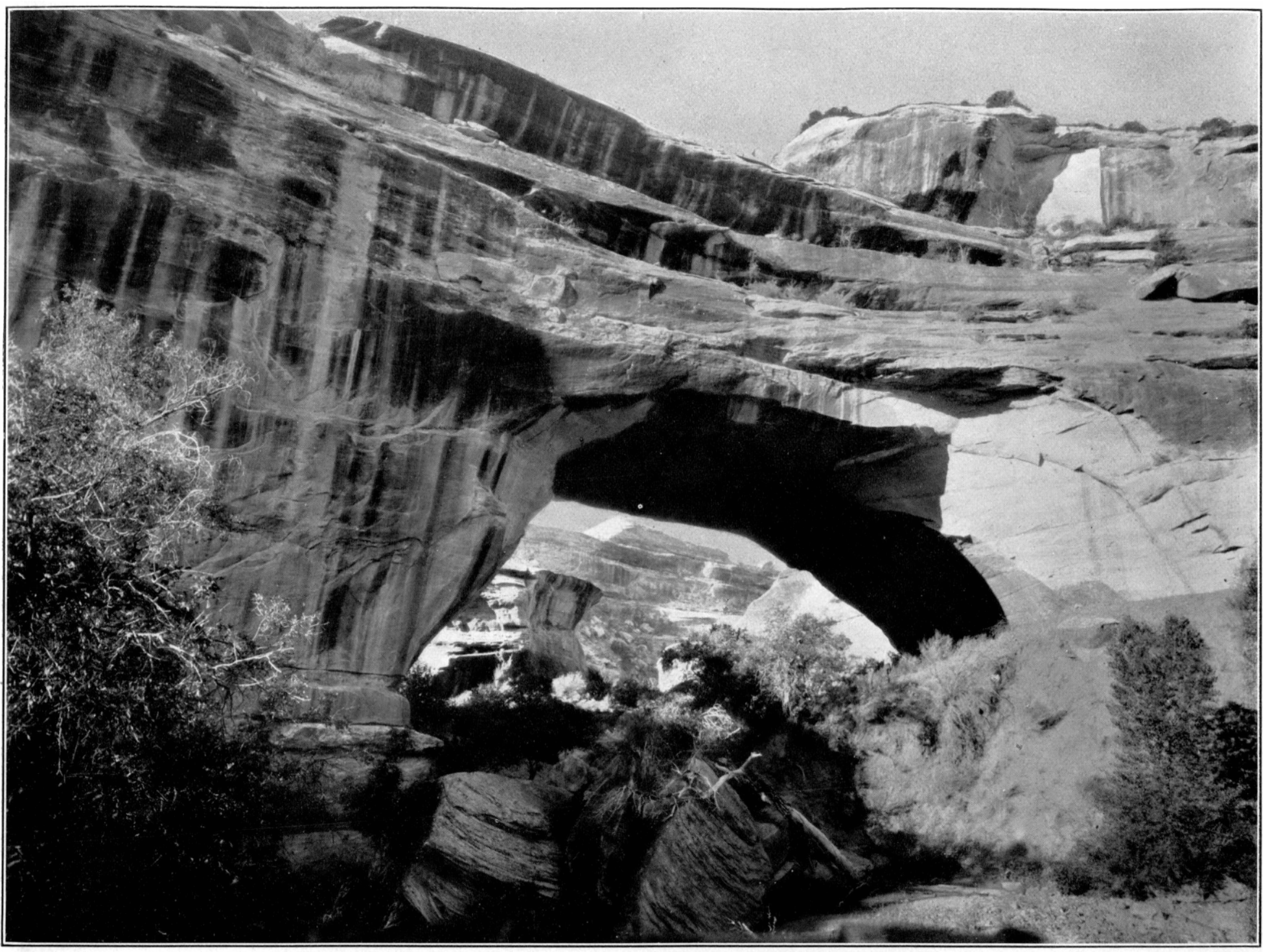

KACHINA NATURAL BRIDGE, WHITE CANYON.

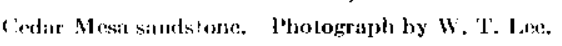




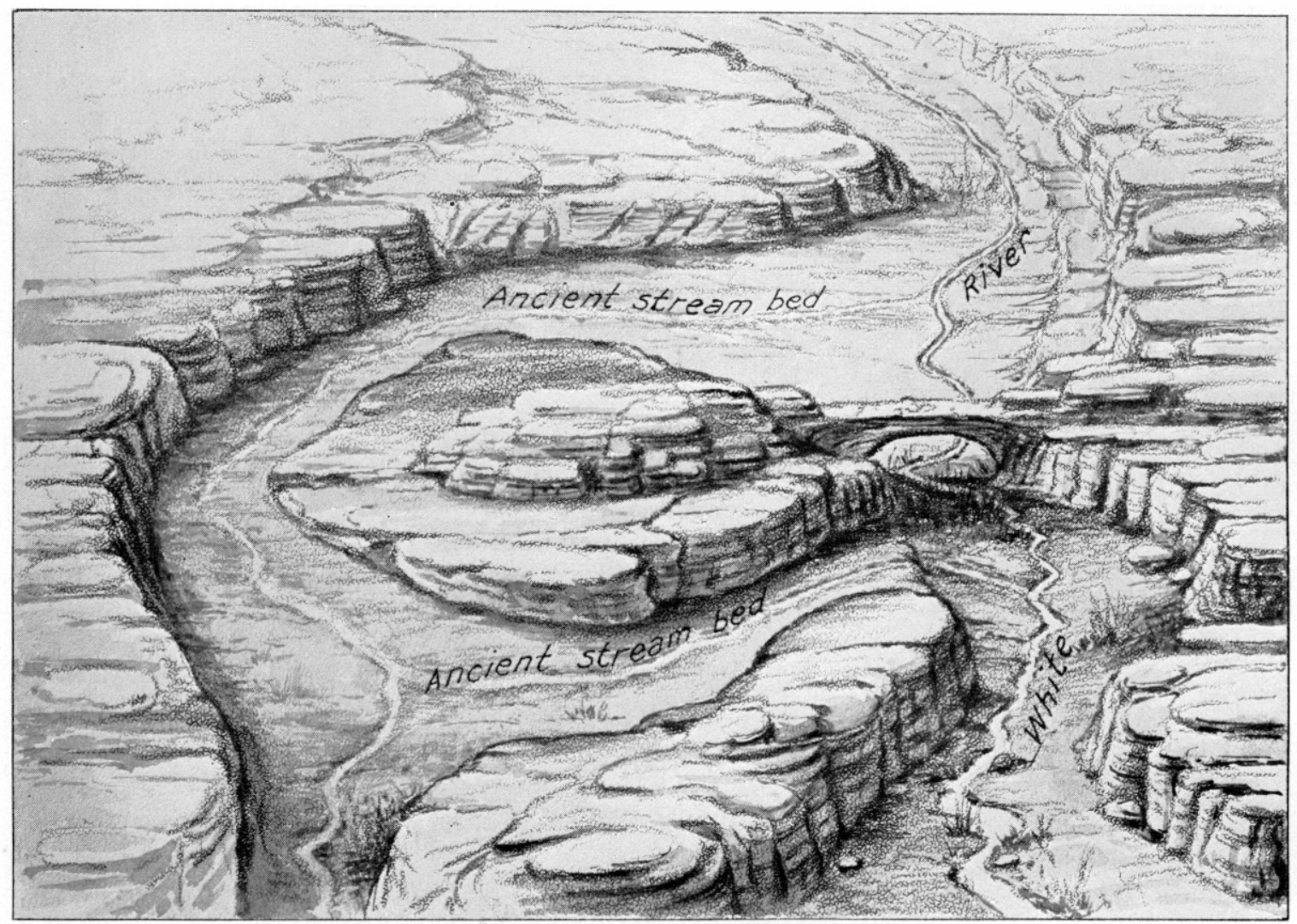

A. SIPAPU NATLHAL BHIDGL.

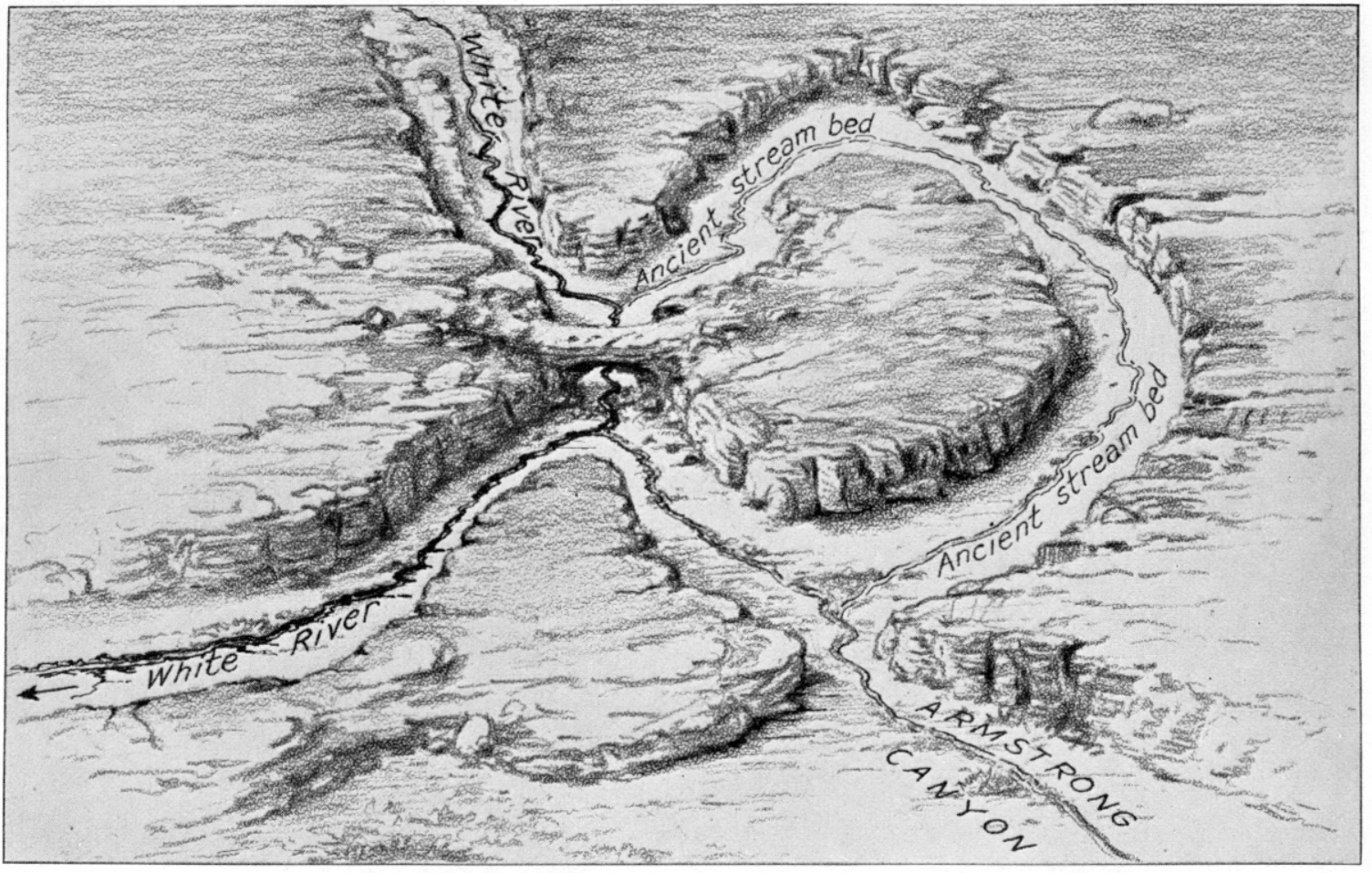

B. KACHINA NATURAL BRIDGF.

DIAGRAMS SHOWING FORMATION OF NATURAL BRIDGES. 


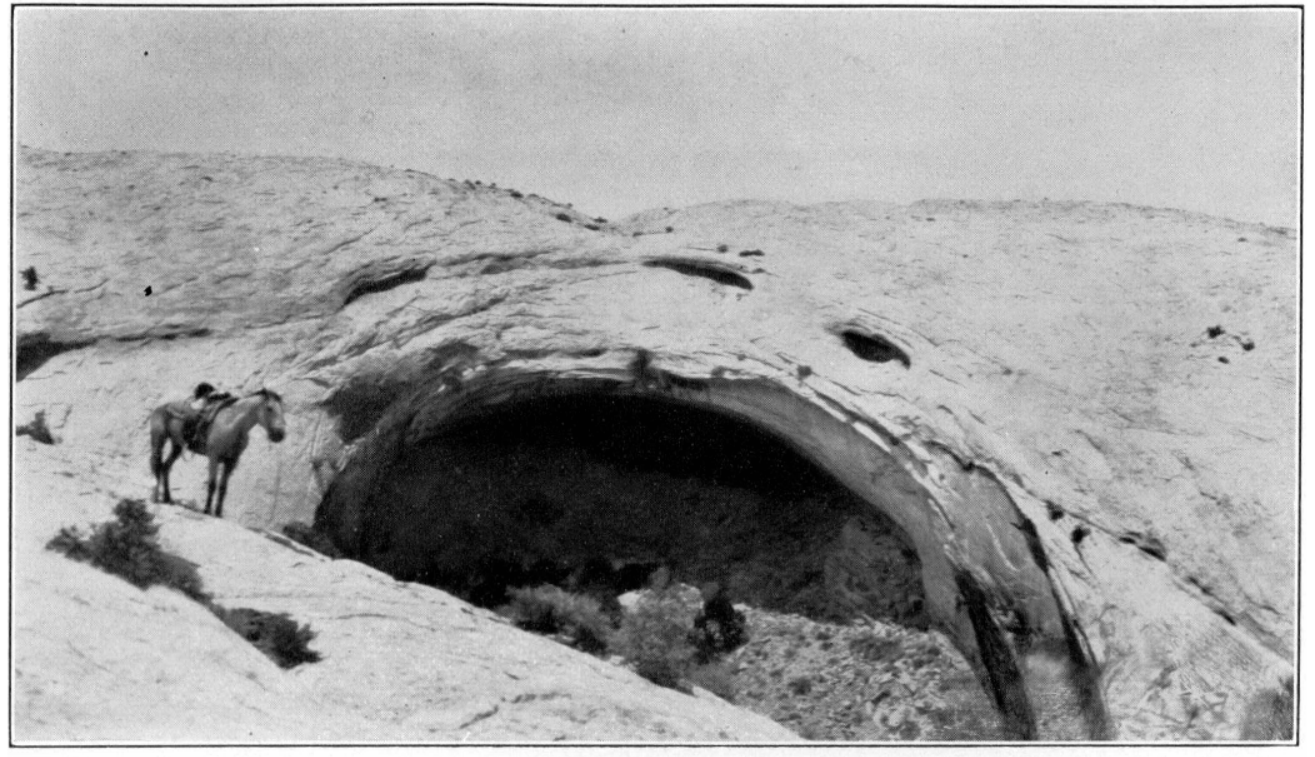

A. FISHMOUTH CAVE.

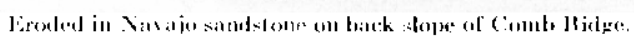

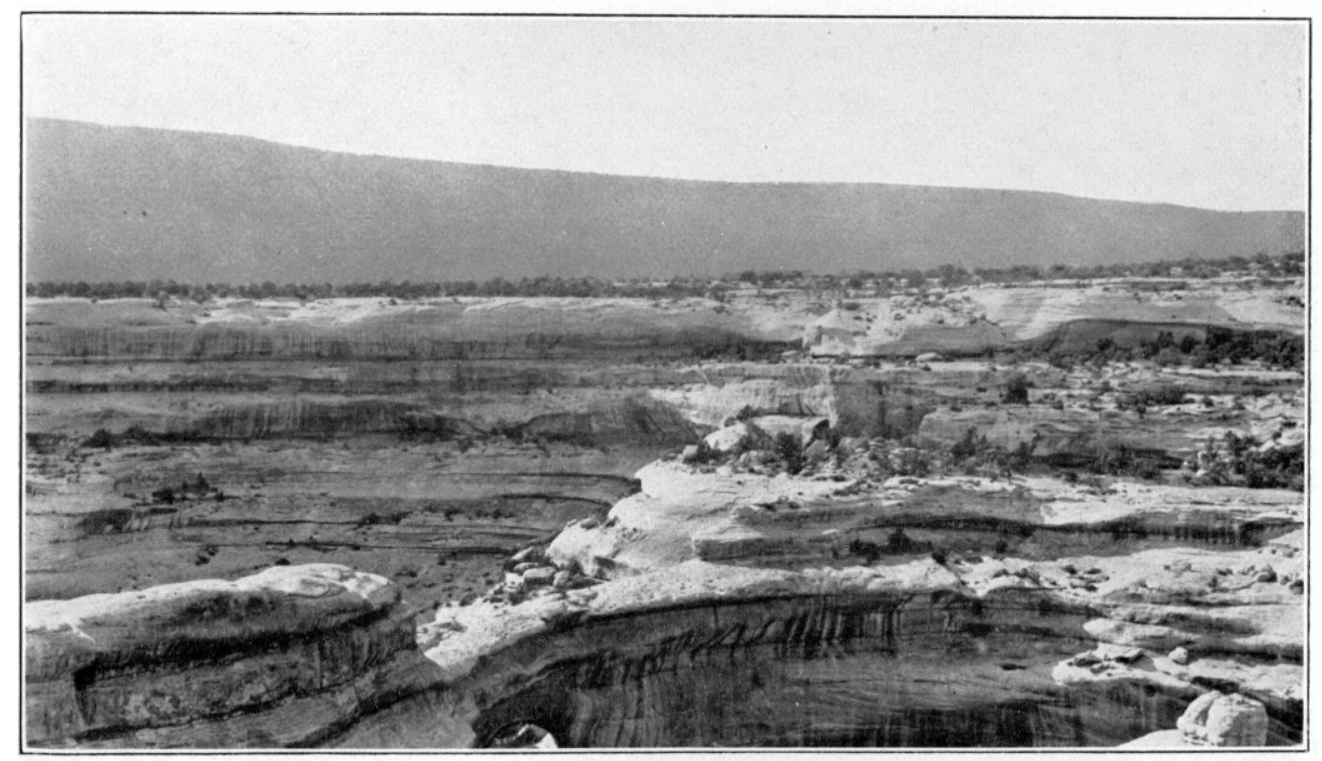

B. VIEW ACROSS WHITE CANYON AT SIPAPU NATURAL BRIDGE.

The canyon at this place is cut 600 feet in Cedar Mesa sandstone. In foreground, neck of abandoned meander through
which stream now flows.

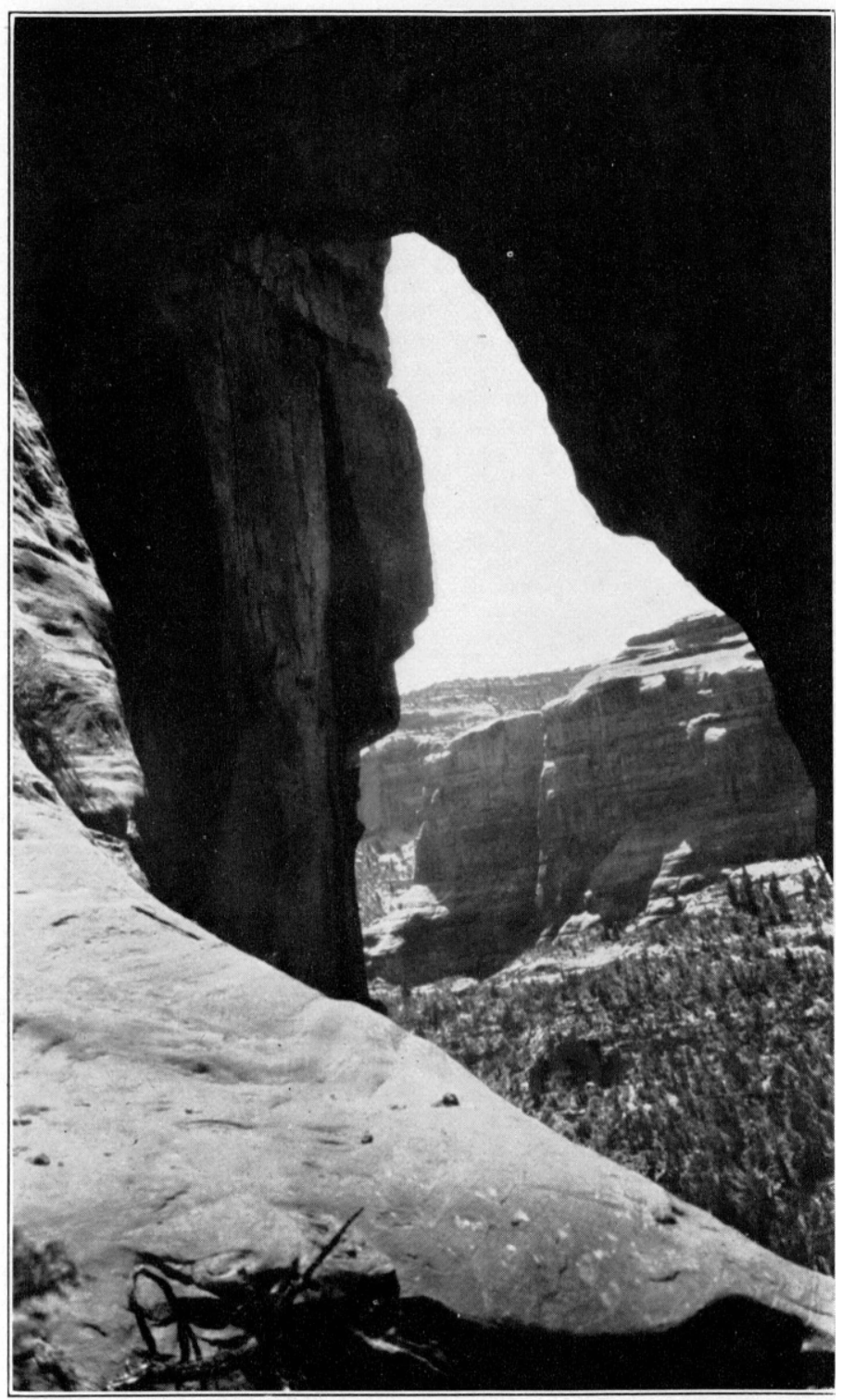

C. CATHEDRAL ARCH, ARCH CANYON. Cidlar Mrsi samlston. 


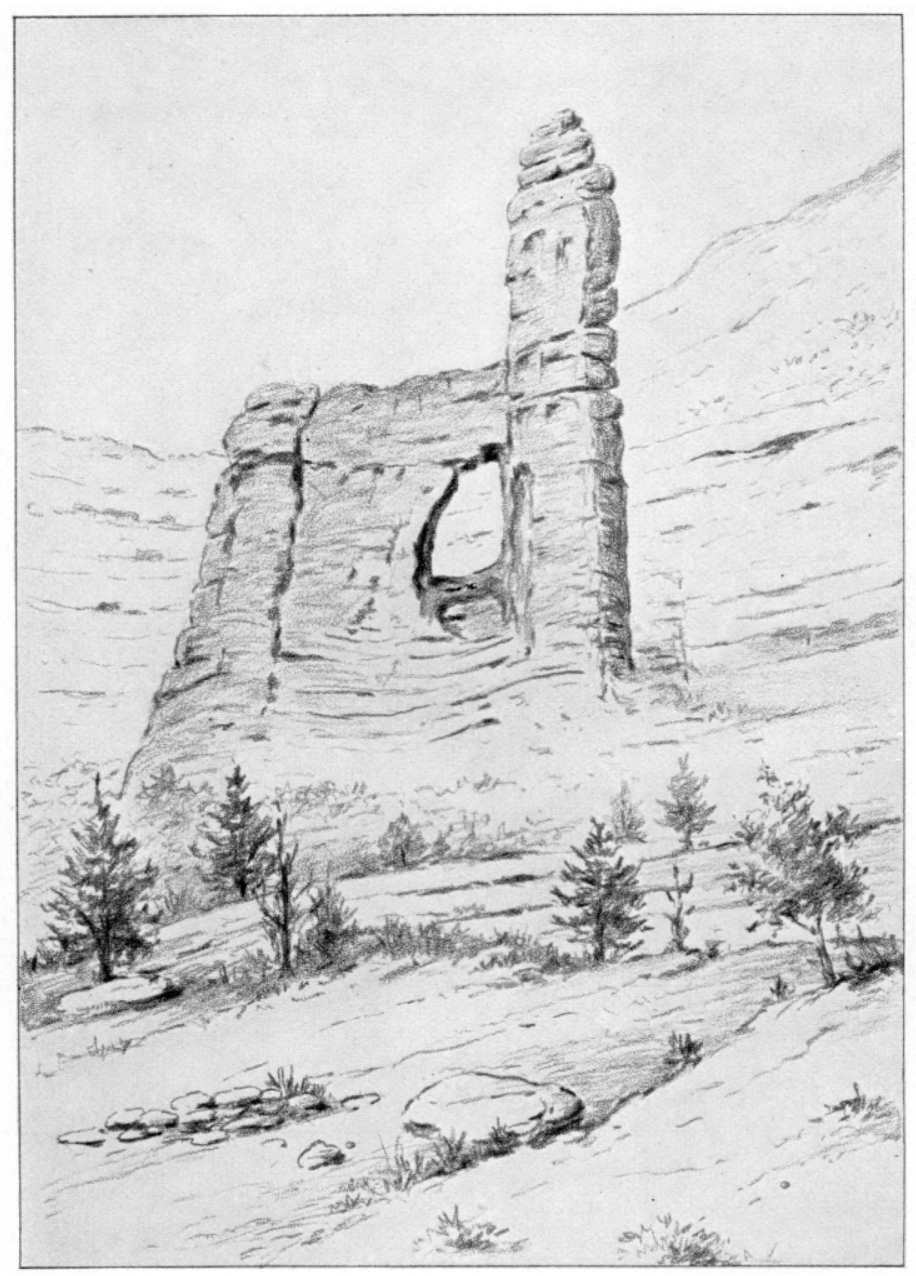

A. CATHEDRAL ARCH.

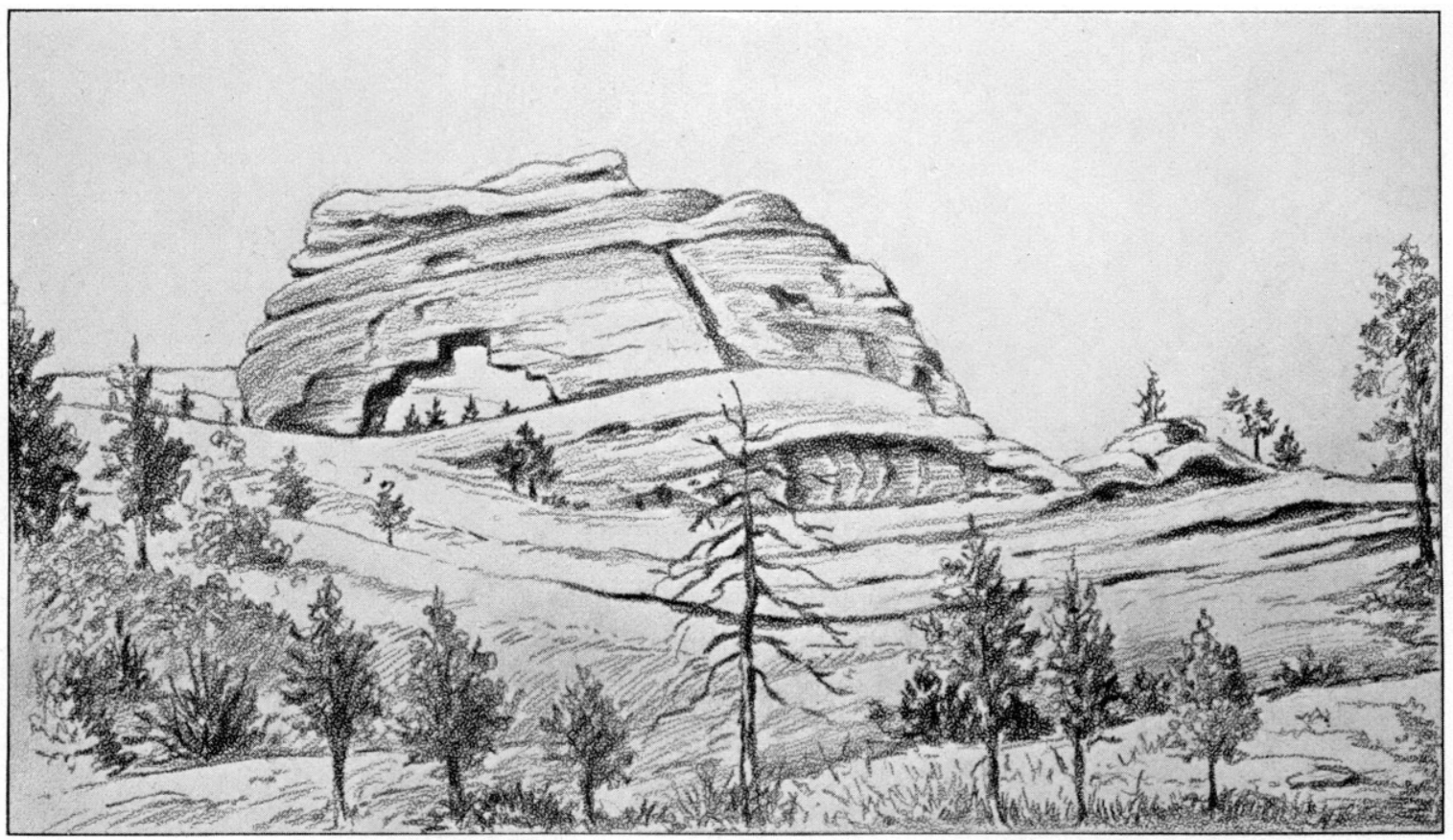

B. KEYSTONE ARCH 

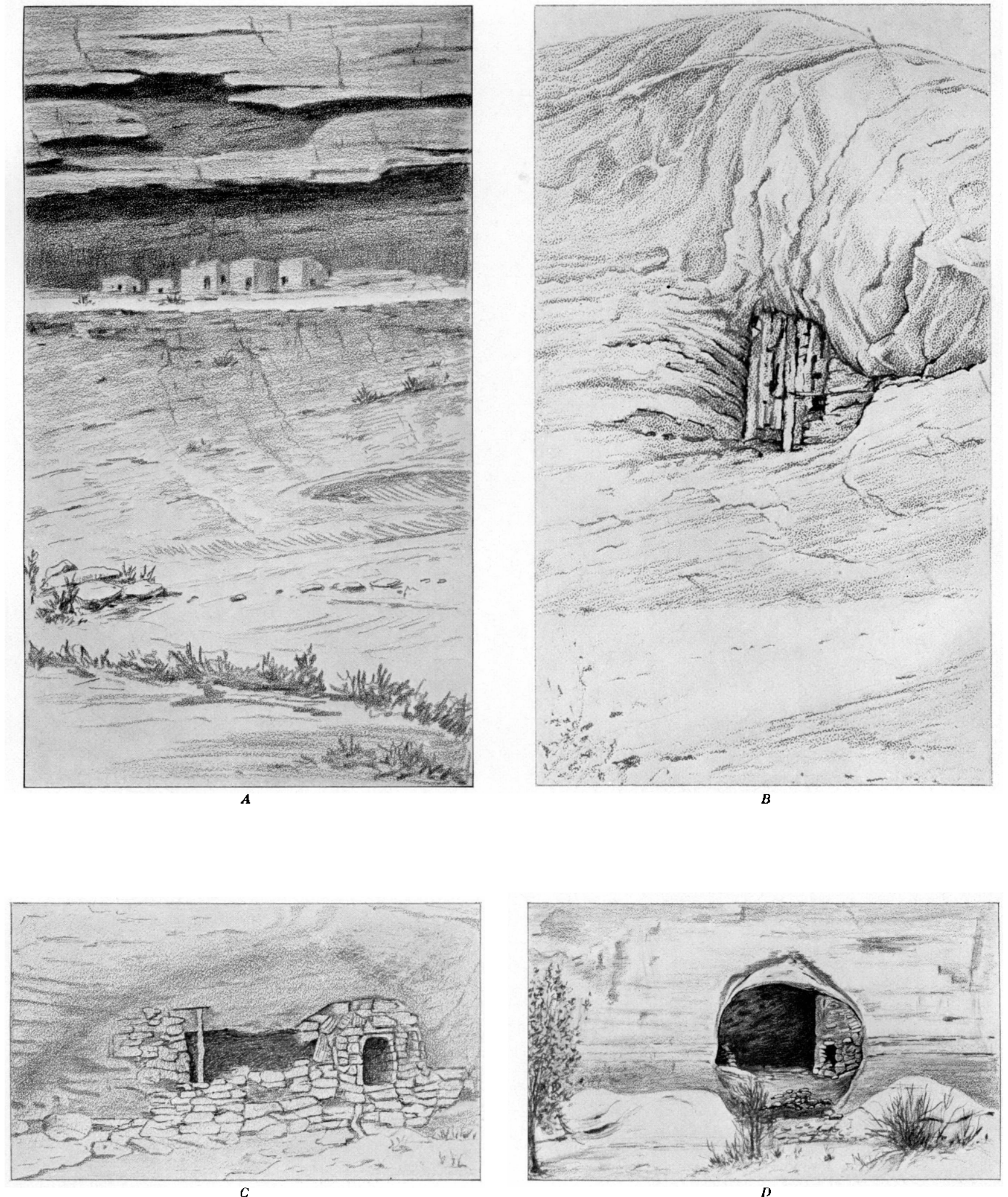

ROCK SHELTERS.

$A, B, C$. In Cedar Mesa strata in White Canyon. D. In Bluff sandstone member of the Morrison on the north kide of San Juan River near Bluff. 

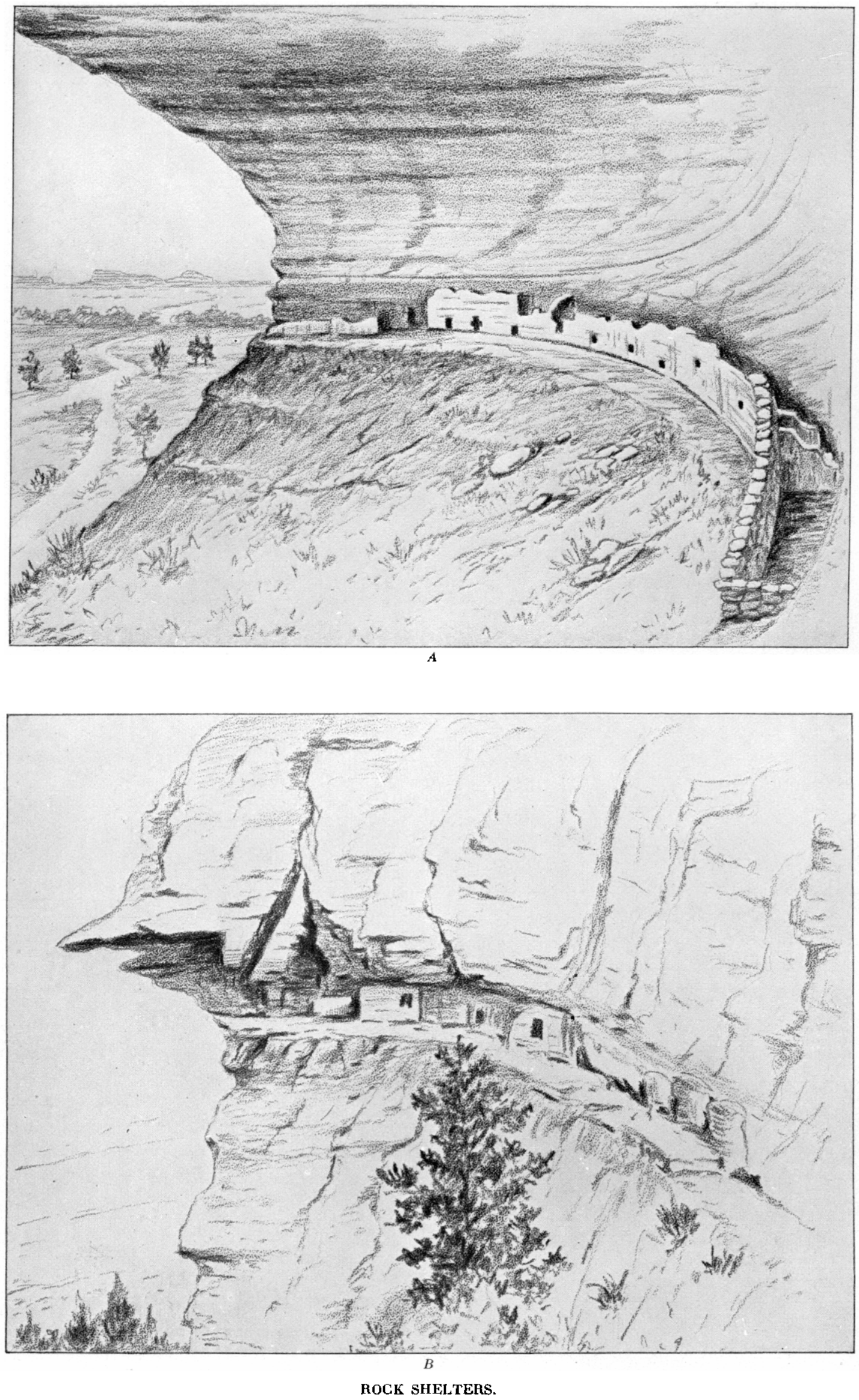

A. At contact of Bluff sandstone and San Rafael strata on the south side of San Juan River near Bluff. (After Jackson, W. H., U. S. Geol. and Geog. Survey Terr. 10th Ann. Rept. for 1876, pl. 49, 1878.) B. In Cedar Mesa sandstone, Foble Vailey. 


\section{Chapter 6. ECONOMIC GEOLOGY}

The San Juan country is poorly supplied with minerals of economic interest. Gold is a constituent of the gravel in the San Juan and Colorado Canyons and of the contact rocks of the Abajo Mountains; copper sufficient for mill tests is iucluded in the "green spots" of several sedimentary formations; vanadiumuranium minerals, largely carnotite, appear here and there in Morrison sandstone; and concretionary masses of manganese and iron are common. None of these minerals have been found in quantities that justify commercial exploitation. Likewise the coal seams in the Dakota (?) shales are too thin and too discontinuous to repay the cost of mining, and the petroleum obtained after expending "more than $\$ 2,000,000$ " in development is valued at "a few thousand dollars." Stone suitable for the construction of buildings is abundant, and lime could be manufactured from beds in the Hermosa and Rico formations of Lime Creek Valley. The one economic resource of high value is the water available in the streams about the Abajo Mountains and Elk Ridge, in the San Juan River, in springs, and in artesian wells.

\section{COPPER}

\section{DISTRIBUTION AND ORIGIN}

Malachite, azurite, chalcocite, and other copper minerals are widely distributed in the San Juan country. In small quantities they are constituents of the Triassic, Jurassic, and Cretaceous beds, particularly of the Chinle, the Shinarump, and the Navajo formations, where they appear along joints, bedding planes, and cross-bedded laminae, in spherical and lenticular areas of copperimpregnated sandstone, and as widely scattered grains in the calcareous cement that surrounds quartz grains. The copper ore is restricted to the sedimentary beds, and the largest accumulations are on folds and minor wrinkles in regions where the continuity of the strata has been interrupted by closely spaced jointing, fissuring, and incipient faulting. No ore has been found within intrusive rocks or in such relations to them as to suggest igneous origin.

All the copper deposits in the San Juan country are "red beds" ores of the type found in sandstones at many other places in the plateau province and in Colorado and Texas as well.

The deposits are small and difficult of access. Mines in the Abajo Mountains and in White Canyon have proved to be unprofitable.

\section{COPPER QUEEN MINE}

In the Abajo Mountains the Dakota (?) and Navajo sandstones show areas impregnated with coppergreen spots on otherwise red or gray rock. Samples from such spots contain copper in considerable quan. tity. The Copper Queen mine, in North Canyon, has been developed by the construction of two tunnels, three shafts, and an open cut. From one of the shafts a lenticular mass of malachite 2 feet wide is said to have yielded $\$ 14$ a ton. The ore is in Dakota (?) sandstone, here quartzitic, and is concentrated in a zone of fractures.

\section{DOLLY VARDEN AND BLUE DIKE MINES}

In White Canyon many prospect holes record the hope that blue-stained sandstones in the Shinarump and Chinle formations might mark the position of workable deposits of copper ore. Prospecting began as early as 1880 (?) and was especially active in 1906 and 1907, when the price of copper attained high levels. As late as 1916 ore was sent to the mill for testing. The mining claims considered most promising are the Dolly Varden, Blue Dike, and Frey Cabin. At Dolly Varden, about 10 miles from the mouth of White Canyon, a mineralized zone of white sandstone is about 500 feet long, 200 feet wide, and 1 to 20 feet thick. A tunnel driven about 180 feet into the deposit at the base of the Shinarump shows considerable copper irregularly distributed along the bedding and tiny fissure planes, in amounts decreasing with depth, with distance from fracture zones, and with scarcity of fossil plants. As shown by laboratory tests, the ore is chiefly bornite, replaced in part by chalcocite, and the black minerals cementing the grains are cobalt oxides.

At Blue Dike, about 15 miles from the mouth of White Canyon, copper minerals associated with plant remains are exposed in a lens of sandstone about 200 feet long and 1 to 10 feet thick. The outcrop and the walls of an old tunnel are coated with efflorescent salts. As determined by Butler, ${ }^{79}$ the blue and green salts are sulphates of copper, the yellow salts are sulphates of uranium, and the pink salts give tests for cobalt. The ores studied contain chalcopyrite, covellite, and chalcocite. Butler states: "There seems little doubt that the iron, cobalt, and uranium were all present in the sulphide ore."

it Butler, B. S., Loughlin, G. F., Heikes, V. C., and others: The ore deposits of Utah: U. S. Geol. Survey Prof. Paper, 111, p. 622, 1920. 
Near the mouth of Frey Canyon copper ore is revealed in several prospect holes, the so-called Harshberger claims.

\section{GOLD}

In the San Juan country gold has been recovered from placers in the San Juan Valley, in Glen Canyon, and in Johnson Creek and from mines developed in the mineralized zone near the roof of the Abajo Mountain laccolith. In pioneer history the search for gold in the unexplored canyons far from sources of supply is a chapter of absorbing interest, but as a commercial enterprise it has led only to disappointment. With pan and sluice box many prospectors have made day wages, but mining companies whose operations call for the installation of machinery have failed. The value of the gold recovered is an insignificant fraction of the cost.

\section{RIVER PLACERS}

The discovery of gold in gravel along the upper tributaries of the San Juan River led to a search for the metal throughout its course. Starting from Animas City, Colo., in 1879, E. L. Goodridge worked his way by boat to the mouth of the San Juan-the first known traverse of the river. He discovered flake gold at several places but gave discouraging reports regarding quantity and cost of recovery. After the settlement of Bluff (1880) some gold was panned by a Mr. Moss and others in sand bars above the mouth of Recapture Creek. Intermittent prospecting by local residents continued until 1891, when from unknown sources-chiefly, it seems, from the notorious Indian trader, Bill Williams-rumors spread that the gravel bars and terraces in the San Juan Canyon were rich in gold, particularly in the stretch below Clay Hill Crossing. Thus originated the "Bluff excitement" of 1892-93. A. L. Raplee reports that during these years some 1,200 men were working along the river between the mouth of Montezuma Creek and Glen Canyon. "Every sand bank and gravel bar was prospected and mud dipped out of the river's bed." To reach claims in the deepest part of the canyon the famous Honaker trail was built. Most of the prospectors returned empty-handed, a few obtained some gold, and it is reported that the Nephi claim yielded the equivalent of $\$ 3,000$. Since 1893 the unprofitable search for gold along the San Juan has been continued at Zahns Camp, at Spencer Camp, near the mouths of Montezuma and Copper Canyons, and at other places thought favorable.

In Glen Canyon placer gold was discovered near the mouth of Trachyte Creek by Cass Hite in 1883, and during the period 1886-89 mining was vigorously in progress at claims on 21 bars distributed along the river from the mouth of White Canyon nearly to Lees Ferry. Since that time the most promising claims have been worked intermittently. In 1927 the only man on the Colorado River in the San Juan country was a prospector at the mouth of Red Canyon.
In Glen Canyon all the gold obtained has the form of flour or microscopic flakes and when concentrated in the rockers and sluice boxes is accompanied by black sands--mostly magnetite and hematite but also garnet, zircon, rutile, and other resistant minerals. The tiny particles of gold are thoroughly disseminated within the bars exposed at high water and in those perched higher on the canyon walls. It seems equally abundant "at the grass roots", within the gravel, and just above bedrock but is most concentrated in thin short streaks of "blue marl" and "red marl"-impalpable sticky mud, readily disintegrated in water. Samples from this material showed as much as 0.06 ounce of gold to the ton.

The gold in the placers of the San Juan and Colorado Rivers is believed to have two sources. Some of it, doubtless, has been derived from areas of disintegrated auriferous rock in Colorado, transported and deposited by the present streams during their long life. The shape and size of the particles that make up the flour gold in Glen Canyon render them suitable for long transportation by streams of moderate volume and for deposition without marked sorting. Likewise the largest of the tiny flakes in the San Juan Canyon are like those mined along the Animas and other tributaries that rise in the gold-bearing San Juan Mountains. Probably most of the gold is derived from erosion of the Jurassic and Triassic rocks into which Glen Canyon, San Juan Canyon, and their many tributaries have been cut. These rocks, particuarly the Chinle, Wingate, and Navajo formations, are known to contain gold in amounts that average something like 5 cents a cubic yard. Some dunes made of disintegrated sandstone are as rich in gold as some of the river silts and gravel. Placer mining in San Juan and Glen Canyons is further discussed in reports previously published by the Geological Survey. ${ }^{80}$

\section{GOLD IN THE ABAJO MOUNTAINS}

Systematic search for gold in the Abajo Mountains began about 1892, at the time of the "gold rush" on the San Juan. In fact, many of the early prospectors were men whose experiences in mining on the river below Bluff had proved disappointing. After the discovery of placer gold in the bed of Johnson Creek and of ore at the head of that stream in 1893 , the mountains were thoroughly explored, some 300 claims were staked, and many thousand dollars was expended in the construction of shafts, tunnels, and mills. The ruins of workings appear at many places, and the mountains are pitted with prospect holes from which samples of ore were taken. On some claims assessment work is

\footnotetext{
${ }^{20}$ Gregory, H. E., Geology of the Navajo country, a reconnaissance of parts 0 . Arizona, New Mexico, and Utah: U. S. Geol. Survey Prof. Paper 93, pp. 139-140, 1917. Butler, B. S., Loughlin, G. F., Heikes, V. C., and others: The ore deposits of Utah: U. S. Geol. Survey Prof. Paper 111, pp. 152-158, 1920. Miser, H. D., The San Juan Canyon of southwestern Utah: U. S. Geol. Survey Water-Supply Paper 538, pp. 21-22, 1924. Gregory, H. E., and Moore, R. C., The Kaiparowits region, a geographic and geologic reconnaissance of parts of Utah and Arizona: U. S. Geol. Survey Prot. Paper 164, pp. 147-148, 1931.
} 
kept up, and prospecting intermittently continues in places that are still considered promising; but in the opinion of experienced miners the unfruitfulness of the Abajo Mountains as a gold country has been demonstrated. The results of mineral exploitation bear out the prediction of Gilbert ${ }^{81}$ that, as in the Henry Mountains, "gold and silver will not be found in paying quantity in Navajo Mountain, the Sierra La Sal, the Sierra Abajo, the Sierra Carisso [Carrizo], or the Sierra La Plata [Ute Mountain?]." It seems that the quantity of metalliferous material in the original igneous masses of these laccoliths was too small and the changes incident to cooling at the contacts too slight to develop large ore bodies.

From a manuscript descriptive of gold mining in the Abajo Mountains prepared by Malcolm R. Thorpe in 1915, the following information has been abstracted:

Sometime previous to 1892 Frank Dixon, the pioneer prospector in the Abajo Mountains, located several gold claims at the head of Dixon Gulch, between South Peak and Gold Queen Gulch, on a mineralized belt about 500 feet wide at the contact of Dakota (?) sandstone and blue porphyry. No gold was found on the surface or in the many tunnels driven into the mountain. The last work on this property was done about 1900 .

In the cement of stream and terrace gravel along Johnson Creek at the base of the Abajo Mountains two prospectors, Parker and Owens, discovered placer gold in 1893. Within a few months the deposit was exhausted, and, the "Johnson Creek placer boom" collapsed.

In an effort to relocate the old "Spanish mine", said to have been worked " 300 years ago before it was buried in a landslide", Andrew Straus located the Alma mine, at the south base of South Peak, in 1900 and, taking into partnership William Straus and S. J. Houser, worked the property for some years. Several tunnels driven into a mineralized zone in the porphyry yielded no valuable minerals, but a small amount of free gold was found nearby on Recapture Creek. That some gold-bearing ore was shipped from this vicinity is shown by records at Santa Fe.

The Gold Queen mine, at the head of Gold Queen Gulch, southeast of Abajo Peak, was once the scene of considerable activity. The discovery of a small vein of rich ore led to the construction of two tunnels, three shafts, cabins for miners, and a mill, at a reported cost of about $\$ 80,000$. The mine is located on a mineralized zone about 600 feet wide that crosses the crest of a ridge. The igneous rock in this contact zone is filled with minute veins of iron ore, a little copper ore, and calcite. Extensive exploration by Carlson, Olsen, and Innis proved that the ore-bearing veins were tiny and the gold in them superficial. Operations were suspended about 1903 .

\footnotetext{
ot Gilbert, G. K., Geology of the Henry Mountains, 2d ed., p. 146, U. S. Geol. and Geog. Survey Rocky Mtn. Reglon, 1880.
}

The Viking mine, located by James Hewett and Henry Rose on the ridge northeast of the Dream mine, was developed by sinking two shafts and driving a tunnel 400 feet long into the mountain at the contact between porphyry and Dakota (?) sandstone. No valuable ore was found. Just east of the Viking mine the owners of that property staked out the Log Cabin claim and sunk a shaft and a tunnel into the decomposed igneous rock near its upper contact. Small fissures in this rock are filled with iron ore and calcite associated with gold in amounts too small for profitable mining.

At the Duckett mine, on Duckett Ridge east of Mount Linnaeus, a shaft 35 feet deep has been sunk by the owners, J. A. and J. B. Duckett. A little ore taken from a narrow bank at the contact between porphyry and a metamorphosed calcareous bed in the Morrison formation showed "a few dollars per ton."

The Enterprise mine, on the first ridge west of the Viking mine, has been developed by a shaft and tunnel at the contact of porphyry with Dakota (?) sandstone and Mancos shale. Seams in the Dakota (?) are filled with a fine mesh of quartz crystals. The Mancos includes vugs and seams that contain minute crystals of quartz and calcite. It is reported that before the property was abandoned ore containing silver and gold was mined.

The Dream mine, a group of seven claims at the head of Johnson Creek, was located by C. A. Cooley and S. J. Houser in 1893. After working the mine intermittently for 6 or 8 years, Cooley leased his interest to C. W. Houser, who is said to have taken out and sent to the mill $\$ 3,000$ in gold. While the Housers controlled the property, Capt. Calvin Jackson, of Colorado, leased the Dream mine from them and founded Camp Jackson, where he built the first stamp mill in the mountains. His violent death soon after the mill was constructed ended the "Camp Jackson boom." Then the Housers failed, and the Dream mine changed hands several times until it came into the charge of $\mathrm{A}$. P. Adams, who built roads and a stamp mill at a cost of about $\$ 35,000$. After this Hansen and Young expended about $\$ 20,000$, only to fail after extracting a small amount of gold. The Alamo Mining Co. next came into possession of the property, spent several thousand dollars in working it, then failed, and sold out to the present owners, S. J. and C. W. Houser. The mine workings consist of more than 2,000 feet of tunnels and crosscuts on three levels, two shafts, and a stamp mill. The tunnels are designed to penetrate the mineralized zone at the contact of the laccolith and its roof. The most valuable ore is near the surface. The gold is confined to the bedding planes of the metamorphosed sedimentary rocks and to a thin zone of igneous rock. All the ore is free-milling. Most of it has the form of fine flakes, but nuggets as large as nail heads have been found. A small amount of copper is present but not enough to prevent the use of cyanide. At the 
end of the largest tunnel the gold ore is a conglomerate of fragments of porphyry and argillite with much iron pyrite that has a reported value of $\$ 1$ to $\$ 27$ a ton. In one of the crosscut tunnels gold has been found in a breccia composed of fragments of Dakota (?) sandstone, Morrison shale, and blue porphyry. In another tunnel a band of sulphide ore was encountered. According to the owners 50 tons of rich ore is stored in the mine, 3,000 tons is on the dump, and 6,000 tons is in sight in the underground workings. S. J. Houser, who as owner or operator has been connected with the property since its discovery in 1893 , states that the large sums spent on the development of the Dream mine and the nearby Goodhope and Puzzle workings have yjelded returns.

The Illinois mine, on the west side of North Canyon between Innis' sawmill and the Copper Queen mine, was discovered some 35 years ago by Martin Hobbs. The workings consist of a shaft, three tunnels, and an open cut, and the property includes a stamp mill and crusher. The most extensive work was done on a tunnel 500 feet long that penetrates in turn 106 feet of Dakota (?) quartzite, 26 feet of porphyry, 62 feet of quartz, $10 \frac{1}{2}$ feet of Morrison shale, 7 feet of porphyry, and 14 foet of decomposed oxidized rock and terminates in mineralized porphyry. Mr. Innis, one of the present owners of the mine, states that a band of oxidized rock 260 feet from the entrance of the tunnel yielded $\$ 8$ to $\$ 40$ a ton in gold and that a streak of black rock less than 1 inch wide was even richer. The bulk of the ore is of low grade.

\section{COAL}

Coal appears at many places in eastern San Juan County as beds in the Dakota (?) formation. Its usual expression is a series of short, thin carbonaceous lenses that include bituminous shale, carbonaceous shale, and layers of macerated plants as well as true coal. Tracing of coal lenses along outcrops shows a wide range in thickness and purity within distances of a few hundred feet. No thick beds and no continuous beds of uniform quality were seen; the region contains no deposits of large commercial value. However, a detailed study by Boyer ${ }^{82}$ of exposures in the region about Blanding and Monticello and eastward to the Colorado line shows that coal for local domestic use may be found at several localities.

Along Recapture and Johnson Creeks outcrops examined show only thin streaks of carbonaceous and bituminous shale. Near Monticello several openings reveal coal stringers 2 to 10 inches thick, and at a place 4 miles north of the village a short bed 2 feet 9 inches thick is reported, but most of the coal produces much ash and clinker, and its mining involves the removal of

Boyer, W. W., Coal in the Dakota (?) formstion in southwestern Colorado and eastern Utah (manuseript on file. U. 8. Geol. Survey).

large amounts of "bone" and country rock. It is unlikely to be much used until the abundant supply of wood fuel is exhausted. About 2 miles northeast of Lockerby post office coal exposed in a shallow wash tributary to Coal Bed Canyon yields fuel sufficient for local use. The characteristics of the beds in four prospect holes are illustrated by the following section of the Crepo mine measured by Boyer:

\section{Section in Crepo mine}

Sandstone, gray to buff, medium-grained, cross-bedded _ $\quad 17$

Shale, carbonaceous $\ldots \ldots$

Shale, gray, sandy $\ldots \ldots \ldots$

Coal, streaked with shale

Shale, gray $\ldots \ldots \ldots \ldots$

Coal, bony

Shale, carbonaceous, and streaks of poor coal

Shale, gray, floor $\ldots \ldots$

Ft. in. 17

6

9

10

7

9

i

In Piute Draw near Ucolo, where several small mines are intermittently worked, the thin coal beds are of fair quality. The beds are remarkably discontinuous. In no two of the six mines and prospect holes is the same bed visible. The arrangement of beds is illustrated by the following two sections measured by Boyer:

Section in Rassmussen mine, at Ucolo, 80 feet from the mouth of Piute Draw

Sandstone roof.

Ft. in.

Shale, gray .......

Coal, dirty, and streaks of bituminous shale.........

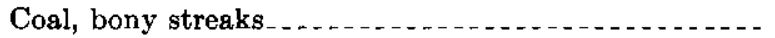

Coal, dirty, and streaks of bituminous shale.......

Bone

Coal

Shale floor.

Section in Pendergraff mine, Piute Draw, 1 mile east of UtahColorado boundary

Sandstone, gray, quartzitic on top surface $\ldots \ldots \ldots 10$

Clay, gray and blue

Shale, carbonaceous.

Shale, carbonaceous, and bony coal intermixed.....

Shale, red and yellow; appears burned(?) $\ldots \ldots \ldots$.

Shale, bituminous, and streaks of coal...........

Shale, blue, sandy, with carbonaceous layers. . . . . .

Coal and carbonaceous shale intermixed . . . . . . .

Bone, dense, hard, sandy . . . . . . . . . . . . . . .

Coal, good.

Shale, blue, floor.

As shown by the analyses given below, the coal mined at Ucolo is of better quality than the coal from Cortez and inferior to that from Nucla, Colo. As the heating value of the coals from these three adjoining localities, calculated on moisture- and ash-free content, is essentially the same, the difference in quality is the result of impurities. The table of analyses shows also the quality of coal from the Book Cliffs-a region that would be a competitor if the coal from San Juan County were to be commercially exploited. 
ECONOMIC GEOLOGY

Analyses of coal from the San Juan country and the Book Cliffs

\begin{tabular}{|c|c|c|c|c|c|c|c|c|c|c|c|c|c|}
\hline \multirow[b]{2}{*}{ Source } & \multicolumn{3}{|c|}{ Location } & \multirow[b]{2}{*}{$\begin{array}{c}\text { Laborstory } \\
\text { no. }\end{array}$} & \multirow[b]{2}{*}{$\begin{array}{l}\text { Air- } \\
\text { drying } \\
\text { loss }\end{array}$} & \multirow[b]{2}{*}{$\left|\begin{array}{l}\text { Form of } \\
\text { anslysis }\end{array}\right|$} & \multicolumn{5}{|c|}{ Proximate anslysis } & \multicolumn{2}{|c|}{ Heating value } \\
\hline & Sec. & $\mathrm{T}$. & R. & & & & $\begin{array}{l}\text { Mois- } \\
\text { ture }\end{array}$ & $\begin{array}{l}\text { Volatile } \\
\text { matter }\end{array}$ & $\begin{array}{l}\text { Fixed } \\
\text { carbon }\end{array}$ & Asb & Sulphur & Calories & $\begin{array}{l}\text { British } \\
\text { thermal } \\
\text { units }\end{array}$ \\
\hline Drott mine, Nucla_.... & 13 & $46 \mathrm{~N}$. & $16 \mathrm{~W}$ & A. 14442 & 1. 1 & $\begin{array}{l}\mathbf{A}_{----} \\
\mathbf{B}_{-\cdots-} \\
\mathbf{C}_{-\cdots}\end{array}$ & $\begin{array}{c}2.5 \\
-\ldots\end{array}$ & $\begin{array}{l}32.5 \\
33.3 \\
38.0\end{array}$ & $\begin{array}{l}52.9 \\
54.3 \\
62.0\end{array}$ & $\begin{array}{l}12.1 \\
12.4 \\
-.--\end{array}$ & $\begin{array}{l}.8 \\
.9 \\
1.01\end{array}$ & $\begin{array}{l}6,933 \\
7,111 \\
8,122\end{array}$ & $\begin{array}{l}12,480 \\
12,800 \\
14,620\end{array}$ \\
\hline Oberding mine, Nucla..- & 36 & $47 \mathrm{~N}$ & $16 \mathrm{~W}$ & A. 14444 & 4. 2 & $\begin{array}{l}\mathbf{A}_{----} \\
\mathbf{B}_{----} \\
\mathbf{C}_{----}\end{array}$ & $\begin{array}{c}6.5 \\
----- \\
------\end{array}$ & $\begin{array}{l}33.0 \\
35.2 \\
39.4\end{array}$ & $\begin{array}{l}\text { 50. } 7 \\
54.3 \\
60.6\end{array}$ & $\begin{array}{c}9.8 \\
10.5 \\
-\end{array}$ & $\begin{array}{l}\text { 1. } 1 \\
\text { 1. } 1 \\
\text { 1. } 3\end{array}$ & $\begin{array}{l}6,861 \\
7,339 \\
8,200\end{array}$ & $\begin{array}{l}12,350 \\
13,210 \\
14,760\end{array}$ \\
\hline $\begin{array}{l}\text { Rassmussen m i n e, } \\
\text { Ucolo-bone and bi- } \\
\text { tuminous - shale lay- } \\
\text { ers. }\end{array}$ & 35 & $33 \mathrm{~S}$. & $26 \mathrm{E}$ & 86825 & 1. 7 & $\begin{array}{l}\mathbf{A}_{----} \\
\mathbf{B}_{-\cdots-} \\
\mathbf{C}_{----}\end{array}$ & $\begin{array}{c}2.7 \\
----\end{array}$ & $\begin{array}{l}\text { 24. } 1 \\
24.7 \\
36.2\end{array}$ & $\begin{array}{l}42.3 \\
43.6 \\
63.8\end{array}$ & $\begin{array}{l}30.9 \\
31.7 \\
-\end{array}$ & $\begin{array}{l}2.0 \\
2.9\end{array}$ & $\begin{array}{l}5,167 \\
5,311 \\
7,774\end{array}$ & $\begin{array}{r}9,300 \\
9,560 \\
14,000\end{array}$ \\
\hline $\begin{array}{l}\text { Rassmussen } \mathrm{m} \text { i } \mathrm{n} \mathrm{e}, \\
\text { Ucolo-coal. }\end{array}$ & 35 & $33 \mathrm{~s}$. & $26 \mathrm{E}$. & 86825 & 3. 3 & $\begin{array}{l}\mathbf{A}_{\ldots--} \\
\mathbf{B}_{-\cdots} \\
\mathbf{C}_{-\ldots}\end{array}$ & $\begin{array}{c}4.3 \\
-\ldots-\end{array}$ & $\begin{array}{l}32.3 \\
33.8 \\
38.2\end{array}$ & $\begin{array}{l}52.3 \\
54.6 \\
61.8\end{array}$ & $\begin{array}{l}11.1 \\
11.6 \\
-\end{array}$ & $\begin{array}{l}\text { 3. } 8 \\
\text { 3. } 9 \\
\text { 4. } 5\end{array}$ & $\begin{array}{l}6,933 \\
7,244 \\
8,194\end{array}$ & $\begin{array}{l}12,480 \\
13,040 \\
14,750\end{array}$ \\
\hline $\begin{array}{l}\text { Mowry mine, near } \\
\text { Cortez, Colo. }\end{array}$ & 35 & $36 \mathrm{~N}$. & $16 \mathrm{~W}$ & 12586 & 3. 1 & $\begin{array}{l}\mathbf{A}_{-\cdots-} \\
\mathbf{B}_{----} \\
\mathbf{C}_{----}\end{array}$ & $\begin{array}{c}4.84 \\
-\ldots\end{array}$ & $\begin{array}{l}\text { 34. } 56 \\
36.32 \\
44.97\end{array}$ & $\begin{array}{l}42.30 \\
44.45 \\
55.03\end{array}$ & $\begin{array}{c}18.30 \\
19.23 \\
-\end{array}$ & $\begin{array}{l}7.56 \\
7.94 \\
9.83\end{array}$ & $\begin{array}{l}6,147 \\
6,460 \\
7,998\end{array}$ & $\begin{array}{l}11,065 \\
11,625 \\
14,396\end{array}$ \\
\hline $\begin{array}{l}\text { No. } 1 \text { mine, American } \\
\text { Fuel Co., Book Cliffs, } \\
\text { Utah } \rightarrow \text { middle bed. }\end{array}$ & 27 & $20 \mathrm{~s}$. & $20 \mathrm{E}$. & 17577 & 2.0 & $\begin{array}{l}\mathbf{A}_{-\cdots-} \\
\mathbf{B}_{-\cdots-} \\
\mathbf{C}_{----}\end{array}$ & $\begin{array}{c}7.13 \\
---- \\
-----\end{array}$ & $\begin{array}{l}37.03 \\
39.87 \\
44.92\end{array}$ & $\begin{array}{l}45.40 \\
48.89 \\
55.08\end{array}$ & $\begin{array}{c}10.44 \\
11.24 \\
--.--\end{array}$ & $\begin{array}{l}.66 \\
.71 \\
.80\end{array}$ & $\begin{array}{l}6,509 \\
7,009 \\
7,896\end{array}$ & $\begin{array}{l}11,716 \\
12,616 \\
14,213\end{array}$ \\
\hline
\end{tabular}

1 A, As received; B, moisture-free; C, moisture- and ash-free.

OIL

\section{DISTRIBUTION}

After his discovery of "little streams of oil coming from loose boulders on the bottom of the [San Juan] canyon" above the mouth of Slickhorn Gulch, in 1879 , E. L. Goodridge located an oil claim near the present Goodridge bridge on the San Juan (1882), where "rock beds like those at the oil seeps are bent down into a basin." After discouraging efforts, funds necessary to develop the claim were obtained in 1907 , and on March 4, 1908, oil was struck at a depth of 225 feet"a gusher, throwing oil to a height of 70 feet above the floor of the derrick." The success of this pioneer well (Crossing No. 1) led to the drilling of more than 50 wells in the Goodridge field and adjoining regions and to the study of oil possibilities in all southeastern Utah. Most of the geologic investigation and most of the development has been along the San Juan River, but potential oil-bearing anticlines have been mapped at Fish Creek, Elk Ridge, and Beef Basin, and some hundreds of claims have been staked on northern Sage Plain, Grand Gulch Plateau, and westward to Glen Canyon. A deep well has been drilled in Reservoir Canyon, Elk Ridge (1926-27), and another at Boulder Knoll, east of Monticello (1926-28). The $\log$ of the Reservoir Canyon well ("Gerald Hughes No. 1 Elk Ridge well"), made available by the Midwest Refining Co., shows that the drill penetrated 4,422 feet of strata, chiefly limestone, in the Rico and older formations and terminated in "granite schist." Fresh water was encountered at 3,000 feet, and salt water at 2,595 and
4,090 feet, but no oil at any horizon. This well may reasonably be cited as proof of the nonproductiveness of the anticlines on the crest of the Monument upwarp.

The well at Boulder Knoll, in sec. 17, T. 34 S., R. $25 \mathrm{E}$., about 6 miles southeast of Monticello, was drilled to a depth of 2,640 feet. Unlike the other wells in the San Juan country it penetrates Cretaceous, Jurassic, and Triassic strata. The well log, furnished by Albert Galloway, of the Boulder Knoll Oil \& Gas Co., shows that water was encountered in Dakota (?) and Morrison beds and "heavy gas" and a "showing of oil" in the Chinle (?). It is reported that gas bubbling through salt water flowed continuously during the winter of 1928-29.

\section{SAN JUAN OIL FIELD}

\section{By H. D. Miser}

OL SEEPS

Several oil seeps deriving their oil from the Hermosa and Rico formations occur in the bottom of San Juan Canyon between Goodridge (Mexican Hat) and the mouth of Slickhorn Gulch. The largest of these is a rather continuous series of seeps extending for a distance of $1 \frac{1}{4}$ miles up the canyon from the mouth of the gulch. The seeps were observed on the right bank of the river; the left bank was not visited. The oil comes up as bubbles in the water and as minute streams through sand and also through boulders of sandstone and limestone at the edge of the water. The boulders, which have fallen from the adjacent cliffs, are cut by cracks through which the oil passes. The drops of oil break on reaching the surface of the river and spread as thin 
iridescent films. The oil is a brown liquid that flows easily, and although its odor is strong the odor of gasoline is not noticeable. A black asphaltic residue cements rather large patches of sand and rock fragments. At one seep a film of oil covering several square feet of a sand bar is used by flies as a breeding place, and hundreds of larvae live in the oily substance on the bare surface of the sand bar, in spite of the intensely hot rays of a summer's sun which beat down on them during the day. Westward-dipping beds of the Hermosa formation, which form the lower canyon walls near the seeps, are cut by a normal fault with a northeastward trend and a downthrow of 4 feet on the east side. The presence of this fault suggests that the oil ascends along the fault plane to the alluvial material, through which it passes to the surface.

Seeps are reported in Johns Canyon about 2 miles above its mouth.

About 1 $1 / 2$ miles southeast of the head of the Honaker trail minute trickles of oil and gas issue from a sand bar in the edge of the river. A chip saturated with the oil was set on fire. Gasoline, as indicated by its strong odor in this part of the eanyon, forms a considerable part of the crude petroleum.

About 4 miles farther upstream a seep is reported on the right bank of the river in or near the Second Narrows.

The Goodridge oil sand, which forms a gorge and a superjacent bench at the Goodridge Bridge, contains small dark areas of oil in its joints and cracks for a distance of 200 feet along the river east of the bridge. The sandstone, which is here 27 feet thick, dips $2^{\circ} \mathrm{E}$.

The Goodridge oil sand also contains showings of oil on the right bank of the San Juan half a mile northeast of the store at Mexican Hat.

\section{DEVELOPMENT}

Of the early development in the San Juan region Woodruff ${ }^{83}$ says:

Though oil springs must have been seen by prospectors and traders who operated along San Juan River, they seem to have received only casual notice until 1882 , when E. L. Goodridge made the first location of a claim. No drilling was done, however, until the fall of 1907, when the first well, Crossing No. 1, was begun. This well encountered oil March 4, 1908, at a depth of 225 feet. It was a gusher, throwing oil to a height of 70 feet above the floor of the derrick, and led to considerable excitement. Other wells followed in rapid succession in 1908 and 1909 , but most of them were only prospect holes put down to validate the titles to claims and not with serious intention of determining the oil resources of the field. By the summer of 1910 considerable capital had been enlisted to exploit the field. One standard rig was in operation, and others were reported to have been ordered. There were 10 portable deep-well rigs in the area and several more on the way to it. During midsummer active development was somewhat retarded on account of the heat, but in the later part of August preparations were made to renew operations with greater vigor than before. Reports received from reliable sources

s3 Woodruff, E. G., Geology of the San Juan oil field, Utah; U. S. Geol, Survey Bull. 471, pp. 98-98, 1912. during the winter of 1910-11 indicate that the expection of activity has been fully realized. On February 1, 1911, according to a report by $A$. L. Raplee, there were 27 drilling rigs in the field and equipment for more on the way. Two oil wells were brought in during the winter, and there was considerable improvement at old wells. A small town had been established near Mexican Hat, and the roads and general facilities much improved.

Between 1911 and 1920 there was comparatively little drilling in the region, but since that time several wells have been drilled in the field and in the surrounding region. Most of these wells were deeper tests than the earlier wells.

The Mexican Hat Co. drilled a well in 1922 in the San Juan oil field, $1 \frac{11}{2}$ miles southwest of the Mexican Hat town site. The well was drilled to a depth of 362 feet and yielded a daily production of 50 barrels of oil said to have a gravity of $47^{\circ}$ Baumé.

A well at Halgaito (formerly spelled Hulkito) Spring, in sec. 35, T. 42 S., R. 17 E., south of the San Juan River, was drilled by the Monumental Oil Co. about 1920 to a depth of 1,300 feet or more. As far as the writer knows, no showings of oil or gas were obtained. A second well was drilled with a diamond drill by this company in 1923 , in sec. 23 , T. 42 S., R. 17 E., also south of the San Juan River. It was abandoned at a depth of 756 feet. No showings of oil or gas were reported. Another well near the same location was bored by the company with a diamond drill to a depth of 1,622 feet in 1923 and 1924. No production was obtained. In 1926 this company drilled a fourth well to a depth of 1,140 feet in sec. 19 , T. 42 S., R. 18 E. (unsurveyed), south of the San Juan River. This well obtained small showings of oil and gas at depths of 800 to 812 and 890 to 900 feet.

The London-San Juan Oil Co. drilled a well 213 feet deep in sec. 13, T. 41 S., R. 18 E., in 1923. No showings of oil or gas were reported.

Between 1924 and 1928 the Utah Southern Oil Co. drilled a well in the canyon of the San Juan River in sec. 27, T. 41 S., R. 19 E. Several small showings of oil and gas were found. The well was abandoned at a depth of 1,850 feet after drilling into mica schist.

The Utah Petroleum Corporation drilled a well in 1926 in sec. 36, T. 41 S., R. 17 E., south of the San Juan River, to a depth of 1,707 feet. No showings of oil or gas were found.

In 1926 the Utah Southern Oil Co. started a well in sec. 28 , T. 40 S., R. 18 E. The well was abandoned at a depth of 3,633 feet after drilling into mica schist.

In 1930 a new well was started by the Arcola Oil Co. in sec. 6 , T. $42 \mathrm{~S}$., T. 19 E., near the wells that had formerly produced oil in the San Juan oil field. The well, 263 feet in depth, obtained a small production of oil.

The only notable production has been obtained from a few wells of small individual capacity, near Mexican Hat and Goodridge. These wells, which are named 
below, are all in T. 42 S., R. 19 E., within a radius of $11 / 4$ miles of the common corner of secs. $5,6,7$, and 8 :

Hudson well, sec. 5 .

Bryce No. 1 well, sec. 6.

Bryce No. 2 well, sec. 6.

Mexican Hat well, sec. 6.

Arcola well, sec. 6 .

Crossing No. 1 well, sec. 7 .

Monticello well, sec. 7 .

Other wells within the same radius have bailed small quantities of oil or furnished showings of oil, and north of that locality showings of oil have been reported at various depths from scattered wells in T. 40 S., R. 19 E., T. 41 S., Rs. 18 and 19 E., and T. 42 S., R. 18 E. Showings of oil are also reported from wells as far west as Johns Canyon and the mouth of Slickhorn Gulch.

The production of the field has all been consumed locally. No reliable estimate of the output of the field in the period of activity is available, though records of sales from the Bryce No. 2 well show that some 5,000 barrels of oil was disposed of for field use in 1910 and 1911 , in addition to many barrels of oil either wasted or consumed in drilling by the owners of the well.

\section{DIFFICULTIES OF EXPLORATION}

The difficulties of exploration in this rough arid region, 150 to 200 miles from a railroad, are many. There are few inhabitants, and most laborers must be imported. All so-called roads west of Bluff and north of Kayenta are poor indeed and at times are impassable for wagons and automobiles. Most parts of the canyon country are not traversed by roads. The rainfall does not exceed about 6 inches a year, so that water for drilling as well as for drinking is scarce and generally has to be hauled or carried long distances. No timber is available for fuel except driftwood along the San Juan and scrub cedar and piñon on Cedar Mesa and other mesas of similar height farther west. The principal fuel for drilling has been oil from wells in the San Juan oil field. The cost of bauling coal into the region from the vicinity of Monticello or from other places is prohibitive.

\section{GEOLOGIC OCCURRENCE OF OIL}

The small producing wells enumerated above are 1 to 2 miles west of the northward-trending axis of the moderately depressed Mexican Hat syncline and penetrate beds that $\operatorname{dip} 2^{\circ}-4^{\circ} \mathrm{E}$., toward the trough of that fold. The oil showings to the northeast were found in strata of low dip on both flanks of the syncline. The oil showings in Johns Canyon were apparently found on the crest of the Mitten Butte anticline. The showings in the well at the mouth of Slickhorn Gulch, where there are numerous oil seeps, are in strata that $\operatorname{dip} 2^{\circ} \mathrm{W}$. on the west flank of the anticline. The fault that cuts the strata at the mouth of the gulch may have influenced the accumulation of the oil by providing a channel for it.

The oil in the San Juan country occurs in the Hermosa and Rico formations, which contain many oil- bearing sands. All the wells in the field, including those mentioned above, were drilled in these formations, and two of them-those of the Utah Southern Oil Co. in sec. 28, T. 40 S., R. 18 E., and sec. 27 , T. 41 S., R. 19 E.passed entirely through the Hermosa and possibly older limestone and entered mica schist of pre-Cambrian age.

The sands vary in thickness from place to place, and some of them are as much as 50 feet thick. At some places the oil saturates the unbroken rock, indicating that such rock is uniformly porous, but at others, as at the seep in the Goodridge sand at the Goodridge Bridge, the oil stains are irregularly distributed along joints and other cracks, indicating that the sandstone is not uniformly porous.

The fact that only a few of the rather large number of wells drilled in the vicinity of Goodridge and Mexican Hat have produced more than meager quantities of oil suggests that the oil in the sands is pockety and that its discovery with the drill is more or less accidental. This suggestion seems to be borne out by the character of one of the principal sands-the Goodridge-as revealed at the Goodridge Bridge, where oil is not uniformly disseminated through the sandstone but is confined to joints and other cracks.

The original source of petroleum in the San Juan oil field is undetermined. It may have come from the animals now represented by fossils in the Hermosa and Rico formations, in which the oil is found. There is also the remote possibility that the oil is of inorganic origin and was produced by the igneous rocks intruded in the sedimentary beds. Whatever its origin, the accumulation of oil along the San Juan has been controlled by local structure, climate, and geomorphic features. A series of north-south anticlines and synclines are favorable for accumulation, but the aridity of the region and deep trenching by canyons are unfavorable. As oil remains above water underground as well as above ground, it will be forced up under the arches of anticlines in regions where the rocks are saturated with water and will rest on the limbs of anticlines or in the troughs of synclines where ground water is deficient.

In the San Juan field throughout long periods of aridity the strata are drained of water nearly down to the bottoms of the major canyons, and rainfall is insufficient to compensate for the loss. The height to which oil may rise depends somewhat on the composition of the oil-bearing rock, but chiefly on the amount of water and oil available to fill its pores. Ground water and oil seeps emerge into the bottom of San Juan Canyon. Above that level the rocks have been drained of liquids.

The history of drilling in the San Juan field bears out the predictions of Gregory and Woodruff that the geologic conditions are unfavorable for large yields.

\section{SURFACE WATER}

In the San Juan country the surface water is utilized for household purposes, for livestock, and for irrigation. 
The development of power on the San Juan, particularly at the sharp meanders ("Goose Necks") below Goodridge and at the Great Bend, is feasible but at present not economical. Furthermore, as a control for flood waters on the lower Colorado, dams on the San Juan below the mouth of Comb Wash ("Bluff dam site") and in Glen Canyon just above the mouth of Lake Canyon ("Bedrock dam site") would have no purpose not equally well served by the proposed dam in Glen Canyon, above Lees Ferry. ${ }^{84}$

The flow of the San Juan River has been observed at a gaging station in the vicinity of Goodridge during the periods October 1914 to September 1917 and March 1927 to September 1933. During these periods the maximum discharge was about 70,000 second-feet on September 10, 1927, and the minimum discharge 26 second-feet on December 30, 1932.

\section{WATER FOR STOCK}

Surface water for sheep and cattle that range on the public domain is available in water pockets, ponds, and streams.

The water pockets ("rock holes", "rock tanks") are depressions in rock that fill with water after rains. They range in size from irregularly oval saucers a few inches deep and some tens of feet in diameter to round pits a few feet in diameter and as much as 6 feet deep; some of them are true potholes. They appear on bare surfaces at places where intersecting joints, abrupt change in direction of cross-bedding laminae, or weakly cemented rock facilitate local decomposition or local scour--conditions best provided by the Navajo and Cedar Mesa sandstones. The deepest ones are just above and just below dry waterfalls. In the shallow depressions the water disappears within a few days after the shower or the sheet flood that supplies it. In the narrow deep ones it may last for months or even throughout the year, and at times when the streams in the washes and canyons have ceased to flow it may be the only supply within a large area. As much of the best forage is on plateau tops and distant from established drainage channels, these water pockets, even though ephemeral, have obvious value.

Most of the "ponds", "lakes", and "dry lakes" are little more than very shallow water pockets in bare rock enlarged to diameters of 50 to 100 feet, or swamps about springs. Those on Elk Ridge and at the head of Johnson, Montezuma, and other creeks on the Abajo Mountains, where rainfall is relatively abundant, are nearly or quite perennial; those on Sage Plain and Grand Gulch, Red Rock, and Dark Canyon Plateaus are quickly emptied by evaporation but last long enough to supplement supplies from other sources.

In the San Juan country, as elsewhere in the plateau province, streams are the most abundant and the most

" La Rue, E. C., Water power and flood control of Colorado River below Green River, Utah: U. S. Geol. Survey Water-Supply Paper 556, pp. 20-24, 51-52, 1925. generally reliable sources of surface water. Their utilization, however, is seriously hampered by extreme fluctuation in volume and by inaccessibility. Of the master streams the San Juan is essentially perennial, but in its canyoned stretch of 135 miles below Comb Ridge it is accessible to stock at only three places. The water in the Colorado likewise is held within outer walls of rock and inner walls of alluvium and is readily reached only at the mouths of White Canyon and Red Canyon. On Sage Plain the construction of stock trails from the canyon rims to water in the intermittent and ephemeral streams presents no particular difficulties, but on the plateaus west of Comb Ridge-the chief free grazing districts-stream beds easy of access are usually dry, and cattle find water by descending tortuous trails along precipitous walls 600 to 1,200 feet high. Once on the canyon floor, even in time of drought, water can usually be found in potholes or in "sand pools" where bedrock emerges from the alluvial fill. In most of the deep canyons during dry months these supplies are spaced at distances of a mile or less, but in some the intervening distances are 3 to 5 miles, and in lower White Canyon nearly 20 miles. The persistently reliable streams are the headwater tributaries within the national forests about the Abajo Mountains and Elk Ridge and the rills that flow for short distanees from such springs as those in Johns Canyon, Spring Gulch, Woodenshoe Canyon, and Fable Canyon.

Much more surface water could be made available for stock by the excavation of small reservoirs and the construction of short, low dams along the washes and on the plateau tops at some of the many places where the topography and rock texture are favorable. The usefulness to the stockman of such inexpensive development has been amply demonstrated on the nearby Navajo Reservation, where the rainfall, washes, canyons, and exposed rock surfaces are closely similar. ${ }^{85}$

\section{IRRIGATION}

The pioneers in southeastern Utah placed their hopes of prosperity on the probability that the waters of the San Juan and its tributaries could be used for the irrigation of the extensive terraces and flood plains adjoining those streams. For some years after settlement, ditches at Bluff, at the mouths of Cottonwood, Recapture, Montezuma, and McElmo Creeks, and at intermediate sites along the San Juan River supplied cheap water for successful crops. But the river proved unreliable. With the conversion of brushland and reed swamps into agricultural land and the extension of grazing on river bluffs, the San Juan, which once maintained a well-defined course, became a destructive agent, cutting deeply into its banks, changing its channel, and spreading its mud-laden waters over farms and pasture lands. The cost and effort of maintaining head gates, disposing of silt, and protecting

${ }^{\text {s }}$ Gregory, H. E., The Navajo country: U. S. Geol. Survey Water-Supply Paper 380, pp. 102-122, 1916. 
fields from floods and erosion are proving too great for the decreasing population. Fortunately at Bluff the water from the intermittently filled ditch is supplemented by that from artesian wells, and at Aneth water for irrigating some 40 acres of river flat can be taken from McElmo Creek. Irrigation at other places alung the San Juan has been abandoned.

Irrigation practice at Blanding rests on a solider basis. After the great drought of 1896, when no water flowed in the San Juan during the irrigation season, and the still drier year of 1898-99, attention was given to the small but perennial streams flowing from the Abajo Mountains. Along the southeast base of the mountains the construction of a few short ditches for individual farms was followed by the development on "White Mesa" of an irrigation district that gave rise to the village of Grayson (Blanding). Here the main channels and many branches reach about 7,000 acres of irrigable land, 3,000 acres of which is partly irrigated and the remaining 4,000 acres used for dry farming. The upper canal, from Johnson Creek, and the lower canal, from Recapture Creek, take all the water from those streams during the irrigation season. This is insufficient to irrigate all the land available and in many seasons is inadequate for the fields under cultivation. To increase the supply and especially to insure regularity of flow in the ditches now in use, it is proposed to divert the surplus waters of Indian Creek by constructing a tunnel through the Abajo Mountains and a trench leading to Johnson Creek. By this method it is thought possible to obtain 1,600 to 1,800 acre-feet of water at an estimated initial cost of about $\$ 45$ an acre.

At Monticello water for irrigation and part of the water for domestic use is obtained from canals heading in North Creek and South Creek (Pole Creek), branches of Montezuma Creek. About Carlisle the farms and ranches are irrigated from Vega Creek. At Verdure Verdure Creek supplies water for farms within the bordering walls of its valley. For the total area under irrigation, listed as 4,500 acres, the water from the ditches is usually sufficient during the critical monthsApril, May, and June.

Irrigation farming is practiced on a small scale on the Indian reservation at Allen Canyon, in the northern Allen Canyon country, in lower Cottonwood Canyon, at the mouth of Red Canyon, and in some years at a few places along Montezuma Creek and other streams on Sage Plain. The irrigated ranch at the mouth of Arch Canyon is an oasis on the otherwise inhospitable floor of Comb Wash.

An ambitious prospect for using the waters of the Dolores River to reclaim some 50,000 acres along the Utah-Colorado line calls for the construction of a dam 270 feet high, several miles of ditches, and a tunnel 4,800 feet long through the low divide separating the Dolores and San Juan drainage basins. The estimated cost, about $\$ 175$ an acre, seems prohibitive for this land of moderate fertility without access to profitable markets.

In the San Juan country the conditions for utilization of water by irrigation are unfavorable. Most of the alluvial flats are narrow, the canyons are deep, the soil on the plateau tops is thin, and the supply of water obtainable without prohibitive expense is inadequate. With the fullest development of surface water the cultivated fields about the Abajo Mountains would be green patches in a broad expanse of brush lands. Elsewhere they would be dots in many square miles of bare-rock surface and canyon floor.

\section{GROUND WATER}

In the San Juan country most of the rain water comes from short-lived showers and hurries away through thousands of ready-made channels, with the result that little is imbibed by the rocks. Except on talus slopes and highly porous flood plains only a small part (probably less than 5 percent) of the annual precipitation is absorbed by soil and rocks, and of this amount much or even all may be brought back to the surface by evaporation. A series of field tests showed that heavy showers during June, July, and August barely wet the surface of the Permian and Triassic shales, soaked into the Navajo and Cedar Mesa sandstones about a quarter of an inch, and soaked into the gravel and sand of washes and canyon floors 2 to 8 inches. At most of the places tested this wet zone was dried by evaporation before the next shower renewed the supply. It seems that in the dry, hot months some rain water becomes ground water by descending through open cracks and joints and that during periods of melting snow percolation into the rocks is general. Nearly all the ground water in the alluvium of the flood plains and canyon floors comes directly from lateral or vertical percolation of ephemeral and intermittent streams.

In this region the terms "ground-water reservoir" and "water table", as usually defined, are applicable only to the high talus deposits of the Abajo Mountains and the rim of Elk Ridge, and less definitely to the gravel deposits of the piedmont slopes and the sands of the narrow flood plains. In rocks of other kinds the saturated areas are discontinuous. For distances of miles horizontally and hundreds of feet vertically, deep-seated wet rocks are separated by dry rocks, and in many areas the ground water remains but a short time: it is on the way to the wall of some canyon that is cut below its horizon. Most of the water revealed in springs and wells occupies relatively thin zones of saturated rock between strata that are substantially dry.

\section{SPRINGS}

In cutting their deep trenches the hundreds of intermittent and ephemeral streams of the San Juan country have revealed water-bearing beds that in sequence and texture favor the emergence of springs. The 
Dakota(?), Westwater Canyon, Bluff, Navajo, Wingate, Shinarump, and De Chelly sandstones have estimated porosities of 6 to 15 percent, and the unconsolidated sand and gravel 10 to 40 percent. The water they may contain is prevented from passing upward or downward by relatively impervious shales, limestones, and mudstones but is free to escape where the edges of the strata are exposed in cliffs and canyon walls.

The position of springs is determined by topography and the stratigraphic sequence of beds; their number, permanency, and size by the amount of rainfall received by the aquifer at nearby or distant places and by the effectiveness of evaporation. Thus the most numerous permanent springs are at the base of the Shinarump cliffs on Elk Ridge, where favorable conditions are provided by heavy snowfall, retarded run-off, a fractured, relatively porous aquifer, underlying beds of dense sandstone and shale, and a cover of talus that lessens evaporation. Similar conditions prevail on the slopes of the Abajo Mountains, where water from rain and snow accumulates in the thick talus at its contact with impervious igneous rock. On Sage Plain the spring zone is the contact of the porous Dakota (?) sandstone and the watertight Morrison shales. On Red Rock Plateau most of the springs emerge at the base of the loose-textured Navajo sandstone, where downward percolation is arrested by the shales and limestone of the Kayenta formation, and at the base of the muchjointed Wingate, which rests on compact Chinle shales. On canyon floors and along washes most of the springs are at the contact of alluvium and bedrock. For the region as a whole these division planes between relatively porous and relatively impervious formations are the spring zones, but some springs emerge directly from formations that as a whole are watertight: their position is determined by thin beds or lenses of limestone or dense sandstone that lie below layers of porous sandstone. Controlled by this arrangement of subordinate beds, springs issue from the Hermosa formation along the San Juan at the Narrows, at Soda Basin, and above the mouth of Slickhorn Gulch; from the Halgaito member in Johns Canyon; from the Cedar Mesa sandstone at the head of Fish Creek, in Arch Canyon, in Fable Canyon, and in Beef Basin; from the Organ Rock member at Red House and below the mouth of Frey Canyon (Rock Spring); from the Chinle at the Clay Hills and at the head of Comb Wash; from the Moenkopi at places about Elk Ridge; and from the Kayenta in Cedar Canyon, Castle Wash, Moki Canyon, and along the Red House Cliffs. Many of the springs that issue from these generally impervious formations are connected by joint cracks with water-bearing beds from which their supply is derived.

In the formations that are generally saturated water may find its way to the surface before reaching the impervious layer below. Springs of this sort are numerous in the massive sandstones. In the Navajo and the
Wingate they emerge between cross-bedding laminae or at the top of limestone lenses; in the Dakota(?) at the contact of conglomerate with green shale or coal. Some of these springs yield small perennial supplies, but most of them are tiny seeps tucked away in alcoves and tunnels high on canyon walls and flow only during the night or during cold months. On hot days evaporation removes the water at a surprising rate. A spot on a bare wall marked in the daytime only by efflorescence and patches of vegetation may yield at night water sufficient for camp needs.

Springs in the San Juan country supply much of the water used in homes and part of that needed for stock. Monticello derives its domestic supply from strong springs in the Abajo Mountains, and Blanding from spring-fed streams. Several ranches near Ucolo use the water from a spring in Piute Draw, and elsewhere on Sage Plain small springs supply the scattered farm houses. As a source of water for stock, springs in the forested area about the Abajo Mountains and Elk Ridge are adequate and conveniently placed, but those in the large grazing districts west and south of Elk Ridge are widely spaced. Many of them yield small supplies, and others are inaccessible. Green Water and Irish Green Springs, in upper Castle Wash, and Home Spring, in Beef Basin, are fortunately placed in broad expanses of unwatered country, and the strong springs in Johns Canyon and lower Castle Wash may be reached by roundabout trails cut in canyon walls. It has been found impracticable to make use of the water that emerges in Clay Creek, Alcove Creek, and Wilson Creek and at the box heads of several other short, deep canyons tributary to the San Juan and the Colorado. Rock Spring, which makes possible the traverse of White Canyon in the dry season, provides enough water for about three horses. The other horses in the pack train must wait 20 to 30 minutes until the supply is renewed. In general the springs on the grazing lands merely serve to supplement the supply accessible in canyons and water pockets. When these surface supplies fail, the cattle drift to high lands where water is available. It is entirely possible to increase the yield of the springs in use and to develop new springs by methods adopted on the Navajo Reservation, where the controlling conditions are similar.

\section{WELLS}

In the San Juan country little attention has been given to the construction of wells; water for household use, for irrigation, and for livestock is derived almost entirely from surface water. The well at the Indian agency at Allen Canyon is representative of the few wells sunk in unconsolidated sediments that border the larger washes, and the shallow dug wells at Monticello and eastward on Sage Plain demonstrate the feasibility of obtaining small amounts of good water from the piedmont gravel deposits extending outward from the Abajo Mountains. Along the Monticello-Cortez road 
a few wells obtain water of good quality from the Dakota (?) sandstone.

The artesian wells at Bluff are the source of water much needed to replace that from shallow dug wells, weak springs, and the San Juan River. Drilling was recommended here because the region is structurally a basin (Sage Plain downwarp, Gothic Mesa syncline) toward which dip the water-bearing Navajo, Wingate, and Shinarump sandstones, each bordered above and below by relatively impervious strata. Two of the six flowing wells start in alluvium; the others in beds of the San Rafael group (Carmel (?) and Entrada formations). Four of them obtain most of their water from the Wingate or the base of the Navajo sandstone at depths of about 800 feet. The two other wells, reported as 1,085 and 1,165 feet deep (one informant gives 1,325 feet), probably tap water also in the Shinarump conglomerate. The flow of the first successful well tested in 1909 was 80 gallons a minute. Unfortunately the wells have been permitted to flow freely even when the water was not needed, with the result that increasingly smaller yields are recorded. At the present time the flowing wells at Bluff provide all the water for domestic use and for irrigating about 70 acres of gardens, orchards, and hay fields. One well flowing about 30 gallons a minute has been left standing in the channel of the San Juan River by erosion of alluvial banks.

Between the San Juan River and Blanding and eastward across Sage Plain the conditions that permit the development of artesian wells are similar to those at Bluff, but the strata above the aquifers are thicker. At Boulder Knoll an oil well encountered water in the "Chinle" [probably Shinarump] at a depth of 2,640 feet. At Blanding a well drilled to a depth of 1,100 feet, most of it in Morrison shales and sandstones, found water at the base of the Dakota (?) sandstone at a depth of 800 feet. At the experiment station east of Monticello a well drilled in 1925 to a depth of 405 feet reached water at horizons between 215 and 230 feet. 



\section{N D E X}

$A$

A bajo Mountains, aititude of. geologic and topographle map of mineral deposits of. petrography of scenic interest of

springs on. stresms flowing from ............ 8 structure of.

vegetation of

views of.

Abajo Peak, rocks of

Acknowledgments.

作 101

Agriculture, climate in relation to

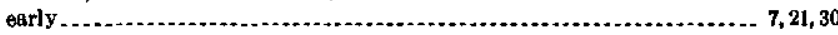

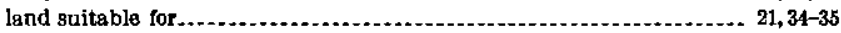

statistics of

wator avallable for

Allen Canyon country, description of

irrigstion [n ..................................................... 115

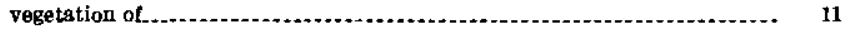

view in ....................... pl. 13, $C$

Alluvial terraces, origin and character of .

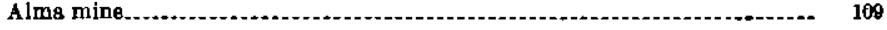

Altitude of the area.

Andesite, occurrence of.

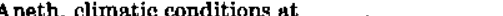

irrigation at.....

Angel Arch, origin and festures of........................................ 105

Animal life of the area.

Arch Canyon, erosion leatures in

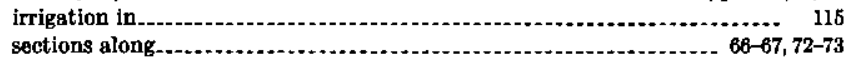
structure in vlews in

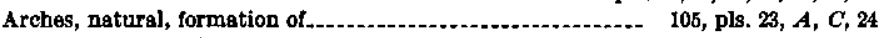

Arcola Oil Co., well of.

Armstrong Canyon, views in

Artesian wells pls. $5, B, 9, D, 19, B$

B

Balanced Rock antleline, description of view of

Basket Makers, areas settled by culture of

Bears Ears, section at view of.

Bears Ears Platesu, use of name.

Beaver anticline, location of

Beef Basin, general features of oll possibllitios in structural relations of

Bell Butte dike, rock forming

Birds of the area

Black Mese, view of west face of

Blanding, climatic conditions at

establishment of settlement st.

irrigation at. population of

Blue Dike mine.

Bluft, climstic conditions at establisbment of settlement at irrigation at.

placer mining near. population of section at.

Bluff sandstone, description of rock shelters in section of. topographic features of view of
Boulder Knoll, oll well at..

Page

Bridges, natursl, tormation of natural, views of view in.................... ${ }^{77}$

Brushy Basin shale, description of sections of ............ 76, 77 views of Bryce No. 1 well $\ldots \ldots \ldots \ldots$

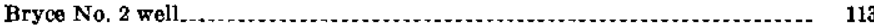

Bulldog Canyon, section in ............................................ 78

Butler Wash, cliff dwelling in......... $B$ Navajo summer house near mouth of .............................. pl. $\theta, A$ sections along......... 75, 76-77 view of valley of ... . . $\mathrm{C}$

Canyons, down-cutting of fll ins, down-cutting of
general form of natural bridges in 103-105, pls. $19, B, 20, B, 21,22$ sediments deposited in............................... 100-102, pl. $A$

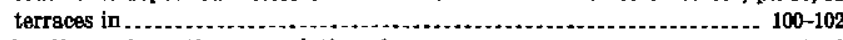
Carboniferous formations, correlation ot

Carlisle, irrigation at

Carmel (?) formation, description of . sections of .............. 74-76

Castle Wash, features of view of wall of

pl. $13, B$

Cataract Canyon, view in

Cathedral Arch, origin and features of

pl. $5, A$

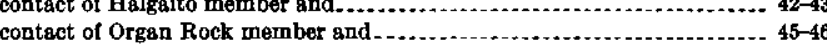
description of. sections of stratigraphic relations of . . . . topographic features of . . . . . views of $\ldots$ pls. $5, B, 6, A, 8, C, 9, C, D, 11,20, B, 21,23, B, C$

Chimney Park, use of name...

Chinle formation, description of

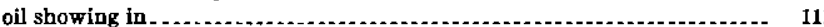
sections of

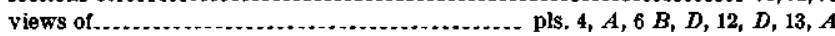

Church of Latter Day Saints, colonization by . .

Clsy Hills, views of ....................................... $B, B$

Clay Hills Pess, section at section of cliffis north of view of entrance to.

Cliff caves, sites of views of

Clift Dwellers, culture of houses of. pls. $8, B, C, 25,26$ ites ocen 28, 106, pls. 8, 25, 20

Climate of the ares. . erosion influenced by

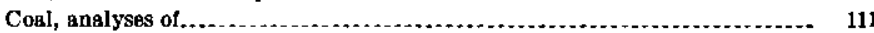
occurrence and quality of

Cosl Bed Canyon, cosl in .............................................. 110

Cobalt, occurrence of

Coffin, R. C., quoted.

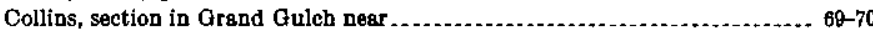

Colorado Plateaus province, previous surveys of

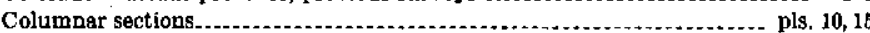

Comb monocline, description of . . .

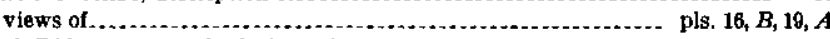

Comb Ridge, structural relations of

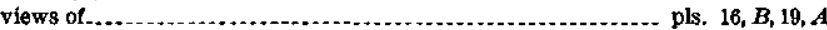

Comb Wash, section at head of

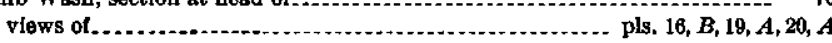
Copper, occurrence of ............ 107-108

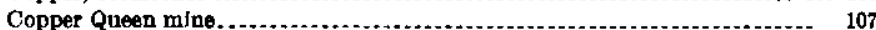


Page Jurassic.

Cottonwood Canyon, features of

irrigation in section in

Cottonwood Wash, view near mouth of

Crepo mine, section in

Cretaceous formations, description of sections of

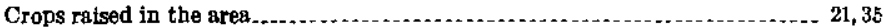

Crossing No. 1 well _ 111,112

Cutler formation, correlation of deseription of..................... $41-47$ sections of

terminology of

Cycles of erosion

Dacite, occurrence of

81,83

Dakota (?) sandstone, cosl in

contact of Morrison formation and

lithologic features of

sections of.

stratigraphy and correlation of

topographic expression of

Dendy Crossing, location of

Dark Canyon, features of fossils from.

section in.

Dark Canyon Platean, features of . . .

De Chelly sandstone, occurrence and character of section of

Decker ranch, section at

Denudation, rate of

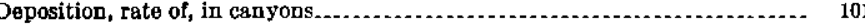

Dixon Gulch, prospecting along........ 109

Dolly Varden mine

Dolores River, proposed irrigation from.

Drainsge system of the area, general features of . possible age ot

Dream mine, development at rock at.

Drought of 1898 in the area

Dry farming in the ares...

Dry Wash (Allen Canyon country), features of .................... 13, $C$ section in...

Dry Wash (branch of Fish Creek), section in

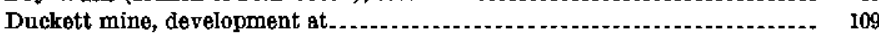
rock at..

Duckett Ridge, rocks of

Eastwood, Alice, plants collected by ................................. 25-26

Economic geology of the area. . .

Elk Ridge, description of

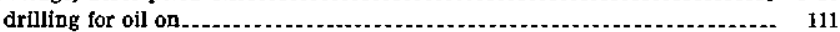
sections on.

springs on

structure of

vegetation of

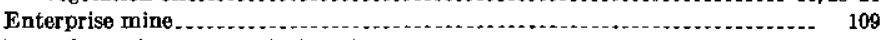

Entrada sandstone, description of....... 57 sections of .

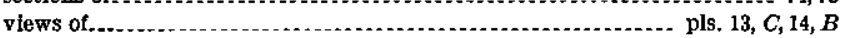

Erosion, base-level of

by ground water....... 106

cycles of

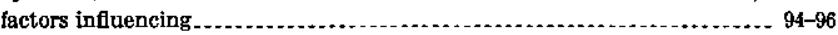

forms produced by, general features of

"goblet," view of.............................. 14, $B$

natural bridges. ................... 103-104, pls. 19, $B, 20, B, 21,22$

plateaus and mesas.

rock shelters.................................... 28-29, 106, pls. 8, $B, C, 25,26$

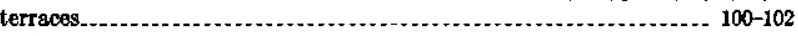

valleys.

windows and arches.................................. pls. 23, $A, C, 24$

present conditions of. rate of.

Escalante, Juan, route followed by

Exploration in southeastern U tah

(

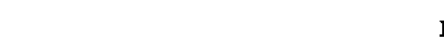

Fable Valley, cliff dwellings in

Farming in the area, by early inhabitants of

general features of ........................................... 34-35

in Allen Canyon country ........ 11,115

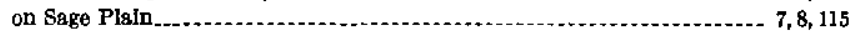

relation of elimate to

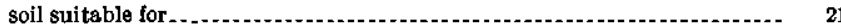

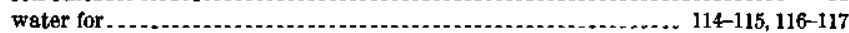

Faults in the area

Fsuna of the area....................... 26-27

Fish Creek, oil possibilities near.

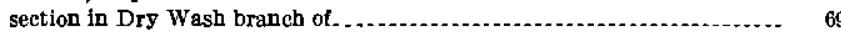

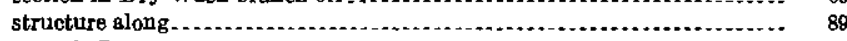

Fishmouth Cave, view of................... pl. 23, $A$

Flora of the area. .....

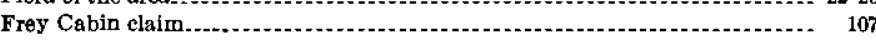

Frost, erosion effected by action of

G

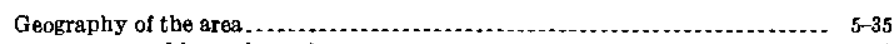

names used by early explorers. .................................................

Geologic maps and sections.......................................................... pls. 1,17

Garald Hughes No. 1 Elk Ridge well .............. 111

Gilmore, C. W., quoted...

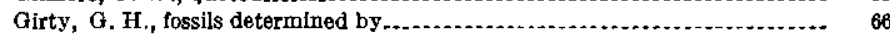

Glaciation, lack of evidence of . . . . . . .

Glen Canyon, features of....................... gold in

Glen Canyon group, correlation of ................................... 51-53, pl. 15 description of

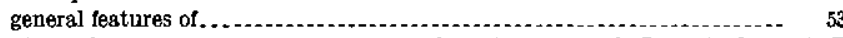
views of

Goblet of Venus, view of

Gold, in Abajo Mountains..................... 108-110

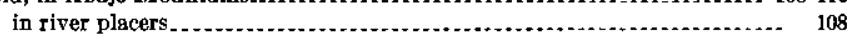

Gold ore, character of

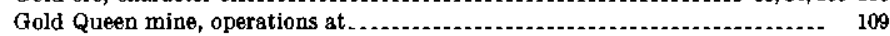
rock at . . .

Goodridge, E. L., exploration and prospecting by

Goodridge formation, name discarded. 39

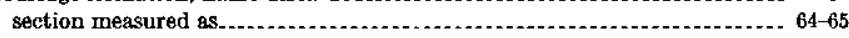

Goodridge oil field, drilling in.................... 111

Goodridge sand, occurtence of oil in .............. 112, 113

Grand Gulch, erosion features in 05 sections along

Grand Gulch Plateau, description of

oil claims on

Grasses, lists of species..................... 24-26

Gravel, occurrence and character of

Gravel terraces, relative height of

Gray Mesa, use of name

Grayson. See Blanding.

Ground water in the area

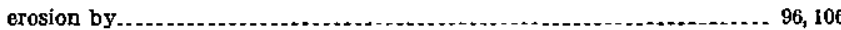

Gundlock Creek, use of name................ 11

Gunnison formation, use of name

\section{H}

Halgaito member of Cutler formation, contact of Cedar Mesa sandstone and.. 42-43

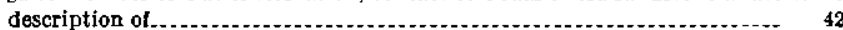

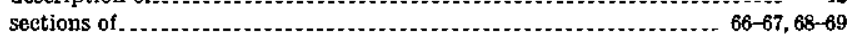
topographic features of viows of

Halgaito Spring, well at.......... 112

Hammond Canyon, features of

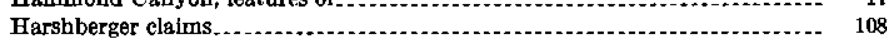

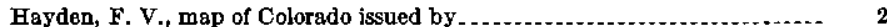

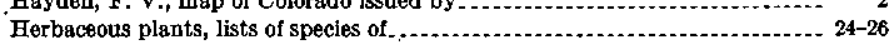

Hermoss formation, description of oil in

section of .................... 65

views of . ......... pls, $5, A, 11, A$

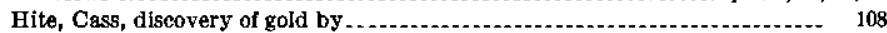

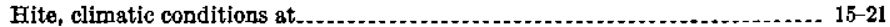

location of ............... 13

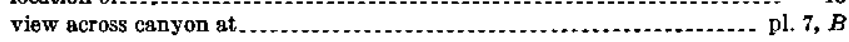

Hole in the Rock Road, view along . . .

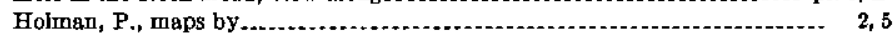


Holmes, W. H., exploration by

Honaker trail, section at

Hornblende andesite, occurrence of

Bornblende latite, occurrence of

Hornstone, occurrence of

Horsehead Peak, rocks of $\ldots . . . . . . . . . . . . . . . . . . . . . .81,82,90$

Hoskinnini tongue of Cutler formation, occurrence of

Hovenweep National Monument, cliff house in

Hudson well

Hulkito. See Halgaito.

Igneous rocks, regional relations of

Illizois mine

Indian Creek, proposed diversion from

Indisns, number of, in the area

Industries of the area

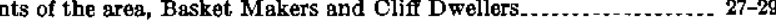

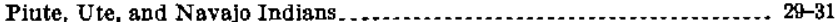

white settlers

Innis mine, rock at.

Innis' sawmill, rocks near.

Iron, occurrence of

Irrigation, general features of water for ............................. 114-115

Jackson, W. H., exploration by quoted.

Jackson, Camp, gold mining at.

Jackson D1vide, rocks of

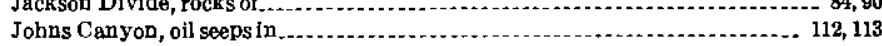
section in ... views in

Johnson Creek, gold placers on ..................... 108, 109 irrigation from

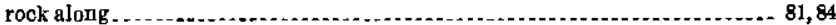

Jurassic formations, correlation of ........ description of ......... $53-60$ general features of major divisions of . . sections of.

Kachina Bridge, origin and features of $\ldots \ldots \ldots . . \ldots 103,104, \mathrm{pls}, 21,22, B$ section southwest of

Kayenta formation, occurrence and character of

Keystone Arch, origin and features of

$105, \mathrm{pl}, 24, B$

Laccoliths composing Abajo Mountains.

Lacustrine deposits, occurrence and character of

Lake Canyon, festures of

Landslides, conditions fav

La Plata formition, use of name

La Rue, E. C, survey by

La Sal, population of

Lav8, nature of rocks locally known as

Lime, resources of.

Lime Creek Valley, description of

oil wells in vegetation of views in.

Lithology, influence of, on topography.

Location of the area

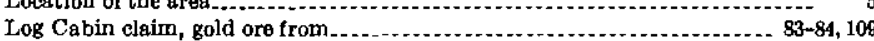

London-San Juan Oil Co., drilling by

Long Point, section at

Loper, Bert, exploration by

\section{$\mathbf{M}$}

Macomb, J. N., exploration by.

Malpais, nature of rock known as

Mancos shale, occurrence and character of sections of. topographic expression of

Manganese, occurrence of

Maps of the area, notes on

Marl in Clay Hills, view of.

McElmo Creek, Irrigation from

$89-90$

McElmo formation, nee of nam

Meanders, development of

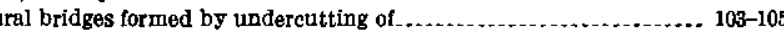

Mendenhall, W. E., exploration by

Mexican Hat, view of

pl, 4, $B$

Mexican Hat Co., well of . . . . . . . . . .
Mexican Hat syncline, features of Page

oil in $\ldots . . .88,113$

Minerals of the area . . . . .

Miser, H. D., section on San Juan oil feld by . . .

Mitten Butte anticline, description of . . . . .

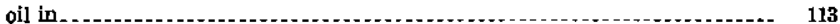

Moenkopi formation, description of sections of ..................................... $67,70-73$

topographic features of

views of $\ldots \ldots \ldots$ pl. $12, B, C$

Moki Canyon, features of............................................. 6

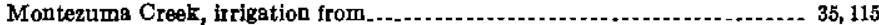

Monticello, climatic conditions at _ 15-21

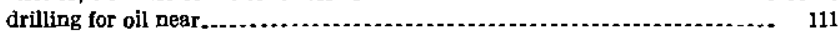

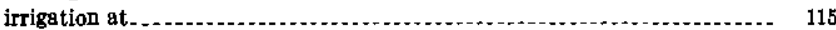

population of

Monticello well.................... 113

Monument upwarp, description of

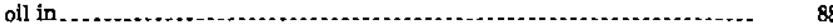

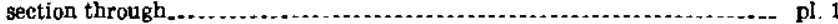

views of $\ldots \ldots \ldots \ldots$ pl. 16, $B, C$

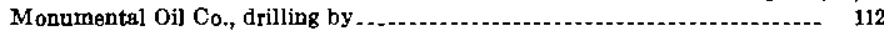

Mormon colonization in the area

Morrison-Dakota (?) contact . .

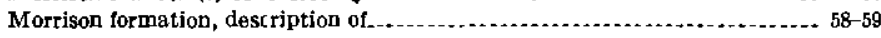
general features of . . . . . . . . . . rock shelters in sections of .

topographic features of views of

Mount Linnaeus, rocks of .................................................... 90

Names of geographic leatures used by early explorers

Natural bridges, formation of views of.

$103-104$, pl. 22

vatural Brides Nationel Monument, establishment of dwellings of

Nevajo Mountain anticline, location of . ................................. 88

Navajo sandstone, cliff dwellings in ............... 106, pl. 8, $B$ description of...................... $55-56$ topographic features of views of .......... pls. $6, C, 7, A, C, 8, B, 13, B, 23, A$ water from

Navajo Springs, section on Raplee anticline near

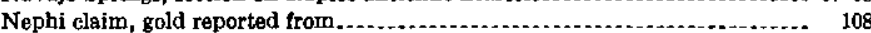

Newberry, J. S., geologic reconnaissance by quoted. ................................. 7

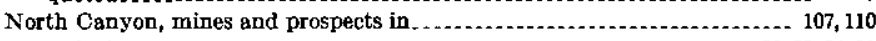
rocks in ........................................ 82, 91

North Creek, rock at head of . . ............ 82

North Peak, rocks of ........ 81,90

Occupations in the area

34-35

Oil, distribution of exploration for, difficulties of

geologic occurrence of

wells drilled for

Oljeto syncline, features of $\ldots$

Olson, $O$. F., plants collected by

Organ Rock anticline, description of 88

Organ Rock member of Cutler formation, contact of Cedar Mess sandstone and. 45-46 description of.

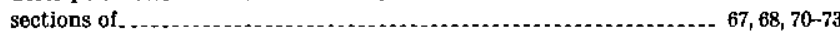

views of $\ldots$ pl. $9, B, 12, A, B$

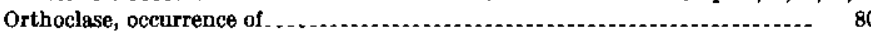

Owachomo Bridge, origin and features of...

Peat, occurrence of in Lake Canyon................... 64

Pendergraff mine, section in

Pennsylvanian formation, description of ...................................... 40 section of views of

Permian formations, correlation of description of sections of .

Permian fossils . . .

Physiography of the area

Piute Basin, use of name

Piute Draw, sections of cosl beds at.

Piute Indians, culture of

early history of . ... . . .

present status of 
Piute Park, use of name

$P$ lagioclase, occurrence of

Population of the ares.

Posada, Fray Alonzo de, exploration by .

Power, passibilities for development of.

Precipitation in the area, distribution of erosion in relation to.

rapid evaporation of

records of

Quaternary formations, occurrence and character of.

$63-64$

Radium, search for

Rainfall in the area, distribution of erosion in relation to records of-

Rapid syncline, location of

Raplee anticline, description of oil in.. section on enst flank of views of

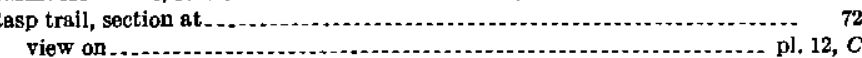

Recapture Canyon, fault forming wall of

Recapture Creek, gold on ................................................. 83-84, 109

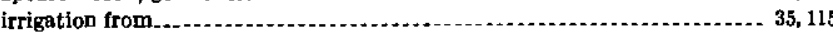
sections along

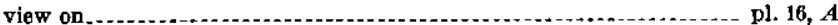

Recepture sbale, description of sections of.

Red Canyon, view of divide between White Canyon and

pl. $16, A$

$76,77,78$

Red Cone Spring, view st

pl. 13, $A$

Red House Cliffs, views o

pl. $6, C$ views on Canyon, drilling for oil in.....

Rhyolite, occurrence of.-

Rico formation, correlation of

description of

82,83

$40-41$

oil in

111,113

sections of

$64-65,66$

topographic festures of

views of ....................... pls. $A, 11, A, 16, D$

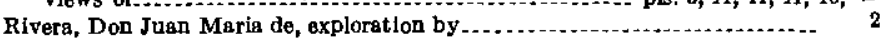

Road Canyon, view in ........................ pl. $B$

Rogds in the area

Rock shelters.... 28-29, 106, pls. 8, $B, C, 25,26$

Rock Spring, supply of water from ............. 116

Rock Springs, section at................................. 71-72

Rock tanks, water supply from
Run-off, erosion Influenced by 114

94-95
14

Rustlers Flat, use of name

Sage Plain, description of irrigation on

ail claims on

vegetation of

view of part of.

Sage Plain downwar

Sand, in valley fil wind-blown

San Juan oll fleld, development of

San Juan River, canyons of

cliff dwellings alon

flow of.

general features of

gold placers on

irrigation along.

$7-8$

7,115

load carried by .

$7-8$, pl. $2, A$

pl. 2, $A$

oil fleld near.

, 101-102, pl. $20, A$

63, 106

power possibllities

previous surveys of

section at Honaker trail on

$97,98-99$, pl. $3, A, B$

terraces along -

vegetation along, list of species

views along.

28,106 , pls. $8, B, 25, D, 26, A$
San Kafael group, correlation of

Page

distribution of

general features of . . .

sections of

Sedimentary rocks, columnar sections of

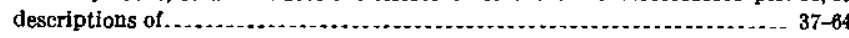
Beneral stratigraphic relations of . . sections of ............................ 36-37,64-78, pls. 10, 15

Bettlement of the area, history of

Shay Mountain, structure of

Shinar ump conglomerate, description of .

sections of .............. $71,72,73$

topographic features of

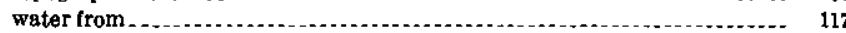

Shrubs, lists of species of

Sipapu Bridge, origin and features of . ............. 103, 104, pls. 20, $B, 22, A, 23, B$

Slickhorn Gulch, oil well at mouth of ...................

Soil in the area

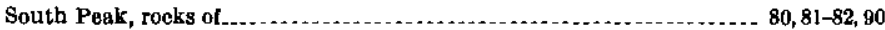

Spanish mine, reports of

Spring Gulch, location of . .

Spring syncline, location of .............. 88

Springs in the area................. 115-116

Star Springs, view of cliff near.............

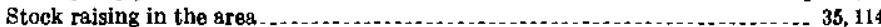

Stratigraphy, descriptions of formations

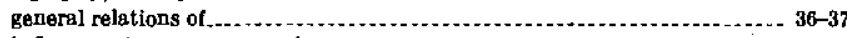

influence of, upon topography .......... 96

sections showing ............................................ 36-37, 64-78, pls. 10, 15

Streams, courses of in relation to structure debris transported by

from Abajo Mountains.

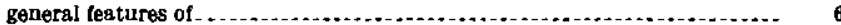

grsdient of

meanders of . . .

run-off of ...................... 94-95

valleys of, form of

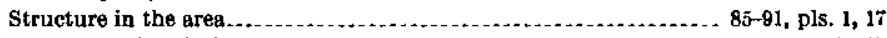
streams in relation to ....................................

Summerville (?) formation, occurrence and character of ............ 57-58, pl. 14, $A$ sections of ................. 74-75

$\mathrm{T}$

Tables of the Sun, location of

Talus in the area, features of formation of.

Tank Mesa, section on south face of ........... 74

Temperature in the area, records of ........ 20-2! run-off influenced by

Terraces, origin and features of . .

Tertiary formations, probable occurrence of, in San Juan country ............ 63

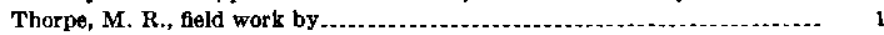
section on petrography of Absjo Mountains by section on structure of Abajo Mountains by ...

Topography of the area, age of present features of controlling factors of general features of .

Trachyte, occurrence of......................... 82-83

Travel in the area................. 3-5

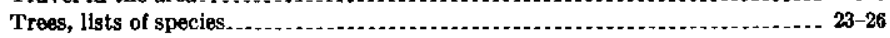

Triassic formations, description of

reglonal relations of

sections of

Trimble, $\mathbf{K}$. W., surveys by .

Twin Peaks, rocks of

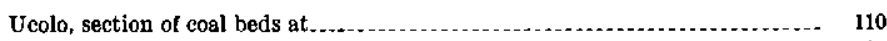

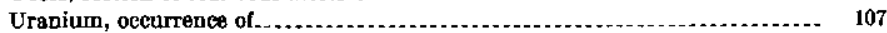

Utah, southeastern, early exploration in .................................... 1-2

Utah Petroleum Corporation, drilling by ......................... 112

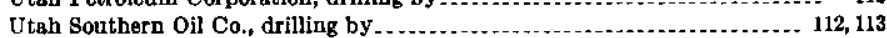

Ute Indians, early history of present status of

$\mathbf{V}$

Valleys, deposition and erosion in

form of .............

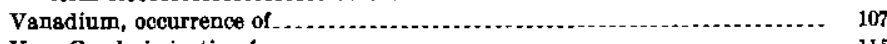

Vega Creek, irrigation from ................................................ 115 


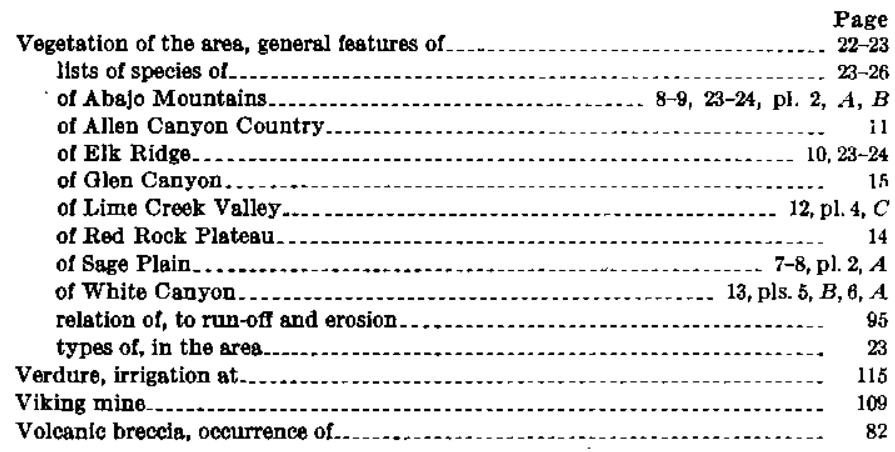

w

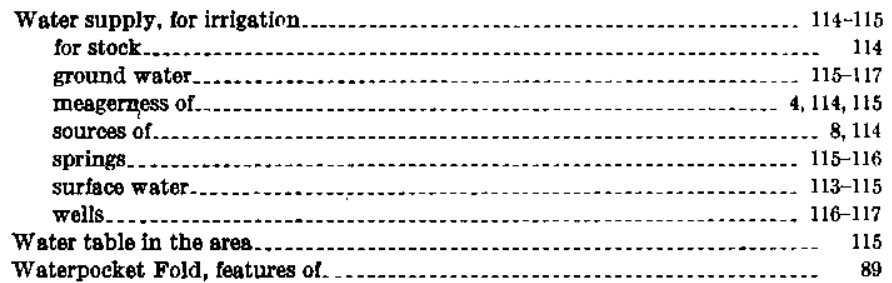

Wells in the area Westwater Canyon topographic features of

White Canyon, cliff dwellings in...................... 13, pls. 8, $C, 25, A, B, C$

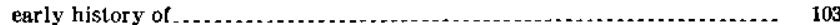
general features of . $\ldots \ldots \ldots \ldots \ldots \ldots \ldots$

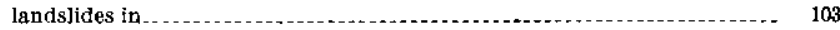

natural bridges in......................... 103-104, pls. 20, $B, 21,22$ prospecting in $\ldots \ldots \ldots \ldots$
sections in

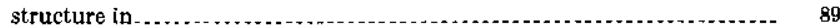

veretation of....................... 13, pls. $5, B, 6, A$ views in and near........... pls. $5, B, 6, A, 12, A, 13, A, 20, B, 21,22,23, B$

White Cliffs sandstone, use of name

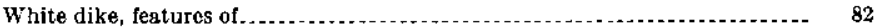

White Mesa, irricition on . . . .

Wilson Mesa, features of . . . . .

section at west edge of

structure of

Wind, ditection of, in the area

Windows, natural, formation of

Wingate sandstone, occurrence and character of .... $5 \nmid$, pls. $3, B, 4, A, 6, D, 13, A$

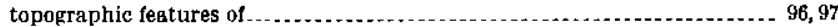

water from . .

Woodruff, F. G., quoted 






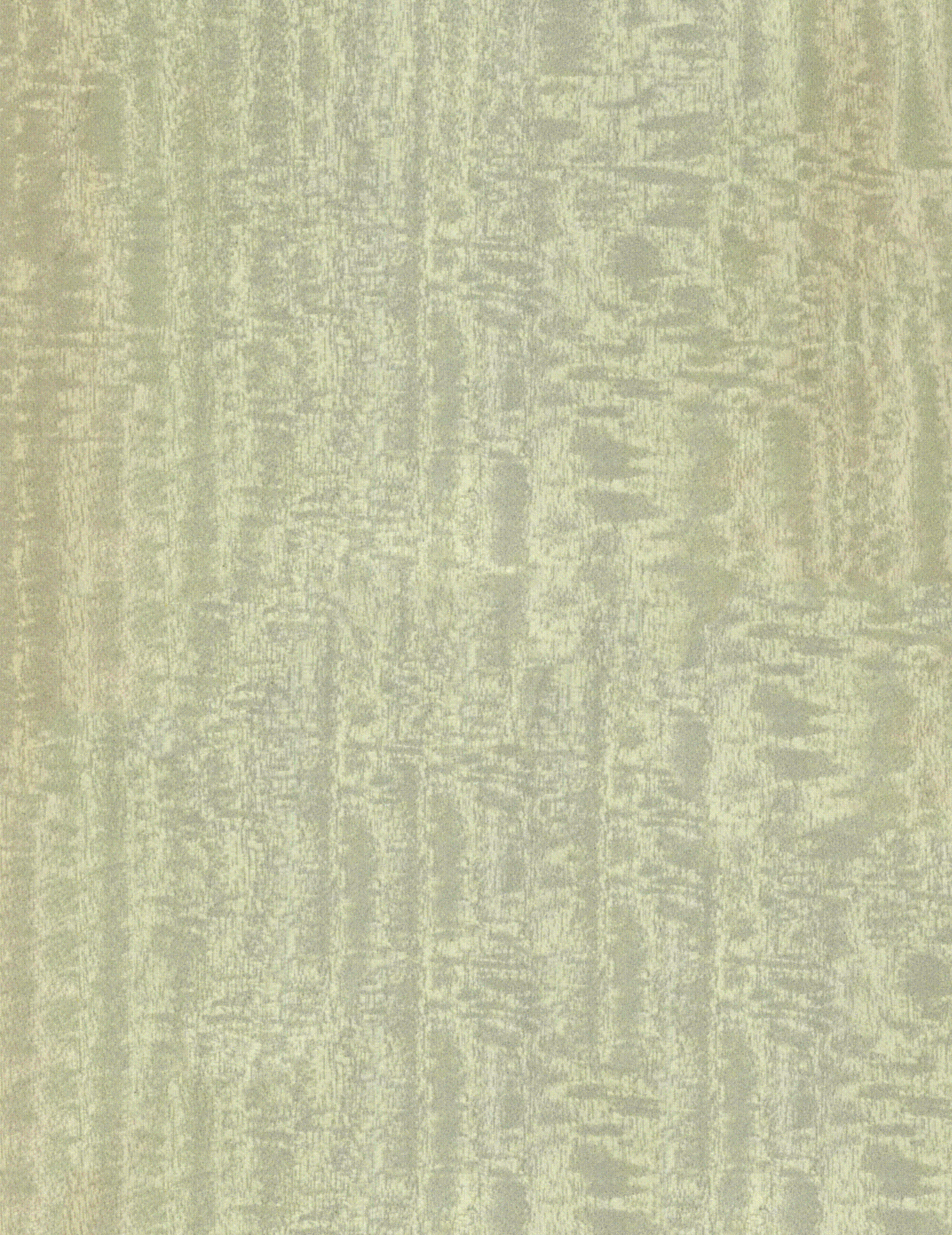

